UC-NRLF

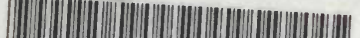

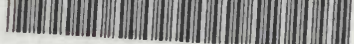

B 3 룰 4 르 


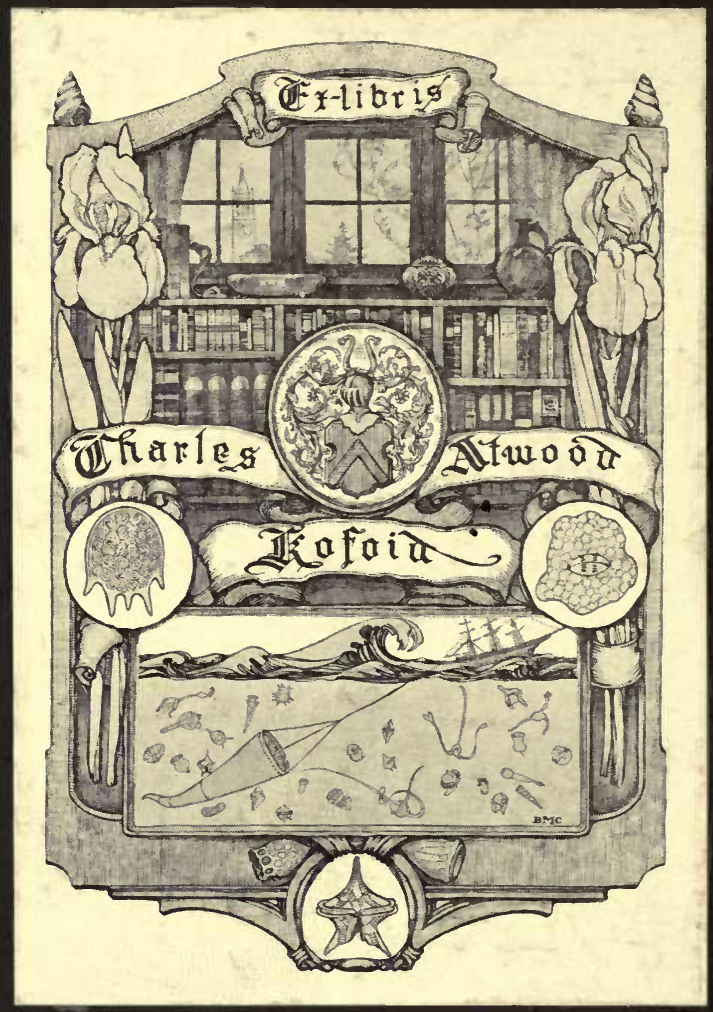




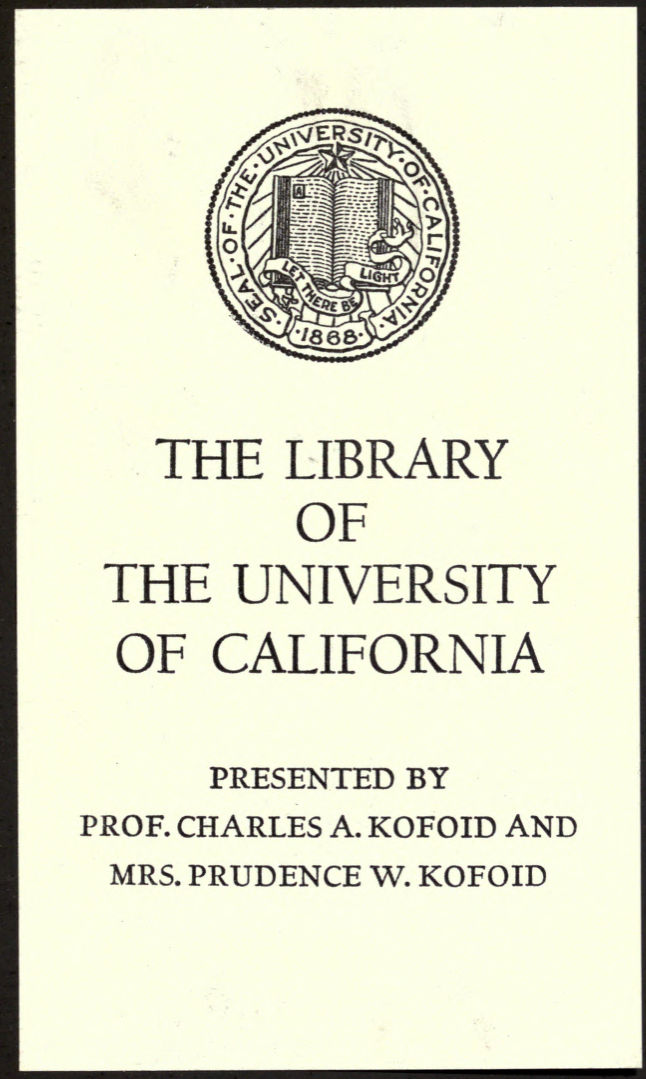


if 
THE NATURAL HISTORY OF SELBORNE. 




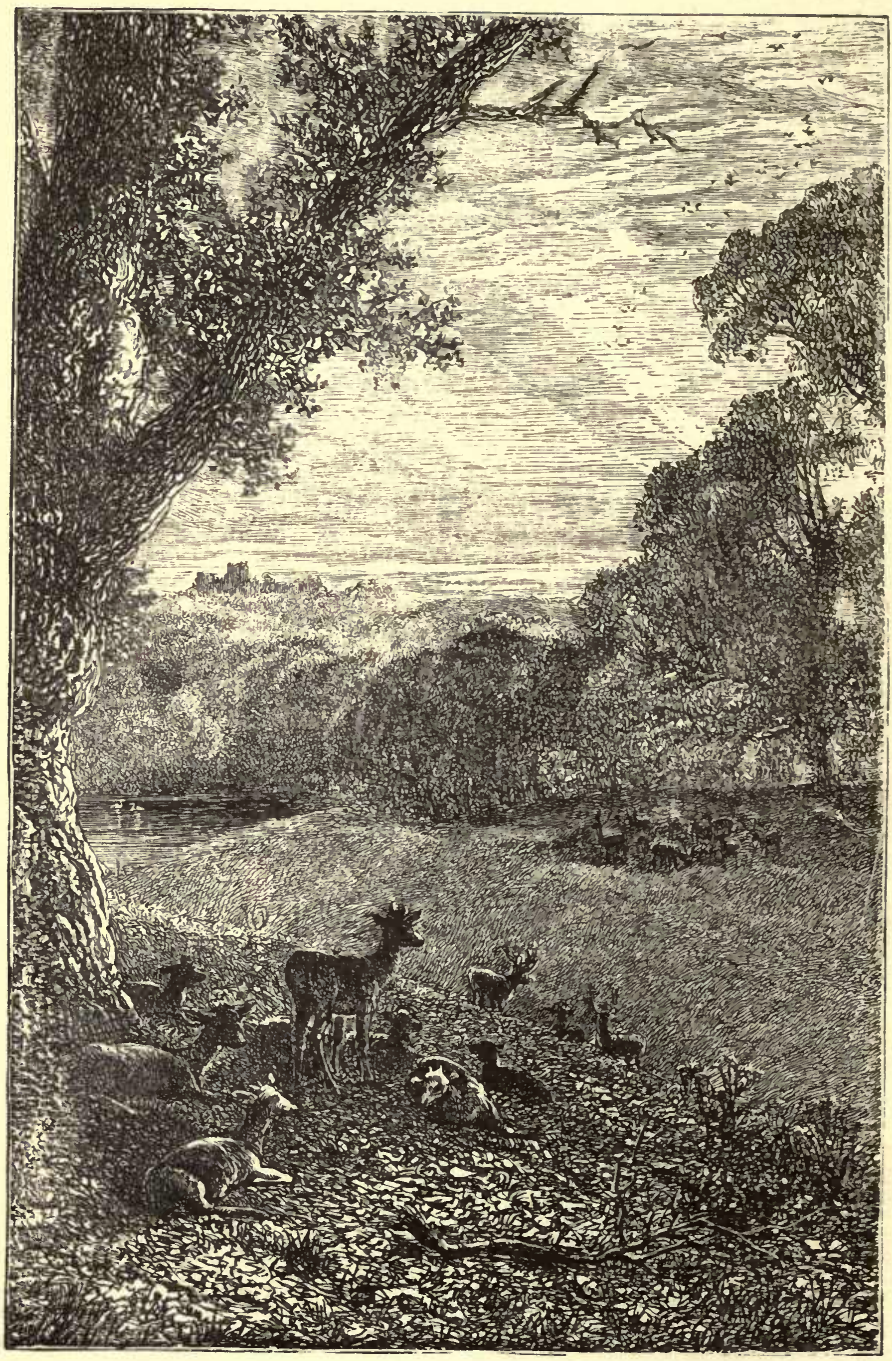


THE " CHANDOS CLASSICS."

THE

\title{
NATURAL HISTORY OF
}

\author{
SELBORNE, \\ AND \\ Clye Aaturalist's Calendar.
}

By THE REV. GILBERT WHITE, A.M.

\author{
A NEW EDITION, \\ EDITED, WJTH NOTES, BY \\ G. CHRISTOPHER DAVIES, \\ Author of "The 'Swan' and Her Crewe," etc., etc.
}

FULLY ILLUSTRATED.

迎ondon and Aletw 篹ork:

FREDERICK WARNE AND CO. 
Richard Clay \& Sons, Limited, London \& Bungay. 


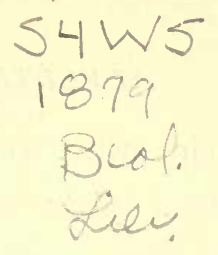

\section{$\triangle \triangle D V E R T I S E M E N T$ TO ORIGINAL EDITION.}

THE Author of the following Letters takes the liberty, with all proper deference, of laying before the public his idea of parochial history, which, he thinks, ought to consist of natural productions and occurrences as well as antiquities. $\mathrm{He}$ is also of opinion that if stationary men would pay some attention to the districts on which they reside, and would publish their thoughts respecting the objects that surround them, from such materials might be drawn the most complete countyhistories, which are still wanting in several parts of this kingdom, and in particular in the county of Southampton.

And here he seizes the first opportunity, though a late one, of returning his most grateful acknowledgments to the reverend the President and the reverend and worthy the Fellows of Magdalen College in the University of Oxford, for their liberal behaviour in permitting their archives to be searched by a member of 
their own society, so far as the evidences therein contained might respect the parish and priory of Selborne. To that gentleman also, and his assistant. whose labours and attention could only be equalled by the very kind manner in which they were bestowed, many and great obligations are also due.

Of the authenticity of the documents above-mentioned there can be no doubt, since they consist of the identical deeds and records that were removed to the College from the Priory at the time of its dissolution; and, being carefully copied on the spot, may be depended on as genuine; and, never having been made public before, may gratify the curiosity of the antiquary, as well as establish the credit of the history.

If the writer should at all appear to have induced any of his readers to pay a more ready attention to the wonders of the Creation, too frequently overlooked as common occurrences; or if he should by any means, through his researches, have lent a helping hand towards the enlargement of the boundaries of historical and topographical knowledge; or if he should have thrown some small light upon ancient customs and manners, and especially on those that were monastic; his purpose will be fully answered. But if he should not have been successful in any of these his intentions, yet there remains this consolation behind-that these his pursuits, by 
keeping the body and mind employed, have, under Providence, contributed to much health and cheerfulness of spirits, even to old age; and, what still adds to his happiness, have led him to the knowledge of a circle of gentlemen whose intelligent communications, as they have afforded him much pleasing information, so, could he flatter himself with a continuation of them, would they ever be deemed a matter of singular satisfaction and improvement.

Selborne,

Fanuary $\mathrm{i} s t, \mathrm{i} 788$. 


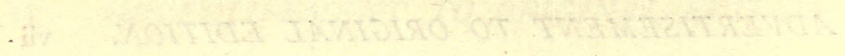

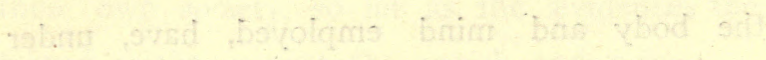

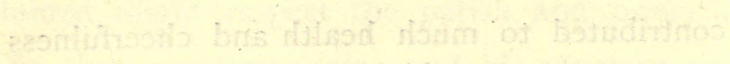

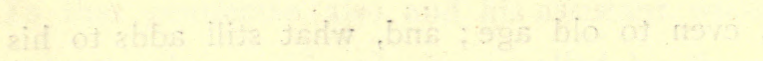

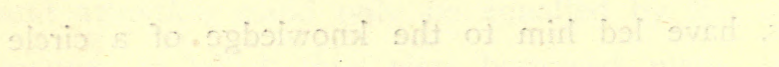

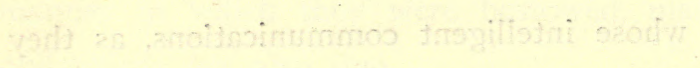

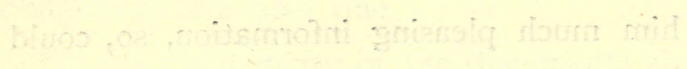

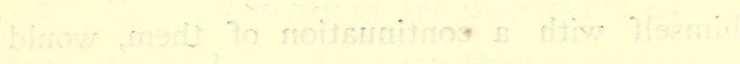

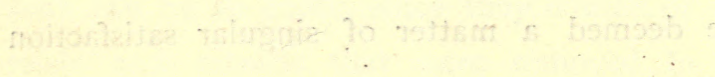




\section{INTRODUCTION.}

HERE is a singular parallel in the popularity of the two old

1 books, the "Complete Angler" of Isaac Walton, and the "Natural History of Selborne," by the Rev. Gilbert White. This popularity has gone on steadily increasing in both cases, until both books are of that class which everyone has read or is supposed to have read, or, with reference to the coming generation of readers, ought to read. The cause of the esteem in which the two books are held is mainly the same. Honest, manly, and godly in their tone, simple and clear in their style, with no ostentation, clearness and accuracy of observation in those subjects which each particularly affected, and with the charm of enthusiasm, and enthusiasm with respect to the glorious "out of doors," they are models for all succeeding writers on kindred subjects. The Editor of this Volume, when a boy, wrote almost his first essay on White and Walton, little thinking at the time that he would ever have the pleasure of editing both books for the series in which this appears.

The temptation which besets any Naturalist author who undertakes to edit such a work as this, is to use it as a line on which to hang out his own knowledge of Natural History. Such a course, though pleasant to oneself, is not fair to the original Author. The present Editor has done his best to limit the use of notes (a nuisance at the best) to as few as might be consistent with the 
present advanced state of knowledge, not forgetting the Publishers' kindly warning that "the Editor should not make himself of more moment than the original author." Where notes appear at the foot of a page they are White's own. Those at the end of each chapter are by the Editor.

The village of Selborne presents no more special features of interest nor greater facilities for the study of Natural History than hundreds of other of our charming English villages; and it is the patient and close observation by one man of the natural world around him which has given it a name above its fellows. The general features of it do not vary very much from the time of White; and any description of it here would only challenge comparison with the close description of it given by the Author; but of the author himself we may tell all we know, for in his modesty he has told us nothing.

The materials for a sketch $\urcorner$ White's life are singularly scanty. He kept no personal diary, and left no portrait of himself. In an edition of his book published in 5802 , nine years after his death, his brother John wrote the following short sketch of his life.

"Gilbert White was the eldest son of John White of Selborne, Esq., and of Anne, the daughter of Thomas Holt, rector of Streatham in Surrey. He was born at Selburne on July r8th, 1720; and received his school education at Basingstoke, under the Rev. 'Thomas Warton, vicar of that place, and father of those two distinguished literary characters, Dr. Joseph Warton, master of Winchester school; and Mr. Thomas Warton, poetry-professor at Oxford. He was admitted at Oriel College, Oxford, in December, 1739, and took his degree of Bachelor of Arts in June, I 743. In March, I 744, he was elected fellow of his college. He became Master of Arts in October, 1746, and was admitted as one of the senior proctors of the University in April, $\mathbf{7 5 2}$. Being of an unambitious temper, and strongly attached to the charms of rural 
scenery, he early fixeci his residence in his native village, where he spent the greater part of his life in literary occupations, and especially in the study of nature. This he followed with a patient assiduity, and a mind ever open to the lessons of piety and benevolence, which such a study is so well calculated to afford. Though several occasions offered of settling upon a college living, he could never persuade himself to quit the beloved spot, which was indeed a peculiarly happy situation for an observer. He was much esteemed by a select society of intelligent and worthy friends, to whom he pard occasional visits. Thus his days passed tranquil and serene, with scarcely any other vicissitudes than those of the seasons, till they closed at a mature age on June 26 th, I793."

White was the eldest of the eleven children which followed the union of John White and Anne his wife. Eight of them grew up; but the only one which calls for mention now was Benjamin, who became a publisher, his specialité being works on Natural History, and he it was who published his brother's book.

Gilbert White was ordained a deacon when he was twenty-seven. and priest when he was twenty-nine, years old. In 1755 , he being thirty-five years old, he took up his residence with his father at Selborne; and on his father's death in $175^{8}$, he became the occupier of the house, and shortly afterwards the owner, and there he lived until his death. He had a curacy at Faringdon, an adjoining parish, until I 784 , when he became curate of Selborne. He several times refused livings which were offered to him, though he accepted one which required neither residence, service, nor attention on his part, the duties being performed by others. White had a sufficiency of income to enable him to live a quiet and comfortable life in the old house at Selborne. He was never married; but this was from no lack of good qualities on his part, for he was an affectionate and kind brother, uncle, and neighbour. He is described as being a pleasant little man, brisk in manner and 
kindly in speech, getting on well with his neighbours, helping with money and with advice where help was needed, and taking as great an interest in the human affairs of the parish as he did in the bird, animal, and insect life of it. It is not known at what time he turned his attention to the study of Natural History. $\mathrm{He}$ was acquainted with many persons of note, and it is by the medium of letters to two of those, Pennant and Daines Barrington, that his work on Natural History was written. The tone of the letters themselves, and the lack of system or arrangement in them, would point to the conclusion that at first White did not intend them for publication, and that when the idea occurred to him, he fortunately did not fuse them into one whole, according to method, but presented them to the vorld just as they were written. And this book was his only book. It is clear that he was not smitten with the vanity of authorship. His book was first published, in the fashionable quarto size, in 1789 , he then being sixty-nine years of age. The book was a success, and brought him into favourable notice. He is said to have been very nervous at first as to its reception by Reviewers ; and in the Gentleman's Magazine is a friendly review, written by his brother Thomas, which is rather amusing. It says :- "Contemplative persons see with regret the country more and more deserted every day, as they know that every well-regulated family of property, which quits a village to reside in a town, injures the place that is forsaken in many material circumstances. It is with pleasure, therefore, we observe, that so rational an employment of leisure time as the study of nature, promises to become popular; since whatever adds to the number of rural amusements, and consequently counteracts the allurements of the metropolis, is, on this consideration, of national importance.

"Most of the local histories which have fallen into our hands have been taken up with descriptions of the vestiges of ancient art and industry, while natural observations have been too much 
neglected. But we agree with $\mathrm{Mr}$. White in his idea of parochial history, which, he thinks, ought to consist of natural productions and occurrences, as well as antiquities : for antiquities, when once surveyed, seldom recall further attention, and are confined to one spot ; whereas the pleasures of the naturalist continue through the year, return with unabated attractions every spring, and may be extended over the kingdom.

"Mr. White is the gentleman who some years ago favoured the world with a monography of the British Hirundines, published in the Philosophical Transactions, which we reviewed in a former volume. It is now reprinted, and the same sagacity of observation runs through the work before us.

* $\quad * \quad * \quad * \quad * \quad *$

"If this author should be thought by any to have been too minute in his researches, be it remembered that his studies have been in the great book of Nature. It must be confessed, that the economy of the several kinds of crickets, and the distinction between the stock-dove and the ring-dove, are humble pursuits, and will be esteemed trivial by many; perhaps by some to be objects of ridicule. However, before we condemn any pursuits, which contribute so much to health by calling us abroad, let us consider how the studious have employed themselves in their closets. In a former century, the minds of the learned were engaged in determining whether the name of the Roman poet should be spelt Vergilius or Virgilius; and the number of letters in the name of Shakespear still remains a matter of much solicitude and criticism. Nor can we but think that the conjectures about the migration of Hirundines are fully as interesting as the Chattertonian controversy.

"We could have wished that this gentleman had uniformly, as he has frequently, used the Linnæan names. No naturalist can 
now converse intelligibly in any other language than that of the celebrated Swede. And impartiality compels us to say, that we are disappointed in not finding a particular account of the tillage of the district where Selborne is situate. A person with this writer's patient observation would have made many remarks highly valuable. Men of intelligence, like him, are wanted to promote an intimacy between the library and the plough. The man of books sees many errors which he supposes he could correct; while the practical cultivator laughs at the essays of the theorist. Much the greater part of renting farmers are prevented, by their anxiety to wind the bottom round the year, from engaging in experiments ; and many think it nearly criminal to deviate from the practice of their forefathers; so that, at this day, it remains for gentlemen of property and enlarged minds to determine whether it is best to sow three bushels of wheat, or one, on an acre of land. In other words, whether there be not as much corn yearly wasted by superfluous, perhaps injurious, seeding, as would furnish an annual and ample supply for the largest city. Though agriculture has of late been attended to, still he would be one of the greatest benefactors to his countrymen in general, who would convince them that the richest mine of national wealth lies within six inches of the surface, and who would teach them the most advantageous method of working it.

"On the whole, we will pronounce that the inquirers into natural knowledge will find Mr. White to be no unequal successor of Ray and Derham; and that the History of the Priory is a curious tract of local antiquity. We should not hesitate to speak so favourably of this work even though it had much less rural anecdote and literary allusion to recommend it."

A translation of his book was published at Berlin in I 792. In June, I 793, White died. His body lies in the fifth grave to the north of the chancel wall, and on the headstone is- 


$$
\begin{aligned}
& \text { G. W. } \\
& 26 \text { June, } \\
& \text { I } 793 .
\end{aligned}
$$

Cr a tablet, formerly on the outside of the wall, but now in the chancel, is the following inscription :-

IN THE FIFTH GRAVE FROM THIS WALL ARE BURIED THE REMAINS OF

The Rev. GILBERT WHite, m.A.,

FIFTY YEARS FELLOW OF ORIEL COLLEGE, IN OXFORD,

AND HISTORIAN OF THIS HIS NATIVE PARISH.

HE WAS ELDEST SON OF JOHN WHITE, ESQUIRE, BARRISTF.R-AT-LAW,

AND ANNE, HIS WIFE, ONLY CHILD OF

THOMAS HOLT, RECTOR OF STREATHAM, IN SURREY,

WHICH SAID JOHN WHITE WAS THE ONLY SON OF GILBERT W HITE,

FORMERLY VICAR OF THIS PARISH.

HE WAS KIND AND BENEFICENT TO HIS RELATIONS,

BENEVOLENT TO THE POOR,

AND DESERVEDLY RESPECTED BY ALI HIS FRIENDS AND NEIGHBOUKS.

HE WAS BORN "'LY I8TH, I720, O. S.,

AND DIED JUNE 26TH, 1793.

NEC BONO QUICQUAM MALI EVENIRE POTEST,

NEC VIVO, NEC MORTUO.

The irregular, old-fashioned, and charming house in which White lived, is now the property of an eminent naturalist, Professor Thomas Bell. This gentleman, in the year 1877 , published a very complete edition of the book, but an expensive one. In a second volume, Mr. Bell gives a great number of letters written by White to his relatives and friends, a sermon of his, and an account book in which are entered in his neat and plain handwriting all his petty expenses. The facsimile of his handwriting there given shows that he vas not accustomed to hurry himselt. 
xvi IN TRODUCTION.

These letters give one a better idea of White's personal life thain all else that we know of him. To call attention to the noteworthy points in them, would perhaps trench too closely on what Professor Bell has made his own, but they fully bear out all that ras been said in eulogy of hin.. 


\section{CONTENTS.}

THE NATURAL HISTORY OF SELBORNE

THE ANTICUITIES OF SELBORN E . . . . . . . $23 \mathrm{I}$

OBSERVATIONS ON VARIOUS PARTS OF NATURE • . . 38 I SUMMARY OF THE WEATHER • • • • • • • • 437

A COMPARATIVE VIEW OF THE NATURALIST'S CALENDAR AS

KEPT BY THE LATE GILBERT WHITE AND WILLIAM

MARKWICK, ESQ. • • • • • • • • • • • 4.47

POEMS SELECTED FROM THE MSS. OF THE REV. GILBERT

WHITE .

BIOENTENARY OF A GREAT NATURALTST. $4 \hat{u} 1$

Sunday, July 18, marks the bicentenary of the birth of Gilbert White, the famous naturalist. Always quick to utilise oocasions in order to draw public attention to the literary resources of the Bristol Libraries, Mr Acland Taylor, the city librarian, has arranged an exhibition of books dealing with White's life and work. This will be in the Central Reference Library. The exhibition includes a fine copy of the first edition of the "Natural History of Selborne" and other editions of the same work, notably that published in 1889 and illustrated with woodcuts by Thomas Bewick. There is also a first edition of White's Naturalists' Calendar published after his death in 1795. The fact that White spent " a seren weeks' season at the Hot Well at Bristol, from July 9 to August 30, 1753," will interest Bristolians. 

THE

\section{NATURAL HISTORY OF SELBORNE.}

LETTERS ADDRESSED TO THOMAS PENNANT ESQ.

\section{LETTER I.}

THE parish of Selborne lies in the extreme eastern corner of 1 the county of Hampshire, bordering on the county of Sussex, and not far from the county of Surrey; is about fifty miles southwest of London, in latitude fifty-one, and near mid-way between the towns of Alton and Petersfield. Being very large and extensive, it abuts on twelve parishes, two of which are in Sussex, viz., Trotton and Rogate. If you begin from the south and proceed westward, the adjacent parishes are Emshot, Newton Valence, Faringdon, Harteley Mauduit, Great Ward le ham, Kingsley, Hadleigh, Bramshot, Trotton, Rogate, Lyffe, and Greatham. The soils of this district are almost as various and diversified as the views and aspects. The high part of the south-west consists of a vast hill of chalk, rising three hundred feet above the village, and is divided into a sheep-down, the high wood and a long hanging wood, called The Hanger. The covert of this eminence is altogether beech, the most lovely of all forest trees, whether we consider its smooth rind or bark, its glossy foliage, or graceful pendulous boughs. $^{1}$ The down, or sheepwalk, is a pleasing park-like spot, of about one mile by half that space, jutting out on the verge of the hill-country, where it begins to break down into the plains, and commanding a very engaging view, being an assemblage of hill, dale, wood-lands, heath, and water. The prospect is bounded to the south-east and east by the vast range of mountains called the Sussex Downs, by Guild-down near Guildford, and by the 


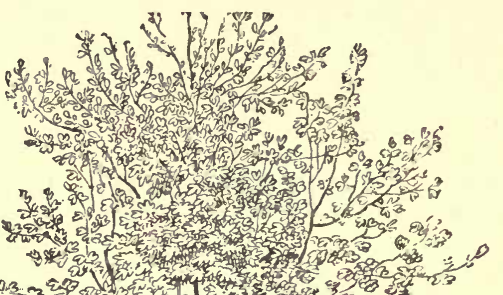

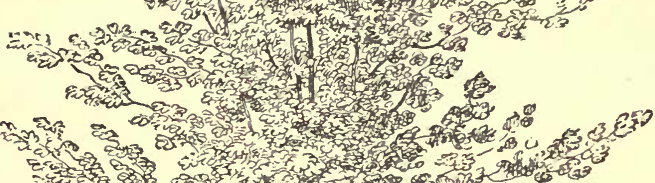

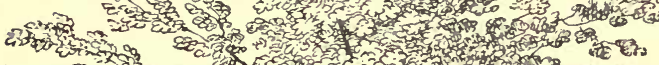
is

Q203

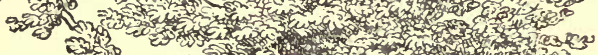

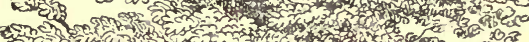

S月, 8 \%

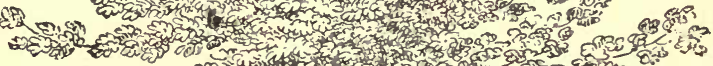

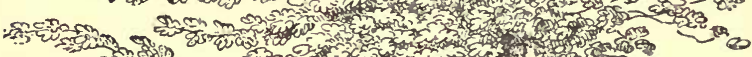

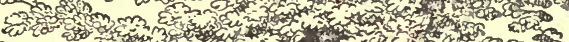

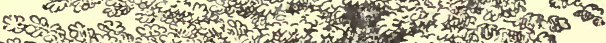

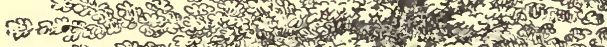

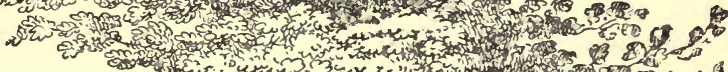

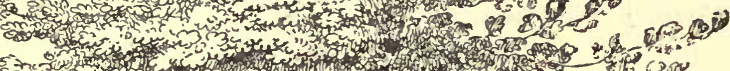

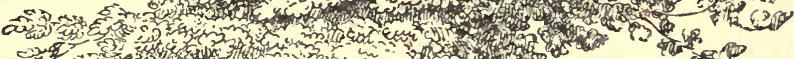

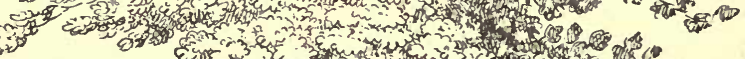

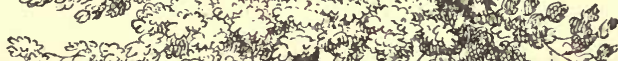
an

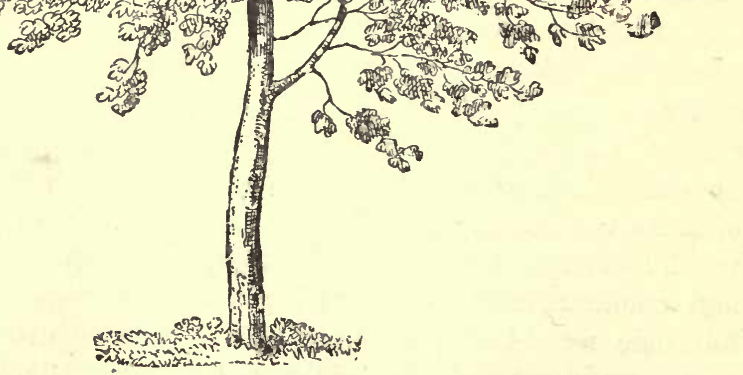

BeEcir. 
Downs round Dorking, and Ryegate in Surrey, to the north-east, which altogether, with the country beyond Alton and Farnham, form a noble and extensive outline.

At the foot of this hill, one stage or step from the uplands, lies the village, which consists of one single straggling street, threequarters of a mile in length, in a sheltered vale, and running parallel with The Hanger. The houses are divided from the hill by a vein of stiff clay (good wheat-land), yet stand on a rock of white stone, little in appearance removed from chalk; but seems so far from being calcareous, that it endures extreme heat. Yet that the freestone still preserves somewhat that is analogous to chalk, is plain from the beeches which descend as low as those rocks extend, and no farther, and thrive as well on them, where the ground is steep, as on the chalks.

The cart-way of the village divides, in a remarkable manner, two very incongruous soils. To the south-west is a rank clay, that requires the labour of years to render it mellow; while the gardens to the north-east, and small enclosures behind, consist of a warm, forward, crumbling mould, called black malm, which seems highly saturated with vegetable and animal manure; and these may perhaps have been the original site of the town; while the woods and coverts might extend down to the opposite bank. ${ }^{2}$

At each end of the village, which runs from south-east to northwest, arises a small rivulet: that at the north-west end frequently fails; but the other is a fine perennial spring, little influenced by drought or wet seasons, called Well-head.* This breaks out of some high grounds joining to Nore Hill, a noble chalk promontory, remarkable for sending forth two streams into two different seas. The one to the south becomes a branch of the Arun, running to Arundel, and so sailing into the British Channel : the other to the north. The Selborne stream makes one branch of the Wey ; and, meeting the Black-down stream at Hedleigh, and the Alton and

* This spring produced, September Ioth, 1871, after a severe hot summer, and a preceding dry spring and winter, nine gallons of water in a minute, which is $54^{\circ}$ in an hour, and 12,960, or 216 hogsheads, in twenty-four hours, or one natural day. At this time many of the wells failed, and all the ponds in the vale were dry. 
Farnham stream at Tilford-bridge, swells into a considerable river, navigable at Godalming ; from whence it passes to Guildford ${ }_{2}$ and so into the Thames at Weybridge; and thus at the Nore into the German Ocean.

Our wells, at an average, run to about sixty-three feet, and when sunk to that depth seldom fail; but produce a fine limpid water, soft to the taste, and much commended by those who drink the pure element, but which does not lather well with soap.

To the north-west, north and east of the village, is a range of fair enclosures, consisting of what is called a white malm, a sort of rotten or rubble stone, which, when turned up to the frost and rain, moulders to pieces, and becomes manure to itself.*

Still on to the north-east, and a step lower, is a kind of white land, neither chalk nor clay, neither fit for pasture nor for the plough, yet kindly for hops, which root deep in the freestone, and have their poles and wood for charcoal growing just at hand. The white soil produces the brightest hops.

As the parish still inclines down towards Wolmer-forest, at the juncture of the clays and sand the soil becomes a wet, sandy loam, remarkable for timber, and infamous for roads. The oaks of Temple and Blackmoor stand high in the estimation of purveyors, and have furnished much naval timber; while the trees on the freestone grow large, but are what workmen call shaky, and so brittle as often to fall to pieces in sawing. Beyond the sandy loam the soil becomes a hungry lean sand, till it mingles with the forest; and will produce little without the assistance of lime and turnips.

\section{NOTES TO LETTER I.}

1 A noticeable feature about the beech is the peculiar absence of underwood beneath it. Thus the stem is seen in its full beauty. The decaying beech-mast and leaves lying upon the ground are apparently inimical to other vegetable life.

2 The north-east part of Selborne stands upon the Upper Greensand, while to the south-west is the Chalk Marl, abruptly divided from each other as mentioned by White.

* This soil produces good wheat and clover. 


\section{LETTER II.}

IN the court of Norton farmhouse, a manor farm to the northwest of the village, on the white malms, stood within these twenty

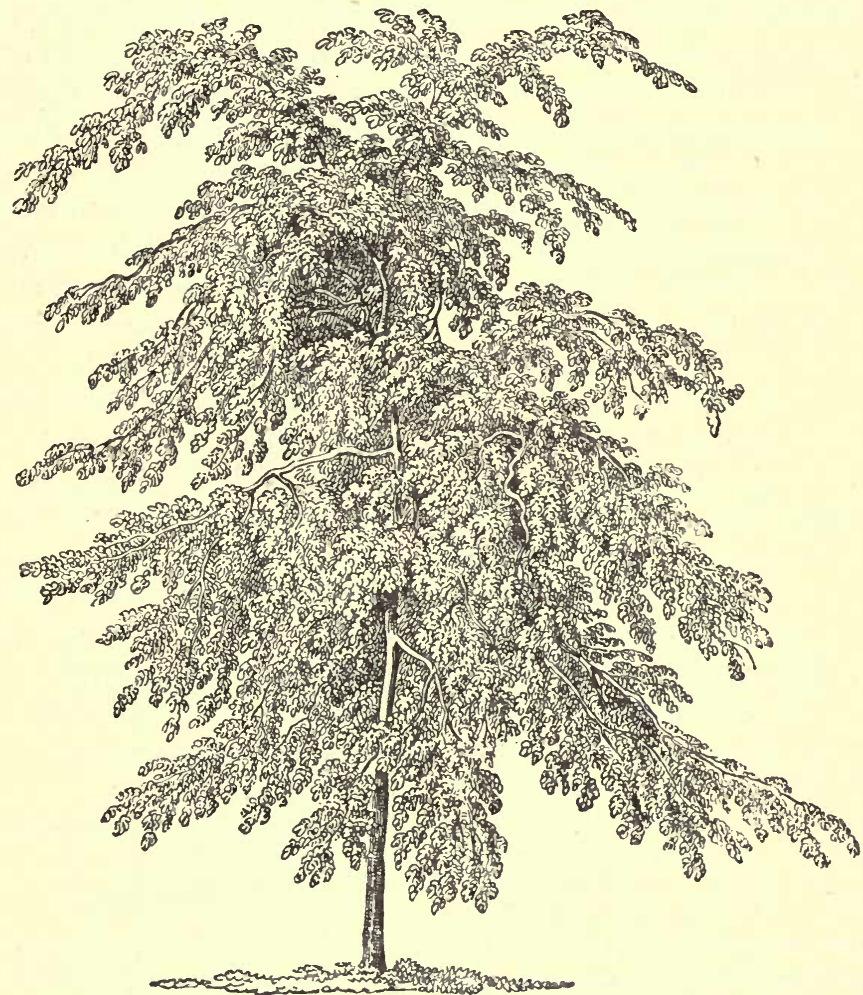

WYCH ELM.

years a broad-leaved elm, or wych hazel, ulmus folio latissimo scabro of Ray, which, though it had lost a considerable leading bough in the great storm in the year $\mathrm{s} 703$, equal to a moderate tree, yet, 
when felled, contained eight loads of timber; and, being too bulky for a carriage, was sawn off at seven feet above the butt, where it measured near eight feet in the diameter. This elm I mention to show to what a bulk planted elms may attain; as this tree must certainly have been such from its situation.

In the centre of the village, and near the church, is a square piece of ground surrounded by houses, and vulgarly called "'The Plestor." In the midst of this spot stood, in old times, a vast oak, with a short squat body, and huge horizontal arms extending almost to the extremity of the area. This venerable tree, surrounded with stone steps, and seats above them, was the delight of old and young, and a place of much resort in summer evenings ; where the former sat in grave debate, while the latter frolicked and danced before them. Long might it have stood, had not the amazing tempest in 1703 overturned it at once, to the infinite regret of the inhabitants, and the vicar, who bestowed several pounds in setting it in is place again : but all his care could not avail ; the tree sprouted for a time, then withered and died. This oak I mention to show to what a bulk planted oaks also may arrive: and planted this tree must certainly have been, as will appear from what will be said farther concerning this area, when we enter on the antiquities of Selborne.

On the Blackmoor estate there is a small wood called Losel's, of a few acres, that was lately furnished with a set of oaks of a peculiar growth and great value; they were tall and taper like firs, but standing near together had very small heads, only a little brush without any large limbs. About twenty years ago the bridge at the Toy, near Hampton Court, being much decayed, some trees were wanted for the repairs that were fifty feet long without bough, and would measure twelve inches diameter at the little end. Twenty such trees did a purveyor find in this little wood, with this advantage, that many of them answered the description at sixty feet. These trees were sold for twenty pounds apiece.

In the centre of this grove there stood an oak, which, though shapely and tall on the whole, bulged out into a large excrescence about the middle of the stem. On this a pair of ravens had fixed their residence for such a series of years, that the oak was dis- 
tinguished by the title of the Raven Tree. Many were the attempts of the neighbouring youths to get at this eyry: the difficulty whetted their inclinations, and each was ambitious of surmounting the arduous task. But, when they arrived at the swelling, it jutted out so in their way, and was so far beyond their grasp, that the most daring lads were awed, and acknowledged the undertaking to be too hazardous : so the ravens built on, nest upon nest, in perfect security, till the fatal day arrived in which the wood was to be levelled. It was in the month of February, when these birds usually sit. The saw was applied to the butt,the wedges were inserted into the opening,- - the woods echoed to the heavy blow of the beetle or mall or mallet,- the tree nodded to its fall; but still the dam sat on. At last, when it gave way, the bird was flung from her nest; and, though her parental affection deserved a better fate, was whipped down by the twigs, which brought her dead to the ground. ${ }^{1}$

\section{NOTE TO LETTER II.}

1 The landrail, that shyest of birds, often sits upon its eggs on the ground in the hayfield until it is slain by the scythe of the mowers. Instances innumerable of the tenacity with which birds will sit on their eggs when they are nearly hatched may be cited. I once lifted a hen blackbird off her nest, and she came back again when we had moved a few feet away. All birds and animals are bold in the defence of their young, and it seems strange that this affection should so completely vanish as it does when the young are able to shift for themselves.

\section{LETTER III.}

THE fossil-shells of this district, and sorts of stone, such as have fallen within my observation, must not be passed over in silence. And first I must mention, as a great curiosity, a specimen that was ploughed up in the chalky fields, near the side of the Down, and given to me for the singularity of its appearance, which, to an incurious eye, seems like a petrified fish of about four inches 
long, the cardo passing for a head and mouth. It is in reality a bivalve of the Linnæan Genus of Mytilus, and the species of Crista Galli ; called by Lister, Rastellum; by Rumphius, Ostreum plicatum minus; by D'Argenville, Auris Porci, s. Crista Galli; and by those who make collections, Cock's Comb. ${ }^{1}$ Though I applied to several such in London, I never could meet with an entire specimen; nor could I ever find in books any engraving from a perfect one. In the superb museum at Leicester House, permission was given me to examine for this article; and, though I was disappointed as to the fossil, I was highly gratified with the sight of several of the shells themselves in high preservation. This bivalve is only known to inhabit the Indian ocean, where it fixes itself to a zoophyte, known by the name Gorgonia. The curious foldings of the suture the one into the other, the alternate flutings or grooves, and the curved form of my specimen are much easier expressed by the pencil than by words.

Cornua Ammonis ${ }^{2}$ are very common about this village. As we were cutting an inclining path up the Hanger, the labourers found them frequently on that steep, just under the soil, in the chalk, and of a considerable size. In the lane above Wall-head, in the way to Emshot, they abound in the bank in a darkish sort of marl ; and are usually very small and soft: but in Clay's Pond, a little farther on, at the end of the pit, where the soil is dug out for manure, I have occasionally observed them of large dimensions, perhaps fourteen or sixteen inches in diameter. But as these did not consist of firm stone, but were formed of a kind of terra lapidosa, or hardened clay, as soon as they were exposed to the rains and frost they mouldered away. These seemed as if they were a very recent production. In the chalk-pit, at the northwest end of the Hanger, large nautili are sometimes observed.

In the very thickest strata of our freestone, and at considerable depths, well-diggers often find large scallops or pectines, having both shells deeply striated, and ridged and furrowed alternately. They are highly impregnated with, if not wholly composed of, the stone of the quarry. 


\section{NOTES TO LETTER III.}

1 This fossil is not what White supposes, but is a different species, belonging to the upper greensand, known as Ostrea carinata.

${ }^{2}$ The Ammonite is a very striking-looking fossil, and a common one. When I was a small boy I used to delight in playing with a very large one belonging to my father's collection, which would take to pieces, each section of the shell being loose, showing the formation admirably.

\section{LETTER IV.}

As in a former letter the freestone of this place has been only mentioned incidentally, I shall here become more particular.

This stone is in great request for hearth-stones, and the beds of ovens : and in lining of lime-kilns it turns to good account; for the workmen use sandy loam instead of mortar; the sand of which fluxes,* and runs by the intense heat, and so cases over the whole face of the kiln with a strong vitrified coat-like glass, that it is well preserved from injuries of weather, and endures thirty or forty years. When chiseled smooth, it makes elegant fronts for houses, equal in colour and grain to Bath stone; and superior in one respect, that, when seasoned, it does not scale. Decent chimney-pieces are worked from it of much closer and finer grain than Portland; and rooms are floored with it; but it proves rather too soft for this purpose. It is a freestone cutting in all directions; yet has something of a grain parallel with the horizon, and therefore should not be surbedded, but laid in the same position that it grows in the quarry. + On the ground abroad this firestone will not succeed for pavements, because,

* There may probably be also in the chalk itself that is burnt for lime a proportion of sand : for few chalks are so pure as to have none.

† To surbed stone is to set it edgewise, contrary to the posture it had in the quarry, says Dr. Plot, "Oxfordshire," p. 77. But surbedding does not succeed in our dry walls ; neither do we use it so in ovens, though he says it is best for Teynton stone. 
probably some degrees of saltness prevailing within it, the rain tears the slabs to pieces.* Though this stone is too hard to be acted on by vinegar, yet both the white part, and even the blue rag, ferments strongly in mineral acids. Though the white stone will not bear wet, yet in every quarry at intervals there are thin strata of blue rag, which resist rain and frost; ard are excellent for pitching of stables, paths, and courts, and for building of dry walls against banks, a valuable species of fencing much in use in this village, and for mending of roads. This rag is rugged and stubborn, and will not hew to a smooth face, but is very durable; yet, as these strata are shallow and lie deep, large quantities cannot be procured but at considerable expense. Among the blue rags turn up some blocks tinged with a stain of yellow or rust colour, which seem to be nearly as lasting as the blue; and every now and then balls of a friable substance, like rust of iron, called rust balls.

In Wolmer Forest I see but one sort of stone, called by the workmen sand, or forest-stone. This is generally of the colour of rusty iron, and might probably be worked as iron ore ; is very hard and heavy, and of a firm, compact texture, and composed of a small roundish crystalline grit, cemented together by a brown, terrene, ferruginous matter; will not cut without difficulty, nor easily strike fire with steel. Being often found in broad flat pieces, it makes good pavement for paths about houses, never becoming slippery in frost or rain; is excellent for dry walls, and is sometimes used in buildings. In many parts of that waste it lies scattered on the surface of the ground; but is dug on Weaver's Down, a vast hill on the eastern verge of that forest, where the pits are shallow and the stratum thin. This stone is imperishable.

From a notion of rendering their work the more elegant, and giving it a finish, masons chip this stone into small fragments about the size of the head of a large nail, and then stick the pieces into the wet mortar along the joints of their freestone

* "Firestone is full of salts, and has no sulphur : must be close-grained, and have no interstices. Nothing supports fire like salts; saltstone perishes exposed to wet and frost."-PLOT's Staff., p. 152. 
walls; this embellishment carries an odd appearance, and has occasioned strangers sometimes to ask us pleasantly, "whether we fastened our walls together with tenpenny nails."

\section{LETTER V.}

Among the singularities of this place the two rocky hollow lanes, the one to Alton, and the other to the forest, deserve our attention. These roads, running through the malm lands, are, by the traffic of ages, and the fretting of water, worn down through the first stratum of our freestone, and partly through the second; so that they look more like water-courses than roads; and are bedded with naked rag for furlongs together. In many places they are reduced sixteen or eighteen feet beneath the level of the fields ; and after floods, and in frosts, exhibit very grotesque and wild appearances, from the tangled roots that are twisted among the strata, and from the torrents rushing down their broken sides; and especially when those cascades are frozen into icicles, hanging in all the fanciful shapes of frost-work. These rugged gloomy scenes affright the ladies when they peep down into them from the paths above, and make timid horsemen shudder while they ride along them; but delight the naturalist with their various botany, and particularly with their curious filices with which they abound.

The manor of Selborne, was it strictly looked after, with all its kindly aspects, and all its sloping coverts, would swarm with game ; even now hares, partridges, and pheasants abound; and in old days woodcocks were as plentiful. There are few quails, because they more affect open fields than enclosures; after harves some few landrails are seen.

The parish of Selborne, by taking in so much of the forest, is a vast district. Those who tread the bounds are employed part of three days in the business, and are of opinion that the outline, in all its curves and indentings, does not comprise less than thirty miles. 
The village stands in a sheltered spot, secured by the Hanger from the strong westerly winds. The air is soft, but rather moist from the effluvia of so many trees; yet perfectly healthy and free from agues.

The quantity of rain that falls on it is very considerable, as may be supposed in so woody and mountainous a district. ${ }^{1}$ As my experience of measuring the water is but of short date, I am not qualified to give the mean quantity.* I only know that

From May I, I 779, to the end of the year there fe'l . Inch. Hund.

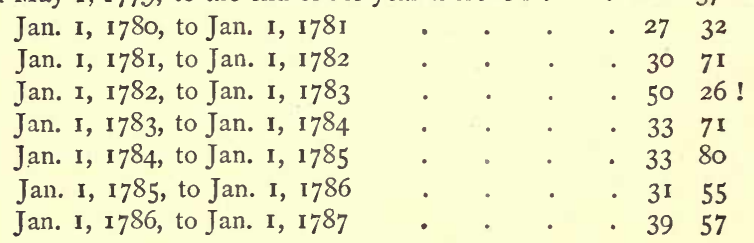

The village of Selborne, and large hamlet of Oakhanger, with the single farms, and many scattered houses along the verge of the forest, contain upwards of six hundred and seventy inhabitants. $\uparrow$

* A very intelligent gentleman assures me (and he speaks from upwards of forty years' experience), that the mean rain of any place cannot be ascertained till a person has measured it for a very long period. "If I had only measured the rain," says he, "for the four first years, from 1740 to 1743 , I should have said the mean rain at Lyndon was $16 \frac{1}{2}$ inches for the year; if from 1740 to 1750, $18 \frac{1}{2}$ inches. The mean rain before 1763 was $20 \frac{1}{4}$ inches, from 1763 and since $25 \frac{1}{2}$ inches, from 1770 to 1780,26 inches. If only 1773 , I 774 and 1775 , had been measured, Lyndon mean rain would have been called 32 inches."

† A State of the Parish of Selborne, taken October 4Th, 1783.

The number of tenements or families, 136 .

The number of inhabitants in the street is 3131 Total 676 ; near five inhabiIn the rest of the parish . . $\quad .363\}$ tants to each tenement.

In the time of the Rev. Gilbert White, Vicar, who died in 1727-8, the number of inhabitants was computed at about 500 .

Average baptisms for 60 years.

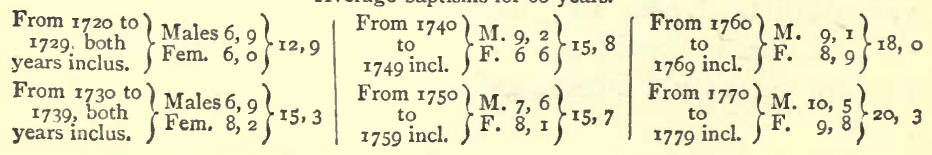


We abound with poor ; many of whom are sober and industrious, and live comfortably in good stone or brick cottages, which are glazed, and have chambers above stairs; mud buildings we have none. Besides the employment from husbandry, the men work in hop-gardens, of which we have many ; and fell and bark timber. In the spring and summer the women weed the corn; and enjoy

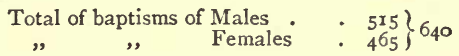

Total of baptisms from 1720 to $\mathbf{1 7 7 9}$, both inclusive, 60 years - 980.

Average of burials for 60 years.

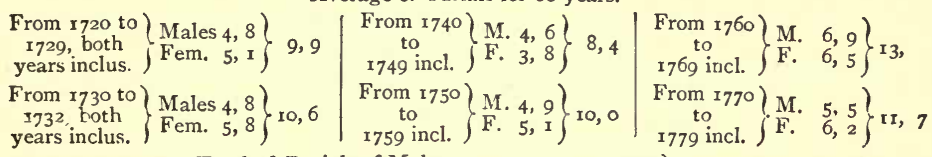

Total of Burials of Males.

Total of Burials from 1720 to 1779 , both inclusive, 60 years . . . . 640

Baptisms exceed Burials by more than one-third.

Baptisms of Males exceed Females by one-tenth, or one in ten.

Burials of Females exceed Males by one in thirty.

It appears that a child, born or bred in this parish, has an equal chance to live above forty years.

Twins thirteen times, many of whom dying young have lessened the chance for life.

Chances for life in men and women appear to be equal.

A Cable of the Baptisms, Burials, and Marriages, from January 2, I76I, to December 25, 1780, in the Parish of Selborne.

\begin{tabular}{|c|c|c|c|c|c|c|c|c|c|c|}
\hline \multirow[b]{3}{*}{$x_{7} 6 \mathrm{x}}$. & & & & \multicolumn{3}{|c|}{ BA 1} & \multicolumn{3}{|c|}{$1 \times 1$} & \multirow{2}{*}{ MAR. } \\
\hline & & & & M. & F. & Tot. & M. & F. & Tot. & \\
\hline & • & . & . & 8 & Io & 18 & 2 & 4 & 6 & 3 \\
\hline 1762. & . & . & . & 7 & 8 & 15 & IO & 14 & 24 & 6 \\
\hline 1763. & . & . & . & 8 & Io & 18 & 3 & 4 & 7 & 5 \\
\hline 1764. & . & . & . & I I & 9 & 20 & Io & 8 & 18 & 6 \\
\hline т & $\because$ & . & . & $\because 2$ & 5 & ;8 & 9 & 7 & xu & 5 \\
\hline 1766. & . & . & . & 9 & $x_{3}$ & 22 & ro & 6 & I6 & 4 \\
\hline 2767. & . & - & . & $x 4$ & 5 & 19 & 6 & 5 & II & 2 \\
\hline 1768. & . & . & . & 7 & 6 & 13 & 2 & 5 & 7 & 6 \\
\hline 1769. & . & . & . & 9 & $I_{4}$ & 23 & 6 & 5 & I I & 2 \\
\hline 1770. & . & . & . & Io & 13 & 23 & 4 & 7 & I I & 3 \\
\hline 1771 . & . & . & . & ro & 6 & $x 6$ & 3 & 4 & 7 & 4 \\
\hline 1772 . & . & . & . & II & Io & $2 I$ & 6 & 10 & x6 & 3 \\
\hline 1773 . & . & . & . & 8 & 5 & 13 & 7 & 5 & 12 & 3 \\
\hline 1774 . & . & . & . & 6 & $x_{3}$ & 19 & 2 & 8 & ro & I \\
\hline 1775. & . & . & . & 20 & 7 & 27 & 13 & 8 & 21 & 6 \\
\hline I776. & . & . & . & II & Io & $2 I$ & 4 & 6 & Io & 6 \\
\hline $1777^{\circ}$ & . & . & . & 8 & 13 & 21 & 7 & 3 & I0 & 4 \\
\hline $177^{8}$. & . & . & . & 7 & 13 & 20 & 3 & 4 & 7 & 5 \\
\hline x779. & & . & . & $\mathrm{I}_{4}$ & 8 & 22 & 5 & 6 & I I & 5 \\
\hline 1780. & & . & - & 8 & 9 & 17 & XI & 4 & 15 & 3 \\
\hline & & & & x98 & 188 & 386 & 123 & 123 & 246 & 83 \\
\hline
\end{tabular}

During this period of twenty years the births of males exceeded those of females . 
a second harvest in September by hop-picking. Formerly, in the dead months they availed themselves greatly by spinning wool, for making of barragons, a genteel corded stuff, much in vogue at that time for summer wear; and chiefly manufactured at Alton, a neighbouring town, by some of the people called Quakers; but from circumstances this trade is at an end.* The inhabitants enjoy a good share of health and longevity; and the parish swarms with children.

\section{NOTE TO LETTER V.}

1 Mr. Bell, who lives in the house which was White's, says that the rainfall at Selborne now is much above the average, and White rightly attributes this to the hilly and wooded nature of the district.

\section{LETTER VI.}

SHould I omit to describe with some exactness the forest of Wolmer, of which three-fifths perhaps lie in this parish, my account of Selborne would be very imperfect, as it is a district abounding with many curious productions, both animal and vegetable; and has often afforded me much entertainment both as a sportsman and as a naturalist.

The royal forest of Wolmer is a tract of land of about seven miles in length, by two and a half in breadth, running nearly from north to south, and is abutted on, to begin to the south, and so to proceed eastward, by the parishes of Greatham, Lysse, Rogate, and Trotton, in the county of Sussex; by Bramshot, Hedleigh, and Kingsley. This royalty consists entirely of sand covered with heath and fern; but is somewhat diversified with hills and dales, without having one standing tree in the whole extent. In the bottoms, where the waters stagnate, are many bogs, which

* Since the passage above was written, I am happy in being able to say that the spinning employment is a little revived, to the no small comfort of the industrious housewife. 
formerly abounded with subterraneous trees; though Dr. Plot says positively, " that "there never were any fallen trees hidden in the mosses of the southern counties." But he was mistaken: for I myself have seen cottages on the verge of this wild district, whose timbers consisted of a black hard wood, looking like oak, which the owners assured me they procured from the bogs by probing the soil with spits, or some such instruments: but the peat is so much cut out, and the moors have been so well examined, that none has been found of late. $t$ Besides the oak, I have also been shown pieces of fossil wood of a paler colour, and softer nature, which the inhabitants called fir: but, upon a nice examination, and trial by fire, I could discover nothing resinous in them; and therefore rather suppose that they were parts of a willow or alder, or some such aquatic tree.

This lonely domain is a very agreeable haunt for many sorts of wild fowls, which not only frequent it in the winter, but breed there in the summer; such as lapwings, snipes, wild-ducks, and, as I have discovered within these few years, teals. Partridges in vast plenty are bred in good seasons on the verge of this forest, into

* See his "History of Staffordshire."

† Old people have assured me, that on a winter's morning they have discovered these trees, in the logs, by the hoar frost, which lay longer over the space where they are concealed than in the surrounding morass. Nor does this seem to be a fanciful notion, but consistent with true philosophy. Dr. Hales saith, "That the warmth of the earth, at some depth under ground, has an influence in promoting a thaw, as well as the change of the weather from a freezing to a thawing state, is manifest from this observation, viz., Nov. 29th, I73i, a little snow having fallen in the night, it was, by eleven the next morning, mostly melted away on the surface of the earth, except in several places in Bushy Park, where there were drains dug and covered with earth, on which the snow continued to lie, whether those drains were full of water or dry; as also where elm-pipes lay under ground : a plain proof this, that those drains intercepted the warmth of the earth from ascending from greater depths below them; for the snow lay where the drain had more than four feet depth of earth over it. $\zeta_{i}$ continued also to lie on thatch, tiles, and the tops of walls."See Hale's "Hæmastatics," p. 360. QUERY, Might not such observations be reduced to domestic use, by promoting the discovery of old obliterated drains and wells about houses; and in Roman stations and camps lead to the finding of pavements, baths and graves, and other hidden relics of curious antiquity? 
which they love to make excursions; and in particular, in the dry summers of 1740 and 1741 , and some years after, they swarmed to such a degree that parties of unreasonable sportsmen killed twenty and sometimes thirty brace in a day.

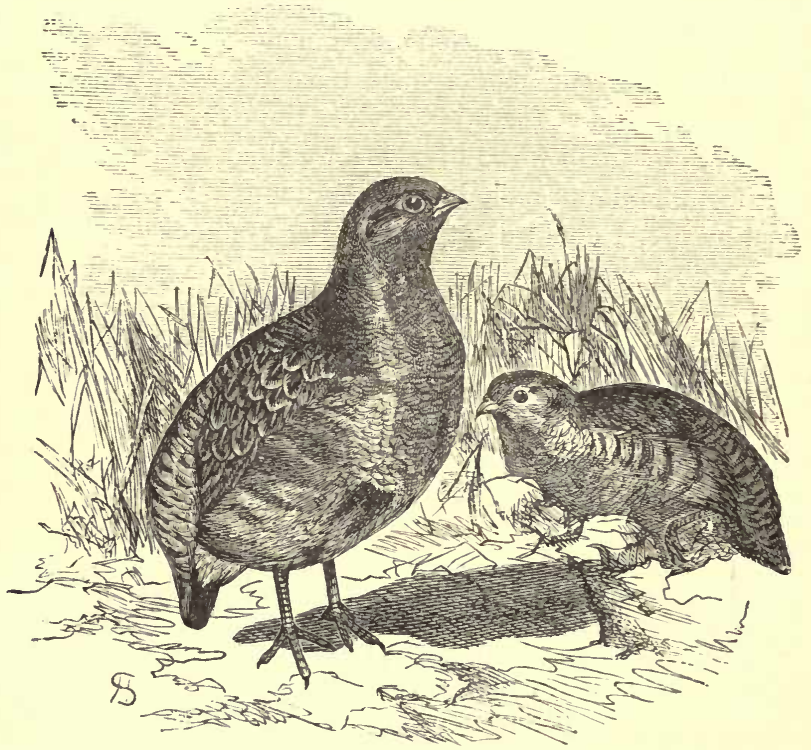

Partridges

But there was a nobler species of game in this forest, now extinct, which I have heard old people say abounded much before shooting flying became so common, and that was the heath-cock, black-game, or grouse. When I was a little boy I recollect one coming now and then to my father's table. The last pack remembered was killed about thirty-five years ago; and within these ten years one solitary greyhen was sprung by some beagles in beating for a hare. The sportsmen cried out "A hen pheasant!" but a gentleman present, who had often seen grouse in the north of England, assured me that it was a greyhen. 
Nor does the loss of our black game prove the only gap in the Fauna Selborniensis; for another beautiful link in the chain of beings is wanting, I mean the red deer, which toward the beginning of this century amounted to about five hundred head, and made a stately appearance. There is an old keeper, now alive, named

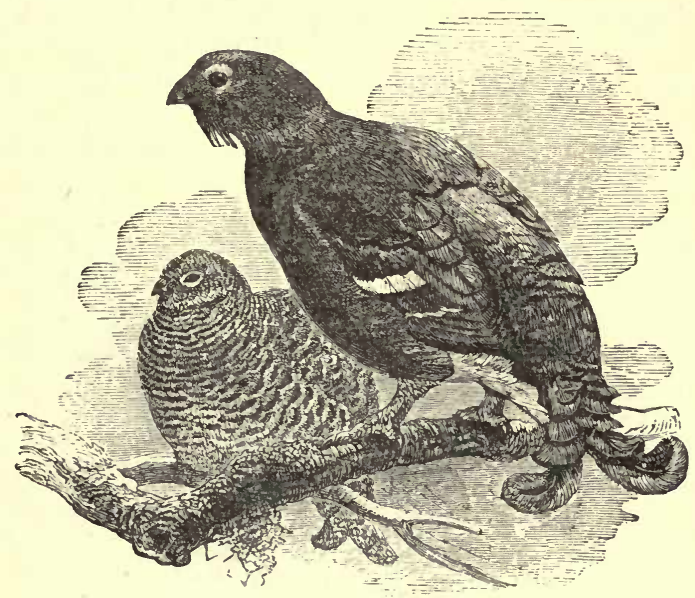

The Black Grouse (Tetrao Tetrix).

Adams, whose great grandfather (mentioned in a perambulation taken in 1635), grandfather, father, and self, enjoyed the head keepership of Wolmer Forest in succession for more than a hundred years. This person assures me, that his father has often told him, that Queen Anne, as she was journeying on the Portsmouth road, did not think the forest of Wolmer beneath her royal regard. For she came out of the great road at Lippock, which is just by, and, reposing herself on a bank smoothed for that purpose, lying about half a mile to the east of Wolmer Pond, and still called Queen's Bank, saw with great complacency and satisfaction the whole herd of red deer brought by the keepers along the vale before her, consisting then of about five hundred head. A sight this, worthy the attention of the greatest sovereign! But he farther 
adds that, by means of the Waltham blacks or, to use his own expression, as soon as they began blacking; they were reduced to about fifty head, and so continued decreasing till the time of the late Duke of Cumberland. It is now more than thirty years ago that His Highness sent down a huntsman, and six yeomanprickers, in scarlet jackets laced with gold, attended by the staghounds; ordering them to take every deer in this forest alive, and to convey them in carts to Windsor. In the course of the summer they caught every stag, some of which showed extraordinary

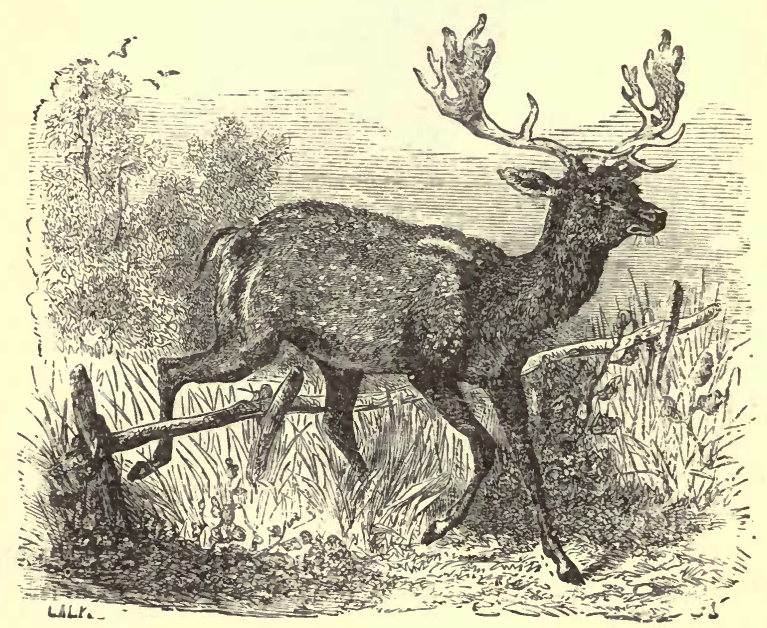

Red Deer.

diversion: but in the following winter, when the hinds were also carried off, such fine chases were exhibited as served the country people for matter of talk and wonder for years afterwards. I saw myself one of the yeoman-prickers single out a stag from the herd, and must confess that it was the most curious feat of activity $I$ ever beheld, superior to anything in Mr. Astley's riding-school. The exertions made by the horse and deer much exceeded all my expectations; though the former greatly excelled the latter in speed. When the devoted deer was separated from his com- 
panions, they gave him, by their watches, law, as they called it, for twenty minutes; when, sounding their horns, the stop-dogs were permitted to pursue, and a most gallant scene ensued.

\section{LETTER VII.}

THOUGH large herds of deer do much harm to the neighbourhood, yet the injury to the morals of the people is of more moment than the loss of their crops. The temptation is irresistible; for most men are sportsmen by constitution : and there is such an inherent spirit for hunting in human nature, as scarce any inhibitions can restrain. Hence, towards the beginning of this century all this country was wild about deer-stealing. Unless he was a hunter, as they affected to call themselves, no young person was allowed to be possessed of manhood or gallantry. The Waltham blacks at length committed such enormities, that government was forced to interfere with that severe and sanguinary act called the "Black Act,"* which now comprehends more felonies than any law that ever was framed before. And, therefore, a late Bishop of Winchester, when urged to re-stock Waltham Chase, $\uparrow$ refused, from a motive worthy of a prelate, replying "that it had done mischief enough already."

Our old race of deer-stealers is hardly extinct yet: it was but a little while ago that, over their ale, they used to recount the exploits of their youth; such as watching the pregnant hind to her lair, and, when the calf was dropped, paring its feet with a penknife to the quick to prevent its escape, till it was large and fat enough to be killed; the shooting at one of their neighbours with a bullet in a turnip-field by moonshine, mistaking him for a deer; and the losing a dog in the following extraordinary manner: Some fellows, suspecting that a calf new-fallen was deposited in a certain spot of thick fern, went, with a lurcher, to surprise it ;

* Statute 9 Geo. I. cap. 22.

$\dagger$ This chase remains unstocked to this day; the bishop was Dr. Hoadly. 
when the parent-hind rushed out of the brake, and, taking a vast spring with all her feet close together, pitched upon the neck of the dog, and broke it short in two. ${ }^{1}$

Another temptation to idleness and sporting was a number of rabbits, which possessed all the hillocks and dry'places : but these being inconvenient to the huntsmen, on account of their burrows, when they came to take away the deer, they permitted the countrypeople to destroy them all.

Such forests and wastes, when their allurements to irregularities are removed, are of considerable service to neighbourhoods that verge upon them, by furnishing them with peat and turf for their firing; with fuel for the burning their lime; and with ashes for their grasses; and by maintaining their geese and their stock of young cattle at little or no expense.

The manor farm of the parish of Greatham has an admitted claim, I see (by an old record taken from the Tower of London), of turning all live stock on the forest, at proper seasons, "bidentibus exceptis." * The reason, I presume, why sheep $\dagger$ are excluded, is, because, being such close grazers, they would pick out all the finest grasses, and hinder the deer from thriving.

Though (by statute 4 and 5 W. and Mary, c. 23) "to burn on any waste, between Candlemas and Midsummer, any grig, ling, heath and furze, goss or fern, is punishable with whipping and confinement in the house of correction;" yet, in this forest, about March or April, according to the dryness of the season, such vast heath-fires are lighted up, that they often get to a masterless head, and, catching the hedges, have sometimes been communicated to the underwoods, woods, and coppices, where great damage has ensued. The plea for these burnings is, that, when the old coat of heath, etc., is consumed, young will sprout up, and afford much tender brouze for cattle; but, where there is large old furze, the fire, following the roots, consumes the very ground; so that for hundreds of acres nothing is to be seen but smother and desola-

* For this privilege the owners of that estate used to pay to the king annually seven bushels of oats.

t In the Holt, where a full stock of fallow-deer has been kept up till lately, no sheep are admitted to this ray. 
tion, the whole circuit round looking like the cinders of a volcano; and, the soil being quite exhausted, no traces of vegetation are to be found for years. ${ }^{2}$ These conflagrations, as they take place usually with a north-east or east wind, much annoy this village with their smoke, and often alarm the country; and, once in particular, I remember that a gentleman, who lives beyond Andover, coming to my house, when he got on the downs between that town and Winchester, at twenty-five miles distance, was surprised much with smoke and a hot smell of fire; and concluded that Alresford was in flames; but, when he came to that town, he then had apprehensions for the next village, and so on to the end of his journey.

On two of the most conspicuous eminences of this forest stand two arbours or bowers, made of the boughs of oak; the one called Waldon Lodge, the other Brimstone Lodge: these the keepers renew annually on the feast of St. Barnabas, taking the old materials for a perquisite. The farm called Blackmoor, in this parish, is obliged to find the posts and brush-wood for the former; while the farms at Greatham, in rotation, furnish for the latter; and are all enjoined to cut and deliver the materials at the spot. This custom I mention, because I look upon it to be of very remote antiquity.

\section{NOTES TO LETTER VII.}

1 Deer will attack serpents by jumping on them with all four feet at once, and $I$ have seen sheep serve obnoxious objects in the same way.

2 On the Welsh hills these conflagrations continually take place, and are very splendid at night. It is often expedient to burn a patch of gorse or heather for the sake of the sheep ; but when the fire gets beyond control, as it sometimes does, the mischief done is enormous. The conical hill in the Vale of Llangollen, known as Crow Castle, clothed on three sides with fir plantations, once caught fire, and from base to summit was a mass of flames, that lit up the country for miles by night, and shaded the valley with its smoke by day. 


\section{LETTER VIII.}

ON the verge of the forest, as it is now circumscribed, are three considerable lakes, two in Oakhanger, of which I have nothing particular to say ; and one called Bin's, or Bean's Pond, which is worthy the attention of a naturalist or a sportsman. For, being crowded at the upper end with willows, and with the carex cespitosa,* it affords such a safe and pleasing shelter to wild ducks, teals, snipes, etc., that they breed there. In the winter this covert is also frequented by foxes, and sometimes by pheasants; and the bogs produce many curious plants. (For which consult Letter XILI. to Mr. Barrington.)

By a perambulation of Wolmer Forest and the Holt, made in 1635 , and the eleventh year of Charles I. (which now lies before me), it appears that the limits of the former are much circumscribed. For, to say nothing of the farther side, with which I am not so well acquainted, the bounds on this side, in old times, came into Binswood; and extended to the ditch of Ward le Ham Park, in which stands the curious mount called King John's Hill, and Lodge Hill; and to the verge of Hartley Mauduit, called Mauduit Hatch; comprehending also Short Heath, Oakhanger, and Oakwoods; a large district, now private property, though once belonging to the royal domain.

It is remarkable that the term purlieu is never once mentioned in this long roll of parchment. It contains, besides the perambulation, a rough estimate of the value of the timbers, which were considerable, growing at that time in the district of the Holt; and enumerates the officers, superior and inferior, of those joint forests, for the time being, and their ostensible fees and perquisites. In those days, as at present, there were hardly any trees in Wolmer Forest.

* I mean that sort which, rising into tall hassocks, is called by the foresters torrets; a corruption, 1 suppose, of turrets.

Note.-In the beginning of the summer of 1787 , the royal forests of Wolmer and Holt were measured by persons sent down by goveriment, 
Within the present limits of the forest are three considerable lakes, Hogmer, Cranmer, and Wolmer; all of which are stocked with carp, tench, eels, and perch : but the fish do not thrive well, because the water is hungry, and the bottoms are a naked sand.

A circumstance respecting these ponds, though by no means peculiar to them, I cannot pass over in silence; and that is, that instinct by which in summer all the kine, whether oxen, cows, calves, or heifers, retire constantly to the water during the hotter hours ; where, being more exempt from flies, and inhaling the coolness of that element, some belly deep, and some only to midleg, they ruminate and solace themselves from about ten in the morning till four in the afternoon, and then return to their feeding. During this great proportion of the day they drop much dung, in which insects nestle; and so supply food for the fish, which would be poorly subsisted but from this contingency. Thus Nature, who is a great economist, converts the recreation of one animal to the support of another! Thomson, who was a nice observer of natural occurrences, did not let this pleasing circumstance escape him. He says, in his "Summer,"

"A various group the herds and flocks compose;

—_ on the grassy bank

Some ruminating lie ; while others stand

Half in the flood, and, often bending, sip

The circling surface."

Wolmer Pond, so called, I suppose, for eminence' sake, is a vast lake for this part of the world, containing, in its whole circumference, 2,646 yards, or very near a mile and a half. The length of the north-west and opposite side is about 704 yards, and the breadth of the south-west end about $45^{6}$ yards. This measurement, which I caused to be made with good exactness, gives an area of about sixty-six acres, exclusive of a large irregular arm at the north-east corner, which we did not take into the reckoning.

On the face of this expanse of waters, and perfectly secure from fowlers, lie all day long, in the winter season, vast flocks of ducks, teals, and widgeons, of various denominations ; where they preen and solace, and rest themselves, till towards sunset, when they 
issue forth in little parties (for in their natural state they are all birds of the night) to feed in the brooks and meadows; returning again with the dawn of the morning. Had this lake an arm or

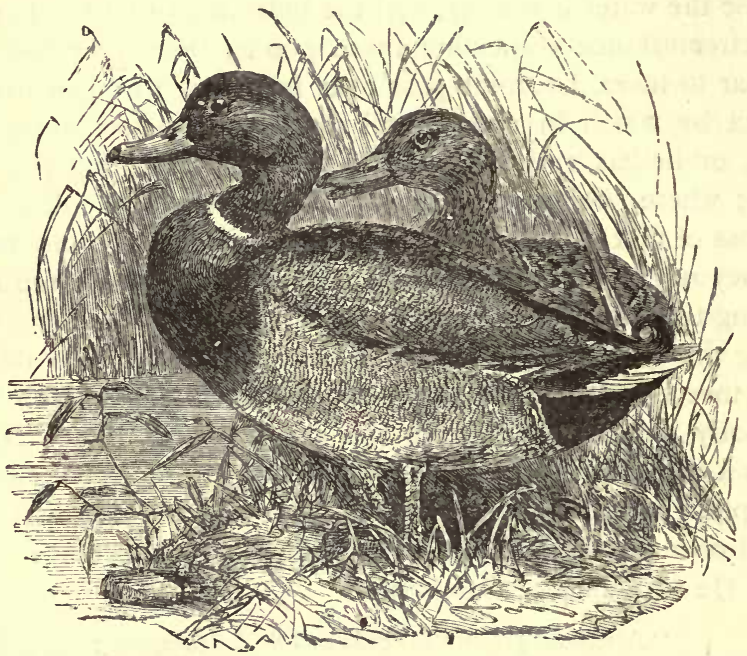

Wild Ducks.

two more, and were it planted round with thick covert (for now it is perfectly naked), it might make a valuable decoy.

Yet neither its extent, nor the clearness of its water, nor the resort of various and curious fowls, nor its picturesque groups of cattle, can render this meer so remarkable as the great quantity of coins that were found in its bed about forty years ago. But, as such discoveries more properly belong to the antiquities of this place, I shall suppress all particulars for the present, till I enter professedly on my series of letters respecting the more remote history of this village and district.

LE'TTER IX.

By way of supplement, I shall trouble you once more on this subject, to inform you that Wolmer, with her sister forest Ayles 
Holt, alias Alice Holt, ${ }^{*}$ as it is called in old records, is held by grant from the crown for a term of years.

The grantees that the author remembers are Brigadier-General Emanuel Scroope Howe, and his lady, Ruperta, who was a natural daughter of Prince Rupert by Margaret Hughes; a Mr. Mordaunt, of the Peterborough family, who married a dowager Lady Pembroke; Henry Bilson Legge and lady; and now Lord Stawell, their son.

The lady of General Howe lived to an advanced age, long surviving her husband; and, at her death, left behind her many curious pieces of mechanism of her father's constructing, who was a distinguished mechanic and artist, $\uparrow$ as well as warrior; and among the rest, a very complicated clock, lately in possession of Mr. Elmer, the celebrated game painter at Farnham, in the county of Surrey.

Though these two forests are only parted by a narrow range of enclosures, yet no two soils can be more different; for the Holt consists of a strong loam, of a miry nature, carrying a good turf, and abounding with oaks that grow to be large timber; while Wolmer is nothing but a hungry, sandy, barren waste.

The former being all in the parish of Binsted, is about two miles in extent from north to south, and near as much from east to west; and contains within it many woodlands and lawns, and the great lodge where the grantees reside, and a smaller lodge called Goose Green; and is abutted on by the parishes of Kingsley, Frinsham, Farnham, and Bentley; all of which have right of common.

One thing is remarkable, that though the Holt has been of old well stocked with fallow-deer, unrestrained by any pales or fences more than a common hedge, yet they were never seen within the limits of Wolmer; nor were the red deer of Wolmer ever known to haunt the thickets or glades of the Holt.

* "In Rot. Inquisit. de statu forest. in Scaccar. 36 Edw. III., it is called Aisholt."

In the same, "Tit. Woolmer and Aisholt Hantisc. Dominus Rex habet unam capellam in haia suâ de Kingesle." " Haia, sepes, sepimentum, parcus; a Gall. haie and haye."-SpELMAN's Glossary.

+ This prince was the inventor of mezzotinto. 
At present the deer of the Holt are much thinned and reduced by the night hunters, who perpetually harass them in spite of the efforts of numerous keepers, and the severe penalties that have been put in force against them as often as they have been detected, and rendered liable to the lash of the law. Neither fines nor imprisonments can deter them; so impossible is it to extinguish the spirit of sporting which seems to be inherent in human nature.

General Howe turned out some German wild boars and sows

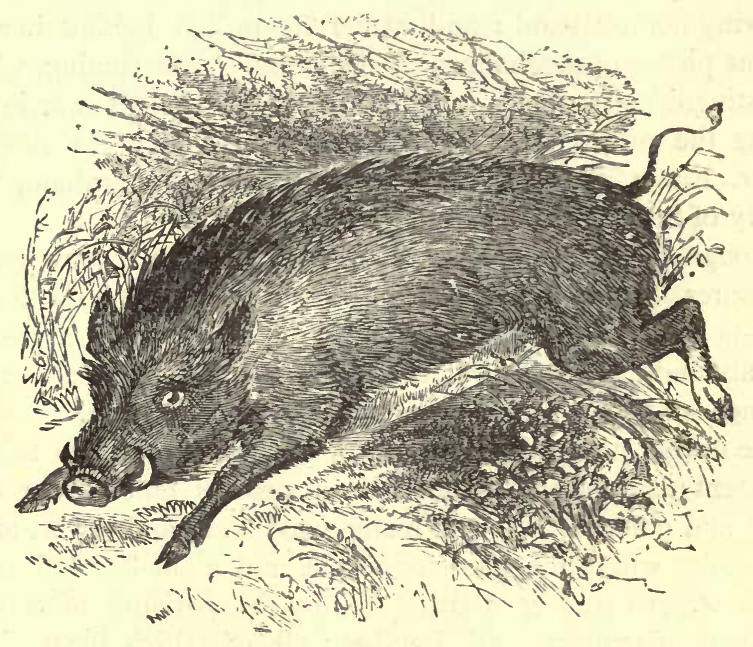

WILD BOAR.

in his torests, to the great terror of the neighbourhood, and, at one time, a wild bull or buffalo; but the country rose upon them and destroyed them.

A very large fall of timber, consisting of about one thousand oaks, has been cut this spring (viz., I 784) in the Holt forest : onefifth of which, it is said, belongs to the grantee, Lord Stawell. He lays claim also to the lop and top; but the poor of the parishes of Binsted and Frinsham, Bentley and Kingsley, assert that it belongs to them, and assembling in a riotous manner, have actually taken it all away. One man, who keeps a team, 
has carried home for his share forty stacks of wood. Forty-five of these people his lordship has served with actions. These trees, which were very sound and in high perfection, were winter-cut, viz., in February and March, before the bark would run. In old times the Holt was estimated to be eighteen miles, computed measure from water-carriage, viz., from the town of Chertsey, on the Thames; but now it is not half that distance, since the Wey is made navigable up to the town of Godalming in the county of Surrey.

LETTER X.

August $4^{\text {th }}$, 7667 .

IT has been my misfortune never to have had any neighbours whose studies have led them towards the pursuit of natural knowledge; so that, for want of a companion to quicken my industry

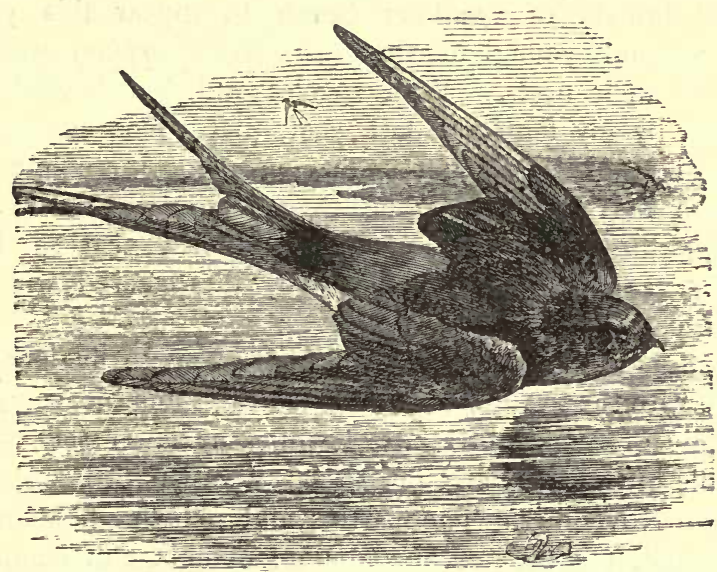

The Swallow.

and sharpen my attention, I have made but slender progress in a kind of information to which I have been attached from my childhood. 
As to swallows (hirundines rustica) being found in a torpid state during the winter in the Isle of Wight or any part of this country, I never heard any such account worth attending to. ${ }^{1}$ But a clergyman, of an inquisitive turn, assures me, that when he was a great boy, some workmen, in pulling down the battlements of a church tower early in the spring, found two or three swifts (nirundines apodes) among the rubbish, which were at first appearance dead, but on being carried towards the fire revived. He told me, that out of his great care to preserve them, he put them in a paper bag, and hung them by the kitchen fire, where they were suffocated.

Another intelligent person has informed me, that while he was a schoolboy at Brighthelmstone, in Sussex, a great fragment of the chalk cliff fell down one stormy winter on the beach, and that many people found swallows among the rubbish; but on my questioning him whether he saw any of those birds himself, to my no small disappointment, he answered me in the negative; but that others assured him they did.

Young broods of swallows began to appear this year on July IIth, and young martins (hirundines urbica) were then fledged in their nests. Both species will breed again once, For I see by my fauna of last year, that young broods came forth so late as September 18th. Are not these late hatchings more in favour of hiding than migration? Nay, some young martins remained in their nests last year so late as September $29^{\text {th }}$; and yet they totally disappeared with us by the $5^{\text {th }}$ October.

How strange it is that the swift, which seems to live exactly the same life with the swallow and house-martin, should leave us before the middle of August invariably ! while the latter stay often till the middle of October; and once I saw numbers of house-martins

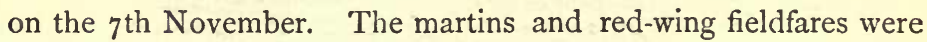
flying in sight together, an uncommon assemblage of summer and winter birds!

A little yellow bird ${ }^{2}$ (it is either a species of the alauda trivialis, or rather perhaps of the motacilla trochilus) still continues to make a sibilous shivering noise in the tops of tall woods. The stoparola 
of Ray (for which we have as yet no name in these parts) is called in your zoology the fly-catcher. There is one circumstance characteristic of this bird which seems to have escaped observation, and that is, it takes its stand on the top of some stake or post, from whence it springs forth on its prey, catching a fly in the air, and hardly ever touching the ground, but returning still to the same stand for many times together.

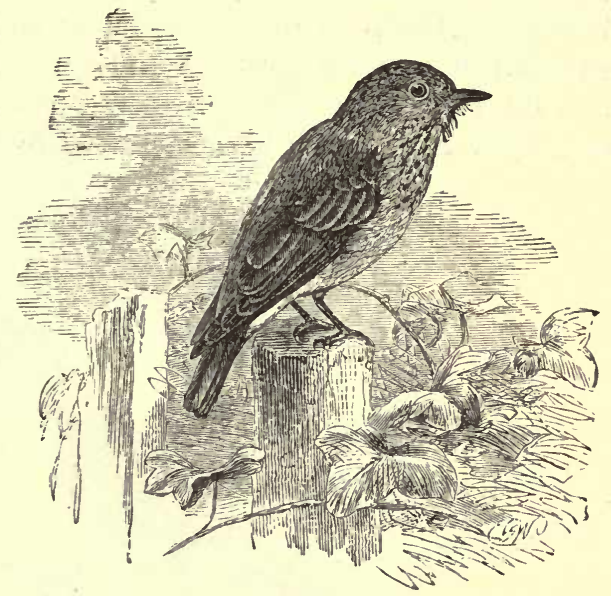

The Spotted Fly-Catcher (Muscicapa grisola).

I perceive there are more than one species of the motacilla trochilus. Mr. Derham supposes, in "Ray's Philos. Letters," that he has discorered three. In these there is again an instance of some very common birds that have as yet no English name.

Mr. Stillingfleet makes a question whether the black-cap (motacilla atricapilla) be a bird of passage or not ${ }^{4}$ : I think there is no doubt of it: for, in April, in the first fine weather, they come trooping all at once, into these parts, but are never seen in the winter. They are delicate songsters.

Numbers of snipes breed every summer in some moory ground on the verge of this parish. It is very amusing to see the cock bird on wing at that time, and to hear his piping and humming notes. ${ }^{5}$

I have had no opportunity yet of procuring any of those mice which I mentioned to you in town. The person that brought me the last says they are plenty in harvest, at which time I will take care to get more ; and will endeavour to put the matter out of doubt, whether it be a nondescript species or not. 
I suspect much there may be two species of water-rats. ${ }^{6}$ Ray says, and Linnæus after him, that the water-rat is web-footed behind. Now I have discovered a rat on the banks of our little stream that is not web-footed, and yet is an excellent swimmer and diver: it answers exactly to the mus amphibius of Linnæus (see Syst. Nat.) which he says " natat in fossis et urinatur." I

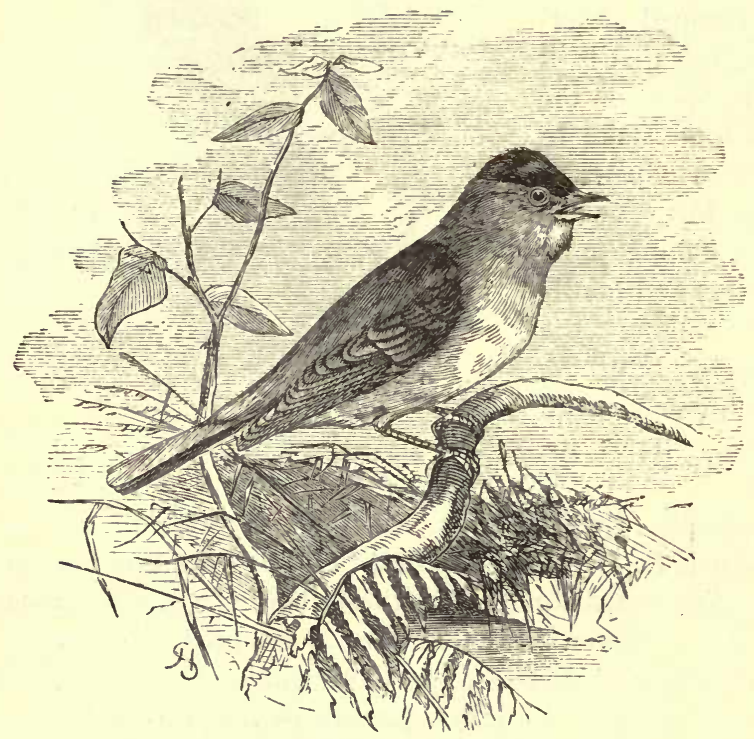

The Blackcap.

should be glad to procure one "plantis palmatis." Linnæus seems to be in a puzzle about his mus amphibius, and to doubt whether it differs from his mus terrestris; which if it be, as he allows, the "mus agrestis capite grandi brachyuros," of Ray, is widely different from the water-rat, both in size, make, and manner of life.

As to the falco, which I mentioned in town, I shall take the liberty to send it down to you into Wales; presuming on your candour, that you will excuse me if it should appear as familiar to you as it is strange to me. Though mutilated "qualem dices ... antehac fuisse, tales cum sint reliquia !" 
It haunted a marshy piece of ground in quest of wild-ducks and snipes; but, when it was shot, had just knocked down a rook, which it was tearing in pieces. I cannot make it answer to any of our English hawks; neither could I find any like it at the

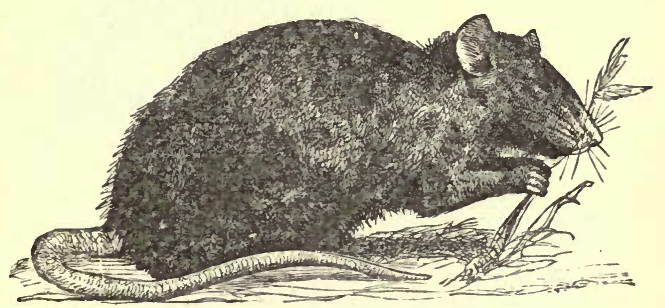

Common Rat.

curious exhibition of stuffed birds in Spring Gardens. I found it nailed up at the end of a barn, which is the countryman's museum. ${ }^{7}$

The parish I live in is a very abrupt, uneven country, full of hills and woods, and therefore full of birds.

\section{NOTES TO LETTER $\mathrm{x}$.}

1 The reader will observe, as he proceeds, that White leans more and more to the idea that swallows live in a state of torpidity through the winter, and do not migrate. He never, however, discovered any proof of this theory. It has been ascertained beyond a doubt that swallows do migrate, and that if any solitary individuals do lie torpid, it is because they were too weak at the end of the summer to undertake their long journey to warmer countries. It is qurestionable, however, whether any such specimens live through the winter, although it is of corrse possible that they might exist in some sheltered crevice where insects might aiso hide and cluster. The late appearance of solitary swallows simply shows that some have lingered beyond others, and the early appearance of some in spring is in accordance with the usual practice of migratory birds, pioneers arriving before the main body.

If any swallows appeared during some of the warm days we sometimes have in December and January, when insects are abroad, it would point to the hybernation of some specimens, but I am not aware of any such occurrences. Mr. Jesse, in his edition of White, gives an instance of a pair of swallows (presumably house-martins) sealing up their young in their nest, and the young ones lived until the next spring, when they pecked their way out. This interesting instance, however, did not come under his own observation. The 

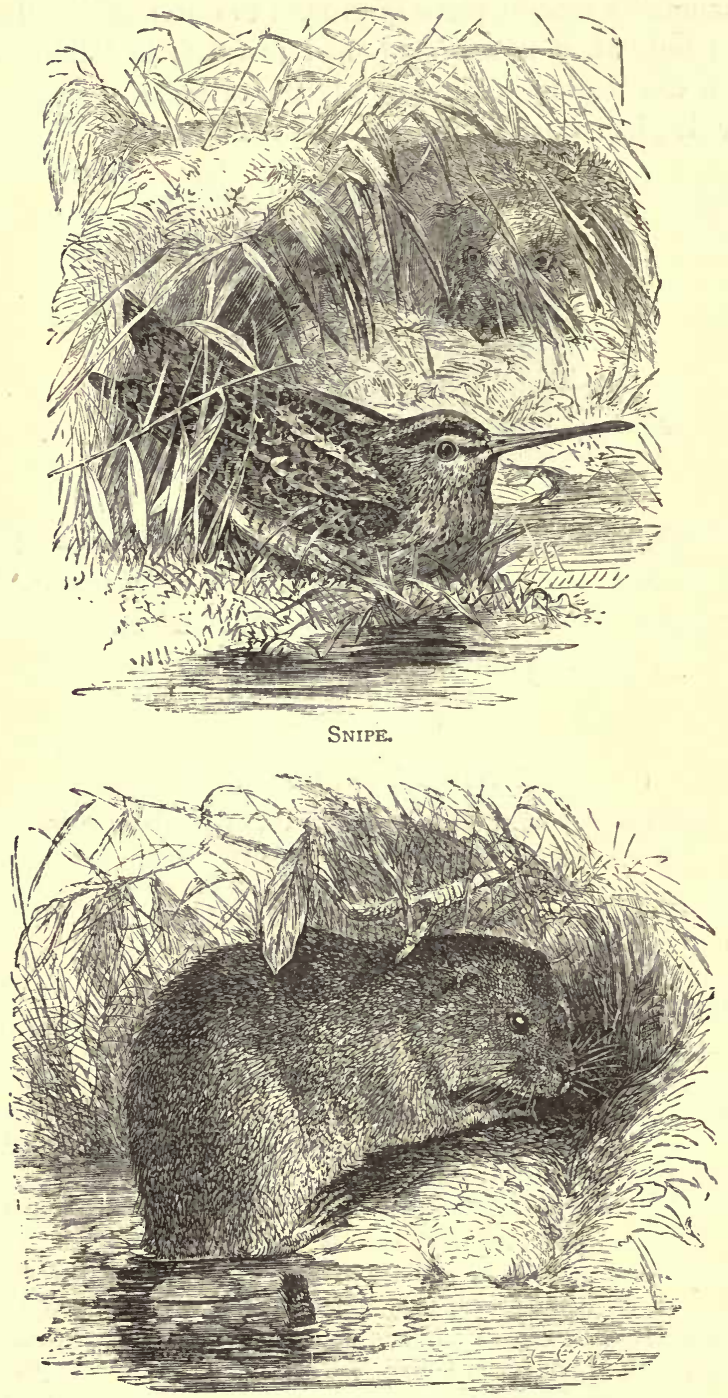

WATER-RAT. 
reader must bear this long explanation in mind when he sees the numerous allusions to the subject in the subsequent pages.

The sand-martin is the first of the swallow kind to arrive, and the swift the last.

In the Field of April 12th, 1879, I see the following note by Mr. Henry Smith, which is apropos of the subject :-

"On Sunday last, April 6th, I saw a single swallow flying over the town of Ringwood; and on going out of the town across the river, where a large tract of meadow is generally inundated in wet weather, I saw, to my astonishment, a multitude of martins skimming over the surface of the water. This was early in the morning, just before a tremendous downpour of rain, lasting six hours. At 3 p.m., when the rain had ceased, and the sky had become clear, I went out again, and found that the air was resounding with the twittering of the birds, which were flying at a great altitude, and in vast numbers. The low flight in the early morning, and the exalted position of the birds in the afternoon, indicated on the one hand the forthcoming heavy rain, and on the other presaged the fine afternoon which followed. In all my observations of the arrival of the hirundines, I have never before noticed them in a large flock; but at their earliest date of arrival, one generally has marked their advent here and there in small numbers; their congregating in large flocks generally precedes their departure."

${ }^{2}$ Possibly the Grasshopper Warbler. This little bird has a peculiar sibilant warble, which, like the cry of the corncrake, is apparently ventriloquous. The sound seems here, there, and everywhere, and it is only by the closest observation and the greatest caution that a sight of the tiny songster can be obtained.

${ }^{3}$ In the verandah of my father's house in Shropshire, four or five pairs of fly-catchers used to build, and there were other nests on a ledge in the orchard wall, so that in the summer the standard roses and the gateposts each had a fly-catcher using it as a raiding-point. The birds which rested in the verandah took not the slightest notice of people passing and repassing. Sparrows, wrens, and chaffinches also nested among the roses which trailed up it.

4 The Blackcap does migrate.

5 The humming of the snipe has puzzled many a naturalist to say how it was made. It is also called bleating, and, in Norfolk, "lamming," because the noise is something like that caused by a lamb. I have noticed great numbers of snipe bleating on the Norfolk Roads, and I am satisfied that it is made by the rapid vibration of the long feathers of the tail and wings. The sound is only made when the snipe is in the air and descending a little, rapidly, in an oblique direction against the wind.

${ }^{6}$ There is only one species of water-rat, and strictly speaking it is not a rat. It differs anatomically and in its mode of life from the rat. Its proper name is the water-vole. Its feet are not webbed. Its food is entirely vegetable, while the common rat, which is found in numbers by the waterside, will eat fish or 
animal matter. Of the rat proper there are two species, the original black English rat, which is exceedingly rare, and the Norway rat, which is the one now so common. It has completely ousted the black rat.

7 This hawk was apparently a variety of the Peregrine Falcon.

\section{LETTER XI.}

SELBORNe, September 9 th, I767.

IT will not be without impatience that I shall wait for your

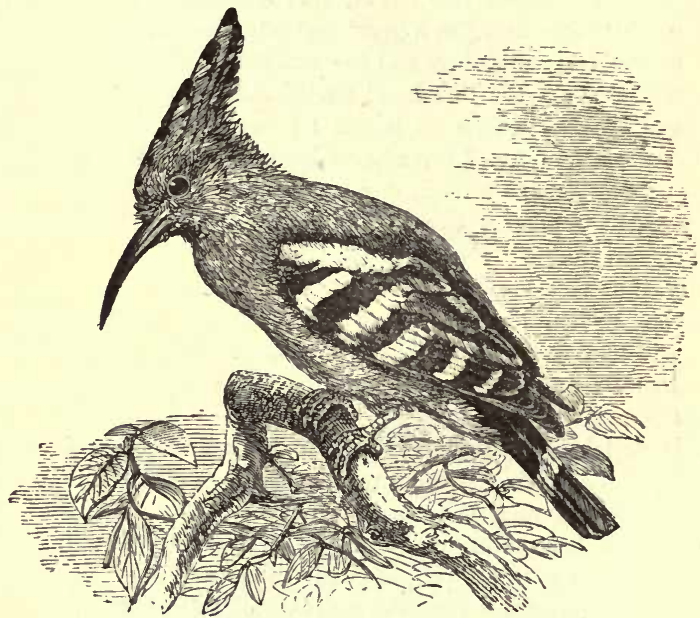

The Hoopor.

thoughts with regard to the falco; as to its weight, breadth, etc., 1 wish I had set them down at the time; but, to the best of my remembrance, it weighed two pounds and eight ounces, and measured, from wing to wing, thirty-eight inches. Its cere and feet were yellow, and the circle of its eyelids a bright yellow. As it had been killed some days, and the eyes were sunk, I could make no good observation on the colour of the pupils and the irides.

The most unusual birds I ever observed in these parts were a pair of hoopoes (upupa), ${ }^{1}$ which came several years ago in the 
summer, and frequented an ornamented piece of ground, which joins to my garden, for some weeks. They used to march about in a stately manner, feeding in the walks, many times in the day; and seemed disposed to breed in my outlet; but were frighted and persecuted by idle boys, who would never let them be at rest.

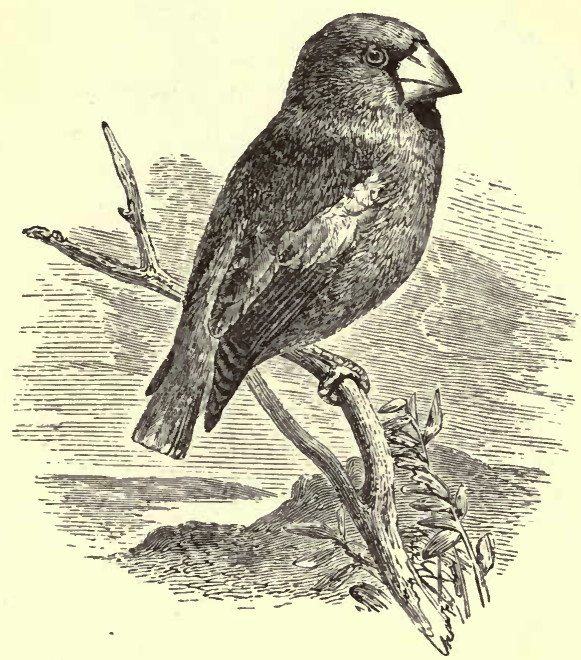

The Grossbeak.

Three grossbeaks ${ }^{2}$ (loxia coccothraustes) appeared some years ago in my fields, in the winter; one of which I shot. Since that, now and then, one is occasionally seen in the same dead season.

A crossbill ${ }^{3}$ (loxia curvirostra) was killed last year in this neighbourhood.

Our streams, which are small, and rise only at the end of the village, yield nothing but the bull's head or miller's thumb ${ }^{4}$ (gobius fuviatilis capitatus), the trout (trutta fuviatilis), the eel ${ }^{5}$ (anguilla), the lampern ${ }^{6}$ (lampatra parva et fluviatilis), and the stickle-back ${ }^{7}$ (pisciculus aculeatus).

We are twenty miles from the sea, and almost as many from a great river, and therefore see but little of sea birds. As to wild fowls, we have a few teems of ducks bred in the moors where the 
snipes breed ; and multitudes of widgeons and teals in hard weather frequent our lakes in the forest.

Having some acquaintance with a tame brown owl, I find that it casts up the fur of mice, and the feathers of birds in pellets, after

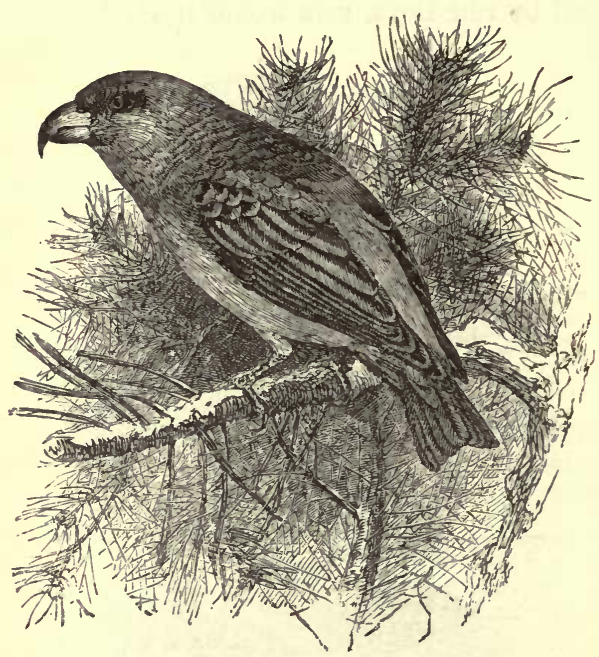

The Common Crossbill.

the manner of hawks; when full, like a dog, it hides what it cannot eat.

The young of the barn-owl are not easily raised, as they want a constant supply of fresh mice; whereas the young of the brown

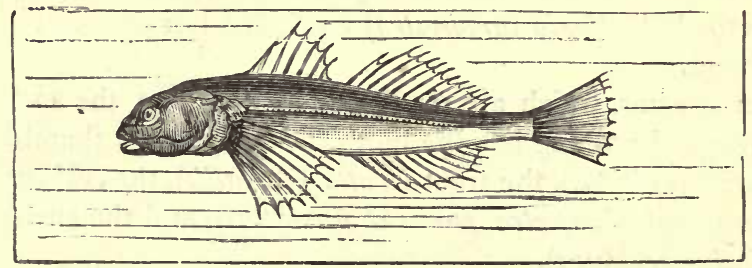

Miller's 'Thumb, or Bui.l's Head

owl will eat indiscriminately all that is brought; snails, rats, kittens, puppies, magpies, and any kind of carrion or offal. 
The house-martins have eggs still, and squab young. The last. swift I observed was about the 2 Ist August : it was a straggler.

Red-starts, fly-catchers, white-throats, and reguli non cristati, still appear: but I have seen no black-caps lately.

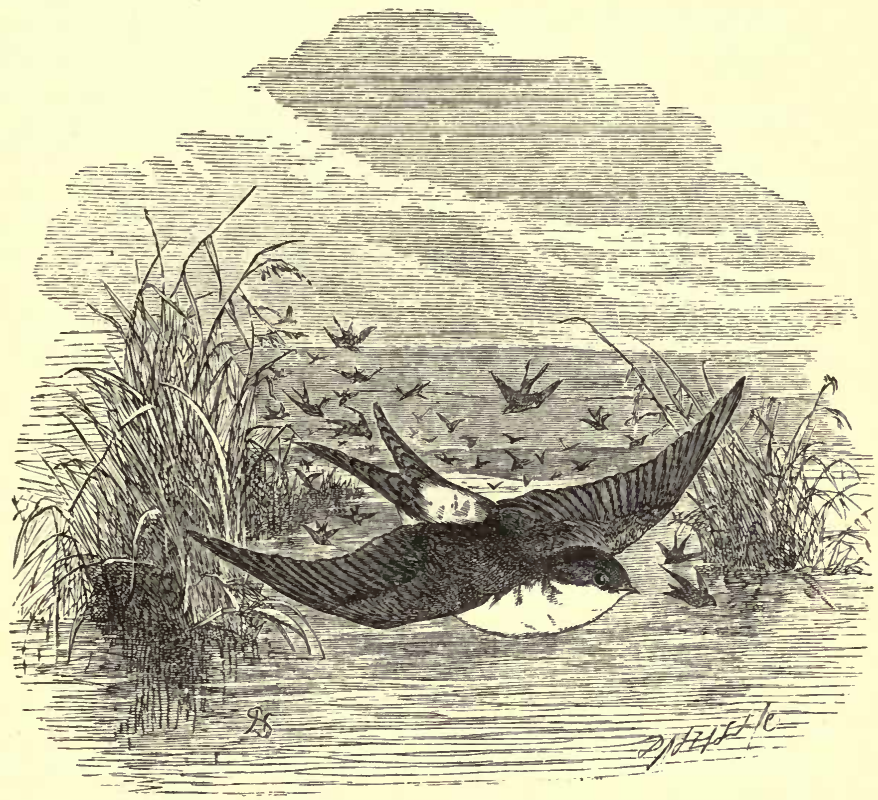

The House-Martin.

I forgot to mention that I once saw, in Christ Church College quadrangle in Oxford, on a very sunny warm morning, a housemartin flying about, and settling on the parapet, so late as the 2oth November.

At present I know only two species of bats, the common vespertilio murinus and the vespertilio auribus. ${ }^{8}$

I was much entertained last summer with a tame bat, which would take flies out of a person's hand. If you gave it anything to eat, it brought its wings round before the mouth, hovering and hiding its head in the manner of birds of prey when they feed. 
The adroitness it showed in shearing off the wings of the flies, which were always rejected, was worthy of observation, and pleased me much. Insects seemed to be most acceptable, though it did not refuse raw flesh when offered; so that the notion, that

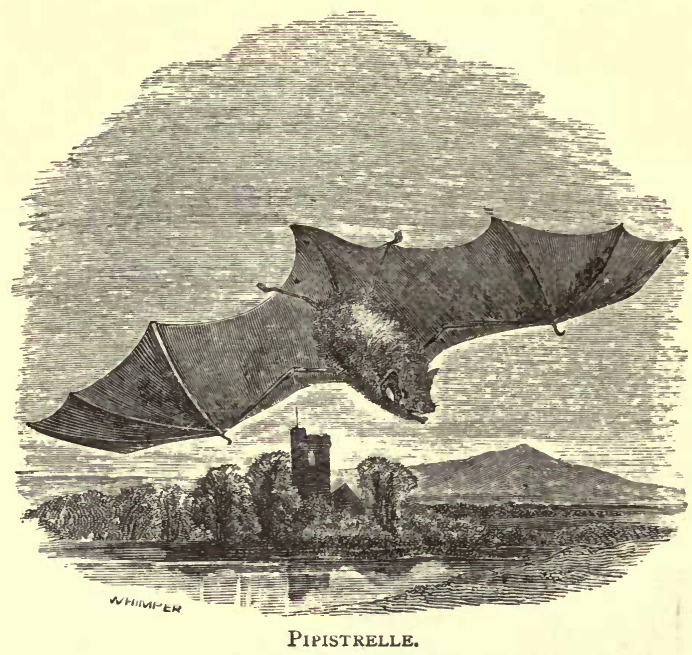

bats go down chimneys and gnaw men's bacon, seems no improbable story. While I amused myself with this wonderful quadruped, I saw it several times confute the vulgar opinion, that bats when down upon a flat surface cannot get on the wing again, by rising with great ease from the floor. It ran, I observed, with more dispatch than I was aware of; but in a most ridiculous and grotesque manner.

Bats drink on the wing, like swallows, by sipping the surface, as they play over pools and streams. They love to frequent waters, not only for the sake of drinking, but on account of insects, which are found over them in the greatest plenty. As I was going some years ago, pretty late, in a boat from Richmond to Sunbury, on a warm summer's evening, I think I saw myriads of bats between the two places; the air swarmed with them all along the Thames, so that hundreds were in sight at a time.

I am, etc. 


\section{NOTES TO LETTER XI.}

1 One occasionally sees mention made in the scientific and natural history periodicals of the occurrence of the hoopoe (upupa epops). Of course it is generally shot, and no chance is given it of breeding. Its nest has only rarely been found in England.

2 The grossbeak (coccothraustes vulgaris), or as it is more commonly called, the hawfinch, is not so rare as is generally supposed. Its shyness prevents ito being easily observed.

3 The crossbill may occasionally be seen, in small flocks, in districts where the larch is plentiful. With its peculiar curved mandibles, it extracts the seeds from the fir-cones. The birds vary greatly in size and colour, according to age and sex. They are yellow, green, red, or brown at different times, so if it were not for their crossed bills, it would be rather hard to distinguish them. They breed in Norway and Sweden, and very occasionally in England.

${ }^{4}$ We used, when I was a boy, to catch great numbers of bull-heads to bait our eel lines with. They were found under every flat stone in the Shropshire streams, in company with the loach, also an excellent bait.

${ }^{5}$ It is now well known that there are three kinds of eels which inhabit our rivers and pools, - the snig, and the broad-nosed and sharp-nosed species. The habits of eels are very peculiar. Nothing certain is known about their breeding, but it is believed that the young are born alive. In the autumn the eels descend the rivers in vast numbers, and go either to sea or to the brackish waters, where they breed. In the spring the little eels, or elvers, ascend the rivers in columns so dense that they may be scooped out by the bucketful.

${ }^{6}$ In the Dee at Llangollen, lamperns were very numerous. They hold on to stones by means of their round sucker-like mouths, and can move very heavy ones.

7 There are six kinds of sticklebacks. Everyone knows the common threefinned one. One kind builds a nest among the weeds, and guards it with the utmost vigilance.

8 There seem to be about twenty species of British bats. Four or five species are tolerably common. The squeak made by the bat is so very fine, that while to some ears it is loud, by others it cannot be heard. I once, when a boy, was exploring a hollow tree after owls' nests, when the smell from one particular hole was so dreadful that we put some lighted paper down to see what would come out; and to our astonishment dozens of large, reddish bats flew out, and dashed madly about in the bright sunlight. The bat has more vermin upon it than any other creature of its size. It seems needless to state that the bat is an animal, and not a bird or an insect; but I saw it gravely stated in the columns of a local journal by two correspondents that it was either of the two latter. 


\section{LETTER XII.}

November $4^{t h}, \mathbf{1 7} 67$.

SIR,-It gave me no small satisfaction to hear that the falco turned out an uncommon one. I must confess I should have been better pleased to have heard that I had sent you a bird that you had never seen before; but that, I find, would be a difficult task.

I have procured some of the mice mentioned in my former letters, a young one and a female with young, both of which I have preserved in brandy. From the colour, shape, size, and manner of nesting, I make no doubt but that the species is nondescript. They are much srnaller, and more slender, than the mus domesticus medius of Ray; and have more of the squirrel or dormouse colour; their belly is white, a straight line along their

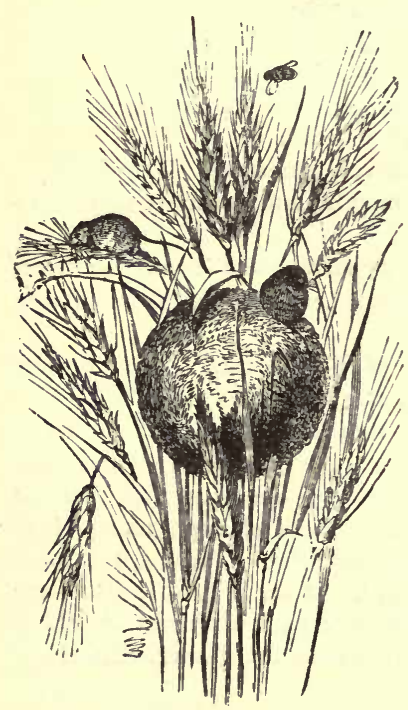

Harvest Mouse and Nest. sides divides the shades of their back and belly. They never enter into houses; are carried into ricks and barns. with the sheaves; abound in harvest; and build their nests amidst the straws of the corn above the ground, and sometimes in thistles. They breed as many as eight at a litter, in a little round nest composed of the blades of grass or wheat. ${ }^{1}$

One of these nests I procured this autumn, most artificially platted, and composed of the blades of wheat, perfectly round, and about the size of a cricket-ball; with the aperture so ingeniously closed, that there was no discovering to what part it belonged. It was so compact and well filled, that it would roll across the table without being discomposed, though it contained eight little mice that were 
naked and blind. As this nest was perfectly full, how could the dam come at her litter respectively so as to administ $\mathrm{r}$ a teat to each? Perhaps she opens different places for that purpose, adjusting them again when the business is over; but she could not possibly be contained herself in the ball with her young, which moreover would be daily increasing in bulk. This wonderful procreant cradle, an elegant instance of the efforts of instinct, was found in a wheat-field suspended in the head of a thistle.

A gentleman, curious in birds, wrote me word that his servant had shot one last January, in that severe weather, which he believed would puzzle me. I called to see it this summer, not knowing what to expect, but the moment I took it in hand, I pronounced it the male garrulus bohemicus or German silk-tail, from the five peculiar crimson tags or points which it carries at the ends of five of the short remiges. It cannot, I suppose, with any propriety, be called an English bird; and yet I see, by Ray's "Philosophical Letters," that great flocks of them, feeding on haws, appeared in this kingdom in the winter of 1685 .

The mention of haws puts me in mind that there is a total failure of that wild fruit, so conducive to the support of many of the winged nation. For the same severe weather, late in the spring, which cut off all the produce of the more tender and curious trees, destroyed also that of the more hardy and common.

Some birds, haunting with the missel-thrushes, and feeding on the berries of the yew tree, which answered to the description of the merula torquata, or ring-ouzel, were lately seen in this neighbourhood. I employed some people to procure me a specimen, but without success. (See Letter VIII.)

Query.-Might not canary birds be naturalised to this climate, provided their eggs were put, in the spring, into the nests of some of their congeners, as goldfinches, greenfinches, etc.? Before winter perhaps they might be hardened, and able to shift for themselves.

About ten years ago I used to spend some weeks yearly at Sunbury, which is one of those pleasant villages lying on the Thames, near Hampton Court. In the autumn, I could not help being much amused with those myriads of the swallow kind which 
assemble in those parts. But what struck me most was, that, from the time they began to congregate, forsaking the chimneys and houses, they roosted every night in the osier-beds of the aits of that river. ${ }^{2}$ Now this resorting towards that element, at that season of the year, seems to give some countenance to the northern opinion (strange as it is) of their retiring under water. A Swedish naturalist is so much persuaded of that fact, that he talks, in his calendar of Flora, as familiarly of the swallow's going under water in the beginning of September, as he would of his poultry going to roost a little before sunset.

An observing gentleman in London writes me word that he saw a house-martin, on the twenty-third of last October, flying in and out of its nest in the Borough. And I myself, on the twenty-ninth of last October (as I was travelling through Oxford), saw four or five swallows hovering round and settling on the roof of the county hospital.

Now is it likely that these poor little birds (which perhaps had not been hatched but a few weeks) should, at that late season of the year, and from so midiand a county, attempt a voyage to Goree or Senegal, almost as far as the equator?*

$I$ acquiesce entirely in your opinion-that, though most of the swallow kind may migrate, yet that some do stay behind and hide with us during the winter.

As to the short-winged soft-billed birds, which come trooping in such numbers in the spring, I am at a loss even what to suspect about them. I watched thein narrowly this year, and saw them abound till about Michaelmas, when they appeared no longer. Subsist they cannot openly among us, and yet elude the eyes of the inquisitive : and, as to their hiding, no man pretends to have found any of them in a torpid state in the winter. But with regard to their migration, what difficulties attend that supposition! that such feeble bad fliers (who the summer long never flit but from hedge to hedge) should be able to traverse vast seas and contınents in order to enjoy milder seasons amidst the regions of Africa!

* See “Adanson's Voyage to Senegal." 


\section{NOTES TO LETTER XII.}

1 The harvest mouse is the smallest of British animals. Unlike its relatives, it builds its nest on the stalks of grass or corn at a little distance from the ground. The nest is globular in shape, made of woven grass, and has a small entrance like that of a wren's. It is tolerably common in some of the southern counties, but it is not easily found.

${ }^{2}$ There was a pool in Shropshire where I used to fish for roach, and I was always struck with the number of swallows which roosted on the willow bushes fringing the banks. One could almost take them in one's hand. At Acle, in Norfolk, one August, the swallows roosted on the telegraph wires in such extraordinary numbers that they formed continuous black festoons as far as the eye could reach.

\section{LETTER XIII.}

SELBORNe, $\dot{f}$ an. 22nd, I768.

SiR,-As in one of your former letters you expressed the more satisfaction from my correspondence on account of my living in the most southerly county; so now I may return the compliment, and expect to have my curiosity gratified by your living much more to the North.

For many years past I have observed that towards Christmas vast flocks of chaffinches have appeared in the fields ; many more, I used to think, than could be hatched in any one neighbourhood. But, when I came to observe them more narrowly, I was amazed to find that they seemed to me to be almost all hens. I communicated my suspicions to some intelligent neighbours, who, after taking pains about the matter, declared that they also thought them mostly females,- at least fifty to one. This extraordinary occurrence brought to my mind the remark of Linnæus, that "before winter all their hen chaffinches migrate through Holland 
into Italy." Now I want to know, from some curious person in

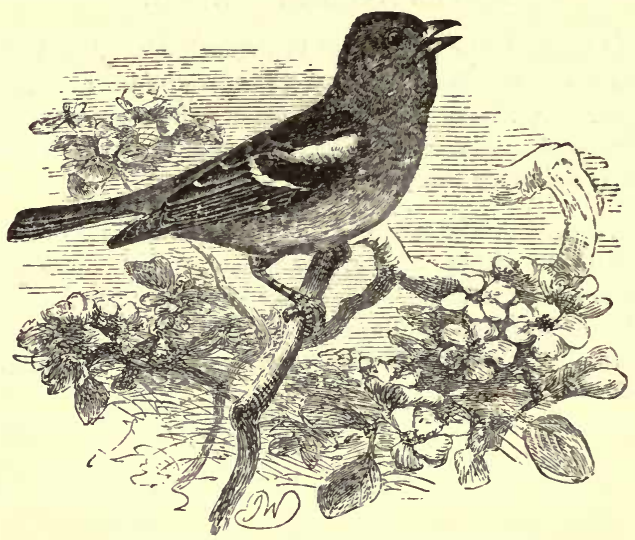

'Ihe Chaffinch (Fringilla colebs).

the north, whether there are any large flocks of these finches with them in the winter, and of which sex they mostly consist? For

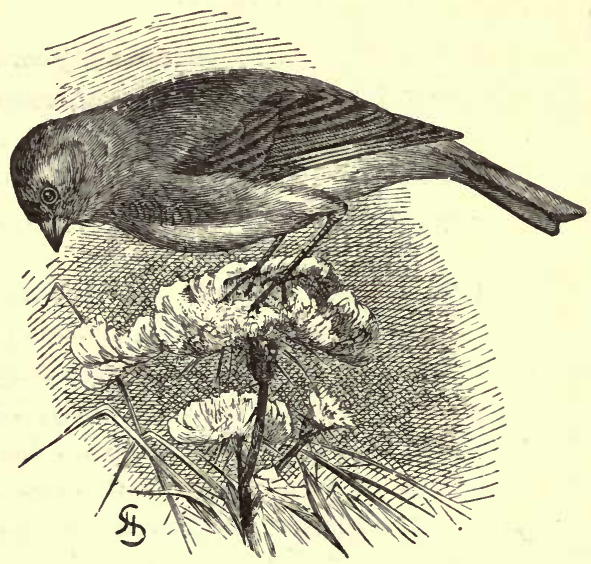

The Common Linnet.

from such intelligence, one might be able to judge whether our 
female flocks migrate from the other end of the island, or whether they come over to us from the continent.

We have, in the winter, vast flocks of the common linnets; more, I think, than can be bred in any one district. These, I observe, when the spring advances, assemble on some tree in the sunshine, and join all in a gentle sort of chirping, as if they were about to break up their winter quarters and betake themselves to their proper summer homes. It is well known, at least, that the swallows and the fieldfares do congregate with a gentle twittering before they make their respective departure.

You may depend on it that the bunting, Emberiza miliaria, does not leave this county in the winter. In January, I 767 , I

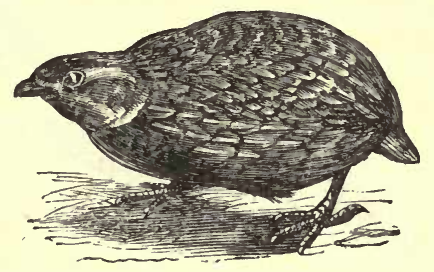

Quail.

saw several dozen of them, in the midst of a severe frost, among the bushes on the downs near Andover : in our woodland enclosed district it is a rare bird.

Wagtails, both white and yellow, are with us all the winter. Quails crowd to our southern coast, and are often killed in numbers by people that go on purpose.

Mr. Stillingfleet, in his Tracts, says that "if the wheatear (enanthe) does not quit England, it certainly shifts places; for about harvest they are not to be found, where there was before great plenty of them." This well accounts for the vast quantities that are caught about that time on the south downs near Lewes, where they are esteemed a delicacy. There have been shepherds, I have been credibly informed, that have made many pounds in a season by catching them in traps. And though such multitudes 
are taken, I never saw (and I am well acquainted with those parts) above two or three at a time, for they are never gregarious. They may perhaps migrate in general ; and, for that purpose, draw towards the coast of Sussex in autumn: but that they do not all withdraw I am sure; because I see a few stragglers in many counties, at all times of the year, especially about warrens and stone quarries.

I have no acquaintance, at present, among the gentlemen of the navy; but have written to a friend, who was a sea-chaplain in the late war, desiring him to look into his minutes, with respect to birds that settled on their rigging during their voyage up or down the Channel. What Hasselquist says on that subject is

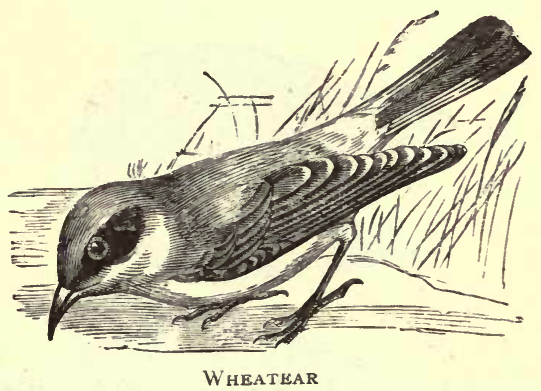

remarkable ; there were little short-winged birds frequently coming on board his ship all the way from our channel quite up to the Levant, especially before squally weather.

What you suggest, with regard to Spain, is highly probable. The winters of Andalusia are so mild, that, in all likelihood, the soft-billed birds that leave us at that season may find insects sufficient to support them there.

Some young man, possessed of fortune, health, and leisure, should make an autumnal voyage into that kingdom; and should spend a year there, investigating the natural history of that vast country. Mr. Willughby* passed through that kingdom on such an errand; but he seems to have skirted along in a superficial

"See "Ray's Travels," p. 466. 
manner and an ill-humour, being much disgusted at the rude dissolute manners of the people.

I have no friend left now at Sunbury to apply to about the swallows roosting on the aits of the Thames: nor can I hear any more about those birds which I suspected were Merula torquate.

As to the small mice, I have farther to remark, that though they hang their nests for breeding up amidst the straws of the standing corn, above the ground; yet I find that, in the winter, they burrow deep in the earth, and make warm beds of grass : but their grand rendezvous seems to be in corn-ricks, into which they are carried at harvest. A neighbour housed an oat-rick lately, under the thatch of which were assembled nearly a hundred, most of which were taken, and some I saw. I measured them; and found that, from nose to tail, they were just two inches and a quarter, and their tails just two inches long. Two of them, in a scale, weighed down just one copper halfpenny, which is about the third of an ounce avoirdupois: so that I suppose they are the smallest quadrupeds in this island. A full-grown Mus medius domesticus weighs, I find, one ounce lumping weight, which is more than six times as much as the mouse above; and measures from nose to rump four inches and a quarter, and the same in its tail. We have had a very severe frost and deep snow this month. My thermometer was one day fourteen degrees and a half below the freezing-point, within doors. The tender evergreens were injured pretty much. It was very providential that the air was still, and the ground well covered with snow, else vegetation in general must have suffered prodigiously. There is reason to believe that some days were more severe than any since the year $1739-40$.

I am, etc., etc. 


\section{LETTER XIV.}

SELBORNe, March 12 th, 1768.

DEAR SiR,-If some curious gentleman would procure the head of a fallow-deer, and have it dissected, he would find it furnished with two spiracula, or breathing places, besides the nostrils; probably analogous to the puncta lachrymalia in the human head. When deer are thirsty they plunge their noses, like some horses, very deep under water, while in the act of drinking, and continue them in that situation for a considerable time : but, to obviate any inconveniency, they can open two vents, one at the inner corner of each eye, having a communication with the nose. Here seems to be an extraordinary provision of nature worthy our attention; and which has not, that I know of, been noticed by any naturalist. For it looks as if these creatures would not be suffocated, though both their mouths and nostrils were stopped. This curious formation of the head may be of singular service to beasts of chase, by affording them free respiration: and no doubt these additional nostrils are thrown open when they are hard run. Mr. Ray observed that at Malta, the owners slit up the nostrils of such asses as were hard worked: for they, being naturally straight or small, did not admit air sufficient to serve them when they travelled, or laboured, in that hot climate. And we know that grooms, and gentlemen of the turf, think large nostrils necessary, and a perfection, in hunters and running horses.

Oppian, the Greek poet, by the following line, seems to have had some notion that stags have four spiracula:

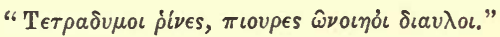

"Quadrifidæ nares, quadruplices ad respirationem canales."

Opp. Cyn. Lib. ii. 1. I8I.

Writers, copying from one another, make Aristotle say that goats breathe at their ears; whereas he asserts just the con-

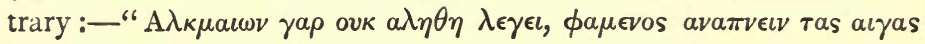




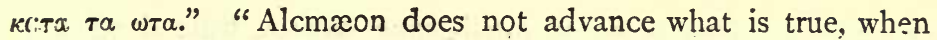
l.e avers that goats breathe through their ears."- "History of Animals." Book I. chap. xi. ${ }^{1}$

\section{NOTE TO LETTER XIV.}

Naturalists seem now agreed that the curious slits referred to in the foregoing chapter are not and cannot be used for breathing, but for some other sense of which we can but guess the nature.

\section{LETTER XV.}

Selborne, March $30 t h$, 768.

DEAR SIR,-Some intelligent country people have a notion that we have in these parts, a species of the genus mustelinum, besides

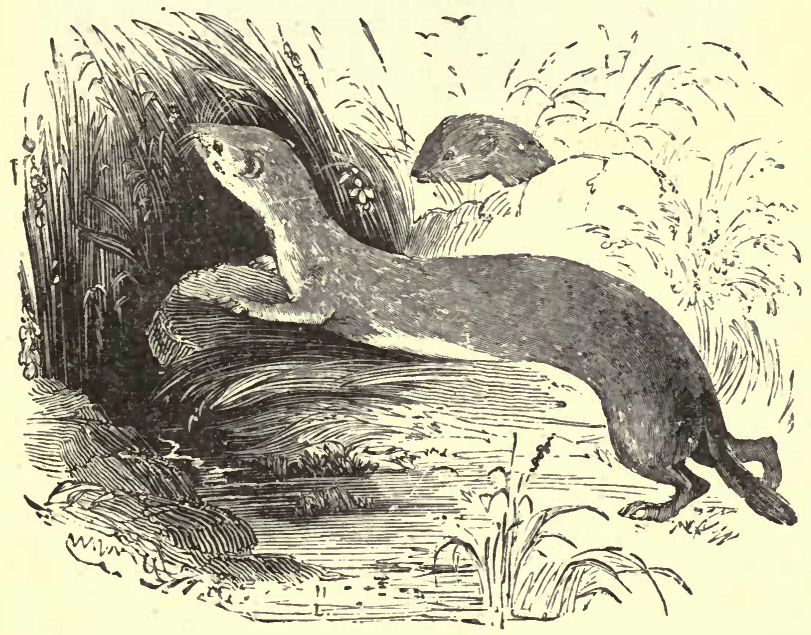

WFASEL.

the weasel, stoat, ferret, and polecat; a little reddish beast, not much bigger than a field-mouse, but much longer, which they 
call a cane. This piece of intelligence can be little depended on; but farther inquiry may be made. ${ }^{1}$

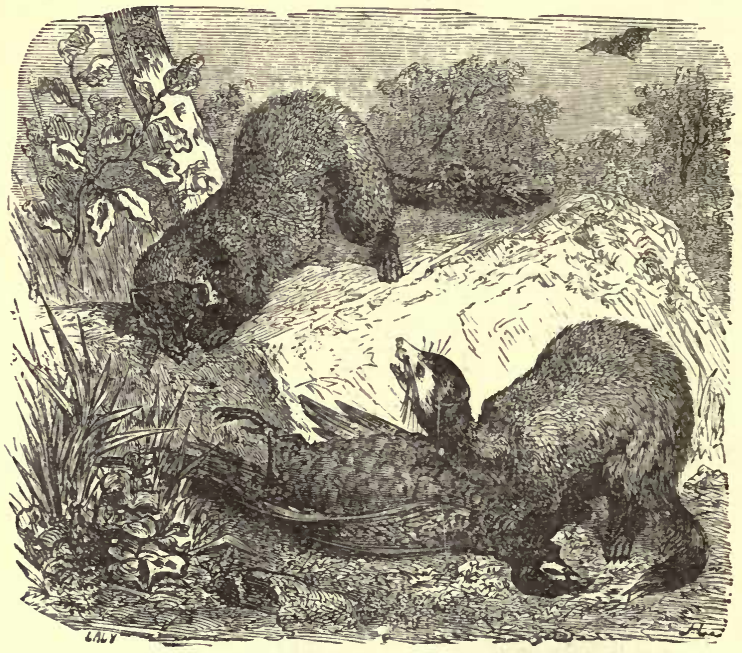

Polecat

A gentleman in this neighbourhood had two milkwhite rooks in one nest. A booby of a carter, finding them before they were able to fly, threw them down and destroyed them, to the regret of the owner, who would have been glad to have preserved such a curiosity in his rookery. I saw the birds myself nailed against the end of a barn, and was surprised to find that their bills, legs, feet, and claws were milkwhite.

A shepherd saw, as he thought, some white larks on a down above my house this winter: were not these the Emberiza nivalis, the snow-flake of the Brit. Zool.? No doubt they were.

A few years ago I saw a cock bullfinch in a cage, which had been caught in the fields after it was come to its full colours. In about a year it began to look dingy; and, blackening every succeeding year, it became coal-black at the end of four. Its chief food was hempseed. Such influence has food on the colour of 
animals! The pied and mottled colours of domesticated animals are supposed to be owing to high, various, and unusual food.

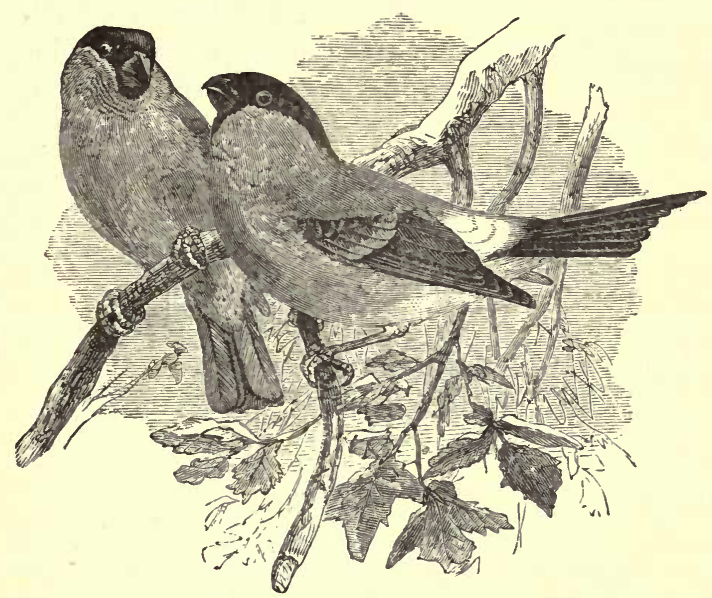

The Bullfinch (Pyrrhula rubicilla).

I had remarked, for years, that the root of the cuckoo-pint (arum) was frequently scratched out of the dry banks of hedges, and eaten in severe snowy weather. After observing, with some exactness, myself, and getting others to do the same, we found it was the thrush kind that searched it out. The root of the arum is remarkably warm and pungent.

Our flocks of female chaffinches have not yet forsaken us. The blackbirds and thrushes are very much thinned down by that fierce weather in January.

In the middle of February I discovered, in my tall hedges, a little bird that raised my curiosity: it was of that yellow-green colour that belongs to the salicaria kind, and, I think, was softbilled. It was no parus; and was too long and too big for the golden-crowned wren, appearing most like the largest willow-wren. It hung sometimes with its back downwards, but never continuing one moment in the same place. I shot at it, but it was so desultory that I missed my aim. 
I wonder that the stone-curlew, Charadrius cedicnemus, should be mentioned by the writers as a rare bird: it abounds in all the champaign parts of Hampshire and Sussex, and breeds, I think, all the summer, having young ones, I know, very late in the autumn. Already they begin clamouring in the evening. They cannot, I think, with any propriety, be called, as they are by Mr. Ray, "circa aquas versantes;" for with us, by day at least, they haunt only the most dry, open, upland fields and sheep-walks, far removed from water: what they may do in the night I cannot say. Worms are their usual food, but they also eat toads and frogs.

I can show you some good specimens of my new mice. Linnæus perhaps would call the species Mus minimus.

\section{NOTE TO LETTER XV.}

${ }^{1}$ The cane is simply a local name for the weasel. It is called mouse-hunter in Norfolk. A peculiarity of the weasel is its curiosity. If you startle it and it runs into a hole, wait a few moments, and it will probably come out again to look at you in a very impertinent kind of way.

\section{LETTER XVI.}

Selborne, April 18th, 1768.

DFar Sir,-The history of the stone-curlew, Charadrius adicnemus, is as follows. It lays its eggs, usually two, never more than three, on the bare ground, without any nest, in the field; so that the countryman, in stirring his fallows, often destroys them. The young run immediately from the egg like partridges, etc., and are withdrawn to some flinty field by the dam, where they skulk among the stones, which are their best security; for their feathers are so exactly of the colour of our grey spotted flints, that the most exact observer, unless he catches the eye of the young bird, may be eluded. The eggs are short and round; of a dirty white, spotted with dark bloody blotches. Though I might not be able, 
just when I pleased, to procure you a bird, yet I could show jou them almost any day; and any evening you may hear them round the village, for they make a clamour which may be heard a mile. Oedicnemus is a most apt and expressive name for them, since their legs seem swoln like those of a gouty man. After harvest I have shot them before the pointers in turnip-fields.

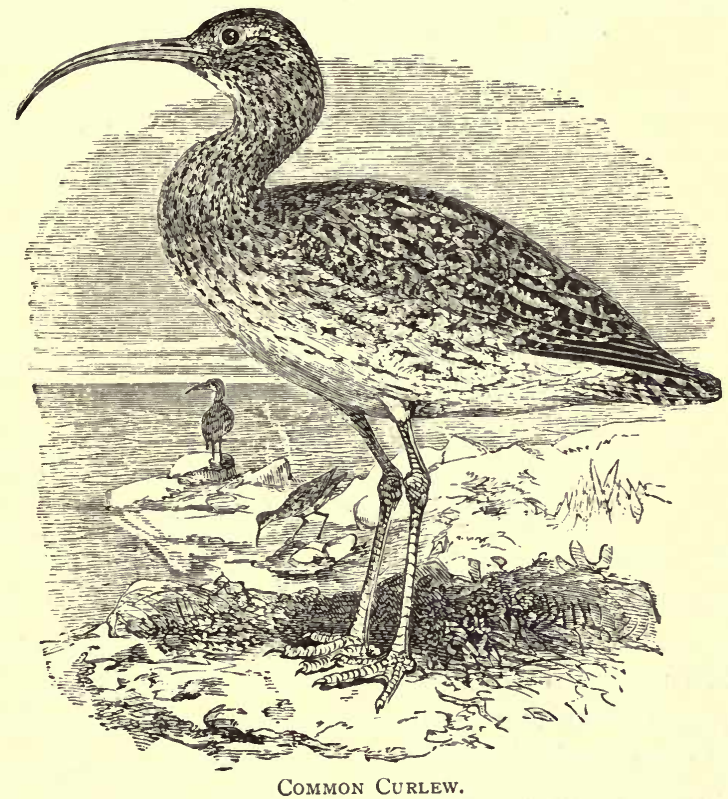

I make no doubt but there are three species of the willow-wrens; two I know perfectly, but have not been able yet to procure the third. No two birds can differ more in their notes, and that constantly, than those two that I am acquainted with ; for the one has a joyous, easy, laughing note, the other a harsh loud chirp. The former is every way larger, and three-quarters of an inch longer, and weighs two drams and a half, while the latter weighs but two; so the songster is one-fifth heavier than the chirper. The chirper (being the first summer-bird of passage that is heard, the wryneck sometimes excepted) begins his two notes in the middle 
of March, and continues them through the spring and summer tilt the end of August, as appears by my journals. The legs of the larger of these two are flesh-coloured; of the less black.

The grasshopper-lark began his sibilous note in my fields last

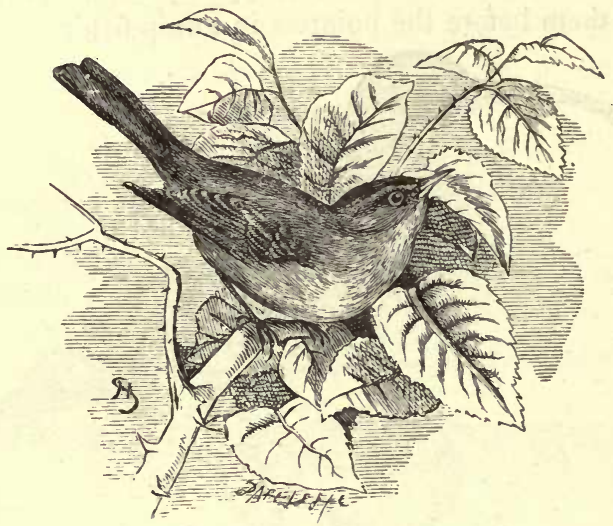

The Chiff-Chaff (Sylvia hippolais).

Saturday. Nothing can be more amusing than the whisper of this little bird, which seems to be close by though at a hundred yards distance ; and when close at your ear, is scarce any louder than when a great way off. Had I not been a little acquainted with insects, and known that the grasshopper kind is not yet hatched, I should have hardly believed but that it had been a locusta whispering in the bushes. The country people laugh when you tell them that it is the note of a bird. It is a most artful creature, sculking in the thickest part of a bush; and will sing at a yard distance, provided it be concealed. I was obliged to get a person to go on the other side of the hedge where it haunted, and then it would run, creeping like a mouse, before us for a hundred yards together, through the bottom of the thorns; yet it would not come into fair sight; but in a morning early, and when undisturbed, it sings on the top of a twig, gaping and shivering with its wings. Mr. Ray himself had no knowledge of this bird, but received his account from Mr. Johnson, who apparently confounds it with the 
reguli non cristati, from which it is very distinct. See Ray's " Philos. Letters," p. ro8.

The fly-catcher (stoparola) has not yet appeared; it usually breeds in my vine. The redstart begins to sing, its note is short and imperfect, but is continued till about the middle of June. The willow-wrens (the smaller sort) are horrid pests in a garden, destroying the peas, cherries, currants, etc, ; and are so tame that a gun will not scare them.

A List of the summer Birds of Passage discovered in this NeIGHBOURHOOD, RANGED SCMEWHAT IN THE ORDER IN WHICH THEX APPEAR.

$\begin{array}{ll}\text { Smallest willow-wren, } & \text { Motacilla trochilus. } \\ \text { Wryneck, } & \text { Fynx torquilla. } \\ \text { House-swallow, } & \text { Hirundo rustica. } \\ \text { Martin, } & \text { Hirundo urbica. } \\ \text { Sand-martin, } & \text { Hirundo riparia. } \\ \text { Cuckoo, } & \text { Cuculus canorus. } \\ \text { Nightingale, } & \text { Motacilla luscinia. } \\ \text { Blackcap, } & \text { Motacilla atricapilla. } \\ \text { Whitethroat, } & \text { Motacilla sylvia. } \\ \text { Middle willow-wren, } & \text { Motacilla trochilus. } \\ \text { Swift, } & \text { Hirundo apus. } \\ \text { Stone-curlew? } & \text { Charadrius adicnemus? } \\ \text { Turtle-dove? } & \text { Turtur aldrovandi? } \\ \text { Grasshopper-lark, } & \text { Alauda trivialis. } \\ \text { Landrail, } & \text { Rallus crex. } \\ \text { Largest willow-wren, } & \text { Motacilla trochilus. } \\ \text { Redstart, } & \text { Motacilla phanicurus. } \\ \text { Goat-sucker, or fern-owl, } & \text { Caprimulgus europaus. } \\ \text { Fly-catcher, } & \text { Muscicapa grisola. }\end{array}$

My countrymen talk much of a bird that makes a clatter with its bill against a dead bough, or some old pales, calling it a jarbird. I procured one to be shot in the very fact; it proved to be the Sitta europaa (the nuthatch). Mr. Ray says that the less spotted woodpecker does the same. This noise may be heard a furlong or more.

Now is the only time to ascertain the short-winged summer birds; for, when the leaf is out, there is no making any remarks 
on such a restless tribe; and when once the young begin to appear it is all confusion : there is no distinction of genus, species, or sex. In breeding-time snipes play over the moors, piping and lum.

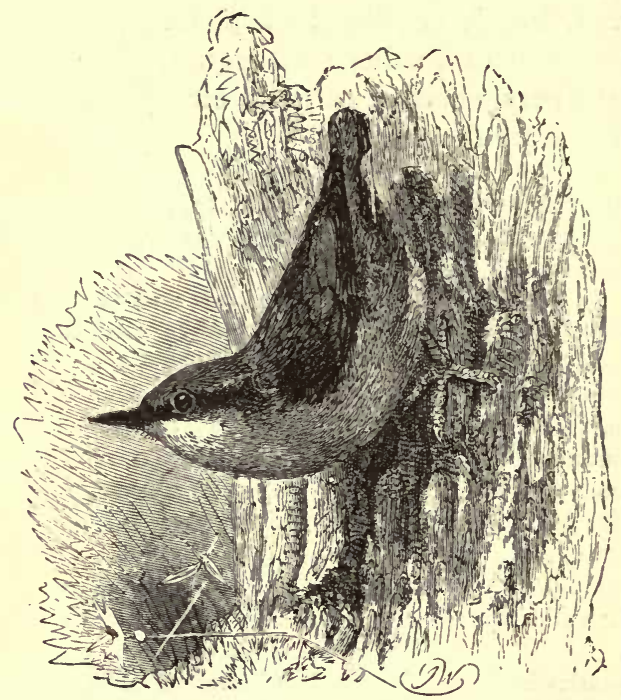

Nuthatch.

ming ; they always hum as they are descending. Is not their hum ventriloquous like that of the turkey? Some suspect it is made by their wings.

This morning I saw the golden-crowned wren, whose crown glitters like burnished gold. ${ }^{3}$ It often hangs like a titmouse, with its back downwards.

Yours, etc., etc.

\section{NOTES TO LETTER XVI.}

1 White probably means the willow-wren and chiff-chaff which are common, and the wood-wren which is rare.

2 The nuthatch builds in holes in trees, and if the opening is too large, it builds it up with mud, leaving only sufficient room for its own egress and ingress. 
3 The golden-crested wren suspends its deep purse-like nest beneath some thick fir branch, and lays a number of tiny yellow-brown eggs, like green-peas in size. All the winter through this wren and the long-tailed tit frequented the hedgerows and coppices in Shropshire, and were frequent victims to a schoolboy's love of chevying.

\section{LETTER XVII.}

SELBORNe, Fune r8th, i768.

DEAR SIR,-On Wednesday last arrived your agreeable letter of June roth. It gives me great satisfaction to find that you pursue these studies still with such vigour, and are in such forwardness with regard to reptiles and fishes.

The reptiles, few as they are, I am not acquainted with, so well as I could wish, with regard to their natural history. There is a degree of dubiousness and obscurity attending the propagation of this class of animals, something analogous to that of the cryptogamia in the sexual system of plants: and the case is the same with regard to some of the fishes ; as the eel, etc. ${ }^{1}$

The method in which toads procreate and bring forth seems to be very much in the dark. Some authors say that they are viviparous: and yet Ray classes them among his oviparous animals; and is silent with regard to the manner of their bringing forth.

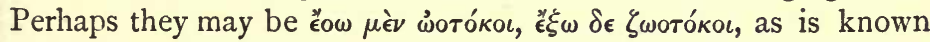
to be the case with the viper.

The copulation of frogs (or at least the appearance of it; for .Swammerdam proves that the male has no penis intrans) is notorious to everybody: because we see them sticking upon each other's backs for a month together in the spring: and yet I never saw, or read of toads being observed in the same situation. It is strange that the matter with regard to the venom of toads has not been yet settled. That they are not noxious to some animals is plain: for ducks, buzzards, owls, stone-curlews, and snakes, eat them, to my knowledge, with impunity. And I well remember the time, but was not eyewitness to the fact (though numbers of persons were) when 
a quack, at this village, ate a toad to make the country-people stare; afterwards he drank oil. ${ }^{2}$

I have been informed also, from undoubted authority, that some ladies (ladies you will say of peculiar taste) took a fancy to a toad, which they nourished summer after summer, for many years, till he grew to a monstrous size, with the maggots which turn to flesh-flies. The reptile used to come forth every evening from a hole under the garden-steps; and was taken up, after supper, on the table to be fed. But at last a tame raven, kenning him as he put forth his head, gave him such a severe stroke with his horny beak as put out one eye. After this accident the creature languished for some time and died.

I need not remind a gentleman of your extensive reading of the excellent account there is from Mr. Derham, in Ray's "Wisdom of God in the Creation" (p. 365 ), concerning the migration of frogs from their breeding ponds. In this account he at once subverts that foolish opinion of their dropping from the clouds in rain; showing that it is from the grateful coolness and moisture of those showers that they are tempted to set out on their travels, which they defer till those fall. ${ }^{3}$ Frogs are as yet in their tadpole state; but, in a few weeks, our lanes, paths, fields, will swarm for a few days with myriads of those emigrants, no larger than my little finger nail. Swammerdam gives a most accurate account of the method and situation in which the male impregnates the spawn of the female. How wonderful is the economy of Providence with regard to the limbs of so vile a reptile! While it is an aquatic it has a fish-like tail, and no legs; as soon as the legs sprout, the tail drops off as useless, and the animal betakes itself to the land !

Merret, I trust, is widely mistaken when he advances that the Rana arborea is an English reptile; it abounds in Germany and Switzerland. 4

It is to be remembered that the Salamandra aquatica of Ray (the water-newt or eft) will frequently bite at the angler's bait, and is often caught on his hook. I used to take it for granted that the Salamandra aquatica was hatched, lived, and died, in the water. But John Ellis, Esq., F.R.S. (the coralline Ellis), asserts, 
in a letter to the Royal Society, dated June 5 th, $\mathrm{x} 766$, in his account of the mud inguana, an amphibious bipes from South

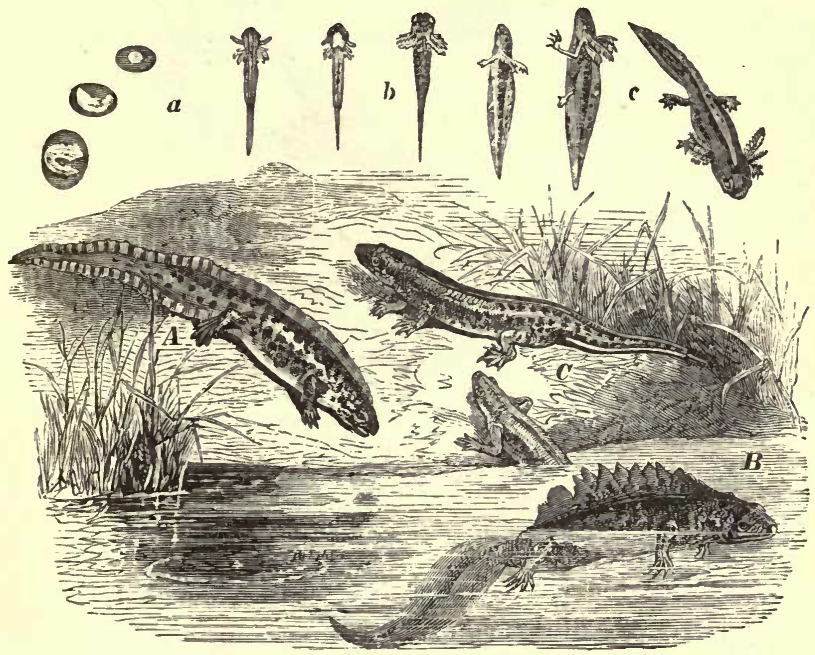

Metamorphoses of Newt.

Carolina, that the water-eft, or newt, is only the larva of the land-eft, as tadpoles are of frogs. ${ }^{5}$ Lest I should be suspected to misunderstand his meaning, I shall give it in his own words. Speaking of the opercula or coverings to the gills of the mud inguana, he proceeds to say that, "The form of these pennated coverings approaches very near to what I have some time ago observed in the larva or aquatic state of our English lacerta, known by the name of eft, or newt ; which serve them for coverings to their gills, and for fins to swim with while in this state; and which they lose, as well as the fins of their tails, when they change their state and become land animals, as I have observed, by keeping them alive for some time myself."

Linnæus, in his "Systema Naturæ," hints at what Mr. Ellis advances more than once.

Providence has been so indulgent to us as to allow of but one venomous reptile of the serpent kind in these kingdoms, and that 
is the viper. As you propose the good of mankind to be an

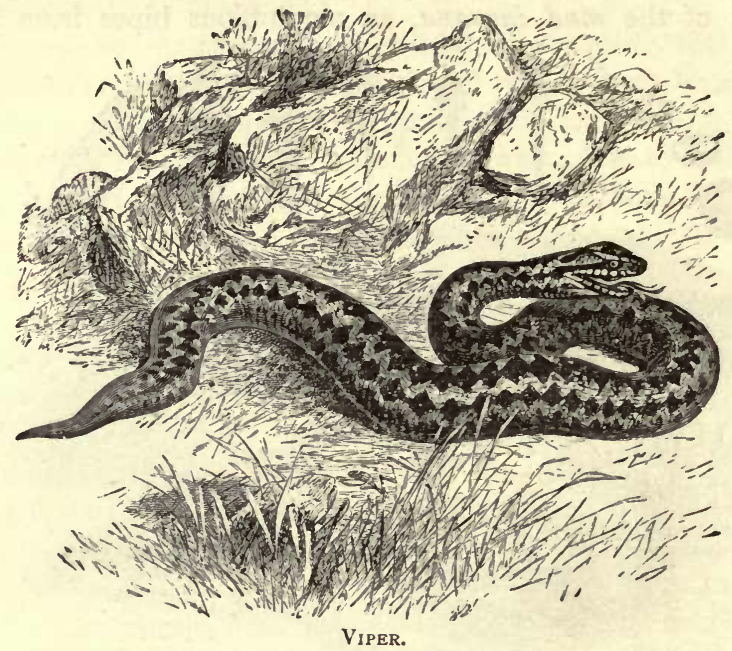

object of your publications, you will not omit to mention common

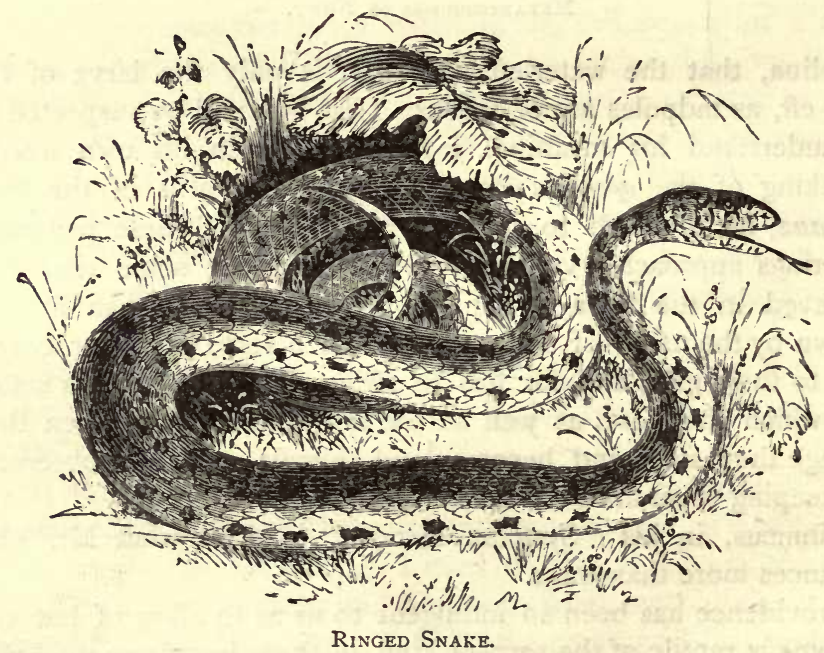

salad-oil as a sovereign remedy against the bite of the viper. 
to the blind worm (Anguis fragilis, so-called because it snaps in sunder with a small blow), I have found, on examination, that it is perfectly innocuous. ${ }^{6}$ A neighbouring yeoman (to whom I am indebted for some good hints) killed and opened a female viper about the 27 th May: he found her filled with a chain of eleven eggs, about the size of those of a blackbird; but none of them were advanced so far towards a state of maturity as to contain any rudiments of young. Though they are oviparous, yet they are viviparous also, hatching their young within their bellies, and

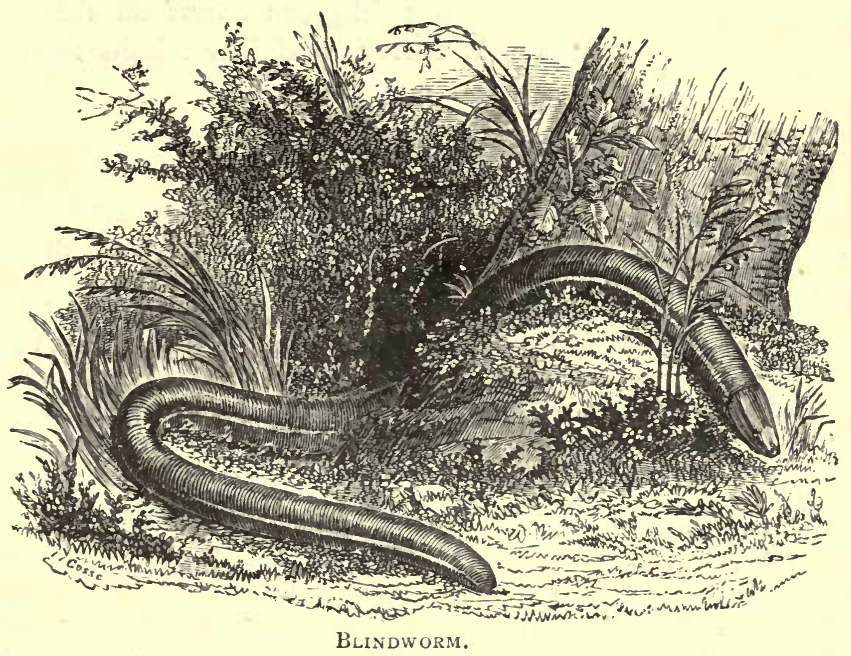

then bringing them forth. Whereas snakes lay chains of eggs every summer in my melon beds, in spite of all that my people can do to prevent them; which eggs do not hatch till the spring following, as I have often experienced. Several intelligent folks assure me that they have seen the viper open her mouth and admit her helpless young down her throat on sudden surprises, just as the female opossum does her brood into the pouch under her belly, upon the like emergencies; and yet the London vipercatchers insist. on it, to Mr. Barrington, that no such thing ever happens. ${ }^{7}$ The serpent kind eat, I believe, but once in a year; 
or rather, but only just at one season of the year. ${ }^{8}$ - Countiy people talk much of a water-snake, but, I am pretty sure, without any reason; for the common snake (Coluber natrix) delights much to sport in the water, perhaps with a view to procure frogs and other food. ${ }^{9}$

I cannot well guess how you are to make out your twelve species of reptiles, unless it be by the various species, or rather varieties, of our lacerti, of which Ray enumerates five. I have not had opportunity of ascertaining these; but remember well to have seen, formerly, several beautiful green lacerti on the sunny sandbanks near Farnham, in Surrey; and Ray admits there are such in Ireland.

\section{NOTES TO LETTER XVII.}

1 Toads lay eggs as frogs do. Every dweller in the country will be familiar with the masses of jelly-like substance in the ditches which constitutes the spawn of frogs. That of toads forms long strings instead of masses.

2 There seems to be little doubt that the secretion which exudes from the tubercles on the toad's skin is very offensive, and might irritate a delicate skin. Dogs will not mouth them a second time.

${ }^{3}$ There are so many accounts of frogs actually falling with the rain, as well as small fish, that the possibility of this happening should not be too incredulously denied. It is possible, and indeed no other explanation can be entertained, that they may have been swept up from the earth or water by a whirlwind, as sticks and straws are, and then dropped down. Those who have seen a reed stack carried into the air by a "rodges blast" on the Norfolk marshes, would not consider this suggestion an impossible one.

4 This pretty green frog which lives on trees, and is sometimes kept as a pet, is not considered a native species. Mr. J. G. Wood says he saw a colony of them in a hole in an apple-tree at Marston, near Oxford; but they must have been introduced there, or strayed from someone who kept them.

${ }_{5}^{5}$ There is but one species of newt, which goes through all its changes in the water. The male has a beautiful waving crest along its back and tail. When young it has gills; but when it reaches the perfect state it has to rise constantly to the surface to take in a supply of air. It is possible that by the term landeft, White may refer to the lizard, which belongs to a different family. Most country people of the lower order are dreadfully afraid of newts or effets, and think their bite is deadly. As a fact, however, they are quite harmless.

6 The blind-worm or slow-worm does not need a blow to induce it to cast off its tail. A sudden fright is sufficient. While you are looking at the tail wriggling and jumping about, the body quietly makes its escape. 
7 The story of the viper swallowing her young ones for their safety is so persistently told from all parts of the country by persons of veracity, that it seems cruel to doubt their accuracy of observation. No scientific and accurate naturalist has, as far as I am aware, actually seen the occurrence. Mr. Jesse seems satisfied that it does happen from the evidence he has collected, and he says that a viper-catcher on the Brighton Downs told him that he had often witnessed the fact. I think the question is still unsettled. I have never seen it myself, and I have seen a great number of vipers in close proximity.

${ }^{8}$ Snakes eat oftener than once a year, but still one meal of a frog or mouse will take a good-sized snake a long time to digest.

${ }^{9}$ The common snake takes readily to the water, and swims-sometimes altogether beneath it, and sometimes with the head and neck above. I have very often seen them doing this; and although I knew they were harmless, I did not like them diving close by me when I was swimming. There is no English species of "water-snake."

\section{LETTER XVIII.}

SELBoRne, Fuly 27 th, I 768 .

DEAR SIR, - I received your obliging and communicative letter of June 28 th, while I was on a visit at a gentleman's house, where I had neither books to turn to, nor leisure to sit down, to return you an answer to many queries, which $I$ wanted to resolve in the best manner that I am able.

A person, by my order, has searched our brooks, but could find no such fish as the Gasterosteus pungitius $;^{1}$ he found the Gasterosteus aculeatus in plenty. This morning, in a basket, I packed a little earthen pot full of wet moss, and in it some sticklebacks, male and female; the females big with spawn: some lamperns; some bull's heads ; but I could procure no minnows. This basket will be in Fleet Street by eight this evening; so I hope Mazel will have them fresh and fair to-morrow morning. I gave some directions, in a letter, to what particulars the engraver should be attentive.

Finding, while I was on a visit, that I was within a reasonable distance of Ambresbury, I sent a servant over to that town, and procured several living specimens of loaches, whicn he brought, 
safe and brisk, in a glass decanter. They were taken in the gullies that were cut for watering the meadows. From these fishes (which measured from two to four inches in length) I took the following description: "The loach, in its general aspect, has a pellucid appearance; its back is mottled with irregular collections of small black dots, not reaching much below the linea lateralis, as are the back and tail fins; a black line runs from each eye down to the nose; its belly is of a silvery white; the upper jaw projects beyond the lower, and is surrounded with six feelers, three on each side; its pectoral fins are large, its ventral much smaller; the fin behind its anus small; its dorsal-fin large, containing eight spines; its tail, where it joins to the tail-fin, remarkably broad, without any taperness, so as to be characteristic of this genus; the tail-fin is broad, and square at the end. From the breadth and muscular strength of the tail it appears to be an active nimble fish."

In my visit I was not very far from Hungerford, and did not forget to make some inquiries concerning the wonderful method of curing cancers by means of toads. Several intelligent persons, both gentry and clergy, do I. find give a great deal of credit to what is asserted in the papers, and I myself dined with a clergyman who seemed to be persuaded that what is related is matter of fact ; but, when I came to attend to his account, I thought I discerned circumstances which did not a little invalidate the woman's story of the manner in which she came by her skill. She says of herself "that, labouring under a virulent cancer, she went to some church where there was a vast crowd; on going into a pew, she was accosted by a strange clergyman, who, after expressing compassion for her situation, told her that if she would make such an application of living toads as is mentioned she would be well." Now is it likely that this unknown gentleman should express so much tenderness for this single sufferer, and not feel any for the many thousands that daily languish under this terrible disorder? Would he not have made use of this invaluable nostrum for his own emolument; or at least, by some means of publication or other, have found a method of making it public for the good of mankind? In short, this woman (as it appears to me) having set up for a 
cancer-doctress, finds it expedient to amuse the country with this dark and mysterious relation.

The water-eft has not, that I can discern, the least appearance of any gills ; for want of which it is continually rising to the surface of the water to take in fresh air. I opened a big-bellied one indeed, and found it full of spawn. Not that this circumstance at all invalidates the assertion that they are larva; for the larvice of insects are full of eggs, which they exclude the instant they enter their last state. The water-eft is continually climbing over the brims of the vessel, within which we keep it in water, and wandering away; and people every summer see numbers crawling out of the pools where they are hatched up the dry banks. There are varieties of them, differing in colour ; and some have fins up their tail and back, and some have not.

NOTE TO LETTER XVIII.

1 The Gasterostens pungitius is the ten-spined stickleback. The other is the common one with three spines.

LETTER XIX.

Selborne, August $\mathbf{1}$ th, $\mathbf{1} 768$.

DEAR SIR,-I have now, past dispute, made out three distinct species of the willow-wrens (motacilla trockili) which constantly and invariably use distinct notes. But at the same time I am obliged to confess that I know nothing of your willow-lark. In my letter of April I8th, I had told you peremptorily that I knew your willow-lark, but had not seen it then; but when I came to procure it, it proved in all respects a very motacilla trochilus, only that it is a size larger than the two other, and the ycllowgreen of the whole upper part of the body is more vivid, and the belly of a clearer white. I have specimens of the three sorts now lying before me, and can discern that there are three gradations of sizes, and that the least has black legs, and the other two flesh- 
coloured ones. The yellowest bird is considerably the largest, and has its quill-feathers and secondary feathers tipped with white, which the others have not. This last haunts only the tops of trees in high beechen woods, and makes a sibilous grasshopper-like noise, now and then, at short intervals, shivering a little with its wings when it sings; and is, I make no doubt now, the regulus non cristatus of Ray, which he says "cantat voce stridulâ locuste." Yet this great ornithologist never suspected that there were three species.

\section{LETTER XX.}

SELBORne, October 8 th, 1768 .

IT is I find in zoology as it is in botany; all nature is so full that that district produces the greatest variety which is the most examined. Several birds, which are said to belong to the north only, are it seems often in the south. I have discovered this summer three species of birds with us, which writers mention as only to be seen in the northern counties. The first that was brought me (on the $14^{\text {th }}$ May), was the sandpiper, tringa hypoleucus: it was a cockbird, and haunted the banks of some ponds near the village; and, as it had a companion, doubtless intended to have bred near that water. Besides, the owner has told me since, that on recollection, he has seen some of the same birds round his ponds in former summers.

The next bird that I procured (on the 2 Ist May) was a male red-backed butcher bird, lanius collario. My neighbour, who shot it, says that it might easily have escaped his notice, had not the outcries and chattering of the whitethroats and other small birds drawn his attention to the bush where it was; its craw was filled with the legs and wings of beetles.

The next rare birds (which were procured for me last week) were some ring-ousels, turdi torquati. ${ }^{1}$

This week twelve months a gentleman from London, being with us, was amusing himself with a gun, and found, he told us, on an 
old yew hedge where there were berries, some birds like blackbirds, with rings of white round their necks: a neighbouring farmer also at the same time observed the same; but, as no specimens were procured, little notice was taken. I mentioned this circumstance to you in my letter of November $4^{\text {th }}, 1767$ (you, however, paid but small regard to what I said, as I had not seen these birds myself); but last week the aforesaid farmer, seeing a large flock, twenty or thirty of these birds, shot two cocks and two hens, and says, on recollection, that he remembers to

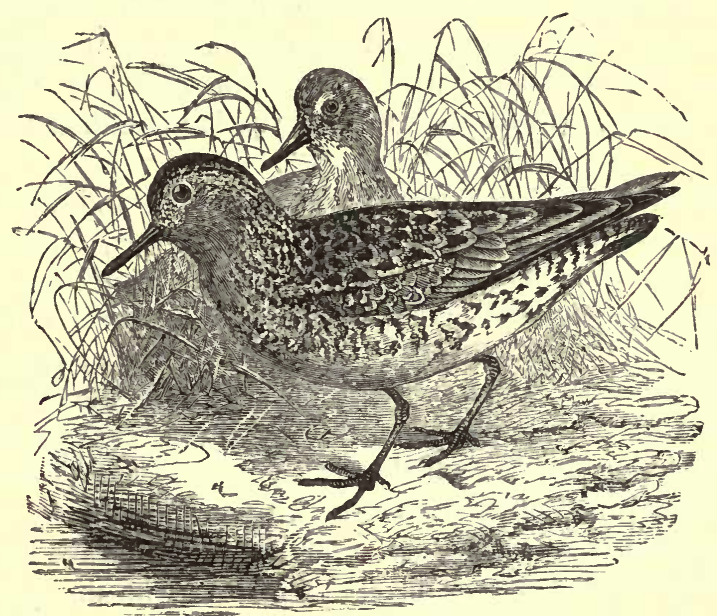

The KNot SANdPIPER (Tringa canutus).

have observed these birds again last spring, about Lady-day, as it were on their return to the north. Now perhaps these ousels are not the ousels of the north of England, but belong to the more northern parts of Europe; and may retire before the excessive rigour of the frosts in those parts, and return to breed in the spring, when the cold abates. If this be the case, here is discovered a new bird of winter passage, concerning whose migrations the writers are silent; but if these birds should prove the ousels of the north of England, then here is a migration disclosed within our own kingdom never before remarked. It does not yet appear 
whether they retire beyond the bounds of our island to the south; but it is most probable that they usually do, or else one cannot suppose that they would have continued so long unnoticed in the southern countries. The ousel is larger than a blackbird, and feeds on haws; but last autumn (when there were no haws) it fed on yew-berries: in the spring it feeds on ivy-berries, which ripen only at that season, in March and April.

I must not omit to tell you (as you have been so lately on the study of reptiles) that my people, every now and then of late, draw up with a bucket of water from my well, which is sixty-three feet deep, a large black warty lizard with a fin-tail and yellow belly. How they first came down at that depth, and how they were ever to have got out thence without help, is more than I am able to say.

My thanks are due to you for your trouble and care in the examination of a buck's head. As far as your discoveries reach at present, they seem much to corroborate my suspicions; and I hope Mr. — may find reason to give his decision in my favour; and then, I think, we may advance this extraordinary provision of nature as a new instance of the wisdom of God in the creation.

As yet I have not quite done with my history of the adicnemus, or stone-curlew ; for I shall desire a gentleman in Sussex (near whose house these birds congregate in vast flocks in the autumn) to observe nicely when they leave him (if they do leave him), and when they return again in the spring: I was with this gentleman lately, and saw several single birds.

\section{NOTE TO LETTER XX.}

1 The ring-ousel was common on the Eglwyseg Rocks bordering the Vale of Llangollen. It appears to make a partial migration to the south of England in the autumn. 


\section{LFTTER XXI.}

Selborne, Nov. 28th, 1768.

DEAR SIR,-With regard to the cedicnemus, or stone-curlew, I intend to write very soon to my friend near Chichester, in whose neighbourhood these birds seem most to abound; and shall urge him to take particular notice when they begin to congregate, and

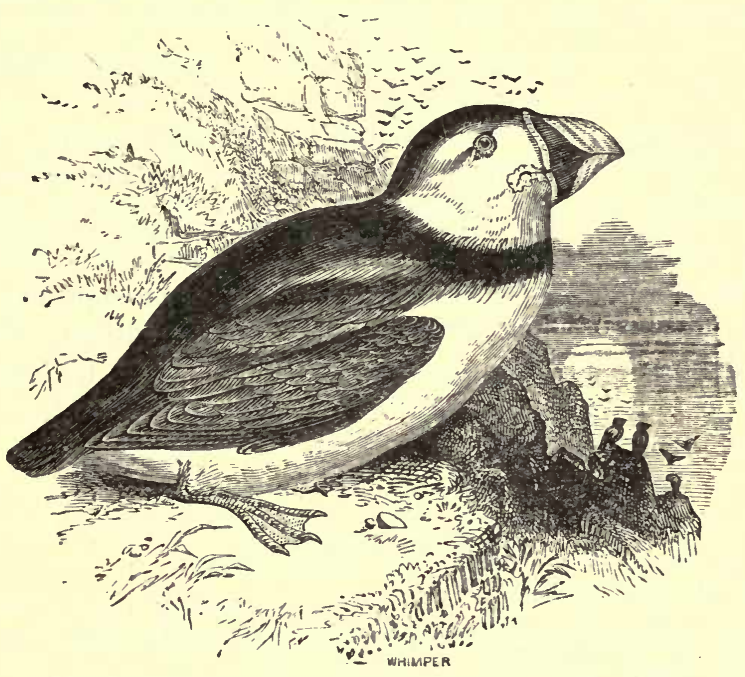

The Puffin (Puffinus arcticus).

afterwards to watch them most narrowly whether they do not withdraw themselves during the dead of the winter. When I have obtained information with respect to this circumstance, I shall have finished my history of the stone-curlew, which I hope will prove to your satisfaction, as it will be, I trust, very near the truth. This gentleman, as he occupies a large farm of his own, and is abroad early and late, will be a very proper spy upon the motions of these birds; and besides, as I have prevailed on him to buy the 
Naturalist's Journal (with which he is much delighted), I shall expect that he will be very exact in his dates. It is very extraordinary, as you observe, that a bird so common with us should never struggle to you.

And here will be the properest place to mention, while I think of it, an anecdote which the above-mentioned gentleman told me when I was last at his house; which was that, in a warren joining to his outlet, many daws (corvi moneduloe) build every year in the rabbit-burrows under ground. The way he and his brothers used to take their nests, while they were boys, was by listening at the mouths of the holes; and, if they heard the young ones cry, they twisted the nest out with a forked stick. Some water-fowls (viz., the puffins) breed, I know, in that manner; but I should never have suspected the daws of building in holes on the flat ground. ${ }^{1}$

Another very unlikely spot is made use of by daws as a place to breed in, and that is Stonehenge. These birds deposit their nests in the interstices between the upright and the impost stones of that amazing work of antiquity: which circumstance alone speaks the prodigious height of the upright stones, that they should be tall enough to secure those nests from the annoyance of shepherd-boys, who are always idling round that place.

One of my neighbours last Saturday, November 26 th, saw a martin in a sheltered bottom : the sun shone warm, and the bird was hawking briskly after flies. I am now perfectly satisfied that they do not all leave this island in the winter.

You judge very right, I think, in speaking with reserve and caution concerning the cures done by toads : for, let people advance what they will on such subjects, yet there is such a propensity in mankind towards deceiving and being deceived, that one cannot safely relate anything from common report, especially in print, without expressing some degree of doubt and suspicion.

Your approbation, with regard to my new discovery of the migration of the ring-ousel, gives me satisfaction; and I find you concur with me in suspecting that they are foreign birds which visit us. You will be sure, I hope, not to omit to make inquiry whether your ring-ousels leave your rocks in the autumn. What puzzles me most, is the very short stay they make with us; for in 
about three weeks they are all gone. I shall be very curious to remark whether they will call on us at their return in the spring, as they did last year.

I want to be better informed with regard to ichthyology. If fortune had settled me near the seaside, or near some great river, my natural propensity would soon have urged me to have made myself acquainted with their productions: but as I have lived mostly in inland parts, and in an upland district, my knowledge of fishes extends little farther than to those common sorts which our brooks and lakes produce.

$$
\text { I am, etc. }
$$

\section{NOTE TO LETTER XXI.}

1 At Craigyrhiw, a limestone cliff near Oswestry, on the Welsh border, where the jackdaws bred by the thousand, numbers of them made their nests in the rabbit holes at the foot of the rocks. I often used to find a stock-dove's nest in a rabbit hole there too. We would sit and watch them from a crag, until we saw a bird leave or enter. On the Norfolk warrens, too, stock-doves breed in the rabbit holes.

\section{LETTER XXII.}

SELBORNe, fan. 2nd, 1769 .

DeAr Sir,-As to the peculiarity of jackdaws building with us usider the ground in rabbit-burrows, you have, in part, hit upon the reason; for, in reality, there are hardly any towers or steeples in all this county. And perhaps, Norfolk excepted, ${ }^{1}$ Hampshire and Sussex are as meanly furnished with churches as almost any counties in the kingdom. We have many livings of two or three hundred pounds a year, whose houses of worship make little better appearance than dovecots. When I first saw Northamptonshire, Cambridgeshire, and Huntingdonshire, and the fens of Lincolnshire, I was amazed at the number of spires which presented themselves in every point of view. As an admirer of prospects, I have 
reason to lament this want in my own county; for such objects are very necessary ingredients in an elegant landscape.

What you mention with respect to reclaimed toads raises my curiosity. An ancient author, though no naturalist, has well remarked that " every kind of beasts, and of birds, and of serpents, and things ill the sea, is tamed, and hath been tamed, of mankind."

It is a satisfaction to me to find that a green lizard has actually been procured for you in Devonshire; because it corroborates my discovery, which I made many years ago, of the same sort, on a

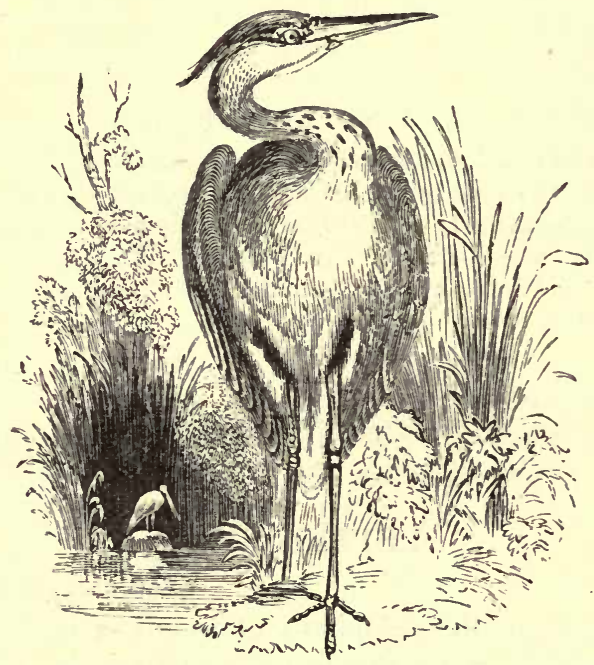

HERON.

sunny sandbank near Farnham, in Surrey. I am well acquainted with the South Hams of Devonshire ; and can suppose that district, from its southerly situation, to be a proper habitation for such animals in their best colours.

Since the ring-ousels of your vast mountains do certainly not forsake them against winter, our suspicions that those which visit this neighbourhood about Michaelmas are not English birds, but driven from the more northern parts of Europe by the frosts, 
are still more reasonable; and it will be worth your pains to endeavour to trace from whence they come, and to inquire why they make so very short a stay.

In your account of your error with regard to the two species of herons, you incidentally gave me great entertainment in your description of the heronry at Cressi Hall ; which is a curiosity I never could manage to see. Fourscore nests of such a bird on one tree is a rarity which I would ride half as many miles to have a sight of. Pray be sure to tell me in your next whose seat Cressi Hall is, and near what town it lies. I have often thought that those vast extents of fens have never been sufficiently explored. If half-a-dozen gentlemen, furnished with a good strength of waterspaniels, were to beat them over for a week, they would certainly find more species. ${ }^{2}$

There is no bird, I believe, whose manners I have studied more than that of the caprimulgus (the goat-sucker), as it is a wonderful and curious creature ; but I have always found that though sometimes it may chatter as it flies, as I know it does, yet in general it utters its jarring note sitting on a bough ; and I have for many a half hour watched it as it sat with its under mandible quivering, and particularly this summer. It perches usually on a bare twig, with its head lower than its tail, in an attitude well expressed by your draughtsman in the folio "British Zoology." 3 This bird is most punctual in beginning its song exactly at the close of day; so exactly that I have known it strike up more than once or twice just at the report of the Portsmouth evening gun, which we can hear when the weather is still It appears to me past all doubt that its notes are formed by organic impulse, by the powers of the parts of its windpipe, formed for sound, just as cats pur. You will credit me, I hope, when I assure you that, as my neighbours were assembled in an hermitage on the side of a steep hill where we drink tea, one of these churn-owls came and settled on the cross of that little straw edifice and began to chatter, and continued his note for many minutes; and we were all struck with wonder to find that the organs of that little animal, when put in motion, gave a sensible vibration to the whole building! This bird also sometimes makes a small squeak, repeated four or five 
times; and I have observed that to happen when the cock has been pursuing the hen in a toying way through the boughs of a tree.

It would not be at all strange if your bat, which you have procured, should prove a new one, since five species have been found in a neighbouring kingdom. The great sort that I mentioned is certainly a nondescript; I saw but one this summer, and that I had no opportunity of taking.

Your account of the Indian grass was entertaining. I am no angler myself; but inquiring of those that are, what they supposed that part of their tackle to be made of ?-they replied, "Of the intestines of a silkworm." 4

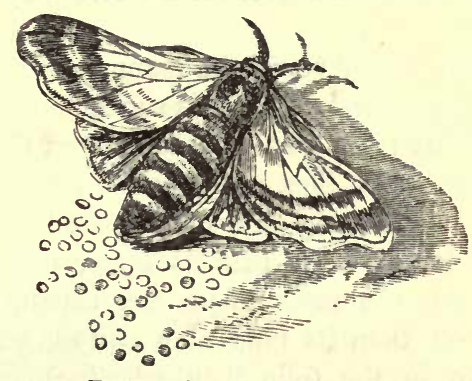

Female Silkworm Moth

Though I must not pretend to great skill in entomology, yet I cannot say that I am ignorant of that kind of knowledge; I may now and then perhaps be able to furnish you with a little information.

The vast rains ceased with us much about the same tine as with you, and since we have had delicate weather. Mr. Barker, who has measured the rain for more than thirty years, says, in a late letter, that, more has fallen this year than in any he ever attended to; though from July $I_{76}$ to January 1764 , more fell than in any seven months of this year. 


\section{NOTES TO LETTER XXII.}

I White cannot have known much of Norfolk, for it is as thickly studded with churches as it well can be, and many of them remarkably fine.

${ }^{2}$ The fens are now well drained and well explored. They were indeed "happy hunting grounds" for the naturalist. The Norfolk Broads are still left, and offer somewhat the same features as the fens.

3 The goat-sucker or nightjar perches lengthwise on a bough instead of across it as other birds do. The eggs, which it lays on the ground, in an apology for a nest, are most beautifully marbled.

4 The gut used by anglers is made from the silkworm, and is the substance from which the silk would be spun if the caterpillar were allowed to continue its existence. The Indian grass is of very little use for fishing, as it is brittle.

\section{LETTER XXIII.}

Selborne, Feb. 28th, I769.

DEAR SIR,-It is not improbable that the Guernsey lizard and our green lizards may be specifically the same; all that I know is, that, when some years ago many Guernsey lizards were turned loose in Pembroke College garden, in the University of Oxford, they lived a great while, and seemed to enjoy themselves very well, but never bred. Whether this circumstance will prove anything either way I shall not pretend to say.

I return you thanks for your account of Cressi Hall; but recollect, not without regret, that in June 1746. I was visiting for a week together at Spalding, without ever being told that such a curiosity was just at hand. Pray send me word in your next what sort of tree it is that contains such a quantity of herons' nests; and whether the heronry consists of a whole grove of wood, or only of a few trees.

It gave me satis action to find we accorded so well about the caprimulgus; all I contended for was to prove that it often chatters sitting as well as flying; and therefore the noise was voluntary, and from organic impulse, and not from the resistance ot the air against the hollow of its mouth and throat.

If ever I saw anything like actual migration, it was last Michael- 
mas Day. I was travelling; and out early in the morning; at first there was a vast fog; but, by the time that I was got seven or eight miles from home towards the coast, the sun broke out into a delicate warm day. We were then on a large heath or common, and I could discern, as the mist began to break away, great numbers of swallows (hirundines rustica) clustering on the stunted shrubs and bushes, as if they had roosted there all night. As soon as the air became clear and pleasant they were all on the wing at once; and, by a placid and easy flight, proceeded on southward towards the sea; after this I did not see any more flocks, only now and then a straggler.

I cannot agree with those persons that assert that the swallow kind disappear some and some gradually, as they come, for the bulk of them seem to withdraw at once; only some stragglers stay behind a long while, and do never, there is the greatest reason to believe, leave this island. Swallows seem to lay themselves up, and to come forth in a warm day, as bats do continually of a warm evening, after they have disappeared for weeks. For a very respectable gentleman assured me that, as he was walking with some friends under Merton Wall on a remarkably hot noon, either in the last week in December or the first week in January, he espied three or four swallows huddled together on the moulding of one of the windows of that college. I have frequently remarked that swallows are seen later at Oxford than elsewhere; is it owing to the vast massy buildings of that place, to the many waters round it, or to what else?

When I used to rise in the morning last autumn, and see the swallows and martins clustering on the chimneys and thatch of the neighbouring cottages, I could not help being touched with a secret delight, mixed with some degree of mortification; with delight, to observe with how much ardour and punctuality those poor little birds obeyed the strong impulse towards migration, or hiding, imprinted on their minds by their great Creator; and with some degree of mortification, when I reflected that, after ali our pains and inquiries, we are yet not quite certain to what regions they do migrate; and are still farther embarrassed to find that some do not actually migrate at all. 
These reflections made so strong an impression on my imagination, that they became productive of a composition that may perhaps amuse you for a quarter of an hour when next I have the honour of writing to you.

\section{LETTER XXIV.}

Selborne, May $29 t h$, i7ég.

DeAR Sir,-The scarabcaus fullo I know very well, having seen it in collections; but have never been able to discover one wild in its natural state. Mr. Banks told me he thought it might be found on the seacoast. ${ }^{1}$

On the $13^{\text {th }}$ April I went to the sheep-down, where the ringousels have been observed to make their appearance at spring and fall, in their way perhaps to the north or south; and was much pleased to see these birds about the usual spot. We shot a cock and a hen; they were plump and in high condition. The hen had but very small rudiments of eggs within her, which proves they are late breeders; whereas those species of the thrush kind that remain with us the whole year have fledged young before that time. In their crops was nothing very distinguishable, but somewhat that seemed like blades of vegetables nearly digested. In autumn they feed on haws and yew-berries, and in the spring on ivy-berries. I dressed one of these birds, and found it juicy and well flavoured. It is remarkable that they make but a few days' stay in their spring visit, but rest near a fortnight at Michaelmas. These birds, from the observations of three springs and two autumns, are most punctual in their return; and exhibit a new migration unnoticed by the writers, who supposed they never were to be seen in any southern countries.

. One of my neighbours lately brought me a new salicaria, which at first I suspected might have proved your willow-lark, but on a. nicer examination, it answered much better to the description 
of that species which you shot at Revesby, in Lincolnshire. My bird I describe thus : "It is a size less than the grasshopper-lark; the head, back, and coverts of the wings, of a dusky brown, without those dark spots of the grasshopper-lark; over each eye is a milk-white stroke; the chin and throat are white, and the under parts of a yellowish white; the rump is tawny, and the feathers of the tail sharp-pointed; the bill is dusky and sharp, and the legs are dusky; the hinder claw long and crooked." The person that shot it says that it sung so like a reed-sparrow that he took it for one; and that it sings all night: but this account merits farther inquiry. For my part, I suspect it is a second sort of locustela, hinted at by Dr. Derham in Ray's Letters : see p. I08. He also procured me a grasshopper-lark.

The question that you put with regard to those genera of animals that are peculiar to America, viz., how they came there, and whence? is too puzzling for me to answer; and yet so obvious as often to have struck me with wonder. If one looks into the writers on that subject little satisfaction is to be found. Ingenious men will readily advance plausible arguments to support whatever theory they shall choose to maintain; but then the misfortune is, every one's hypothesis is each as good as another's, since they are all founded on conjecture. The late writers of this sort, in whom may be seen all the arguments of those that have gone before, as I remember, stock America from the western coast of Africa and the south of Europe; and then break down the Isthmus that bridged over the Atlantic. But this is making use of a violent piece of machinery; it is a difficulty worthy of the interposition of a god! "Incredulus odi." 
TO THOMAS PENNANT, ESQUIRE.

\title{
THE NATURALIST'S SUMMER-EVENING WALK.
}

\author{
- equidem credo, quia sit divinitus illis \\ Ingenium. \\ VIRG. Georg.
}

When day declining sheds a milder gleam, What time the may-fly* haunts the pool or strean;

When the still owl skims round the grassy mead, What time the timorous hare limps forth to feed; Then be the time to steal adown the vale, And listen to the vagrant† cuckoo's tale; To hear the clamorous $\ddagger$ curlew call his mate, Or the soft quail his tender pain relate; 'T'o see the swallow sweep the dark'ning plain Belated, to support her infant train; To mark the swift in rapid giddy ring Dash round the steeple, unsubdued of wing: Amusive birds! - say where your hid retreat When the frost rages and the tempests beat; Whence your return, by such nice instinct led, When spring, soft season, lifts her bloomy head $\boldsymbol{t}^{\prime}$ Such baffled searches mock man's prying pride, 'The God of NATURE is your secret guide!

While deep'ning shades obscure the face of day; 'T'o yonder bench leaf-shelter'd let us stray, 'Till blended objects fail the swimming sight, And all the fading landscape sinks in night;

* T $T l_{\mathrm{ie}}$ angler's may-fly, the ephemera vulgata LinN., comes forth from its aureli.ı state, and emerges out of the water about six in the evening, and dies about eleven at night, determining the date of its fly state in about five or six hours. They usually begin to appear about the $4^{\text {th }}$ June, and continue in succession for near a fortnight. See Swammerdam, Derham, Scopoli, etc.

$\dagger$ Vagrant cuckoo ; so called because, being tied down by no incubation or attendance about the nutrition of its young, it wanders without control.

f Charadrius adicnemus. 
'I'o hear the drowsy ${ }^{1}$ dor come brushing by

With buzzing wing, or the shrill* cricket cry;

To see the feeding bat glance through the wood;

To catch the distant falling of the flood;

While o'er the cliff th' awaken'd churn-owl hung

Through the still gloom protracts his chattering song;

While high in air, and poised upon his wings,

Unseen, the soft enamour'd † woodlark sings :

These, Nature's works, the curious mind employ,

Inspire a soothing melancholy joy :

As fancy warms; a pleasing kind of pain

Steals o'er the cheek, and thrills the creeping vein!

Each rural sight, each sound, each smell, comivine;

The tinkling sheep-bell or the breath of kine;

The new-mown hay that scents the swelling breeze,

Or cottage-chimney smoking through the trees.

The chilling night-dews fall :-away, retire !

For see, the glow-worm lights her amorous fire $! \ddagger$

Thus, ere night's veil had half obscured the sky,

Th' impatient damsel hung her lamp on high :

True to the signal, by love's meteor led,

Leander hasten'd to his Hero's bed. §

I am, etc.

\section{NOTE TO LETTER XXIV.}

1 This insect, the Kentish chafer, is said to be only found in Ksnt.

* Gryllus campestris.

† In hot summer nights wood-larks soar to a prodigious height, and hang singing in the air.

$\ddagger$ The light of the female glow-worm (as she often crawls up the stalk of a grass to make herself more conspicuous) is a signal to the male, which is a slender dusky scarabaus.

$\S$ See the story of Hero and Leander. 


\section{LETTER XXV.}

Seloorne, Aug. 3oth, I 769 .

DEAR Sir,--It gives me satisfaction to find that my account of the ousel migration pleases you. You put a very shrewd question when you ask me how I know that their autumnal migration is southward? Was not candour and openness the very life of natural history, I should pass over this query just as a sly commentator does over a crabbed passage in a classic ; but common ingenuousness obliges me to confess, not without some degree of shame, that I only reasoned in that case from analogy. For as all other autumnal birds migrate from the northward to us, to partake of our milder winters, and return to the northward again when the rigorous cold abates, so I concluded that the ring-ousels did the same, as well as their congeners the fieldfares; and especially as ring-ousels are known to haunt cold mountainous countries : but I have good reason to suspect since that they may come to us from the westward; because I hear from very good authority, that they breed on Dartmoor; and that they forsake that wild district about the time that our visitors appear, and do not return till late in the spring.

I have taken a great deal of pains about your salicaria and mine, with a white stroke over its eye and a tawny rump. ${ }^{1}$ I have surveyed it alive and dead, and have procured several specimens, and am perfectly persuaded myself (and trust you will soon become convinced of the same) that it is no more nor less than the passer arundinaceus minor of Ray. This bird, by some means or other, seems to be entirely omitted in the British Zoology; and one reason probably was because it is so strangely classed in Ray, who ranges it among his picis affines. It ought no doubt to have gone among his avicula caudâ unicolore, and among your slenderbilled small birds of the same division. Linnæus might with great propriety have put it into his genus of motacilla; and motacilla salicaria of his fauna suecica seems to come the nearest to it. It is no uncommon bird, haunting the sides of ponds and rivers 
where there is covert, and the reeds and sedges of moors. The country people in some places call it the sedge-bird. It sings incessantly night and day during the breeding-time, imitating the note of a sparrow, a swallow, a skylark; and has a strange hurrying manner in its song. My specimens correspond most minutely to the description of your fen salicaria shot near Revesby. Mr. Ray has given an excellent characteristic of it when he says, "Rostrum et pedes in hâc aviculâ multò majores sunt quâm pro corporis ratione." See letter, May 29th, I769. (Preceding letter, xxiv.)

I have got you the egg of an redicnemus, or stone-curlew, which was picked up in a fallow on the naked ground; there were two, but the finder inadvertently crushed one with his foot before he saw them.

When I wrote to you last year on reptiles, I wish I had not forgot to mention the faculty that snakes have of stinking se defendendo. I knew a gentleman who kept a tame snake, which was in its person as sweet as any animal while in good humour and unalarmed; but as soon as a stranger, or a dog or cat, came in, it fell to hissing, and fiiled the room with such nauseous effluvia as rendered it hardly supportabie. Thus the squnck, or stonck, of Ray's "Synop. Quadr." is an innocuous and sweet animal; but, when pressed hard by dogs and men, it can eject such a most pestilent and fetid smell and excrement, that nothing can be more horrible.

A gentleman sent me lately a fine specimen of the lanius minor cinerascens cum maculâ in scapulis albâ, Raii; which is a bird that, at the time of your publishing your two first volumes of "British Zoology," I find you had not seen. You have described it well from Edwards's drawing.

\section{NOTE TO LETTER XXV.}

1 The bird referred to is the sedge-warbler. White says it sings like a reedsparrow. The reed-sparrow has no song, but the reed-wren or reed-warbler ha;, and White must mean this species by the term reed-sparrow. 


\section{LETTER XXVI.}

Selborne, December 8 th, i769.

DEAR SiR, - I was much gratified by your communicative letter on your return from Scotland, where you spent some considerable time, and gave yourself good room to examine the natural curiosities of that extensive kingdom, both those of the islands, as well

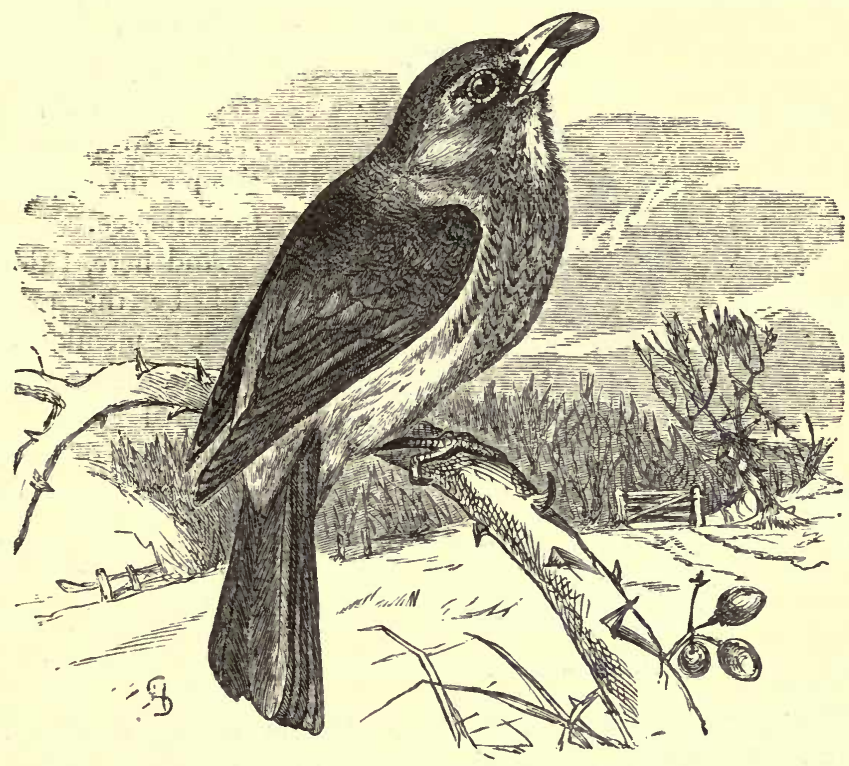

The Fieldfare.

as those of the highlands. The usual bane of such expeditions is hurry, because men seldom allot themselves half the time they should do ; but, fixing on a day for their return, post from place to place, rather as if they were on a journey that required dispatch, than as philosophers investigating the works of nature. You must have made, no doubt, many discoveries, and laid up a good fund of materials for a future edition of the "British Zoology;" and 
will have no reason to repent that you have bestowed so much pains on a part of Great Britain that perhaps was never so well examined before.

It has always been matter of wonder to me that fieldfares, which are so congenerous to thrushes and blackbirds, should never choose to breed in England; but that they should not think even the highlands cold and northerly, and sequestered enough, is a circumstance still more strange and wonderful. The ring-ousel, you find, stays in Scotland the whole year round; so that we have

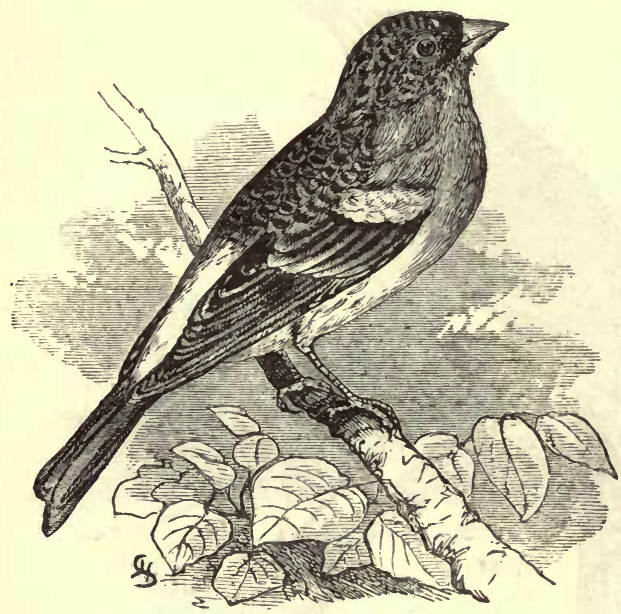

The Brambling. reason to conclude that those migrators that visit us for a short space every autumn do not come from thence.

And here, I think, will be the proper place to mention that those birds were most punctual again in their migration this autumn, appearing, as before, about the 3 oth September; but their flocks were larger than common, and their stay protracted somewhat beyond the usual time. If they came to spend the whole winter with us, as some of their congeners do, and then left us, as they॰do, in spring, I should not be so much struck with the occurrence, since it would be similar to that of the other winter birds of passage; but when I see them for a fortnight at Michaelmas, and again for about a week in the middle of April, I am seized with wonder, and long to be informed whence these travellers come, and whither they go, since they seem to use our hills merely as an inn or baiting place.

Your account of the greater brambling, or snow-fleck, is very 
amusing; and strange it is that such a short-winged bird should delight in such perilous voyages over the northern ocean! Some country people in the winter time have every now and then told me that they have seen two or three white larks on our downs but, on considering the matter, I begin to suspect that these are some stragglers of the birds we are talking of, which sometimes perhaps may rove so far to the southward.

It pleases me to find that white hares are so frequent on the Scottish mountains, and especially as you inform me that it is a distinct species; for the quadrupeds of Britain are so few, that every new species is a great acquisition.

The eagle-owl, could it be proved to belong to us, is so majestic a bird, that it would grace our fauna much. I never was informed before where wild-geese are known to breed.

You admit, I find, that I have proved your fen salicaria to be the lesser reed-sparrow of Ray; and I think you may be secure that I am right, for I took very particular pains to clear up that matter, and had some fair specimens; but, as they were not well preserved, they are decayed already. You will, no doubt, insert it in its proper place in your next edition. Your additional plates will much improve your work.

De Buffon, I know, has described the water shrew-mouse: but still I am pleased to find you have discovered it in Lincolnshire, for the reason I have given in the article of the white hare.

As a neighbour was lately ploughing a dry, chalky field, far removed from any water, he turned out a water-rat, that was curiously lain up in a hybernaculum artificially formed of grass and leaves. At one end of the burrow lay above a gallon of potatoes regularly stowed, on which it was to have supported itself for the winter. But the difficulty with me is how this amphibius mus came to fix its winter station at such a distance from the water. Was it determined in its choice of that place by the mere accident of finding the potatoes which were planted there; or is it the constant practice of the aquatic rat to forsake the neighbourhood of the water in the colder months?

Though I delight very little in analogous reasoning, knowing how fallacious it is with respect to natural history; yet, in the 
following instance, I cannot help being inclined to think it may conduce towards the explanation of a difficulty that I have mentioned before, with respect to the invariable early retreat of the hirundo apus, or swift, so many weeks before its congeners; and that not only with us, but also in Andalusia, where they also begin to retire $a b$ sut the beginning of August.

The great large bat (which by-the-by is at present a nondescript in England, and what I have never been able yet to procure) retires or migrates very early in the summer; it also ranges very high for its food, feeding in a different region of the air; and that is the reason I never could procure one. Now this is exactly the case with the swifts; for they take their food in a more exalted region than the other species, and are very seldom seen hawking for flies near the ground, or over the surface of the water. From hence I would conclude that these hirundines and the larger bats are supported by some sorts of high-flying gnats, scarabs, or phalcence, that are of short continuance; and that the short stay of these strangers is regulated by the defect of their food.

By my journal it appears that curlews clamoured on to October 3rst; since which I have not seen nor heard any. Swallows were observed on to Nov zmber 3 rd.

\section{LETTER XXVII.}

Selborne, Feb. 22nd, 1770 .

DEAR SIR,-Hedgehogs abound in my gardens and fields. The manner in which they eat the roots of the plantain in my grass-walks is very curious; with their upper mandible, which is much longer than their lower, they bore under the plant, and so eat the root off upwards, leaving the tuft of leaves untouched. In this respect they are serviceable, as they destroy a very troublesome weed; but they deface the walks in some measure by digging little round holes. It appears, by the dung that they 
drop upon the turf, that beetles are no inconsiderable part of their food. 1 In June last I procured a litter of four or five young hedgehogs, which appeared to be about five or six days old: they, I find, like puppies, are born blind, and could not see when they came to my hands. No doubt their spines are soft and flexible at the time of their birth, or else the poor dam would have but a bad time of it in the critical moment of parturition, but it is plain they soon harden; for these little pigs had such stiff prickles on their backs and sides as would easily have fetched

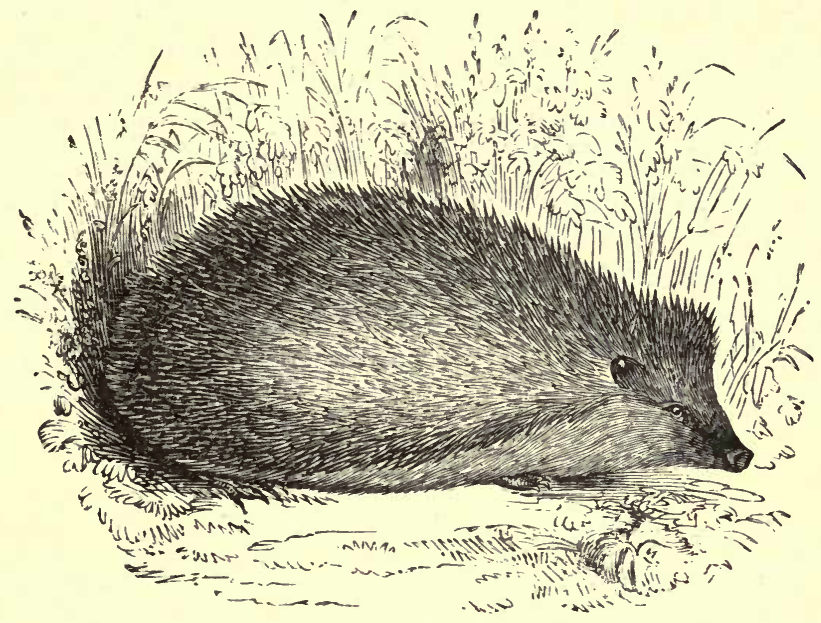

HEDGEHOG.

blood, had they not been handled with caution. Their spines are quite white at this age; and they have little hanging ears, which I do not remember to be discernible in the old ones. They can, in part, at this age draw their skin down over their faces; but are not able to contract themselves into a ball, as they do, for the sake of defence, when full grown. The reason, I suppose, is, because the curious muscle that enables the creature to roll itself up in a ball was not then arrived at its full tone and firmness. Hedgehogs make a deep and warm hybernaculum with leaves and moss, in which they conceal themselves for the winter: 
but I never could find that they stored in any winter provision, as some quadrupeds certainly do.

I have discovered an anecdote with respect to the fieldfare (turdus pilaris), which I think is particular enough; this bird, though it sits on trees in the day-time, and procures the greatest part of its food from white-thorn hedges; yea, moreover, builds on very high trees, as may be seen by the fauna suecica; yet always appears with us to roost on the ground. They are seen to come in flocks just before it is dark, and to settle and nestle among the heath on our forest. ${ }^{2}$ And besides, the larkers in dragging their nets by night, frequently catch them in the wheat stubbles; while the bat-fowlers, who take many red-wings in the hedges, never entangle any of this species. Why these birds, in the matter of roosting, should differ from all their congeners, and from themselves also with respect to their proceedings by day, is a fact for which I am by no means able to account.

I have somewhat to inform you of concerning the moose-deer; but in general foreign animals fall seldom in my way; my little intelligence is confined to the narrow sphere of my own observations at home.

\section{NOTES TO LETTER XXVII.}

1 Hedgehogs are indiscriminate feeders upon flesh or vegetables, insects or eggs. It is persistently asserted by country people, and as persistently denied by naturalists, that the nedgehog will suck the teats of sleeping cows. That it is occasionally up to mischief the following note copied from the Field of May 24th, 1879, will show :-

"Some few days ago a farmer had an ewe caught in some brambles, and when he went to see his sheep in the morning, he found that something had eaten the ewe's udder off. Of course he killed the sheep at once, and, as he was taking it home in the cart, I thought it was a strange case, and got up into the cart and examined the part that had been bitten. I saw the marks of small teeth on the skin, and told the farmer I thought it was a hedgehog. I set some traps where the blood had been spilt on the ground, and strewed some small portions of half-decayed liver round about the traps for one or two nights. About the third night the portions of liver were all gone. I left the traps set, and strewed more liver, and this morning $I$ had got a very large hedgehog, a little over $2 \mathrm{lb}$. weight. I skinned him, and examined the 
stomach, and found in it some soft dark-brown pulpy substance, mixed with a small quantity of wool.

"W. R. SMITH, GaMeKeEPER, "Okehampton, N. Devon."

2 The fieldfare and red-wing nest among the pines and firs of Norway and Sweden, and arrive in England in large flocks in the winter.

\section{LETTER XXVIII.}

Selborne, March, I77o.

ON Michaelmas-day I768 I managed to get a sight of the female moose belonging to the Duke of Richmond, at Goodwood ; but was greatly disappointed, when I arrived at the spot, to find that it died, after having appeared in a languishing way for some time on the morning before. However, understanding that it was not stripped, I proceeded to examine this rare quadruped; I found it in an old greenhouse, slung under the belly and chin by ropes, and in a standing posture; but, though it had been dead for so short a time, it was in so putrid a state that the stench was hardly supportable. The grand distinction between this deer, and any other species that I have ever met with, consisted in the strange length of its legs; on which it was tilted up much in the manner of the birds of the gralla order. I measured it, as they do a horse, and found that, from the ground to the withers it was just five feet four inches; which height answers exactly to sixteen hands, a growth that few horses arrive at: but then, with this length of legs, its neck was remarkably short, no more than twelve inches; so that, by straddling with one foot forward and the other backward, it grazed on the plain ground, with the greatest difficulty, between its legs; the ears were vast and lopping, and as long as the neck; the head was about twenty inches long, and ass-like; and had such a reaundancy of upper lip as I never saw before, with huge nostrils. This lip, travellers say, is esteemed a dainty dish in North America. It is very reasonable to suppose that this creature supports itself chiefly by 
browsing of trees, and by wading after water plants; towards which way of livelihood the length of legs and great lip must contribute much. I have read somewhere that it delights in eating the nymphaa, or water-lily. From the fore-feet to the belly behind the shoulder it measured three feet and eight inches : the length of the legs before and behind consisted a great deal in the tibia, which was strangely long; but, in my haste to get out of the stench, I forgot to measure that joint exactly. Its scut seemed to be about an inch long; the colour was a grizzly black; the mane about four inches long; the fore-hoofs were upright and shapely, the hind flat and splayed. The spring before it was only two years old, so that most probably it was not then come to its growth. What a vast tall beast must a full grown stag be ! I have been told some arrive at ten feet and a half! This poor creature had at first a female companion of the same species, which died the spring before. In the same garden was a young stag, or red deer, between whom and this moose it was hoped that there might have been a breed; but their inequality of height must have always been a bar to any commerce of the amorous kind. I should have been glad to have examined the teeth, tongue, lips, hoofs, etc., minutely ; but the putrefaction precluded all farther curiosity. This animal, the keeper told me, seemed to enjoy itself best in the extreme frost of the former winter. In the house they showed me the horn of a male moose, which had no front antlers, but only a broad palm with some snags on the edge. The noble owner of the dead moose proposed to make a skeleton of her bones.

Please to let me hear if my female moose corresponds with that you saw; and whether you think still that the American moose and European elk are the same creature.

I am, with the greatest esteem, etc. 


\section{LETTER XXIX.}

Selborne, May $\mathbf{1} 2 t h$, 1770 .

DEER SiR,--Last month we had such a series of cold turbulent weather, such a constant succession of frost, and snow, and hail, and tempest, that the regular migration or appearance of the summer birds was much interrupted. Some did not show themselves (at least were not heard) till weeks after their usual time ; as the blackcap and whitethroat; and some have not been heard yet, as the grasshopper-lark and largest willow-wren. As to the fly-catcher, I have not seen it ; it is indeed one of the latest, but should appear about this time : and yet, amidst all this meteorous strife and war of the elements, two swallows discovered themselves as long ago as April $\mathrm{I} \mathrm{rth}$, in frost and snow; but they withdrew quickly, and were not visible again for many days. House-martins, which are always more backward than swallows, were not observed till May came in.

Among the monogamous birds several are to be found, after pairing-time, single, and of each sex; but whether this state of celibacy is matter of choice or necessity, is not so easy discoverable. When the house-sparrows deprive my martins of their nests, as soon as I cause one to be shot, the other, be it cock or hen, presently procures a mate, and so for several times following.

I have known a dove-house infested by a pair of white owls, which made great havoc among the young pigeons: one of the owls was shot as soon as possible; but the survivor readily found a mate, and the mischief went on. After some time the new pair were both destroyed, and the annoyance ceased.

Another instance I remember of a sportsman, whose zeal for the increase of his game being greater than his humanity, after pairing-time he always shot the cock-bird of every couple of partridges upon his grounds; supposing that the rivalry of many males interrupted the breed : he used to say, that, though he had widowed the same hen several times, yet he found she was still 
provided with a fresh paramour, that did not take her away from her usual haunt.

Again; I knew a lover of setting, an old sportsman, who has often told me that soon after harvest he has frequently taken small coveys of partridges, consisting of cock-birds alone; these he pleasantly used to call old bachelors.

There is a propensity belonging to common house-cats that is very remarkable; I mean their violent fondness for fish, which appears to be their most favourite food: and yet nature in this

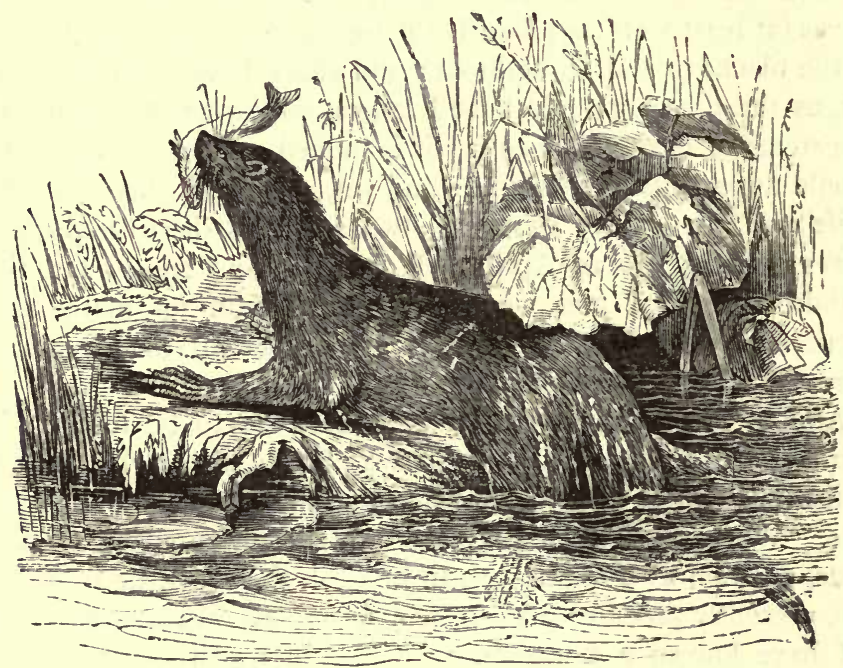

OTTER.

instance seems to have planted in them an appetite that, unassisted, they know not how to gratify: for of all quadrupeds cats are the least disposed towards water; and will not, when they can avoid it, deign to wet a foot, much less to plunge into that element.

Quadrupeds that prey on fish are amphibious : such is the otter, which by nature is so well formed for diving, that it makes great havoc among the inhabitants of the waters. Not supposing that we had any of those beasts in our shallow brooks, I was much pleased to see a male otter, brought to me, weighing twenty-one 
pounds, that had been shot on the bank of our stream below the Priory, where the rivulet divides the parish of Selborne from Harteley Wood. ${ }^{1}$

NOTE TO LETTER XXIX.

${ }^{1}$ Shy as the otter is, a pair made their home in a hole under some stonework on the banks of the canal at Llangollen, within six yards of several cottages.

\section{LETTER XXX.}

Selborne, Aug. ist', r i'jo.

DeAR SIR,-The French, I think, in general are strangely prolix in their natural history. What Linnæus says with respect to insects holds good in every other branch : "Verbositas presentis saculi, calamitas artis."

Pray how do you approve of Scopoli's new work? As I admire his "Entomologia," I long to see it.

I forgot to mention in my last letter (and had not room to insert in the former) that the male moose, in rutting time, swims from island to island, in the lakes and rivers of North America, in pursuit of the females. My friend, the chaplain, saw one killed in the water as it was on that errand in the river St. Lawrence : it was a monstrous beast, he told me; but he did not take the dimensions.

When I was last in town our friend Mr. Barrington most obligingly carried me to see many curious sights. As you were then writing to him about horns, he carried me to see many strange and wonderful specimens. There is, I remember, at Lord Pembroke's at Wilton, a horn room furnished with more than thirty different pairs; but I have not seen that house lately.

Mr. Barrington showed me many astonishing collections of stuffed and living birds from all quarters of the world. After I had studied over the latter for a time, I remarked that every species almost that came from distant regions, such as South America, the coast of Guinea, etc., were thick-billed birds of the 
loxia and fringilla genera; and no motacilla, or muscicapa, were to be met with. When I came to consider, the reason was obvious enough; for the hard-billed birds subsist on seeds which are easily carried on board; while the soft-billed birds, which are supported by worms and insects, or, what is a succedaneum for them, fresh raw meat, can meet with neither in long and tedious voyages. It is from this defect of food that our collections (curious as they are) are defective, and we are deprived of some of the most delicate and lively genera.

I am, etc.

\section{LETTER XXXI.}

SELBorne, Sept. I4th, I770.

DFAR SIR,-You saw, I find, the ring-ousels again among their native crags; and are farther assured that they continue resident in those cold regions the whole year. From whence then do our ring-ousels migrate so regularly every September, and make their appearance again, as if in their return, every April? They are more early this year than common, for some were seen at the usual hill on the fourth of this month.

An observing Devonshire gentleman tells me that they frequent some parts of Dartmoor, and breed there; but leave those haunts about the end of September, or beginning of October, and return again about the end of March.

Another intelligent person assures me that they breed in great abundance all over the peak of Derby, and are called there tor-ousels; withdraw in October and November, and return in spring. This information seems to throw some light on my new migration.

Scopoli's new work (which I have just procured) has its merit in ascertaining many of the birds of the Tirol and Carniola. Monographers, come from whence they may, have, I think, fair pretence to challenge some regard and approbation from the lovers of natural history; for, as no man can alone investigace 
the works of nature, these partial writers may, each in their department, be more accurate in their discoveries, and freer from errors, than more general writers; and so by degrees may pave the way to an universal correct natural history. Not that Scopoli is so circumstantial and attentive to the life and conversation of his birds as I could wish : he advances some false facts; as when he says of the hirundo urbica that "pullos extra nidum non nutrit." This assertion I know to be wrong from repeated observation this summer; for house-martins do feed their young flying, though it must be acknowledged not so commonly as the bouse-swallow; and the feat is done in so quick a manner as not to be perceptible to indifferent observers. He also advances some (I was going to say) improbable facts; as when he says of the woodcock that "pullos rostro portat fugiens ab hoste." But candour forbids me to say absolutely that any fact is false, because I have never been witness to such a fact. I have only to remark that the long unwieldy bill of the woodcock is perhaps the worst adapted of any among the winged creation for such a feat of natural affection. ${ }^{1}$

I am, etc.

\section{NOTE TO LETTER XXXI.}

1 It is a fact that the woodcock does carry its young. The legs and beak are both employed in holding the young one to the parent's breast as it flies.

\section{LETTER XXXII.}

SelboRne, October 29th, I770.

DEAR SiR,-After an ineffectual search in Linnæus, Brisson, etc., I begin to suspect that I discern my brother's hirundo hyberna in Scopoli's new discovered hirundo rupestris, p. 167. His description of "Supra murina, subtus allida; rectrices macula ovali albâ in latere interno; pedes nudi, nigri; rostrum nigrum; remiges obscuriores quam plume dorsales; rectrices remigibus con- 
colores; caudâ emarginatâ, nec forcipatâ ;" agrees very well with the bird in question: but when he comes to advance that it is "statura hirundinis urbice," and that "definitio hirundinis riparia Linnai huic quoque conveniit," he in sorne measure invalidates all he has said; at least he shows at once that he compares them to these species merely from memory : for I have compared the birds themselves, and find they differ widely in every circumstance of shape, size, and colour. However, as you will have a specimen, I shall be glad to hear what your judgment is in tise matter.

Whether my brother is forestalled in his non-descript or not, he will have the credit of first discovering that they spend their winters under the warm and sheltry shores of Gibraltar and Barbary.

Scopoli's characters of his ordines and genera are clear, just, and expressive, and much in the spirit of Linnæus. These few remarks are the result of my first perusal of Scopoli's "Antus Primus."

The bane of our science is the comparing one animal to the other by memory: for want of caution in this particular Scopoli falls into errors: he is not so full with regard to the manners of his indigenous birds as might be wished, as you justly observe: his Latin is easy, elegant, and expressive, and very superior to Kramer's. *

I am pleased to see that my description of the moose corresponds so well with yours.

I am, etc.

\section{LETTER XXXIII.}

SFLbORne, Nov. $26 t h$, I 770.

DEAR SIR, - I was much pleased to see, among the collection of birds from Gibraltar, some of those short-winged English summer birds of passage, concerning whose departure we have made so

* See his "Elenchus Vegetabilium et Animalium per Austriam Inferiorem, etc." 
much inquiry. Now if these birds are found in Andalusia to migrate to and from Barbary, it may easily be supposed that those that come to us may migrate back to the continent, and spend their winters in some of the warmer parts of Europe. This is certain, that many soft-billed birds that come to Gibraltar appear there only in spring and autumn, seeming to advance in pairs towards the northward, for the sake of breeding during the summer months; and retiring in parties and broods towards the south at the decline of the year; so that the rock of Gibraltar is the great rendezvous, and place of observation, from whence they take their departure each way towards Europe or Africa. It is therefore no mean discovery, I think, to find that our small short-winged summer birds of passage are to be seen spring and autumn on the very skirts of Europe ; it is presumptive proof of their emigrations.

Scopoli seems to me to have found the hirundo melba, the great Gibraltar swift, in Tirol, without knowing it. For what is his hirundo alpina but the afore-mentioned bird in other words? Says he "Omnia prioris" (meaning the swift); "sed pectus album; paulo major priore." I do not suppose this to be a new species. It is true also of the melba, that " nidificat in excelsis Alpium rupibus." Vid. Annuir Promum.

My Sussex friend, a man of observation and good sense, but no naturalist, to whom I applied on account of the stone-curlew, adicnemus, sends me the following account : "In looking over my Naturalist's Journal for the month of April, I find the stone-curlews are first mentioned on the seventeenth and eighteenth, which date seems to me rather late. They live with us all the spring and summer, and at the beginning of autumn prepare to take leave by getting together in flocks. They seem to me a bird of passage that may travel into some dry hilly country south of us, probably Spain, because of the abundance of sheep-walks in that country; for they spend their summers with us in such districts. This conjecture I hazard, as I have never met with any one that has seen them in England in the winter. I believe they are not ford of going near the water, but feed on earth-worms, that are common on sheep-walks and downs. They breed on fallows and lay-fields abounding with grey mossy flints, which much resemble their 
young in colour; among which they skulk and conceal themselves. They make no nest, but lay their eggs on the bare ground, producing in common but two at a time. There is reason to think their young run soon after they are hatched; and that the old ones do not feed them, but only lead them about at the time of feeding, which, for the most part, is in the night." Thus far, my friend.

In the manners of this bird you see there is something very analogous to the bustard, whom it also somewhat resembles in aspect and make, and in the structure of its feet.

For a long time I have desired my relation to look out for these birds in Andalusia ; and now he writes me word that, for the first time, he saw one dead in the market on the 3 rd September.

When the cedicnemus flies it stretches out its legs straight behind, like a heron.

\section{I am, etc.}

\section{LETTER XXXIV.}

SELBORNE, March 3 oth, $177 \mathrm{I}$.

DEAR SIR,-There is an insect with us, especially on chalky districts, which is very troublesome and teasing all the latter end of the summer, getting into people's skins, especially those of women and children, and raising tumours which itch intolerably. This animal (which we call a harvest bug) is very minute, scarce discernible to the naked eye; of a bright scarlet colour, and of the genus of Acarus. They are to be met with in gardens on kidneybeans, or any legumens, but prevail only in the hot months of summer. Warreners, as some have assured me, are much infested by them on chalky downs; where these insects swarm sometimes to so infinite a degree as to discolour their nets, and to give them a reddish cast, while the men are so bitien as to be thrown into fevers.

There is a small long shining fly in these parts very troublesome to the housewife, by getting into the chimneys, and laying its eggs 
in the bacon while it is drying; these eggs produce maggots called jumpers, which, harbouring in the gammons and best parts of the hogs, eat down to the bone, and make great waste. This fly I suspect to be a variety of the musca putris of Linnæus ; it is to be seen in the summer in farm-kitchens on the bacon-racks and about the mantel-pieces, and on the ceilings.

The insect that infests turnips and many crops in the garden (destroying often whole fields while in their seedling leaves) is an animal that wants to be better known. The country people here call it the turnip-fly and black-dolphin; but I know it to be one of the coleoptera; the "chrysomela oleracea, saltatoria, femoribus posticis crassissimis." In very hot summers they abound to an amazing degree, and, as you walk in a field or in a garden, make a pattering like rain, by jumping on the leaves of the turnips or cabbages.

There is an oestrus, known in these parts to every ploughboy; which, because it is omitted by Linnæus, is also passed over by late writers ; and that is the curvicauda of old Mouset, mentioned by Derham in his "Physico-Theology," p. 250; an insect worthy of remark for depositing its eggs as it flies in so dextrous a manner on the single hairs of the legs and flanks of grass-horses. But then Derham is mistaken when he advances that this oestrus is the parent of that wonderful star-tailed maggot which he mentions afterwards ; for more modern entomologists have discovered that singular production to be derived from the egg, or the musca chamaleon; see Geoffroy, t. xvii. f. 4 .

A full history of noxious insects hurtful in the field, garden and house, suggesting all the known and likely means of destroying them, would be allowed by the public to be a most useful and important work. What knowledge there is of this sort lies scattered, and wants to be collected; great improvements would soon follow of course. A knowledge of the properties, economy, propagation, and in short of the life and conversation of these animals, is a necessary step to lead us to some method of preventing their depredations.

As far as I am a judge, nothing would recommend entomology more than some neat plates that should well express the generic 
distinctions of insects according to Linnæus; for I am well assured that many people would study insects, could they set out with a more adequate notion of those distinctions than can be conveyed at first by words alone.

\section{LETTER XXXV.}

SEI.BORNE, I77 1.

DEAR SIR,-Happening to make a visit to my neighbour's

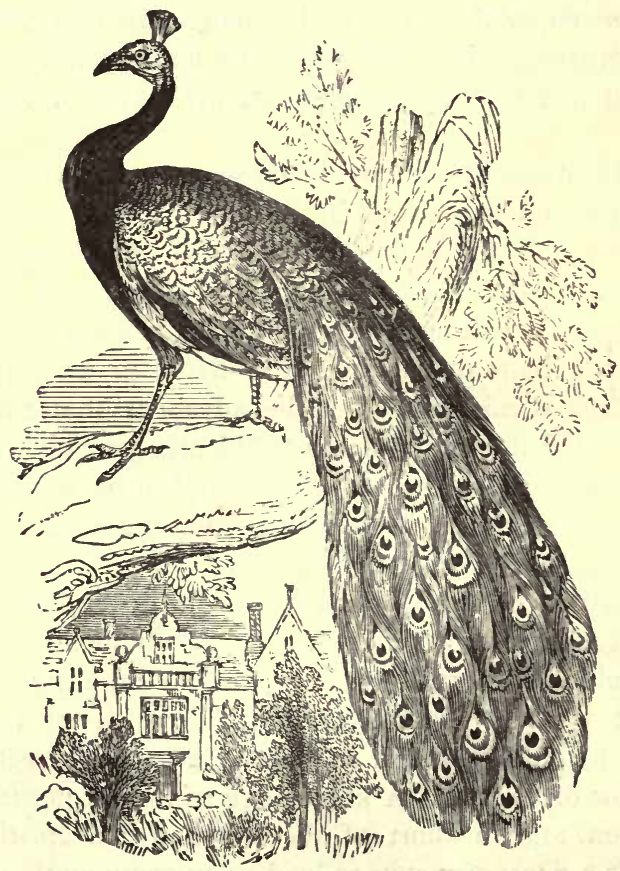

The Common Peacock (Pavo cristatus).

peacocks, I could not help observing that the trains of those magnificent birds appear by no means to be their tails; those 
long feathers growing not from their uropygium, but all up their backs. A range of short brown stiff feathers, about six inches long, fixed in the uropygium, is the real tail, and serves as the fulcrum to prop the train, which is long and top-heavy, when set on end. When the train is up, nothing appears of the bird before but its head and neck; but this would not be the case were those long feathers fixed only in the rump, as may be seen by the turkey cock when in a strutting attitude. By a strong muscular vibration these birds can make the shafts of their long feathers clatter like the swords of a sword dancer; they then trample very quick with their feet, and run backwards towards the females.

I should tell you that I have got an uncommon calculus agogropila, taken out of the stomach of a fat ox ; it is perfectly round, and about the size of a large Seville orange; such are, I think, usually flat.

\section{LETTER XXXVI.}

Sept. $\mathbf{1 7 7 1 .}$

DEAR Sir,-The summer through I have seen but two of that large species of bat which I call vespertilio altivolans, from its manner of feeding high in the air; I procured one of them, and found it to be a male; and made no doubt, as they accompanied together, that the other was a female; but, happening in an evening or two to procure the other likewise, I was somewhat disappointed, when it appeared to be also of the same sex. This circumstance, and the great scarcity of this sort, at least in these parts, occasions some suspicions in my mind whether it is really a species, or whether it may not be the male part of the more known species, one of which may supply many females; as is known to be the case in sheep and some other quadrupeds. But this doubt can only be cleared by a farther examination, and some attention to the sex, of more specimens: all that I know at present is, that my two were amply furnished with $t \cdot:$ parts of generation, much resembling those of a boar. 
In the extent of their wings they measured fourteen inches and a half; and four inches and a half from the nose to the tip of the tail; their heads were large, their nostrils bilobated, their shoulders broad and muscular; and their whole bodies fleshy and plump. Nothing could be more sleek and soft than their fur, which was of a bright chesnut colour; their maws were full of food, but so macerated that the quality could not be distinguished; their livers, kidneys and hearts, were large, and their bowels covered with fat. They weighed each, when entire, full one ounce and one drachm. Within the ear there was somewhat of a peculiar structure that I did not understand perfectly! but refer it to the observation of the curious anatomist. These creatures sent forth a very rancid and offensive smell.

\section{LETTER XXXVII.}

SELBORNE, I77 I.

DEAR SiR,-On the $\mathrm{I} 2$ th July I had a fair opportunity of contemplating the motions of the caprimulgus, or fern-owl, as it was playing round a large oak that swarmed with scaraboi solstitiales, or fern-chafers. The powers of its wing were wonderful, exceeding, if possible, the various evolutions and quick turns of the swallow genus. But the circumstance that pleased me most was, that I saw it distinctly, more than once, put out its short leg while on the wing, and, by a bend of the head, deliver somewhat into its mouth. If it takes any part of its prey with its foot, as I have now the greatest reason to suppose it does these chafers, I no longer wonder at the use of its middle toe, which is curiously furnished with a serrated claw.

Swallows and martins, the bulk of them I mean, have forsaken us sooner this year than usual ; for on September zand they rendezvoused in a neighbour's walnut-tree, where it seemed probable they had taken up their lodging for the night. At the dawn of the day, which was foggy, they arose all together in infinite 
numbers, occasioning such a rushing from the strokes of their wings against the hazy air, as might be heard to a considerable distance : since that no flock has appeared, only a few stragglers.

Some swifts stayed late, till the 2 and August-a rare instance! for they usually withdraw within the first week.

On September 24th three or four ring-ousels appeared in my fields for the first time this season; how punctual are these visitors in their autumnal and spring migrations!

\section{LETTER XXXVIII.}

\section{SelBorne, March I 5 th, I773.}

DEAR SiR,-By my journal for last alitumn it appears that the house-martins bred very late, and stayed very late in these parts; for, on the rst October, I saw young martins in their nest nearly fledged; and again on the 2 1st October, we had at the next house a nest full of young martins just ready to fly; and the old ones were hawking for insects with great alertness. The next morning the brood forsook their nest, and were flying round the village. From this day I never saw one of the swallow kind till November $3^{\text {rd }}$; when twenty, or perhaps thirty, housemartins were playing all day long by the side of the hanging wood, and over my field. Did these small weak birds, some of which were nestling twelve days ago, shift their quarters at this late season of the year to the other side of the northern tropic? Or rather, is it not more probable that the next church, ruin, chalk-cliff, steep covert, or perhaps sandbank, lake or pool (as a more northern naturalist would say), may become their hybernaculum, and afford them a ready and obvious retreat?

We now begin to expect our vernal migration of ring-ousels every week. Persons worthy of credit assure me that ring-ousels were seen at Christmas I 770 in the forest of Bere, on the southern verge of this county. Hence we may conclude that their migrations are only internal, and not extended to the continent south- 
ward, if they do at first come at all from the northern parts of this island only, and not from the north of Europe. Come from whence they will, it is plain, from the fearless disregard that they show for men or guns, that they have been little accustomed to places of much resort. Navigators mention that in the Isle of Ascension, and other such desolate districts, birds are so little acquainted with the human form that they settle on men's shoulders; and have no more dread of a sailor than they would have of a goat that was grazing. ${ }^{1} \quad$ A young man at Lewes, in Sussex, assured me that about seven years ago ring-ousels abounded so about that town in the autumn that he killed sixteen himself in one afternoon; he added further, that some had appeared since in every autumn; but he could not find that any had been observed before the season in which he shot so many. I myself have found these birds in little parties in the autumn cantoned all along the Sussex downs, wherever there were shrubs and bushes, from Chichester to Lewes; particularly in the autumn of 1770.

I am, etc.

\section{NOTE TO LETTER XXXXVII.}

${ }^{1}$ Even in England birds often show great confidence in man. I seem to have a peculiar knack of making friends with them and with wild animals. One evening last summer I was sitting in Jesmond Dene, Newcastle-on-Tyne, when a robin hopped close by me, and as I kept perfectly still, it inspected me closely, flew on to my boot, on to the seat by my side, and closely inspected my hand, then hopped on to my knee, and finally on to my shoulder. This familiarity was repeated on a subsequent occasion, to my great satisfaction. While lying down by some rabbit holes on a summer's afternoon, the bunnies have sat at the mouths of their burrows, coolly gazing at me, and proceeding with their toilets within three yards of my head. Squirrels, too, have made friends with me; but then, I prefer quietly watching birds and animals to killing them. 


\section{LETTER XXXIX.}

Selborne, Nov. 9th, I 773 .

DEAR Sir,-As you desire me to send you such observations as may occur, I take the liberty of making the following remarks, that you may, according as you think me right or wrong, admit or reject what $I$ here advance, in your intended new edition of the "British Zoology."

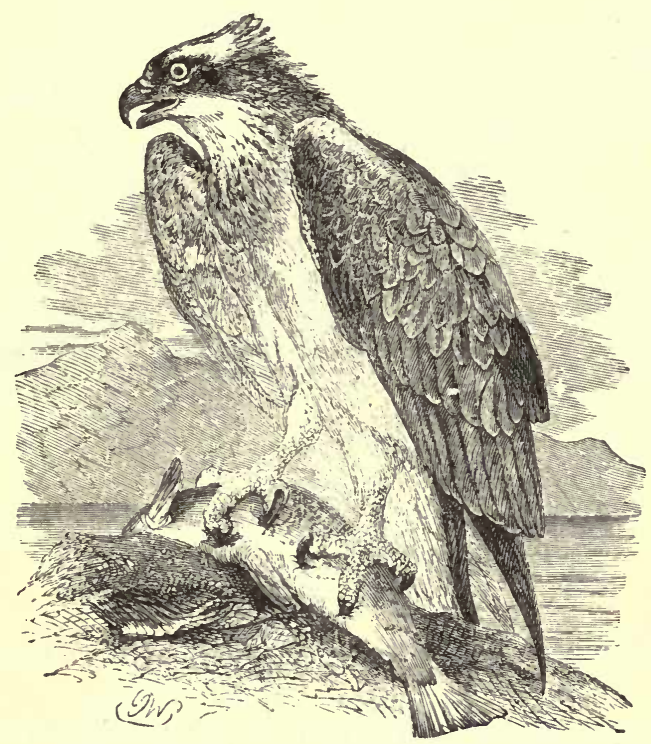

The Osprey (Pandion).

The osprey was shot about a year ago at Frinsham Pond, a great lake, at about six miles from hence, while it was sitting on the handle of a plough and devouring a fish : it used to precipitate itself into the water, and so take its prey by surprise.

A great ash-coloured butcher-bird was shot last winter in Tisted Park, and a red-backed butcher-bird [shrike] at Selborne: they are rare aves in this county. ${ }^{1}$ 
Crows go in pairs all the year round.

Cornish choughs abound, and breed on Beechy Head, and on all the cliffs of the Sussex coast.

The common wild pigeon, or stock-dove, ${ }^{2}$ is a bird of passage in the south of England, seldom appearing till towards the end of November; is usually the latest winter-bird of passage. Before our beechen woods were so much destroyed we had myriads of them, reaching in strings for a mile together as they went out in

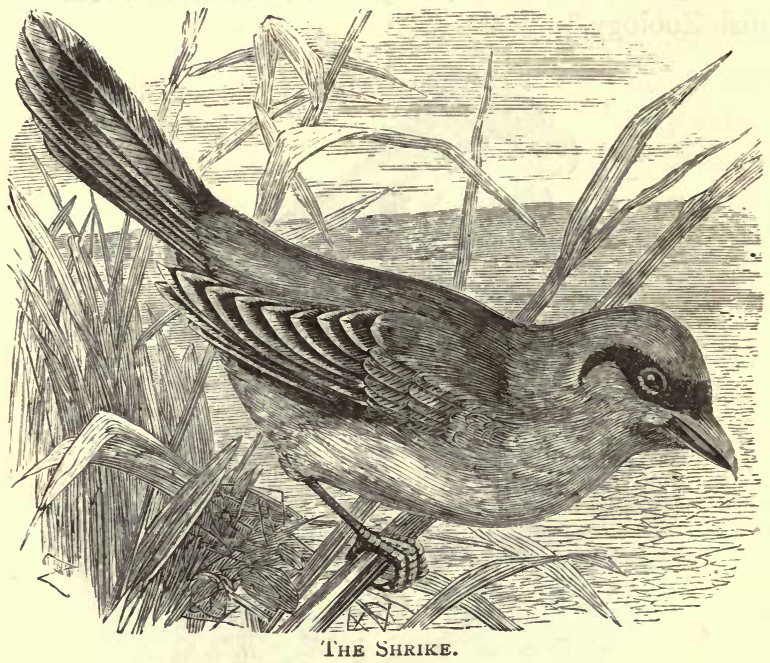

a morning to feed. They leave us early in spring: where do they breed?

The people of Hampshire and Sussex call the missel-bird the storm-cock, because it sings early in the spring in blowing showery weather; its song often commences with the year: with us it builds much in orchards.

A gentleman assures me he has taken the nests of ring-ousels on Dartmoor : they build in banks on the sides of streams.

Titlarks not only sing sweetly as they sit on trees, but also as they play and toy about on the wing ; and particularly while they are descending, and sometimes they stand on the ground. 
Adanson's testimony seems to me to be a very poor evidence

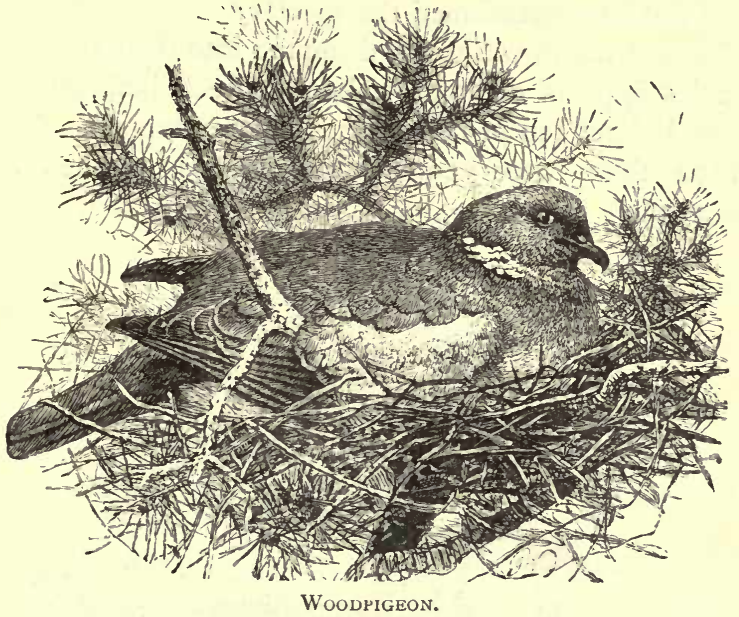

that European swallows migrate during our winter to Senegal : he does not talk at all like an ornithologist; and probably saw only

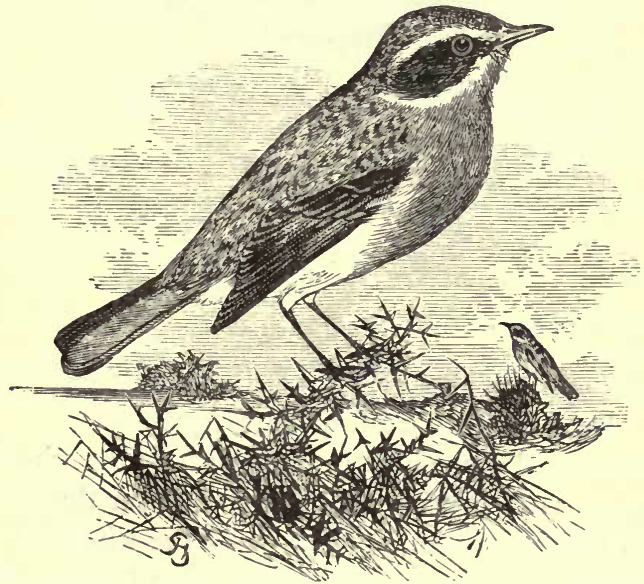

The Whin-Chat.

the swallows of that country, which I know build within Governor 
O'Hara's hall against the roof. Had he known European swallows, would he not have mentioned the species?

The house-swallow washes by dropping into the water as it flies: this species appears commonly about a week before the housemartin, and about ten or twelve days before the swift.

In 1772 there were young house-martins in their nest till October 23 rd.

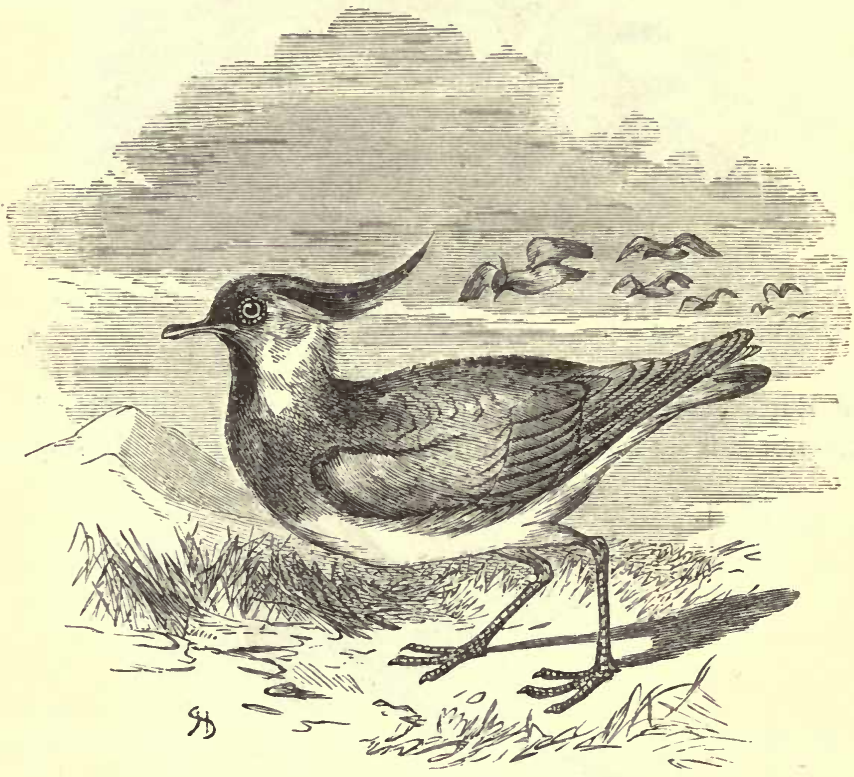

LAPWING.

The swift appears about ten or twelve days later than the houseswallow : viz., about the $24^{\text {th }}$ or 26 th April.

Whin-chats and stone-chatters stay with us the whole year. ${ }^{3}$

Some wheat-ears continue with us the winter through.

Wag-tails, all sorts, remain with us all the winter. ${ }^{4}$

Bullfinches, when fed on hempseed, often become wholly black.

We have vast flocks of female chaffinches all the winter, with hardly any males among them. 
When you say that in breeding-time the cock-snipes make a bleating noise, and I a drumming (perhaps I should rather have said a humming), I suspect we mean the same thing. However, while they are playing about on the wing they certainly make a loud piping with their mouths : but whether that bleating or humming is ventriloquous, or proceeds from the motion of their wings, I cannot say; but this I know, that when this noise happens the bird is always descending, and his wings are violently agitated.

Soon after the lapwings have done breeding they congregate, and, leaving the moors and marshes, betake themselves to downs and sheep-walks.

Two years ago last spring the little auk was found alive and unhurt, but fluttering and unable to rise, in a lane a few miles from Alresford, where there is a great lake : it was kept awhile, but died.

I saw young teals taken alive in the ponds of Wolmer Forest in the beginning of July last, along with flappers, or young wildducks.

Speaking of the swift, that page says "its drink the dew;" whereas it should be "it drinks on the wing;" for all the swallow kind sip their water as they sweep over the face of pools or rivers: like Virgil's bees, they drink flying ; "flumina summa libant." In this method of drinking perhaps this genus may be peculiar.

Of the sedge-bird be pleased to say it sings most part of the night; its notes are hurrying, but not unpleasing, and imitative of several birds ; as the sparrow, swallow, skylark. When it happens to be silent in the night, by throwing a stone or clod into the bushes where it sits you immediately set it a-singing; or in other words, though it slumbers sometimes, yet as soon as it is awakened it reassumes its song.

\section{NOTES TO LETTER XXXIX.}

1 The red-backed butcher-bird, or shrike, is common enough in some districts. I found several nests one year in some thorn trees in a small field in Norfolk. The shrike has a habit of impaling the beetles or other small live creatures it feeds upon, on the thorns, to await its convenience for eating them, and some spots have quite the appearance of a well-stocked larder. 
2 The stock-dove is not the common wild pigeon. The pigeons usually found in England are the ring-dove, which makes its nests on trees, and is called the cushat. or in Shropshire the quice, the stock-dove, which breeds in holes in trees, and also in rabbit holes; the rock-dove, and the pretty little turtle-dove, which builds so slight a nest in a tree or big bush that the small white eggs can be seen through it from below.

${ }^{3}$ Whin-chats migrate, but stone-chats do not as a rule.

4 The yellow-wagtail migrates, but the pied and grey wagtails do not.

\section{LETTER XL.}

Selborne, Sept. 2nd, I774.

DEAR SiR,-Before your letter arrived, and of my own accord, I had been remarking and comparing the tails of the male and

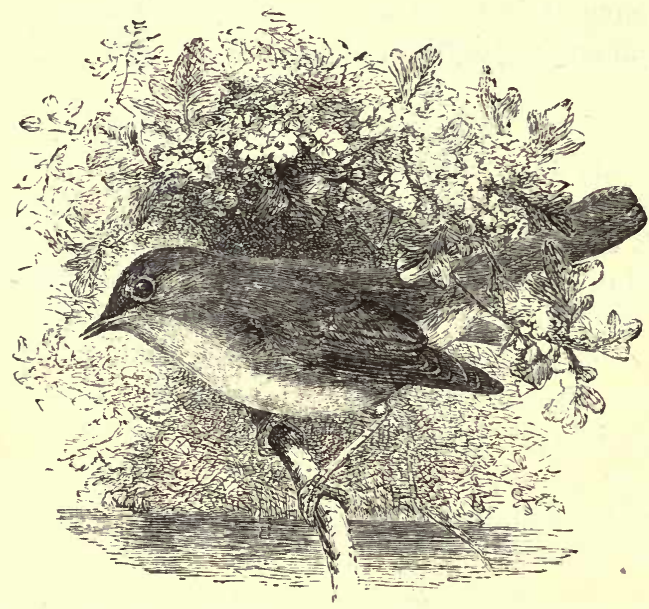

The Nightingale (Philomela luscinia).

female swallow, and this ere any young broods appeared; so that there was no danger of confounding the dams with their pulli: and besides, as they were then always in pairs, and busied in the employ of nidification, there could be no room for mistaking the 
sexes, nor the individuals of different chimneys the one for the other. From all my observations, it constantly appeared that each sex has the long feathers in its tail that give it that forked shape; with this difference, that they are longer in the tail of the male than in that of the female.

Nightingales, when their young first come abroad, and are helpless, make a plaintive and a jarring noise ; and also a snapping or cracking, pursuing people along the hedges as they walk: these last sounds seem intended for menace and defiance.

The grasshopper-lark chirps all night in the height of summer.

Swans turn white the second year, and breed the third.

Weasels prey on moles, as appears by their being sometimes caught in mole-traps.

Sparrow-hawks sometimes breed in old crows' nests, and the kestril in churches and ruins.

There are supposed to be two sorts of eels in the island of Ely. The threads sometimes discovered in eels are perhaps their young: the generation of eels is very dark and mysterious.

Hen-harriers breed on the ground, and seem never to settle on trees.

When redstarts shake their tails they move them horizontally, as dogs do when they fawn: the tail of a wagtail, when in motion, bobs up and down like that of a jaded horse.

Hedge-sparrows have a remarkable flirt with their wings in breeding-time; as soon as frosty mornings come they make a very piping plaintive noise.

Many birds which become silent about Midsummer reassume their notes again in September; as the thrush, blackbird, woodlark, willow-wren, etc.; hence August is by much the most mute month, the spring, summer, and autumn through. Are birds induced to sing again because the temperament of autumn resembles that of spring ?

Linnæus ranges plants geographically; palms inhabit the tropics, grasses the temperate zones, and mosses and lichens the polar circles ; no doubt animals may be classed in the same manner with propriety.

House-sparrows build under eaves in the spring; as the weather 
becomes hotter they get out for coolness, and nest in plum-trees and apple-trees. These birds have been known sometimes to build in rooks' nests, and sometimes in the forks of boughs under rooks' nests.

As my neighbour was housing a rick he observed that his dogs devoured all the little red mice that they could catch, but rejected the common mice; and that his cats ate the common mice, refusing the red.

Red-breasts sing all through the spring, summer, and autumn. The reason that they are called autumn songsters is, because in the two first seasons their voices are drowned and lost in the general chorus; in the latter their song becomes distinguishable. Many songsters of the autumn seem to be the young cock redbreasts of that year : notwithstanding the prejudices in their favour, they do much mischief in gardens to the summer-fruits.*

The titmouse, which early in February begins to make two quaint notes, like the whetting of a saw, is the nuarsh titmouse : the great titmouse sings with three cheerful joyous notes, and beg ins about the same time.

Wrens sing all the winter through, frost excepted.

House-martins came remarikably late this year both in Hampshire and Devonshire: is this circumstance for or against either hiding or migration?

Most birds drirk sipping at intervals ; but pigeons take a long continued draught, like quadrupeds.

Notwithstanding what I have said in a former letter, no gray crows were ever known to breed on Dartmoor ; it was iny mistake.

The appearance and flying of the Scarabaus solstitialis, or fernchafer, commence with the month of July, and cease about the end of it. These scarabs are the constant food of Caprimulgi, or fern owls, through that period. They abound on the chalky downs and in some sandy districts, but not in the clays.

In the garden of the Black Bear inn in the town of Reading, is a stream or canal running under the stables and out into the fields on the other side of the road: in this water are many carps, which

* They eat also the berries of the ivy, the honey-suckle, and the Euonymus europaus, or spindle-tree. 
lie rolling about in sight, being fed by travellers, who amuse themselves by tossing them bread; but as soon as the weather grows at all severe, these fishes are no longer seen, because they retire under the stables, where they remain till the return of spring. Do they lie in a torpid state? If they do not, how are they supported ? 1

The note of the white-throat, which is continually repeated, and often attended with odd gesticulations on the wing, is harsh and

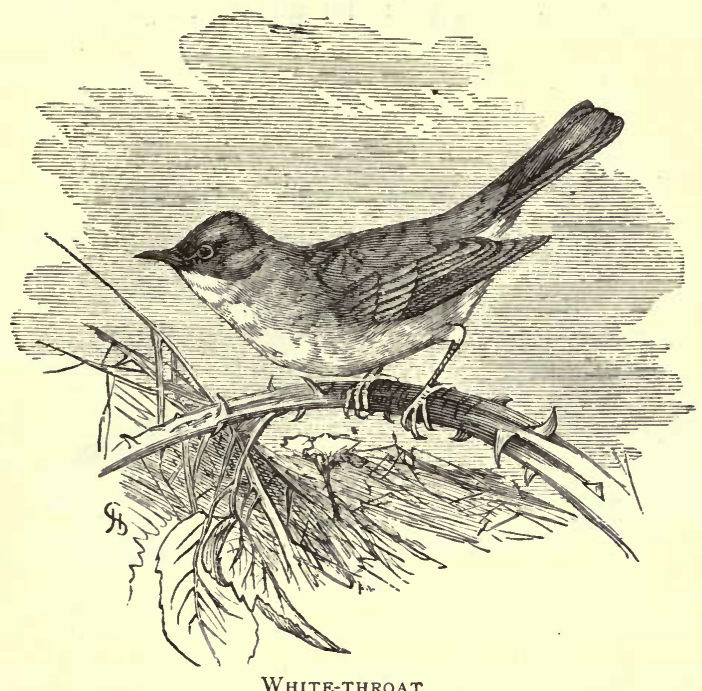

displeasing. These birds seem of a pugnacious disposition; for they sing with an erected crest and attitudes of rivalry and defiance; are shy and wild in breeding-time, avoiding neighbourhoods, and haunting lonely lanes and conmons; nay, even the very tops of the Sussex Downs, where there are bushes and covert; but in July and August they bring their broods into gardens and orchards, and make great havoc among the summer-fruits.

The black-cap has in common a full, sweet, deep, loud, and wild pipe ; yet that strain is of short continuance, and his motions are desultory; but when that bird sits calmly and engages in song 
in earnest, he pours forth very sweet, but inward melody. and expresses great variety of soft and gentle modulations, superior perhaps to those of any of our warblers, the nightingale excepted.

Black-caps mostly haunt orchards and gardens; while they warble their throats are wonderfully distended.

The song of the redstart is superior, though somewhat like that of the white-throat; some birds have a few more notes than others. Sitting very placidly on the top of a tall tree in a village, the cock sings from morning to night: he affects neighbourhoods, and

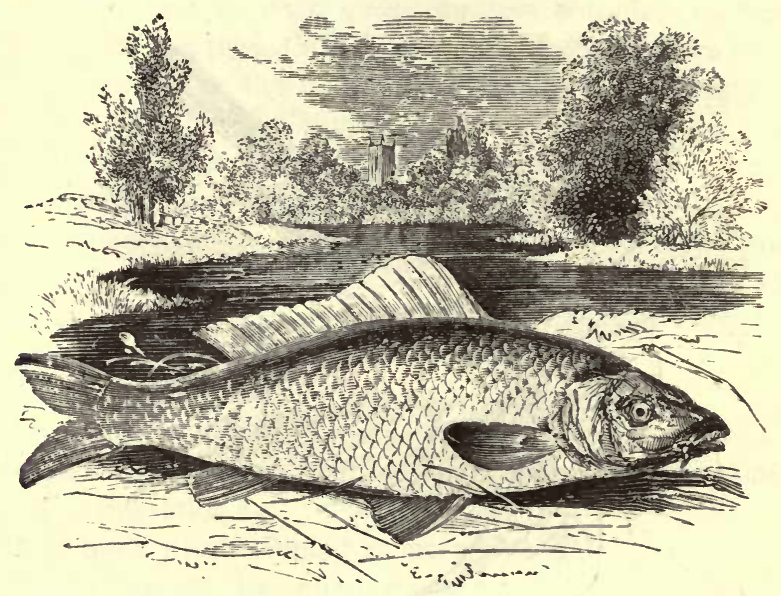

The Carp.

avoids solitude, and loves to build in orchards and about houses; with us he perches on the vane of a tall maypole.

The fly-catcher is of all our summer birds the most mute and the most familiar; it also appears the last of any. It builds in a vine, or a sweetbriar, against the wall of a house, or in the hole of a wall, or on the end of a beam or plate, and often close to the post of a door where people are going in and out all day long. This bird does not make the least pretension to song, but uses a little inward wailing note when it thinks its young in danger from cats or other annoyances; it breeds but once, and retires early. 
Selborne parish alone can and has exhibited at times more than half the birds that are ever seen in all Sweden; the former has produced more than one hundred and twenty species, the latter only two hundred and twenty-one. Let me add also that it has shown near half the species that were ever known in Great Britain.

On a retrospect, I observe that my long letter carries with it a quaint and magisterial air, and is very sententious; but when I recollect that you requested stricture and anecdote, I hope you will pardon the didactic manner for the sake of the information it may happen to contain.

\section{NOTE TO LETTER XL.}

1 Carp, tench, and eels retire into the mud, if it is soft enough, in the very cold weather, but cannot be said to become torpid, like a tortoise does. Fish can do for a long time with very little food, and the mud itself is full of eatabla (in the fish view) things even in the winter.

\section{LETTER XLI.}

IT is matter of curious inquiry to trace out how those species of soft-billed birds that continue with us the winter through, subsist during the dead months. The imbecility of birds seems not to be the only reason why they shun the rigour of our winters; for the robust wryneck (so much resembling the hardy race of woodpeckers) migrates, while the feeble little golden-crowned wren, that shadow of a bird, braves our severest frosts without availing himself of houses or villages, to which most of our winter birds crowd in distressful seasons, while this keeps aloof in fields and woods; but perhaps this may be the reason why they may often perish, and why they are almost as rare as any bird we know.

I have no reason to doubt but that the soft-billed birds, which winter with us, subsist chiefly on insects in their aurelia state. All the species of wagtails in severe weather haunt shallow streams 
near their spring-heads, where they never freeze; and, by wading, pick out the aurelias of the genus of Phryganea, etc.

Hedge-sparrows frequent sinks and gutters in hard weather, where they pick up crumbs and other sweepings; and in mild weather they procure worms, which are stirring every month in the year, as any one may see that will only be at the trouble of taking a candle to a grass-plot on any mild winter's night. Red-

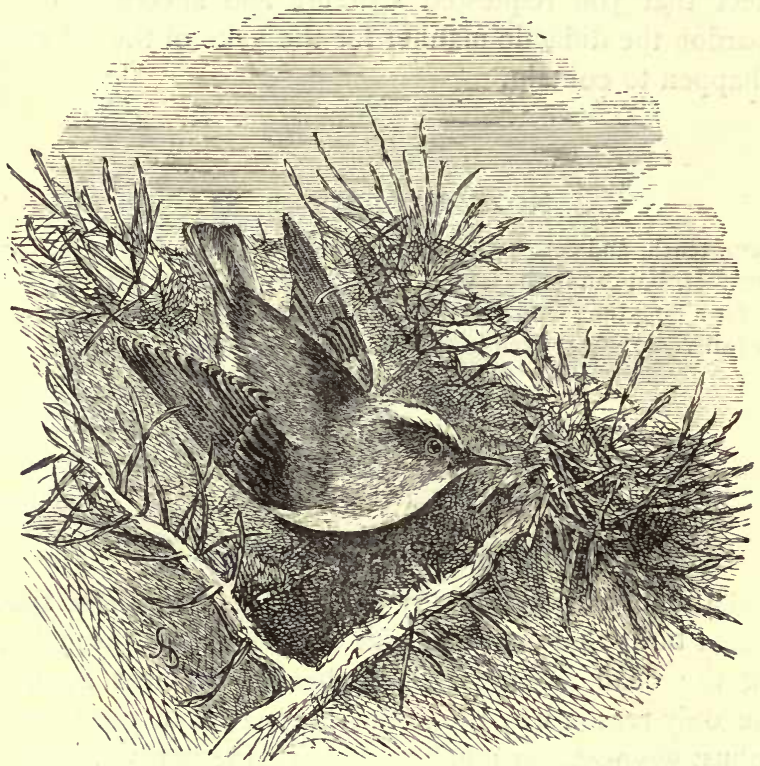

The GOLDCREST.

breasts and wrens in the winter haunt outhouses, stables, and barns, where they find spiders and flies that have laid themselves up during the cold season. But the grand support of the softbilled birds in winter is that infinite profusion of aurelia of the Lepidoptera ordo, which is fastened to the twigs of trees and their trunks; to the pales and walls of gardens and buildings; and is found in every cranny and cleft of rock or rubbish, and even in the ground itself. 
Every species of titmouse winters with us; they have what I call a kind of intermediate bill between the hard and the soft, between the Linnæan genera of Fringilla and Motacilla. One species alone spends its whole time in the woods and fields, never retreating for succour in the severest seasons to houses and neighbourhoods; and that is the delicate long-tailed titmouse, which is

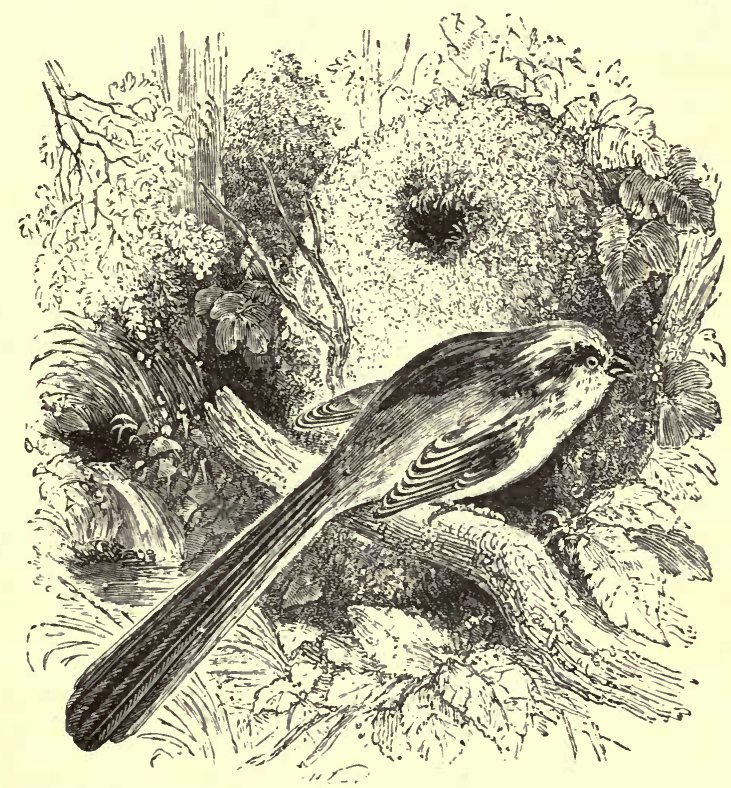

Long-tailed Tit and Nest.

almost as minute as the golden-crowned wren; but the blue titmouse or nun (Parus caruleus), the cole-mouse (Parus ater), the great black-headed titmouse (Fringillago), and the marsh titmouse (Parus palustris), all resort at times to buildings, and in hard weather particularly. The great titmouse, driven by stress of weather, much frequents houses ; and, in deep snows, I have seen this bird, while it hung with its back downwards (to my no small delight and admiration), draw straws lengthwise from out the eaves of thatched houses, in order to pull out the flies that were con- 
cealed between them, and that in such numbers that they quite defaced the thatch, and gave it a ragged appearance.

The blue titmouse, or nun, is a great frequenter of houses, and a general devourer. Besides insects, it is very fond of flesh; for it frequently picks bones on dunghills : it is a vast admirer of suet, and haunts butchers' shops. When a boy, I have known twenty in a morning caught with snap mouse-traps, baited with tallow or suet. It will also pick holes in apples left on the ground, and be

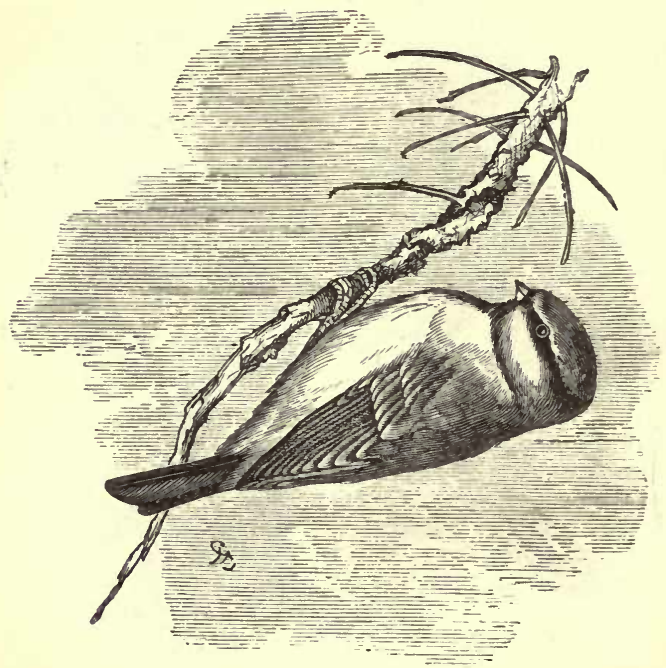

Blue Titmouse.

well entertained with the seeds on the head of a sunflower. 'The blue, marsh, and great titmice will, in very severe weather, carry away barley and oat-straws from the sides of ricks.

How the wheat-ear and whin-chat support themselves in winter cannot be so easily ascertained, since they spend their time on wild heaths and warrens; the former especially, where there are stone quarries: most probably it is that their maintenance arises from the aureliæ of the Lepidoptera ordo, which furnish them with a plentiful table in the wilderness. 


\section{LETTER XLII.}

Selborne, March 9th, I 775 .

DEAR SiR,-Some future faunist, a man of fortune, will, I hope, extend his visits to the kingdom of Ireland; a new field and a country little known to the naturalist. He will not, it is to be wished, undertake that tour unaccompanied by a botanist, because the mountains have scarcely been sufficiently examined; and the southerly counties of so mild an island may possibly afford some plants little to be expected within the British dominions. A person of a thinking turn of mind will draw many just remarks from the modern improvements of that country, both in arts and agriculture, where premiums obtained long before they were heard of with us. The manners of the wild natives, their superstitions, their prejudices, their sordid way of life, will extort from him many useful reflections. He should also take with him an able draughtsman; for he must by no means pass over the noble castles and seats, the extensive and picturesque lakes and waterfalls, and the lofty stupendous mountains, so little known, and so engaging to the imagination when described and exhibited in a lively manner; such a work would be well received.

As I have seen no modern map of Scotland, I cannot pretend to say how accurate or particular any such may be; but this I know, that the best old maps of that kingdom are very defective.

The great obvious defect that I have remarked in all maps of Scotland that have fallen in my way is a want of a coloured line, or stroke, that shall exactly define the just limits of that district called the Highlands. Moreover, all the great avenues to that mountainous and romantic country want to be well distinguished. The military roads formed by General Wade are so great and Roman-like an undertaking that they well merit attention. My old map, Moll's Map, takes notice of Fort William, but could not mention the other forts that have been erected long since; therefore a good representation of the chain of forts should not be omitted. 
The celebrated zigzag up the Coryarich must not be passed over. Moll takes notice of Hamilton and Drumlanrig, and such capital houses; but a new survey, no doubt, should represent every seat and castle remarkable for any great event, or celebrated for its paintings, etc. Lord Breadalbane's seat and beautiful policy are too curious and extraordinary to be omitted.

The seat of the Earl of Eglingtoun, near Glasgow, is worthy of notice. The pine plantations of that nobleman are very grand and extensive indeed.

I am, etc.

LETTER XLIII.

A PAIR of honey-buzzards, Buteo opivorus, sive Vespivorus Raii,

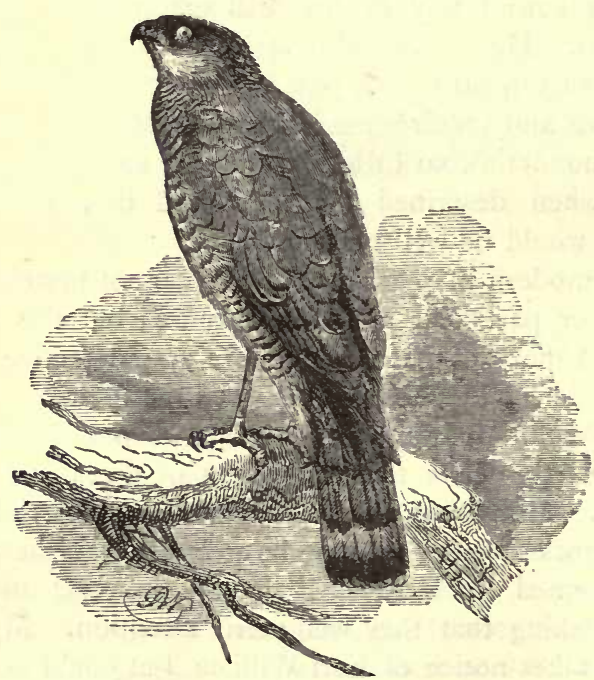

The Sparrow-hawk (Accifiter nisus). built them a large shallow nest, composed of twigs and lined with dead beechen leaves, upon a tall slender beech near the middle of Selborne Hanger, in the summer of $\mathrm{I} 780$. In the middle of the month of June a bold boy climbed this tree though standing on so steep and dizzy a situation, and brought down an egg, the only one in the nest, which had been sat on for some time, and contained the embryo of a. young bird. The egg was smaller, and not so round as those of the common buzzard; was dotted at 
each end with small red spots, and surrounded in the middle with a broad bloody zone.

The hen-bird was shot, and answered exactly to Mr. Ray's description of that species; had a black cere, short thick legs, and a long tail. When on the wing this species may be easily distinguished from the common buzzard by its hawk-like appearance, small head, wings not so blunt, and longer tail. This specimen contained in its craw some limbs of frogs and many grey snails without shells. The irides of the eyes of this bird were of a beautiful bright yellow colour.

About the roth July in the same summer a pair of sparrowhawks bred in an old crow's nest on a low beech in the same hanger; and as their brood, which was numerous, began to grow up, became so daring and ravenous, that they were a terror to all the dames in the village that had chickens or ducklings under their care. A boy climbed the tree, and found the young so fledged that they all escaped from him; but discovered that a good house had been kept: the larder was well-stored with provisions ; for he brought down a young blackbird, jay, and housemartin, all clean picked, and some half devoured. The old birds had been observed to make sad havoc for some days among the new-flown swallows and martins, which, being but lately out of their nests, had not acquired those powers and command of wing that enable them, when more mature, to set such enemies at defiance.

\section{LETTER XLIV.}

Selborne, Nov. 3 oth, 1780 .

DEAR SiR,-Every incident that occasions a renewal of our correspondence will ever be pleasing and agreeable to me.

As to the wild wood-pigeon, the CEnas, or Vinago, of Ray, I am much of your mind ; and see no reason for making it the origin of the common house-dove: but suppose those that have advanced 
that opinion may have been misled by another appellation, often miven to the Enas, which is that of stock-dove.

Unless the stock-dove in the winter varies greatly in manners from itself in summer, no species seems more unlikely to be domesticated, and to make a house-dove. We very rarely see the latter settle on trees at all, nor does it ever haunt the woods; but the former as long as it stays with us, from November perhaps to February, lives the same wild life with the ring-dove, Palumbus

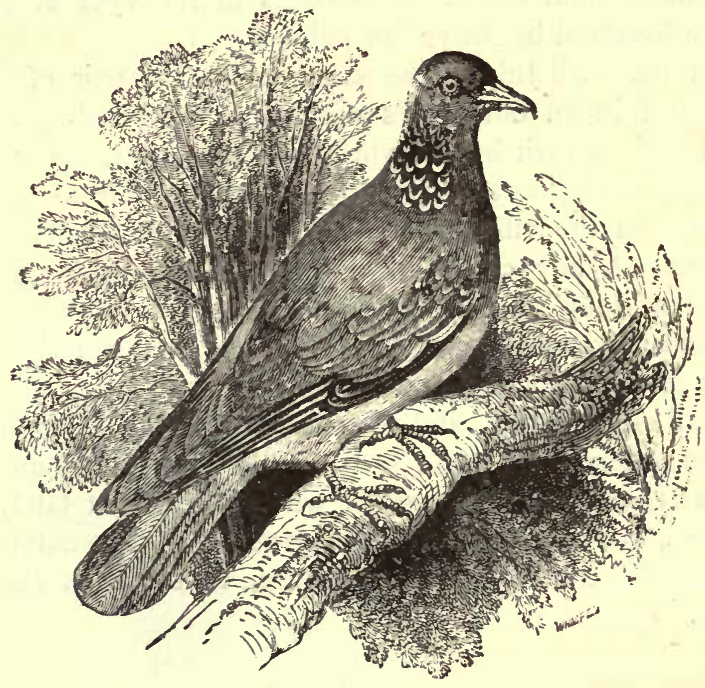

Srock-Dove.

torquatus; frequents coppices and groves, supports itself chiefly by mast, and delights to roost in the tallest beeches. Could it be known in what manner stock-doves build, the doubt would be settled with me at once, provided they construct their nests on trees, like the ring-dove, as I much suspect they do.

You received, you say, last spring a stock-dove from Sussex; and are informed that they sometimes breed in that county. But why did not your correspondent determine the place of its nidification, whether on rocks, cliffs, or trees? If he was not an adroit 
ornithologist I should doubt the fact, because people with us perpetually confound the stock-dove with the ring-dove.

For my own part, I readily concur with you in supposing that house-doves are derived from the small blue rock-pigeon, for many reasons. In the first place the wild stock-dove is manifestly larger than the common house-dove, against the usual rule of domestication, which generally enlarges the breed. Again, those two remarkable black spots on the remiges of each wing of the stock-dove, which are so characteristic of the species, would not, one should think, be totally lost by its being reclaimed; but would often break out among its descendants. But what is worth a hundred arguments is, the instance you give in Sir Roger Mostyn's house-doves in Cærnarvonshire; which, though tempted by plenty of food and gentle treatment, can never be prevailed on to inhabit their cote for any time; but, as soon as they begin to breed, betake themselves to the fastnesses of Ormshead, and deposit their young in safety amidst the inaccessible caverns, and precipices of that stupendous promontory.

“ Naturam expellas furcâ . . . tamen usque recurret."

I have consulted a sportsman, now in his seventy-eighth year, who tells me that fifty or sixty years back, when the beechen woods were much more extensive than at present, the number of wood-pigeons was astonishing; that he has often killed near twenty in a day : and that with a long wild-fowi piece he has shot seven or eight at a time on the wing as they came wheeling over his head : he moreover adds, which I was not aware of, that often there were among them little parties of small blue doves, which he calls rockiers. The food of these numberless emigrants was beech-mast and some acorns ; and particularly barley, which they collected in the stubbles. But of late years, since the vast increase of turnips, that vegetable has furnished a great part of their support in hard weather; and the holes they pick in these roots greatly damage the crop. From this food their flesh has contracted a rancidness which occasions them to be rejected by nicer judges of eating, who thought them before a delicate dish. They were shot not only as they were feeding in the fields, and especially 
in snowy weather, but also at the close of the evening, by men who lay in ambush among the woods and groves to kill them as they came in to roost.* These are the princinal circumstances relating to this wonderful internal migration, which with us takes place towards the end of November, and ceases early in the spring. Last winter we had in Selborne high wood about a hundred of these doves; but in former times the flocks were so vast, not only with us but all the district round, that on mornings and evenings they traversed the air, like rooks, in strings, reaching for a mile together. When they thus rendezvoused here by thousands, if they happened to be suddenly roused from their roost-trees on an evening,

"Their rising all at once was like the sound Of thunder heard remote."

It will by no means be foreign to the present purpose to add, that I had a relation in this neighbourhood who made it a practice, for a time, whenever he could procure the eggs of a ring-dove, to place them under a pair of doves that were sitting in his own pigeon-house ; hoping thereby, if he could bring about a coalition, to enlarge his breed, and teach his own doves to beat out into the woods, and to support themselves by mast; the plan was plausible, but something always interrupted the success; for though the birds were usually hatched, and sometimes grew to half their size, yet none ever arrived at maturity. I myself have seen these foundlings in their nest displaying a strange ferocity of nature, so as scarcely to bear to be looked at, and snapping with their bills by way of menace. In short, they always died, perhaps for want of proper sustenance : but the owner thought that by their fierce and wild demeanour they frighted their foster mothers, and so were starved.

Virgil, as a familiar occurrence; by way of simile, describes a dove haunting the cavern of a rock in such engaging numbers, that I cannot refrain from quoting the passage : and John Dryden

* "Some old sportsmen say that the main part of these flocks used to withdraw as soon as the heavy Christmas frosts were over." 
has rendered it so happily in our language, that without farther excuse I shall add his translation also.

“Qualis speluncâ subitò commota Columba, Cui domus, et dulces latebroso in pumice nidi, Fertur in arva volans, plausumque exterrita pennis, Dat tecto ingentem-mox aere lapsa quieto, Radit iter liquidum, celeres neque commovet alas."

"As when a dove her rocky hold forsakes, Rous'd, in a fright her sounding wings she shakes; The cavern rings with clattering:- out she flies, And leaves her callow care, and cleaves the skies : At first she flutters :- but at length she springs To smoother flight, and shoots upon her wings."

I am, etc. 



\section{LETTERS TO THE HON. DAINES BARRINGTON.}

\section{LETTER I.}

SELBORNE, Fune 3oth, 1769.

DEAR SIR,-When I was in town last month I partly engaged that I would sometimes do myself the honour to write to you on the subject of natural history; and I am the more ready to fulfil my promise, because I see you are a gentleman of great candour, and one that will make allowances; especially where the writer professes to be an outdoor naturalist, one that takes his observations from the subject itself, and not from the writings of others.

The following is a List of the Summer Birds of Passage WHICH I HAVE DISCOVERED IN THIS NEIGHBOURHOOD, RANGED SOMEWHAT IN THE ORDER IN WHICH THEY APPEAR:

RAII NOMINA.

Fynx, sive Torquilla, $\quad\left\{\begin{array}{c}\text { The middle of March : harsh } \\ \text { note. }\end{array}\right.$

I. Wryneck.

2. Smallest willowwren,

3. Swallow,

4. Martin,

5. Sand-martin,

6. Black-cap,

7. Nightingale,

8. Cuckoo,

9. Middle willow-wren, Regulus non cristatus.

ro. White-throat,

I I. Red-start,

I2. Stone-Curlew,

I3. Turtle-dove,
\} Regulus non cristatus.

Hirundo domestica.

Hirundo rustica.

Hirundo riparia.

Atricapilla.

Luscinia.

Cuculus.

Ficedula affinis.

Ruticilla.

Edicnemus.

Turtur.
$\{$ March 23rd: chirps till $\{$ September.

April I3th.

Ditto.

Ditto: a sweet wild note.

Beginning of April.

Middle of April.

Ditto: a sweet plaintive note. $\int$ Ditto : mean note ; sings on $\{$ till September.

Ditto : more agreeable song. $\{$ End of March : loud noc$\{$ turnal whistle.
Ditto. 
RAII NOMINA.

14. Grasshopper-lark, $\left\{\begin{array}{c}\text { Alauda minima locusta } \\ \text { voce. }\end{array}\left\{\begin{array}{c}\text { Middle April : a small sibi- } \\ \text { lous note, till the end of } \\ \text { July. }\end{array}\right.\right.$ I5. Swift,

Hirundo apus.

16. Less reed-sparrow, $\} \begin{gathered}\text { Passer arundinaceus } \\ \text { minor. }\end{gathered}$

I7. Land-rail,

Ortygometra.

18. Largest willow-
wren,

19. Goat-sucker, or fern-owl,

\} Caprimulgus.

20. Fly-catcher,

Stoparola.
USUALLY APPEARS ABOUT.

About April 27th.

$\left\{\begin{array}{l}\text { A sweet polyglot, but hurry- } \\ \text { ing; it has the notes of } \\ \text { many birds. }\end{array}\right.$

A loud harsh note, crex, crex. (Cantat voce stridulâ locusta; end of April, on the tops of high beeches.

Beginning of May : chatters

$\left\{\begin{array}{l}\text { by night with a singular } \\ \text { noise. }\end{array}\right.$ $\left\{\begin{array}{l}\text { bird; this is the latest } \\ \text { summer bird of passage. }\end{array}\right.$
(May I2th: a very mute

This assemblage of curious and amusing birds belongs to ten several genera of the Linnæan system; and are all of the ordo of passeres save the Fynx and Cuculus, which are pica, and the Charadrius (Edicnemus) and Rallus (Ortygometra), which are gralle.

These birds, as they stand numerically, belong to the following Linnæan genera :

$\begin{array}{lll}\text { 1, } & \text { Fynx. } & \text { 13. Columba. } \\ \text { 2, 6, 7, 9, 10, 11, 16, 18, } & \text { Motacilla. } & \text { 17. Rallus. } \\ 3,4,5,15, & \text { Hirundo. } & \text { 19. Caprimulgus. } \\ 8, & \text { Cuculus. } & \text { 14. Alauda. } \\ \text { 12, } & \text { Charadrius. } & \text { 20. Muscicapa. }\end{array}$

Most soft-billed birds live on insects, and not on grain and seeds; and therefore at the end of summer they retire: but the following soft-billed birds, though insect-eaters, stay with us the year round :

RAII NOMINA.

Redbreast, Rubecila.

Wren,

Passer troglodytes.

Hedge-sparrow,

Curruca.

(These frequent houses; and haunt out-buildings in the winter : eat spiders.

S riaunt sinks for crumbs and $\{$ other sweepings. 
RAII NOMINA.

White-wagtail,

Yellow-wagtail.

Grey-wagtail,

Wheat-ear,

Whin-chat, Stone-chatter,

Gorien-crowned wren, Regulus cristatus. Motacilla flava. Motacilla cinerea.

Enanthe.

Enanthe secunda.

Enanthe tertia.
(These frequent shallow rivulets near the spring heads, where they never freeze: eat the aureliæ of Fhryganea. The

(This is the smallest British bird : haunts the tops of tall trees; stays the winter through.

A List of the Winter Birds of Passage round this NeighBOURHOOD, RANGED SOMEWHAT IN THE ORDER IN WHICH THEY APPEAR.

RAII NOMINA.

1. Ring-ousel, Nienula torouata.

2. Redwing,

Turdus iliacus.

3. Fieldfare,

Turdus pilaris.

4. Royston-crow,

Cornix cinarsú.

5. Woodcock,

6. Snipe.

7. Jack-snipe.

8. Wood-pigeon,

9. Wild-swan.

10. Wild-goose,

I I. Wild-duck,

12. Pochard,

13. Wigeon,

I4. Teal, breeds with

$\left.\begin{array}{l}\text { us in Wolmer } \\ \text { Forest, }\end{array}\right\}$ Querquedula.

I5. Gross-beak,

I6. Cross-bill,

I7. Silk-tail.

Anser ferus.

Anas fera fusca.

Penelope.
Coccothraustes.

Loxia.

Garruius bohemicus.
(This is a new migration, which

I have lately discovered about

Michaelmas week, and again about the I4th March.

About old Michaelmas.

$\{$ Though a percher by day, $\{$ roosts on the ground.

Most frequent on downs.

Appears about old Michaelmas.

S Some snipes constantly breed

$\{$ with us.

S Seldom appears till late; not $\{$ in such plenty as formerly.

On some large waters.

Anas torquata minor.

On our lakes and streams.

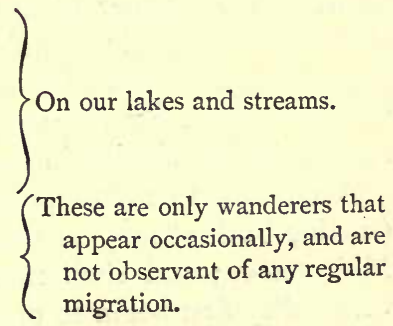


The birds, as they stand numerically, belong to the following Linnæan genera :

$\begin{array}{llll}\text { 1, 2, 3, } & \text { Turdus. } & \text { 9, 10, 11, 12, 13, 14, Anas. } \\ \text { 4, } & \text { Corvus. } & \text { 15, 16, } & \text { Loxia. } \\ \text { 5, 6, 7, } & \text { Scolopax. } & \text { 17, } & \text { Ampelis. } \\ 8, & \text { Columba. } & & \end{array}$

Birds that sing in the night are but few.
Nightingale,
Luscinia.
Woodlark,
Alauda arborea.
Less reed-sparrow, $\left\{\begin{array}{c}\text { Passer arnndinaceus } \\ \text { minor. }\end{array}\right\}$
$\left\{\begin{array}{l}\text { "In shadiest covert hid." } \\ \text { Milton. }\end{array}\right.$ Suspended in mid air.
\} Among reeds and willows.

I should now proceed to such birds as continue to sing after Midsummer, but, as they are rather numerous, they would exceed the bounds of this paper : besides, as this is now the season for remarking on that subject, I am willing to repeat my observations on some birds concerning the continuation of whose song $i$ seem at present to have some drubt.

I dm, etc.

\section{LETTER II.}

Selborne, Nov. 2nd, i? 6 g.

DEAR Sir,-When I did myself the honour to write to you about the end of last June on the subject of natural history, I sent you a list of the summer birds of passage which I have observed in this neighbourhood; and also a list of the winter birds of passage: I mentioned besides those soft-billed birds that stay with us the winter through in the south of England, and those that are remarkable for singing in the night.

According to my proposal, I shall now proceed to such birds (singing birds strictly so called) as continue in full song till after Midsummer; and shall range them somewhat in the order in which they first begin to open as the spring advances. 
RAII NOMINA.

I. Woodlark,

2. Song-thrush,

3. Wren.

4. Redbreast,

5. Hedge-sparrow,

6. Yellow-hammer.

7. Sikylark,

8. Swallow,

9. Black-cap,

ro. Titlark,

II. Blackbird,

12. Whitethroat,

13. Goldfinch,

14. Greenfinch, $\left.\begin{array}{l}\text { 15. Less reed-spar- } \\ \text { row, }\end{array}\right\} \begin{aligned} & \text { Passer arundinaceus } \\ & \text { minor. }\end{aligned}$

Rubecula.

Curruca.

Emberiza fava.

Alauda vulgaris.

Hirundo domestica.

Atricapilla.

Alauda pratorum.

Merula vulgaris.

Ficedula affinis.

Carduelis.

Chloris.

16. Common linnet, Linaria vulgaris. $\left\{\begin{array}{l}\text { In January, and continues to } \\ \text { sing through all the summer } \\ \text { and autumn. }\end{array}\right.$ $\left\{\begin{array}{l}\text { In February and on to August; } \\ \text { re-assume their song in au- } \\ \text { tumn. }\end{array}\right.$ $\left\{\begin{array}{l}\text { All the year, hard frost ex- } \\ \text { cepted. }\end{array}\right.$ Ditto.

Early in February to July Ioth. $\{$ Early in February, and on $\{$ through July to August 2ist. In February and on to October. From April to September.

Beginning of April to July I 3 th. $\left\{\begin{array}{l}\text { From middle of April to July } \\ \text { I6th. }\end{array}\right.$ $\left\{\begin{array}{l}\text { Sometimes in February and } \\ \text { March, and so on to July } \\ 23 \text { rd ; re-assumes in autumn. }\end{array}\right.$ In April, and on to July 23 rd. $\{$ April, and through to SepOn to July and August 2nd.

? May, on to beginning of July. Breeds and whistles on till August; re-assumes its note when they begin to congregate in October, and again early before the flocks separate.

Birds that cease to be in full song, and are usually silent at or before Midsummer :

RAII NOMINA.

17. Middle willow-
wren,

18. Redstart, Ruticilla.

19. Chaffinch, Fringilla.

20. Nightingale,
Ditto : begins in May.

$\{$ Beginning of June; sings first $\{$ in February.

$\left\{\begin{array}{c}\text { Middle of June : sings first in } \\ \text { April. }\end{array}\right.$ 
Birds that sing for a short time, and very early in the spring :

RAII NOMINA.

21. Missel-bird. Turdus viscivorus.

22. Great titmouse, ? or ox-eye, $\}$ Fringillago. $\left\{\begin{array}{l}\text { January 2nd, I770, in February, } \\ \text { Is called in Hampshire and } \\ \text { Sussex the storm-cock, be- } \\ \text { cause its song is supposed to } \\ \text { forbode windy wet weather ; } \\ \text { it is the largest singing bird } \\ \text { we have. }\end{array}\right.$

(In February, March, April : re-assumes for a short time in September.

Birds that have somewhat of a note or song, and yet are hardly to be called singing birds :

$\left.\begin{array}{l}\text { 23. Golden-crowned } \\ \text { wren, }\end{array}\right\}$ Regulus cristatus.

(Its note as minute as its person; frequents the tops of high oaks and firs; the smallest British bird.

S Haunts great woods: two harsh $\left\{\begin{array}{l}\text { sharp notes. } \\ \text { shang }\end{array}\right.$

24. Marsh-titmouse, Parus palustris.

$\int$ Sings in March, and on to Sep-

25. Small willow-wren, Regulus non cristatus.

26. Largest ditto,

Ditto. tember.

S Cantat voce stridula locuste; $\{$ from end of A pril to August. 27. Grasshopper-lark, $\} \begin{gathered}\text { Alauda minıma voce } \\ \text { locusta. }\end{gathered}$ $\int$ Chirps all night, from the mid-

dle of April to the end of July.

28. Martin,

Hiruna'o agrestis.

29. Bullfinch,

30. Bunting,
Fyrrlawlu.

Emberiza alba.
$\{$ All the breeding time; from May to September.

$\{$ From the end of January to $\{$ July.

All singing birds, and those that have any pretensions to song, not only in Britain, but perhaps the world through, come under the Linnæan ordo of Passeres.

The above-mentioned birds, as they stand numerically, belong to the following Linnæan genera:

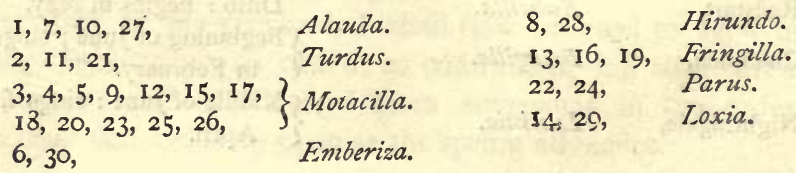


Birds that sing as they fly are but few :

\begin{tabular}{|c|c|c|}
\hline Skylark, & $\begin{array}{l}\text { RAII NOMINa. } \\
\text { Alauda vulgaris. }\end{array}$ & Rising, suspended, and falling. \\
\hline Titlark, & Alauda pratorum. & $\left\{\begin{array}{l}\text { In its descent; also sitting on } \\
\text { trees, and walking on the } \\
\text { ground. }\end{array}\right.$ \\
\hline Woodlark, & Alauda arborea. & $\left\{\begin{array}{c}\text { Suspended ; in hot summer } \\
\text { nights all night long. }\end{array}\right.$ \\
\hline Blackbird, & Merula. & Sometimes from bush to bush. \\
\hline White-throat, & Fïcedula affinis. & $\left\{\begin{array}{c}\text { Uses when singing on the wing } \\
\text { odd jerks and gesticulations. }\end{array}\right.$ \\
\hline $\begin{array}{l}\text { Swallow, } \\
\text { Wren, }\end{array}$ & $\begin{array}{l}\text { Hirundo domestica. } \\
\text { Passer troglodytes. }\end{array}$ & $\begin{array}{l}\text { In soft sunny weather. } \\
\text { Sometimes from bush to bush. }\end{array}$ \\
\hline
\end{tabular}

Birds that breed most early in these parts :

Raven,

Song-thrush,

Blackbird,

Rook,

Woodlark,

Ring-dove,
Corvus.

Turdus.

Merula.

Cornix frugilega.

Alauda arborea.

Palumbus torquatus. $\left\{\begin{array}{c}\text { Hatches in Febuary and } \\ \text { March. }\end{array}\right.$

In March.

In March.

Builds the beginning of March. Hatches in April.

Lays the beginning of April.

All birds iat continue in full song till after Midsummer appear to me to bree 1 more than once.

Most kinds of birds seem to me to be wild and shy somewhat in proportion to their bulk; I mean in this island, where they are much pursued and annoyed; but in Ascension Island, and many other desolate places, mariners have found fowls so unacquainted with a human figure, that they would stand still to be taken; as is the case with boobies, etc. As an example of what is advanced, I remark that the golden-crested wren (the smallest British bird) will stand unconcerned till you come within three or four yards of it, while the bustard (Otis), the largest British land fowl, does not care to admit a person within so many furlongs. ${ }^{1}$

$$
\text { I am, etc. }
$$

\section{NOTE TO LETTER II.}

1 The bustard, once common in several parts of the country, is now almost extinct. Its last abiding place was the fenny part of Norfolk, but the gun and 
snare, indiscriminately used, have banished it. One way of destroying it was by baiting a spot within range of a battery of shot guns, so laid that a person at a distance could, by means of a long string, discharge them when the bustards came sufficiently near. Two or three years ago a male bustard was seen on the fens, and every effort was made by the landowners to keep it safe. They even turned out two female birds in the hope that it would pair with one and breed ; but after staying about for a few days it flew away, and was not. again seen.

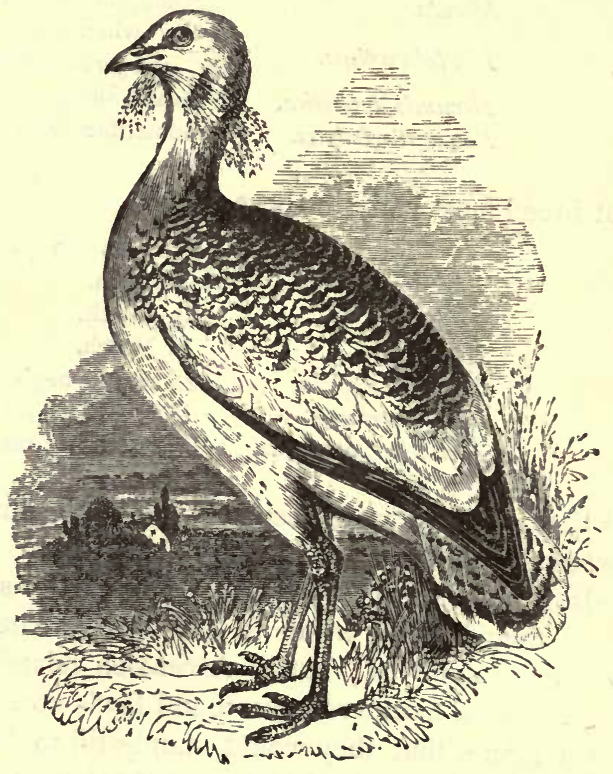

The Great Bustard (Otis tara).

LETTER III.

SELborne, fan. 15 th, 1770.

DEAR SIR,-It was no small matter of satisfaction to me to find that you were not displeased with my little methodus of birds. If there was any merit in the sketch, it must be owing to its punctuality. For many months I carried a list in my pocket of 
the birds that were to be remarked, and, as I rode or walked apout my business, I noted each day the continuance or omission of each bird's song; so that I am as sure of the certainty of my facts as a man can be of any transaction whatsoever.

I shall now proceed to answer the several queries which you put in your two obliging letters, in the best manner that I am able. Perhaps Eastwick, and its environs, where you heard so very few birds, is not a woodland country, and therefore not stocked with such songsters. If you will cast your eye on my last letter, you will find that many species continued to warble after the beginning of July.

The titlark and yellow-hammer breed late, the latter very late; and therefore it is no wonder that they protract their song: for I lay it down as a maxim in ornithology, that as long as there is any incubation going on there is music. As to the redbreast and wren, it is well known to the most incurious observer that they whistle the year round, hard frost excepted; especially the latter.

It was not in my power to procure you a black-cap, or a less reed-sparrow, or sedge-bird, alive. As the first is undoubtedly, and the last, as far as I can yet see, a summer bird of passage, they would require more nice and curious management in a cage than I should be able to give them: they are both distinguished songsters. The note of the former has such a wild sweetness that it always brings to my mind those lines in a song in "As You Like It :"

"And tune his merry note

Unto the wild bird's throat."-SHAKESPEARE.

The latter has a surprising variety of notes resembling the song of several other birds; but then it has also a hurrying manner, not at all to its advantage: it is notwithstanding a delicate polyglot.

It is new to me that titlarks in cages sing in the night; perhaps only caged birds do so. I once knew a tame redbreast in a cage that alway's sang as long as candles were in the room; but in their wild state no one supposes they sing in the night.

I should be almost ready to doubt the fact, that there are to be seen much fewer birds in July than in any former month, not 
withstanding so many young are hatched daily. Sure I am that it is far otherwise with respect to the swallow tribe, which increases prodigiously as the summer advances: and I saw at the time mentioned, many hundreds of young wagtails on the banks of the Cherwell, which almost covered the meadows. If the matter appears as you say in the other species, may it not be owing to the dams being engaged in incubation, while the young are concealed by the leaves?

Many times have I had the curiosity to open the stomachs of woodcocks and snipes; but nothing ever occurred that helped to explain to me what their subsistence might be : all that I could ever find was a soft mucus, among which lay many pellucid small gravels. ${ }^{1}$

I am, etc.

NOTE TO LETTER III.

1 Upon examining patches of mud on which I have flushed woodcocks and snipes, I have found them riddled with small perforations, clearly made by the bills of the birds, which must have been seeking some insects or worms therein.

LETTER IV.

Selborne, Feb. 19th, 1770.

DEAR SIR,-Your observation that "the cuckoo does not deposit its egg indiscriminately in the nest of the first bird that comes in its way, but probably looks out a nurse in some degree congenerous, with whom to intrust its young," is perfectly new to me; and struck me so forcibly, that I naturally fell into a train of thought that led me to consider whether the fact was so, and what reason there was for it. When I came to recollect and inquire, I could not find that any cuckoo had ever been seen in these parts, except in the nest of the wagtail, the hedge-sparrow, the titlark, the white-throat, and the redbreast, all soft-billed insectivorous birds. The excellent Mr. Willughby mentions the nest of the Palumbus 
(ring-dove), and of the fringilla (chaffinch), birds that subsist on acorns and grains, and such hard food: but then he does not mention them as of his own knowledge; but says afterwards that he saw himself a wagtail feeding a cuckoo. It appears hardly possible that a soft-billed bird should subsist on the same food with the hard-billed: for the former have thin membranaceous stomachs suited to their soft food; while the latter, the granivorous tribe, have strong muscular gizzards, which, like mills, grind, by the help of small gravelsand pebbles, what is swallowed. This proceeding of the cuckoo, of dropping its eggs as it were by chance, is such a monstrous outrage on maternal affection, one of the first great dictates of nature; and such a violence on instinct; that, had it only been related of a bird in the Brazils, or Peru, it would never have merited our belief. But yet, should it farther appear that this simple bird, when divested of

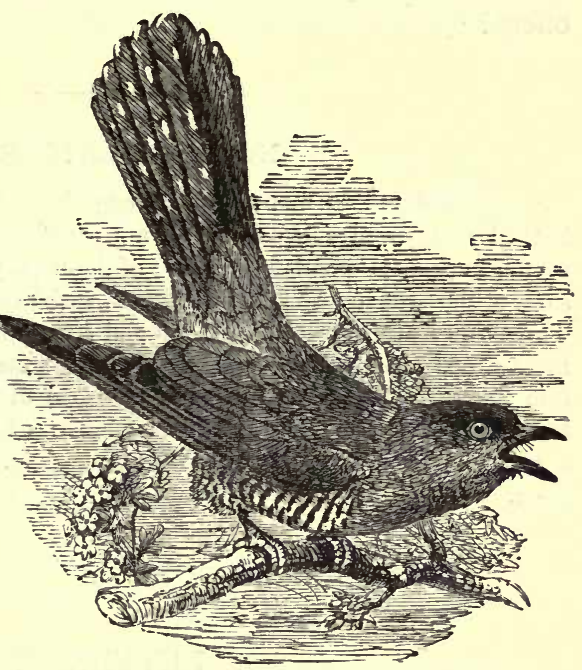

'The Common Cuckoo (Cuculus canorus). that natural $\sigma \tau o \rho \gamma \eta$ that seems to raise the kind in general above themselves, and inspire them with extraordinary degrees of cunning and address, may be still endued with a more enlarged faculty of discerning what species are suitable and congenerous nursingmothers for its disregarded eggs and young, and may deposit them only under their care, this would be adding wonder to wonder, and instancing, in a fresh manner, that the methods of Providence are not subjected to any mode or rule, but astonish us in new lights, and in various and changeable appearances.

What was said by a very ancient and sublime writer concerning 
the defect of natural affection in the ostrich, may be well applied to the bird we are talking of :

"She is hardened against her young ones, as though they were not hers :

"Because God hath deprived her of wisdom, neither hath $\mathrm{He}$ imparted to her understanding." *

Query.-Does each female cuckoo lay but one egg in a season, or does she drop several in different nests according as opportunity offers ? 1

I am, etc.

\section{NO'TE TO LETTER IV.}

1 I have found so many cuckoos' eggs in a district where there were but a limited number of cuckoos, that I am satisfied it lays several eggs. The egg of the cuckoo is small for the size of the bird, yet it often looks a morster in some of the nests in which it is deposited, such as sedge-warblers and reed-wrens. Three times at least it has been found in a grasshopper warbler's, where the font or the beak must have been the agent in transferring the egg after being laid into the nest. One July at Wroxham Broad in Norfolk, there were thirty or forty cuckoos flying restlessly about from tree to tree, and uttering frequently a treble cry; thus: cuck-cuckoo-cuck-cuckoo. A week later they were all gone.

\section{LETTER V.}

Selborne, April $12 t h$, I 770.

DeAR SiR,-I heard many birds of several species sing last year after Midsummer; enough to prove that the summer solstice is not the period that puts a stop to the music of the woods. The yellow-hammer no doubt persists with more steadiness than any other; but the woodlark, the wren, the redbreast, the swallow, the white-throat, the goldfinch, the common linnet, are all undoubted instances of the truth of what I advanced.

If this severe season does not interrupt the regularity of the summer migrations, the black-cap will be here in two or three days.

* Job xxxix 16,17 . 
I wish it was in my power to procure you one of those songsters ; but I arn no birdcatcher; and so little used to birds in a cage, that I fear if I had one it would soon die for want of skill in feeding.

Was your reed-sparrow, which you kept in a cage, the thickbilled reed-sparrow of the Zoology, p. 320 ; or was it the less reed-sparrow of Ray, the sedge-bird of Mr. Pennant's last publication, p. I6?

As to the matter of long-billed birds growing fatter in moderate frosts, I have no doubt within myself what should be the reason.

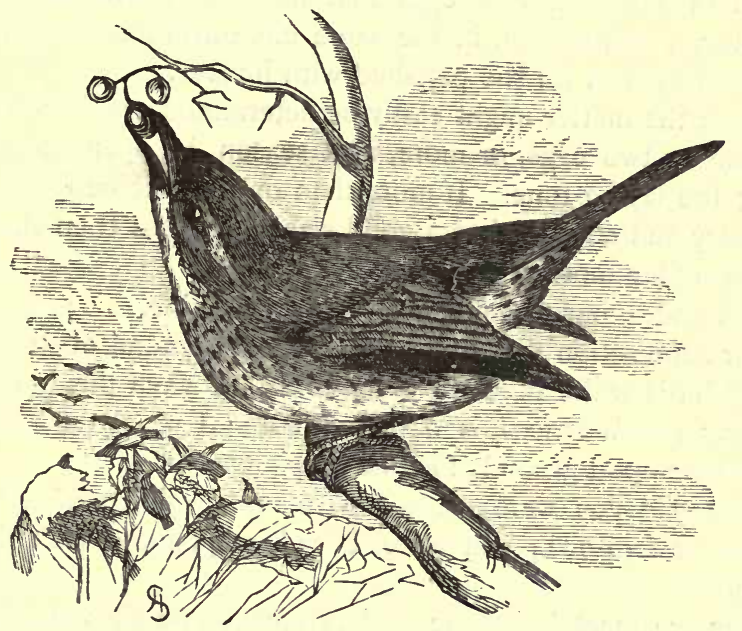

The Redwing.

The thriving at those times appears to me to arise altogether from the gentle check which the cold throws upon insensible perspiration. The case is just the same with blackbirds, etc.; and farmers and warreners observe, the first, that their hogs fat more kindly at such times, and the latter that their rabbits are never in such good case as in a gentle frost. But when frosts are severe, and of long continuance, the case is soon altered; for then a want of food soon overbalances the repletion occasioned by a checked perspiration. I have observed, moreover, that some human constitutions are more inclined to plumpness in winter than in summer. 
When birds come to suffer by severe frost, I find that the first that fail and die are the redwing-fieldfares, and then the songthrushes.

You wonder, with good reason, that the hedge-sparrows, etc., can be induced at all to sit on the egg of the cuckoo without being scandalised at the vast disproportionate size of the supposititious egg; but the brute creation, I suppose, have very little idea of size, colour, or number. For the common hen, I know, when the fury of incubation is on her, will sit on a single shapeless stone instead of a nest full of eggs that have been withdrawn: and, moreover, a hen-turkey, in the same circumstances, would sit on in the empty nest till she perished with hunger.

I think the matter might easily be determined whether a cuckoo lays one or two eggs, or more, in a season, by opening a female during the laying-time. If more than one was come down out of the ovary and advanced to a good size, doubtless then she would that spring lay more than one.

I will endeavour to get a hen, and to examine.

Your supposition that there may be some natural obstruction in singing birds while they are mute, and that when this is removed the song recommences, is new and bold: I wish you could discover some good grounds for this suspicion.

I was glad you were pleased with my specimen of the caprimulgus, or fern-owl; you were, I find, acquainted with the bird before.

When we meet I shall be glad to have some conversation with you concerning the proposal you make of my drawing up an account of the animals in this neighbourhood. Your partiality towards my small abilities persuades you, I fear, that I am able to do more than is in my power: for it is no small undertaking for a man unsupported and alone to begin a natural history from his own autopsia! Though there is endless room for observation in the field of nature, which is boundless, yet investigation (where a man endeavours to be sure of his facts) can make but slow progress; and all that one could collect in many years would go into a very narrow compass.

Some extracts from your ingenious "Investigations of the Differ- 
ence between the Present Temperature of the Air in Italy," etc., have fallen in my way, and gave me great satisfaction: they have removed the objections that always arose in my mind whenever i came to the passages which you quote. Surely the judicious Virgil, when writing a didactic poem for the region of Italy, could never think of describing freezing rivers, unless such severity of weather pretty frequently occurred!

P.S.-Swallows appear amidst snows and frost.

\section{LETTER VI.}

Selborne, May 21 st, I 770 .

DEAR SIR,-The severity and turbulence of last month so interrupted the regular process of summer migration, that some of the birds do but just begin to show themselves, and others are apparently thinner than usual; as the white-throat, the black-cap, the red-start, the fly-catcher. I well remember that after the very severe spring in the year I 739-40, summer birds of passage were very scarce. They come probably hither with a south-east wind, or when it blows between those points; but in that unfavourable year the winds blowed the whole spring and summer through from the opposite quarters. And yet amidst all these disadvantages two swallows, as I mentioned in my last, appeared this year as early as the I Ith April amidst frost and snow; but they withdrew again for a time.

I am not pleased to find that some people seem so little satisfied with Scopoli's new publication; there is room to expect great things from the hands of that man, who is a good naturalist : and one would think that a history of the birds of so distant and southern a region as Carniola would be new and interesting. I could wish to see that work, and hope to get it sent down. Dr. Scnnoli is physician to the wretches that work in the quicksilver mines of that district.

When you talked of keeping a reed-sparrow, and giving it seeds, I could not help wondering; because the reed-sparrow which I 
mentioned to you (Passer arundinaceus minor Raii) is a soft-billed bird; and most probably migrates hence before winter; whereas the bird you kept (Passer torquatus Raii) abides all the year, and is a thick-billed bird. I question whether the latter be much of a songster; but in this matter I want to be better informed. The former has a variety of hurrying notes, and sings all night. Some part of the song of the former, I suspect, is attributed to the latter. We have plenty of the soft-billed sort; which Mr. Pennant had entirely left out of his "British Zoology," till I reminded him of his omission. See "British Zoology" last published, p. I6.

I have somewhat to advance on the different manners in which different birds fly and walk; but as this is a subject that I have not enough considered, and is of such a nature as not to be contained in a small space, I shall say nothing further about it at present.

No doubt the reason why the sex of birds in their first plumage is so difficult to be distinguished is, as you say, "because they are not to pair and discharge their parental functions till the ensuing spring." As colours seem to be the chief external sexual distinction in many birds, these colours do not take place till sexual attachments begin to obtain. And the case is the same in quadrupeds; among whom, in their younger days, the sexes differ but little: but, as they advance to maturity, horns and shaggy manes, beards and brawny necks, etc., etc., strongly discriminate the male from the female. We may instance still farther in our own species, where a beard and stronger features are usually characteristic of the male sex: but this sexual diversity does not take place in earlier life; for a beautiful youth shall be so like a beautiful girl that the difference shall not be discernible;

"Quem si puellarum insereres choro,

Mirè sagaces falleret hospites

Discrimen obscurum, solutis

Crinibus, ambiguoque vultu."

HOR. ODES. II. od. 5-2I, p. $13 \%$, orig. ediit. 


\section{LETTER VII.}

Ringmer, near LeWES, Oct. 8th, I770.

Dear Sir,-I am giad to hear that Kuckalm is to furnish you with the birds of Jamaica; a sight of the hirundines of that hot and distant island would be a great entertainment to me.

The Anni of Scopoli are now in my possession; and I have read the Annus Primus with satisfaction; for though some parts of this work are exceptionable, and he may advance some mistaken observations, yet the ornithology of so distant a country as Carniola is very curious. Men that undertake only one district are much more likely to advance natural knowledge than those that grasp at more than they can possibly be acquainted with: every kingdom, every province, should have its own monographer.

The reason perhaps why he mentions nothing of Ray's Ornithology may be the extreme poverty and distance of his country, into which the works of our great naturalist may have never yet found their way. You have doubts, I know, whether this Ornithology is genuine, and really the work of Scopoli ; as to myself, I think I discover strong tokens of authenticity; the style corresponds with that of his Entomology; and his characters of his Ordines and Genera are many of them new, expressive, and masterly. He has ventured to alter some of the Linnæan genera with sufficient show of reason.

It might perhaps be mere accident that you saw so many swifts and no swallows at Staines; because, in my long observation of those birds, I never could discover the least degree of rivalry or hostility between the species.

Ray remarks that birds of the galline order, as cocks and hens, partridges, and pheasants, etc., are pulveratrices, such as dust themselves, using that method of cleansing their feathers, and rid̈ding themselves of their vermin. As far as I can observe, many birds that dust themselves never wash; and I once thought that those iirds that wash themselves would never dust; but here $\ddot{i}$ tind myself mistaken: for common house-sparrows are, 
great pulveratrices, being frequently seen grovelling and wallowing in dusty roads; and yet they are great washers. Does not the skylark dust?

Query.-Might not Mahomet and his followers take one method of purification from these pulveratrices? because I find from travellers of credit, that if a strict Mussulman is journeying in a sandy desert where no water is to be found, at stated hours he strips off his clothes, and most scrupulously rubs his body over with sand or dust.

A countryman told me he had found a young fern-owl in the nest of a small bird on the ground; and that it was fed by the little bird. I went to see this extraordinary phenomenon, and found that it was a young cuckoo hatched in the nest of a titlark; it was become vastly too big for its nest, appearing

\section{Majores pennas nido extendisse . .
.}

and was very fierce and pugnacious, pursuing my finger, as $\ddot{i}$ teased it, for many feet from the nest, and sparring and buffeting with its wings like a game-cock. The dupe of a dam appeared at a distance, hovering about with meat in its mouth, and expressing the greatest solicitude.

In July I saw several cuckoos skimming over a large pond; and found, after some observation, that they were feeding on the Libelluloe, or dragon-flies; some of which they caught as they settled on the weeds, and some as they were on the wing. Notwithstanding what Linnæus says, I cannot be induced to believe that they are birds of prey.

This district affords some birds that are hardly ever heard of at Selborne. In the first place considerable flocks of cross-beaks (Loxice curvirostra) have appeared this summer in the pine-groves belonging to this house; the water-ousel is said to haunt the mouth of the Lewes river, near Newhaven; and the Cornish chough builds, I know, all along the chalky cliffs of the Sussex shore.

I was greatiy pleased to see little parties of ring-ousels (my newly discovered migraters) scattered, at intervals, ali along the 
Sussex downs, from Chichester to Lewes. Let them come from whence they will, it looks very suspicious that they are cantoned along the coast in order to pass the channel when severe weather advances. They visit us again in April, as it should seem, in their return ; and are not to be found in the dead of winter. It is remarkable that they are very tame, and seem to have no manner of apprehensions of danger from a person with a gun. There are bustards on the wide downs near Brighthelmstone. No doubt you are acquainted with the Sussex downs; the prospects and rides round Lewes are most lovely!

As I rode along near the coast I kept a very sharp look-out in the lanes and woods, hoping I might, at this time of the year, have discovered some of the summer short-winged birds of passage crowding towards the coast in order for their departure : but it was very extraordinary that I never saw a red-start, white-throat, black-cap, uncrested wren, Hy-cat.her, etc. And I remember to have made the same remark in former years, as I usually come to this place annually about this time. The birds most common along the coast, at present, are the stone-chatters, whinchats, buntings, linnets, some few wheatears, titlarks, etc. Swallows and house-martins abound yet, induced to prolong their stay by this soft, still, dry season.

A land tortoise, which has been kept for thirty years in a little walled court belonging to the house where I now am visiting, retires under ground about the middle of November, and comes forth again about the middle of April. When it first appears in the spring it discovers very little inclination towards food; but in the height of summer grows voracious; and then as the summer declines its appetite declines; so that for the last six weeks in autumn it hardly eats at all. Milky plants, such as lettuces, dandelions, sowthistles, are its favourite dish. In a neighbouring village one was kept till by tradition it was supposed to be a hundred years old. An instance of vast longevity in such a poor reptile ! 


\section{LETTER VIII.}

Selborne, Dec. $20 t h, 1770$.

DEAR SIR,-The birds that I took for aberdavines were reedsparrows (Passeres torquati).

There are doubtless many home internal migrations within this kingdom that want to be better understood: witness those vast flocks of hen-chaffinches that appear with us in the winter without hardly any cocks among them. Now was there a due proportion of each sex, it should seem very improbable that any one district should produce such numbers of these little birds; and much more when only one-half of the species appears; therefore we may conclude that the Fringilla calebes, for some good purposes, have a peculiar migration of their own in which the sexes part. Nor should it seem so wonderfu that the intercourse of sexes in this species of bird should be interrupted in winter; since in many animals, and particularly in bucks and does, the sexes lierd separately, except at the season when commerce is necessary for the continuance of the breed. For this matter of the chaffinches see "Fauna Suecica," p. 58, and "Systema Naturæ," p. 318. I see every winter vast flights of hen-chaffinches, but none of cocks.

Your method of accounting for the periodical motions of the British singing birds, or birds of flight, is a very probable one; since the matter of food is a great regulator of the actions and proceedings of the brute creation; there is but one that can be set in competition with it, and that is love. But I cannot quite acquiesce with you in one circumstance when you advance that, "when they have thus feasted, they again separate into small parties of five or six, and get the best fare they can within a certain district, having no inducement to go in quest of freshturned earth." Now if you mean that the business of congregating is quite at an end from the conclusion of wheat sowing to the season of barley and oats, it is not the case with us ; for larks and chaffinches, and particularly linnets, flock and congregate as much 
in the very dead of winter as when the husbandman is busy with his ploughs and harrows.

Sure there can be no doubt but that woodcocks and fieldfares leave us in the spring, in order to cross the seas, and to retire to some districts more suitable to the purpose of breeding. That the former pair before they retire, and that the hens are forward with egg, I myself, when I was a sportsman, have often experienced. It cannot indeed be denied but that now and then we hear of a woodcock's nest, or young birds, discovered in some part or other of this island; but then they are all always mentioned as rarities, and somewhat out of the common course of things : ${ }^{1}$ but as to redwings and fieldfares, no sportsman or naturalist has ever yet, that I could hear, pretended to have found the nest or young of those species in any part of these kingdoms. And I the more admire at this instance as extraordinary, since, to all

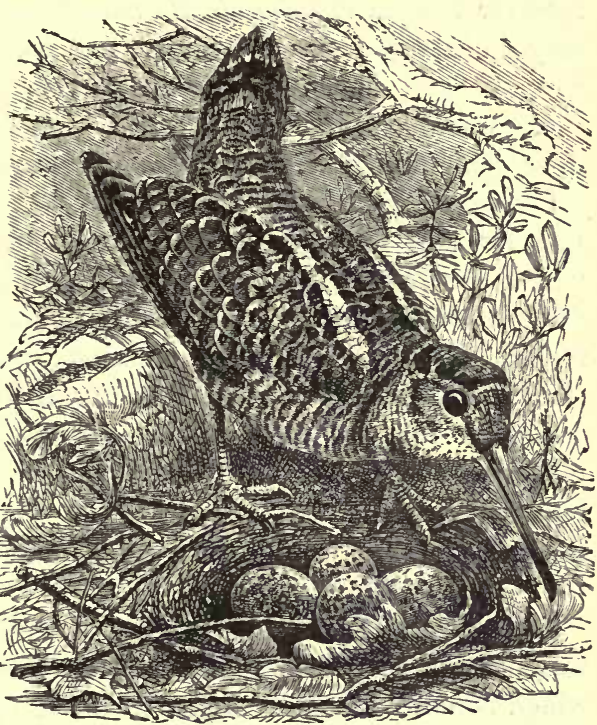

Woodcock. appearance, the same food in summer as well as in winter might support them here which maintains their congeners, the blackbirds and thrushes, did they choose to stay the summer through. From hence it appears that it is not food alone which determines some species of birds with regard to their stay or departure. Fieldfares or redwings disappear sooner or later according as the warm weather comes on earlier or later. For I well remember,

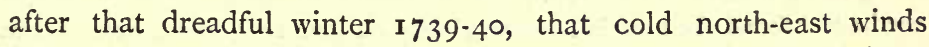
continued to blow on through April and May, and that these 
kind of birds (what few remained of them) did not depart as usual, but were seen lingering about till the beginning of June.

The best authority that we can have for the nidification of the birds above-mentioned in any district, is the testimony of faunists that have written professedly the natural history of particular countries. Now as to the fieldfare, Linnæus, in his "Fauna Suecica," says of it, that "maximis in arboribus nidificat;" and of the redwing he says, in the same place, that "nidificat in mediis arbusculis, sive sepibus: ova sex coruleo-viridia maculis nigris variis." Hence we may be assured that fieldfares and redwings build in Sweden. Scopoli says, in his "Annus Primus," of the woodcock, that "nupta ad nos venit circd aquinoctium vernale;" meaning in Tyrol, of which he is a native. And afterwards he adds "nidificat in paludibus alpinis: ova ponit 3-5." It does not appear from Kramer that woodcocks breed at all in Austria; but he says, "Avis hac septentrionalium provinciarum astivo tempore incola est; ubi plerumque nidificat. Appropinquante hyeme australiores provincias petit; hinc circd plenilunium mensis Octobris plerumque Austriam transmigrat. Tune rursis circd plenilunium potissimum mensis Martii per Austriam matrimonio juncta ad septentrionales provincias redit." For the whole passage (which I have abridged) see "Elenchus," etc., p. 35 r. This seems to be a full proof of the migration of woodcocks; though little is proved concerning the place of breeding.

P.S.-There fell in the county of Rutland, in three weeks of this present very wet weather, seven inches and a half of rain, which is more than has fallen in any three weeks for these thirty years past in that part of the world. A mean quantity in that county for one year is twenty inches and a half.

\section{NOTE TO LETTER VIII.}

1 Every year several woodcocks' nests are found in Norfolk and Suffolk. While reading my Field last Saturday, May 31st, 1879, I came upon the following most interesting note :-

"I had a curious adventure with a woodcock last week. My keeper told me he had found the bird in a covert sitting on four eggs, and I went at once with him to see it. The woodcock remained on its nest perfectly motionless 
for about ten minutes while we watched it. Next day I went again with a photographic camera and exposed three plates, the lens being within six feet of the bird, and the front leg of the stand being well within two feet. On trying to get a fourth view still nearer, the bird rose. As I do not suppose a photograph of a sitting woodcock has ever been taken before, I enclose you a print from one of my negatives The nest to-day was empty, with signs of the young birds having been satisfactorily hatched."

"R. C. GRAHAM,

"Skipness, Argyllshire."

\section{LETTER IX.}

Fyfield, near ANdover, Feb. 12th, 1772.

DeAr Sir,-You are, I know, no great friend to migration; and the well-attested accounts from various parts of the kingdom seem to justify you in your suspicions, that at least many of the swallow kind do not leave us in the winter, but lay themselves up like insects and bats in a torpid state, and slumber away the more uncomfortable months till the return of the sun and fine weather awakens them.

But then we must not, I think, deny migration in general; because migration certainly does subsist in some places, as my brother in Andalusia has fully informed me. Of the motions of these birds he has ocular demonstration, for many weeks together, both spring and fall; during which periods myriads of the swallow kind traverse the straits from north to south, and from south to north, according to the season. And these vast migrations consist not only of hirundines but of bee-birds, hoopoes, Oro pendolos, or golden thrushes; etc., etc., and also of many of our soft-billed summer birds of passage; and moreover of birds which never leave us, such as all the various sorts of hawks and kites. Old Belon, two hundred years ago, gives a curious account of the incredible armies of hawks and kites which he saw in the springtime traversing the Thracian Bosphorus from Asia to Europe. Besides the above mentioned, he remarks that the procession is swelled by whole troops of eagles and vultures.

Now it is no wonder that birds residing in Africa should retreat 
before the sun as it advances, and retire to milder regions, and especially birds of prey, whose blood being heated with hot animal food, are more impatient of a sultry climate; but then I cannot help wondering why kites and hawks, and such hardy birds as are known to defy all the severity of England, and even of Sweden and all north Europe, should want to migrate from the south of Europe, and be dissatisfied with the winters of Andalusia.

It does not appear to me that much stress may be laid on the difficulty and hazard that birds must run in their migrations, by reason of vast oceans, cross winds, etc.; because, if we reflect, a bird may travel from England to the Equator without launching out and exposing itself to boundless seas, and that by crossing the water at Dover, and again at Gibraltar. And I with the more confidence advance this obvious remark, because my brother has always found that some of his birds, and particularly the swallow kind, are very sparing of their pains in crossing the Mediterranean; for when arrived at Gibraltar they do not

\section{" Rang'd in figure wedge their way,}

. . . . And set forth

Their airy caravan high over seas

Flying, and over lands with mutual wing

Easing their flight:" . . . -Milton.

but scout and hurry along in littie detached parties of six or seven in a company; and sweeping low, just over the surface of the land and water, direct their course to the opposite continent at the narrowest passage they can find. They usually slope across the bay to the south-west, and so pass over opposite to Tangier, which, it seems, is the narrowest space.

In former letters we have considered whether it was probable that woodcocks in moonshiny nights cross the German Ocean from Scandinavia. As a proof that birds of less speed may pass that sea, considerable as it is, I shall relate the following incident, which, though mentioned to have happened so many years ago, was strictly matter of fact:-As some people were shooting in the parish of Trotton, in the county of Sussex, they killed a duck in that dreadful winter, I 708-9, with a silver collar about its neck, ${ }^{*}$

* "I have read a like anecdote of a swan." 
on which were engraven the arms of the king of Denmark. This anecdote the rector of Trotton at that time has often told to a near relation of mine ; and, to the best of my remembrance, the collar was in the possession of the rector. ${ }^{1}$

At present I do not know anybody near the sea-side that will take the trouble to remark at what time of the moon woodcocks first come; if I lived near the sea myself I would soon tell you more of the matter. One thing I used to observe when I was a sportsman, that there were times in which woodcocks were so sluggish and sleepy that they would drop again when flushed just before the spaniels, nay, just at the muzzle of a gun that had been fired at them; whether this strange laziness was the effect of a recent fatiguing journey I shall not presume to say. ${ }^{1}$

Nightingales not only never reach Northumberland and Scotland, but also, as I have been always told, Devonshire and Cornwall. In those two last counties we cannot attribute the failure of them to the want of warmth; the defect in the west is rather a presumptive argument that these birds come over to us from the continent at the narrowest passage, and do not stroll so far westward.

Let me hear from your own observation whether skylarks do not dust. I think they do ; and if they do, whether they wash also.

The Alauda pratensis of Ray was the poor dupe that was educating the booby of a cuckoo mentioned in my letter of October last.

Your letter came too late for me to procure a ring-ousel for Mr. Tunstal during their autumnal visit; but I will endeavour to get him one when they call on us again in April. I am glad that you and that gentleman saw my Andalusian birds; I hope they answered your expectation. Royston, or grey crows, are winter birds that come much about the same time with the woodcock; they, like the fieldfare and redwing, have no apparent reason for migration; for as they fare in the winter like their congeners, so might they in all appearance in the summer. Was not Tenant, when a boy, mistaken? did he not find a missel-thrush's nest, and take it for the nest of a fieldfare?

The stock-dove, or wood-pigeon, Enas Raii, is the last winter bird of passage which appears with us; it is not seen till towards 
the end of November: about twenty years ago they abounded in the district of Selborne; and strings of them were seen morning and evening that reached a mile or more; but since the beechen woods have been greatly thinned they are much decreased in number. The ring-dove, Palumbus Raii, stays with us the whole year, and breeds several times through the summer.

Before I received your letter of Ociober last I had just remarked in my journal that the trees were unusually green. This uncommon verdure lasted on late into November; and may be accounted for from a late spring, a cool and moist summer; but more particularly from vast armies of chafers, or tree-beetles, which, in many places, reduced whole woods to a leafless naked state. These trees shot again at Midsummer, and then retained their foliage till very late in the year. ${ }^{2}$

My musical friend, at whose house I am now visiting, has tried all the owls that are his near neighbours with a pitch-pipe set at concert pitch, and finds they all hoot in B flat. He will examine the nightingales next spring.

I am, etc., etc.

\section{NOTES TO LETTER IX.}

1 I have observed woodcocks sluggish and owl-like in their movements during a continuance of bright cool weather in the autumn, and have attributed it to fatigue after a long flight.

${ }^{2}$ The leaves of a number of currant bushes in my garden were destroyed this spring by a vast number of the caterpillars of the magpie moth, so that the trees were black and apparently lifeless; yet after Midsummer, when the caterpillars had turned into moths, the bushes budded again and were soon in full leaf, but bore no fruit.

LETTER X.

Selborne, Aug. 1st, 1771.

DEAR SrR,-From what follows, it will appear that neither owls nor cuckoos, keep to one note. A friend remarks that many (most) 
of his owls hoot in B flat; but that one went almost half a note below $A$. The pipe he tried their notes by was a common halfcrown pitch-pipe, such as masters use for tuning of harpsichords; it was the common London pitch.

A neighbour of mine, who is said to have a nice ear, remarks that the owls about this village hoot in three different keys, in $\mathrm{G}$ flat, or F sharp, in B flat and A flat. He heard two hooting to each other, the one in A flat, and the other in B flat. Query: Do these different notes proceed from different species, or only from various individuals? The same person finds upon trial that the note of the cuckoo (of which we have but one species) varies in different individuals; for, about Selborne wood, he found they were mostly in $\mathrm{D}$ : he heard two sing together, the one in $\mathrm{D}$, the other in D sharp, who made a disagreeable concert : he afterwards heard one in D sharp, and about Wolmer Forest some in C. As to nightingales, he says that their notes are so short, and their transitions so rapid, that he cannot well ascertain their key. Perhaps in a cage, and in a room, their notes may be more distinguishable. This person has tried to settle the notes of a swift, and of several other small birds, but cannot bring them to any criterion.

As I have often remarked that redwings are some of the first birds that suffer with us in severe weather, it is no wonder at all that they retreat from Scandinavian winters : and much more the ordo of gralla, who, all to a bird, forsake the northern parts of Europe at the approach of winter. "Gralla tanquam conjurate, unanimiter in fugam se conjiciunt; ne earum unicam quidem inter nos habitantem invenire possimus; ut enim astate in australibus degere nequeunt ob defectum lumbricorum, terramque siccam; ita nec in frigidis ob eandem causam," says Ekmarck the Swede, in his ingenious little treatise called "Migrationes Avium," which by all means you ought to read while your thoughts run on the subject of migration. See "Amœnitates Academicæ," vol. iv., p. 565.

Birds may be so circumstanced as to be obliged to migrate in one country, and not in another: but the gralle (which procure their food from marshes and boggy grounds), must in winter forsake the more northerly parts of Europe, or perish for want of food. 
I am glad you are making inquiries from Linnæus concerning the woodcock: it is expected of him that he should be able to account for the motions and manner of life of the animals of his own "Fauna."

Faunists, as you observe, are too apt to acquiesce in bare descriptions, and a few synonyms : the reason is plain ; because all that may be done at home in a man's study, but the investigation of the life and conversation of animals, is a concern of much more trouble and difficulty, and is not be attained but by the active and inquisitive, and by those that reside much in the country.

Foreign systematics are, I observe, much too vague in their specific differences; which are almost universally constituted by one or two particular marks, the rest of the description running in general terms. But our countryman, the excellent Mr. Ray, is the only describer that conveys some precise idea in every term or word, maintaining his superiority over his followers and imitators in spite of the advantage of fresh discoveries and modern information.

At this distance of years it is not in my power to recollect at what periods woodcocks used to be sluggish or alert when I was a sportsman: but, upon my mentioning this circumstance to a friend, he thinks he has observed them to be remarkably listless against snowy foul weather; if this should be the case, then the inaptitude for flying arises only from an eagerness for food; as sheep are observed to be very intent on grazing against stormy wet evenings.

I am, etc., etc.

\section{LETTER XI.}

Selborne, Feb. 8th, 1772.

DEAR SIR, - When I ride about in the winter, and see such prodigious flocks of various kinds of birds, I cannot help admiring at these congregations, and wishing that it was in my power to account for those appearances almost peculiar to the season. The 
two great motives which regulate the proceedings of the brute creation are love and hunger; the former incites animals to perpetuate their kind; the latter induces them to preserve individuals : whether either of these should seem to be the ruling passion in the matter of congregating is to be considered. As to love, that is out of the question at a time of the year when that soft passion is not indulged : besides, during the amorous season, such a jealousy prevails between the male birds that they can hardly bear to be together in the same hedge or field. Must of the singing and elation of spirits of that time seem to me to be the effect of rivalry and emulation: and it is to this spirit of jealousy that I chiefly attribute the equal dispersion of birds in the spring over the face of the country.

Now as to the business of food: as these animals are actuated by instinct to hunt for necessary food, they should not, one would suppose, crowd together in pursuit of sustenance at a time when it is most likely to fail; yet such associations do take place in hard weather chiefly, and thicken as the severity increases. As some kind of self-interest and self-defence is no doubt the motive for the proceeding, may it not arise from the helplessness of their state in such rigorous seasons; as men crowd together, when under great calamities, though they know not why? Perhaps approximation may dispel some degree of cold; and a crowd may make each individual appear safer from the ravages of birds of prey and other dangers.

If $I$ admire when I see how much congenerous birds love to congregate, I am the more struck when I see incongruous ones in such strict amity. If we do not much wonder to see a flock of rooks usually attended by a train of daws, yet it is strange that the former should so frequently have a flight of starlings for their satellites. Is it because rooks have a more discerning scent than their attendants, and can lead them to spots more productive of food? Anatomists say that rooks, by reason of two large nerves which run down between the eyes into the upper mandible, have a more delicate feeling in their beaks than other round-billed birds, and can grope for their meat when out of sight. Perhaps, then, their associates attend them on the motive of interest, as 
greyhounds wait on the motions of their finders; and as lions are said to do on the yelpings of jackals. Lapwings and starlings sometimes associate.

\section{LETTER XII.}

March 9 th, 1772.

DEAR SIR, - As a gentleman and myself were walking on the $4^{\text {th }}$ of last November round the sea-banks at Newhaven, near the mouth of the Lewes river, in pursuit of natural knowledge, we were surprised to see three house-swallows gliding very swiftly by us. That morning was rather chilly, with the wind at north-west; but the tenor of the weather for some time before had been delicate, and the noons remarkably warm. From this incident, and from repeated accounts which I meet with, I am more and more induced to believe that many of the swallow kind do not depart from this island, but lay themselves up in holes and caverns; and do, insect-like and bat-like, come forth at mild times, and then retire again to their latebra. Nor make I the least doubt but that, if I lived at Newhaven, Seaford, Brighthelmstone, or any of those towns near the chalk cliffs of the Sussex coast, by proper observations, I should see swallows stirring at periods of the winter, when the noons were soft and inviting, and the sun warm and invigorating. And I am the more of this opinion from what I have remarked during some of our late springs, that though some swallows did make their appearance about the usual time, viz., the $13^{\text {th }}$ or $14^{\text {th }}$ April, yet meeting with a harsh reception, and blustering cold north-east winds, they immediately withdrew. absconding for several days, till the weather gave them better encouragement. 


\section{LETTER XIII.}

April 12th, 1772.

DEAR SIR, - While I was in Sussex last autumn my residence was at the village near Lewes, from whence I had formerly the pleasure of writing to you. On the Ist Novenuber I remarked that the old tortoise, formerly mentioned, began first to dig the ground in

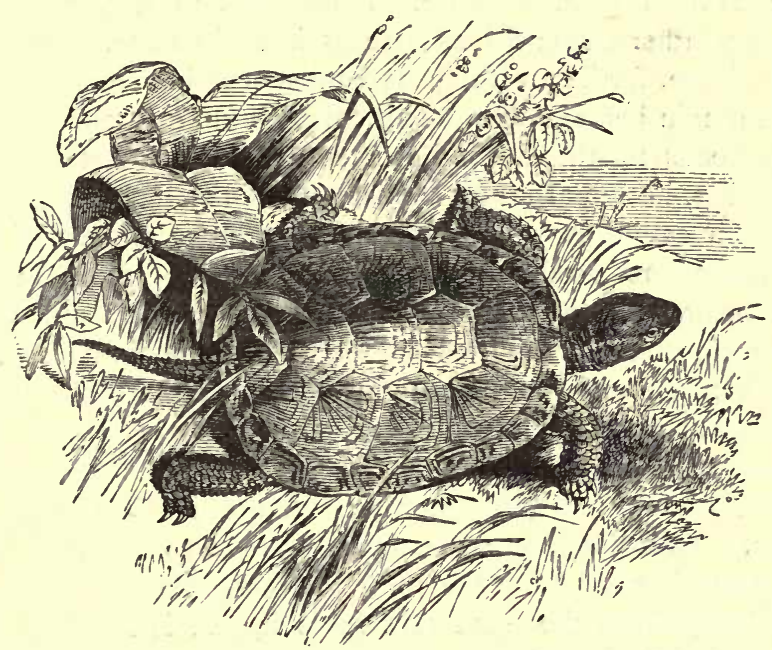

THE TORTOISE.

order to the forming its hybernaculum, which it had fixed on just beside a great tuft of hepaticas. It scrapes out the ground with its fore-feet, and throws it up over its back with its hind; but the motion of its legs is ridiculously slow, little exceeding the hourhand of a clock; and suitable to the composure of an animal said to be a whole month in performing one feat of copulation. Nothing can be more assiduous than this creature night and day in scooping the earth, and forcing its great body into the cavity; but, as the noons of that season proved unusually warm and 
sunny, it was continually interrupted, and called forth by the heat in the middle of the day; and though I continued there till the I 3 th November, yet the work remained unfinished. Harsher weather, and frosty mornings, would have quickened its operations. No part of its behaviour ever struck me more than the extreme timidity it always expresses with regard to rain; for though it has a shell that would secure it against the wheel of a loaded cart, yet does it discover as much solicitude about rain as a lady dressed in all her best attire, shuffling away on the first sprinklings, and running its head up in a corner. If attended to, it becomes an excellent weather-glass; for as sure as it walks elate, and as it were on tiptoe, feeding with great earnestness in a morning, so sure will it rain before night. It is totally a diurnal animal, and never pretends to stir after it becomes dark. The tortoise, like other reptiles, has an arbitrary stomach as well as lungs; and can refrain from eating as well as breathing for a great part of the year. When first awakened it eats nothing; nor again in the autumn before it retires: through the height of the summer it feeds voraciously, devouring all the food that comes in its way. I was much taken with its sagacity in discerning those that do it kind offices; for, as soon as the good old lady comes in sight who has waited on it for more than thirty years, it hobbles towards its benefactress with awkward alacrity; but remains inattentive to strangers. Thus not only "the ox knoweth his owner, and the ass his master's crib,"* but the most abject reptile and torpid of beings distinguishes the hand that feeds it, and is touched with the feelings of gratitude!

I am, etc., etc.

P.S.- In about three days after I left Sussex the tortoise retired into the ground under the hepatica.

$$
\text { * Isa. i. } 3 .
$$




\section{LETTER XIV.}

Sel.boRne, March 26th, 1773.

DEAR SIR,-The more I reflect on the $\sigma \tau$ Topy more I am astonished at its effects. Nor is the violence of this affection more wonderful than the shortness of its duration. Thus every hen is in her turn the virago of the yard, in proportion to the helplessness of her brood; and will fly in the face of a dog or a sow in defence of those chickens, which in a few weeks she will drive before her with relentless cruelty.

This affection sublimes the passions, quickens the invention, and sharpens the sagacity of the brute creation. Thus a hen, just become a mother, is no longer that placid bird she used to be, but with feathers standing on end, wings hovering, and clocking note, she runs about like one possessed. Dams will throw themselves in the way of the greatest danger in order to avert it from their progeny. Thus a partridge will tumble along before a sportsman in order to draw away the dogs from her helpless covey. In the time of nidification the most feeble birds will assault the most rapacious. All the hirundines of a village are up in arms at the sight of a hawk, whom they will persecute till he leaves that district. A very exact observer has often remarked that a pair of ravens nesting in the rock of Gibraltar would suffer no vulture or eagle to rest near their station, but would drive them from the hill with an amazing fury; even the blue thrush at the season of breeding would dart out from the clefts of the rocks to chase away the kestril, or the sparrow-hawk. ${ }^{1}$. If you stand near the nest of a bird that has young, she will not be induced to betray them by an inadvertent fondness, but will wait about at a distance with meat in her mouth for an hour together.

Should I farther corroborate what I have advanced above by some anecdotes which I probably may have mentioned before in conversation, yet you will, I trust, pardon the repetition for the sake of the illustration.

The fly-catcher cf the "Zoology" (the Stoparola of Ray), builds 
every year in the vines that grow on the walls of my house. A pair of these little birds had one year inadvertently placed their nest on a naked bough, perhaps in a shady time, not being aware of the inconvenience that followed. But a hot sunny season coming on before the brood was half fledged, the reflection of the wall became insupportable, and must inevitably have destroyed the tender young, had not affection suggested an expedient, and prompted the parent birds to hover over the nest all the hotter hours, while with wings expanded, and mouths gaping for breath, they screened off the heat from their suffering offspring.

A farther instance I once saw of notable sagacity in a willowwren, which had built in a bank in my fields. This bird a friend and myself had observed as she sat in her nest ; but were particularly careful not to disturb her, though we saw she eyed us with some degree of jealousy. Some days after as we passed that way we were desirous of remarking how this brood went on; but no nest could be found, till I happened to take a large bundle of long green moss, as it were, carelessly thrown over the nest in order to dodge the eye of any impertinent intruder.

A still more remarkable mixture of sagacity and instinct occurred to me one day as my people were pulling off the lining of a hotbed, in order to add some fresh dung. From out of the side of this bed leaped an animal with great agility that made a most grotesque figure; nor was it without great difficulty that it could be taken; when it proved to be a large white-bellied field-mouse with three or four young clinging to her teats by their mouths and feet. It was amazing that the desultory and rapid motions of this dam should not oblige her litter to quit their hold, especially when it appeared that they were so young as to be both naked and blind!

To these instances of tender attachment, many more of which might be daily discovered by those that are studious of nature, may be opposed that rage of affection, that monstrous perversion of the $\sigma \tau о \rho \gamma \eta$, which induces some females of the brute creation to devour their young because their owners have handled them too freely, or removed them from place to place! Swine, and sometimes the more gentle race of dogs and cats, are guilty of 
this horrid and preposterous murder. When $I$ hear now and then of an abandoned mother that destroys her offspring, I am not so much amazed; since reason perverted, and the bad passions let loose, are capable of any enormity; but why the parental feelings of brutes, that usually flow in one most uniform tenor, should sometimes be so extravagantly diverted, I leave to abler philosophers than myself to determine.

I am, etc.

\section{NOTE TO LETTER XIV.}

${ }^{1}$ I once saw a small balloon pass just over a large rookery during the nesting time. The rooks "mobbed" the balloon, uttering a terrific clangour, and circling close around it with angry sweeps until it passed well away.

\section{LETTER XV.}

SELBORNe, Fuly 8th, I773.

DEAR SIR,-Some young men went down lately to a pond on the verge of Wolmer Forest to hunt flappers, or young wild-ducks, many of which they caught, and, among the rest, some very minute yet well-fledged wild-fowls alive, which upon examinatior I found to be teals. I did not know till then that teals ever brec' in the south of England, and was much pleased with the discovery: this I look upon as a great stroke in natural history.

We have had, ever since I can remember, a pair of white owls that constantly breed under the eaves of this church. As I have paid good attention to the manner of life of these birds during their season of breeding, which lasts the summer through, the following remarks may not perhaps be unacceptable:-About an hour before sunset (for then the mice begin to run) they sally forth in quest of prey, and hunt all round the hedges of meadows and small enclosures for them, which seen to be their only food. In this irregular country we can stand on an eminence and see them beat the fields over like a setting-dog, and often drop down in the 
grass or corn. I have minuted these birds with my watch for an hour together, and have found that they return to their nest, the one or the other of them, about once in five minutes; reflecting at the same time on the adroitness that every animal is possessed of as far as regards the well-being of itself and offspring. But a piece of address, which they show when they return loaded, should not, I think, be passed over in silence.-As they take their prey with their claws, so they carry it in their claws to their nest; but, as the feet are necessary in their ascent under the tiles, they con-

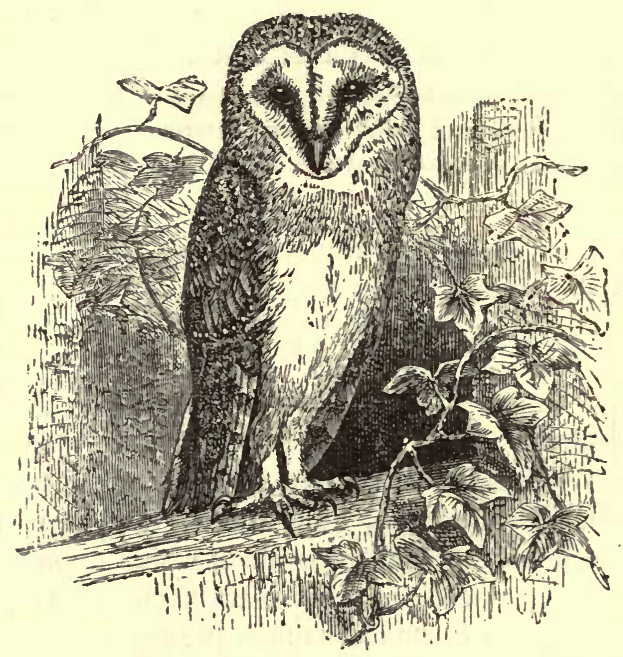

The Barn Owl (Strix fammea).

stantly perch first on the roof of the chancel, and shift the mouse from their claws to their bill, that their feet may be at liberty to take hold of the plate on the wall as they are rising under the eaves.

White owls seem not (but in this I am not positive) to hoot at all $;^{1}$ all that clamorous hooting appears to me to come from the wood kinds. The white owl does indeed snore and hiss in a tremendous manner ; and these menaces well answer the intention of intimidating ; for I have known a whole village up in arms on such an occasion, imagining the churchyard to be full of goblins and spectres. White owls also often scream horribly as they fly 
along; from this screaming probably arose the common people's imaginary species of screech-owl, which they superstitiously think attends the windows of dying persons. The plumage of the remiges of the wings of every species of owl that $I$ have yet examined is remarkably soft and pliant. Perhaps it may be necessary that the wings of these birds should not make much resistance or rushing, that they may be enabled to steal through the air unheard upon a nimble and watchful quarry.

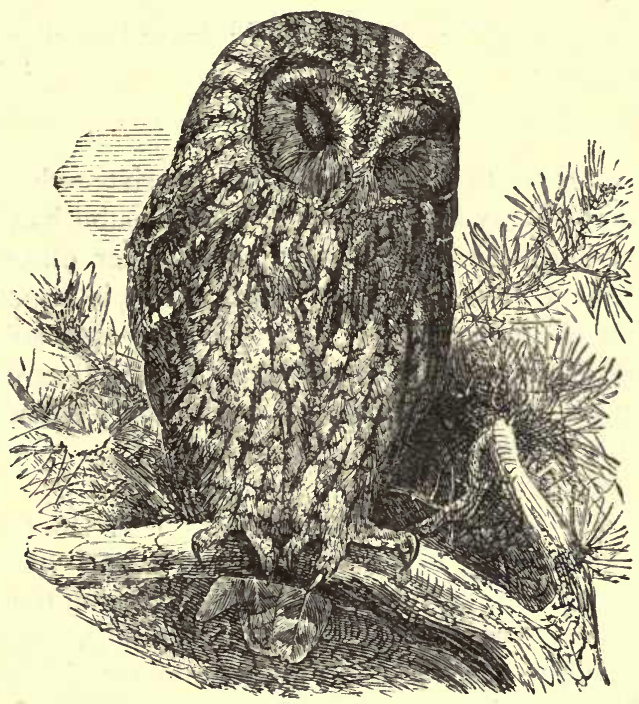

The Brown Owl (Syrnium Aluco).

While I am talking of owls, it may not be improper to mention what I was told by a gentleman of the county of Wilts. As they were grubbing a vast hollow pollard-ash that had been the mansion of owls for centuries, he discovered at the bottom a mass of matter that at first he could not account for. After some examination he found that it was a congeries of the bones of mice (and perhaps of birds and bats) that had been heaping together for ages, being cast up in pellets out of the crops of many generations of inhabitants. For owls cast up the bones, fur, and feathers, 
of what they devour, after the manner of hawks. He believes, he told me, that there were bushels of this kind of substance.

When brown owls hoot their throats swell as big as a hen's egg. I have known an owl of this species live a full year without any water. Perhaps the case may be the same with all birds of prey. When owls fly they stretch out their legs behind them as a balance to their large heavy heads, for as most nocturnal birds have large eyes and ears they must have large heads to contain them. Large eyes I presume are necessary to collect every ray of light, and large concave ears to command the smallest degree of sound or noise.

I am, etc.

[It will be proper to premise here that the sixteenth, eighteenth, twentieth, and twenty-first letters have been published already in the "Philosopinical Transactions;" but as nicer observation has furnished several corrections and additions, it is hoped that the republication of them will not give offence; especially as these sheets would be very imperfect without them, and as they will be new to many readers who had no opportunity of seeing them when they made their first appearance.]

"The hirundines are a most inoffensive, harmless, entertaining, social, and useful tribe of birds; they touch no fruit in our gardens; delight, all except one species, in attaching themseives to our houses ; amuse us with their migrations, songs, and marvellous agility; and clear our outlets from the annoyances of gnats and other troublesome insects. Some districts in the south seas, near Guiaquil,* are desolated, it seems, by the infinite swarms of venomous mosquitoes, which fill the air, and render those coasts insupportable. It would be worth inquiring whether any species of hirundines is found in those regions. Whoever contemplates the myriads of insects that sport in the sunbeams of a summer evening in this country, will soon be convinced to what a degree our atmosphere would be choked with them was it not for the friendly interposition of the swallow tribe.

* See "Ulloa's Travels." 
"Many species of birds have their peculiar lice; but the hirundines alone seem to be annoyed with dipterous insects, which infest every species, and are so large, in proportion to themselves, that they must be extremely irksome and injurious to them. These are the hippobosce hirundinis, with narrow subulated wings, abounding in every nest; and are hatched by the warmth of the bird's own body during incubation, and crawl about under its feathers.

"A species of them is familiar to horsemen in the south of England under the name of forest-fly; and to some of side-fly, from its running sideways like a crab. It creeps under the tails, and about the groins, of horses, which, at their first coming out of the north, are rendered half frantic by the tickling sensation; while our own breed little regards them.

"The curious Reaumur discovered the large eggs, or rather pupa, of these flies as big as the flies themselves, which he hatched in his own bosom. Any person that will take the trouble to examine the old nests of either species of swallows may find in them the black shining cases or skins of the pupa of these insects; but for other particulars, too long for this place, we refer the reader to 'L'Histoire d'Insectes' of that admirable entomologist. Tom. iv., pl. ii."

NOTE TO LETTER XV.

1 The white owl does hoot, although it is not its most frequent cry.

\section{LETTER XVI.}

Selrorne, Nov. 20th, 1773 .

DEAR SIR,-In obedience to your injunctions I sit down to give you some account of the house-martin, or martlet; and if my monography of this little domestic and familiar bird should happen to meet with your approbation, I may probably soon extend my inquiries to the rest of the British hirundines - the swallow, the swift, and the bank-martin. 
A few house-martins begin to appear about the I6th April; usually some few days later than the swallow. For some time after they appear the hirundines in general pay no attention to the business of nidification, but play and sport about, either to recruit from the fatigue of their journey, if they do migrate at all, or else that their blood may recover its true tone and texture after it has been so long benumbed by the severities of winter. About the middle of May, if the weather be fine, the martin begins to think in earnest of providing a mansion for its family. The crust or shell of this nest seems to be formed of such dirt or loam as comes most readily to hand, and is tempered and wrought together with little bits of broken straws to render it tough and tenacious. As this bird often builds against a perpendicular wall without any projecting ledge under, it requires its utmost efforts to get the first foundation firmly fixed, so that it may safely carry the superstructure. On this occasion the bird not only clings with its claws, but partly supports itself by strongly inclining its tail against the wall, making that a fulcrum; and thus steadied, it works and plasters the materials into the face of the brick or stone. But then, that this work may not, while it is soft and green, pull itself down by Its own weight, the provident architect has prudence and forbearance enough not to advance her work too fast; but by building only in the morning, and by dedicating the rest of the day to food and amusement, gives it sufficient time to dry and harden. About half an inch seems to be a sufficient layer for a day. Thus careful workmen, when they build mud-walls (informed at first perhaps by this little bird), raise but a moderate layer at a time, and then desist, lest the work should become top-heavy, and so be ruined by its own weight. By this method in about ten or twelve days is formed a hemispheric nest with a small aperture towards the top, strong, compact, and warm; and perfectly fitted for all the purposes for which it was intended. But then nothing is more common than for the house-sparrow, as soon as the shell is finished, to seize on it as its own, to eject the owner, and to line it after its own manner.

After so much labour is bestowed in erecting a mansion, as Nature seldom works in vain, martins will breed on for several 
years together in the same nest, where it happens to be well sheltered and secure from the injuries of weather. The shell or crust of the nest is a sort of rustic work, full of knobs and protuberances on the outside; nor is the inside of those that I have examined smoothed with any exactness at all ; but is rendered soft and warm, and fit for incubation, by a lining of small straws, grasses, and feathers, and sometimes by a bed of moss interwoven with wool. In this nest they tread, or engender, frequently during the time of building ; and the hen lays from three to five white eggs.

At first when the young are hatched, and are in a naked and helpless condition, the parent birds, with tender assiduity, carry out what comes away from their young. Was it not for this affectionate cleanliness the nestlings would soon be burnt up, and destroyed in so deep and hollow a nest, by their own caustic excrement. In the quadruped creation the same neat precaution is made use of ; particularly among dogs and cats, where the dams lick away what proceeds from their young. But in birds there seems to be a particular provision, that the dung of nestlings is enveloped in a tough kind of jelly, and therefore is the easier conveyed off without soiling or daubing. Yet, as nature is cleanly in all her ways, the young perform this office for themselves in a little time by thrusting their tails out at the aperture of their nest. As the young of small birds presently arrive at their í $\lambda$ ıкía, or full growth, they soon become impatient of confinement, and sit all day with their heads out at the orifice, where the dams, by clinging to the nest, supply them with food from morning to night. For a time the young are fed on the wing by their parents; but the feat is done by so quick and almost imperceptible a flight that a person must have attended very exactly to their motions before he would be able to perceive it. As soon as the young are able to shift for themselves, the dams immediately turn their thoughts to the business of a second brood; while the first flight, shaken off and rejected by their nurses, congregate in great flocks, and are the birds that are seen clustering and hovering on sunny mornings and evenings round towers and steeples, and on the roofs of churches and houses. These congregatings usually begin to take place about the first week in August; and therefore we may con- 
clude that by that time the first flight is pretty well over. The young of this species do not quit their abodes altogether; but the more forward birds get abroad some days before the rest. These approaching the eaves of buildings, and playing about before them, make people think that several old ones attend one nest. They are often capricious in fixing on a nesting-place, beginning many edifices, and leaving them unfinished; but when once a nest is completed in a sheltered place, it serves for several seasons. Those which breed in a ready finished house get the start in hatching of those that build new by ten days or a fortnight. These industrious artificers are at their labours in the long days before four in the morning. When they fix their materials they plaster them on with their chins, moving their heads with a quick vibratory motion. They dip and wash as they fly sometimes in very hot weather; but not so frequently as swallows. It has been observed that martins usually build to a north-east or north-west aspect, that the heat of the sun may not crack and destroy their nests; but instances are also remembered where they bred for many years in vast abundance in a hot stifled inn-yard against a wall facing to the south.

Birds in general are wise in their choice of situation; but in this neighbourhood every summer is seen a strong proof to the contrary at a house without eaves in an exposed district, where some martins build year by year in the corners of the windows. But, as the corners of these windows (which face to the south-east and south-west) are too shallow, the nests are washed down every hard rain; and yet these birds drudge on to no purpose from summer to summer, without changing their aspect or house. It is a piteous sight to see them labouring when half their nest is washed away and bringing dirt ...."generis lapsi sarcire ruinas." Thus is instinct a most wonderful unequal faculty; in some instances so much above reason, in other respects so far below it! Martins love to frequent towns, especially if there are great lakes and rivers at hand; nay they even affect the close air of London. And I have not only seen them nesting in the Borough, but even in the Strand and Fleet Street; but then it was obvious from the dinginess of their aspect that their feathers 
partook of the filth of that sooty atmosphere. Martins are by far the least agile of the four species; their wings and tails are short, and therefore they are not capable of such surprising turns and quick and glancing evolutions as the swallow. Accordingly they make use of a placid easy motion in a middle region of the air, seldom mounting to any great height, and never sweeping long together over the surface of the ground or water. They do not wander far for food, but affect sheltered districts, over some lake, or under some hanging wood, or in some hollow vale, especially in windy weather. They breed the latest of all the swallow kind: in 1772 they had nestlings on to October $2 \mathrm{Ist}$, and are never without unfledged young as late as Michaelmas.

As the summer declines the congregating flocks increase in numbers daily by the constant accession of the second broods; till at last they swarm in myriads upon myriads round the villages on the Thames, darkening the face of the sky as they frequent the aits of that river, where they roost. They retire, the bulk of them I mean, in vast flocks together about the beginning of October; but have appeared of late years in a considerable flight in this neighbourhood, for one day or two, as late as November $3^{\text {rd }}$ and 6th, after they were supposed to have been gone for more than a fortnight. 'They therefore withdraw with us the latest of any species. Unless these birds are very short-lived indeed, or unless they do not return to the districts where they are bred, they must undergo vast devastations somehow, and somewhere; for the birds that return yearly bear no manner of proportion to the birds that retire.

House-martins are distinguished from their congeners by having their legs covered with soft downy feathers down to their toes. They are no songsters; but twitter in a pretty inward soft manner in their nests. During the time of breeding they are often greatly molested with fleas.

I am, etc. 


\section{LETTER XVII.}

\section{Ringmer, near Lewes, Dec. 9 th, 1773.}

DEAR SIR,-I received your last favour just as I was setting out for this place; and am pleased to find that my monography met with your approbation. My remarks are the result of many years' observation; and are I trust true in the whole, though I do not pretend to say that they are perfectly void of mistake, or that a more nice observer might not make many additions, since subjects of this kind are inexhaustible.

If you think my letter worthy the notice of your respectable society, you are at liberty to lay it before them; and they will consider it, I hope, as it was intended, as a humble attempt to promote a more minute inquiry into natural history; into the life and conversation of animals. Perhaps, hereafter, I may be induced to take the house-swallow under consideration; and from that proceed to the rest of the British hirundines.

Though I have now travelled the Sussex Downs upwards of thirty years, yet I still investigate that chain of majestic mountains with fresh admiration year by year; ard I think I see new beauties every time I traverse it. This range, which runs from Chichester eastward as far as East Bourn, is about sixty miles in length, and is called the South Downs, properly speaking, only round Lewes. As you pass along you command a noble view of the wild, or weald, on one hand, and the broad downs and sea on the other. Mr. Ray used to visit a family just at the foot of these hills, and was so ravished with the prospect from Plumpton Plain, near Lewes, that he mentions those scapes in his "Wisdom of God in the Works of the Creation" with the utmost satisfaction, and thinks them equal to anything he had seen in the finest parts of Europe.

For my own part, I think there is somewhat peculiarly sweet and amusing in the shapely-figured aspect of chalk-hills in preference to those of stone, which are rugged, broken, abrupt, and shapeless. 
Perhaps I may be singular in my opinion, and not so happy as to convey to you the same idea; but I never contemplate these mountains without thinking I perceive somewhat analogous to growth in their gentle swellings and smooth fungus-like protuberances, their fluted sides, and regular hollows and slopes, that carry at once the air of vegetative dilation and expansion .....

- Or was there ever a time when these immense masses of calcareous matter were thrown into fermentation by some adventitious moisture; were raised and leavened into such shapes by some plastic power; and so made to swell and heave their broad backs into the sky so much above the less animated clay of the wild below?

By what I can guess from the admeasurements of the hills that have been taken round my house, I should suppose that these hills surmount the wild at an average at about the rate of five hundred feet.

One thing is very remarkable as to the sheep: from the westward till you get to the river Adur all the flocks have horns, and smooth white faces, and white legs, and a hornless sheep is rarely to be seen; but as soon as you pass that river eastward, and mount Beeding Hill, all the flocks at once become hornless, or as they call them, poll-sheep; and have, moreover, black faces with a white tuft of wool on their foreheads, and speckled and spotted legs, so that you would think that the flocks of Laban were pasturing on one side of the stream, and the variegated breed of his son-in-law Jacob were cantoned along on the other. And this diversity holds good respectively on each side from the valley of Bramber and Beeding to the eastward, and westward all the whole length of the downs. If you talk with the shepherds on this subject, they tell you that the case has been so from time immemorial ; and smile at your simplicity if you ask them whether the situation of these two different breeds might not be reversed? However, an intelligent friend of mine near Chichester is determined to try the experiment ; and has this autumn, at the hazard of being laughed at, introduced a parcel of black-faced hornless rams among his horned western ewes. The black-faced pollsheep have the shortest legs and the finest wool. 
As I had hardly ever before travelled these downs at so late a season of the year, I was determined to keep as sharp a look-out as possible so near the southern coast, with respect to the summer short-winged birds of passage. We make great inquiries concerning the withdrawing of the swallow kind, without examining enough into the causes why this tribe is never to be seen in winter; for, entre nous, the disappearing of the latter is more marvellous than that of the former, and much more unaccountable. The hirundines, if they please, are certainly capable of migration, and yet no doubt are often found in a torpid state; but red-starts, nightingales, white-throats, black-caps, etc., etc., are very ill provided for long flights; have never been once found, as I ever heard of, in a torpid state, and yet can never be supposed, in such troops, from year to year to dodge and elude the eyes of the curious and inquisitive, which from day to day discern the other small birds that are known to abide our winters. But, notwithstanding all my care, I saw nothing like a summer bird of passage ; and what is more strange not one wheat-ear, though they abound so in the autumn as to be a considerable perquisite to the shepherds that take them; and though many are to be seen to my knowledge all the winter through in many parts of the south of England. The most intelligent shepherds tell me that some few of these birds appear on the downs in March, and then withdraw to breed probably in warrens and stone-quarries: now and then a nest is ploughed up in a fallow on the downs under a furrow, but it is thought a rarity. At the time of wheat-harvest they begin to be taken in great numbers; are sent for sale in vast quantities to Brightelmstone and Tunbridge; and appear at the tables of all the gentry that entertain with any degree of elegance. About Mich $x$ elmas they retire and are seen no more till March. Though these birds are, when in season, in great plenty on the south downs round Lewes, yet at East Bourn, which is the eastern extremity of those downs, they abound much more. One thing is very remarkable, that though in the height of the season so many hundreds of dozens are taken, yet they never are seen to flock; and it is a rare thing to see more than three or four at a time; so that there must be a perpetual flitting and constant 
progressive succession. It does not appear that any wheat-ears are taken to the westward of Houghton Bridge, which stands on the river Arun.

I did not fail to look particularly after my new migration of ring-ousels; and to take notice whether they continued on the downs to this season of the year; as I had formerly remarked them in the month of October all the way from Chichester to Lewes wherever there were any shrubs and covert: but not one bird of this sort came within my observation. I only saw a few larks and whin-chats, some rooks, and several kites and buzzards.

About Midsummer a flight of cross-bills comes to the pinegroves about this house, but never makes any long stay.

The old tortoise, that I have mentioned in a former letter, still continues in this garden; and retired under ground about the 2oth November, and came out again for one day on the 30 th : it lies now buried in a wet swampy border under a wall facing to the south, and is enveloped at present in mud and mire!

Here is a large rookery round this house, the inhabitants of which seem to get their livelihood very easily; for they spend the greatest part of the day on their nest-trees when the weather is mild. These rooks retire every evening all the winter from this rookery, where they only call by the way, as they are going to roost in deep woods : at the dawn of day they always revisit their nest-trees, and are preceded a few minutes by a flight of daws, that act, as it were, as their harbingers.

I am, etc.

\section{LETTER XVIII.}

SELBORNe, Fan. $29 t h, 1774$.

DEAR SIR, - The house-swallow, or chimney-swallow, is undoubtedly the first comer of all the British hirundines; and appears in general on or about $\mathrm{I}_{3}$ th April, as I have remarked from many years' observation. Not but now and then a straggler is seen much earlier; and, in particular, when I was a boy I observed a swallow for a whole day together on a sunny warm 
Shrove Tuesday; which day could not fall out later than the middle of March, and often happened early in February.

It is worth remarking that these birds are seen first about lakes and mill-ponds ; and it is also very particular, that if these early visitors happen to find frost and snow, as was the case of the two dreadful springs of 1770 and $177 \mathrm{I}$, they immediately withdraw for a time. A circumstance this much more in favour of hiding thian migration; since it is much more probable that a bird should retire to its hybernaculum just at hand, than return for a week or two to warmer latitudes.

The swallow, though called the chimney-swallow, by no means builds altogether in chimneys, but often within barns and outhouses against the rafters; and so she did in Virgil's time :

\section{Garrula quàm tignis nidos suspendat hirundo."}

In Sweden she builds in barns, and is called ladu swala, the barn swallow. Besides, in the warmer parts of Europe there are no chimneys to houses, except they are English-built : in these countries she constructs her nest in porches, and gateways, and galleries, and open halls.

Here and there a bird may affect some odd, peculiar place; as we have known a swallow build down the shaft of an old well, through which chalk had been formerly drawn up for the purpose of manure: but in general with us this hirundo breeds in chimneys; and loves to haunt those stacks where there is a constant fire, no doubt for the sake of warmth. Not that it can subsist in the immediate shaft where there is a fire; but prefers one adjoining to that of the kitchen, and disregards the perpetual smoke of that funnel, as I have often observed with some degree of wonder.

Five or six or more feet down the chimney does this little bird begin to form her nest about the middle of May, which consists, like that of the house-martin, of a crust or shell composed of dirt or mud, mixed with short pieces of straw to render it tough and permanent; with this difference, that whereas the shell of the martin is nearly hemispheric, that of the swallow is open at 
the top, and like half a deep dish : this nest is lined with fine grasses, and feathers, which are often collected as they float in the air.

Wonderful is the address which this adroit bird shows all day long in ascending and descending with security through so narrow a pass. When hovering over the mouth of the funnel, the vibrations of her wings acting on the confined air occasion a rumbling like thunder. It is not improbable that the dam submits to this inconvenient situation so low in the shaft, in order to secure her broods from rapacious birds, and particularly from owls, which frequently fall down chimneys, perhaps in attempting to get at these nestlings.

The swallow lays from four to six white eggs, dotted with red specks; and brings out her first brood about the last week in June, or the first week in July. The progressive method by which the young are introduced into life is very amusing: first, they emerge from the shaft with difficulty enough, and often fall down into the rooms below : for a day or so they are fed on the chimney-top, and then are conducted to the dead leafless bough of some tree, where, sitting in a row, they are attended with great assiduity, and may then be called perchers. In a day or two more they become flyers, but are still unable to take their own food; therefore they play about near the place where the dams are hawking for flies; and, when a mouthful is collected, at a certain signal given, the dam and the nestling advance, rising towards each other, and meeting at an angle; the young one all the while uttering such a little quick note of gratitude and complacency, that a person must have paid very little regard to the wonders of Nature that has not often remarked this feat.

The dam betakes herself immediately to the business of a second brood as soon as she is disengaged from her first; which at once associates with the first broods of house-martins; and with them congregates, clustering on sunny roofs, towers, and trees. This hirundo brings out her second brood towards the middle and end of August.

All the summer long is the swallow a most instructive pattern ot unwearied industry and affection; for, from morning to night, 
while there is a family to be supported, she spends the whole day in skimming close to the ground, and executing the most sudden turns and quick evolutions. Avenues, and long walks under hedges, and pasture-fields, and mown meadows where cattle graze, are her delight, especially if there are trees interspersed; because in such spots insects most abound. When a fly is taken a smart snap from her bill is heard, resembling the noise at the shutting of a watch-case; but the motion of the mandibles is too quick for the eye.

The swallow, probably the male bird, is the exiubitor to housemartins, and other little birds, announcing the approach of birds of prey. For as soon as a hawk appears, with a shrill alarming note he calls all the swallows and martins about him ; who pursue in a body, and buffet and strike their enemy till they have driven him from the village, darting down from above on his back, and rising in a perpendicular line in perfect security. This bird also will sound the alarm, and strike at cats when they climb on the roofs of houses, or otherwise approach the nests. Each species of hirundo drinks as it flies along, sipping the surface of the water; but the swallow alone, in general, washes on the wing, by dropping into a pool for many times together : in very hot weather house-martins and bank-martins dip and wash a little.

The swallow is a delicate songster, and in soft sunny weather sings both perching and flying; on trees in a kind of concert, and on chimney tops : is also a bold flyer, ranging to distant downs and commons even in windy weather, which the other species seem much to dislike; nay, even frequenting exposed seaport towns, and making little excursions over the salt water. Horsemen on wide downs are often closely attended by a little party of swallows for miles together, which plays before and behind them, sweeping around them, and collecting all the sculking insects that are roused by the trampling of the horses' feet: when the wind blows hard, without this expedient, they are often forced to settle to pick up their lurking prey.

This species feeds much on little Coleoptera, as well as on gnats and flies; and often settles on dug ground, or paths, for gravels to grind and digest its food. Before they depart, for 
some weeks, to a bird, they forsake houses and chimneys, and roost in trees; and usually withdraw about the beginning of October; though some few stragglers may appear on at times till the first week in November.

Some few pairs haunt the new and open streets of London next the fields, but do not enter, like the house-martin, the close and crowded parts of the city.

Both male and female are distinguished from their congeners by the length and forkedness of their tails. They are undoubtedly the most nimble of all the species: and when the male pursues the female in amorous chase, they then go beyond their usual speed, and exert a rapidity almost too quick for the eye to follow.

After this circumstantial detail of the life and discerning $\sigma \tau o \rho \gamma \grave{\eta}$ of the swallow, I shall add, for your farther amusement, an anecdote or two not much in favour of her sagacity :-

A certain swallow built for two years together on the handles of a pair of garden-shears, that were stuck up against the boards in an out-house, and therefore must have her nest spoiled whenever that implement was wanted: and, what is stranger still, another bird of the same species built its nest on the wings and body of an owl, that happened by accident to hang dead and dry from the rafter of a barn. This owl, with the nest on its wings, and with eggs in the nest, was brought as a curiosity worthy the most elegant private museum in Great Britain. The owner, struck with the oddity of the sight, furnished the bringer with a large shell, or conch, desiring him to fix it just where the owl hung: the person did as he was ordered, and the following year a pair, probably the same pair, built their nest in the conch, and laid their eggs.

The owl and the conch make a strange grotesque appearance, and are not the least curious specimens in that wonderful collection of art and nature.

Thus is instinct in animais, taken the least out of its way, an undistinguishing, limited faculty ; and blind to every circumstance that does not immediately respect self-preservation, or lead at once to the propagation or support of their species.

I am, with all respect, etc., etc. 


\section{LETTER XIX.}

Selborne, Feb. 14th, I774.

DEAR SiR,-I received your favour of the 8 th, and am pleased to find that you read my little history of the swallow with your usual candour: nor was I the less pleased to find that you made objections where you saw reason.

As to the quotations, it is difficult to say precisely which species of hirundo Virgil might intend in the lines in question, since the ancients did not attend to specific differences like modern naturalists: yet somewhat may be gathered, enough to incline me to suppose that in the two passages quoted the poet had his eye on the swallow.

In the first place the epithet garrula suits the swallow well, who is a great songster, and not the martin, which is rather a mute bird ; and when it sings is so inward as scarce to be heard. Besides, if tignum in that place signifies a rafter rather than a beam, as it seems to me to do, then I think it must be the swallow that is alluded to, and not the martin, since the former does frequently build within the roof against the rafters; while the latter always, as far as I have been able to observe, builds without the roof against eaves and cornices.

As to the simile, too much stress must not be laid on it; yet the epithet nigra speaks plainly in favour of the swallow, whose back and wings are very black; while the rump of the martin is milk-white, its back and wings blue, and all its under part white as snow. Nor can the clumsy motions (comparatively clumsy) of the martin well represent the sudden and artful evolutions and quick turns which Juturna gave to her brother's chariot, so as to elude the eager pursuit of the enraged Æneas. The verb sonat aiso seems to imply a bird that is somewhat loquacious.*

* “ Nigra velut magnas domini cum divitis ædes Pervolat, et pennis alta atria lustrat hirundo, Pabula parva legens, nidisque loquacibus escas : 
We have had a very wet autumn and winter, so as to raise the springs to a pitch beyond anything since 1764 ; which was a remarkable year for floods and high waters. The land-springs which we call lavants, break out much on the downs of Sussex, Hampshire and Wiltshire. The country people say when the larants rise corn will always be dear; meaning that when the earth is so glutted with water as to send forth springs on the downs and uplands, that the corn-vales must be drowned; and so it has proved for these ten or eleven years past. For landsprings have never obtained more since the memory of man than during that period; nor has there been known a greater scarcity of all sorts of grain, considering the great improvements of modern husbandry. Such a run of wet seasons a century or two ago would, I am persuaded, have occasioned a famine. Therefore pamphlets and newspaper letters, that talk of combinations, tend to inflame and mislead; since we must not expect plenty till Providence sends us more favourable seasons.

The wheat of last year, all round this district, and in the county of Rutland, and elsewhere, yields remarkably bad; and our wheat on the ground, by the continual late sudden vicissitudes from fierce frost to pouring rains, looks poorly; and the turnips rot very fast.

I am, etc.

\section{LE TTER XX.}

Selborne, Feb. $26 t h$, I774.

DeAR Sir,-The sand-martin, or bank-martin, is by much the least of any of the British hirundines ; and as far as we have ever

Et nunc porticibus vacuis, nunc humida circum

Stagna sonat"

"As the black swallow near the palace plies:

O'er empty courts, and under arches flies ;

Now hawks aloft, now skims along the flood,

To furnish her loquacious nests with food."

DRYD, VIRG. AEn. xii. line 69I. 
seen, the smallest known hirundo; though Brisson asserts that there is one much smaller, and that is the hirundo esculenta.

But it is much to be regretted that it is scarce possible for any observer to be so full and exact as he could wish in reciting the circumstances attending the life and conversation of this little bird, since it is fera natura, at least in this part of the kingdom, disclaiming all domestic attachments, and haunting wild heaths

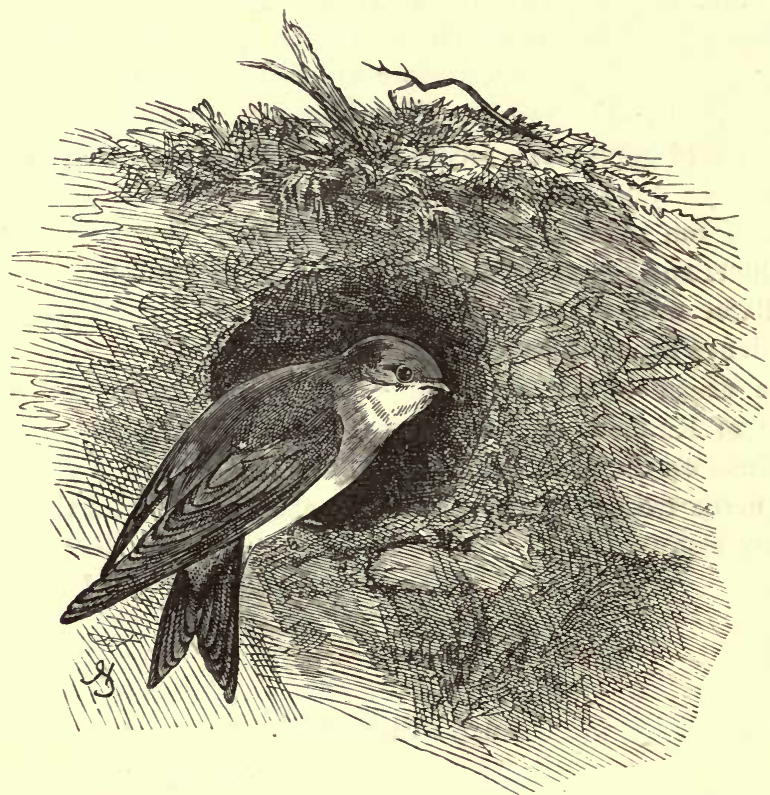

The SAND-Martin (Hirundo riparia).

and commons where there are large lakes; while the other species, especially the swallow and house-martin, are remarkably gentle and domesticated, and never seem to think themselves safe but under the protection of man. ${ }^{1}$

Here are in this parish, in the sand-pits and banks of the lakes of Wolmer forest, several colonies of these birds ; and yet they are never seen in the village; nor do they at all frequent the 
cottages that are scattered about in that wild district. The only instance I ever remember where this species haunts any building is at the town of Bishop's Waltham, in this county, where many sand-martins nestle and breed in the scaffold-holes of the backwall of William of Wykeham's stables ; but then this wall stands in a very sequestered and retired enclosure, and faces upon a large and beautiful lake. And indeed this species seems so to delight in large waters, that no instance occurs of their abounding, but near vast pools or rivers $;^{2}$ and in particular it has been remarked that they swarm in the banks of the Thames in some places below London-bridge.

It is curious to observe with what different degress of architectonic skill Providence has endowed birds of the same genus, and so nearly correspondent in their general mode of life! for while the swallow and the house-martin discover the greatest address in raising and securely fixing crusts or shells of loam as cunabula for their young, the bank-martin terebrates a round and regular hole in the sand or earth, which is serpentine, horizontal, and about two feet deep. At the inner end of this burrow does this bird deposit, in a good degree of safety, her rude nest, consisting of fine grasses and feathers, usually goose-feathers, very inartificially laid together.

Perseverance will accomplish anything; though at first one would be disinclined to believe that this weak bird, with her soft and tender bill and claws, should ever be able to bore the stubborn sand-bank without entirely disabling herself; yet with these feeble instruments have I seen a pair of them make great dispatch, and could remark how much they had scooped that day by the fresh sand which ran down the bank, and was of a different colour from that which lay loose and bleached in the sun.

In what space of time these little artists are able to mine and finish these cavities I have not been able to discover, for reasons given above; but it would be a matter worthy of observation, where it falls in the way of any naturalist to make his remarks. This I have often taken notice of, that several holes of different depths are left unfinished at the end of summer. To imagine that these beginnings were intentionally made in order to be in 
the greater forwardness for next spring is allowing perhaps too much foresight and rerum prudentia to a simple bird. May not the cause of these latebre being left unfinished arise from their meeting in those places with strata too harsh, hard, and solid, for their purpose, which they relinquish, and go to a fresh spot that works more freely? Or may they not in other places fall in with a soil as much too loose and mouldering, liable to flounder, and threatening to overwhelm them and their labours?

One thing is remarkable-that, after some years, the old holes are forsaken and new ones bored; perhaps because the old habitations grow foul and fetid from long use, or because they may so abound with fleas as to become untenantable. This species of swallow moreover is strangely annoyed with fleas; and we have seen fleas, bed-fleas (pulex irritans), swarming at the mouths of these holes, like bees on the stools of their hives. ${ }^{3}$

'The following circumstance should by no means be omittedthat these birds do not make use of their caverns by way of hybernacula, as might be expected; since banks so perforated have been dug out with care in the winter, when nothing was found but empty nests.

The sand-martin arrives much about the same time with the swallow, and lays, as she does, from four to six white eggs. But as this species is cryptogame, carrying on the business of nidification, incubation, and the support of its young in the dark, it would not be so easy to ascertain the time of breeding, were it not for the coming forth of the broods, which appear much about the time, or rather somewhat earlier than those of the swallow. The nestlings are supported in common like those of their congeners, with gnats and other small insects; and sometimes they are fed with libellula (dragon-flies) almost as long as themselves. In the last week in June we have seen a row of these sitting on a rail near a great pool as perchers, and so young and helpless, as easily to be taken by hand; but whether the dams ever feed them on the wing, as swallows and house-martins do, we have never yet been able to determine; nor do we know whether they pursue and attack birds of prey.

When they happen to breed near hedges and enclosures, they 
are dispossessed of their breeding holes by the house-sparrow, which is on the same account a fell adversary to house-martins.

These hirundines are no songsters, but rather mute, making only a little harsh noise when a person approaches their nests. They seem not to be of a sociable turn, never with us congregating with their congeners in the autumn. Undoubtedly they breed a second time, like the house-martin and swallow; and withdraw about Michaelmas.

Though in some particular districts they may happen to abound, yet in the whole, in the south of England at least, is this much the rarest species. For there are few towns or large villages but what abound with house-martins ; few churches, towers, or steeples, but what are haunted by some swifts; scarce a hamlet or single cottage-chimney that has not its swallow; while the bank-martins, scattered here and there, live a sequestered life among some abrupt sand-hills, and in the banks of some few rivers.

These birds have a peculiar manner of flying; flitting about with odd jerks, and vacillations, not unlike the motions of a butterfly. Doubtless the flight of all hirundines is influenced by, and adapted to, the peculiar sort of insects which furnish their food. Hence it would be worth inquiry to examine what particular genus of insects affords the principal food of each respective species of swallow.

Notwithstanding what has been advanced above, some few sand-martins, I see, haunt the skirts of London, frequenting the dirty pools in Saint George's Fields, and about Whitechapel. The question is where these build, since there are no banks or bold shores in that neighbourhood; perhaps they nestle in the scaffold holes of some old or new deserted building. They dip and wash as they fly sometimes, like the house-martin and swallow.

Sand-martins differ from their congeners in the diminutiveness of their size, and in their colour, which is what is usually called a mouse-colour. Near Valencia, in Spain, they are taken, says Willughby, and sold in the markets for the table; and are called by the country people, probably from their desultory jerking manner of flight, Papilion de Montagna. ${ }^{4}$ 
1 At Brandon, in Norfolk, are great heaps of sawdust which have settled down into solid masses. In these the sand-martins have burrowed and nested, iust as they do in sand-banks. My attention was first drawn to this singular breeding-place by a note in the Transactions of the Norfolk and Norwich Naturalist's Field Club.

2 The largest colony of sand-martins I have ever seen was in a large gravelpit at Oswestry, far from any large pool or river, although as a general rule these birds like the neighbourhood of water as White says.

${ }^{3}$ This insect is not the bed-flea, but another, distinct also from those which trouble the swallow and the swift.

${ }^{4}$ I once, late one evening, took a sand-martin off its nest, and it lay in the palm of my hand, not attempting to fly away, but apparently arranging itself again for sleep, and almost too lazy to scramble back again into its hole.

\section{LETTER XXI.}

SElboRne, Sept. 28th, 1774 .

Dear Sir,-As the swift or black-martin is the largest of the British hirundines, so it is undoubtedly the latest comer. For I remember but one instance of its appearing before the last week in April ; and in some of our late frosty, harsh springs, it has not been seen till the beginning of May. This species usually arrives in pairs.

The swift, like the sand-martin, is very defective in architecture, making no crust, or shell, for its nest; but forming it of dry grasses and feathers, very rudely and inartificially put together. With all my attention to these birds, I have never been able once to discover one in the act of collecting or carrying in materials; so that I have suspected (since their nests are exactly the same) that they sometimes usurp upon the house-sparrows, and expel them, as sparrows do the house and sand-martin; well remembering that $I$ have seen them squabbling together at the entrance of their holes, and the sparrows up in arms, and much disconcerted at these intruders. And yet I am assured, by a nice observer in such matters, that they do collect feathers for their nests in Andalusia, and that he has shot them with such materials in their mouths. 
Swifts, like sand-martins, carry on the business of nidification quite in the dark, in crannies of castles, and towers, and steeples, and upon the tops of the walls of churches under the roof; and therefore cannot be so narrowly watched as those species that build more openly; but, from what I could ever observe, they begin nesting about the middle of May; and I have remarked, from eggs taken, that they have sat hard by the 9 th June. In general they haunt tall buildings, churches, and steeples, and breed only in such; yet in this village some pairs frequent the

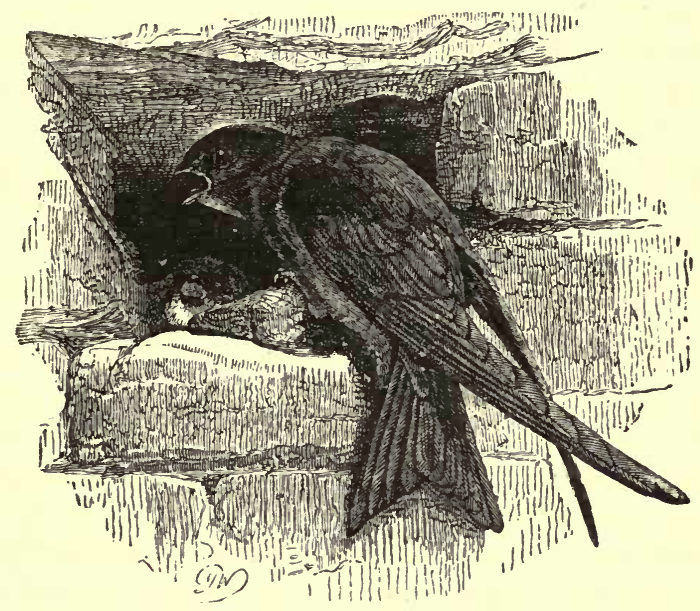

The Common Swift (Cypselus apus).

lowest and meanest cottages, and educate their young under those thatched roofs. We remember but one instance where they breed out of buildings, and that is in the sides of a deep chalk-pit near the town of Odiham, in this county, where we have seen many pairs entering the crevices, and skinıming and squeaking round the precipices.

As I have regarded these amusive birds with no small attention, if I should advance something new and peculiar with respect to them, and different from all other birds, I might perhaps be credited; especially as my assertion is the result of many years' 
exact observation. The fact that I would advance is, that swifts tread, or copulate, on the wing; and I would wish any nice observer, that is startled at this supposition, to use his own eyes, and I think he will soon be convinced. In another class of animals, viz. the insect, nothing is so common as to see the different species of many genera in conjunction as they fly. The swift is almost continually on the wing; and as it never settles on the ground, on trees, or roofs, would seldom find opportunity for amorous rites, was it not enabled to indulge them in the air. If any person would watch these birds of a fine morning in May, as they are sailing round at a great height from the ground, he would see, every now and then, one drop on the back of another, and both of them sink down together for many fathoms with a loud piercing shriek. This I take to be the juncture when the business of generation is carrying on.

As the swift eats, drinks, collects materials for its nest, and, as it seems, propagates on the wing, it appears to live more in the air than any other bird, and to perform all functions there save those of sleeping and incubation.

This hirundo differs widely from its congeners in laying invariably but two eggs at a time, which are milk-white, long, and peaked at the small end; whereas the other species lay at each brood from four to six. It is a most alert bird, rising very early, and retiring to roost very late; and is on the wing in the height of summer at least sixteen hours. In the longest days it does not withdraw to rest till a quarter before nine in the evening, being the latest of all day-birds. Just before they retire whole groups of them assemble high in the air, and squeak, and shoot about with wonderful rapidity. But this bird is never so much alive as in sultry thundery weather, when it expresses great alacrity, and calls forth all its powers. In hot mornings several, getting together in little parties, dash round the steeples and churches, squeaking as they go in a very clamorous manner; these, by nice observers, are supposed to be males serenading their sitting hens; and not without reason, since they seldom squeak till they come close to the walls or eaves, and since those within utter at the same time a little inward note of complacency. 
When the hen has sat hard all day, she rushes forth just as it is almost dark, and stretches and relieves her weary limbs, and snatches a scanty meal for a few minutes, and then returns to her duty of incubation. Swifts, when wantonly and cruelly shot while they have young, discover a little lunp of insects in their mouths, which they pouch and hold under their tongue. In general they feed in a much higher district than the other species; a proof that gnats and other insects do also abound to a considerable height in the air ; they also range to vast distances, since locomotion is no labour to them who are endowed with such wonderful powers of wing. Their powers seem to be in proportion to their levers; and their wings are longer in proportion than those of almost any other bird. When they mute, or case themselves in flight, they raise their wings, and make them meet over their backs.

At some certain times in the summer I had remarked that swifts were hawking very low for hours together over pools and streams ; and could not help inquiring into the object of their pursuit that induced them to descend so much below their usual range. After some trouble, I found that they were taking phryganere, ephemera, and libellula (cadew-flies, may-flies, and dragon-flies), that were just emerged out of their aurelia state. I then no longer wondered that they should be so willing to stoop for a prey that afforded them such plentiful and succulent nourishment.

They bring out their young about the middle or latter end of July; but as these never become perchers, nor, that ever I could discern, are fed on the wing by their dams, the coming forth of the young is not so notorious as in the other species.

On the 3 oth of last June, I untiled the eaves of a house where many pairs build, and found in each nest only two squab, naked pulli; on the 8th July I repeated the same inquiry, and found that they had made very little progress towards a fledged state, but were still naked and helpless. From whence we may conclude that birds whose way of life keeps them perpetually on the wing would not be able to quit their nest till the end of the month. Swallows and martins, that have numerous families, are continually feeding them every two or three minutes; while swifts, 
that have but two young to maintain, are much at their leisure, and do not attend on their nest for hours together.

Sometimes they pursue and strike at hawks that come in their way; but not with that vehemence and fury that swallows express on the same occasion. They are out all day long in wet days, feeding about, and disregarding still rain : from whence two things may be gathered; first, that many insects abide high in the air, even in rain; and next, that the feathers of these birds must be well preened to resist so much wet. Windy, and particularly windy weather, with heavy showers, they dislike; and on such days withdraw, and are scarce ever seen.

There is a circumstance respecting the colour of swifts, which seems not to be unworthy of our attention. When they arrive in the spring, they are all over of a glossy, dark soot-colour, except their chins, which are white; but, by being all day long in the sun and air, they become quite weather-beaten and bleached before they depart, and yet they return glossy again in the spring. Now, if they pursue the sun into lower latitudes, as some suppose, in order to enjoy a perpetual summer, why do they not return bleached? Do they not rather perhaps retire to rest for a season, and at that juncture moult and change their feathers, since all other birds are known to moult soon after the season of breeding?

Swifts are very anomalous in many particulars, dissenting from all their congeners not only in the number of their young, but in breeding but once in a summer; whereas all the other British hirundines breed invariably twice. It is past all doubt that swifts can breed but once, since they withdraw in a short time after the flight of their young, and some time before their congeners bring out their second broods. We may here remark, that, as swifts breed but once in a summer, and only two at a time, and the other hirundines twice, the latter, who lay from four to six eggs, increase at an average five times as fast as the former.

But in nothing are swifts more singular than in their early retreat. They retire, as to the main body of them, by the Ioth August, and sometimes a few days sooner; and every straggler invariably withdraws by the 20 th, while their congeners, all of them, stay till the beginning of October; many of them all through that month, 
and some occasionally to the beginning of November. This early retreat is mysterious and wonderful, since that time is often the sweetest season in the year. But what is more extraordinary, tney begin to retire still earlier in the most southerly parts of Andalusia, where they can be in no ways influenced by any defect of heat; or, as one might suppose, failure of food. Are they regulated in their motions with us by a defect of food, or by a propensity to moulting, or by a disposition to rest after so rapid a life, or by what? This is one of those incidents in natural history that not only baffles our searches, but almost eludes our guesses!

These hirundines never perch on trees or roofs, and so never congregate with their congeners. They are fearless while haunting their nesting-places, and are not to be scared with a gun; and are often beaten down with poles and cudgels as they stoop to go under the eaves. Swifts are much infested with those pests to the genus called hippoboscce hirundinis; and often wriggle and scratch themselves in their flight to get rid of that clinging annoyance.

Swifts are no songsters, and have only one harsh screaming note; yet there are ears to which it is not displeasing, from an agreeable association of ideas, since that note never occurs but in the most lovely summer weather.

They never can settle on the ground but through accident; and when down, can hardly rise, on account of the shortness of their legs and the length of their wings; neither can they walk, but only crawl ; but they have a strong grasp with their feet, by which they cling to walls. Their bodies being flat they can enter a very narrow crevice; and where they cannot pass on their bellies they will turn up edgewise.

The particular formation of the foot discriminates the sivift from all the British hirundines; and indeed from all other known birds, the hirundo melba, or great white-bellied swift of Gibraltar, excepted; for it is so disposed as to carry "omnes quatuor digitos anticos"-all its four toes forward; besides, the least toe, which should be the back toe, consists of one bone alone, and the other inree only of two apiece, - a construction most rare and peculiar, 
but nicely adapted to the purposes in which their feet are employed. This and some peculiarities attending the nostrils and under mandible, have induced a discerning * naturalist to suppose that this species might constitute a genus per se.

In London a party of swifts frequents the Tower, playing and feeding over the river just below the bridge; others haunt some of the churches of the Borough, next the fields, but do not venture, like the house-martin, into the close crowded part of the town.

The Swedes have bestowed a very pertinent name on this swallow, calling it "ring swala," from the perpetual rings or circles that it takes round the scene of its nidification.

Swifts feed on coleoptera, or small beetles with hard cases over their wings, as well as on the softer insects; but it does not appear how they can procure gravel to grind their food, as swallows do, since they never settle on the ground. Young ones, over-run with hippobosce, are sometimes found, under their nests, fallen to the ground; the number of vermin rendering their abode insupportable any longer. They frequent in this village several abject cottages; yet a succession still haunts the same unlikely roofs, - a good proof this that the same birds return to the same spots. As they must stoop very low to get up under these humble eaves, cats lie in wait, and sometimes catch them on the wing.

On July 5th, I 775, I again untiled part of a roof over the nest of a swift. The dam sat in the nest; but so strongly was she affected by natural $\sigma \tau \rho \rho \gamma \eta$ for her brood, which she supposed to be in danger, that, regardless of her own safety, she would not stir, but lay sullenly by them, permitting herself to be taken in hand. The squab young we brought down and placed on the grass-plot, where they tumbled about, and were as helpless as a new-born child. While we contemplated their naked bodies, their unwieldy disproportioned abdomina, and their heads, too heavy for their necks to support, we could not but wonder when we reflected that these shiftless beings in a little more than a fortnight would be able to dash through the air almost with the inconceivable swiftness of a meteor; and perhaps in their emigration must traverse

* John Antony Scopoli, of Carniola, M.D. 
vast continents and oceans as distant as the equator. So soon does Nature advance small birds to their $\dot{\eta} \lambda \iota \kappa \iota a$, or state of perfection; while the progressive growth of men and large quadrupeds is slow and tedious!

I am, etc.

\section{LETTER XXII.}

Selborne, Sept. $13^{t h}$, 1774 .

DeAR SiR,-By means of a straight cottage chimney I had an opportunity this summer of remarking, at my leisure, how swallows ascend and descend through the shaft; but my pleasure in con. templating the address with which this feat was performed to a considerable depth in the chimney, was somewhat interrupted by apprehensions lest my eyes might undergo the same fate with those of Tobit.*

Perhaps it may be some amusement to you to hear at what times the different species of hirundines arrived this spring in three very distant counties of this kingdom. With us the swallow was seen first on April 4th, the swift on April 24th, the bankmartin on April I 2 th, and the house-martin not till April 3 oth. At South Zele, Devonshire, swallows did not arrive till April 25th, swifts in plenty on May Ist, and house-martins not till the middle of May. At Blackburn, in Lancashire, swifts were seen April 28th, swallows April 29th, house-martins May ist. Do these different dates, in such distant districts, prove anything for or against migration?

A farmer, near Weyhill, fallows his land with two teams of asses; one of which works till noon, and the other, in the afternoon. When these animals have done their work, they are penned all

* "The same night also I returned from the burial and slept by the wall of my courtyard, being polluted, and my face was uncovered.--

"And I knew not that there were sparrows (swallows?) in the wall, and mine eyes being open, the sparrows muted warm dung into mine eyes, and a whiteness came in mine eyes; and I went to the physicians, but they helped lit nut."-'Товiт ii. 10. 
night, like sheep, on the fallow. In the winter they are confined and foddered in a yard, and make plenty of dung.

Linnæus says that hawks "paciscuntur inducia scum avibus. quamdiu cuculus cuculat;" but it appears to me, that during that period, many little birds are taken and destroyed by birds of prey, as may be seen by their feathers left in lanes and under hedges.

The missel-thrush is, while breeding, fierce and pugnacious,

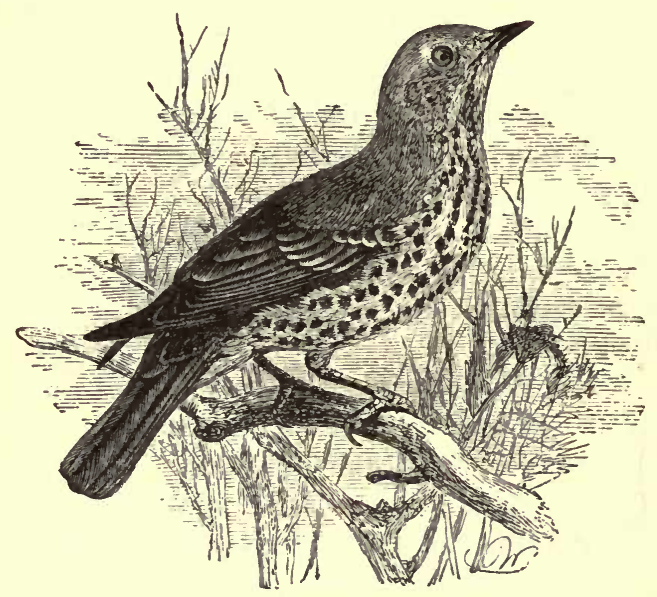

The Missel-Thrush (Turdus viscivorus).

driving such birds as approach its nest with great fury to a distance. The Welsh call it "pen y llwyn," the head or master of the coppice. He suffers no magpie, jay, or blackbird, to enter the garden where he haunts; and is, for the time, a good guard to the new-sown legumens. In general, he is very successful in the defence of his family; but once I observed in my garden, that several magpies came determined to storm the nest of a missel-thrush : the dams defended their mansion with great vigour, and fought resolutely pro aris et focis; but numbers at last prevailed, they tore the nest to pieces, and swallowed the young alive.

In the season of nidification the wildest birds are comparatives tame. Thus the ring-dove breeds in my fields, though they are 
continually frequented; and the missel-thrush, though most shy and wild in the autumn and winter, builds in my garden close to a walk where people are passing all day long.

Wall-fruit abounds with me this year; but my grapes, that used to be forward and good, are at present backward beyond all precedent: and this is not the worst of the story; for the same ungenial weather, the same black cold solstice, has injured the more necessary fruits of the earth, and discoloured and blighted our wheat. The crop of hops promises to be very large.

Frequent returns of deafness incommode me sadly, and half disqualify me for a naturalist; for, when those fits are upon me, I lose all the pleasing notices and little intimations arising from rural sounds; and May is to me as silent and mute with respect to the notes of birds, etc., as August. My eyesight is, thank God, quick and good; but with respect to the other sense, I an, at times, disabled :

"And Wisdom at one entrance quite shut out."

LETTER XXIII.

SELUORNe, fune 8th, 1775 .

DeAR SiR,-On September $21 \mathrm{~S}^{\mathrm{t}}$, I74I, being then on a visit, and intent on field-diversions, I rose before daybreak: when I came into the enclosures, I found the stubbles and clover-grounds matted all over with a thick coat of cobweb, in the meshes of which a copious and heavy dew hung so plentifully that the whole face of the country seemed, as it were, covered with two or three setting-nets drawn one over another. When the dogs attempted to hunt, their eyes were so blinded and hoodwinked that they could not proceed, but were obliged to lie down and scrape the incumbrances from their faces with their fore-feet, so that, finding my sport interrupted, I returned home musing in my mind on the oddness of the occurrence.

As the morning advanced the sun became bright and warm, 
and the day turned out one of those most lovely ones which no season but the autumn produces; cloudless, calm, serene, and worthy of the South of France itself.

About nine an appearance very unusual began to demand our attention, a shower of cobwebs falling from very elevated regions, and continuing, without any interruption, till the close of the day. These webs were not single filmy threads, floating in the air in all directions, but perfect flakes or rags; some near an inch broad, and five or six long, which fell with a degree of velocity that showed they were considerably heavier than the atmosphere.

On every side as the observer turned his eyes might he behold a continual succession of fresh flakes falling into his sight, and twinkling like stars as they turned their sides towards the sun.

How far this wonderful shower extended would be difficult to say; but we know that it reached Bradley, Selborne, and Alresford, three places which lie in a sort of a triangle, the shortest of whose sides is about eight miles in extent.

At the second of those places there was a gentleman (for whose veracity and intelligent turn we have the greatest veneration) who observed it the moment he got abroad; but concluded that, as soon as he came upon the hill above his house, where he took his morning rides, he should be higher than this meteor, which he imagined might have been blown, like thistle-down, from the common above; but, to his great astonishment, when he rode to the most elevated part of the down, three hundred feet above his fields. he found the webs in appearance still as much above him as before; still descending into sight in a constant succession, and twinkling in the sun, so as to draw the attention of the most incurious.

Neither before nor after was any such fall observed; but on this day the flakes hung in the trees and hedges so thick that a diligent person sent out might have gathered baskets full.

The remark that I shall make on these cobweb-like appearances, called gossamer, is, that, strange and superstitious as the notions about them were formerly, nobody in these days doubts but that they are the real production of small spiders, which warm in the fields in fine weather in autumn, and have a power of shooting ou: 
webs from their tails so as to render themselves buoyant, and iighter than air. But why these apterous insects should that day take such a wonderful aërial excursion, and why their webs should at once become so gross and material as to be considerably more weighty than air, and to descend with precipitation, is a matter beyond my skill. If I might be allowed to hazard a supposition, I should imagine that those filmy threads, when first shot, might be entangled in the rising dew, and so drawn up, spiders and all, by a brisk evaporation, into the regions where clouds are formed: and if the spiders have a power of coiling and thickening their webs in the air, as Dr. Lister says they have [see his Letters to Mr. Ray], then, when they were become heavier than the air, they must fall.

Every day in fine weather, in autumn chiefly, do I see those spiders shooting out their webs and mounting aloft: they will go off from your finger if you will take them into your hand. Last summer one alighted on my book as I was reading in the parlour; and, running to the top of the page, and shooting out a web, took its departure from thence. But what I most wondered at was, that it went off with considerable velocity in a place where no air was stirring; and I am sure that I did not assist it with my breath. So that these little crawlers seem to have, while mounting, some locomotive power without the use of wings, and to move in the air faster than the air itself. ${ }^{1}$

\section{NOTE TO LETTER XXIII.}

${ }^{1}$ The appearance of the gossamer-covered fields will be familiar to all who live in the country. It seems clear that the "locomotive power" of the tiny spiders is due solely to the movement of the atmosphere. On the quietest days, if you will wet your finger and hold it up, you will find it grow sensibly cooler on one side than the other, and on that side is there a faint wind blowing. If you will then watch the spiders, you will see them shoot out long silvery threads, which will incline to leeward, and presently the spiders will let go their hold of the grass, and launch themselves into the air, floating away on the slightest movement of it. 


\section{LETTER XXIV.}

Selborne, Aug. I5th, 1775 .

DEAR SIR,-There is a wonderful spirit of sociality in the brute creation, independent of sexnal attachment : the congregating of gregarious birds in the winter is a remarkable instance.

Many horses, though quiet with company, will not stay one minute in a field by themselves: the strongest fences cannot restrain them. My neighbour's horse will not only not stay by himself abroad, but he will not bear to be left alone in a strange stable without discovering the utmost impatience, and endeavouring to break the rack and manger with his fore feet. $\mathrm{He}$ has been known to leap out at a stable-window, through which dung was thrown, after company ; and yet in other respects is remarkably quiet. Oxen and cows will not fatten by themselves; but will neglect the finest pasture that is not recommended by society. It would be needless to instance in sheep, which constantly flock together.

But this propensity seems not to be confined to animals of the same species ; for we know a doe, still alive, that was brought up from a little fawn with a dairy of cows; with them it goes a-field, and with them it returns to the yard. The dogs of the house take no notice of this deer, being used to her; but, if strange dogs come by, a chase ensues; while the master smiles to see his favourite securely leading her pursuers over hedge, or gate, or stile, till she returns to the cows, who, with fierce lowings and menacing horns, drive the assailants quite out of the pasture.

Even great disparity of kind and size does not always prevent social advances and mutual fellowship. For a very intelligent and observant person has assured me that, in the former part of his life, keeping but one horse, he happened also on a time to have but one solitary hen. These two incongruous animals spent much of their time together in a lonely orchard, where they saw no creature but each other. By degrees an apparent regard began to take place between these two sequestered individuals. The fowl 
would approach the quadruped with notes of complacency, rubbing herself gently against his legs : while the horse would look down with satisfaction, and move with the greatest caution and circumspection, lest he should trample on his diminutive companion. Thus, by mutual good offices, each seemed to console the vacant hours of the other: so that Milton, when he puts the following sentiment in the mouth of Adam, seems to be somewhat mistaken :

"Much less can bird with beast, or fish with fowl, So well converse, nor with the ox the ape."

I am, etc.

\section{LETTER XXV.}

SELBORNe, Oct. 2nd, 1775 .

Dear Sir,-We have two gangs or hordes of gypsies which infest the south and west of England, and come round in their circuit two or three times in the year. One of these tribes calls itself by the noble name of Stanley, of which I have nothing particular to say; but the other is distinguished by an appellative somewhat remarkable. As far as their harsh gibberish can be understood, they seem to say that the name of their clan is Curleople; now the termination of this word is apparently Grecian, and as Mezeray and the gravest historians all agree that these vagrants did certainly migrate from Egypt and the East, two or three centuries ago, and so spread by degrees over Europe, may not this family-name, a little corrupted, be the very name they brought with them from the Levant? It would be matter of some curiosity, could one meet with an intelligent person among them, to inquire whether, in their jargon, they still retain any Greek words ; the Greek radicals will appear in hand, foot, head, water, earth, etc. It is possible that amidst their cant and corrupted dialect many mutilated remains of their native language might still be discovered.

With regard to those peculiar people, the gypsies, one thing is very remarkable, and especially as they came from warmer 
climates; and that is, that while other beggars lodge in barns, stables, and cow-houses, these sturdy savages seem to pride them-

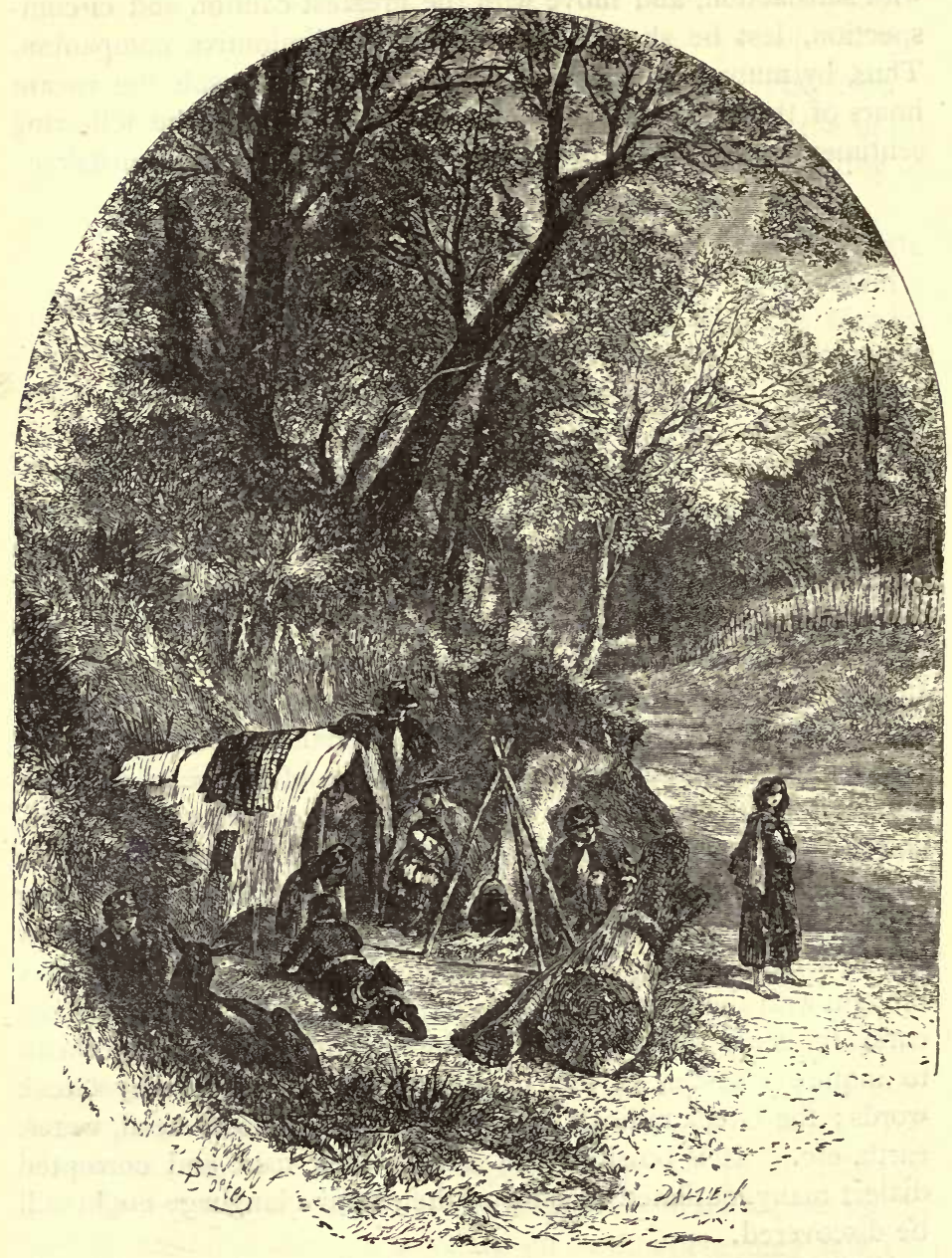

The Gypsies.

selves in braving the severities of winter, and in living sub dio the 
whole year round. Last September was as wet a month as ever was known; and yet during those deluges did a young gipsy girl lie in the midst of one of our hop-gardens, on the cold ground, with nothing over her but a piece of a blanket extended on a few hazel-rods bent hoop-fashion, and stuck into the earth at each end, in circumstances too trying for a cow in the same condition; yet within this garden there was a large hop-kiln, into the chambers of which she might have retired, had she thought shelter an object worthy her attention.

Europe itself, it seems, cannot set bounds to the rovings of these vagabonds; for Mr. Bell, in his return from Peking, met a gang of those people on the confines of Tartary, who were endeavouring to penetrate those deserts, and try their fortune in China.

Gypsies are called in French, Bohemians; in Italian and modern Greek, Zingari.

I am, etc.

\section{LETTER XXVI.}

Selborne, Nov. Ist, 1775 .

"Hic ... . tædæ pingues, hic plurimus ignis

Semper, et assiduâ postes fuligine nigri."

DEAR SIR,-I shall make no apology for troubling you with the detail of a very simple piece of domestic economy, being satisfied that you think nothing beneath your attention that tends to utility; the matter alluded to is the use of rushes instead of candles, which I am well aware prevails in many districts besides this; but as I know there are countries also where it does not obtain, and as I have considered the subject with some degree of exactness, I shall proceed in my humble story, and leave you to judge of the expediency.

The proper species of rush for this purpose seems to be the juncus effusus, or common soft rush, which is to be found in most moist pastures, by the sides of streams, and under hedges. These rushes are in best condition in the height of summer; but may be 
gathered, so as to serve the purpose well, quite on to autumn. It would be needless to add that the largest and longest are best. Decayed labourers, women, and children, make it their business to procure and prepare them. As soon as they are cut, they must be flung into water, and kept there, for otherwise they will dry and shrink, and the peel will not run. At first a person would find it no easy matter to divest a rush of its peel or rind, so as to leave one regular, narrow, even rib from top to bottom that may support the pith; but this, like other feats, soon becornes familiar even to children; and we have seen an old woman, stone blind, performing this business with great dispatch, and seldom failing to strip them with the nicest regularity. When these junci are thus far prepared, they must lie out on the grass to be bleached, and take the dew for some nights, and afterwards be dried in the sun.

Some address is required in dipping these rushes in the scaiding fat or grease; but this knack also is to be attained by practice. The careful wife of an industrious Hampshire labourer obtains all her fat for nothing; for she saves the scummings of her bacon-pot for this use; and, if the grease abounds with salt, she causes the salt to precipitate to the bottom, by setting the scummings in a warm oven. Where hogs are not much in use, and especially by the sea-side, the coarser animal-oils will come very cheap. A pound of common grease may be procured for fourpence, and about six pounds of grease will dip a pound of rushes, and one pound of rushes may be bought for one shilling; so that a pound of rushes, medicated and ready for use, will cost three shillings. If men that keep bees will mix a little wax with the grease, it will give it a consistency, and render it more cleanly, and make the rushes burn longer; mutton-suet would have the same effect.

A good rush, which measured in length two feet four inches and a half, being minuted, burnt only three minutes short of an hour; and a rush of still greater length has been known to burn one hour and a quarter.

These rushes give a good clear light. Watch-lights (coated with tallow), it is true, shed a dismal one, "darkness visible ;" but then the wick of those have two ribs of the rind, or peel, to support the pith, while the wick of the dipped rush has but one. 
The two ribs are intended to impede the progress of the flame and make the candle last.

In a pound of dry rushes, avoirdupois, which I caused to be weighed and numbered, we found upwards of one thousand six hundred individuals. Now suppose each of these burns, one with another, only half an hour, then a poor man will purchase eight hundred hours of light, a time exceeding thirty-three entire days, for three shillings. According to this account each rush, before dipping, costs $\frac{1}{33}$ of a farthing, and $\frac{1}{11}$ afterwards. Thus a poor family will enjoy five and a half hours of comfortable light for a farthing. An experienced old housekeeper assures me that one pound and a half of rushes completely supplies his family the year round, since working people burn no candles in the long days, because they rise and go to bed by daylight.

Little farmers use rushes much in the short days both morning and evening, in the dairy and kitchen; but the very poor, who are always the worst economists, and therefore must continue very poor, buy a halfpenny candle every evening, which in their blowing open rooms, does not burn much more than two hours. Thus have they only two hours' light for their money instead of eleven.

While on the subject of rural economy, it may not be improper to mention a pretty implement of housewifery that we have seen nowhere else; that is, little neat besoms which our foresters make from the stalks of the polytricum commune, or great golden maiden hair, which they call silk-wood, and find plenty in the bogs. When this moss is well combed and dressed, and divested of its outer skin, it becomes of a beautiful bright-chesnut colour; and, being soft and pliant, is very proper for the dusting of beds, curtains, carpets, hangings, etc. If these besoms were known to the brush-makers in town, it is probable they might come much in use for the purpose above-mentioned.

I am, $\in$ tc. 


\section{LETTER XXVII.}

Selborne, Dec. $12 t h, 1775$.

DEAR SIR, - We had in this village more than twenty years ago an idiot boy, whom I well remember, who, from a child, showed a strong propensity to bees; they were his food, his amusement, his sole object. And as people of this caste have seldom more than one point in view, so this lad exerted all his few faculties on this one pursuit. In the winter he dozed away his time, within his father's house, by the fireside, in a kind of torpid state, seldom departing from the chimney-corner; but in the summer he was all alert, and in quest of his game in the fields, and on sunny banks. Honey-bees, humble-bees, and wasps, were his prey wherever he found them; he had no apprehensions from their stings, but would seize them mudis manibus, and at once disarm them of their weapons, and suck their bodies for the sake of their honey-bags. Sometimes he would fill his bosom between his shirt and his skin with a number of these captives, and sometimes would confine them in bottles. He was a very merops apiaster, or bee-bird, and very injurious to men that kept bees; for he would slide into their bee-gardens, and, sitting down before the stools, would rap with his finger on the hives, and so take the bees as they came out. He has been known to overturn hives for the sake of honey, of which he was passionately fond. Where metheglin was making he would linger round the tubs and vessels, begging a draught of what he called bee-wine. As he ran about he used to make a humming noise with his lips, resembling the buzzing of bees. This lad was lean and sallow, and of a cadaverous complexion; and, except in his favourite pursuit, in which he was wonderfully adroit, discovered no manner of understanding. Had his capacity been better, and directed to the same object, he had perhaps abated much of our wonder at the feats of a more modern exhibitor of bees; and we may justly say of him now,--

Had thy presiding star propitious shone,

Shouldst Wildman' be 
When a tall youth he was removed from hence to a distant village, where he died, as I understand, before he arrived at manhood.

I am, etc.

NOTE TO LETTER XXVII.

${ }^{1}$ Wildman was a writer on bees and their management.

\section{LETTER XXVIII.}

Selborne, Fan. 8th, 1776 .

DEAR Sir, - It is the hardest thing in the world to shake off superstitious prejudices: they are sucked in, as it were, with our mother's milk; and, growing up with us at a time when they take the fastest hold and make the most lasting impressions, become so interwoven into our very constitutions, that the strongest good sense is required to disengage ourselves from them. No wonder, therefore, that the lower people retain them their whole lives through, since their minds are not invigorated by a liberal education, and therefore not enabled to make any efforts adequate to the occasion.

Such a preamble seems to be necessary before we enter on the superstitions of this district, lest we should be suspected of exaggeration in a recital of practices too gross for this enlightened age.

But the people of Tring, in Hertfordshire, would do well to remember, that no longer ago than the year $175_{1}^{1}$, and within twenty miles of the capital, they seized on two superannuated wretches, crazed with age, and overwhelmed with infirmities, on a suspicion of witchcraft; and, by trying experiments, drowned them in a horse-pond.

In a farm-yard near the middle of this village stands, at this day, a row of pollard-ashes, which, by the seams and long cicatrices down their sides, manifestly show that, in former times, they have been cleft asunder. 'These trees, when young and flexible, 
were severed and held open by wedges, while ruptured children, stripped naked, were pushed through the apertures, under a persuasion that, by such a process, the poor babes would be cured of their infirmity. As soon as the operation was over, the tree, in the suffering part, was plastered with loam, and carefully swathed up. If the parts coalesced and soldered together, as usually fell out, where the feat was performed with any adroitness at all, the party was cured; but, where the cleft continued to gape, the operation, it was supposed, would prove ineffectual. Having

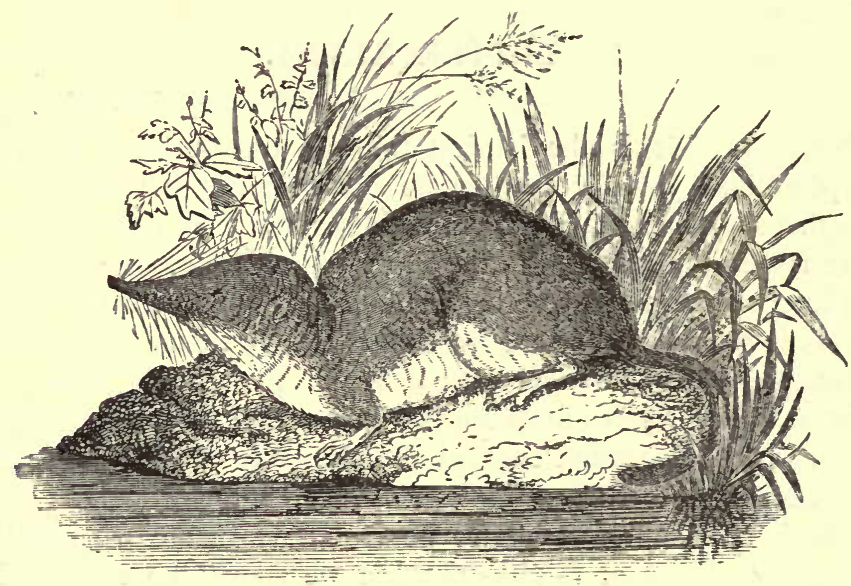

The Shrew

occasion to enlarge my garden not long since, I cut down two or three such trees, one of which did not grow together.

We have several persons now living in the village, who, in their childhood, were supposed to be healed by this superstitious ceremony, derived down perhaps from our Saxon ancestors, who practised it before their conversion to Christianity.

At the fourth corner of the Plestor, or area, near the church, there stood, about twenty years ago, a very old grotesque hollow pollard-ash, which for ages had been looked on with no small veneration as a shrew-ash. Now a shrew-ash is an ash whose twigs or branches, when gently applied to the limbs of cattle, will 
immediately relieve the pains which a beast suffers from the running of a shrew-mouse over the part affected; for it is supposed that a shrew-mouse is of so baneful and deleterious a nature, that wherever it creeps over a beast, be it horse, cow, or sheep, the suffering animal is afflicted with cruel anguish, and threatened with the loss of the use of the limb.* Against this accident, to which they were continually liable, our provident forefathers always kept a shrew-ash at hand, which, when once medicated, would maintain its virtue for ever. A shrew-ash was made thus : -Into the body of the tree a deep hole was bored with an auger, and a poor devoted shrew-mouse was thrust in alive, and plugged in, no doubt, with several quaint incantations long since forgotten. As the ceremonies necessary for such a consecration are no longer understood, all succession is at an end, and no such tree is known to subsist in the manor, or hundred.

As to that on the Plestor

"The late Vicar stubb'd and burnt it,"

when he was way-warden, regardless of the remonstrances of the bystanders, who interceded in vain for its preservation, urging its power and efficacy, and alleging that it had been

'Religione patrum multos servata per annos.'

I am, etc.

\section{LETTER XXIX.}

SELBORNe, Feb. 7 th, 1776.

DEAR SIR,-In heavy fogs, on elevated situations especially, trees are perfect alembics; and no one that has not attended to such matters can imagine how much water one tree will distil in a night's time, by condensing the vapour, which trickles down the

* "When a horse in the fields happened to be suddenly seized with anything like a numbness in his legs, he was immediately judged by the old persons to be either planet-struck, or shrew-struck. The mode of cure which they prescribed, and which they considered in all cases infallible, was to drag the animal through a piece of bramble that grew at both ends." - BINGLEY. 
twigs and boughs, so as to make the ground below quite in a float. In Newton Lane, in October 1775 , on a misty day, a particular oak in leaf dropped so fast that the cart-way stood in puddles and the ruts ran with water, though the ground in general was dusty.

In some of our smaller islands in the West Indies, if I mistake not, there are no springs or rivers; but the people are supplied with that necessary element, water, merely by the dripping of some large teak trees, which, standing in the bosom of a mountain, keep their heads constantly enveloped with fogs and clouds, from which they dispense their kindly never-ceasing moisture; and so render those districts habitable by condensation alone.

Trees in leaf have such a vast proportion more of surface than those that are naked, that, in theory, their condensations should greatly exceed those that are stripped of their leaves; but, as the former imbibe also a great quantity of moisture, it is difficult to say which drip most; but this I know, that deciduous trees that are entwined with much ivy seem to distil the greatest quantity. Ivy-leaves are smooth, and thick, and cold, and therefore condense very fast ; and besides, evergreens imbibe very little. These facts may furnish the intelligent with hints concerning what sorts of trees they should plant round small ponds that they would wish to be perennial; and show them how advantageous some trees are in preference to others.

Trees perspire profusely, condense largely, and check evaporation so much, that woods are always moist; no wonder, therefore, that they contribute much to pools and streams.

That trees are great promoters of lakes and rivers appears from a well-known fact in North America; for, since the woods and forests have been grubbed and cleared, all bodies of water are much diminished; so that some streams, that were very considerable a century ago, will not now drive a common mill. Besides, most woodlands, forests, and chases, with us abound with pools and morasses; no doubt for the reason given above.

To a thinking mind few phenomena are more strange than the state of little ponds on the summits of chalk-hills, many of which are never dry in the most trying droughts of summer. On chalkhills I say, because in many rocky and gravelly soils springs usually 
break out pretty high on the sides of elevated grounds and mountains; but no person acquainted with chalky districts will allow that they ever saw springs in such a soil but in valleys and bottoms, since the waters of so pervious a stratum as chalk all lie on one dead level, as well-diggers have assured me again and again.

Now we have many such little round ponds in this district ; and one in particular on our sheep-down, three hundred feet above my house; which, though never above three feet deep in the middle, and not more than thirty feet in diameter, and containing perhaps not more than two or three hundred hogsheads of water, yet never is known to fail, though it affords drink for three hundred or four hundred sheep, and for at least twenty head of large cattle beside. This pond, it is true, is overhung with two moderate beeches, that, doubtless, at times afford it much supply : but then we have others as small, that, without the aid of trees, and in spite of evaporation from sun and wind, and perpetual consumption by cattle, yet constantly maintain a moderate share of water, without overflowing in the wettest seasons, as they would do if supplied by springs. By my journal of May, 1775 , it appears that " the small and even considerable ponds in the vales are now dried up, while the small ponds on the very tops of hills are but little affected." Can this difference be accounted for from evaporation alone, which certainly is more prevalent in bottoms? or rather have not those elevated pools some unnoticed recruits, which in the night time counterbalance the waste of the day; without which the cattle alone nust soon exhaust them? And here it will be necessary to enter more minutely into the cause. Dr. Hales, in his Vegetable Statics, advances, from experiment, that "the moister the earth is the more dew falls on it in a night; and more than a double quantity of dew falls on a surface of water than there does on an equal surface of moist earth." Hence we see that water, by its coolness, is enabled to assimilate to itself a large quantity of moisture nightly by condensation; and that the air, when loaded with fogs and vapours, and even with copious dews, can alone advance a considerable and never-failing resource. Persons that are much abroad, and travel early and late, such as shepherds, fishermen, etc., can tell what prodigious fogs prevail in the night 
on elevated downs, even in the hottest parts of summer; and how much the surfaces of things are drenched by those swimming vapours, though, to the senses, all the while, little moisture seems to fall.

I am, etc.

\section{LETTER XXX.}

SElborne, April 3rd, 1776.

DEAR Sir,-Monsieur Herissant, a French anatomist, seems persuaded that he has discovered the reason why cuckoos do not hatch their own eggs; the impediment, he supposes, arises from the internal structure of their parts, which incapacitates them for incubation. According to this gentleman, the crop, or craw, of a cuckoo does not lie before the sternum at the bottom of the neck, as in the gallina, columba, etc., but immediately behind it, on and over the bowels, so as to make a large protuberance in the belly.

Induced by this assertion, we procured a cuckoo; and, cutting open the breast-bone, and exposing the intestines to sight, found the crop lying as mentioned above. This stomach was large and round, and stuffed hard, like a pincushion, with food, which, upon nice examination, we found to consist of various insects; such as small scarabs, spiders, and dragon-flies; the last of which we have seen cuckoos catching on the wing as they were just emerging out of the aurelia state. Among this farrago also were to be seen maggots, and many seeds, which belonged either to gooseberries, currants, cranberries, or some such fruit; so that these birds apparently subsist on insects and fruits; nor was there the least appearance of bones, feathers, or fur, to support the idle notion of their being birds of prey.

The sternum in this bird seemed to us to be remarkably short, between which and the anus lay the crop, or craw, and immediately behind that the bowels against the back-bone.

It must be allowed, as this anatomist observes, that the crop placed just upon the bowels must, especially when full, be in a 
very uneasy situation during the business of incubation; yet the test will be to examine whether birds that are actually known to sit for certain are not formed in a similar manner. This inquiry I proposed to myself to make with a fern-owl, or goat-sucker, as soon as opportunity offered: because, if their formation proves the same, the reason for incapacity in the cuckoo will be allowed to have been taken up somewhat hastily.

Not long after a fern-owl was procured, which, from its habit and shape, we suspected might resemble the cuckoo in its internal construction. Nor were our suspicions ill-grounded; for, upon the dissection, the crop, or craw, also lay behind the sternum, immediately on the viscera, between them and the skin of the belly. It was bulky, and stuffed hard with large phalene, moths of several sorts, and their eggs, which no doubt had been forced out of those insects by the action of swallowing.

Now as it appears that this bird, which is so well known to practise incubation, is formed in a similar manner with cuckoos, Monsieur Herissant's conjecture, that cuckoos are incapable of incubation from the disposition of their intestines, seems to fall to the ground; and we are still at a loss for the cause of that strange and singular peculiarity in the instance of the cuculus cancrus.

We found the case to be the same with the ring-tail hawk, in respect to formation; and, as far as I can recollect, with the swift; and probably it is so with many more sorts of birds that are not granivorous.

I am, etc.

\section{LETTER XXXI.}

Selborne, April 29th, I776.

DEEAR SIR,-On August 4th, I 775, we surprised a large viper, which seemed very heavy and bloated, as it lay in the grass basking in the sun. When we came to cut it up, we found that the abdomen was crowded with young, fifteen in number; the shortest of which measured full seven inches, and were about the size of 
full-grown earth-worms. This little fry issued into the world with the true viper-spirit about them, showing great alertness as soon as disengaged from the belly of the dam : they twisted and wriggled about, and set themselves up, and gaped very wide when touched with a stick, showing manifest tokens of menace and defiance, though as yet they had no manner of fangs that we could und, even with the help of our glasses.

To a thinking mind nothing is more wonderful than that early instinct which impresses young animals with a notion of the situation of their natural weapons, and of using them properly in their own defence, even before those weapons subsist or are formed. Thus a young cock will spar at his adversary before his spurs are grown; and a calf or a lamb will push with their heads before their horns are sprouted. In the same manner did these young adders attempt to bite before their fangs were in being. The dam however was furnished with very formidable ones, which we lifted up (for they fold down when not used) and cut them of with the point of our scissors.

There was little room to suppose that this brood had ever been in the open air before; and that they were taken in for refuge, at the mouth of the dam, when she perceived that danger was approaching; because then probably we should have found them scmewhere in the neck, and not in the abdomen.

\section{LETTER XXXII.}

Castration has a strange effect: it emasculates both man, beast, and bird, and brings them to a near resemblance of the other sex. Thus eunuchs have smooth unmuscular arms, thighs and legs; and broad hips, and beardless chins, and squeaking voices. Gelt stags and bucks have hornless heads, like hinds and does. Thus wethers have small horns, like ewes; and oxen large bent horns, and hoarse voices when they low, like cows: for bulls have short straight horns; and though they mutter and grumble in a deep 
tremendous tone, yet they low in a shrill high key. Capons have small combs and gills, and look pallid about the head, like pullets; they also walk without any parade, and hover chickens like hens. Barrow-hogs have also small tusks like sows.

Thus far it is plain that the deprivation of masculine vigour puts a stop to the growth of those parts or appendages that are looked upon as its insignia. But the ingenious Mr. Lisle, in his book on husbandry, carries it much farther; for he says that the loss of those insignia alone has sometimes a strange effect on the ability itself: he had a boar so fierce and venereous, that, to prevent mischief, orders were given for his tusks to be broken off. No sooner had the beast suffered this injury than his powers forsook him, and he neglected those females to whom before he was passionately attached, and from whom no fences would resilain him.

\section{LETTER XXXIII.}

THE natural term of a hog's life is little known, and the reason is plain-because it is neither profitable nor convenient to keep that turbulent animal to the full extent of its time: however, my neighbour, a man of substance, who had no occasion to study every little advantage to a nicety, kept a half-bred bantam-sow, who was as thick as she was long, and whose belly swept on the ground till she was advanced to her seventeenth year, at which period she showed some tokens of age by the decay of her teeth and the decline of her fertility.

For about ten years this prolific mother produced two litters in the year of about ten at a time, and once above twenty at a litter; but, as there were near double the number of pigs to that of teats, many died. From long experience in the world this female was grown very sagacious and artful. When she found occasion to converse with a boar she used to open all the intervening gates, and march, by herself, up to a distant farm where one was kept; and when her purpose was served would return by 
the same means. At the age of about fifteen her litters began to be reduced to four or five; and such a litter she exhibited when in her fatting-pen. She proved, when fat, good bacon, juicy, and tender ; the rind, or sward, was remarkably thin. At a moderate computation she was allowed to have been the fruitful parent of three hundred pigs : a prodigious instance of fecundity in so large a quadruped! She was killed in spring 1775 .

I am, etc.

\section{LETTER XXXIV.}

Selborne, May $9 t h$, I7?

“ . . . admôrunt ubera tigres."

DEAR SIR,-We have remarked in a former letter* how much incongruous animals, in a lonely state, may be attached to each other from a spirit of sociality; in this it may not be amiss to recount a different motive which has been known to create as strange a fondness.

My friend had a little helpless leveret brought to him, which the servants fed with milk in a spoon, and about the same time his cat kittened and the young were dispatched and buried. The hare was soon lost, and supposed to be gone the way of most fondlings, to be killed by some dog or cat. However, in about a fortnight, as the master was sitting in his garden in the dusk of the evening, he observed his cat, with tail erect, trotting towards him, and calling with little short inward notes of complacency, such as they use towards their kittens, and something gambling after, which proved to be the leveret that the cat had supported with her milk, and continued to support with great affection. ${ }^{1}$

Thus was a graminivorous animal nurtured by a carnivorous and predaceous one!

Why so cruel and sanguinary a beast as a cat, of the ferocious genus of Felis, the murium leo, as Linnæus calls it, should be 
affected with any tenderness towards an animal which is its natural prey, is not so easy to determine.

This strange affection probably was occasioned by that desiderium, those tender maternal feelings, which the loss of her kittens had awakened in her breast; and by the complacency and ease she derived to herself from the procuring her teats to be drawn, which were too much distended with milk, till, from habit, she became as much delighted with this foundling as if it had been her real offspring.

This incident is no bad solution of that strange circumstance which grave historians as well as the poets assert, of exposed children being sometimes nurtured by female wild beasts that probably had lost their young. For it is not one whit more marvellous that Romulus and Remus, in their infant state, should be nursed by a she-wolf, than that a poor little sucking leveret should be fostered and cherished by a bloody grimalkin.

". . viridi foetam Mavortis in antro
Ludere pendentes pueros, et lambere matrem
Impavidos : illam tereti cervice reflexam
Mulcere alternos, et corpora fingere linguâ." *

\section{NOTE TO LETTER XXXIV.}

1 An incident told me by Mr. Harrett, of Kirkwhelpington, may well be told here. He has a fine colley bitch which had young ones. She was annoyed by a cat prowling about them, and killed it. This cat had one small kitten, which the maids tried to rear by hand in the kitchen. The bitch hearing its cries fetched it away and laid it among her own pups, suckling it until they were all weaned together, thus atoning as far as she could for the murder of its mother.

* "The cave of Mars was dressed with mossy greens :

There by the wolf were laid the martial twins,

Intrepid on her swellings dugs they hung ;

The foster dam loll'd out her fawning tongue :

They suck'd secure, while bending back her head,

She lick'd their tender limbs ; and formed them as they fed."

DRYD. VIRG. En, viii. line 840 . 


\section{LETTER XXXV.}

SELBORNe, May 20 th, 1777 .

DEAR SIR, - Lands that are subject to frequent inundations are always poor; and probably the reason may be because the worms are drowned. The most insignificant insects and reptiles are of much more consequence, and have much more influence in the economy of Nature, than the incurious are aware of; and are mighty in their effect, from their minuteness, which renders them less an object of attention; and from their numbers and fecundity. Earth-worms, though in appearance a small and despicable link in the chain of Nature, yet, if lost, would make a lamentable chasm. For to say nothing of half the birds, and some quadrupeds, which are almost entirely supported by them, worms seem to be the great promoters of vegetation, which would proceed but lamely without them, by boring, perforating, and loosening the soil, and rendering it pervious to rains and the fibres of plants, by drawing straws and stalks of leaves and twigs into it; and, most of all, by throwing up such infinite numbers of lumps of earth called worm-casts, which, being their excrement, is a fine manure for grain and grass. Worms probably provide new soil for hills and slopes where the rain washes the earth away; and they affect slopes, probably to avoid being flooded. Gardeners and farmers express their detestation of worms; the former because they render their walks unsightly, and make them much work; and the latter because, as they think, worms eat their green corn. But these men would find that the earth without worms would soon become cold, hard-bound, and void of fermentation, and consequently sterile; and besides, in favour of worms, it should be hinted that green corn, plants, and flowers, are not so much injured by them as by many species of coleoptera (scarabs), and tipula (long-legs) in their larva, or grub-state; and by unnoticed myriads of small shell-less snails, called slugs, which silently and imperceptibly make amazing havoc in the field and garden.*

* Farmer Young, of Norton Farm, says, that this spring (I777) about four acres of his wheat in one field were entirely destroyed by slugs, which swarmed on the blades of corn, and devoured it as fast as it sprang. 
These hints we think proper to throw out in order to set the inquisitive and discerning to work.

A good monography of worms would afford much entertainment and information at the same time, and would open a large and new field in natural history. Worms work most in the spring; but by no means lie torpid in the dead months: are out every mild night in the winter, as any person may be convinced that will take the pains to examine his grass-plots with a candle; are hermaphrodites, and much addicted to venery, and consequently very prolific.

I am, etc.

\section{LET'TER XXXVI.}

Selborne, Nov. 22nd, 1777 .

DeAr Sir,- You cannot but remember that the 26 th and 27 th of last March were very hot days,--so sultry that everybody complained and were restless under those sensations to which they had not been reconciled by gradual approaches.

This sudden summer-like heat was attended by many summer coincidences; for on those two days the thermometer rose to $66^{\circ}$ in the shade; many species of insects revived and came forth; some bees swarmed in this neighbourhood; the old tortoise, near Lewes, in Sussex, awakened and came forth out of its dormitory; and, what is most to my present purpose, many house-swallows appeared and were very alert in many places, and particularly at Chobham, in Surrey.

But as that short warm period was succeeded as well as preceded by harsh severe weather, with frequent frosts and ice, and cutting winds, the insects withdrew, the tortoise retired again into the ground, and the swallows were seen no more until the Ioth April, when, the rigour of the spring abating, a softer season began to prevail.

Again; it appears by my journals for many years past that house-martins retire, to a bird, about the beginning of October; 
so that a person not very observant of such matters would conclude that they had taken their last farewell; but then it may be seen in my diaries also that considerable flocks have discovered themselves again in the first week of November, and often on the fourth day of that month only for one day; and that not as if they were in actual migration, but playing about at their leisure and feeding calmly, as if no enterprise of moment at all agitated their spirits. And this was the case in the beginning of this very month ; for on the $4^{\text {th }}$ November, more than twenty housemartins, which, in appearance, had all departed about the 7 th October, were seen again for that one morning only sporting between my fields and the Hanger, and feasting on insects which swarmed in that sheltered district. The preceding day was wet and blustering, but the $4^{\text {th }}$ was dark, and mild, and soft, the wind at south-west, and the thermometer at $5^{8 \frac{1}{2}^{\circ}}$; a pitch not common at that season of the year. Moreover, it may not be amiss to add in this place, that whenever the thermometer is above $50^{\circ}$, the bat comes flitting out in every autumnal and winter-month.

From all these circumstances laid together, it is obvious that torpid insects, reptiles, and quadrupeds, are awakened from their profoundest slumbers by a little untimely warmth; and therefore that nothing so much promotes its death-like stupor as a defect of heat. And farther, it is reasonable to suppose that two whole species, or at least many individuals of those two species of British hirundines do never leave this island at all, but partake of the same benumbed state; for we cannot suppose, that after a month's absence, house-martins can return from southern regions to appear for one morning in November, or that house-swallows should leave the districts of Asia to enjoy in March the transient summer of a couple of days. 


\section{LETTER XXXVII.}

SElboRne, Fan. 8th, 1778.

DEAR SIR, - There was in this village several years ago a miserable pauper, who from his birth was afflicted with a leprosy, as far as we are aware of a singular kind, since it affected only the palms of his hands and the soles of his feet. This scaly eruption usually broke out twice in the year, at the spring and fall; and, by peeling away, left the skin so thin and tender that neither his hands nor feet were able to perform their functions; so that the poor object was half his time on crutches, incapable of employ, and languishing in a tiresome state of indolence and inactivity. His habit was lean, lank and cadaverous. In this sad plight he dragged on a miserable existence, a burden to himself and his parish, which was obliged to support him till he was relieved by death at more than thirty years of age.

The good women, who love to account for every defect in children by the doctrine of longing, said that his mother felt a violent propensity for oysters, which she was unable to gratify; and that the black rough scurf on his hands and feet were the shells of that fish. We knew his parents, neither of which were lepers; his father in particular lived to be far advanced in years.

In all ages the leprosy has made dreadful havoc among mankind. The Israelites seem to have been greatly afflicted with it from the most remote times, as appears from the peculiar and repeated injunctions given them in the Levitical law.* Nor was the rancour of this foul disorder much abated in the last period of their commonwealth, as may be seen in many passages of the New Testament.

Some centuries ago this horrible distemper prevailed all Europe over : and our forefathers were by no means exempt, as appears by the large provision made for objects labouring under this calamity. There was an hospital for female lepers in the diocese of Lincoln; a noble one near Durham; three in London and

* See Lev. xiii., xiv. 
Southwark; and perhaps many more in or near our great towns and cities. Moreover, some crowned heads, and other wealthy and charitable personages, bequeathed large legacies to such poor people as languished under this hopeless infirmity.

It must, therefore, in these days be to a humane and thinking person a matter of equal wonder and satisfaction, when he con. templates how nearly this pest is eradicated, and observes that a leper now is a rare sight. $\mathrm{He}$ will, moreover, when engaged in such a train of thought naturally inquire for the reason. This happy change, perhaps, may have originated and been continued from the much smaller quantity of salted meat and fish now eaten in these kingdoms; from the use of linen next the skin; from the plenty of better bread; and from the profusion of fruits, roots, legumes, and greens, so common in every family. Three or four centuries ago, before there were any enclosures, sown-grasses, field-turnips, or field-carrots, or hay, all the cattle which had grown fat in summer, and were not killed for winter use, were turned out soon after Michaelmas to shift as they could through the dead months; so that no fresh meat could be had in winter or spring. Hence the marvellous account of the vast stores of salted flesh found in the larder of the eldest Spencer* in the days of Edward II., even so late in the spring as the $3^{\text {rd }}$ May. It was from magazines like these that the turbulent barons supported in idleness their riotous swarms of retainers ready for any disorder or mischief. But agriculture is now arrived at such a pitch of perfection that our best and fattest meats are killed in the winter; and no man need eat salted flesh unless he prefers it, that has money to buy fresh.

One cause of this distemper might be, no doubt, the quantity of wretched fresh and salt fish consumed by the commonalty at all seasons as well as in Lent; which our poor now would hardly be persuaded to touch.

The use of linen changes, shirts or shifts, in the room of sordid and filthy woollen, long worn next the skin, is a matter of neatness comparatively modern; but must prove a great means of preventing cutaneous ails. At this very time woollen, instead of linen, prevails among the poorer Welch, who are subject to foul eruptions. * Viz., six hundred bacons, eighty carcasses of beef, and six hundred muttons. 
The plenty of good wheaten bread that now is found among all ranks of people in the south, instead of that miserable sort which used in old days to be made of barley or beans, may contribute not a little to the sweetening their blood and correcting their juices; for the inhabitants of mountainous districts to this day are still liable to the itch and other cutaneous disorders, from a wretchedness and poverty of diet.

As to the produce of a garden, every middle-aged person of observation may perceive, within his own memory, both in town and country, how vastly the consumption of vegetables is increaser. Green-stalls in cities now support multitudes in a comfortable state, while gardeners get fortunes. Every decent labourer also has his garden, which is half his support, as well as his delight; and common farmers provide plenty of beans, peas, and greens, for their hinds to eat with their bacon; and those few that do not are despised for their sordid parsimony, and looked upon as regardless of the welfare of their dependents. Potatoes have prevailed in this little district by means of premiums within these twenty years only; and are much esteemed here now by the poor, who would scarce have ventured to taste them in the last reign.

Our Saxon ancestors certainly had some sort of cabbage, because they call the month of February "sprout-cale;" but long after their days the cultivation of gardens was little attended to. The religious, being men of leisure, and keeping up a constant correspondence with Italy, were the first people among us that had gardens and fruit-trees in any perfection within the wall of their abbeys * and priories. The barons neglected every pursuit that did not lead to war or tend to the pleasure of the chase.

It was not till gentlemen took up the study of horticulture themselves that the knowledge of gardening made such hasty advances. Lord Cobham, Lord Ila, and Mr. Waller, of Beaconsfield, were some of the first people of rank that promoted the

* "In monasteries the lamp of knowledge continued to burn, however dimly. In them men of business were formed for the state: the art of writing was cultivated by the monks ; they were the only proficients in mechanics, gardening, and architecture."-DALRYMPLE's Annals of Scotland. 
elegant science of ornamenting without despising the superintendence of the kitchen quarters and fruit walls.

A remark made by the excellent Mr. Ray, in his "Tour of Europe," at once surprises us, and corroborates what has been advanced above; for we find him observing so late as his days, that, "The Italians use several herbs for sallets, which are not yet, or have not been but lately, used in England, viz., selleri (celery), which is nothing else but the sweet smallage; the young shoots whereof, with a little of the head of the root cut off, they eat raw with oil and pepper ;" and further adds : "curled endive blanched is much used beyond seas; and for a raw sallet, seemed to excell lettuce itself." Now this journey was undertaken no longer ago than in the year 1663 .

I am, etc.

\section{LETTER XXXVIII.}

Selborne, Feb. 12th, 1778.

" Fortè puer, comitum seductus ab agmine fido,

Dixerat, ecquis adest ? et, adest, responderat echo,

Hic stupet; utque aciem partes divisit in omnes ;

Voce, veni, clamat magnâ. Vocat llla vocantem."*

DeAr Sir,-In a district so diversified as this, so full of hollow vales and hanging woods, it is no wonder that echoes should abound. Many we have discovered that return the cry of a pack of dogs, the notes of a hunting-horn, a tunable ring of bells, or the melody of birds very agreeably; but we were still at a loss for a polysyllabical articulate echo, till a young gentleman, who had parted from his company in a summer evening walk, and was calling after them, stumbled upon a very curious one in a spot where it might least be expected. At first he was much surprised, and could not be persuaded but that he was mocked by some boy; but repeating his trials in several languages, and finding his

* "Chance parts the youth from his companions dear, He cries "Who's here?" and Echo answers "Here ;"

He stares around, and for a while stands dumb,

Then shouts out, "Come," and Echo answers "Come." 
respondent to be a very adroit polyglot, he then discerned the deception.

This echo in an evening, before rural noises cease, would repeat ten syllables most articulately and distinctly, especially if quick dactyls were chosen. The last syllables of

"Tityre, tu patulæ recubans . . ."

were as audibly and intelligibly returned as the first ; and there is no doubt, could trial have been made, but that at midnight, when the air is very elastic, and a dead stillness prevails, one or two syllables more might have been obtained; but the distance rendered so late an experiment very inconvenient.

Quick dactyls, we observed, succeeded best ; for when we came to try its powers in slow, heavy, embarrassed spondees of the same number of syllables,

“Monstrum horrendum, informe, ingens . . ."

we could perceive a return but of four or five.

All echoes have some one place to which they are returned stronger and more distinct than to any other; and that is always the place that lies at right angles with the object of repercussion, and is not too near, nor too far off. Buildings, or naked rocks, re-echo much more articulately than hanging woods or vales; because in the latter the voice is as it were entangled, and embarrassed in the covert, and weakened in the rebound.

The true object of this echo, as we found by various experiments, is the stone-built, tiled hop-kiln in Gally-lane, which measures in front forty feet, and from the ground to the eaves twelve feet. The true centrum phonicum, or just distance, is one particular spot in the king's field, in the path to Nore-hill, on the very brink of the steep balk above the hollow cart-way. In this case there is no choice of distance; but the path, by mere contingency, happens to be the lucky, the identical spot, because the ground rises or falls so immediately, if the speaker either retires or advances, that his mouth would at once be above or below the object.

We measured this polysyllabical echo with great exactness, and 
found the distance to fall very short of Dr. Plot's rule for distinct articulation; for the Doctor, in his history of Oxfordshire, allows a hundred and twenty feet for the return of each syllable distinctly; hence this echo, which gives ten distinct syllables, ought to measure four hundred yards, or one hundred and twenty feet to each syilable; whereas our distance is only two hundred and fifty-eight yards, or near seventy-five feet, to each syllable. Thus our measure falls short of the Doctor's, as five to eight ; but then it must be acknowledged that this candid philosopher was convinced afterwards, that some latitude must be admitted of in the distance of echoes according to time and place.

When experiments of this sort are making, it should always be remembered that weather and the time of day have a vast influence on an echo; for a dull, heavy, moist air deadens and clogs the sound; and hot sunshine renders the air thin and weak, and deprives it of all its springiness, and a ruffling wind quite defeats the whole. In a still, clear, dewy evening the air is most elastic; and perhaps the later the hour the more so.

Echo has always been so amusing to the imagination, that the poets have personified her; and in their hands she has been the occasion of many a beautiful fiction. Nor need the gravest man be ashamed to appear taken with such a phenomenon, since it may become the subject of philosophical or mathematical inquiries.

One should have imagined that echoes, if not entertaining, must at least have been harmless and inoffensive; yet, Virgil advances a strange notion, that they are injurious to bees. After enumerating some probable and reasonable annoyances, such as prudent owners would wish far removed from their bee-gardens, he adds-

This wild and fanciful assertion will hardly be admitted by the philosophers of these days, especially as they all now seem agreed that insects are not furnished with any organs of hearing at all. But if it should be urged, that though they cannot hear yet perhaps they may feel the repercussions of sounds, I grant it is possible they may. Yet that these impressions are distasteful or hurtful, I 
deny, because bees, in good summers, thrive well in my outlet, where the echoes are very strong; for this village is another Anathoth, a place of responses and echoes. Besides, it does not appear from experiment that bees are in any way capable of being affected by sounds; for I have often tried my own with a large speaking-trumpet held close to their hives, and with such an exertion of voice as would have hailed a ship at the distance of a nile, and still these insects pursued their various employments undisturbed, and without showing the least sensibility or resentment.

Some time since its discovery this echo is become totally silent, though the object, or hop-kiln, remains ; nor is there any mystery in this defect; for the field between is planted as a hop-garden, and the voice of the speaker is totally absorbed and lost among the poles and entangled foliage of the hops. And when the poles are removed in autumn the disappointment is the same; because a tall quick-set hedge, nurtured up for the purpose of shelter to the hop ground, entirely interrupts the impulse and repercussion of the voice; so that till those obstructions are removed no more of its garrulity can be expected.

Should any gentleman of fortune think an echo in his park or outlet a pleasing incident, he might build one at littie or no expense. For whenever he had occasion for a new barn, stable, dog-kennel, or the like structure, it would be only needful to erect this building on the gentle declivity of a hill, with a like rising opposite to it, at a few hundred yards distance; and perhaps success might be the easier insured could some canal, lake, or stream intervene. From a seat at the centrum phonicum he and his friends might amuse themselves sometimes of an evening with the prattle of this loquacious nymph; of whose complacency and decent reserve more may be said than can with truth of every individual of her sex; since she is

"___ quæ nec reticere loquenti,

Nec prior ipsa loqui didicit resonabilis echo."

$\ddot{i}$ am, etc.

P.S.-The classic reader will, I trust, pardon the following lovely 
quotation, so finely describing echoes, and so poetically accounting for their causes from popular superstition :-

"Quæ benè quom videas, rationem reddere possis

Tute tibi atque aliis, quo pacto per loca sola

Saxa paries formas verborum ex ordine reddant,

Palanteis comites quom monteis inter opacos

Quærimus, et magna dispersos voce ciemus.

Sex etiam, aut septem loca vidi reddere voces

Unam quom jaceres : ita colles collibus ipsis

Verba repulsantes iterabant dicta referre.

Hæc loca capripedes Satyros, Nymphasque tenere

Finitimi fingunt, et Faunos esse loquuntur;

Quorum noctivago strepitu, ludoque jocanti

Adfirmant volgo taciturna silentia rumpi,

Chordarumque sonos fieri, dulceisque querelas,

Tibia quas fundit digitis pulsata canentum :

Et genus agricolûm latè sentiscere, quom Pan

Pinea semiferi capitis velamina quassans,

Unco sæpe labro calamos percurrit hianteis,

Fistula silvestrem ne cesset fundere musam." *

LUCRETIUS, Lib. iv. 1. 576 .

* "Whence may'st thou solve, ingenuous! to the world

The rise of echoes, formed in desert scenes,

Mid rocks, and mountains, mocking every sound,

When late we wander through their solemn glooms,

And, with loud voice, some lost companion call.

And oft re-echoes echo till the peal

Rings seven times round; so rock to rock repels

The mimic shout, reiterated close.

"Here haunt the goat-foot satyrs, and the nymphs,

As rustics tell, and fauns whose frolic dance,

And midnight revels oft, they say, are heard

Breaking the noiseless silence; while soft strains

Melodious issue, and the vocal band

Strike to their madrigals the plaintive lyre,

Such, feign they, sees the shepherd obvious oft,

I.ed on by Pan, with pine-leaved garland crown'd

And seven-mouth'd reed his labouring lip beneath,

Waking the woodland muse with ceaseless song." 


\section{LETTER XXXIX.}

Seldorne, May i $3 t h$, 1778 .

DEAR SIR,-Among the many singularities attending those amusing birds the swifts, I am now confirmed in the opinion that we have every year the same number of pairs invariably; at least the result of my inquiry has been exactly the same for a long time past. The swallows and martins are so numerous, and so widely distributed over the village, that it is hardly possible to recount them; while the swifts, though they do not build in the church, yet so frequently haunt it, and play and rendezvous round it, that they are easily enumerated. The number that I constantly find are eight pairs; about half of which reside in the church, and the rest build in some of the lowest and meanest thatched cottages. Now as these eight pairs, allowance being made for accidents, breed yearly eight pairs more, what becomes annually of this increase; and what determines every spring which pairs shall visit us, and reoccupy their ancient haunts?

Ever since I have attended to the subject of ornithology, I have always supposed that that sudden severse of affection, that strange $\alpha \nu \tau \iota \sigma \tau о \rho \gamma \eta$, which immediately succeeds in the feathered kind to the most passionate fondness, is the occasion of an equal dispersion of birds over the face of the earth. Without this provision one favourite district would be crowded with inhabitants, while others would be destitute and forsaken. But the parent birds seem to maintain a jealous superiority, and to oblige the young to seek for new abodes; and the rivalry of the males in many kinds, prevents their crowding the one on the other. Whether the swallows and house-martins return in the same exact number annually is not easy to say, for reasons given above; but it is apparent, as I have remarked before in my Monographies, that the numbers returning bear no manner of proportion to the numbers retiring. 


\section{LETTER XL.}

SElborne, Fune 2nd, 1778.

DEAR SiR,--The standing objection to botany has always been, that it is a pursuit that amuses the fancy and exercises the memory, without improving the mind or advancing any real knowledge; and, where the science is carried no farther than a mere systematic classification, the charge is but too true. But the botanist that is desirous of wiping off this aspersion should be by no means content with a list of names; he should study plants philosophically, should investigate the laws of vegetation, should examine the powers and virtues of efficacious herbs, should promote their cultivation; and graft the gardener, the planter, and the husbandman, on the phytologist. Not that system is by any means to be thrown aside; without system the field of Nature would be a pathless wilderness; but system should be subservient to, not the main object of, pursuit.

Vegetation is highly worthy of our attention; and in itself is of the utmost consequence to mankind, and productive of many of the greatest comforts and elegances of life. To plants we owe timber, bread, beer, honey, wine, oil, linen, cotton, etc., what not only strengthens our hearts, and exhilarates our spirits, but what secures us from inclemencies of weather and adorns our persons. Man, in his true state of nature, seems to be subsisted by spontaneous vegetation; in middle climes, where grasses prevail, he mixes some animal food with the produce of the field and garden; and it is towards the polar extremes only that, like his kindred bears and wolves, he gorges himself with flesh alone, and is driven to what hunger has never been known to compel the very beasts, to prey on his own species. ${ }^{1}$

The productions of vegetation have had a vast influence on the commerce of nations, and have been the great promoters of navigation, as may be seen in the articles of sugar, tea, tobacco, opium, ginsing, betel, paper, etc. As every climate has its peculiar produce, our natural wants bring on a mutual intercourse; so 
that by means of trade each distinct part is supplied with the growth of every latitude. But, without the knowledge of plants and their culture, we must have been content with our hips and haws, without enjoying the delicate fruits of India and the salutiferous drugs of Peru.

Instead of examining the minute distinctions of every various species of each obscure genus, the botanist should endeavour to make himself acquainted with those that are useful. You shall see a man readily ascertain every herb of the field, yet hardly know wheat from barley, or at least one sort of wheat or barley from another.

But of all sorts of vegetation the grasses seem to be most neglected; neither the farmer nor the grazier seem to distinguish the annual from the perennial, the hardy from the tender, nor the succulent and nutritive from the dry and juiceless.

The study of grasses would be of great consequence to a northerly, and grazing kingdom. The botanist that could improve the sward of the district where he lived would be an useful member of society : to raise a thick turf on a naked soil would be worth volumes of systematic knowledge; and he would be the best commonwealth's man that could occasion the growth of "two blades of grass where one alone was seen before."

I am, etc.

\section{NOTE TO LETTER XL.}

1 Man seems to have a natural craving for flesh meat, and in some parts of Africa where vegetable food is in plenty and even luxuriance, but animal food is not so easily obtained, the desire to eat flesh causes cannibalism. It is not hunger, because hunger could be satisfied by vegetable food, but an irresistible craving for meat. The same cause may first have given rise to the odious custom in some of the South Sea Islands. 


\section{LETTER XLI.}

Selborne, fuin $3 r d, 1778$.

Dear Sir,-In a district so diversified with such a variety of hill and dale, aspects, and soils, it is no wonder that great choice of plants should be found. Chalks, clays, sands, sheep-walks and downs, bogs, heaths, woodlands, and champaign fields, cannot but furnish an ample Flora. The deep rocky lanes abound with filices, and the pastures and moist woods with fungi. If in any branch of botany we may seem to be wanting, it must be in the large aquatic plants, which are not to be expected on a spot far removed from rivers, and lying up amidst the hill country at the spring heads. To enumerate all the plants that have been discovered within our limits would be a needless work; but a short list of the more rare, and the spots where they are to be found, may be neither unacceptable nor unentertaining :-

Helleborus fotidus, stinking hellebore, bear's foot, or setterworth,-all over the High-wood and Coney-croft-hanger: this continues a great branching plant the winter through, blossoming about January, and is very ornamental in shady walks and shrubberies. The good women give the leaves powdered to children troubled with worms; but it is a violent remedy, and ought to be administered with caution.

Helleborus viridis, green hellebore,-in the deep stony lane on the left hand just before the turning to Norton-farm, and at the top of Middle Dorton under the hedge : this plant dies down to the ground early in autumn, and springs again about February, flowering almost as soon as it appears above the ground.

Vaccinium oxycoccos, creeping bilberries, or cranberries, -in the bogs of Bin's-pond.

Vaccinium myriillus, whortle, or bleaberries, -on the dry hillocks of Wolmer-forest.

Drosera rotundifolia, round leaved sundew, -in the bogs of Bin's-pond.

Drosera longifolia, long-leaved sunclew, -in the bogs of Bin'spond. 
Comarum palustre, purple comarum, or marsh cinquefoil,-in the bogs of Bin's-pond.

Hypericum androsamum, 'Tutsan, St. John's Wort,-in the stony, hollow lanes.

Vinca minor, less periwinkle,-in Selborne-hanger and Shrubwood.

Monotropa hypopithys, yellow monotropa, or birds' nest,-in Selborne-hanger under the shady beeches, to whose roots it seems to be parasitical, at the north-west end of the Hanger.

Chlora perfoliata, Blackstonia perfoliata, Hudsoni, perfoliated yellow-wort, - on the banks in the King's-field.

Paris quadrifolia, herb of Paris, true-love, or one-berry,-in the Church-litten-coppice.

Chrysosplenium oppositifolium, opposite golden saxifrage,-in the dark and rocky hollow lanes.

Gentiana amarella, autumnal gentian, or fellwort,-on the Zigzag and Hanger.

Lathrea squamaria, tooth-wort,-in the Church-litten-coppice under some hazels near the foot-bridge, in Trimming's garuen hedge, and on the dry wall opposite Grange-yard.

Dipsacus pilosus, small teasel,-in the Short and Long Lith.

Lathyrus sylvestris, narrow-leaved, or wild lathyrus,-in the bushes at the foot of the Short Lith, near the path.

Oplirys spiralis, ladies' traces, - -in the Long Lith, and towards the south corner of the common.

Ophrys nidus avis, birds' nest ophrys, --in the Long Lith under the shady beeches among the dead leaves; in Great Dortun among the bushes, and on the Hanger plentifully.

Serapias latifolia, helleborine,-in the High-wood under the shady beeches.

Daphne laureola, spurge laurel,-in Selborne-Hanger and the High-wood.

Daphne mezereum, the mezereon,--in Selborne-Hanger among the shrubs, at the south-east end above the cottages.

Lycoperdon tuber, truffles,-in the Hanger and High wocd.

Sambucus ebulus, dwarf elder, walwort, or danewort-among the rubbish and ruined foundations of the Priory. 
Of all the propensities of plants, none seem more strange than their different periods of blossoming. Some produce their flowers in the winter, or very first dawnings of spring; many when the spring is established; some at midsummer, and some not till autumn. When we see the helleborus foetidus and helleborus niger blowing at Christmas, the helleborus hyemalis in January, and the helleborus viridis as soon as ever it emerges out of the ground, we do not wonder, because they are kindred plants that we expect should keep pace the one with the other; but other congenerous vegetables differ so widely in their time of flowering, that we cannot but admire. I shall only instance at present in the crocus sativus, the vernal and the autumnal crocus, which have such an affinity, that the best botanists only make them varieties of the same genus, of which there is only one species, not being able to discern any difference in the corolla, or in the internal structure. Yet the vernal crocus expands its flowers by the beginning of March at farthest, and often in very rigorous weather; and cannot be retarded but by some violence offered; while the autumnal (the saffron) defies the influence of the spring and summer, and will not blow till most plants begin to fade and run to seed. This circumstance is one of the wonders of the creation, little noticed because a common occurrence; yet ought not to be overlooked on account of its being familiar, since it would be as difficult to be explained as the most stupendous phenomenon in nature.

"Say, what impels, amidst surrounding snow Congeal'd, the crocus, flamy bud to glow? Say, what retards, amidst the summer's blaze, Th' autumnal bulb, till pale, declining days? The God of SEASONS ; whose pervading power Controls the sun, or sheds the fleecy shower : Je bids each flower His quickening word obey, Or to each lingering bloom enjoins delay." 


\section{LETTER XLII.}

"Omnibus animalibus reliquis certus et uniusmodi, et in suo cuique genere incessus est : aves solæ vario meatu feruntur, et in terrâ, et in äere."

\section{Selborne, Aug. $7_{\text {th }}$ i 778 .}

Dear Sir,-A good ornithologist should be able to distinguish birds by their air as well as by their colours and shape; on the ground as well as on the wing: and in the bush as well as in the hand. For, though it must not be said that every species of birds has a manner peculiar to itself, yet there is somewhat in most genera at least, that at first sight discriminates them, and enables a judicious observer to pronounce upon them with some certainty. Put a bird in motion

$$
\text { "—— Et verâ incessu patuit ——" }
$$

Thus kites and buzzards sail round in circles with wings expanded and motionless; and it is from their gliding manner that the former are still called in the north of England gleads, from the Saxon verb glidan, to glide. The kestrel, or wind-hover, has a peculiar mode of lianging in the air in one place, his wings all the while being briskly agitated. Hen-harriers fly low over heaths or fields of corn, and beat the ground regularly like a pointer or setting-dog. Owls move in a buoyant manner, as if lighter than the air ; they seem to want ballast. There is a peculiarity belonging to ravens that must draw the attention even of the most incurious-they spend all their leisure time in striking and cuffing each other on the wing in a kind of playful skirmish; and, when they move from one place to another, frequently turn on their backs with a loud croak, and seem to be falling to the ground. When this odd gesture betides them, they are scratching themselves with one foot, and thus lose the centre of gravity. Rooks sometimes dive and tumble in a frolicksome manner; crows and daws swagger in their walk; wood-peckers fly volatu undoso, opening and closing their wings at every stroke, and so are always rising or falling in curves. All of this genus use their tails, which 
incline downward, as a support while they run up trees. Parrots, like all other hooked-clawed birds, walk awkwardly, and make use of their bill as a third foot, climbing and descending with ridiculous caution. All the galline parade and walk gracefully, and run nimbly; but fly with difficulty, with an impetuous whirring, and in a straight line. Magpies and jays flutter with

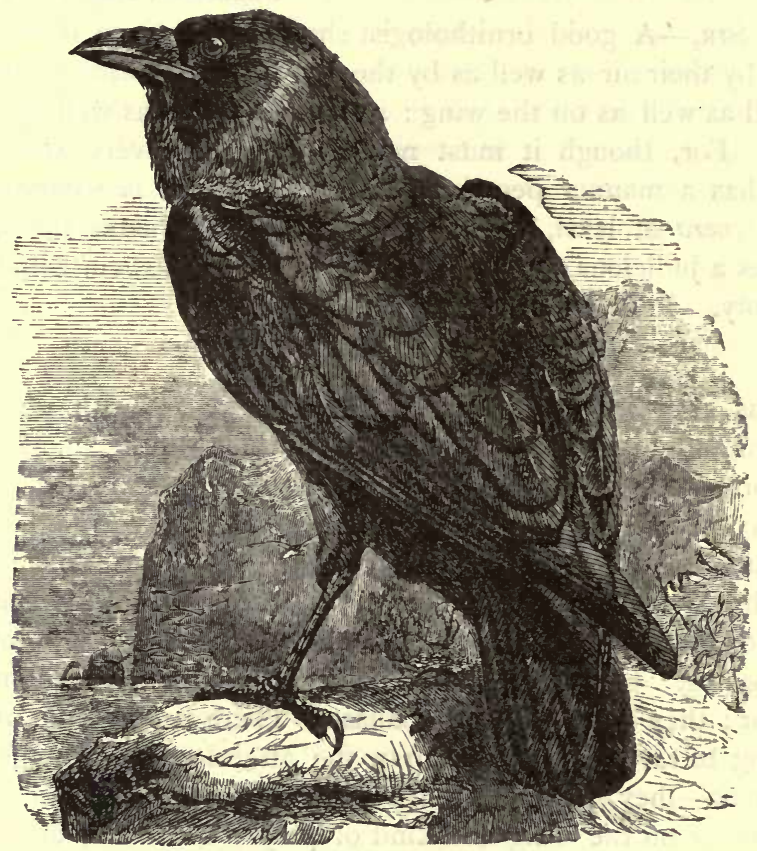

The Raven (Corvus Corax).

powerless wings, and make no dispatch; herons seem encumbered with too much sail for their light bodies, but these vast hollow wings are necessary in carrying burdens, such as large fishes and the like $;^{1}$ pigeons, and particularly the sort called smiters, have a way of clashing their wings the one against the other over their backs with a loud snap; another variety, called tumblers, turn themselves over in the air. Some birds have 
movements peculiar to the season of love : thus ringdoves, though strong and rapid at other times, yet in the spring hang about on

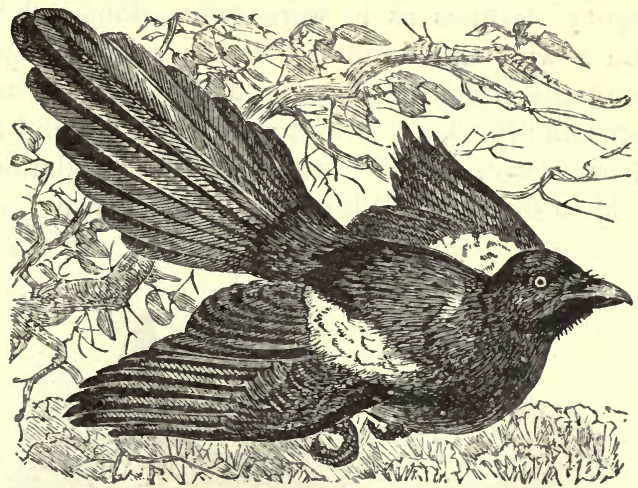

The MagPiE.

the wing in a toying and playful manner; thus the cock-snipe while breeding, forgetting his former flight, fans the air like the

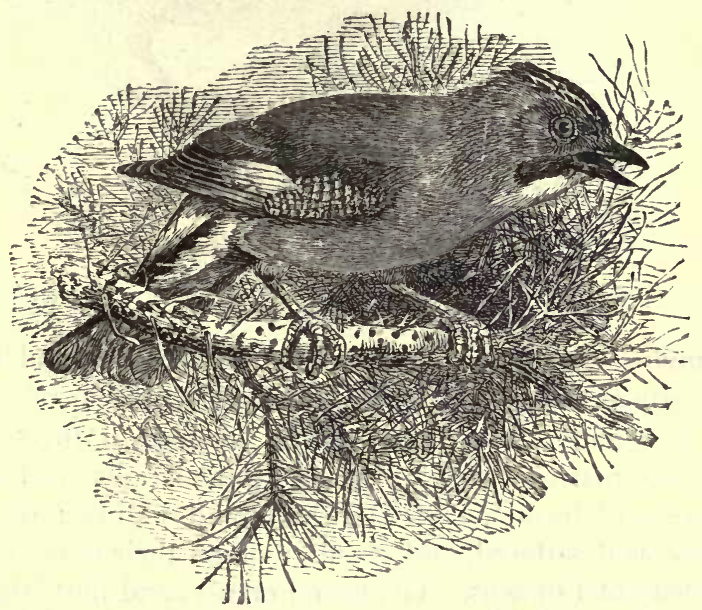

The JAY (Garrulus glandarius).

wind-hover; and the green-finch in particular, exhibits such languishing and faltering gestures as to appear like a wounded 
and dying bird; the king-fisher darts along like an arrow; fernowls, or goat-suckers, glance in the dusk over the tops of trees like a meteor; starlings as it were swim along, while misselthrushes use a wild and desultory flight; swallows sweep over the surface of the ground and water, and distinguish themselves by rapid turns and quick evolutions; swifts dash round in circles ; and the bank-martin moves with frequent vacillations like a butterfly. Most of the small birds fly by jerks, rising and falling as they advance. Most small birds hop; but wagtails and larks

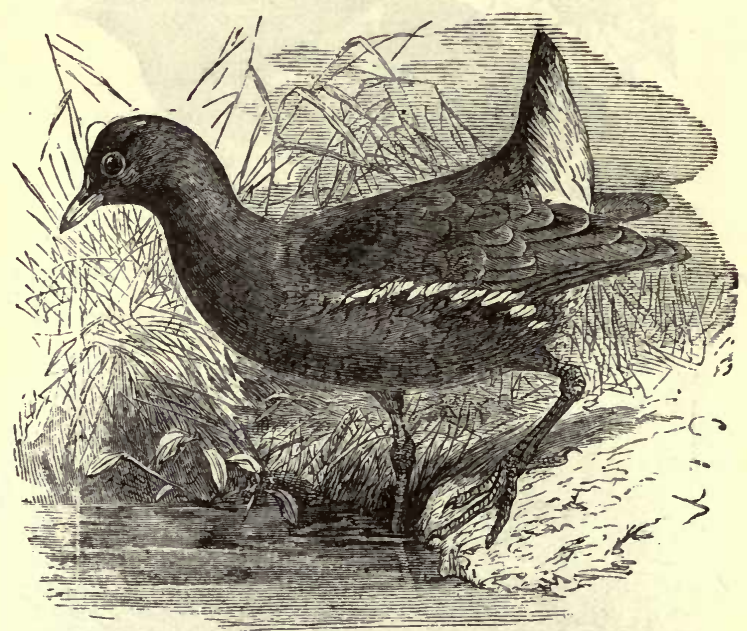

The Common Moorhen (Gallinula chloropus).

walk, moving their legs alternately. Skylarks rise and fall perpendicularly as they sing; woodlarks hang poised in the air; and titlarks rise and fall in large curves, singing in their descent. The white-throat uses odd jerks and gesticulations over the tops of hedges and bushes. All the duck-kind waddle; divers and auks walk as if fettered, and stand erect on their tails : these are the compedes of Linnæus. Geese and cranes, and most wild fowls, move in figured flights, often changing their position. The secondary remiges of Tringæ, wild-ducks, and some others, are very long, and give their wings, when in motion, a hooked 
appearance. Dabchicks, moor-hens, and coots, fly erect, with their legs hanging down, and hardly make any dispatch; the reason is plain, their wings are placed too forward out of the

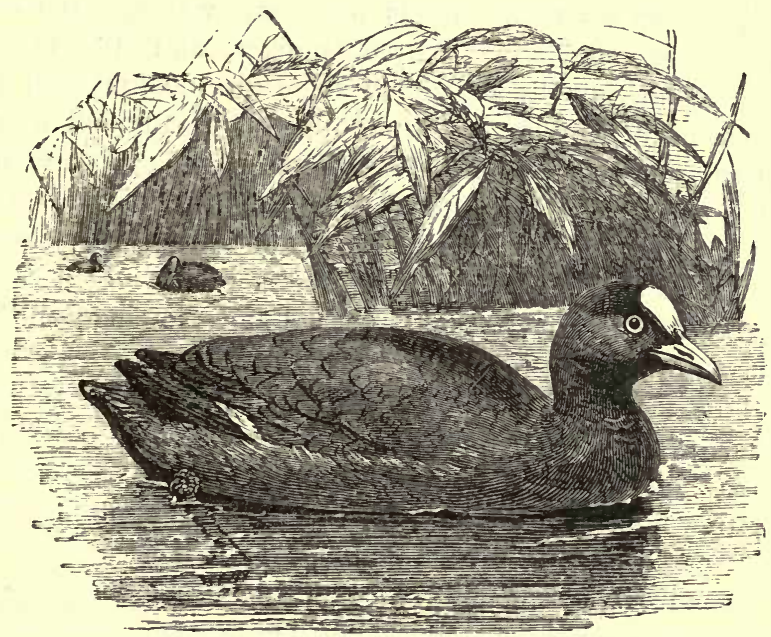

The Common Coot.

true centre of gravity; as the legs of auks and divers are situated too backward.

\section{NOTE TO LETTER XLII.}

1 The flight of the heron seems particularly slow, yet the beats of its wings average one huadred and twenty in a minute, and it makes very rapid progress.

\section{LETTER XLIII.}

Selborne, Sept. $9 i \bar{n}, \mathbf{1 7 7} \&$.

DEAR SIR,-From the motion of birds, the transition is natural enough to their notes and language, of which I shall say something. Not that I would pretend to understand their language like the vizier; who, by the recital of a conversation which passed 
between two owls, reclaimed a sultan,* before delighting in conquest and devastation; but I would be thought only to mean that many of the winged tribes have various sounds and voices adapted to express their various passions, wants, and feelings ; such as anger, fear, love, hatred, hunger, and the like. All species are not equally eloquent; some are copious and fluent as it were in their utterance, while others are confined to a few important sounds: no bird, like the fish kind, is quite mute, ${ }^{1}$ though some are rather silent. The language of birds is very ancient, and, like other ancient modes of speech, very elliptical; little is said, but much is meant and understood.

The notes of the eagle-kind are shrill and piercing; and about the season of nidification much diversified, as I have been often assured by a curious observer of Nature, who long resided at Gibraltar, where eagles abound. The notes of our hawks much resemble those of the king of birds. Owls have very expressive notes; they hoot in a fine vocal sound, much resembling the vox humana, and reducible by a pitch-pipe to a musical key. This note seems to express complacency and rivalry among the males; they use also a quick call and a horrible scream; and can snore and hiss when they mean to menace. Ravens, besides their loud croak, can exert a deep and solemn note that makes the woods to echo; the aniorous sound of a crow is strange and ridiculous; rooks, in the breeding season, attempt sometimes in the gaiety of their hearts to sing, but with no great success; the parrot-kind have many modulations of voice, as appears by their aptitude to learn human sounds; doves coo in an amorous and mournful manner, and are emblems of despairing lovers; the woodpecker sets up a sort of loud and hearty laugh; the fern-owl, or goatsucker, from the dusk till day-break,.serenades his mate with the clattering of castanets. All the tuneful passeres express their complacency by sweet modulations, and a variety of melody. 'The swallow, as has been observed in a former letter, by a shrill alarm bespeaks the attention of the other hirundines, and bids them be aware the hawk is at hand. Aquatic and gregarious birds, especially the nocturnal, that shift their quarters in the dark, are * See Spectator, Vol. vii., No. 5 I2. 
very noisy and loquacious; as cranes, wild-geese, wild-ducks, and the like; their perpetual clamour prevents them from dispersing and losing their companions.

In so extensive a subject, sketches and outlines are as much as can be expected; for it would be endless to instance in all the infinite variety of the feathered nation. We shall therefore confine the remainder of this letter to the few domestic fowls of our yards, which are most known, and therefore best understood. And first the peacock, with his gorgeous train, demands our attention; but, like most of the gaudy birds, his notes are grating and shocking to the ear: the yelling of cats, and the braying of an ass, are not more disgustful. The voice of the goose is trumpet-like, and clanking; and once saved the Capitol at Rome, as grave historians assert; the hiss, also, of the gander, is formidable and full of menace, and "protective of his young." Among ducks the sexual distinction of voice is remarkable; for, while the quack of the female is loud and sonorous, the voice of the drake is inward and harsh, and feeble, and scarce discernible. The cock turkey struts and gobbles to his mistress in a most uncouth manner; he hath also a pert and petulant note when he attacks his adversary. When a hen turkey leads forth her young brood she keeps a watchful eye ; and if a bird of prey appear, though ever so high in the air, the careful mother announces the enemy with a little inward moan, and watches him with a steady and attentive look; but, if he approach, her note becomes earnest and alarming, and her outcries are redoubled.

No inhabitants of a yard seem possessed of such a variety of expression and so copious a language as common poultry. Take a chicken of four or five days old, and hold it up to a window where there are flies, and it will immediately seize its prey, with little twitterings of complacency ; but if you tender it a wasp or a bee, at once its note becomes harsh, and expressive of disapprobation and a sense of danger. When a pullet is ready to lay she intimates the event by a joyous and easy soft note. Of all the occurrences of their life that of laying seems to be the most important; for no sooner has a hen disburdened herself, than she rushes forth with a clamorous kind of joy, which the cock and 
the rest of his mistresses immediately adopt. The tumult is not confined to the family concerned, but catches from yard to yard, and spreads to every homestead within hearing, till at last the whole village is in an uproar. As soon as a hen becomes a mother her new relation demands a new language; she then runs clocking and screaming about, and seems agitated as if possessed. The father of the flock has also a considerable vocabulary; if he finds food, he calls a favourite concubine to partake; and if a bird of prey passes over, with a warning voice he bids his family beware. The gallant chanticleer has, at command, his amorous phrases and his terms of defiance. But the sound by which he is best known is his crowing: by this he has been distinguished in all ages as the countryman's clock or larum, as the watchman that proclaims the divisions of the night. Thus the poet elegantly styles him :

\section{"__ the crested cock, whose clarion sounds}

The silent hours."

A neighbouring gentleman one summer had lost most of his chickens by a sparrow-hawk, that came gliding down between a faggot pile and the end of his house to the place where the coops stood. The owner, inwardly vexed to see his flock thus diminished, hung a setting-net adroitly between the pile and the house, into which the caitiff dashed, and was entangled. Resentment suggested the law of retaliation; he therefore clipped the hawk's wings, cut off his talons, and, fixing a cork on his bill, threw him down among the brood-hens. Imagination cannot paint the scene that ensued; the expressions that fear, rage, and revenge inspired, were new, or at least such as had been unnoticed before: the exasperated matrons upbraided, they execrated, they insulted, they triumphed. In a word, they never desisted from buffeting their adversary till they had torn him in a hundred pieces.

\section{NOTE TO LETTER XLIII.}

1 Several species of fish utter sounds while dying. The gurnard utters a croak, the bream a gasping sound; but these sounds are accidental and not natural. 


\section{LETTER XLIV.}

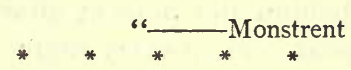

Quid tantum Oceano properent se tingere soles Hyberni ; vel quæ tardis mora noctibus obstet."

SELBORNe.

Gentlemen who have outlets might contrive to make ornament subservient to utility : a pleasing eye-trap might also contribute to promote science : an obelisk in a garden or park might be both an embellishment and an heliotrope.

Any person that is curious, and enjoys the advantage of a good horizon, might, with little trouble, make two heliotropes; the one for the winter, the other for the summer solstice: and the two erections might be constructed with very little expense; for two pieces of timber frame-work, about ten or twelve feet high, and four feet broad at the base, and close lined with plank, would answer the purpose.

The erection for the forrier should, if possible, be placed within sight of some window in the common sitting-parlour; because men, at that dead season of the year, are usually within doors at the close of the day; while that for the latter might be fixed for any given spot in the garden or outlet; whence the owner might contemplate, in a fine summer's eveuing, the utmost extent that the sun makes to the northward at the season of the longest days. Now nothing would be necessary but to place these two objects with so much exactness, that the westerly limb of the sun, at setting, might but just clear the winter heliotrope to the west of it on the shortest day; and that the whole disc of the sun, at the longest day, might exactly at setting also clear the summer heliotrope to the north of it.

By this simple expedient it would soon appear that there is no such thing, strictly speaking, as a solstice; for, from the shortest day, the owner would, every clear evening, see the disc advancing at its setting, to the westward of the object ; and, from the longest day, observe the sun retiring backwards every evening at its 
setting, towards the object westward, till, in a few nights, it would set quite behind it, and so by degrees, to the west of it : for when the sun comes near the summer solstice, the whole disc of it would at first set behind the object; after a time the northern limb would first appear, and so every night gradually more, till at length the whole diameter would set northward of it for about three nights; but on the middle night of the three, sensibly more remote than the former or following. When beginning its recess from the summer tropic, it would continue more and more to be hidden every night, till at length it would descend quite behind the object again; and so nightly more and more to the westward.

LETTER XI,V.

"___ Mugire videbis

Sub bedibus terram, et descendere montibus ornos."

SElborne.

When I was a boy I used to read, with astonishment and implicit assent, accounts in "Baker's Chronicle" of walking hills and travelling mountains. John Philips, in his "Cyder," alludes to the credit that was given to such stories with a delicate but quaint vein of humour peculiar to the author of the "Splendid Shilling."

"I nor advise, nor reprehend the choice

Of Marcely Hill ; the apple no where finds

A kinder mould; yet 'tis unsafe to trust

Deceitful ground ; who knows but that once more

This mount may journey, and his present site

Forsaken, to thy neighbour's bounds transfer

Thy goodly plants, affording matter strange

For law debates?"

But, when I came to consider better, I began to suspect that though our hills may never have journeyed far, yet that the ends of many of them have slipped and fallen away at distant periods, 
leaving the cliffs bare and abrupt. This seems to have been the case with Nore and Whetham Hills; and especially with the ridge between Harteley Park and Ward-le-Ham, where the ground has slid into vast swellings and furrows; and lies still in such romantic confusion as cannot be accounted for from any other cause. A strange event, that happened not long since, justifies our suspicions; which, though it befel not within the limits of this parish, yet as it was within the hundred of Selborne, and as the circumstances were singular, may fairly claim a place in a work of this nature.

The months of January and February, in the year I774, were remarkable for great melting snows and vast gluts of rain; so that by the end of the latter month the land-springs, or lavants, began to prevail, and to be near as high as in the memorable winter of I 764. The beginning of March also went on in the same tenor; when, in the night between the 8th and 9th of that month, a considerable part of the great woody hanger at Hawkley was torn from its place, and fell down, leaving a high free-stone cliff naked and bare, and resembling the steep side of a chalk-pit. It appears that this huge fragment, being perhaps sapped and undermined by waters, foundered, and was ingulfed, going down in a perpendicular direction; for a gate which stood in the field, on the top of the hill, after sinking with its posts for thirty or forty feet, remained in so true and upright a position as to open and shut with great exactness, just as in its first situation. Several oaks also are still standing, and in a state of vegetation, after taking the same desperate leap. That great part of this prodigious mass was absorbed in some gulf below, is plain also from the inclining ground at the bottom of the hill, which is free and unincumbered; but would have been buried in heaps of rubbish, had the fragment parted and fallen forward. About a hundred yards from the foot of this hanging coppice stood a cottage by the side of a lane; and two hundred yards lower, on the other side of the lane, was a farm-house, in which lived a labourer and his family; and, just by, a stout new barn. The cottage was inhabited by an old woman and her son, and his wife. These people in the evening, which was very dark and tempestuous, observed that the brick floors of thetr 
kitchens began to heave and part; and that the walls seemed to open, and the roofs to crack; but they all agree that no tremor of the ground, indicating an earthquake, was ever felt; only that the wind continued to make a most tremendous roaring in the woods and hangers. 'The miserable inhabitants, not daring to go to bed, remained in the utmost solicitude and confusion, expecting every moment to be buried under the ruins of their shattered edifices. When daylight came they were at leisure to contemplate the devastations of the night: they then found that a deep rift, or chasm, had opened under their houses, and torn them, as it were, in two; and that one end of the barn had suffered in a similar manner: that a pond near the cottage had undergone a strange reverse, becoming deep at the shallow end, and so vice versâ ; that many large oaks were removed out of their perpendicular, some thrown down, and some fallen into the heads of neighbouring trees; and that a gate was thrust forward, with its hedge, full six feet, so as to require a new track to be made to it. From the foot of the cliff the general course of the ground, which is pasture, inclines in a moderate descent for half a mile, and is interspersed with some hillocks, which were rifted, in every direction, as well towards the great woody hanger, as from it. In the first pasture the deep clefts began; and running across the lane, and under the buildings, made such vast shelves that the road was impassable for some time; and so over to an arable field on the other side, which was strangely torn and disordered. The second pasture-field, being more soft and springy, was protruded forward without many fissures in the turf, which was raised in long ridges resembling graves, lying at right angles to the motion. At the bottom of this enclosure the soil and turf rose many feet against the bodies of some oaks that obstructed their farther course, and terminated this awful commotion.

The perpendicular height of the precipice in general is twentythree yards ; the length of the lapse or slip as seen from the fields below, one hundred and eighty-one ; and a partial fall, concealed in the coppice, extends seventy yards more; so that the total length of this fragment that fell was two hundred and fifty-one yards. About fifty acres of land suffered from this violent con- 
vulsion; two houses were entirely destroyed; one end of a new barn was left in ruins, the walls being cracked through the very stones that composed them; a hanging coppice was changed to a naked rock; and some grass grounds and an arable field so broken and rifted by the chasms as to be rendered for a time neither fit for the plough nor safe for pasturage, till considerable labour and expense had been bestowed in levelling the surface and filling in the gaping fissures.

LETTER XLVI.

"—_ resonant arbusta —_."

SELBORNE.

THERE is a steep abrupt pasture field and interspersed with furze close to the back of this village, well known by the name of Short Lithe, consisting of a rocky dry soil, and inclining to the afternoon sun. This spot abounds with the gryllus campestris, or field-cricket; which, though frequent in these parts, is by no means a common insect in many other counties.

As their cheerful summer cry cannot but draw the attention of a naturalist, I have often gone down to examine the economy of these grylli, and study their mode of life ; but they are so shy and cautious that it is no easy matter to get a sight of them; for feeling a person's footsteps as he advances, they stop short in the midst of their song, and retire backward nimbly into their burrows, where they lurk till all suspicion of danger is over.

At first we attempted to dig them out with a spade, but without any great success; for either we could not get to the bottom of the hole, which often terminated under a great stone; or else in breaking up the ground we inadvertently squeezed the poor insect to death. Out of one so bruised we took a multitude of eggs, which were long and narrow, of a yellow colour, and covered with a very tough skin. By this accident we learned to distinguish the male from the female; the former of which is shining 
black, with a golden stripe across his shoulders; the latter is more dusky, more capacious about the abdomen, and carries a long sword-shaped weapon at her tail, which probably is the instrument with which she deposits her eggs in crannies and safe receptacles.

Where violent methods will not avail, more gentle means will often succeed, and so it proved in the present case; for, though a spade be too boisterous and rough an implement, a pliant stalk of grass, gently insinuated into the caverns, will probe their windings to the bottom, and quickly bring out the inhabitant; and thus the humane inquirer may gratify his curiosity without injuring the object of it. It is remarkable, that though these insects are furnished with long legs behind, and brawny thighs for leaping, like grasshoppers; yet when driven from their holes they show no activity, but crawl along in a shiftless manner, so as easily to be taken; and again, though provided with a curious apparatus of wings, yet they never exert them when there seems to be the greatest occasion. The males only make that shrilling noise, perhaps, out of rivalry and emulation, as is the case with many animals which exert some sprightly note during their breedingtime. It is raised by a brisk friction of one wing against the other. They are solitary beings, living singly male and female, each as it may happen; but there must be a time when the sexes have some intercourse, and then the wings may be useful perhaps during the hours of night. When the males meet they will fight fiercely, as I found by some which I put into the crevices of a dry stone wall, where I should have been glad to have made them settle. For though they seemed distressed by being taken out of their knowledge, yet the first that got possession of the chinks would seize on any other that were intruded upon them with a vast row of serrated fangs. With their strong jaws, toothed like the shears of a lobster's claws, they perforate and round their curious regular cells, having no fore-claws to dig, like the molecricket. When taken in hand I could not but wonder that they never offered to defend themselves, though armed with such formidable weapons. Of such herbs as grow before the mouths of their burrows they eat indiscriminately, and on a little platform 
which they make just by, they drop their dung; and never, in the day time, seem to stir more than two or three inches from home. Sitting in the entrance of their caverns they chirp all night as well as day from the middle of the month of May to the middle of July; and in hot weather, when they are most vigorous, they make the hills echo, and in the stiller hours of darkness may be heard to a considerable distance. In the beginning of the season their notes are more faint and inward; but become louder as the summer advances, and so die away again by degrees.

Sounds do not always give us pleasure according to their sweetness and melody; nor do harsh sounds always displease. We are more apt to be captivated or disgusted with the associations which they promote than with the notes themselves. Thus the shrilling of the field-cricket, though sharp and stridulous, yet marvellously delights some hearers, filling their minds with a train of summer ideas of everything that is rural, verdurous, and joyous.

About the roth March the crickets appear at the mouths of their cells, which they then open and bore, and shape very elegantly. All that ever I have seen at that season were in their pupa state, and had only the rudiments of wings, lying under a skin or coat, which must be cast before the insect can arrive at its perfect state; from whence I should suppose that the old ones of last year do not always survive the winter. In August their holes begin to be obliterated, and the insects are seen no more till spring.

Not many summers ago I endeavoured to transplant a colony to the terrace in my garden, by boring deep holes in the sloping turf. The new inhabitants stayed some time, and fed and sung; but wandered away by degrees, and were heard at a farther distance every morning, so that it appears that on this einergency they made use of their wings in attempting to return to the spot from which they were taken.

One of these crickets when confined in a paper cage and set in the sun, and supplied with plants moistened with water, will feed and thrive, and become so merry and loud as to be irksome in the same room where a person is sitting; if the plants are not wetted it will die. 


\section{LETTER XLVII.}

"Far from all resort of mirth

Save the cricket on the hearth."

Milton's Il Penseroso.

SELBORNE.

DeAR Sir,-While many other insects must be sought after in fields, and woods, and waters, the gryllus domesticus, or housecricket, resides altogether within our dwellings, intruding itself upon our notice whether we will or no. This species delights in new-built houses, being, like the spider, pleased with the moisture of the walls; and besides, the softness of the mortar enables them

to burrow and mine between the

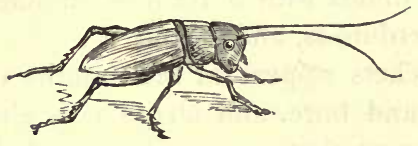

House-Cricket. joints of the bricks or stones, and to open communications from one room to another. They are particularly fond of kitchens and bakers' ovens, on account of their perpetual warmth.

Tender insects that live abroad either enjoy only the short period of one summer, or else doze away the cold uncomfortable months in profound slumbers; but these, residing as it were in a torrid zone, are always alert and merry,-a good Christmas fire is to them like the heats of the dog-days. Though they are frequently heard by day, yet is their natural time of motion only in the night. As soon as it grows dusk, the chirping increases, and they come running forth, and are from the size of a flea to that of their full stature. As one should suppose, from the burning atmosphere which they inhabit, they are a thrifty race, and show a great propensity for liquids, being found frequently drowned in pans of water, milk, broth, or the like. Whatever is moist they affect; and therefore often gnaw holes in wet woollen stockings and aprons that are hung to the fire: they are the housewife's barometer, foretelling her when it will rain, and are prognostic sometimes she thinks of ill or good luck, of the death of a near 
relation, or the approach of an absent lover. By being the constant companions of her solitary hours they naturally become the objects of her superstition. These crickets are not only very thrifty, but very voracious; for they will eat the scummings of pots, and yeast, salt, and crumbs of bread, and any kitchen offal or sweepings. In the summer we have observed them to fly when it became dusk out of the windows, and over the neighbouring roofs. This feat of activity accounts for the sudden manner in which they often leave their haunts, as it does for the method by which they come to houses where they were not known before. It is remarkable that many sorts of insects seem never to use their wings but when they have a mind to shift their quarters and settle new colonies. When in the air they move "volatu undoso," in waves or curves, like wood-peckers, opening and shutting their wings at every stroke, and so are always rising or sinking.

When they increase to a great degree, as they did once in the house where I am now writing, they become noisome pests, flying into the candles, and dashing into people's faces; but may be blasted and destroyed by gunpowder discharged into their crevices and crannies. In families at such times they are like Pharaoh's plague of frogs, - "in their bedchambers, and upon their beds, and in their ovens, and in their kneading troughs." * Their shrilling noise is occasioned by a brisk attrition of their wings. Cats catch hearth-crickets, and, playing with them as they do with mice, devour them. Crickets may be destroyed, like wasps, by phials half filled with beer, or any liquid, and set in their haunts; for being always eager to drink, they will crowd in till the bottles are full.

\section{LETTER XLVIII.}

SELBORNE.

How diversified are the modes of life not only of incongruous but even of congenerous animals; and yet their specific distinctions are not more various than their propensities. Thus, while 
the field-cricket delights in sunny dry banks, and the house-cricket rejoices amidst the glowing heat of the kitchen hearth or oven, the Gryllus gryllo talpa (the mole-cricket), haunts moist meadows, and frequents the sides of ponds and banks of streams, performing all its functions in a swampy wet soil. With a pair of fore-feet, curiously adapted to the purpose, it burrows and works under ground like the mole, raising a ridge as it proceeds, but seldom throwing up hillocks.

As mole-crickets often infest gardens by the sides of canals, they are unwelcome guests to the gardener, raising up ridges in

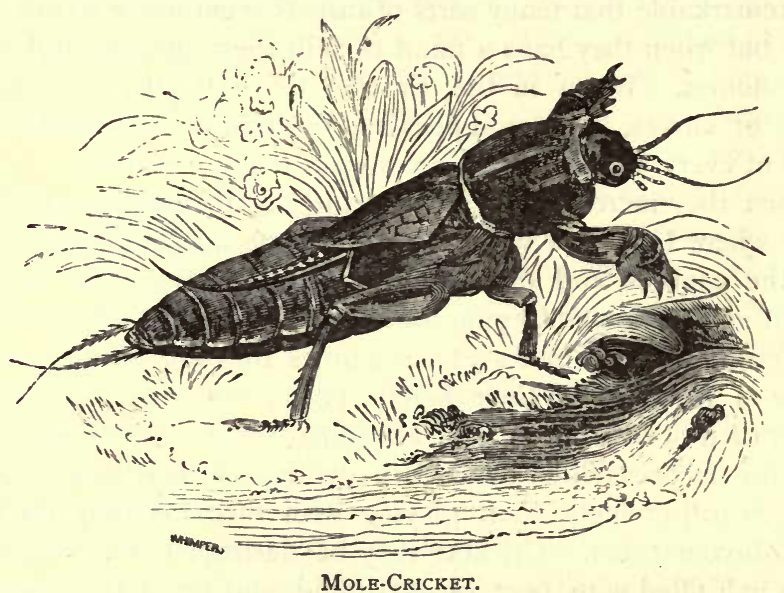

their subterraneous progress, and rendering the walks unsightly. If they take to the kitchen quarters they occasion great damage among the plants and roots, by destroying whole beds of cabbages, young legumes, and flowers. When dug out they seem very slow and helpless, and make no use of their wings by day; but at night they come abroad, and make long excursions, as I have been convinced by finding stragglers, in a morning, in improbable places. In fine weather, about the middle of April, and just at the close of day, they begin to solace themselves with a low, dull, jarring note, continued for a long time without interruption, and not unlike the chattering of the fern-owl, or goat-sucker, but more inward. 
About the beginning of May they lay their eggs, as I was once an eye-witness ; for a gardener at a house where I was on a visit, happening to be mowing, on the 6th of that month, by the side of a canal, his scythe struck too deep, pared off a large piece of turf, and laid open to view a curious scene of domestic economy :-

“ Ingentem lato dedit ore fenestram :

Apparet domus intus, et atria longa patescunt :

Apparent-penetralia."

There were many caverns and winding passages leading to a kind of chamber, neatly smoothed and rounded, and about the size of a moderate snuff-box. Within this secret nursery were deposited near a hundred eggs of a dirty yellow colour, and enveloped in a tough skin, but too lately excluded to contain any rudiments of young, being full of a viscous substance. The eggs lay but shallow, and within the influence of the sun, just under a little heap of fresh-mowed mould, like that which is raised by ants.

When mole-crickets fly they move "cursu undoso," rising and falling in curves, like the other species mentioned before. In different parts of this kingdom people call them fen-crickets, churr-worms, and eve-churrs, all very apposite names.

Anatomists, who have examined the intestines of these insects, astonish me with their accounts; for they say that, from the structure, position, and number of their stomachs, or maws, there seems to be goxd reason to suppose that this and the two former species ruminate or chew the cud like many quadrupeds $!^{1}$

\section{NOTE TO LETTER XLVIII.}

1 The use of this peculiar formation of the stomach of the cricket (and the locust has the same peculiarity) is not yet clear to naturalists, but it seems quite clear that it does not chew the cud, and that it would be impossible for the food to be returned for that purpose. 


\section{LETTER XLIX.}

Selborne, May 7 th, 1779 .

$\mathrm{I}_{\mathrm{T}}$ is now more than forty years that $\mathrm{I}$ have paid some attention to the ornithology of this district, without being able to exhaust the subject: new occurrences still arise as long as any inquiries are kept alive.

In the last week of last month five of those most rare birds, too uncommon to have obtained an English name, but known to naturalists by the terms of himantopus, or loripes, and charadrius himantopus, ${ }^{1}$ were shot upon the verge of Frinsham-pond, a large lake belonging to the Bishop of Winchester, and lying between Wolmer-forest and the town of Farnham, in the county of Surrey. The pond keeper says there were three brace in the flock: but, that after he had satisfied his curiosity, he suffered the sixth to remain unmolested. One of these specimens I procured, and found the length of the legs to be so extraordinary, that, at first sight, one might have supposed the shanks had been fastened on to impose on the credulity of the beholder: they were legs in caricatura; and had we seen such proportions on a Chinese or Japan screen we should have made large allowances for the fancy of the draughtsman. These birds are of the plover family, and might with propriety be called the stilt plovers. Brisson, under that idea, gives them the apposite name of l'echasse. My specimen, when drawn and stuffed with pepper, weighed only four ounces and a quarter, though the naked part of the thigh measured three inches and a half, and the legs four inches and a half. Hence we may safely assert that these birds exhibit, weight for inches, incomparably the greatest length of legs of any known bird. The flamingo, for instance, is one of the most long-legged birds, and yet it bears no manner of proportion to the himantopus; for a cock flamingo weighs, at an average, about four pounds avoirdupois; and his legs and thighs measure usuaily about twenty inches. But four pounds are fifteen times and a fraction more than four ounces, and one quarter; and if four ounces and a quarter have 
eight inches of legs, four pounds must have one hundred and twenty inches and a fraction of legs; viz., somewhat more than ten feet; such a monstrous proportion as the world never saw! If you should try the experiment in still larger birds the disparity would still increase. It must be matter of great curiosity to see the stilt plover move; to observe how it can wield such a length of lever with such feeble muscles as the thighs seem to be furnished with. At best one should expect it to be but a bad walker : but what adds to the wonder is, that it has no back toe. Now without that steady prop to support its steps it must be liable, in speculation, to perpetual vacillations, and seldom able to preserve the true centre of gravity.

The old name of himantopus is taken from Pliny; and, by an awkward metaphor, implies that the legs are as slender and pliant as if cut out of a thong of leather. Neither Willughby nor Ray, in all their curious researches, either at home or abroad, ever saw this bird. Mr. Pennant never met with it in all Great Britain, but observed it often in the cabinets of the curious at Paris. Hasselquist says that it migrates to Egypt in the autumn : and a most accurate observer of Nature has assured me that he has found it on the banks of the streams in Andalusia.

Our writers record it to have been found only twice in Great Britain. From all these relations it plainly appears that these long-legged plovers are birds of South Europe, and rarely visit our island; and when they do, are wanderers and stragglers, and impelled to make so distant and northern an excursion from motives or accidents for which we are nut able to account. One thing may fairly be deduced, that these birds come over to us from the continent, since nobody can suppose that a species not noticed once in an age, and of such a remarkable make, can constantly breed unobserved in this kingdom.

\section{NOTE TO LETTER XLIX.}

1 The bird referred to is the black-winged stilt, which is only an occasional visitant to England. 


\section{LETTER L.}

Selborne, April 21 st, i 780 .

DEAR Sir,-The old Sussex tortoise, that I have mentioned to you so often, is become my property. I dug it out of its winter dormitory in March last, when it was enough awakened to express its resentments by hissing; and, packing it in a box with earth, carried it eighty miles in post-chaises. The rattle and hurry of the journey so perfectly roused it that, when I turned it out on a border, it walked twice down to the bottom of my garden; however, in the evening, the weather being cold, it buried itself in the loose mould, and continues still concealed.

As it will be under my eye, I shall now have an opportunity of enlarging my observations on its mode of life, and propensities ; and perceive already that, towards the time of coming forth, it opens a breathing place in the ground near its head, requiring, I conclude, a freer respiration as it becomes more alive. This creature not only goes under the earth from the middle of November to the middle of April, but sleeps great part of the summer : for it goes to bed in the longest days at four in the afternoon, and often does not stir in the morning till late. Besides, it retires to rest for every shower; and does not move at all in wet days.

When one reflects on the state of this strange being, it is a matter of wonder to find that Providence should bestow such a profusion of days, such a seeming waste of longevity, on a reptile that appears to relish it so little as to squander more than twothirds of its existence in a joyless stupor, and be lost to all sensation for months together in the profoundest of slumbers.

While I was writing this letter, a moist and warm afternoon, with the thermometer at $50^{\circ}$, brought forth troops of shell-snails; and, at the same juncture, the tortoise heaved up the mould and put out its head; and the next morning came forth, as it were, raised from the dead; and walked about till four in the afternoon. This was a curious coincidence! a very amusing occurrence! to 
see such a similarity of feelings between the two фєрєоєко ! for so the Greeks called both the shell-snail and the tortoise.

Summer birds are, this cold and backward spring, unusually late: I have seen but one swallow yet. This conformity with the weather convinces me more and more that they sleep in the winter.

\section{LETTER LI.}

Selborne, Sept. $3 r d$, i 78 i.

I HAVE now read your miscellanies through with much care and satisfaction ; and am to return you my best thanks for the honourable mention made in them of me as a naturalist, which I wish I may deserve.

In some former letters I expressed my suspicions that many of the house-martins do not depart in the winter far from this village. I therefore determined to make some search about the south-east end of the hill, where I imagined they might slumber out the uncomfortable months of winter. But supposing that the examination would be made to the best advantage in the spring, and observing that no martins had appeared by the IIth April last; on that day I employed some men to explore the shrubs and cavities of the suspected spot. The persons took pains, but without any success; however, a remarkable incident occurred in the midst of our pursuit: while the labourers were at work a housemartin, the first that had been seen this year, came down the village in the sight of several people, and went at once into a nest, where it stayed a short time, and then flew over the houses; for some days after no martins were observed, not till the r6th April, and then only a pair. Martins in general were remarkably late this year. 


\section{LETTER LII.}

SELBORNe, Sept. $9 t h, \mathbf{I} 78 \mathbf{I}$.

I HAVE just met with a circumstance respecting swifts, which furnishes an exception to the whole tenor of my observations ever since I have bestowed any attention on that species of hirundines. Our swifts, in general, withdrew this year about the first day of August, all save one pair, which in two or three days was reduced to a single bird. The perseverance of this individual made me suspect that the strongest of motives, that of an attachment to her young, could alone occasion so late a stay. I watched therefore till the 24th August, and then discovered that, under the eaves of the church, she attended upon two young, which were fledged, and now put out their white chins from a crevice. These remained till the 27 th, looking more alert every day, and seeming to long to be on the wing. After this day they were missing at once; nor could I ever observe them with their dam coursing round the church in the act of learning to fly, as the first broods evidently do. On the 3 ist I caused the eaves to be searched, but we found in the nest only two callow, dead, stinking swifts, on which a second nest had been formed. This double nest was full of the black shining cases of the hippobosca hirundinis.

The following remarks on this unusual incident are obvious. The first is, that though it may be disagreeable to swifts to remain beyond the beginning of August, yet that they can subsist longer is undeniable. The second is, that this uncommon event, as it was owing to the loss of the first brood, so it corroborates my former remark, that swifts breed regularly but once; since, was the contrary the case, the occurrence above could neither be new nor rare.

P.S.-One swift was seen at Lyndon, in the county of Rutland, in $\mathrm{I} 782$, so late as the 3 rd September. 


\section{LETTER LIII.}

As I have sometimes known you make inquiries about several kinds of insects, I shall here send you an account of one sort which I little expected to have found in this kingdom. I had often observed that one particular part of a vine growing on the walls of my house was covered in the autumn with a black dustlike appearance, on which the flies fed eagerly; and that the shoots and leaves thus affected did not thrive; nor did the fruit ripen. To this substance I applied my glasses; but could not discover that it had anything to do with animal life, as I at first expected: but, upon a closer examination behind the larger boughs, we were surprised to find that they were coated over with husky shells, from whose sides proceeded a cotton-like substance, surrounding a multitude of eggs. This curious and uncommon production put me upon recollecting what $I$ have heard and read concerning the coccus vitis vinifere of Linnæus, which, in the south of Europe, infests many vines, and is a horrid and loathsome pest. As soon as I had turned to the accounts given of this insect, I saw at once that it swarmed on my vine; and did not appear to have been at all checked by the preceding winter, which had been uncommonly severe.

Not being then at all aware that it had anything to do with England, I was much inclined to think that it came from Gibraltar among the many boxes and packages of plants and birds which I had formerly received from thence; and especially as the vine infested grew immediately under my study-window, where I usually kept my specimens. True it is that I had received nothing from thence for some years: but as insects, we know, are conveyed from one country to another in a very unexpected manner, and have a wonderful power of maintaining their existence till they fall into a nidus proper for their support and increase, I cannot but suspect still that these cocci came to me originally from Andalusia. Yet, all the while, candour obliges me to confess that Mr. Lightfoot has written me word that he once, and but once, saw these insects 
on a vine at Weymouth in Dorsetshire; which, it is here to be observed, is a sea-port town to which the coccus might be conveyed by shipping.

As many of my readers may possibly never have heard of this strange and unusual insect, I shall here transcribe a passage from a natural history of Gibraltar, written by the Reverend John White, late vicar of Blackburn in Lancashire, but not yet published :-

"In the year I 770 a vine, which grew on the east side of my house, and which had produced the finest crops of grapes for years past, was suddenly overspread on all the woody branches with large lumps of a white fibrous substance resembling spiders' webs, or rather raw cotton. It was of a very clammy quality sticking fast to everything that touched it, and capable of being spun into long threads. At first I suspected it to be the product of spiders, but could find none. Nothing was to be seen connected with it but many brown oval husky shells, which by no means looked like insects, but rather resembled bits of the dry bark of the vine. The tree had a plentiful crop of grapes set, when this pest appeared upon it; but the fruit was manifestly injured by this foul encumbrance. It remained all the summer, still increasing, and loaded the woody and bearing branches to a vast degree. I often pulled off great quantities by handfuls; but it was so slimy and tenacious that it could by no means be cleared. The grapes never filled to their natural perfection, but turned watery and vapid. Upon perusing the works afterwards of $M$. de Reaumur, I found this matter perfectly described and accounted for. Those husky shells, which I had observed, were no other than the female coccus, from whose side this cotton-like substance exudes, and serves as a covering and security for their eggs."

To this account I think proper to add, that, though the female cocci are stationary, and seldom remove from the place to which they stick, yet the male is a winged insect; and that the black dust which I saw was undoubtedly the excrement of the females, which is eaten by ants as well as flies. Though the utmost severity of our winter did not destroy these insects, yet the attention of the gardener in a summer or two has entirely relieved my vine from this filthy annoyance. 
As we have remarked above that insects are often conveyed from one country to another in a very unaccountable manner, I shall here mention an emigration of small aphides, which was observed in the village of Selborne no longer ago than August ist, I 785 .

About three o'clock in the afternoon of that day, which was very hot, the people of this village were surprised by a shower of aphides, or smother-flies, which fell in these parts. Those that were walking in the.street at that juncture found themselves covered with these insects, which settled also on the hedges and gardens, blackening all the vegetables where they alighted. My annuals were discoloured with them, and the stalks of a bed of onions were quite coated over for six days after. These armies were then, no doubt, in a state of emigration, and shifting their quarters; and might have come, as far as we know, from the great hop plantations of Kent or Sussex, the wind being all that day in the easterly quarter. They were observed at the same time in great clouds about Farnham, and all along the vale from Farnham to Alton.

\section{LETTER LIV.}

DEAR Sir, - When I happen to visit a family where gold and silver fishes are kept in a glass bowl, I am always pleased with the occurrence, because it offers me an opportunity of observing the actions and propensities of those beings with whom we can be little acquainted in their natural state. Not long since I spent a fortnight at the house of a friend where there was such a vivary, to which I paid no small attention, taking every occasion to remark what passed within its narrow limits. It was here that I first observed the manner in which fishes die. ${ }^{1}$ As soon as the creature sickens, the head sinks lower and lower, and it stands as it were on its head; till, getting weaker, and losing all poise, the tail turns over, and at last it floats on the surface of the water with its belly uppermcst. The reason why fishes, when dead 
swim in that manner is very obvious; because, when the body is no longer balanced by the fins of the belly, the broad muscular back preponderates by its own gravity, and turns the belly uppermost, as lighter from its being a cavity, and because it contains the swimming-bladders, which contribute to render it buoyant. Some that cielight in gold and silver fishes have adopted a notion that they need no aliment. True it is that they will subsist for a long time without any apparent food but what they can collect from pure water frequently changed; yet they must draw some support from animalcula, and other nourishment supplied by the water; because, though they seem to eat nothing, yet the consequences of eating often drop from them. That they are best pleased with such jejune diet may easily be confuted, since if you toss them crumbs they will seize them with great readiness, not to say greediness; however, bread should be given sparingly, lest, turning sour it corrupt the water. They will also feed on the water-plant called Lemina (ducks' meat), and also on small fry. ${ }^{2}$

When they want to move a little, they gently protrude themselves with their Pinne pectorales; but it is with their strong muscular tails only that they and all fishes shoot along with such inconceivable rapidity. It has been said that the eyes of fishes are immoveable; but these apparently turn them forward or backward in their sockets as occasions require. They take little notice of a lighted candle, though applied close to their heads, but flounce and seem much frightened by a sudden stroke of the hand against the support whereon the bowl is hung; especially when they have been motionless, and are perhaps asleep. As fishes have no eyelids, it is not easy to discern when they are sleeping or not, because their eyes are always open.

Nothing can be more amusing than a glass bowl containing such fishes; the double refractions of the glass and water represent them, when moving, in a shifting and changeable variety of dimensions, shades, and colours; while the two mediums, assisted by the concavo-convex shape of the vessel, magnify and distort them vastly; not to mention that the introduction of another element and its inhabitants into our parlours engages the fancy in a very agreeable manner. 
Gold and silver fishes, though originally natives of China and Japan, yet are become so well reconciled to our climate as to thrive and multiply very fast in our ponds and stews. Linnæus ranks this species of fish under the genus of Cyprinus, or carp, and calls it Cyprinus auratus.

Some people exhibit this sort of fish in a very fanciful way; for they cause a glass bowl to be blown with a large hollow space within, that does not communicate with it. In this cavity they put a bird occasionally; so that you may see a goldfinch or a linnet hopping as it were in the midst of the water, and the fishes swimming in a circle round it. The simple exhibition of the fishes is agreeable and pleasant; but in so complicated a way becomes whimsical and unnatural, and liable to the objection due to him,

“Qui variare cupit rem prodigialitèr unam."

I am, etc.

\section{NOTES TO LETTER LIV.}

1 Only fish which are very heavy in the head and shoulders die in the way described by White. Other fish, such as trout, swim with their noses at the surface of the water, standing on their tails, as it were, until they turn, bellies up, and die.

2 In favourable waters the gold-fish breeds very fast, and grows to a large size. I know a small pond which is kept warm by waste water from the boilers of an adjoining paper-mill, where these fish are in incredible numbers for so small a space, and grow to four or five pounds in weight. It is excellent sport angling for the larger ones. They take paste freely, and fight well.

\section{I.ETTER LV.}

October $10 \mathrm{th}, \mathbf{1 7} 8 \mathrm{I}$.

DEAR SiR,-I think I have observed before that much of the most considerable part of the house-martins withdraw from hence about the first week in October; but that some, the latter broods I am now convinced, linger on till towards the middle of that month; and that at times, once perhaps in two or three years, 
a flight, for one day only, has shown itself in the first week in November.

Having taken notice, in October, 1780 , that the last flight was numerous, amounting perhaps to one hundred and fifty; and that the season was soft and still; I was resolved to pay uncommon attention to these late birds; to find, if possible, where they roosted, and to determine the precise time of their retreat. The mode of life of these latter Hirundines is very favourable to such a design; for they spend the whole day in the sheltered district, between me and the Hanger, sailing about in a placid, easy manner, and feasting on those insects which love to haunt a spot so secure from ruffling winds. As my principal object was to discover the place of their roosting, I took care to wait on them before they retired to rest, and was much pleased to find that for several evenings together, just at a quarter-past five in the afternoon, they all scudded away in great haste towards the south-east, and darted down among the low shrubs above the cottages at the end of the hill. This spot in many respects seemed to be well calculated for their winter residence; for in many parts it is as steep as the roof of any house, and therefore secure from the annoyances of water; and it is moreover clothed with beechen shrubs, which, being stunted and bitten by sheep, make the thickest covert imaginable; and are so entangled as to be impervious to the smallest spaniel; besides, it is the nature of underwood beech never to cast its leaf all the winter; so that, with the leaves on the ground and those on the twigs, no shelter can be more complete. I watched them on the I $3^{\text {th }}$ and 14 th October, and found their evening retreat was exact and uniform; but after this they made no regular appearance. Now and then a straggler was seen; and on the 22 nd October, I observed two in the morning over the village, and with them my remarks for the season ended.

From all these circumstances put together, it is more than probable that this lingering flight, at so late a season of the year, never departed from the island. Had they indulged me that autumn with a November visit, as I much desired, I presume that, with proper assistants, I should have settled the matter past 
all doubt; but though the 3 rd November was a sweet day, and in appearance exactly suited to my wishes, yet not a martin was to be seen; and so I was forced, reluctantiy, to give up the pursuit.

I have only to add that were the bushes, which cover some acres, and are not my own property, to be grubbed and carefully examined, probably those late broods, and perhaps the whole aggregate body of the house-martins of this district, night be found there, in different secret dormitories; and that, so far from withdrawing into warmer climes, it would appear that they never depart three hundred yards from the village.

\section{LETTER LVI.}

THEY who write on natural history cannot too frequently advert to instinct, that wonderful limited faculty, which in some instances, raises the brute creation, as it were, above reason, and in others leaves them so far below it. Philosophers have defined instinct to be that secret influence by which every species is compelled naturally to pursue, at all times, the same way or track, without any teaching or example; whereas reason, without instruction, would often vary and do that by many methods which instinct effects by one alone. Now this maxim must be taken in a qualified sense; for there are instances in which instinct does vary and conform to the circumstances of place and convenience.

It has been remarked that every species of bird has a mode of nidification peculiar to itself, so that a schoolboy would at once proncunce on the sort of nest before him. This is the case among fields and woods, and wilds; but, in the villages round London, where mosses and gossamer, and cotton from vegetables, are hardly to be found, the nest of the chaffinch has not that elegant finished appearance, nor is it so beautifully studded with lichens, as in a more rural district; and the wren is obliged to construct its house with straws and dry grasses, which do not give it that rotundity and compactness so remarkable in the edi- 
fices of that little architect. Again, the regular nest of the housemartin is hemispheric ; but where a rafter, or a josst, or a cornice, may happen to stand in the way, the nest is so contrived as to conform to the obstruction, and becomes flat, or compressed.

In the following instances instinct is perfectly uniform and consistent. There are three creatures, the squirrel, the field-mouse, and the bird called the nut-hatch (sitta Europiea), which live much on hazel-nut; and yet they open them each in a different way. The first after rasping off the small end, splits the shell in two

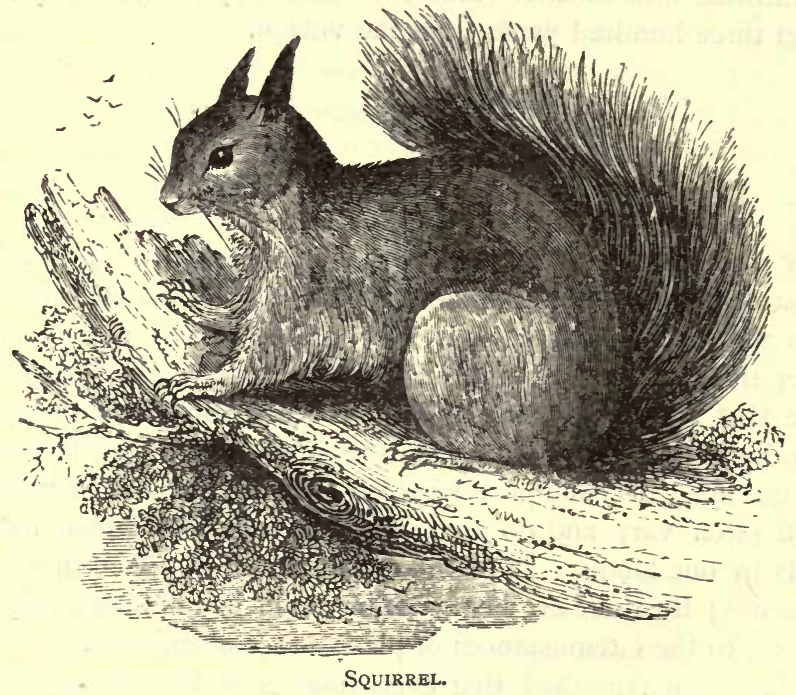

with his long fore-teeth, as a man does with his knife; the second nibbles a hole with his teeth, so regular as if drilled with a wimble, and yet so small that one could wonder how the kernel can be extracted through it; while the last picks an irregular ragged hole with its bill : but as this artist has no paws to hold the nut firm while he pierces it, like an adroit workman, he fixes it, as it were, in a vice, in some cleft of a tree, or in some crevice; when standing over it, he perforates the stubborn shell. We have often placed nuts in th a chink of a gate-post where nut-hatches have 
been known to haunt, and have always found that those birds have readily penetrated them. While at work they make a rapping noise that may be heard at a considerable distance.

You that understand both the theory and practical part of music may best inform us why harmony or melody should so strangely assist some men, as it were by recollection, for days after the concert is over. What I mean the following passage will most readily explain :-

"Præhabebat porrò vocibus humanis, instrumentisque harmonicis musicam illam avium: non quod aliâ quoque non delectaretur: sed quod ex musicâ humanâ relinqueretur in animo continens quædam, attentionemque et somnum conturbans agitatio; dum ascensus, exscensus, tenores, ac mutationes illæ sonorum, et consonantiarum euntque, redeuntque per phantasiam:-cum nihil tale relinqui possit ex modulationibus avium, quæ, quod non sunt perinde a nobis imitabiles, non possunt perinde internam facultatem commovere."-Gassendus in Vitâ Peireskii.

This curious quotation strikes me much by so well representing my own case, and by describing what I have so often felt, but never could so well express. When I hear fine music I am haunted with passages therefrom night and day; and especially at first waking, which, by their importunity, give me more uneasiness than pleasure; elegant lessons still tease my imagination, and recur irresistibly to my recollection at seasons, and even when I am desirous of thinking of more serious matters.

I am, etc.

\section{LETTER LVII.}

A RARE, and I think a new, little bird frequents my garden, which I have great reason to think is the pettichaps : it is common in some parts of the kingdom; and I have received formerly several dead specimens from Gibraltar. This bird much resembles the white-throat, but has a more white or rather silvery breast and belly; is restless and active, like the willow-wrens, and hops from 
bough to bough, examining every part for food; it also runs up the stems of the crown-imperials, and, putting its head into the bells of those flowers, sips the liquor which stands in the nectarium of each petal. Sometimes it feeds on the ground like the hedgesparrow, by hopping about on the grass-plots and mown walks. ${ }^{1}$

One of my neighbours, an intelligent and observing man, informs me that, in the beginning of May, and about ten minutes before eight o'clock in the evening, he discovered a great cluster of houseswallows, thirty, at least, he supposes, perching on a willow that hung over the verge of James Knight's upper-pond. His attention was first drawn by the twittering of these birds, which sat motionless in a row on the bough, with their heads all one way, and, by their weight, pressing down the twig so that it nearly touched the water. In this situation he watched them till he could see no longer. Repeated accounts of this sort, spring and fall, induce us greatly to suspect that house-swallows have some strong attachment to water, independent of the matter of food; and, though they may not retire into that element, yet they may conceal themselves in the banks of pools and rivers during the uncomfortable months of winter.

One of the keepers of Wolmer Forest sent me a peregrine-falcon, which he shot on the verge of that district as it was devouring a wood-pigeon. The falco peregrinus, or haggard-falcon, is a noble species of hawk seldom seen in the southern counties. In winter I 767, one was killed in the neighbouring parish of Farringdon, and sent by me to Mr. Pennant into North Wales.* Since that time I have met with none till now. The specimen mentioned above was in fine preservation, and not injured by the shot: it measured forty-two inches from wing to wing, and twenty-one from beak to tail, and weighed two pounds and a half standing weight. This species is very robust, and wonderfully formed for rapine; its breast was plump and muscular ; its thighs long, thick, and brawny ; and its legs remarkably short and well set: the feet were armed with most formidable, sharp, long talons : the eyelids and cere of the bill were yellow; but the irides of the eyes dusky; the beak was thick and hooked, and of a dark colour, and had a jagged process

* See my tenth and eleventh letter to that gentleman. 
near the end of the upper mandible on each side : its tail, or train, was short in proportion to the bulk of its body; yet the wings, when closed, did not extend to the end of the train. From its large and fair proportions it might be supposed to have been a female ; but I was not permitted to cut open the specimen. ${ }^{2}$ For one of the birds of prey, which are usually lean, this was in high

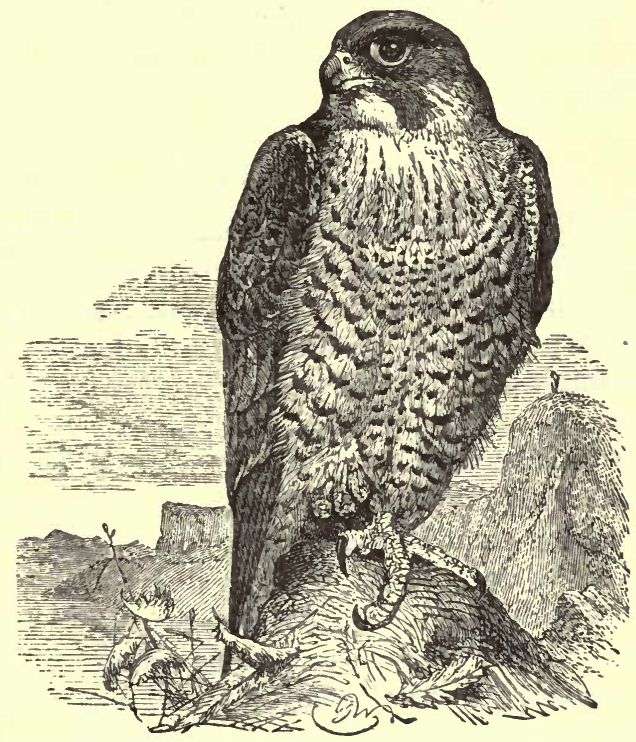

Peregrine Falcon.

case : in its craw were many barley-corns, which probably came from the crop of the wood-pigeon, on which it was feeding when shot; for voracious birds do not eat grain, but, when devouring their quarry, with undistinguishing vehemence swallow bones and feathers, and all matters, indiscriminately. This falcon was probably driven from the mountains of North Wales or Scotland, where they are known to breed, by rigorous weather and deep snows that had lately fallen.

I am, etc. 


\section{NOTES TO LETTER LVII.}

1 The pettichaps is more usually known by the name of the garden warbler, but White's description is more like the lesser white-throat, which is peculiarly restless and active, and has a very silvery breast and belly.

${ }^{2}$ Of the hawk tribe, the female is always the larger, stronger, and handsomer

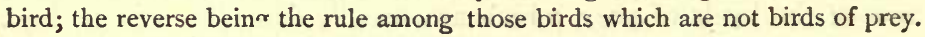

\section{LETTER LVIII.}

My near neighbour, a young gentleman in the service of the East India Company, has brought home a dog and a bitch of the Chinese breed from Canton, such as are fattened in that country for the purpose of being eaten: they are about the size of a moderate spaniel ; of a pale yellow colour, with coarse bristling hairs on their backs ; sharp upright ears, and peaked heads, which give them a very fox-like appearance. Their hind legs are unusually straight, without any bend at the hock or ham, to such a degree as to give them an awkward gait when they trot. When they are in motion their tails are curved high over their backs like those of some hounds, and have a bare place each on the outside from the tip midway, that does not seem to be matter of accident, but somewhat singular. Their eyes are jet-black, small, and piercing; the insides of their lips and mouths of the same colour, and their tongues blue. The bitch has a dew-claw on each hind leg; the dog has none. When taken out into a field the bitch showed some disposition for hunting, and dwelt on the scent of a covey of partridges till she sprung them, giving her tongue all the time. The dogs in South America are dumb; but these bark much in a short thick manner like foxes, and have a surly, savage demeanour like their ancestors, which are not domesticated, but bred up in sties, where they are fed for the table with rice-meal and other farinaceous food. These dogs, having been taken on board as soon as weaned, could not learn much from their danı; yet they did not relish flesh when they came to England. In the islands 
of the Pacific Ocean the dogs are bred upon vegetables, and would not eat flesh when offered them by our circumnavigators.

We believe that all dogs, in a state of nature, have sharp, upright, fox-like ears ; and that hanging ears, which are esteemed so graceful, are the effect of choice breeding and cultivation. Thus, in the "Travels of Ysbrandt Ides from Muscovy to China," the dogs which draw the Tartars on snow-sledges, near the river Oby, are engraved with prick-ears, like those from Canton. The Kamschatdales also train the same sort of sharp-eared, peak-nosed dogs to draw their sledges; as may be seen in an elegant print engraved for Captain Cook's last voyage round the world.

Now we are upon the subject of dogs, it may not be impertinent to add that spaniels, as all sportsmen know, though they hun partridges and pheasants as it were by instinct, and with much delight and alacrity, yet will hardly touch their bones when offered as food; nor will a mongrel dog of my own, though he is remarkable for finding that sort of game. But, when we came to offer the bones of partridges to the two Chinese dogs, they devoured them with much greediness, and licked the platter clean.

No sporting dogs will flush woodcocks till inured to the scent and trained to the sport, which they then pursue with vehemence and transport; but then they will not touch their bones, but turn from them with abhorrence, even when they are hungry.

Now, that dogs should not be fond of the bones of such birds as they are not disposed to hunt is no wonder; but why they reject and do not care to eat their natural game is not so easily accounted for, since the end of hunting seems to be, that the chase pursued should be eaten. Dogs again will not devour the more rancid water-fowls, nor indeed the bones of any wild fowls; nor will they touch the foetid bodies of birds that feed on offal and garbage; and indeed there may be somewhat of providential instinct in this circumstance of dislike ; for vultures, ${ }^{*}$ and kites, and ravens, and crows, etc., were intended to be messmates with

* "Hasselquist, in his travels to the Levant, observes that the dogs and vultures at Grand Cairo maintain such a friendly intercourse as to bring up their young together in the same place." 
dogs * over their carrion; and seem to be appointed by Nature as fellow-scavengers to remove all cadaverous nuisances from the face of the earth.

$$
\text { I am, etc. }
$$

\section{LETTER LIX.}

ThE fossil wood buried in the bogs of Wolmer Forest is not yet all exhausted; for the peat-cutters now and then stumble upon a log. I have just seen a piece which was sent by a labourer of Oak hanger to a carpenter of this village; this was the butt-end of a small oak, about five feet long, and about five inches in diameter. It had apparently been severed from the ground by an axe, was very ponderous, and as black as ebony. Upon asking the carpenter for what purpose he had procured it, he told me that it was to be sent to his brother, a joiner at Farnham, who was to make use of it in cabinet-work, by inlaying it along with whiter woods.

Those that are much abroad on evenings after it is dark, in spring, and summer, frequently hear a nocturnal bird passing by on the wing, and repeating often a short, quick note. This bird I have remarked myself, but never could make out till lately. I am assured now that it is the stone-curlew (charadrius cedicnemus). Some of them pass over or near my house almost every evening after it is dark, from the uplands of the hill and North Fields, away down towards Dorton, where, among the streams and meadows, they find a greater plenty of food. Birds that fly by night are obliged to be noisy; their notes often repeated become signals or watch-words to keep them together, that they may not stray or lose each the other in the dark.

The evening proceedings and manœuvres of the rooks are curious and amusing in the autumn. Just before dusk they return in long strings from the foraging of the day, and rendezvous by thousands over Selborne Down, where they wheel round in the

* "The Chinese word for a dog to an European ear sounds like quihloh." 
air, and sport and dive in a playful manner, all the while exerting their voices, and making a loud cawing, which, being blended and softened by the distance that we at the village are below them, becomes a confused noise or chiding; or rather a pleasing murmur, very engaging to the imagination, and not unlike the cry of a pack of hounds in hollow, echoing woods, or the rushing of the wind in tall trees, or the tumbling of the tide upon a pebbly shore. When this ceremony is over, with the last gleam of day, they retire for the night to the deep beechen woods of Tisted and Ropley. We remember a little girl who, as she was going to bed, used to remiark on such an occurrence, in the true spirit of physico-theology, that the rooks were saying their prayers ; and yet this child was much too young to be aware that the Scriptures have said of the Deity-that "He feedeth the ravens who call upon Him."

I am, etc.

\section{LETTER LX.}

IN reading Dr. Huxam's “Observationes de Aëre," etc., written at Plymouth, I find by those curious and accurate remarks, which contain an account of the weather from the year 1727 to the year $\mathrm{I} 748$, inclusive, that though there is frequent rain in that district of Devonshire, yet the quantity falling is not great; and that some years it has been very small : for in $173 \mathrm{I}$ the rain measured only 17.266 in.; and in $1741,20.354$ in.; and again, in 1743 , only $20^{\circ} 908$ in. Places near the sea have frequent scuds, that keep the atmosphere moist, yet do not reach far up into the country; making thus the maritime situations appear wet, when the rain is not considerable. In the wettest years at Plymouth the Doctor measured only once 36 ; and again once, viz., $1734,37.114$ in.a quantity of rain that has twice been exceeded at Selborne in the short period of my observations. Dr. Huxam remarks that frequent small rains keep the air moist; while heavy ones render it more dry, by beating down the vapours. $\mathrm{He}$ is also of opinion 
that the dingy, smoky appeara nce in the sky, in very dry seasons, arises from the want of moisture sufficient to let the light through, and render the atmosphere transparent ; because he had observed several bodies more diaphanous when wet than dry; and did never recollect that the air had that look in rainy seasons.

$\mathrm{My}$ friend, who lives just beyond the top of the down, brought his three swivel guns to try them in my outlet, with their muzzles towards the Hanger, supposing that the report would have had a great effect; but the experiment did not answer his expectation. He then removed them to the alcove on the Hanger, when the sound, rushing along the I,ythe and Comb Wood, was very grand; but it was at the hermitage that the echoes and repercussions delighted the hearers; not only filling the Lythe with the roar, as if all the beeches were tearing up by the roots; but, turning to the left, they pervaded the vale above Combwood ponds; and after a pause seemed to take up the crash again, and to extend round Hartley Hangers, and to die away at last among the coppices and coverts of Ward-le-Ham. It has been remarked before that this district is an Anathoth, a place of responses or echoes, and therefore proper for such experiments: we may farther add that the pauses in echoes, when they cease and yet are taken up again, like the pauses in music, surprise the hearers, and have a fine effect on the imagination.

The gentleman above-mentioned has just fixed a barometer in his parlour at Newton Valence. The tube was first filled here (at Selborne) twice with care, when the mercury agreed and stood exactly with my own; but, being filled twice again at Newton, the mercury stood, on account of the great elevation of that house, three-tenths of an inch lower than the barometers at this village, and so continues to do, be the weight of the atmosphere what it may. The plate of the barometer at Newton is figured as low as 27 ; because in stormy weather the mercury there will sometimes descend below 28. We have supposed Newton House to stand two hundred feet higher than this house: but if the rule holds good, which says that mercury in a barometer sinks one-tenth of an inch for every hundred feet elevation, then the Newton barometer, by standing three-tenths lower than that of Selborne, proves 
that Newton House must be three hundred feet higher than that in which I am writing, instead of two hundred.

It may not be impertinent to add that the barometers at Selborne stand three-tenths of an inch lower than the barometers at South Lambeth : whence we may conclude that the former place is about three hundred feet higher than the latter; and with good reason, because the streams that rise with us run into the Thames at Weybridge, and so to London. Of course therefore there must be lower ground all the way from Selborne to South Lambeth; the distance between which, all the windings and indentings of the streams considered, cannot be less than a hundred miles.

$$
\text { I am, etc. }
$$

\section{LETTER LXI.}

SINCE the weather of a district is undoubtedly part of its natural history, I shall make no further apology for the four following letters, which will contain many particulars concerning some of the great frosts, and a few respecting some very hot summers, that have distinguished themselves from the rest during the course of my observations.

As the frost in January 1768 was, for the small time it lasted, the most severe that we had then known for many years, and was remarkably injurious to evergreens, some account of its rigour, and reason of its ravages, may be useful, and not unacceptable to persons that delight in planting and ornamenting; and may particularly become a work that professes never to lose sight of utility.

For the last two or three days of the former year there were considerable falls of snow, which lay deep and uniform on the ground without any drifting, wrapping up the more humble vegetation in perfect security. From the first day to the fifth of the new year more snow succeeded; but from that day the air became entirely clear; and the heat of the sun about noon had a considerable influence in sheltered situations. 
It was in such an aspect that the snow on the author's evergreens was melted every day, and frozen intensely every night; so that the laurustines, bays, laurels, and arbutuses looked, in three or four days, as if they had been burnt in the fire ; while a neighbour's plantation of the same kind, in a high cold situation, where the snow was never melted at all, remained uninjured.

From hence $I$ would infer that it is the repeated melting and freezing of the snow that is so fatal to vegetation, rather than the severity of the cold. Therefore it highly behoves every planter, who wishes to escape the cruel mortification of losing in a few days the labour and hopes of years, to bestir himself on such emergencies; and if his plantations are small, to avail himself of mats, cloths, pease-haum, straw, reeds, or any such covering, for a short time; or, if his shrubberies are extensive, to see that his people go about with prongs and forks, and carefully dislodge the snow from the boughs: since the naked foliage will shift much better for itself, than where the snow is partly melted and frozen again.

It may perhaps appear at first like a paradox; but doubtless the more tender trees and shrubs should never be planted in hot aspects ; not only for the reason assigned above, but also because, thus circumstanced, they are disposed to shoot earlier in the spring, and to grow on later in the autumn than they would otherwise do, and so are sufferers by lagging or early frosts. For this reason also plants from Siberia will hardly endure our climate; because, on the very first advances of spring, they shoot away, and so are cut off by the severe nights of March or April.

Dr. Fothergill and others have experienced the same inconvenience with respect to the more tender shrubs from North America, which they therefore plant under north walls. There should also perhaps be a wall to the east to defend them from the piercing blasts from that quarter.

This observation might without any impropriety be carried into animal life; for discerning bee-masters now find that their hives should not in the winter be exposed to the hot sun, because such unseasonable warmth awakens the inhabitants too early from their slumbers; and, by putting their juices into motion too soon, 
subjects them afterwards to inconveniences when rigorous weather returns.

The coincidents attending this short but intense frost were, that the horses fell sick with an epidemic distemper, which injured the winds of many, and killed some; that colds and coughs were general among the human species; that it froze under people's beds for several nights; that meat was so hard frozen that it could not be spitted, and could not be secured but in cellars; that several red-wings and thrushes were killed by the frost; and that the large titmouse continued to pull straws lengthwise from the eaves of thatched houses and barns in a most adroit manner, for a purpose that has been explained already. ${ }^{1}$

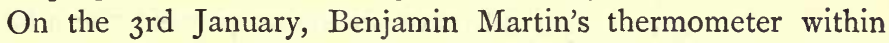
doors, in a close parlour where there was no fire, fell in the night to $20^{\circ}$, and on the 4 th, to $18^{\circ}$, and on the 7 th, to $17 \frac{1}{2}^{\circ}$, a degree of cold which the owner never since saw in the same situation; and he regrets much that he was not able at that juncture to attend his instrument abroad. All this time the wind continued north and north-east; and yet on the 8th roost-cocks, which had been silent, began to sound their clarions, and crows to clamour, as prognostic of milder weather; and, moreover, moles began to heave and work, and a manifest thaw took place. From the latter circumstance we may conclude that thaws often originate under ground from warm vapours which arise; else how should subterraneous animals receive such early intimations of their approach? Moreover, we have often observed that cold seems to descend from above; for, when a thermometer hangs abroad in a frosty night, the intervention of a cloud shall immediately raise the mercury $10^{\circ}$; and a clear sky shall again compel it to descend to its former guage.

And here it may be proper to observe, on what has been said above, that though frosts advance to their utmost severity by somewhat of a regular gradation, yet thaws do not usually come on by as regular a declension of cold; but often take place immediately from intense freezing; as men in sickness often mend at once from a paroxysm.

To the great credit of Portugal laurels and American junipers, 
be it remembered that they remained untouched amidst the general havoc: hence men should learn to ornament chiefly with such trees as are able to withstand accidental severities, and not subject themselves to the vexation of a loss which may befal them once perhaps in ten years, yet may hardly be recovered through the whole course of their lives. ${ }^{2}$

As it appeared afterwards, the ilexes were much injured, the cypresses were half destroyed, the arbutuses lingered on, but never recovered; and the bays, laurustines, and laurels, were killed to the ground; and the very wild hollies, in hot aspects, were so much affected that they cast all their leaves.

By the I 4 th January the snow was entirely gone; the turnips emerged not damaged at all, save in sunny places; the wheat looked delicately, and the garden plants were well preserved; for snow is the most kindly mantle that infant vegetation can be wrapped in: were it not for that friendly meteor no vegetable life could exist at all in northerly regions. Yet in Sweden the earth in April is not divested of snow for more than a fortnight before the face of the country is covered with flowers.

\section{NOTES TO LETTER LXI.}

1 The winter of $1878-9$ will long be remembered for its unexampled severity. There were $34^{\circ}$ and $35^{\circ}$ of frost several nights running in Northumberland. Some tench and eels were frozen in a shallow pond and died. Some gold-fish I had were exposed to the cold one night, and in the morning they were all lying at the bottom of the water motionless, and apparently dead ; but on being put in a warmer place four out of seven gradually recovered, but three aied.

${ }^{2}$ At the same time the snow fell so fast and in such quantity, and lay so long, that all the thick shrubs were bent to the ground with its weight, and unless the snow was constantly shaken off the branches they perished. 


\section{LETTER LXII.}

There were some circumstances attending the remarkable frost in January 1776 , so singular and striking, that a short detail of them may not be unacceptable.

The most certain way to be exact will be to copy the passages from my journal, which were taken from time to time, as things occurred. But it may be proper previously to remark that the first week in January was uncommonly wet, and drowned with vast rains from every quarter: from whence may be inferred, as there is great reason to believe is the case, that intense frosts seldom take place till the earth is perfectly glutted and chilled with water; * and hence dry autumns are seldom followed by rigorous winters.

January 7 th.-Snow driving all the day, which was followed by frost, sleet, and some snow, till the 12 th, when a prodigious mass overwhelmed all the works of men, drifting over the tops of the gates and filling the hollow lanes.

On the i 4 th the writer was obliged to be much abroad; and thinks he never before or since has encountered such rugged Siberian weather. Many of the narrow roads were now filled above the tops of the hedges; through which the snow was driven into most romantic and grotesque shapes, so striking to the imagination as not to be seen without wonder and pleasure. The poultry dared not to stir out of their roosting places ; for cocks and hens are so dazzled and confounded by the glare of snow that they would soon perish without assistance. The hares also lay sullenly in their seats, and would not move till compelled by hunger; being conscious-poor animals - that the drifts and heaps treacherously betray their footsteps, and prove fatal to numbers of them.

* The autumn preceding January I 768 was very wet, and particularly the month of September, during which there fell at Lyndon, in the county of Rutland, six inches and a half of rain. And the terrible long frost in 1739-40 set in after a rainy season, and when the springs were very high. 
From the I $4^{\text {th }}$ the snow continued to increase, and began to stop the road waggons, and coaches, which could no longer keep on their regular stages; and especially on the western roads, where the fall appears to have been deeper than in the south. The company at Bath, that wanted to attend the Queen's birthday, were strangely incommoded : many carriages of persons, who got in their way to town from Bath as far as Marlborough, after strange embarrassments, here met with a ne plus ultra. The ladies fretted, and offered large rewards to labourers if they would shovel them a track to London; but the relentless heaps of snow were too bulky to be removed; and so the I8th passed over, leaving the company in very uncomfortable circumstances at the Castle and other inns.

On the 2oth the sun shone out for the first time since the frost began; a circumstance that has been remarked before much in favour of vegetation. All this time the cold was not very intense, for the thermometer stood at $29^{\circ}, 28^{\circ}, 25^{\circ}$, and thereabout; but on the 2 Ist it descended to $20^{\circ}$. The birds now began to be in a very pitiable and starving condition. Tamed by the season, sky-larks settled in the streets of towns, because they saw the ground was bare; rooks frequented dunghills close to houses; and crows watched horses as they passed, and greedily devoured what dropped from them: hares now came into men's gardens, and, scraping away the snow, devoured such plants as they could find.

On the 2 nd the author had occasion to go to London through a sort of Laplandian scene, very wild and grotesque indeed. But the metropolis itself exhibited a still more singular appearance than the country; for, being bedded cleep in snow, the pavement of the strects could not be touched by the wheels or the horse's feet, so that the carriages ran about without the least noise." Such an exemption from din and clatter was strange, but not pleasant; it seemed to convey an uncomfortable idea of desolation:-

$$
\text { "—-Ipsa silentia terrent." }
$$

On the $27^{\text {th }}$ much snow fell all day, and in the evening the frost became very intense. At South Lambeth, for the four following nights, the thermometer fell to $11^{\circ}, 7^{\circ}, 6^{\circ}, 6^{\circ}$; and a 
Selborne to $7^{\circ}, 6^{\circ}, 10^{\circ}$; and on the 3 Ist January, just before sunrise, with rime on the trees and on the tube of the glass, the quicksilver sunk exactly to zero, being $32^{\circ}$ below the freezing point; but by eleven in the morning, though in the shade, it sprang up to $16 \frac{1}{2}^{\circ}, *$ - a most unusual degree of cold this for the south of England! During these four nights the cold was so penetrating that it occasioned ice in warm chambers and under beds; and in the day the wind was so keen that persons of robust constitutions could scarcely endure to face it. The Thames was at once so frozen over both above and below bridge that crowds ran about on the ice. The streets were now strangely encumbered with snow, which crumbled and trod dusty; and, turning grey, resembled bay-salt ; what had fallen on the roofs was so perfectly dry that, from first to last, it lay twenty-six days on the houses in the city: a longer time than had been remembered by the oldest housekeepers living. According to all appearances we might now have expected the continuance of this rigorous weather for weeks to come, since every night increased in severity; but behold, without any apparent cause, on the Ist February a thaw took place, and some rain followed before night, making good the observation above, that frosts often go off as it were at once, without any gradual declension of cold. On the 2nd February the thaw persisted; and on the 3 rd swarms of little insects were frisking and sporting in a courtyard at South Lambeth, as if they had felt no frost. Why the juices in the small bodies and smaller limbs of such minute beings are not frozen is a matter of curious inquiry.

Severe frosts seem to be partial, or to run in currents; for at the same juncture, as the author was informed by accurate correspondents, at Lyndon, in the county of Rutland, the thermometer stood at $19^{\circ}$; at Blackburn, in Lancashire, at $19^{\circ}$; and at Manchester, at $21^{\circ}, 20^{\circ}$, and $18^{\circ}$. Thus does some unknown

* At Selborne the cold was greater than at any other place that the author could hear of with certainty: though some reported at the time that at a village in Kent the thermometer fell two degrees below zero; viz., thirty-four degrees below the freezing point.

The thermometer used at Selborne was graduated by Benjamin Martin. 
circumstance strangely overbalance latitude, and render the cold sometimes much greater in the southern than the northern parts of this kingdom.

The consequences of this severity were, that in Hampshire, at the melting of the snow, the wheat looked well, and the turnips came forth little injured. The laurels and laurustines were somewhat damaged, but only in hot aspects. No evergreens were quite destroyed; and not half the damage sustained that befell in January I 768. Those laurels that were a little scorched on the south sides were perfectly untouched on their north sides. The care taken to shake the snow day by day from the branches seemed greatly to avail the author's evergreens. A neighbour's laurel-hedge, in a high situation, and facing to the north, was perfectly green and vigorous; and the Portugal laurels remained unhurt.

As to the birds, the thrushes and blackbirds were mostly destroyed; and the partridges, by the weather and poachers, were so thinned that few remained to breed the following year.

\section{LETTER LXIII.}

As the frost in December I 784 was very extraordinary, you, I trust, will not be displeased to hear the particulars ; and especially when I promise to say no more about the severities of winter after I have finished this letter.

The first week in December was very wet, with the barometer very low. On the 7 th, with the barometer at $28.5^{\circ}$-came on a vast snow, which continued all that day and the next, and most part of the following night; so that by the morning of the $9^{\text {th }}$ the works of men were quite overwhelmed, the lanes filled so as to be impassable, and the ground covered twelve or fifteen inches without any drifting. In the evening of the 9 th the air began to be so very sharp that we thought it would be curious to attend to the motions of a thermometer; we therefore hung out two, one made 
by Martin and one by Dollond, which soon began to show us what we were to expect; for by ten o'clock they fell to $2 \mathrm{I}^{\circ}$, and at eleven to $4^{\circ}$, when we went to bed. On the roth, in the morning, the quicksilver of Dollond's glass was down to half a degree below zero ; and that of Martin's, which was absurdly graduated only to four degrees above zero, sunk quite into the brass guard of the ball; so that when the weather became most interesting this was useless. On the roth, at eleven at night, though the air was perfectly still, Dollond's glass went down to one degree below zero! This strange severity of the weather made me very desirous to know what degree of cold there might be in such an exalted and near situation as Newton. We had, therefore, on the morning of the roth, written to $\mathrm{Mr}$. - and intreated him to hang out his thermometer, made by Adams, and to pay some attention to it morning and evening, expecting wonderful phenomena, in so elevated a region, at two hundred feet or more above my house. But, behold! on the roth, at eleven at night, it was down only to $17^{\circ}$, and the next morning at $22^{\circ}$, when mine was at $10^{\circ} / \mathrm{We}$ were so disturbed at this unexpected reverse of comparative local cold, that we sent one of my glasses up, thinking that of $\mathrm{Mr}$. must, somehow, be wrongly constructed. But, when the instruments came to be confronted, they went exactly together; so that, for one night at least, the cold at Newton was $18^{\circ}$ less than at Selborne; and, through the whole frost, $10^{\circ}$ or $\mathrm{I}_{2}^{\circ}$; and indeed, when we came to observe consequences, we could readily credit this ; for all my laurustines, bays, ilexes, arbutuses, cypresses, and even my Portugal laurels, and (which occasions more regret) my fine sloping laurel-hedge, were scorched up; while, at Newton, the same trees have not lost a leaf.

We had steady frost on the $25^{\text {th }}$, when the thermometer in the morning was down to $10^{\circ}$ with us, and at Newton only to $2 \mathrm{I}^{\circ}$. Strong frost continued till the $3 \mathrm{ISt}$, when some tendency to thaw was observed ; and, by January 3 rd, 1785 , the thaw was confirmed, and some rain fell.

A circumstance that I must not omit, because it was new to us, is, that on Friday, December roth, being bright sunshine, the air was full of icy spicula, floating in all directions, like atoms in a 
sunbeam let into a dark room. We thought them at first particles of the rime falling from my tall hedges; but were soon convinced to the contrary, by making our observations in open places where no rime could reach us. Were they watery particles of the air frozen as they floated, or were they evaporations from the snow frozen as they mounted!

We were much obliged to the thermometers for the early information they gave us; and hurried our apples, pears, onions, potatoes, etc., into the cellar, and warm closets ; while those who had not, or neglected such warnings, lost all their store of roots and fruits, and had their very bread and cheese frozen.

I must not omit to tell you that, during these two Siberian days, my parlour cat was so electric, that had a person stroked her, and been properly insulated, the shock might have been given to a whole circle of people.

I forgot to mention before, that, during the two severe days, two men, who were tracing hares in the snow, had their feet frozen, and two men, who were much better employed, had their fingers so affected by the frost, while they were thrashing in a barn, that a mortification followed, from which they did not recover for many weeks.

This frost killed all the furze and most of the ivy, and in many places stripped the hollies of all their leaves. It came at a very early time of the year, before old November ended ; and yet may be allowed from its effects to have exceeded any since 1730.40 .

\section{LETTER LXIV.}

As the effects of heat are seldom very remarkable in the northerly climate of England, where the summers are often so defective in warmth and sunshine as not to ripen the fruits of the earth so well as might be wished, I shall be more concise in my account of the severity of a summer season, and so make a little amends for the prolix account of the degrees of cold, and the inconveniences that we suffered from some late rigorous winters. 
The summers of $\mathrm{I} 78 \mathrm{I}$ and $\mathrm{I} 783$ were unusually hot and dry; to them therefore I shall turn back in my journals, without recurring to any more distant period. In the former of these years my peach and nectarine-trees suffered so much from the heat that the rind on the bodies was scalded and came off; since which the trees have been in a decaying state. This may prove a hint to assiduous gardeners to fence and shelter their wall-trees with mats or boards, as they may easily do, because such annoyance is seldom of long continuance. During that summer also, I observed that my apples were coddled, as it were, on the trees; so that they had no quickness of flavour, and would not keep in the winter. This circumstance put me in mind of what I have heard travellers assert, that they never ate a good apple or apricot in the south of Europe, where the heats were so great as to render the juices vapid and insipid.

The great pests of a garden are wasps, which destroy all the finer fruits just as they are coming into perfection. In $\mathrm{I} 78 \mathrm{I}$ we had none; in 1783 there were myriads; which would have devoured all the produce of my garden, had not we set the boys to take the nests, and caught thousands with hazel-twigs tipped with bird-lime: we have since employed the boys to take and destroy the large breeding wasps in the spring. Such expedients have a great effect on these marauders, and will keep them under. Though wasps do not abound but in hot summers, yet they do not prevail in every hot summer, as I have instanced in the two years above-mentioned.

In the sultry season of $\mathrm{I}_{7} 8_{3}$, honey-dews were so frequent as to deface and destroy the beauties of my garden. My honeysuckles, which were one week the most sweet and levely objects that the eye could behold, became the next the most loathsome; being enveloped in a viscous substance, and loaded with black aphides, or smother-flies. The occasion of this clammy appearance seems to be this, that in hot weather the effluvia of flowers in fields and meadows and gardens are drawn up in the day by a brisk evaporation, and then in the night fall down again with the dews, in which they are entangled; that the air is strongly scented, and therefore impregnated with the particles of flowers in summer weather, our 
senses will inform us; and that this clammy sweet substance is of the vegetable kind we may learn from bees, to whom it is very grateful: and we may be assured that it falls in the night, because it is always first seen in warm still mornings. ${ }^{1}$

On chalky and sandy soils, and in the hot villages about London, the thermometer has been often observed to mount as high as $83^{\circ}$ or $84^{\circ}$; but with us, in this hilly and woody district, I have hardly ever seen it exceed $80^{\circ}$; nor does it often arrive at that pitch. The reason, I conclude, is, that our dense clayey soil, so much shaded by trees, is not so easily heated through as those abovementioned; and, besides, our mountains cause currents of air and breezes; and the vast effluvia from our woodlands temper and moderate our heats.

\section{NOTE TO LETTER LXIV.}

1 White's explanation of the origin of honeydew is ingenious, but incorrect. It is now ascertained to be an exudation from the aphides themselves. It is by some called their excrement.

\section{LETTER LXV.}

THE summer of the year 1783 was an amazing and portentous one, and full of horrible phenomena; for, besides the alarming meteors and tremendous thunder-storms that affrighted and distressed the different counties of this kingdom, the peculiar haze, or smoky fog, that prevailed for many weeks in this island, and in every part of Europe, and even beyond its limits, was a most extraordinary appearance, unlike anything known within the memory of man. By my journal I find that I had noticed this strange occurrence from June 23 rd to July 2 oth inclusive, during which period the wind varied to every quarter without making any alteration in the air. The sun, at noon, looked as blank as a clouded moon, and shed a rust-coloured ferruginous light on the ground, and floors of rooms; but was particularly lurid and blood-coloured 
at rising and setting. All the time the heat was so intense that butchers' meat could hardly be eaten on the day after it was killed; and the flies swarmed so in the lanes and hedges that they rendered the horses half frantic, and riding irksome. The country people began to look with a superstitious awe at the red, louring aspect of the sun; and indeed there was reason for the most enlightened person to be apprehensive; for, all the while, Calabria and part of the Isle of Sicily, were torn and convulsed with earthquakes; and about that juncture a volcano sprang out of the sea on the coast of Norway. On this occasion Milton's noble simile of the sun, in his first book of " Paradise Lost," frequently occurred to my mind; and it is indeed particularly applicable, because, towards the end, it alludes to a superstitious kind of dread, with which the minds of men are always impressed by such strange and unusual phenomena.

" As when the sun, new risen,

Looks through the horizontal, misty air, Shorn of his beams; or from behind the moon,

In dim eclipse, disastrous twilight sheds

On half the nations, and with jear of change

Perplexes monarchs_-."

\section{LETTER LXVI.}

$\mathrm{WE}$ are very seldom annoyed with thunderstorms : and it is no less remarkable than true, that those which arise in the south have hardly been known to reach this village ; for, before they get over us, they take a direction to the east or to the west, or sometimes divide in two, go in part to one of those quarters, and in part to the other; as was truly the case in summer 1783 , when, though the country round was continually harassed with tempests, and often from the south, yet we escaped them all, as appears by my journal of that summer. The only way that I can at all account for this fact-for such it is -is that, on that quarter, between us and the sea, there are continual mountains, hill behind hill, such 
as Nore-hill, the Barnet, Butser-hill, and Ports-down, which somehow divert the storms, and give them a different direction. High promontories, and elevated grounds, have always been observed to attract clouds and disarm them of their mischievous contents, which are discharged into the trees and summits as soon as they come in contact with those turbulent meteors; while the humble vales escape, because they are so far beneath them.

But, when I say I do not remember a thunder-storm from the south, I do not mean that we never have suffered from thunderstorms at all ; for on June 5th, I784, the thermometer in the morning being at $64^{\circ}$, and at noon at $70^{\circ}$, the barometer at $29^{\circ} 6 \frac{1}{2}^{\circ}$ and the wind north, I observed a blue mist, smelling strongly of sulphur, hanging along our sloping woods, and seeming to indicate that thunder was at hand. I was called in about two in the afternoon, and so missed seeing the gathering of the clouds in the north; which they who were abroad assured me had something uncommon in its appearance. At about a quarter after two the storm began in the parish of Hartley, moving slowly from north to south: and from thence it came over Norton-farm, and so to Grange-farm, both in this parish. It began.with vast drops of rain, which were soon succeeded by round hail, and then by convex pieces of ice, which measured three inches in girth. Had it been as extensive as it was violent, and of any continuance (for it was very short), it must have ravaged all the neighbourhood. In the parish of Hartley it did some damage to one farm; but Norton, which lay in the centre of the storm, was greatly injured; as was Grange, which lay next to it. It did but just reach to the middle of the village, where the hail broke my north windows, and all my garden-lights and hand-glasses, and many of my neighbours' windows. The extent of the storm was about two miles in length and one in breadth. We were just sitting down to dinner; but were soon diverted from our repast by the clattering of tiles and the jingling of glass. There fell at the same time prodigious torrents of rain on the farms above-mentioned, which occasioned a flood as violent as it was sudden; doing great damage to the meadows and fallows, by deluging the one and washing away the soil of the other. The hollow lane towards Alton was so torn 
and disordered as not to be passable till mended, rocks being removed that weighed two hundred-weight. Those that saw the effect which the great hail had on ponds and pools say that the dashing of the water made an extraordinary appearance, the froth and spray standing up in the air three feet above the surface. The rushing and roaring of the hail, as it approached, was truly tremendous.

Though the clouds at South Lambeth, near London, were at that juncture thin and light, and no storm was in sight, nor within hearing, yet the air was strongly electric; for the bells of an electric machine at that place rang repeatedly, and fierce sparks were discharged.

When I first took the present work in hand I proposed to have added an "Annus Historico-naturalis, or The Natural History of the Twelve Months of the Year;" which would have comprised many incidents and occurrences that have not fallen in my way to be mentioned in my series of letters; but, as Mr. Aikin of Warrington has lately published somewhat of this sort, and as the length of my correspondence has sufficiently put your patience to the test, I shall here take a respectful leave of you and natural history together, ${ }^{1}$ and am,

With all due deference and regard,

Your most obliged and most humble servant,

GIL. WHITE.

SEL BoRne,

Fune $25^{\text {th }}, 178$

NOTE TO LETTER LXVI.

"White certainly did not "take leave of natural history," for his love of Nature was as keen as ever until he died. 

THE ANTIQUITIES OF SELBORNE. 



\section{LETTER I.}

$\mathrm{T}$ is reasonable to suppose that in remote ages this woody and 1 mountainous district was inhabited only by bears and wolves. Whether the Britons ever thoug ht it worthy their attention, is not in our power to determine; but we may safely conclude, from circumstances, that it was not unknown to the Romans. Old people remember to have heard their fathers and grandfathers say that, in dry summers and in windy weather, pieces of money were sometimes found round the verge of Wolmer pond; and tradition had inspired the foresters with a notion that the bottom of that lake contained great stores of tre asure. During the spring and summer of 1740 there was little rain; and the following summer also, r 74r, was so uncommonly dry, that many springs and ponds failed, and this lake in particular, whose bed became as dusty as the surrounding heaths and wastes. This favourable juncture induced some of the forest-cottagers to begin a search, which was attended with such success, that all the labourers in the neighbourhood flocked to the spot, and with spades and hoes turned up great part of that large area. Instead of pots of coins, as they expected, they found great heaps, the one lying on the other, as if shot out of a bag; many of which were in good preservation. Silver and gold these inquirers expected to find; but their discoveries consisted solely of many hundreds of Roman copper-coins, and some medallions, all of the lower empire. There was not much virti stirring at that time in this neighbourhood; however, some of the gentry and clergy around bought what pleased them best, and some dozens fell to the share of the author. ${ }^{1}$ 
The owners at first held their commodity at a high price; but, finding that they were not likely to meet with dealers at such a rate, they soon lowered their terms, and sold the fairest as they could. The coins that were rejected became current, and passed for farthings at the petty shops. Of those that we saw, the greater part were of Marcus Aurelius, and the Empress Faustina, his wife, the father and mother of Commodus. Some of Faustina were in high relief, and exhibited a very agreeable set of features, which probably resembled that lady, who was more celebrated for her beauty than for her virtues. The medallions in general were of a paler colour than the coins. To pretend to account for the means of their coming to this place would be spending time in conjecture. The spot, I think, could not be a Roman camp, because it is commanded by hills on two sides; nor does it show the least traces of entrencliments; nor can I suppose that it was a Roman town, because I have too good an opinion of the taste and judgment of those polished conquerors to imagine that they would settle on so barren and dreary a waste.

\section{NOTE TO LETTER I.}

1 In October 1873 two earthenware vessels were found two feet under the surface of a field near Selborne containing about thirty thousand Roman and Roman-British coins.

\section{LETTER II.}

THAT Selborne was a place of some distinction and note in the time of the Saxons we can give most undoubted proofs. But, as there are few if any accounts of the villages before Domesday, it will be best to begin with that venerable record. "Ipse rex tenet Selesburne. Eddid regina tenuit, et nunquam geldavit. De isto manerio dono dedit rex Radfredo presbytero dimidiam hidam cum ecclesia. Tempore regis Edwardi et post, valuit duodecim solidos et sex denarios; modo octo solidos et quatuor 
denarios." Here we see that Selborne was a royal manor : and that Editha, the queen of Edward the Confessor, had been lady of that manor, and was succeeded in it by the Conqueror, and that it had a church. Besides these, many circumstances concur to prove it to have been a Saxon village; such as the name of the place itself, ${ }^{*}$ the names of many fields, and some families, $\uparrow$ with a variety of words in husbandry and common life, still subsisting among the country people.

What probably first drew the attention of the Saxons to this spot was the beautiful spring or fountain called Well Head, $\neq$ which induced them to build by the banks of that perennial

* Selesburne, Seleburne, Selburn, Selbourn, Selborne, and Selborn, as it has been variously spelt at different periods, is of Saxon derivation ; for $\mathrm{Sel}$ signifies great, and burn torrens, a brook or rivulet: so that the name seems to be derived from the great perennial stream that breaks out at the upper end of the village. - Sel also signifies bonus, item focundus, fertilis. "Sel zæpr-zun: facunda graminis clausura; fertile pascuum: a meadow in the parish of Godelming is still called Sal-gars-ton."-LyE's Saxon Dictionary, in the Supplement, by Mr. Manning.

$\dagger$ Thus, the name of Aldred signifies all-reverend, and that of Kemp means a soldier. Thus we have a church-litton, or enclosure for dead bodies, and not a church-yard; there is also a Culver-croft near the Grange-farm, being the enclosure where the priory pigeon-house stood, from culver a pigeon. Again there are three steep pastures in this parish called the Lithe, from Hlithe, clivus. The wicker-work that binds and fastens down a hedge on the top is called ether, from ether, a hedge. When the good women call their hogs they cry sic, sic, ${ }^{1}$ not knowing that sic is Saxon, or rather Celtic, for a hog. Coppice or brushwood our countrymen call rise, from hris, frondes and talk of a load of rise. Within the author's memory the Saxon plurals, housen and peason, were in common use. But it would be endless to instance in every circumstance : he that wishes for more specimens must frequent a farmer's kitchen. I have therefore selected some words to show how familiar the Saxon dialect was to this district, since in more than seven hundred years is far from being obliterated.

¥ Well-head signifies spring-head, and not a d eep pit from whence we draw water. For particulars about which see Letter I. to Mr. Pennant.

2 Sıka, porcus, apud Lacones; un Porceau chez les Lacèdemoniens : ce mot a sans doute estè pris des Celtes, qui disoent sic, pour marquer un porceau. Encore aujour'huy quand le Bretons chassent ces animaux, ils ne disent autrement, que sic, sic.-Antiquité de la Nation it de la Langue des Celtes, par Pezron. 
current; for ancient settlers loved to reside by brooks and rivulets, where they could dip for their water without the trouble and expense of digging wells and of drawing.

It remains still unsettled among the antiquaries at what time tracts of land were first appropriated to the chase alone for the amusement of the Sovereign. Whether our Saxon monarchs had any royal forests, does not, I believe, appear on record; but the "Constitutiones de Foresta," of Canute, the Dane, are come down to us. We shall not, therefore, pretend to say whether Wolmer Forest existed as a royal domain before the conquest. If it did not, we may suppose it was laid out by some of our earliest Norman kings, who were exceedingly attached to the pleasures of the chase, and resided much at Winchester, which lies at a moderate distance from this district. The Plantagenet princes seem to have been pleased with Wolmer, for tradition says that King John resided just upon the verge, at Ward-le-ham, on a regular and remarkable mount, still called King John's Hill, and Lodge Hill; and Edward III. had a chapel in his park, or enclosure, at Kingsley.* Humphrey, Duke of Gloucester, and Richard, Duke of York, say my evidences, were both, in their turns, wardens of Wolmer Forest, which seems to have served for an appointment for the younger princes of the royal family, as it may again.

I have intentionally mentioned Edward III. and the dukes Humphrey and Richard, before King Edward II., because I have reserved, for the entertainment of my readers, a pleasant anecdote respecting that prince, with which I shall close this letter.

As Edward II. was hunting on Wolmer Forest, Morris Ken, of the kitchen, fell from his horse several times, at which accidents the king laughed immoderately; and, when the chase was over, ordered him twenty shillings, $t$ an enormous sum for those days!

* The parish of Kingsley lies between and divides Wolmer Forest from Ayles Holt Forest. See Letter IX. to Mr. Pennant.

$\dagger$ "Item, paid at the lodge at Wolmer, when the king was stag-hunting there, to Morris Ken, of the kitchen, because he rode before the king and often fell from his horse, at which the king laughed exceedingly-a gift, by "command, of twenty shillings."-A MS. in possession of Thomas Astle, Esq., containing the private expenses of Edward II. 
Proper allowances ought to be made for the youth of this monarch, whose spirits also, we may suppose, were much exhilarated by the sport of the day; but, at the same time, it is reasonable to remark, that, whatever might be the occasions of Ken's first fall, the subsequent ones seem to have been designed. The scullion appears to have been an artful fellow, and to have seen the king's foible, which furnishes an early specimen of that his easy softness and facility of temper, of which the infamous Gaveston took such advantages, as brought innumerable calamities on the nation, and involved the prince at last in misfortunes and sufferings too deplorable to be mentioned, without horror and amazement.

\section{LETTER III.}

From the silence of Domesday respecting churclies, it has been supposed that few villages had any at the time when that record was taken; but Selborne, we see, enjoyed the benefit of one: hence, we may conclude, that this place was in no abject state even at that very distant period. How many fabrics have succeeded each other since the days of Radfredrus the presbyter, we cannot pretend to say; our business leads us to a description of the present edifice, in which we shall be circumstantial.

Our church, which was dedicated to the Virgin Mary, consists of three aisles, and measures fifty-four feet in length, by forty-seven in breadth, being almost as broad as it is long. The present building has no pretensions to antiquity, and is, as I suppose, of no earlier date than the beginning of the reign of Henry VII. It is perfectly plain and unadorned, without painted glass, carved work, sculpture, or tracery. But when I say it has no claim to antiquity, I would mean to be understood the fabric in general; for the pillars, which support the roof, are undoubtedly old, being of that low, squat, thick order, usually called Saxon. These, I should imagine, upheld the roof of a former church, which, falling into decay, was rebuilt on those massy props, because 
their strength had preserved them from the injuries of time.* Upon these rest blunt Gothic arches, such as prevailed in the reign above-mentioned, and by which, as a criterion, we would prove the date of the building.

At the bottom of the south aisle, between the west and south doors, stands the font, which is deep and capacious, and consists of three massy round stones, piled one on another, without the least ornament or sculpture: the cavity at the top is lined with lead, and has a pipe at the bottom to convey off the water after the sacred ceremony is performed.

The east end of the south aisle is called the South Chancel, and, till within these thirty years, was divided off by old carved Gothic framework of timber, having been a private chantry. In this opinion we are more confirmed by observing two Gothic niches within the space, the one in the east wall and the other in the south, near which there probably stood images and altars.

In the middle aisle there is nothing remarkable : but I remember when its beams were hung with garlands in honour of young women of the parish, reputed to have died virgins; and recollect to have seen the clerk's wife cutting, in white paper, the resemblances of gloves, and ribbons to be twisted in knots and roses, to decorate these memorials of chastity. In the church of Faringdon, which is the next parish, many garlands of this sort still remain.

The north aisle is narrow and low, with a sloping ceiling, reaching within eight or nine feet of the floor. It had originally a flat roof, covered with lead, till, within a century past, a churchwarden stripping off the lead, in order, as he said, to have it mended, sold it to a plumber, and ran away with the money. This aisle has no door, for an obvious reason; because the north side of the churchyard, being surrounded by the vicarage-garden, affords no path to that side of the church. Nothing can be more irregular than the pews of this church, which are of all dimensions and

* In the same manner, to compare great things with small, did Wykeham, when he new-built the cathedral at Winchester, from the tower westward, apply to his purpose the old piers or pillars of Bishop Walkelin's church, by blending Saxon and Gothic architecture together.-See LowTH's Life of Wykeham. 
heights, being patched up according to the fancy of the owners; but whoever nicely examines them will find that the middle aisle had, on each side, a regular row of benches of solid oak, all alike, with a low back-board to each. These we should not hesitate to say are coeval with the present church; and especially as it is to be observed that, at their ends, they are ornamented with carved blunt Gothic niches, exactly correspondent to the arches of the church, and to a niche in the south wall. The fourth aisle also has a row of these benches; but some are decayed through age, and the rest much disguised by modern alterations.

At the upper end of this aisle, and running out to the north, stands a transept, known by the name of the North Chancel, measuring twenty-one feet from south to north, and nineteen feet from east to west: this was intended, no doubt, as a private cliantry ; and was also, till of late, divided off by a Gothic framework of timber. In its north wall, under a very blunt Gothic arch, lies perhaps the founder of this edifice, which, from the shape of its arch, may be deemed no older than the latter end of the reign of Henry VII. The tomb was examined some years ago, but contained nothing except the skull and thigh-bones of a large tall man, and the bones of a youth or woman, lying in a very irregular manner, without any escutcheon or other token to ascertain the names or rank of the deceased. The grave was very shallow, and lined with stone at the bottom and on the sides.

From the east wall project four stone brackets, which I conclude supported images and crucifixes. In the great thick pilaster, jutting out between this transept and the chancel, there is a very sharp Gothic niche, of older date than the present chantry or church. But the chief pieces of antiquity are two narrow stone coffin-lids, which compose part of the floor, and lie from west to east, with the very narrow ends eastward: these belong to remote times; and, if originally placed here, which I doubt, must have been part of the pavement of an older transept. At present there are no coffins under them, whence I conclude they have been removed to this place from some part of a former church. One of these lids is so eaten by time, that no sculpture can be discovered upon it; or, perhaps, it may be the wrong side upper- 
most; but on the other, which seems to be of stone of a closer and harder texture, is to be discerned a discus, with a cross on it, at the end of a staff or rod, the well-known symbol of a Knight Templar.*

This order was distinguished by a red cross on the left shoulder of their cloak, and by this attribute in their hand. Now, if these stones belonged to Knights Templars, they must have lain here many centuries; for this order came into England early in the reign of King Stephen in III3; and was dissolved in the time of Edward II. in 13I2, having subsisted only one hundred and thirty-nine years. Why I should suppose that Knights Templars were occasionally buried at this church, will appear in some future letter, when we come to treat more particularly concerning the property they possessed here, and the intercourse that subsisted between them and the priors of Selborne.

We must now proceed to the chancel, properly so called, which seems to be coeval with the church, and is in the same plain unadorned style, though neatly kept. This room measures thirtyone feet in length, and sixteen feet and a half in breadth, and is wainscoted all round, as high as to the bottom of the windows. The space for the communion-table is raised two steps above the rest of the floor, and railed in with oaken balusters. Here I shall say somewhat of the windows of the chancel in particular, and of the whole fabric in general. They are mostly of that simple and unadorned sort called Lancet, some single, some double, and some in triplets. At the east end of the chancel are two of a moderate size, near each other; and in the north wall two very distant small ones, unequal in length and height : and in the south wall are two, one on each side of the chancel-door, that are broad and squat, and of a different order. At the east end of the south aisle of the church there is a large lancet-window in a triplet ; and two very small, narrow, single ones in the south wall, and a broad squat window beside, and a double lancet one in the west end; so that the appearance is very irregular. In the north aisle are two windows, made shorter when the roof was sloped; and in the

* See Dugdale, Monasticon Anglicanum, vol. ii., where there is a fine engraving of a Knight-Templar, by Hollar. 
north transept a large triple window, shortened at the time of a repair in $172 \mathrm{I}$ : when over it was opened a round one of considerable size, which affords an agreeable light, and renders that chantry the most cheerful part of the edifice.

The church and chancels have all covered roofs, ceiled about the year 1633 ; before which they were open to the tiles and shingles, showing the naked rafters, and threatening the congregation with the fall of a spar, or a blow from a piece of loose mortar.

On the north wall of the chancel is fixed a large oval white marble monument, with the following inscription; and at the foot of the wall, over the deceased, and inscribed with his name, age, arms, and time of death, lies a large slab of black marble :

Prope hunc parietem sepelitur

GILBERTUS WHITE, SAMSONIS WHITE, de

Oxon, militis filius tertius, Collegii Magdale-nensis ibidem alumnus, \& socius. Tandem faven-te collegio ad hanc ecclesiam promotus; ubi primæ-vâ morum simplicitate, et diffusâ erga omnes benevolentiâ feliciter consenuit.

Pastor fidelis, comis, affabilis, Maritus, et pater amantissimus, A conjuge invicem, et liberis, atque

A parochianis impensé dilectus.

Pauperibus ita beneficus ut decimam partem census moribundus piis usibus consecravit.

Meritis demum juxta et annis plenus

ex hac vitâ migravit Feb. $13^{\circ}$

anno salutis $172 \frac{7}{8}$

Atatis suæ 77 .

Hoc posuit Rebecca

Conjux illius mæstissima, mox secutura.

On the same wall is newly fixed a small square table-monument of white marble, inscribed in the following manner: 
Sacred to the memory

of the Rev'. ANDREW ETTY, B.D.

23 Years Vicar of this parish :

In whose character

The conjugal, the parental, and the sacerdotal virtues

were so happily combined

as to deserve the imitation of mankind.

And if in any particular he followed more invariably

the steps of his blessed Master,

It was in his humility.

His parishioners,

especially the sick and necessitous,

as long as any traces of his memory shall remain,

must lament his death.

To perpetuate such an example, this stone is erected;

as while living he was a preacher of righteousness,

so, by it, he being dead yet speaketh.

He died April $8^{\text {th }}$, 1784 , aged 66 years.

\section{LETTER IV.}

WE have now taken leave of the inside of the church, and shall pass by a door at the west end of the middle aisle into the belfry. This room is part of a handsome square embattled tower of fortyfive feet in height, and of much more modern date than the church; but old enough to have needed a thorough repair in I 78I, when it was neatly stuccoed at a considerable expense, by a set of workmen who were employed on it for the greatest part of the summer. The old bells, three in number, loud and out of tune, were taken down in 1735 , and cast into four; to which Sir Simon Stuart, the grandfather of the present baronet, added a fifth at his own expense; and, bestowing it in the name of his favourite daughter, Mrs. Mary Stuart, caused it to be cast with the following motto round it :

"Clara puella dedit, dixitque mihi esto Maria : Illius et laudes nomen ad astra sono." 
The day of the arrival of this tuneable peal was observed as a high festival by the village, and rendered more joyous, by an order from the donor, that the treble bell should be fixed bottom upward in the ground and filled with punch, of which all present were permitted to partake.

The porch of the church, to the south, is modern, and would not be worthy attention did it not shelter a fine sharp Gothic doorway. This is undoubtedly much older than the present fabric ; and, being found in good preservation, was worked into the wall, and is the grand entrance into the church; nor are the foldingdoors to be passed over in silence; since, from their thick and clumsy structure, and the rude flourished-work of their hinges, they may possibly be as ancient as the doorway itself.

The whole roof of the south aisle, and the south side of the roof of the middle aisle, is covered with oaken shingles instead of tiles, on account of their lightness, which favours the ancient and crazy timber-frame. And, indeed, the consideration of accidents by fire excepted, this sort of roofing is much more eligible than tiles. For shingles well seasoned, and cleft from quartered timber, never warp, nor let in drifting snow; nor do they shiver with frost; nor are they liable to be blown off, like tiles; but, when nailed down ast for a long period, as experience has shown us in this place, where those that face to the north are known to have endured, untouched, by undoubted tradition, for more than a century.

Considering the size of the church, and the extent of the parish, the churchyard is very scanty; and especially as all wish to be buried on the south side, which is become such a mass of mortality that no person can be there interred without disturbing or displacing the bones of his ancestors. There is reason to suppose that it once was larger, and extended to what is now the vicarage court and garden; because many human bones have been dug up in those parts several yards without the present limits. At the east end are a few graves; yet none till very lately on the north side; but, as two or three families of best repute have begun to bury in that quarter, prejudice may wear out by degrees, and their example be followed by the rest of the neighbourhood.

In speaking of the church, I have all along talked of the east and 
west-end, as if the chancel stood exactly trie to those points of the compass; but this is by no means the case, for the fabric bears so much to the north of the east that the four corners of the tower, and not the four sides, stand to the four cardinal points. The best method of accounting for this deviation seems to be, that the workmen, who probably were employed in the longest days, endeavoured to set the chancels to the rising of the sun.

Close by the church, at the west end, stands the vicarage-house; an old, but roomy and convenient edifice. It faces very agreeably to the morning sun, and is divided from the village by a neat and cheerful court. According to the manner of old times, the hall was open to the roof; and so continued, probably, till the vicars became family-men, and began to want more conveniences; when they flung a floor across, and, by partitions, divided the space into chambers. In this hall we remember a date, some time in the reign of Elizabeth; it was over the door that leads to the stairs.

Behind the house is a garden of an irregular shape, but well laid out; whose terrace commands so romantic and picturesque a prospect, that the first master in landscape might contemplate it with pleasure, and deem it an object well worthy of his pencil.

\section{LETTER V.}

In the churchyard of this village is a yew-tree, whose aspect bespeaks it to be of a great age : it seems to have seen several centuries, and is probably coeval with the church, and therefore may be deemed an antiquity : the body is squat, short, and thick, and measures twenty-three feet in the girth, supporting a head of suitable extent to its bulk. This is a male tree, which in the spring sheds clouds of dust, and fills the atmosphere around with ts farina.

As far as we have been able to observe, the males of this species kecome much larger than the females; and it has so fallen out 
that most of the yew-trees in the churchyards of this neighbourhood are males : but this must have been matter of mere accident, since men, when they first planted yews, little dreamed that there were sexes in trees.

In a yard, in the midst of the street, till very lately grew a middle-sized female tree of the same species, which commonly bore great crops of berries. By the high winds usually prevailing about the autumnal equinox, these berries, then ripe, were blown down into the road, where the hogs ate them. And it was very remarkable, that, though barrow-hogs and young sows found no inconvenience from this food, yet milch-sows often died after such a repast : a circumstance that can be accounted for only by supposing that the latter, being much exhausted and hungry, devoured a larger quantity.

While mention is making of the bad effects of yew-berries, it may be proper to remind the unwary that the twigs and leaves of yew, though eaten in a very small quantity, are certain death to horses and cows, and that in a few minutes. A horse tied to a yew-hedge, or to a faggot-stack of dead yew, shall be found dead before the owner can be aware that any danger is at hand; and the writer has been several times a sorrowful witness to losses of this kind among his friends; and in the island of Ely had once the mortification to see nine young steers or buliocks of his own all lying dead in a heap from browsing a little on a hedge of yew in an old garden, into which they had broken in snowy weather. Even the clippings of a yew hedge have destroyed a whole dairy of cows when thrown inadvertently into a yard. And yet sheep and turkeys, and, as park-keepers say, deer will crop these trees with impunity.

Some intelligent persons assert that the branches of yew, while green, are not noxious; and that they will kill only when dead and withered, by lacerating the stomach; but to this assertion we cannot by any means assent, because, among the number of cattle that we have known fall victims to this deadly food, not one has been found, when it was opened, but had a lump of green yew in its paunch. True it is, hat yew-trees stand for twenty years or more in a field, and no bad consequences ensue; but at some 
time or other cattle, either from wantonness when full, or from hunger when empty (from both which circumstances we have seen them perish), will be meddling, to their certain destruction; the yew seems to be a very improper tree for a pasture-field.

Antiquaries seem much at a loss to determine at what period this tree first obtained a place in churchyards. A statute passed A.D. 1307 and 35 Edward I., the title of which is " $\mathrm{Ne}$ rector arbores in cemeterio prosternat." Now if it is recollected that we seldom see any other very large or ancient tree in a churchyard but yews, this statute must have principally related to this species of tree; and consequently their being planted in churchyards is or much more ancient date than the year 1307 .

As to the use of these trees, possibly the more respectable parishioners were buried under their shade before the improper custom was introduced of burying within the body of the church, where the living are to assemble. Deborah, Rebekah's nurse,* was buried under an oak; the most honourable place of interment probably next to the cave of Machpelah, $\uparrow$ which seems to have been appropriated to the remains of the patriarchal family alone.

The farther use of yew-trees might be as a screen to churches, by their thick foliage, from the violence of winds; perhaps also for the purpose of archery, the best long bows being made of that material; and we do not hear that they are planted in the churchyards of other parts of Europe, where long bows were not so much in use. They might also be placed as a shelter to the congregation assembling before the church doors were opened, and as an emblem of mortality by their funereal appearance. In the south of England every churchyard almost has its tree, and some two; but in the north, we understand, few are to be found.

The idea of R. C. that the yew-tree afforded its branches instead of palms for the processions on Palm Sunday, is a good one, and deserves attention. See "Gent. Mag." vol. l. p. 128.

* Gen. xxxv. 8.

+ Gen. xxiii. 9 . 


\section{LETTER VI.}

THE living of Selborne was a very small vicarage; but, being in the patronage of Magdalen College, in the university of Oxford, that society endowed it with the great tithes of Selborne, more than a century ago; and since the year $175^{8}$ again with the great tithes of Oakhanger, called Bene's parsonage; so that, together, it is become a respectable piece of preferment, to which one of the fellows is always presented. The vicar holds the great tithes, by lease, under the college. The great disadvantage of this living is, that it has not one foot of glebe near home.*

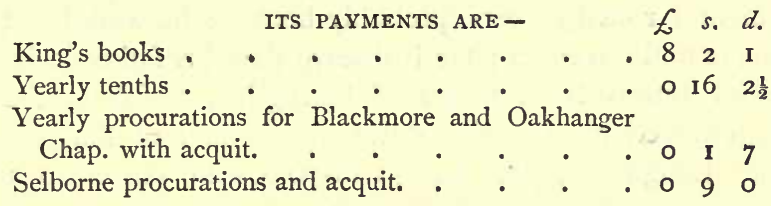

I am unable to give a complete list of the vicars of this parish till towards the end of the reign of Queen Elizabeth; from which period the registers furnish a regular series.

In Domesday we find thus- "De isto manerio dono dedit Rex Radfredo presbytero dimidiam hidam cum ecclesia." So that before Domesday, which was compiled between the years ro8I and ro86, here was an officiating minister at this place.

After this, among my documents, I find occasional mention of a vicar here and there; the first is-

Roger, instituted in 1254 .

In I4 Io John Lynne was vicar of Selborne.

In I4I I Hugo Tybbe was vicar.

The presentations to the vicarage of Selborne generally ran in the name of the prior and the convent; but Tybbe was presented by Prior John Wynechestre only.

* At Bene's, or Bin's, parsonage there is a house and stout barn, and seven acres of glebe; Bene's parsonage is three miles from the church. 
June 29 th, 1528 , William Fisher, vicar of Selborne, resigned to Miles Peyrson.

I594, William White appears to have been vicar to this time. Of this person there is nothing remarkable, but that he hath made a regular entry twice in the register of Selborne of the funeral of Thomas Cowper, bishop of Winchester, as if he had been buried at Selborne; yet this learned prelate, who died $\mathrm{x}_{594}$, was buried at Winchester, in the cathedral, near the episcopal throne.*

I595, Richard Boughton, vicar.

I 596, William Inkforbye, vicar.

May I606, Thomas Phippes, vicar.

June 1031, Ralph Austine, vicar.

July 1632 , John Longworth. This unfortunate gentleman, living in the time of Cromwell's usurpation, was deprived of his preferment for many years, probably because he would not take the league and covenant; for I observe that his father-in-law, the Reverend Jethro Beal, rector of Faringdon, which is the next parish, enjoyed his benefice during the whole of that unhappy period. Longworth, after he was dispossessed, retired to a little tenement about one hundred and fifty yards from the church, where he earned a small pittance by the practice of physic. During those dismal times it was not uncommon for the deposed clergy to take up a medical character; as was the case in particular, I know, with the Reverend Mr. Yalden, rector of Compton, near Guildford, in the county of Surrey. Vicar Longworth used frequently to mention to his sons, who told it to my relations, that, the Sunday after his deprivation, his puritanical successor stepped into the pulpit with no small petulance and exultation: and began his sermon from Psalm xx. 8, "They are brought down and fallen; but we are risen and stand upright." This person lived to be restored in 1660 , and continued vicar for eighteen years ; but was so impoverished by his misfortunes, that he left the vicarage-house and premises in a very abject and dilapidated state.

July 1678. Richard Byfield, who left eighty pounds by will, the interest to be applied to apprentice out poor children; but

* See "Godwin de Præsulibus," Folio Cant. 1743, p. 239. 
this money, lent on private security, was in danger of being lost, and the bequest remained in an unsettled state for near twenty years, till I 700 ; so that little or no advantage was derived from it. About the year 1759 it was again in the utmost danger by the failure of a borrower; but, by prudent management, has since been raised to one hundred pounds stock in the three per cents reduced. The trustees are the vicar and the renters or owners of Temple, Priory, Grange, Blackmore, and Oakhanger-house, for the time being. This gentleman seemed inclined to have put the vicarial premises in a comfortable state; and began by building a solid stone wall round the front court, and another in the lower yard, between that and the neighbouring garden; but was interrupted by death from fulfilling his laudable intentions.

April r680, Barnatas Long became vicar.

June, I68I. This living was now in such low estimation in Magdalen College that it descended to a junior fellow, Gilbert White, M.A., who was instituted to it in the thirty-first year of his age. At his first coming he ceiled the chancel, and also floored and wainscoted the parlour and hall, which before were paved with stone, and had naked walls; he enlarged the kitchen and brewhouse, and dug a cellar and well; he also built a large new barn in the lower yard, removed the hovels in the front court, which he laid out in walks and borders; and entirely planned the back garden, before a rude field with a stone-pit in the midst of it. By his will he gave and bequeathed "the sum of forty pounds to be laid out in the most necessary repairs of the church; that is, in strengthening and securing such parts as seem decaying and dangerous." With this sum two large buttresses were erected to support the east end of the south wall of the church, and the gable-end wall of the west end of the south aisle was new built Irom the ground.

By his will also he gave " one hundred pounds to be laid out on lands; the yearly rents whereof shall be employed in teaching the poor children of Selbourn parish to read and write, and say their prayers and catechism, and to sew and knit;-and be under the direction of his executrix as long as she lives; and, after her; under the direction of such of his children and their issue, as shall 
live in or within five miles of the said parish; and on failure of any such, then under the direction of the vicar of Selbourn for the time being; but still to the uses above-named." With this sum was purchased, of Thomas Turville, of Hawkeley, in the county of Southampton, yeoman, and Hannah his wife, two closes of freehold land, commonly called Collier's, containing, by estimation, eleven acres, lying in Hawkeley aforesaid. These closes are let at this time, 1785 , on lease, at the rate of three pounds by the year.

This vicar also gave by will two hundred pounds towards the repairs of the highways* in the parish of Selborne. That sum was carefully and judiciously laid out in the summer of the year I 730, by his son John White, who made a solid and firm causey from Rood Green, all down Honey Lane, to a farm called Oak Woods, where the sandy soil begins. This miry and gulfy lane was chosen as worthy of repair, because it leads to the forest, and thence through the Holt to the town of Farnham in Surrey, the only market in those days for men who had wheat to sell in this neighbourhood. This causey was so deeply bedded with stone, so properiy raised above the level of the soil, and so well drained, that it has, in some degree, withstood fifty-four years of neglect and abuse; and might, with moderate attention, be rendered a solid and comfortable road. The space from Rood Green to Oak Woods measures about three-quarters of a mile.

In I $_{27}$, William Henry Cane, B.D., became vicar, and, among several alterations and repairs, new-built the back front of the vicarage-house.

On February rst, I740, Duncombe Bristowe, D.D., was instituted to this living. What benefactions this vicar bestowed on the parish will be best explained by the following passages from his will:- "Item, I hereby give and beaqueath to the minister and church-wardens of the parish of Selbourn, in the county of Southampton, a mahogany table, which I have ordered to be made for the celebration of the Holy Communion; and also the

* "Such legacies were very common in former times, before any effectual laws were made for the repairs of highways."-Sir Fohn Cullum's Hawsted, p. 15. 
sum of thirty pounds, in trust, to be applied in manner following ; that is, ten pounds towards the charge of erecting a gallery at the west end of the church; and ten pounds to be laid out for cloathing, and such like necessaries, among the poor (and especially among the ancient and infirm) of the said parish: and the remaining ten pounds to be distributed in bread, at twenty shillings a week, at the discretion of John White, Esq., or any of his family, who shall be resident in the said parish."

On November I2th, I758, Andrew Etty, B.D., became vicar. Among many useful repairs he new-roofed the body of the vicaragehouse; and wainscoted, up to the bottom of the windows, the whole of the chancel; to the neatness and decency of which he always paid the most exact attention.

On September 25th, I784, Christopher Taylor, B.D., was inducted into the vicarage of Selborne.

\section{LETTER VII.}

I SHALL now proceed to the priory, which is undoubtedly the most interesting part of our history.

The Priory of Selborne was founded by Peter de la Roche, or de Rupibus, * one of those accomplished foreigners that resorted to the court of King John, where they were usually caressed, and met with a more favourable reception than ought, in prudence, to have been shown by any monarch to strangers. This adventurer was a Poictevin by birth, had been bred to arms in his youth, and distinguished by knighthood. Historians all agree not to speak very favourably of this remarkable man; they allow that he was possessed of courage and fine abilities, but then they charge him with arbitrary principles, and violent conduct. By his insinuating manners he soon rose high in the favour of John; and in 1205 , early in the reign of that prince, was appointed bishop of Win-

* See "Godwin de Præsulibus Angliæ." Folio. London, 1743, p. 217. 
chester. In I 2 I 4 , he became lord chief justiciary of England, the first magistrate of the state, and a kind of viceroy, on whom depended all the civil affairs in the kingdom. After the death of John, and during the minority of his son Henry, this prelate took upon him the entire management of the realm, and was soon appointed protector of the king and kingdom.

The barons saw with indignation a stranger possessed of all the power and influence, to part of which they thought they had a claim; they therefore entered into an association against him, and determined to wrest some of that authority from him which he had so unreasonably usurped. The bishop discerned the storm at a distance ; and, prudently resolving to give way to that torrent of envy which he knew not how to withstand, withdrew quietly to the Holy Land, where he resided some time.

At this juncture a very small part of Palestine remained in the hands of the Christians ; they had been by Saladine dispossessed of Jerusalem, and all the internal parts, near forty years before; and with difficulty maintained some maritime towns and garrisons; yet the busy and enterprising spirit of de Rupibus could not be at rest; he distinguished himself by the splendour and magnificence of his expenses, and amused his mind by strengthening fortresses and castles, and by removing and endowing of churches. Before his expedition to the east he had signalised himself as the founder of convents, and as a benefactor to hospitals and monasteries.

In the year I23I he returned again to England; and the very next year, in 1232, began to build and endow the Priory of Selborne. As this great work followed so close upon his return, $i$ : is not improbable that it was the result of a vow made during his voyage, and especially as it was dedicated to the Virgin Mary. Why the bishop made choice of Selborne for the scene of his munificence can never be determined now; it can only be said that the parish was in his diocese, and lay almost midway between Winchester and Farnham, or South Waltham and Farnham; from either of which places he could without much trouble overlook his workmen, and observe what progress they made; and that the situation was retired, with a stream running by it, and sequestered 
from the world, amidst woods and meadows, and so far proper for the site of a religious house.*

The first person with whom the founder treated about the purchase of land was Jacobus de Achangre, or Ochangre, a gentleman of property who resided in that hamlet; and, as appears, at the house now called Oakhanger-house. With him he agreed for a croft, or little close of land, known by the name of La liega, or La lyge, which was to be the immediate site of the Priory.

De Achangre also accommodated the bishop at the same instant with three more adjoining crofts, which for a time was all the footing that this institution obtained in the parish. The seller in the conveyance says, "Warantizabimus, defendemus, et æquietabimus contra omnes gentes ;" viz., "We will warrant the thing sold against all claims from any quarter." In modern conveyancing this would be termed a covenant for further assurance. Afterwards is added - "Pro hac autem donacione, \&c., dedit mihi pred. Episcopus sexdecem marcas argenti in Gersumam:" i.e., "The bishop gave me sixteen silver marks as a consideration for the thing purchased."

As the grant from Jac. de Achangre was without date, $\uparrow$ and the next is circumstanced in the same manner, we cannot say exactly what interval there was between the two purchases; but we find that Jacobus de Nortun, a neighbouring gentleman, also soon sold

* The institution at Selborne was a priory of black-canons of the order of St. Augustine, called also canons-regular. Regular-canons were such as lived in a conventual manner under one roof, had a common refectory and dormitory, and were bound by vows to observe the rules and statutes of their order: in fine, they were a kind of religious, whose discipline was less rigid than the monks. The chief rule of these canons was that of St. Augustine, who was constituted bishop of Hippo, A.D. 395; but they were not brought into England till after the conquest; and seem not to have obtained the appellation of Augustine canons till some years after. Their habit was a long black cassock, with a white rocket over it; and over that a black cloak and hood. The monks were always shaved; but these canons wore their hair and beards, and caps on their heads. There were of these canons, and women of the same order called Canonesses, about 175 houses.

$\dagger$ The custom of affixing dates to deeds was not become general in the reign of Henry III. 
to the bishop of Winchester some adjoining grounds, through which our stream passes, that the priory might be accommodated with a mill, which was a common necessary appendage to every manor; he also allowed access to these lands by a road for carts and waggons.- "Jacobus de Nortun concedit Petro Winton episcopo totum cursum aque que descendit de Molendino de Durton usq; ad boscum Will. Mauduit, et croftam terre vocat: Edriche croft, cum extensione ejusdem et abuttamentis; ad fundandam domum religiosam de ordine Sti. Augustini. Concedit etiam viam ad carros, et caretas," etc. This vale, down which runs the brook, is now called the Long Lithe, or Lythe. Bating the following particular expression, this grant runs much in the style of the former: "Dedit mihi episcopus predictus triginta quinque marcas argenti ad me acquietandum versus Fudcos;" that is, "The bishop advanced me thirty-five marks of silver to pay my debts to the Jews," who were then the only lenders of money.

Finding himself still straitened for room, the founder applied to his royal master, Henry, who was graciously pleased to bestow certain lands in the manor of Selborne on the new priory of his favourite minister. These grounds had been the property of Stephen de Lucy; and, abutting upon the narrow limits of th convent, became a very commodious and agreeable acquisition. This grant, I find, was made on March 9 th, in the eighteenth year of Henry, viz., I234, being two years after the foundation of the monastery. The royal donor bestowed his favour with good grace, by adding to it almost every immunity and privilege that could have been specified in the law-language of the times.-_ "Quare volumus prior, \&c., habeant totam terram \&c., cum omnibus libertatibus in bosco et plano, in viis et semitis, pratis et pascuis ; aquis et piscariis ; infra burgum, et extra burgum, cum soka et saca, Thol et Them, Infangenethef et Utfangenethef, et hamsocne et blodwite, et pecunia que dari solet pro murdro et forstal, et flemenestrick, et cum quietancia de omni scotto et geldo, et de omnibus auxiliis regum, vicecomitum, et omn : ministralium suorum; et hidagio et exercitibus, et scutagiis, et tallagiis, et shiris et hundredis, et placitis et querelis, et warda et wardpeny, et opibus 
castellcrum et pontium, et clausuris parcorum, et omni carcio et sumagio, et domor: regal: edificatione, et omnimoda reparatione, et cum omnibus aliis libertatibus." This grant was made out by Richard bishop of Chichester, then chancellor, at the town of Northampton, before the lord chief justiciary, who was the founder himself.

The charter of foundation of the Priory, dated I233, comes next in order to be considered; but being of some length, I shall not interrupt my narrative by placing it here. This my copy, taken from the original, I have compared with Dugdale's copy, and find that they perfectly agree; except that in the latter the preamble and the names of the witnesses are omitted. Yet I think it proper to quote a passage from this charter: "Et ipsa domus religiosa a cujuslibet alterius domûs religiosa subjectione libera permaneat, et in omnibus absoluta," to show how much Dugdale was mistaken when he inserted Selborne among the alien priories; forgetting that this disposition of the convent contradicted the grant that he had published. In the "Monasticon Anglicanum," in English, p. II9, is part of his catalogue of alien priories, suppressed 2 Henry V., viz., I4I4, where may be seen as follows:-

$$
\begin{gathered}
\text { S. } \\
\text { Sele, Sulssex, } \\
\text { selebURN. } \\
\text { Shirburn. }
\end{gathered}
$$

This appeared to me from the first to have been an oversight, before I had seen my authentic evidences. For priories alien, a few conventual ones excepted, were little better than granges to foreign abbeys, and their priors little more than bailiffs removable at will; whereas the priory of Selborne possessed the valuable estates and manors of Selborne, Achangre, Norton, Brompden, Bassinges, Basingstoke, and Natele; and the prior challenged the right of pillory, thurcet, and furcas, and every manorial privilege.

I find next a grant from Jo. de Venur, or Venuz, to the prior of Selborne,- " de tota mora [a moor or bog] ubi Beme oritur, usque ad campum vivarii, et de prato voc. Sydenmeade cum abutt : et de cursu aque molendini." And also a grant in reversion "unius virgate terre" (a yard land), in Achangre at the deat? 
of Richard Actedene his sister's husband, who had no child. $\mathrm{He}$ was to present a pair of gloves of one penny value to the prior and canons, to be given annually by the said Richard; and to quit all claim to the said lands in reversion, provided the prior and canons would engage annually to pay to the king, through the hands of his bailiffs of Aulton, ten shillings at four quarterly payments, "pro omnibus serviciis, consuetudinibus, exactionibus, et demandis."

This Jo. de Venur was a man of property at Oakhanger, and lived probably at the spot now called Chapel-farm. The grant bears date the $I 7$ th year of the reign of Henry III. (viz. r233).

It would be tedious to enumerate every little grant for lands or tenements that might be produced from my vouchers. I shall therefore pass over all such for the present, and conclude this letter with a remark that must strike every thinking person with some degree of wonder. No sooner had a monastic institution got a footing, but the neighbourhood began to be touched with a secret and religious awe. Every person round was desirous to promote so good a work; and either by sale, by grant, or by gift in reversion, was ambitious of appearing a benefactor. They who had not lands to spare gave roads to accommodate the infant foundation. The religious were not backward in keeping up this pious propensity, which they observed so readily influenced the breasts of men. Thus did the more opulent monasteries add house to house, and field to field, and by degrees manor to manor, till at last " there was no place left ;" but every district around became appropriated to the purposes of their founders, and every precinct was drawn into the vortex.

\section{LETTER VIII.}

OUR forefathers in this village were no doubt as busy and bustling, and as important, as ourselves: yet have their names and transactions been forgotten from century to century, and have sunk into oblivion; nor has this happened only to the vulgar, but even 
to men remarkable and famous in their generation. I was led into this train of thinking by finding in my vouchers that Sir Adam Gurdon was an inhabitant of Selborne, and a man of the first rank and property in the parish. By Sir Adam Gurdon I would be understood to mean that leading and accomplished malcontent in the Mountfort faction, who distinguished himself by his daring conduct in the reign of Henry III. The first that we hear of this person in my papers is, that with two others he was bailiff of Alton before the sixteenth of Henry III., viz., about I23I, and then not knighted. Who Gurdon was, and whence he came, does not appear: yet there is reason to suspect that he was originally a mere soldier of fortune, who had raised himself by marrying women of property. The name of Gurdon does not seem to be known in the south; but there is a name so like it in an adjoining kingdom, and which belongs to two or three noble families, that it is probable this remarkable person was a North Briton; and the more so, since the Christian name of Adam is a distinguished one to this day among the family of the Gordons. But, be this as it may, Sir Adam Gurdon has been noticed by all the writers of English history for his bold disposition and disaffected spirit, in that he not only figured during the successful rebellion of Leicester but kept up the war after the defeat and death of that baron, entrenching himself in the woods of Hampshire, towards the town of Farnham. After the battle of Evesham, in which Mountfort fell, in the year 1265 , Gurdon might not think it safe to return to his house for fear of a surprise; but cautiously fortified himself amidst the forests and woodlands with which he was so well acquainted. Prince Edward, desirous of putting an end to the troubles which had so long harassed the kingdom, pursued the arch-rebel into his fastnesses, attacked his camp, leaped over the entrenchments, and, singling out Gurdon, ran him down, wounded him, and took him prisoner.*

There is not perhaps in all history a more remarkable instance of command of temper, and magnanimity, than this before us : that a young prince, in the moment of victory, when he had the fell adversary of the crown and royal family at his mercy, should * M. Paris, p. 675, and Triveti Annale. 
be able to withhold his hand from that vengeance which the vanquished so well deserved. A cowardly disposition would have been blinded by resentment; but this gallant heir apparent saw at once a method of converting a most desperate foe into a lasting friend. He raised the fallen veteran from the ground, he pardoned him, he admitted him into his confidence, and introduced him to the queen, then lying at Guildford, that very evening. This unmerited and unexpected lenity melted the heart of the rugged Gurdon at once; he became in an instant a loyal and useful subject, trusted and employed in matters of moment by Edward when king, and confided in till the day of his death.

\section{LETTER IX.}

IT has been hinted in a former letter that Sir Adam Gurdon had availed himself by marrying women of property. By my evidences it appears that he had three wives, and probably in the following order : Constantia, Ameria, and Agnes. The first of these ladies, who was the companion of his middle life, seems to have been a person of considerable fortune, which she inherited from Thomas Makerel, a gentleman of Selborne, who was either her father or uncle. The second, Ameria, calls herself the quondam wife of Sir Adam, "quæ fui uxor," etc., and talks of her sons under age. Now Gurdon had no son : and beside, Agnes, in another document, says, "Ego Agnes quondam uxor Domini Ada Gurdon in pura et ligea viduitate mea :" but Gurdon could not leave two widows; and therefore it seems probable that he had been divorced from Ameria, who afterwards married and had sons. By Agnes Sir Adam had a daughter Johanna, who was his heiress, to whom Agnes in her life-time surrendered part of her jointure: he had also a bastard son.

Sir Adam seems to have inhabited the house now called Temple, lying about two miles east of the church, which had been the property of Thomas Makerel. 
In the year 1262 he petitioned the prior of Selborne in his own name, and that of his wife Constantia only, for leave to build him an oratory in his manor-house, "in curia sua." Licenses of this sort were frequently obtained by men of fortune and rank from the bishop of the diocese, the archbishop, and sometimes, as I have seen instances, from the Pope; not only for convenience' sake, and on account of distance, and the badness of the roads, but as a matter of state and distinction. Why the owner should apply to the prior, in preference to the bishop of the diocese, and how the former became competent to such a grant, I cannot say; but that the priors of Selborne did take that privilege is plain, because some years afterwards, in $\mathbf{1 2 8 0}$, Prior Richard granted to Henry Waterford and his wife Nicholaa, a licence to build an oratory in their court-house, "curia sua de Waterford," in which they might celebrate divine service, saving the rights of the mother church of Basynges. Yet all the while the prior of Selborne grants with such reserve and caution, as if in doubt of his power, and leaves Gurdon and his lady answerable in future to the bishop, or his ordinary, or to the vicar for the time being, in case they should infringe the rights of the mother church of Selborne.

The manor-house, called "Temple," is at present a single building, running in length from south to north, and has been occupied as a common farmhouse from time immemorial. The south end is modern, and consists of a brewhouse, and then a kitchen. The middle part is a hall twenty-seven feet in length, and nineteen feet in breadth; and has been formerly open to the top, but there is now a floor above it, and also a chimney in the western wall. The roofing consists of strong massive rafterwork ornamented with carved roses. I have often looked for the lamb and flag, the arms of the knights templars, without success; but in one corner found a fox with a goose on his back, so coarsely executed, that it required some attention to make out the device.

Beyond the hall to the north is a small parlour with a vast heavy stone chimney-piece, and at the end of all the chapel or oratory, whose massive thick walls and narrow windows at once 
bespeak great antiquity. This room is only sixteen feet by sixteen feet eight inches; and full seventeen feet nine inches in height. The ceiling is formed of vast joists, placed only five or six inches apart. Modern delicacy would not much approve of such a place of worship; for it has at present much more the appearance of a dungeon than of a room fit for the reception of people of condition. The field on which this oratory abuts is called Chapelfield. The situation of this house is very particular, for it stands upon the immediate verge of a steep abrupt hill.

Not many years since this place was used for a hop-kiln, and was divided into two stories by a loft, part of which remains at present, and makes it convenient for peat and turf, with which it is stowed.

\section{LETTER X.}

THE Priory at times was much obliged to Gurdon and his family. As Sir Adam began to advance in years he found his mind influenced by the prevailing opinion of the reasonableness and efficacy of prayers for the dead; and therefore, in conjunction with his wife Constantia, in the year $127 \mathrm{I}$, granted to the prior and convent of Selborne all his right and claim to a certain place, placea, called "La Playstow," in the village aforesaid, "in liberam, puram, et perpetuam elemosinam." This Pleystow, * locus ludorum, or playplace, is a level area near the church of about forty-four yards by thirty-six, and is known now by the name of the Plestor. $\dagger$

It continues still, as it was in old times, to be the scene of recreation for the youths and children of the neighbourhood; and impresses an idea on the mind that this village, even in Saxon times, could not be the most abject of places, when the inhabitants

* In Saxon Plegestow, or Plegstow.

$\dagger$ At this juncture probably the vast oak was planted by the prior, as an ornament to his new acquired market-place. According to this supposition the oak was aged 432 years when blown down. 
thought proper to assign so spacious a spot for the sports and amusements of its young people.*

As soon as the prior became possessed of this piece of ground, he procured a charter for a market $\uparrow$ from King Henry III., and began to erect houses and stalls, "seldas," around it. From this period Selborne became a market town; but how long it enjoyed that privilege does not appear. At the same time, Gurdon reserved to himself, and his heirs, a way through the said Plestor to a tenement and some crofts at the upper end, abutting on the south corner of the churchyard. This was in old days the manerial house of the street manor, though now a poor cottage, and is known at present by the modern name of Elliot's. Sir Adam also did, for the health of his own soul and that of his wife Constantia, their predecessors and successors, grant to the prior and canons quiet possession of all the tenements and gardens, "curtillagia," which they had built and laid out on the lands in Selborne, on which he and his vassals, "homines," had undoubted right of common; and moreover did grant to the convent the full privilege of that right of common, and empowered the religious to build tenements and make garderss along the king's highway in the village of Selborne.

From circumstances put together, it appears that the above were the first grants obtained by the Priory in the village of Selborne after it had subsisted about thirty-nine years ; moreover, they explain the nature of the mixed manor still remaining in and about the village, where one field or tenement shall belong to Magdalen College in the University of Oxford, and the next to Norton Powlet, Esq., of Rotherfield House, and so down the whole street. The case was, that the whole was once the pro-

* For more circumstances respecting the Plestor, see Letter II. to Mr. Pennant.

† Bishop Tanner, in his " Notitia Monastica," has made a mistake respecting the market and fair at Selborne; for in his references to Dodsworth, cart. 54 Hen. III., m. 3., he says, "De mercatu, et feria de Seleburn." But this reference is wrong; for, instead of Seleburn, it proves that the place there meant was Lekeborne, or Legeborne, in the county of Lincoln. This error was copied from the index of the Cat. MSS. Angl. It does not appear that there ever was a chartered fair at Selborne. For several particulars respecting the present fair at Selborne, see Letter XXVI. of these Antiquities. 
perty of Gurdon, till he made his grants to the convent, since which some belongs to the successors of Gurdon in the manor, and some to the college; and this is the occasion of the strange jumble of property. It is remarkable that the tenement and crofts which Sir Adam reserved at the time of granting the Plestor should still remain a part of the Gurdon Manor, though so desirable an addition to the vicarage, that is not as yet possessed of one inch of glebe at home; but of late, viz., in January, 1785 , Magdalen College purchased that little estate, which is life-holding, in reversion, for the generous purpose of bestowing it, and its lands, being twelve acres (three of which abut on the churchyard and vicarage garden) as an improvement hereafter to the living, and an eligible advantage to future incumbents.

The year after Gurdon had bestowed the Plestor on the Priory, viz., in 1272, Henry III., King of England, died, and was succeeded by his son Edward. This magnanimous prince continued his regard for Sir Adam, whom he esteemed as a brave man, and made him warden, "custos," of the forest of Wolmer.*

* Since the letters respecting Wolmer-forest and Ayles-holt were printed, the author has been favoured with the following extracts :-

" In the 'Act of Resumption, I Hen. VII.' it was provided, that it be not prejudicial to 'Harry at Lode,' ranger of our forest of Wolmere, to him by oure letters patents before tyme gevyn."-Rolls of Parl., vol. vi. p. 370.

"In the II Hen. VII., I495, "Warlham (Wardleham) and the office of forest (forester) of Wolmere,' were held by Edmund, duke of Suffolk." -Rolls, ib. 474 .

"Act of general pardon, 14 Hen. VIII., 1523, not to extend to 'Rich. Bp. of Wynton (bishop Fox) for any seizure or forfeiture of liberties, \&c., within the forest of Wolmer, Alysholt, and Newe Forest; nor to any person for waste, \&c., within the manor of Wardlam, or parish of Wardlam (Wardleham); nor to abusing, \&c., of any office or fee, within the said forests of Wolmer or Alysholt, or the said park of Wardlam." "-County Suth't.-Rolls prefixt to 1 st Vol. of Fournals of the Lords, p. xciii. b.

To these may be added some other particulars, taken from a book lately published, entitled "An Account of all the Manors, Messuages, lands, \&c., in the different Counties of England and Wales, held by Lease from the Crown ; as contained in the Report of the Commissioners appointed to inquire into the State and Condition of the Royal Forests, \&c." London, 1787.

\section{"Southampton.}

P. 64. "A fee-farm rent of $£ 31$ 2s. I1 $d$. out of the manors of East and 
Though little emolument might hang to this appointment, yet are there reasons why it might be highly acceptable ; and, in a few reigns after, it was given to princes of the blood.* In old days gentry resided more at home on their estates, and having fewer resources of elegant indoor amusement, spent most of their leisure hours in the field and the pleasures of the chase. A large domain, therefore, at little more than a mile distance, and well stocked with game must have been a very eligible acquisition, affording him influence as well as entertainment; and especially as the manerial house of Temple, by its exalted situation, could command a view of near two-thirds of the forest.

That Gurdon, who had lived some years the life of an outlaw and at the head of an army of insurgents, was for a considerable time in high rebellion against his sovereign, should have been guilty of some outrages, and should have committed some depredations, is by no means matter of wonder. Accordingly we find a distringas against him, ordering him to restore to the Bishop of Winchester some of the temporalities of that see, which he had taken by violence and detained, viz., some lands in Hocheleye, and a mill. $\uparrow$ By a breve, or writ, from the king, he is also enjoined

West Wardleham; and also the office of lieutenant or keeper of the forest or chase of Aliceholt and Wolmer, with all offices, fees, commodities, and privileges thereto belonging.

" Names of lessees, William, earl of Dartmouth, and others (in trust).

"Date of the last lease, March 23rd, 1780 ; granted for such term as would fill up the subsisting term to $3 \mathrm{I}$ years.

"Expiration March 23, 1811.

"Southampton.

"Hundreds-Selborne and Finchdeane.

"Honours and manors, etc.

"Aliceholt forest, three parks there.

"Bens ted and Kingsley; a petition of the parishioners concerning the three parks in Aliceholt Forest."

" William, first earl of Dartmouth, and paternal grandfather to the present Lord Stawel, was a lessee of the forests of Aliceholt and Wolmer before brigadier-general Emanuel Scroope Howe."

* See Letter II. of these Antiquities.

$f$ Hocheleye, now spelt Hawkley, is in the hundred of Selborne, and has a mil lat this day. 
to readmit the Bishop of Winchester, and his tenants of the parish and town of Farnham, to pasture their horses, and other larger cattle, "averia," in the forest of Wolmer, as had been the usage from time immemorial. This writ is dated in the tenth year of the reign of Edward, viz., I 282 .

All the king's writs directed to Gurdon are addressed in the following manner, "Edwardus Dei gratia, \&c., dilecto et fideli suo Ade Gurdon salutem;" and again, "Custodi foreste sue de Wolvemere."

In the year 1293 a quarrel between the crews of an English and a Norman ship about some trifle, brought on by degrees such serious consequences, that in I 293 a war broke out between the two nations. The French king, Philip the Hardy, gained some advantages in Gascony; and, not content with those, threatened England with an invasion, and by a sudden attempt took and burnt Dover.

Upon this emergency, Edward sent a writ to Gurdon, ordering him and four others to enlist three thousand soldiers in the counties of Surrey, Dorset, and Wiltshire, able-bodied men, " tam sagittare quam balistare potentes;" and to see that they were marched by the feast of All Saints, to Winchelsea, there to be embarked aboard the king's transports.

The occasion of this armament appears also from a summons to the Bishop of Winchester to Parliament, part of which I shall transcribe on account of the insolent menace which is said therein to have been denounced against the English language :- "qualiter rex Franciæ de terra nostra Gascon nos fraudulenter et cautelose decepit, ean nobis nequiter detinendo....... vero predictis fraude et nequitia non contentus, ad expugnationem regni nostri classe maxima et bellatorum copiosa multitudine congregatis, cum quibus regnum nostrum et regni ejusdem incolas hostiliter jam invasurus, linguam Anglicam si concepte iniquitatis proposito detestabili potestas correspondeat, quod Deus avertat omnino de terra delere proponit." Dated 3oth September, in the year of King Edward's reign xxiii.*

* Reg. Winton, Stratford, but query Stratford ; for Stratford was not bishop of Winton till 1323 , near thirty years afterwards. 
The above are the last traces that I can discover of Gurdon's appearing and acting in public. The first notice that my evidences give of him is that in 1232 , being the r6th of Henry III., he was the King's bailiff, with others, for the town of Alton. Now, from 1232 to 1295 is a space of sixty-three years, a long period for one man to be employed in active life! Should any one doubt whether all these particulars can relate to one and the same person, I should wish him to attend to the following reasons why they might. In the first place, the documents from the priory mention but one Sir Adam Gurdon, who had no son lawfully begotten; and in the next, we are to recollect that he must have probably been a man of uncommon vigour, both of mind and body, since no one unsupported by such accomplishments could have engaged in such adventures, or could have borne up against the difficulties which he sometimes must have encountered; and moreover, we have modern instances of persons that have maintained their abilities for near that period.

Were we to suppose Gurdon to be only twenty years of age in 1 232 , in 1295 he would be eighty-three; after which advanced period it could not be expected that he should live long. From the silence, therefore, of my evidences, it seems probable that this extraordinary person finished his life in peace, not long after, at his mansion of Temple. Gurdon's seal had for its device-a man, with a helmet on his head, drawing a cross-bow; the legend, "Sigillum Ade de Gurdon;" his arms were, "Goulis, iii floures argent issant de testes de leopards." *

If the stout and unsubmitting spirit of Gurdon could be so much influenced by the belief and superstition of the times, much more might the hearts of his ladies and daughter. And accordingly we find that Ameria, by the consent and advice of her sons, though said to be all under age, makes a grant for ever of some lands down by the stream at Durton; and also of her right of the common of Durton itself. $\uparrow$ Johanna, the daughter and heiress of

* From the collection of Thomas Martin, Esq., in the "Antiquarian Repertory," p. I09, No. XXXI.

+ Durton, now called Dorton, is still a common for the copyholders of Selberne manor. 
Sir Adam, was married, I find, to Richard Achard; she also grants to the prior and convent lands and tenements in the village of Selborne, which her father obtained from Thomas Makerel; and also all her goods and chattels in Selborne for the consideration of two hundred pounds sterling. This last business was transacted in the first year of Edward II., viz., I 307. It has been observed before that Gurdon had a natural son; this person was called by the name of John Dastard, alias Wastard, but more probably Bastard ; since bastardy, in those days, was not deemed any disgrace, though dastardy was esteemed the greatest. He was married to Gunnorie Duncun ; and had a tenement and some land granted him in Selborne by his sister Johanna.

\section{LETTER XI.}

THE Knights Templars, ${ }^{*}$ who have been mentioned in a former

* The Military Orders of the Religious.

The Knights Hospitalars of St. John of Jerusalem, afterwards called Knights of Rhodes, now of Malta, came into England about the year I joo, I Hen. I.

The Knights Templars came into England pretty early in Stephen's reign, which commenced I135. The order was dissolved in 1312, and their estates given by Act of Parliament to the Huspitalars in 1323 (all in Edw. II.) though many of their estates were never actually enjoyed by the said Hospitalars. Vid. TANNER, p. 24, Io.

The commandries of the Hospitalars, and preceptories of Templars, were each subordinate to the principal house of their respective religion in London. Although these are the different denominations, which "Tanner" at p. 37 assigns to the cells of these different orders, yet throughout the work very frequent instances occur of preceptories attributed to the Hospitalars; and if in some passages of "Notitia Monast." commandries are attributed to the Templars, it is only where the place afterwards became the property of the Hospitalars, and so is there indifferently styled preceptory or commandry ; see p. $243,263,276,577,678$. But, to account for the first observed inaccuracy, it is probable the preceptories of the Templars, when given to the Hospitalars, were still vulgarly, however, called by their old name of preceptories; whereas in propriety societies of the Hospitalars were indeed (as has been said) com. mandaries. And such deviation from the strictness of expression in this case might occasion those societies of Hospitalars also to be indifferently called pre- 
letter, had considerable property in Selborne; and also a preceptory at Sudington, now called Southington, a hamlet lying one mile to the east of the village. Bishop Tanner mentions only two such houses of the Templars in all the county of Southampton, viz., Godesfield, founded by Henry de Blois, bishop of Winchester, and South Badeisley, a preceptory of the Knights Templars, and afterwards of St. John of Jerusalem, valued at one hundred and eighteen pounds sixteen shillings and sevenpence per annum. Here then was a preceptory unnoticed by antiquaries, between the village and Temple. Whatever the edifice of the preceptory might have been, it has long since been dilapidated; and the whole hamlet contains now only one mean farm-house, though there were two in the memory of man.

It has been usual for the religious of different orders to fall into great dissensions, and especially when they were near neighbours. Instances of this sort we have heard of between the monks of Canterbury; and again between the old abbey of St. Swythun,

ceptories, which had originally been vested in them, having never belonged to the Templars at all.-See in ARCHeR, p. 609 ; TANNER, p. 300, col. I, 720, n.e.

It is observable that the very statute for the dissolution of the Hospitalars holds the same language; for there, in the enumeration of particulars occur "commandries, preceptories."-CoDEX, p. I I90. Now this intercommunity of names, and that in an Act of Parliament too, made some of our ablest antiquaries look upon a preceptory and commandry as strictly synonymous; accordingly we find Camden, in his "Britannia," explaining præceptoria in the text by a commandry in the margin, p. 356. 510.-J. L.

Commandry, a manor or chief messuage with lands, etc., belonging to the priory of St. John of Jerusalem; and he who had the government of such house was called the commander, who could not dispose of it but to the use of the priory, only taking thence his own sustenance, according to his degree, who was usually a brother of the same priory.-Cowell. He adds (confounding these with preceptories) they are in many places termed temples, as Temple Bruere in Lincolnshire, etc. Preceptories were possessed by the more eminent sort of Templars, whom the chief master created and called Præceptores Templi. - Cowell, who refers to Stephens De Furisd. lib. iv. c. Io, no. 27.

Placita de juratis et assis coram Salom. de Roff et sociis suis justic. Itiner. apud Wynton, \&c., anno regni R. Edwardi fil. Reg. Hen. octavo. - "et Magr. Milicie Templi in Angl. ht emendassē panis. et suis [cerevisiæ] in Sodington, et nescint $q^{\circ}$. war. et-et magist. Milicie Templi nōn vēn iō distr." - Chapter House, Westminster. 
and the comparatively new minster of Hyde in the city of Win. chester.* These feuds arose probably from different orders being crowded within the narrow limits of a city, or garrison-town, where every inch of ground was precious, and an object of contention. But with us, as far as my evidences extend, and while Robert Saunford was master, $\uparrow$ and Richard Carpenter was preceptor, the Templars and the Priors lived in an intercourse of mutual good offices.

My papers mention three transactions, the exact time of which cannot be ascertained, because they fell out before dates were usually inserted ; though probably they happened about the middle of the thirteenth century, not long after Saunford became master. The first of these is that the Templars shall pay to the priory of Selborne, annually, the sum of ten shillings at two half-yearly payments from their chamber, "camera," at Sudington, "per

\section{Notitia Monastica, p. 155 .}

"Winchester, Newminster. King Alfred founded here first only a house and chapel for the learned monk Grimbald, whom he had brought out of Flanders ; but afterwards projected, and by his will ordered, a noble Church or religious house to be built in the cemetery on the north side of the old minster or cathedral, and designed that Grimbald should preside over it. This was begun A.D. 9oI, and finished to the honour of the Holy Trinity, Virgin Mary, and St. Peter, by his son King Edward, who placed therein secular canons, but A.D. 963 they were expelled, and an abbot and monks put in possession by bishop Ethelwold.

"Now the churches and habitations of these two societies being so very near together, the differences which were occasioned by their singing, bells, and other matters, arose to so great a height, that the religious of the new monastery thought fit, about A.D. III9, to remove to a better and more quiet situation without the walls, on the north part of the city called Hyde, where King Edward I., at the instance of Will. Gifford, Bishop of Winton, founded a stately abbey for them. St. Peter was generally acco unted patron; though it is sometimes called the monastery of St. Grimbald, and sometimes of St. Barnabas," etc.

NOTE. - A few years since a county bridewell, or house of correction, has been built on the immediate site of Hyde Abbey. In digging up the old foundations the workmen found the head of a crosier in good preservation.

$\dagger$ Robert Saunforde was Master of the Temple in I24I ; Guido de Foresta was the next in I292. The formar is fifth in a list of the masters, in a MS. "Bib. Cotton. Nero. E. VI." 
manum preceptoris, vel ballivi nostri, qui pro tempore fuerit ibidem," till they can provide the prior and canons with an equivalent in lands or rents within four or five miles of the said convent. It is also further agreed that, if the Templars shall be in arrears for one year, then the prior shall be empowered to distrain upon their live stock in Bradeseth. The next matter was a grant from Robert de Sunford to the priory for ever, of a good and sufficient road, "cheminum," capable of admitting carriages, and proper for the drift of their larger cattle, from the way which extends from Sudington towards Blakemere, on to the lands which the convent possesses in Bradeseth.

The third transaction (though for want of dates we cannot say which happened first and which last) was a grant from Robert Samford to the priory of a tenement and its appurtenances in the village of Selborne, given to the Templars by Americus de Vasci.* This property, by the manner of describing it,- " "totun tenementum cum omnibus pertinentiis suis, scilicet in terris, \& hominibus, in pratis \& pascuis, \& nemoribus," etc., seems to have. been no inconsiderable purchase, and was sold for two hundred marks sterling, to be applied for the buying of more land for the support of the holy war.

Prior John is mentioned as the person to whom Vasci's land is conveyed. But in Willis's list there is no Prior John till I 339 , several years after the dissolution of the order of the Templars in I 3 I 2, so that, unless Willis is wrong, and has omitted a prior John since 1262 (that being the date of his first prior), these transactions must have fallen out before that date.

I find not the least traces of any concerns between Gurdon and the Knight Templars; but probably after his death his daughter Johanna might have, and might bestow, Temple on that order in support of the holy land; and, moreover, she seems to have been removing from Selborne, when she sold her goods and chattels to the priory, as mentioned above.

Temple, no doubt, did belong to the knights, as may be

* Americus Vasci, by his name, must have been an Italian, and had been probably a soldier of fortune, and one of Gurdon's captains. Americus Vespucio, the person who gave name to the new world, was a Florentine. 
asserted, not only from its name, but also from another corroborating circumstance of its being still a manor, tithe-free ; "for, by virtue of their order," says Blackstone, "the lands of the Knights 'Templars were privileged by the Pope with a discharge from tithes."

Antiquaries have been much puzzled about the terms preceptores and preceptorium, not being able to determine what officer or edifice was meant. But perhaps all the while the passage quoted above from one of my papers, "per manum preseptoris vel ballivi nostri, qui pro tempore fuerit, ibidem," may help to explain the difficulty. For if it be allowed here that preceptor and ballivus are synonymous words, then the brother who took on him that office resided in the house of the Templars at Sudington, a preceptory; where he was their preceptor, superintended their affairs, received their money, and, as in the instance there mentioned, paid from their chamber, "camera," as directed; so that, according to this explanation, a preceptor was no other than a steward, and a preceptorium was his residence. I am well aware that, according to strict Latin, the vel should have been seu or sive, and the order of the words "preceptoris nostri, vel ballivi, qui"- -et "ibidem" should have been $i b i$; ibidem necessarily having reference to two or more persons; but it will hardly be thought fair to apply the niceties of classic rules to the Latinity of the thirteenth century, the writers of which seem to have aimed at nothing farther than to render themselves intelligible.

There is another remark that we have made, which, I think, corroborates what has been advanced; and that is, that Richard Carpenter, preceptor of Sudington, at the time of the transactions between the Templars and Selborne Priory, did always sign last as a witness in the three deeds; he calls himself frater, it is true, among many other brothers, but subscribes with a kind of deference, as if, for the time being, his office rendered him an inferior in the community.*

* In two or three ancient records relating to St. Oswald's Hospital in the city of Worcester, printed by Dr. Nash, pp. 227, 228, of his collections for the history of Worcestershire, the words preceptorium and preceptoria signify the mastership of the said hospital : " ad preceptorium sive magisterium presentavit 


\section{LETTER XII.}

THE ladies and daughter of Sir Adam Gurdon were not the only benefactresses to the Priory of Selborne; for, in the year I28I, Ela Longspee obtained masses to be performed for her soul's health; and the prior entered into an engagement that one of the convent should every day say a special mass for ever for the said benefactress, whether living, or dead. She also engaged within five years to pay to the said convent one hundred marks of silver for the support of a chantry and chantry chaplain, who should perform his masses daily in the parish church of Selborne.* In the east end of the south aisle there are two sharp-pointed Gothic niches; one of these probably was the place under which these masses were performed; and there is the more reason to suppose as much, because, till within these thirty years, this space was fenced off with Gothic wooden railing, and was known by the name of the south chancel. $\uparrow$

--preceptorii sive magisterii patronas. Vacavit dicta preceptoria seu magisterium-ad preceptoriam et regimen dicti hospitalis-Te preceptorem sive magistrum prefecimus."

Where preceptorium denotes a building or apartment it may probably mean the master's lodgings, or at least the preceptor's apartment, whatsoever may have been the office or employment of the said preceptor.

A preceptor is mentioned in Thoresby's "Ducatus Leodiensis," or History of Leeds, p. 225, and a deed witnessed by the preceptor and chaplain before dates were inserted.-Du Fresne's Supplement: "Preceptoriæ, prædia preceptoribus assignata." Cowel, in his "Law Dictionary," enumerates sixteen preceptoriæ, or preceptories, in England; but Sudington is not among them.It is remarkable that Gurtlerus, in his "Historia Templariorum," Amstel. 1691, never once mentions the words preceptor or preceptorium.

* A chantry was a chapel joined to some cathedral or parish church, and endowed with annual revenues for the maintenance of one or more priests to sing mass daily for the soul of the founder, and others.

$\dagger$ For what is said more respecting this chantry see Letter III. of these Antiquities.-Mention is made of a Nicholas Langrish, capellanus de Selborne, in the time of Henry VIII. Was he chantry-chaplain to Ela Longspee, whose masses were probably continued to the time of the Reformation? More will be said of this person hereafter. 
The solicitude expressed by the donor plainly shows her piety and firm persuasion of the efficacy of prayers for the dead; for she seems to have made every provision for the payment of the sum stipulated within the appointed time, and to have felt much anxiety lest her death, or the neglect of her executors or assigns, might frustrate her intentions. - "Et si contingat me in solucione perdicte pecunie annis predictis in parte aut in toto deficere, quod absit; concedo et obligo pro me et assignatis meis, quod ViceComes . . . Oxon et . . . . qui pro tempore fuerint, per omnes terras et tenementa, et omnia bona mea mobilia et immobilia ubicunque in balliva sua fuerint inventa ad solucionem predictam faciendam possent nos compellere." And again-"Et si contingat dictos religiosos labores seu expensas facere circa predictam pecuniam, seu circa partem dicte pecunie; volo quod dictorum religiosorum impense et labores levantur ita quod predicto priori vel uni canonicorum suorum superhiis simplici verbo credatur sine alterius honere probacionis; et quod utrique predictorum virorum in unam marcam argenti pro cujuslibet distrincione super me facienda tenear.-Dat. apud Wareborn die sabati proxima ante festum St. Marci evangeliste, anno regni regis Edwardi tertio decimo."*

But the reader, perhaps, would wish to be better informed respecting this benefactress, of whom as yet he has heard no particulars.

The Ela Longspee, therefore, above-mentioned, was a lady of high birth and rank, and became countess to Thomas de Newburgh, the sixth earl of Warwick : she was the second daughter of the famous Ela Longspee, Countess of Salisbury, by William Longspee, natural son of King Edward II., by Rosamond.

Our lady, following the steps of her illustrious mother, $\uparrow$ " was a

* Ancient deeds are often datel on a Sunday, having been executed in churches and churchyards for the sake of notoriety, and for the conveniency of procuring several witnesses to attest.

$\dagger$ Ela Longspee, Countess of Salisbury, in 1232, founded a monastery at Lacock, in the county of Wilts, and also another at.Hendon, in the county of Somerset, in her widowhood, to the honour of the Blessed Virgin and St. Bernard.-CAMDEN. 
great benefactress to the University of Oxford, to the canons of Oseney, the nuns of Godstow, and other religious houses in Oxfordshire. She died very aged, in the year I300,* and was buried before the high altar in the abbey church of Oseney, at the head of the tomb of Henry D'Oily, under a flat marble, on which was inlaid her portraiture, in the habit of a vowess, engraved on a copper-plate."- "Edmondson's History and Genealogical Account of the Grevilles," p. 23.

\section{LETTER XIII.}

THE reader is here presented with the titles of five forms respecting the choosing of a prior. "Charta petens licentiam elegendi prelatum a Domino episcopo Wintoniensi :"-"Forma licentie concesse :"- "Forma decreti post electionem conficiendi:"-ro8. "Modus procedendi ad electionem per formam scrutinii :"-et "Forma ricte presentandi electum." Such evidences are rare and curious, and throw great light upon the general monastico-ecclesiastical history of this kingdom, not yet sufficiently understood.

In the year 1324 there was an election for a prior at Selborne; when some difficulties occurring, and a devolution taking place, application was made to Stratford, who was bishop of Winchester at that time, and of course the visitor and patron of the convent at the spot above-mentioned. $\uparrow$

An Extract from " Reg. Stratford." Winton.

P. 4. "Commissio facta sub-priori de Selebourne," by the bishop enjoining him to preserve the discipline of the order in the convent during the vacancy made by the late death of the prior, (" nuper pastoris solatio destituta,") dated 4th kal. Maii. ann. 2do sc. of his consecration. [Sc. I324.]

* Thus she survived the foundation of her chantry at Selborne fifteen years. About this lady and her mother consult Dugdale's "Baronage," i. 72, 175, I77; Dugdale's "Warwickshire," i. 383; Leland's "Itin." ii. 45.

† Stratford was Bishop of Winchester from I323 to I333, when he was translated to Canterbury. 
P. 6. "Custodia Prioratus de Seleburne vacantis," committed by the bishop to Nicholas de la _-, a layman, it belonging to the bishop, "ratione vacationis ejusdem," in July, I324, ibid. "negotium electionis de Selebourne. Acta coram Johanne Episcopo, \&c. 1324 in negotio electionis de fratre Waltero de Insula concanonico prioratus de Selebourne," lately elected by the subprior and convent, by way of scrutiny; that it appeared to the bishop, by certificate from the dean of Alton, that solemn citation and proclamation had been made in the church of the convent where the election was held that any who opposed the said election or elected should appear. Some difficulties were started, which the bishop overruled, and confirmed the election, and admitted the new prior sub hac forma :-

"In Dei nomine Amen. Ego Johannes permissione divina, \&c. te Walterum de Insula ecclesie de Selebourne nostre dioceseos nostrique patronatus vacantis, canonicum et cantorem, virum utique providum, et discretum, literarum scientia preditum, vita moribus et conversatione merito commendatum, in ordine sacerdotali et etate legitima constitutum, de legitimo matrimonio procreatum, in ordine et religione Sancti Augustini de Selebourne expresse professum, in spiritualibus et temporalibus circumspectum, jure nobis hac devoluto in hac parte, in dicte ecclesie de Selebourne perfectum priorem; curam et administrationem ejusdem tibi in spiritualibus et temporalibus committentes. Dat. apud Selebourne XIII. kalend. Augusti anno supradicto."

There follows an order to the sub-prior and convent pro obedientia :

A mandate to Nicholas above-named to release the priory to the new prior :

A mandate for the induction of the new prior. 


\section{LETTER XIV.}

"IN the year I 373 Wykeham, bishop of Winchester, held a visitation of his whole diocese; not only of the secular clergy through the several deaneries, but also of the monasteries, and religious houses of all sorts, which he visited in person. The next year he sent his commissioners with power to correct and reform the several irregularities and abuses which he had discovered in the course of his visitation.

"Some years afterward, the bishop having visited three several times all the religious houses throughout his diocese, and being well informed of the state and condition of each, and of the particular abuses which required correction and reformation, besides the orders which he had already given, and the remedies which he had occasionally applied by his commissioners, now issued his injunctions to each of them. They were accommodated to their several exigencies, and intended to ${ }^{\circ}$ correct the abuses introduced, and to recall them all to a strict observation of the rules of their respective orders. Many of these injunctions are still extant, and are evident monuments of the care and attention with which he discharged this part of his episcopal duty." *

Some of these injunctions I shall here produce; and they are such as will not fail, I think, to give satisfaction to the antiquary, both as never having been published before, and as they are a curious picture of monastic irregularities at that time.

The documents that I allude to are contained in the "Notabilis Visitatio de Seleburne," held at the priory of that place, by Wykeham in person, in the year $\mathrm{I}_{3} 87$.

This evidence, in the original, is written on two skins of parchment ; the one large, and the other smaller, and consists of a preamble, thirty-six items, and a conclusion, which altogether evince the patient investigation of the visitor, for which he had always been so remarkable in all matters of moment, and how much he had at heart the regularity of those institutions, of whose efficacy in their prayers for the dead he was so firmly persuaded. As the bishop

* See Lowth's Life of Wykeham. 
was so much in earnest, we may be assured that he had nothing in view but to correct and reform what he found amiss; and was under no bias to blacken, or misrepresent as the commissioners of Thomas Lord Cromwell seem in part to have done at the time of the Reformation.* We may therefore with reason suppose that the bishop gives us an exact delineation of the morals and manners of the canons of Selborne at that juncture; and that what he found they had omitted he enjoins them; and for what they have done amiss, and contrary to their rules and statutes, he reproves them; and threatens them with punishment suitable to their irregularities.

The visitatio is of considerable length, and cannot be introduced into the body of this work; we shall therefore refer the reader to the Appendix, where he will find every particular, while we shall take some notice, and make some remarks on the most singular items as they occur.

In the preamble the visitor says - "Considering the charge lying upon us, that your blood may not be required at our hands, we came down to visit your priory, as our office required: and every time we repeated our visitation we found something still not only contrary to regular rules but also repugnant to religion and good reputation."

In the first article after the preamble- "he commands them on their obedience, and on pain of the greater excommunication, to see that the canonical hours by night and by day be sung in their choir, and the masses of the Blessed Mary, and other accustomed masses, be celebrated at the proper hours with devotion, and at moderate pauses; and that it be not allowed to any to absent themseives from the hours and masses, or to withdraw before they are finished."

Item 2nd. He enjoins them to observe that silence to which they are so strictly bound by the rule of Saint Augustine at stated times, and wholly to abstain from frivolous conversation.

Item 4th. "Not to permit such frequent passing of secular people of both sexes through their convent, as if a thoroughfare, from whence many disorders may and have arisen."

* Letters of this sort from Dr. Layton to Thomas Lord Cromwell are still extant. 
Item 5th. "To take care that the doors of their church and priory be so attended to that no suspected and disorderly females, 'suspectæ et aliæ inhonestæ,' pass through their choir and cloister in the dark;" and to see that the doors of their church between the nave and the choir, and the gates of their cloister opening into the fields, be constantly kept shut until their first choir service is over in the morning, at dinner time, and when they meet at their evening collation.*

Item 6th mentions that several of the canons are found to be very ignorant and illiterate, and enjoins the prior to see that they be better instructed by a proper master.

Item 8th. The canons are here accused of refusing to accept of their statutable clothing year by year, and of demanding a certain specified sum of money, as if it were their annual rent and due. This the bishop forbids, and orders that the canons shall be clothed out of the revenue of the priory, and the old garments be laid by in a chamber and given to the poor according to the rule of Saint Augustine.

In Item 9 th is a complaint that some of the canons are given to wander out of the precincts of the convent without leave; and that others ride to their manors and farms, under pretence of inspecting the concerns of the society, when they please, and stay as long as they please. But they are enjoined never to stir either about their own private concerns or the business of the convent without leave from the prior: and no canon is to go alone, but to have a brave brother to accompany him.

The injunction in Item roth, at this distance of time appears rather ludicrous; but the visitor seems to be very serious on the occasion, and says that it has been evidently proved to him that some of the canons, living dissolutely after the flesh, and not after the spirit, sleep naked in their beds without their breeches and shirts, "absque femoralibus et camisiis." $\dagger \mathrm{He}$ enjoins that these

* A collation was a meal or repast on a fast-day in lieu of a supper.

$\dagger$ The rule alluded to in Item roth, of not sleeping naked, was enjoined the Knights Templars, who were also subject to the rules of St. Augu,tine. See GURTLERI Hist. Templarioin'm. 
culprits shall be punished by severe fasting, especially if they shall be found to be faulty a third time; and threatens the prior and sub-prior with suspension if they do not correct this enormity.

In Item IIth the good bishop is very wroth with some of the canons, whom he finds to be professed hunters and sportsmen, keeping hounds, and publicly attending hunting-matches. These pursuits, he says, occasion much dissipation, danger to the soul and body, and frequent expense ; he, therefore, wishing to extirpate this vice wholly from the convent, "radicibus extirpare," does absolutely enjoin the canons never intentionally to be present at any public noisy tumultuous huntings; or to keep any hounds, by themselves or by others, openly or by stealth, within the convent, or without.*

In Item I 2 th he forbids the canons in office to make their business a plea for not attending the service of the choir; since by these means either divine worship is neglected or their brother canons are over-burdened.

By Item I 4 th we are informed that the original number of canons at the Priory of Selborne was fourteen; but that at this visitation they were found to be let down to eleven. The visitor therefore strongly and earnestly enjoins them that, with all due speed and diligence, they should proceed to the election of proper persons to fill up the vacancies, under pain of the greater excommunication.

In Item $I 7$ th the prior and canons are accused of suffering, through neglect, notorious dilapidations to take place among their manorial houses and tenements, and in the walls and inclosures of the convent itself, to the shame and scandal of the institution; they are therefore enjoined, under pain of suspension, to repair all defects within the space of six months.

* Considering the strong propensity in human nature towards the pleasures of the chase, it is not to be wondered that the canons of Canterbury should languish after hunting, when from their situation so near the precincts of Wolmer Forest, the king's hounds must have been often in hearing, and sometimes in sight from their windows. If the bishop was so offended at these sporting canons, what would he have said to our modern fox-hunting divines 
Item I8th charges them with grievously burthening the said Priory by means of sales, and grants of liveries* and corrodies.t

The bishop, in Item Igth, accuses the canons of neglect and omission with respect to their perpetual chantry-services.

Item 2uth. The visitor here conjures the prior and canons not to withhold their original alms, "eleemosynas;" nor those that they were enjoined to distribute for the good of the souls of founders and benefactors; he also strictly orders that the fragments and broken victuals, both from the hall of their prior and their common refectory, should be carefully collected together by their eleemosynarius, and given to the poor without any diminution; the officer to be suspended for neglect or omission.

Item 23 rd. He bids them distribute their pittances, "pitancias," $\ddagger$ regularly on obits, anniversaries, festivals, etc.

Item $25^{\text {th. All }}$ and every one of the canons are hereby inhibited from standing godfather to any boy for the future, "ne compatres alicujus pueri de cetero fieri presumatis," unless by express license from the bishop obtained; because from such relationship favour and affection, nepotism, and undue influence, arise, to the injury and detriment of religious institutions. $\S$

* "Liberationes, or liberaturæ, allowances of corn, etc., to servants delivered at certain times, and in certain quantities, as clothes were among the allowances from religious houses to their dependents. See the corrodies granted by Croyland Abbey.-Hist. of Croyland, Appendix No. XXXIV.

"It is not improbable that the word in after-ages came to be confined to the uniform of the retainers or servants of the great, who were hence called livery servants."-Sir John Cullum's Hist. of Hawsted.

$\dagger$ A corrody is an allowance to a servant living in an abbey or priory.

$\ddagger$ Pitancia, an allowance of bread and beer, or other provision to any pious use, "especially to the religious in a monastery, \&c., for augmentation of their commons."-Gloss. to Kennet's Par. Ant.

$\S$ The relationship between sponsors and their god-children, who were called spiritual sons and daughters, was formerly esteemed much more sacred than at present. The presents at christenings were sometimes very considerable: the connexion lasted through life, and was closed with a legacy. This last mark of attention seems to have been thought almost indispensable : for, in a will from whence no extracts have been given, the testator left every one of his god-children a bushel of barley."-Sir John Cullu'm's Hist. of Hawsted.

"De Margaretæ filiæ regis primog'enitæ, quam filiolam, quia ejus in bap- 
Item 26 th. The visitor herein severely reprimands the canons for appearing publicly in what would be called in the universities an unstatutable manner, and for wearing of boots, "caligæ de Burneto, et sotularium - in ocrearum loco, ad modum sotu. larium."*

It is remarkable that the bishop expresses more warmth against this than any other irregularity; and strictly enjoins them, under pain of ecclesiastical censures, and even imprisonment if necessary (a threat not made use of before), for the future to wear boots, "ocreis seu botis," according to the regular usage of their ancient order.

Item 2 gth. He here again, but with less earnestness, forbids them foppish ornaments, and the affectation of appearing like beaux with garments edged with costly furs, with fringed gloves, and silken girdles trimmed with gold and silver. It is remarkable that no punishment is annexed to this injunction.

Item 3 ist. He here singly and severally forbids each canon not admitted to a cure of souls to administer extreme unction, or the sacrament, to clergy or laity; or to perform the service of matrimony, till he has taken out the license of the parish priest.

Item 3 2nd. The bishop says in this item that he had observed and found, in his several visitations, that the sacramental plate and cloths of the altar, surplices, etc., were sometimes left in such an uncleanly and disgusting condition as to make the beholders shudder with horror:- "Quod aliquibus sunt horrori:" + he tismo compater fuit, appellat, cyphum aureum et quadraginta libras, legavit." -ARchBishoP PARKer de Antiquitate Eccles. Brit. speaking of Archbishop Morton.

* De Fresne is copious on caligæ of several sorts, "Hoc item de Clericis, presertim beneficiatis : caligis scacatis (chequered) rubeis, et viridibus publice utentibus dicimus esse censendum." -Statut. Eccles. 7 utel. The chequered boots seem to be the highland plaid stockings. - "Burnetum, i.e. Brunetum, pannus non ex lanâ nativi coloris confectus."-"Sotularium, i.e., subtalaris, quia sub talo est. Peculium genus, quibus maxime Monachi nocte utebantur in æstate ; in hyeme vero Soccis."

This writer gives many quotations concerning Sotularia, which were not to be made too shapely; nor were the caligæ to be laced on too nicely.

+ "Men abhorred the offering of the Lord." - I Sam. ii. 17. Strange as this account may appear to modern delicacy, the author, when first in orders, 
therefore enjoins them for the future to see that the plate, cloths, and vestments, be kept bright, clean, and in decent order: and, what must surprise the reader, adds-that he expects for the future that the sacrist should provide for the sacrament good wine, pure and unadulterated; and not, as had often been the practice, that which was sour, and tending to decay:- he says farther, that it seems quite preposterous to omit in sacred matters that attention to decent cleanliness, the neglect of which would disgrace a common convivial meeting.*

Item $33^{\text {rd }}$ says that, though the relics of saints, the plate, holy vestments, and books of religious houses, are forbidden by canonical institutes to be pledged or lent out upon pawn; yet, as the visitor finds this to be the case in his several visitations, he therefore strictly enjoins the prior forthwith to recall those pledges, and to restore them to the convent; and orders that all the papers and title-deeds thereto belonging should be safely deposited, and kept under three locks and keys.

In the course of the "Visitatio Notabilis" the constitutions of Legate Ottobonus are frequently referred to. Ottobonus was afterwards Pope Adrian V., and died in 1 276. His constitutions are in "Lyndewood's Provinciale," and were drawn up in the 52 nd of Henry III.

In the "Visitatio Notabilis" the usual punishment is fasting on bread and beer; and in cases of repeated delinquency on bread and water. On these occasions quarta feria, et sexta feria, are mentioned often, and are to be understood of the davs of the week numerically on which such punishment is to be inflicted.

twice met with similar circumstances attending the sacrament at two churches belonging to two obscure villages. In the first he found the inside of the chalice covered with birds' dung; and in the other the communion-cloth soiled with cabbage and the greasy drippings of a gammon of bacon. The good dame at the great farm-house, who was to furnish the cloth, being a notable woman, thought it best to save her clean linen, and so sent a foul cloth that had covered her own table for two or three Sundays before.

"- ne turpe toral, ne sordida mappa

Corruget nares : ne non et cantharus, et lanx

Ostendat tibi te." 


\section{LETTER XV.}

THOUGH Bishop Wykeham appears somewhat stern and rigid in his visitatorial character towards the Priory of Selborne, yet he was on the whole a liberal friend and benefactor to that convent, which, like every society or individual that fell in his way, partook of the generosity and benevolence of that munificent prelate.

"In the year 1377 William of Wykeham, out of his mere good will and liberality, discharged the whole debts of the prior and convent of Selborne, to the amount of one hundred and ten marks eleven shillings and sixpence ; ${ }^{*}$ and, a few years before he died, he made a free gift of one hundred marks to the same priory : on which account the prior and convent voluntarily engaged for the celebration of two masses a day by two canons of the convent for ten years, for the bishop's welfare, if he should live so long; and for his soul if he should die before the expiration of this term." $\dagger$

At this distance of time it seems matter of great wonder to us how these societies, so nobly endowed, and whose members were exempt by their very institution from every means of personal and family expense, could possibly run in debt without squandering their revenues in a manner incompatible with their function.

Religious houses might sometimes be distressed in their revenues by fires among their buildings or large dilapidations from storms, etc. ; but no such accident appears to have befallen the priory at Selborne. Those situate on public roads, or in great towns where there were shrines of saints, were liable to be intruded on by travellers, devotees, and pilgrims ; and were subject to the importunity of the poor, who swarmed at their gates to partake of doles and broken victuals. Of these disadvantages some convents used to complain, and especially those at Canterbury; but this priory, from its sequestered situation, could seldom be subject to either of these inconveniences, and therefore we

* Yet in ten years' time we find, by the "Notabilis Visitatio," that all their selics, plate, vestments, title-deeds, etc., were in pawn.

† Lowth's Life of Wykeham. 
must attribute its frequent debts and embarrassments, well er.dowed as it was, to the bad conduct of its members, and a general inattention to the interests of the institution.

\section{LETTER XVI.}

BEAUFORT was bishop of Winchester from 1405 to 1447 ; and yet, notwithstanding this long episcopate, only tom. i. of "Beaufort's Register" is to be found. This loss is much to be regretted, as it must unavoidably make a gap in the history of Selborne Priory, and perhaps in the list of its priors.

In 14 IO there was an election for a prior, and again in $\mathbf{I} 4 \mathbf{I}$.

In vol. i., p. 24, of "Beaufort's Register," is the instrument of the election of John Wynchestre to be prior-the substance as follows :-

Richard Elstede, senior canon, signifies to the bishop that brother Thomas Weston, the late prior, died October I 8 th, I 4 ro, and was buried November I I th. That the bishop's license to elect having been obtained he and the whole convent met in the chapter-house, on the same day about the hour of vespers, to consider of the election; that brother John Wynchestre, then subprior, with the general consent, appointed the 12 th November, $a d$ horam ejusdem diei capitularem, for the business; when they met in the chapter-house, post missam de sancto Spiritu, solemnly celebrated in the church ; - to wit, Richard Elstede, Thomas Halyborne, John Lemyngton, sacrista; John Stepe, cantor; Walter Ffarnham, Richard Putworth, celerarius; Hugh London, Henry Brampton, alias Brompton; John Wynchestre, senior, John Wynchestre, junior; then "Proposito primitis verbo Dei," and then ympno "Veni Creator Spiritus" being solemnly sung, cum "versi culo et oratione," as usual, and his letter of license, with the appointment of the hour and place of election being read, alta voce, in valvis of the chapter-house; John Wynchestre, senior, the sub-prior, in his own behalf and that of all the canons, and by 
their mandate, "quasdam monicionem et protestacionem in scriptis redactas fecit, legit, interposuit "- that all persons disqualified, or not having right to be present, should immediately withdraw, and protesting against their voting, etc.; that then having read the constitution of the general council "Quia propter," and explained the modes of proceeding to election, they agreed unanimously to proceed "per viam seu formam simplicis compromissi;" when John Wynchestre, sub-prior, and all the others (ihe commissaries undernamed excepted) named and chose brothers Richard Elstede, Thomas Halyborne, John Lemyngton, the sacrist, John Stepe, chantor, and Richard Putworth, canons, to be commissaries, who were sworn each to nominate and elect a fit person to be prior, and empowered by letters patent under the common seal, to be in force only until the darkness of the night of the same day; that they, or the greater part of them, should elect for the whole convent, within the limited time from their own number, or from the rest of the convent ; that one of them should publish their consent in common before the clergy and people : they then all promised to receive as prior the person these five canons should fix on. These commissaries seceded from the chapter-house to the refectory of the Priory, and were shut in with Master John Penkester, bachelor of laws, and John Couke and John Lynne, perpetual vicars of the parish churches of Newton and Selborne, and with Sampson Maycock, a public notary, where they treated of the election; when they unanimously agreed on John Wynchestre, and appointed Thomas Halyborne to choose him in common for all, and to publish the election as customary, and returned long before it was dark to the chapter-house, where Thomas Halyborne read publicly the instrument of election; when all the brothers, the new prior excepted, singing solemnly the hymn "Te Deum laudamus," fecerunt deportari novum electum, by some of the brothers from the chapter-house to the high altar of the church ; * and the hymn being sung, dictisque versiculo et oratione consuetis in

* It seems here as if the canons used to chair their new elected prior from the chapter-house to the high altar of their Convent Church. In Letter XXI., on the same occasion it is said-"et sic canentes dictum electum ad majus altare ecclesie deduximus, ut apud nos moris est." 
hac parte, Thomas Halyborne, mox tunc ibidem, before the clergy and people of both sexes solemnly published the election in vulgari. Then Richard Elstede, and the whole convent by their proctors and nuncios appointed for the purposes, Thomas Halyborne and John Stepe, required several times the assent of the elected; "et tandem post diutinas interpellationes, et deliberationes, et deliberationem providam penes se habitam, in hac parte divine nolens, ut asseruit, resistere voluntati," within the limited time he signified his acceptance in the usual written form of words. The bishop is then supplicated to confirm their election, and do the needful, under common seal, in the chapter-house. November I 4 th, I 4 IO.

The bishop, January 6th, $14 \mathrm{IO}$, apud Esher in camera inferiori, declared the election duly made, and ordered the new prior to be inducted, for this the archdeacon of Winchester was written to; "stallumque in choro, et locum in capitulo juxta morem preteriti temporis," to be assigned to him, and everything beside necessary to be done.

\section{“Beaufort's Register," Vol. I.}

P. 2. Taxatio spiritualis Decanatus de Aulton, Ecclesia de Selebourn, cum Capella, xxx marc. decima xlib. iii. fol. Vicaria de Selebourn non taxatur propter exilitatem.

P. 9. Taxatio bonorum temporalium religiosorum in Archidiac. Wynton.

\section{Prior de Selebourn habet meneria de}

Bromdene taxat. ad . . . . . xxx s. ii d.

Apud Schete ad . . . . . . . xvii s.

P. Selebourne ad . . . . . . . vi lib.

In civitate Wynton de reddit . . . . . vi lib. viii ob.

Tannaria sua taxat ad . . . . . . x lib. s.

Summa tax. xxxviii iib. xiï: d. ob. ínäe decima. vi lib. s. q. ot. 


\section{LETTER XVII.}

INFORMATion being sent to Rome respecting the havoc and spoil that was carrying on among the revenues and lands of the Priory of Selborne, as we may suppose by the Bishop of Winchester, its visitor, Pope Martin,* as soon as the news of these proceedings came before him, issued forth a bull, in which he enjoins his commissary immediately to revoke all the property that had been alienated.

In this instrument his holiness accuses the prior and canons of having granted away (they themselves and their predecessors) to certain clerks and laymen their tithes, lands, rents, tenements, and possessions, to some of them for their lives, to others for an undue term of years, and to some again for a perpetuity, to the great and heavy detriment of the monastery; and these leases were granted, he continues to add, under their own hands, with the sanction of an oath and the renunciation of all right and claims, and under penalties, if the right was not made good.-But it will be best to give an abstract from the bull.

N. 298. Pope Martin's bull touching the revoking of certaine things alienated from the Priory of Seleburne. Pontif. sui ann. i.

“Martinus. Eps. servus servorum Dei. Dilecto filio Priori de Suthvale $\uparrow$ Wyntonien, dioc. Salutem \& apostolicam ben. Ad audientiam nostram pervenit quam tam dilecti filii prior et conventus monasterii de Seleburn per Priorem soliti gubernari ordinis $\mathrm{S}^{\text {ti }}$. Augustini Winton, dioc. quam de predecessores eorum decimas, terras, redditus, domos, possessiones, vineas, $\ddagger$ et quedam alia bona

* Pope Martin V. chosen about 1417 . He attempted to reform the church, but died in 143I, just as he had summoned the Council of Basil.

$\dagger$ Should have been no doubt Southwick, a priory under Portsdown.

$\ddagger$ Mr. Barrington is of opinion that anciently the English vinea was in almost every instance an orchard; not perhaps always of apples merely, but of other fruits; as cherries, plums, and currants. We still say a plum or cherry-orchard. -See Archroologia, vol. iii.

In the instance above, the Pope's secretary might insert vineas merely because they were a species of cultivation familiar to him in Italy. 
ad monasterium ipsum spectantia, datis super hoc litteris, inter. positis juramentis, factis renuntiationibus, et penis adjectis, in gravem ipsius monasterii lesionem nonnullis clericis et laicis, aliquibus eorum ad vitam, quibusdam vero ad non modicum tempus, \& aliis perpetuo ad firmam, vel sub censu annuo con. cesserunt; quorum aliqui dicunt super hiis a sede aplica in communi forma confirmationis litteras impetrasse. Quia vero nostra interest lesis monasteriis subvenire [He the Pope here commands] ea ad jus et proprietatem monasterii studeas legitime revocare," etc.

The conduct of the religious had now for some time been generally bad. Many of the monastic societies, being very opulent, were become voluptuous and licentious, and had deviated entirely from their original institutions. The laity saw with indignation the wealth and possessions of their pious ancestors perverted to the service of sensuality and indulgence, and spent in gratifications highly unbecoming the purposes for which they were given. A total disregard to their respective rules and discipline drew on the monks and canons a heavy load of popular odium. Some good men there were who endeavoured to oppose the general delinquency; but their efforts were too feeble to stem the torrent of monastic luxury. As far back as the year I38I, Wickliffe's principles and doctrines had made some progress, were well received by men who wished for a reformation, and were defended and maintained by them as long as they dared, till the bishops and clergy began to be so greatly alarmed, that they procured an act to be passed by which the secular arm was empowered to support the corrupt doctrines of the Church; but the first Lollard was not burnt until the year $140 \mathrm{I}$.

The wits also of those times did not spare the gross morals of the clergy, but bodily ridiculed their ignorance and profligacy. The most remarkable of these were Chaucer, and his contemporary Robert Langelande, better known by the name of Piers Plowman. The laughable tales of the former are familiar to almost every reader; while the visions of the latter are but in few hands. With a quotation from the Passus Decimus of this writer I shall conclude my letter; not only on account of the remarkalle 
prediction therein contained, which carries with it somewhat of the air of a prophecy; but also as it seems to have been a striking picture of monastic insolence and dissipation; and a specimen of one of the keenest pieces of satire now perhaps subsisting in any language, ancient or modern.

"Now is religion a rider, a romer by streate;

A leader of love-days, and a loud begger;

A pricker on a palfrey from maner to maner,

A heape of hounds at his arse, as he a lord were.

And but if his knave kneel, that shall his cope bring,

He loureth at him, and asketh him who taught him curtesie,

Little had lords to done, to give lands from her heirs,

To religious that have no ruth if it rain on her altars.

In many places ther they persons be, by himself at ease :

Of the poor have they no pity, and that is her charitie;

And they letten hem as lords, her lands lie so broad.

And there shal come a king, * and confess you religious;

And beate you, as the bible telleth, for breaking your rule,

And amend monials, and monks, and chanons,

And put hem to her penaunce ad pristinum statum ire."

* F. 1. a. "This prediction, although a probable conclusion concerning a king who after a time would suppress the religious houses, is remarkable. I imagined it might have been foisted into the copies in the reign of king Henry VIII., but it is to be found in MSS. of this poem, older than the year 1400."-fol. 1. a. b.

"Again, where he, Piers Plowman, alludes to the Knights Templars, lately suppressed, he says, -

\section{"_- Men of holie kirk}

Shall turn as Templars did; the tyme approacheth nere."

"This I suppose, was a favourite doctrine in Wickliffe's discourses." Warton's Hist. of English Poetry, vol. i. p. 282. 


\section{LETTER XVIII.}

WiLliam of Waynflete became bishop of Winchester in the year I 447, and seems to have pursued the generous plan of Wykeham in endeavouring to reform the priory of Selborne.

When Waynflete came to the see he found prior Stype, alias Stepe, still living, who had been elected as long ago as the year I 4 I I.

Among my documents I find a curious paper of the things put into the custody of Peter Bernes the sacrist, and especially some relics : the title of this evidence is "No. 50 , Indentura prioris de Selborne quorundam tradit Petro Bernes, sacrista ibidem, ann. Hen. VI. . . . . una cum confiss. ejusdem Petri script." The occasion of this catalogue or list of effects, being drawn between the prior and sacrist does not appear, nor the date when; only that it happened in the reign of Hen. VI. This transaction probably took place when Bernes entered on his office; and there is the more reason to suppose that to be the case, because the list consists of vestments and implements, and relics, such as belonged to the church of the priory, and fell under the care of the sacrist. For the numerous items I shall refer the curious reader to the Appendix, and shall just mention the relics, although they are not all specified; and the state of the live stock of the monastery at that juncture.

"Item 2. osculatōr. argent.

"Item I. osculatorium cum osse digit auriculār.-Sti. Johannis Baptiste."*

"Item I. parvam crucem cum V. reliquiis.

* How the Convent came by the bone of the little finger of St. John the Baptist does not appear: probably the founder, while in Palestine, purchased it among the Asiatics, who were at that time great traders in relics. We know from the best authority that as soon as Herod had cruelly beheaded that holy man "his disciples came and took up the body and buried it, and went and told Jesus."-Matt. iv. I2. Farther would be difficult to say. 
"Item I. anulum argent. et deauratum St. Edmunäi.*

"Item 2. osculat. de coper.

"Item r. junctorium St. Ricardi. $\uparrow$

"Item r. pecten St. Ricardi." $\ddagger$

The staurum, or live stock, is quite ridiculous, consisting only of " 2 vacce, I sus, 4 hoggett. et 4 porcsll." viz., two cows one sow, four porkers, and four pigs.

\section{LETTER XIX.}

STEPE died towards the end of the year $\mathbf{1 4 5 3}$, as we may suppose pretty far advanced in life, having been prior forty-four years.

On the very day that the vacancy happened, viz., January 26 th I 453-4, the sub-prior and convent petitioned the visitor- "vos unicum levam en nostrum, et spem unanimiter rogamus, quatinus eligendum ex nobis unum confratrem de gremio nostro, in nostra religione probatum et expertem, licenciam vestram paternalem cum plena libertate nobis concedere dignemini graciose."-Reg. Waynflete, tom. I.

Instead of the license requested we find next a commission " custodie prioratus de Selebourne durante vacatione," addressed to brother Peter Berne, canon-regular of the priory of Selebourne, and of the order of St. Augustine, appointing him keeper of the

* November 2oth, in the calendar, Edmund king and Martyr, in the 9th century. See also a Sanctus Edmundus in Godwin, among the archbishops of Canterbury, in the $13^{\text {th }}$ century; his surname Rich, in 1234.

† April 3rd, ibid. Richard Bishop of Chichester, in the 13th century, his surname De la Wich in 1245 .

Junctorium, perhaps a joint or limb of St. Richard ; but what particular joint the religious were not such osteologists as to specify. This barbarous word was not to be found in any dictionary consulted by the author.

‡ "Pecten inter ministeria sacra recensetur, quo scil. sacerdotes ac clerici, antequam in ecclesiam procederent, crines pecterent. $\mathrm{E}$ quibus colligitur monachos, tunc temporis, non omnino tonsos fuisse."-DU FRESNE.

The author remembers to have seen in great farm-houses a family comb chained to a post for the use of the hinds when they came in to their meals. 
said priory, and empowering him to collect and receive the profits and revenues and "alia bona" of the said priory; and to exercise in every respect the full power and authority of a prior; but to be responsible to the visitor finally, and to maintain this superiority during the bishop's pleasure only. This instrument is dated from the bishop's manor-house in Southwark, March Ist, 1453-4, and the seventh of his consecration.

After this transaction it does not appear that the chapter of the Priory proceeded to any election; on the contrary, we find that at six months' end from the vacancy the visitor declared that a lapse had taken place; and that therefore he did confer the priorship on canon Peter Berne-_" Prioratum vacantem et ad nostram collationem, seu provisionem jure ad nos in hac parte per lapsum temporis legitime devoluto spectantem, tibi (sc. P. Berne) de legitimo matrimonio procreato, \&c.,-conferimus," etc. This deed bears date July 28th, I 454.- -Reg. Waynflete, tom. I. p. 69.

On February 8th, 1462, the visitor issued out a power of sequestration against the priory of Selborne on account of notorious dilapidations, which threatened manifest ruin to the roofs, walls, and edifices, of the said convent; and appointing John Hammond, B.D., rector of the parish church of Hetlegh, John Hylling, vicar of the parish church of Newton Valence, and Walter Gorfin, inhabitant of the parish of Selborne, his sequestrators, to exact, collect, levy, and receive, all the profits and revenues of the said convent: he adds "ac ea sub arcto, et tuto custodiatis, custodirive faciatis ;" as they would answer it to the bishop at their peril.

In consequence of these proceedings Prior Berne, on the last day of February, and the next year, produced a state of the revenues of the Priory, No. 38I, called "A paper conteyning the value of the manors and lands pertayning to the Priory of Selborne, 4 Edward III., with a note of charges yssuing out of it."

This is a curious document, and will appear in the Appendix. From circumstances in this paper it is plain that the sequestration produced good effects ; for in it are to be found bills of repairs to a considerable amount.

By this evidence also it appears that there were at that juncture 
only four canons at the Priory ;* and that these, and their four household servants, during this sequestration for their clothing, wages, and diet, were allowed per annum xxx lib.; and that the annual pension of the lord prior, reside where he would, was to be $x$ lib.

In the year 1468 , Prior Berne, probably wearied out by the dissensions and want of order that prevailed in the convent, resigned his priorship into the hands of the bishop.-Reg. Waynflete, tom. I., pars $\mathrm{I}^{\mathrm{ma}}$, fol. $\mathbf{I} 57$.

March 28th, A.D. I468. "In quadam alta camera juxta magnam portam manerii of the Bishop of Wynton de Waltham coram eodem rev. patre ibidem tunc sedente, Peter Berne, prior of Selborne, ipsum prioratum in sacras, et venerabiles manus of the bishop, viva voce libere resignavit : and his resignation was admitted before two witnesses and a notary-public. In consequence, March 29th, before the bishop, in capella manerii sui ante dicti pro tribunali sedente, comparuerunt fratres" Peter Berne, Thomas London, William Wyndesor, and William Paynell, alias Stretford, canons regular of the priory, "capitulum, et conventum ejusdem ecclesie facientes; ac jus et voces in electione futura prioris dicti prioratus solum et in solidum, ut asseruerunt, habentes;" and after the bishop had notified to them the vacancy of a prior, with his free license to elect, deliberated awhile, and then, by way of compromise, as they affirmed, unanimously transferred their right of election to the bishop before witnesses. In consequence of this the bishop, after full deliberation, proceeded, April 7 th, "in capella manerii sui de Waltham," to the election of a prior; "et fratrem Johannem Morton, priorem ecclesie conventualis de Reygate dicti ordinis $\mathrm{S}^{\text {t? }}$. Augustini Wynton. dioc. in priorem vice et nomine omnium et singulorum canonicorum predictorum elegit, in ordine sacerdotali, et etate licita constitutum, \&c." And on the same day, in the same place, and before the same witnesses, John Morton resigned to the bishop the priorship of Reygate viva voce. The bishop then required his consent to his own election: "qui licet

* If Bishop Wykeham was so disturbed (see "Notab. Visitatio") to find the number of canons reduced from fourteen to eleven, what would he have said to have seen it diminished below one-third of that number? 
in parte renitens tanti reverendi patris se confirmans," obeyed, and signified his consent oraculo vive vocis. Then was there a mandate citing any one who would gainsay the said election to appear before the bishop or his commissary in his chapel at Farnham on the second day of May next. The dean of the deanery of Aulton then appeared before the chancellor, his commissary, and returned the citation or mandate dated April $22 \mathrm{nd}$, 1468, with signification, in writing, of his having published it as required, dated Newton Valence, May Ist, I468. This certificate being read, the four canons of Selborne appeared and required the election to be confirmed; et ex super abundanti appointed William Long their proctor to solicit in their name that he might be canonically confirmed. John Morton also appeared, and proclamation was made; and no one appearing against him, the commissary pronounced all absentees contumacious, and precluded them from objecting at any other time; and, at the instance of John Morton and the proctor, confirmed the election by his decree, and directed his mandate to the rector of Hedley and the vicar of Newton Valence to instal him in the usual form.

'Thus, for the first time, was a person, a stranger to the convent of Selborne, and never canon of that monastery, elected prior; though the style of the petitions in former elections used to run thus,-"Vos -..- rogamus quatinus eligendum ex nobis unum confratrem de gremio nostro,-licentiam vestram-nobis concedere dignemini."

\section{LETTER XX.}

Prior Morton dying in I $40 \mathrm{I}$, two canons, by themselves, proceeded to election, and chose a prior; but two more (one of them Berne) complaining of not being summoned, objected to the proceedings as informal ; till at last the matter was compromised that the bishop should again, for that turn, nominate as he had before. But the circumstances of this election will be best explained by the following extract :- 


\section{REG. WAynflete, tom. II., pars $I^{\mathrm{ma}}$, fol. 7 .}

\section{Memorandum. A.D. 1471. August 22.}

William Wyndesor, a canon-regular of the priory of Selborne, having been elected prior on the death of brother John, appeared in person before the bishop in his chapel at South Waltham. He was attended on this occasion by Thomas London and John Bromesgrove, canons, who had elected him. Peter Berne and William Stratfield, canons, also presented themselves at the same time, complaining that in this business they had been overlooked, and not summoned; and that therefore the validity of the election might with reason be called in question, and quarrels and dissensions might probably arise between the newly chosen prior and the parties thus neglected.

After some altercation and dispute they all came to an agreement with the new prior, that what had been done should be rejected and annulled; and that they would again, for this turn, transfer to the bishop their power to elect, order, and provide them another prior, whom they promised unanimously to admit.

The bishop accepted of this offer before witnesses; and on September 27 th, in an inner chamber near the chapel above-mentioned, after full deliberation, chose brother Thomas Fairwise, vicar of Somborne, a canon-regular of Saint Augustine in the priory of Bruscough, in the diocese of Coventry and Litchfield, to be prior of Selborne. The form is nearly as above in the last election. The canons are again enumerated; W. Wyndesor, sub-prior, P. Berne, T. London, W. Stratfeld, J. Bromesgrove, who had formed the chapter, and had requested and obtained license to elect, but had unanimously conferred their power on the bishop. In consequence of this proceeding, the bishop taking the business upon himself, that the priory might not suffer detriment for want of a governor, appoints the aforesaid T. Fairwise to be prior. A citation was ordered as above for gainsayers to appear October 4 th, before the bishop or his commissaries at South Waltham; but none appearing, the commissaries admitted the said Thomas, ordered him to be installed, and sent the usual letter to the convent to render him due obedience. 
Thus did the bishop of Winchester a second time appoint a stranger to be prior of Selborne, instead of one chosen out of the chapter. For this seeming irregularity the visitor had no doubt good and sufficient reasons, as probably may appear hereafter.

\section{LETTER XXI.}

Whatever might have been the abilities and disposition of Prior Fairwise, it could not have been in his power to have brought about any material reformation in the priory of Selborne, because he departed this life in the month of August, 1472, before he had presided one twelvemonth.

As soon as their governor was buried the chapter applied to their visitor for leave to choose a new prior, which being granted, after deliberating for a time, they proceeded to an election by a scrutiny. But as this mode of voting has not been described but by the mere form in the Appendix, an extract from the bishop's register, representing the manner more fully, may not be disagreeable to several readers.

WAYNEFLETE REG. tom. II. pars. ${ }^{\mathrm{ma}}$, fol. I5.

"Reverendo, \&c., ac nostro patrono graciosissimo vestri humiles, et devote obedientie filii," etc.

To the right reverend Father in God, and our most gracious patron, we, your obedient and devoted sons, William Wyndesor, president of the chapter of the priory of Selborne, and the convent of that place, do make known to your lordship, that our priorship being lately vacant by the death of Thomas Fairwise, our late prior, who died August $\mathrm{I}$ Ith, $\mathbf{1} 47_{2}$, having committed his body to decent sepulture, and having requested, according to custom, leave to elect another, and having obtained it under your seal, we, William Wyndesor, president of the convent on the 2gth August, in our chapter-house assembled, and making a chapter, taking to us in this business Richard ap Jenkyn, and Galfrid Bryan, chaplains, 
that our said priory might not by means of this vacancy incur harm or loss, unanimously agreed on August the last for the day of election; on which day, having first celebrated mass, "De sancto spiritu," at the high altar, and having called a chapter by tolling a bell about ten o' the clock, we, William Wyndesor, president, Peter Berne, Thomas London, and William Stratfeld, canons, who alone had voices, being the only canons, about ten o' the clock, first sung "Veni Creator," the letters and license being read in the presence of many persons there. Then William Wyndesor, in his own name, and that of all the canons, made solemn proclamation, enjoining all who had no right to vote to depart out of the chapter-house. When all were withdrawn except Guyllery de Lacuna, in decretis Baccalarius, and Robert Peverell, notarypublic, and also the two chaplains, the first was requested to stay, that he might direct and inform us in the mode of election; the other, that he might record and attest the transactions; and the two last that they might be witness to them.

Then, having read the constitution of the general council "Quia propter," and the forms of elections contained in it being sufficiently explained to them by De Lacuna, as well in Latin as the vulgar tongue, and having deliberated in what mode to proceed in this election, they resolved on that of scrutiny. Three of the canons, Wyndesor, Bere, and London, were made scrutators; Berne, London, and Stratfeld, choosing Wyndesor; Wyndesor, London, and Stratfeld, choosing Berne; Wyndesor, Berne, and Stratfeld, choosing London.

They were empowered to take each other's vote, and then that of Stratfeld ; "et ad inferiorem partem angularem " of the chapterhouse, "juxta ostium ejusdem declinentes," with the other persons (except Stratfeld, who stayed behind), proceeded to voting, two swearing, and taking the voice of the third, in succession, privately. Wyndesor voted first; "Ego credo Petrum Berne meliorem et utiliorem ad regimen istius ecclesie, et in ipsum consentio, ac eum nomino," etc. Berne was next sworn, and in like manner nominated Wyndesor; London nominated Berne; Stratfeld was then called and sworn, and nominated Berne.

"Quibus in scriptis redactis," by the notary public, they returned 
to the upper part of the chapter-house, where by Wyndesor "sic purecta fecerunt in communi," and then solemnly, in form written, declared the election of Berne ; when all, "antedicto nostro electo excepto, approbantes et ratificantes, cepimus decantare solemniter ' $T e$ Deum laudamus,' et sic canentes dictum electum ad majus altare ecclesie deduximus, ut apud nos est moris. Then Wyndesor electionem clero et populo infra chorum dicte ecclesie congregatis publicavit, et personam electi publice et personaliter ostendit." We then returned to the chapter-house, except our prior; and Wyndesor was appointed by the other two their proctor, to desire the assent of the elected, and to notify what had been done to the bishop ; and to desire him to confirm the election, and do whatever else was necessary. Then their proctor, before the witnesses required Berne's assent in the chapter-house; "qui quidem instanciis et precibus multiplicatis devictus," consented, "licet ndignus electus," in writing. They therefore request the bishop's confirmation of their election "sic canonice et solemniter celebrata," etc., etc. Sealed with their common seal, and subscribed and attested by the notary. Dat. in the chapter-house September $5^{\text {th }}$, I 472.

In consequence, September I Ith, I 472, in the bishop's chapel at Esher, and before the bishop's commissary, appeared W. Wyndesor, and exhibited the above instrument, and a mandate from the bishop for the appearance of gainsayers of the election there on that day ; and no one appearing, the absentees were declared contumacious and the election confirmed; and the vicar of Aulton was directed to induct and instal the prior in the usual manner.

Thus did Canon Berne, though advanced in years, reassume his abdicated priorship for the second time, to the no small satisfaction, as it may seem, of the Bishop of Winchester, who professed, as will be shown not long hence, a high opinion of his abilities and interritv. 


\section{LETTER XXII.}

As Prior Berne, when chosen in 1454 , held his priorship only to 1468, and then made a voluntary resignation, wearied and disgusted, as we may conclude, by the disorder that prevailed in his convent; it is no matter of wonder that, when re-chosen in 1472 , he should not long maintain his station; as old age was then coming fast upon him, and the increasing anarchy and misrule of that declining institution required unusual vigour and resolution to stem that torrent of profligacy which was hurrying it on to its dissolution. We find, accordingly, that in 1478 he resigned his dignity again into the hands of the bishop.

\section{WAYNFLETE REG. fol. 55.}

Resignatio Prioris de Seleborne.

May I4, I 478. Peter Berne resigned the priorship. May I6, the bishop admitted his resignation "in manerio suo de Waltham," and declared the priorship void ; "et priorat. solacio destitutum esse ;" and granted his letters for proceeding to a new election; when all the religious, assembled in the chapter-house, did transfer their power under their seal to the bishop, by the following public instrument.

"In Dei nomine Amen," etc. A.D. I478, Maii 19. In the chapter-house for the election of a prior for that day, on the free resignation of Peter Berne, having celebrated in the first place mass at the high altar "De spiritu sancto," and having called a chapter by tolling a bell, ut moris est; in the presence of a notary and witnesses appeared personally Peter Berne, Thomas Ashford Stephen Clydgrove, and John Ashton, presbyters, and Henry Canwood,* in chapter assembled; and after singing the hymn

* Here we see that all the canons were changed in six years; and that there was quite a new chapter, Berne excepted, between $\mathbf{I} 472$ and $\mathbf{I} 478$; for, instead of Wyndesor, London, and Stratfeld, we find Ashford, Clydgrove, Ashton, and Canwood, all new men, who were soon gone in their turn off the stage, and are heard of no more. For, in six years after, there seem to have been no canons at all. 
" 'Veni Creator Spiritus,' cum versiculo et oratione 'Deus qui corda ;' declaratque licentia Fundatoris et patroni ; futurum priorem eligendi concessa, et constitutione consilii generalis que incipit 'Quia propter' declaratis: viisque per quas possent ad hanc electionem procedere," by the decretorum doctorem, whom the canons had taken to direct them-they all and every one "dixerunt et affirmarunt se nolle ad aliquam viam procedere;"-but for this turn only, renounced their right, and unanimously transferred their power to the bishop, the ordinary of the place, promising to receive whom he should provide; and appointed a proctor to present the instrument to the bishop under their seal ; and required their notary to draw it up in due form, etc., subscribed by the notary.

After the visitor had fully deliberated on the matter, he proceeded to the choice of a prior, and elected, by the following instrument, John Sharp, alias Glastenbury.

\section{Fol. 56. Provisio Prioris per EPM.}

Willmus, etc., to our beloved brother in Christ, John Sharp, alias Glastenbury, Ecclesie conventualis de Bruton, of the order of St. Austin, in the diocese of Bath and Wells, canon-regular-salutem, etc., "De tue circumspectionis industria plurimum confidentes, te virum providum et discretum, literarum scientia, et moribus merito commendandum," etc.-do appoint you prior-under our seal. "Dat in manerio nostro de Suthwaltham, May 20," 1478, "et nostre Consec. 3r."

Thus did the bishop, three times out of the four that he was at liberty to nominate, appoint a prior from a distance, a stranger to the place, to govern the convent of Selborne, hoping by this method to have broken the cabal, and to have interrupted that habit of mismanagement that had pervaded the society; but he acknowledges, in an evidence lying before us, that he never did succeed to his wishes with respect to those late governors,-- "quos tamen male se habuisse, et inutiliter administrare, et administrasse usque ad presentia tempora post debitam investigationem, etc., invenit." The only time that he appointed from among the canons, he made 
choice of Peter Berne, for whom he had conceived the greatest esteem and regard.

When Prior Berne first relinquished his priorship, he returned again to his former condition of canon, in which he continued for some years; but when he was re-chosen, and had abdicated a second time, we find him in a forlorn state, and in danger of being reduced to beggary, had not the Bishop of Winchester interposed in his favour, and with great humanity insisted on a provision for him for life. The reason for this difference seems to have been, that, in the first case, though in years, he might have been hale and capable of taking his share in the duty of the convent; in the second he was broken with age, and no longer equal to the functions of a canon.

Impressed with this idea, the bishop very benevolently interceded in his tavour, and laid his injunctions on the new-elected prior in the following manner:

Fol. 56. "In Dei nomine Amen. Nos Willmus, \&c., considerantes Petrum Berne," late prior, "in administratione spiritualium et temporalium prioratus laudabiliter vixisse et rexisse ; ipsumque senio et corporis debilitate confractum; ne in opprobrium religionis mendicari cogatur; - -idem annuam pensionem a Domino Johanne Sharpe, alias Glastonbury, priore moderno," and his successors, and, from the priory or church, to be paid every year during his life, "de voluntate et ex consensu expressis" of the said John Sharp, "sub ea que sequitur forma verborumassignamus :"

Ist. That the said prior and his successors, for the time being, honeste exhibebunt of the fruits and profits of the priorship, "eidem esculenta et poculenta," while he remained in the priory, "sub consimili portione eorundem prout convenientur priori," for the time being, ministrari contigerit; and in like manner uni famulo, whom he should choose to wait on him, as to the servientibus of the prior.

Item. "Invenient seu exhibebunt eidem unam honestam cameram," in the priory, "cum socalibus necessariis seu opportunis ad eundem."

Item. We will, ordain, etc., to the said P. Berne an annual 
pension of ten marks, from the revenue of the priory, to be paid by the hands of the prior quarterly.

The Bishop decrees farther, that John Sharp, and his successors, shall take an oath to observe this injunction, and that before their installation.

"Lecta et facta sunt hæc in quodam alto oratorio," belonging to the bishop at Suthwaltham, May 25 th, 1478 , in the presence of John Sharp, who gave his assent, and then took the oath before witnesses, with the other oaths before the chancellor, who decreed he should be inducted and installed, as was done that same day.

How John Sharp, alias Glastonbury, acquitted himself in his priorship, and in what manner he made a vacancy, whether by resignation, or death, or whether he was removed by the visitor, does not appear; we only find that some time in the year I 484 there was no prior, and that the bishop nominated Canon Ashford to fill the vacancy.

\section{LETTER。XXIII.}

THrs Thomas Ashford was most undoubtedly the last prior of Selborne; and, therefore, here will be the proper place to say something concerning a list of the priors, and to endeavour to improve that already given by others.

At the end of Bishop Tanner's "Notitia Monastica," the folio edition, among Brown Willis's "Principals of Religious Houses," occur the names of eleven of the priors of Selborne, with dates. But this list is imperfect, and particularly at the beginning; for though the priory was founded in 1232 , yet it commences with Nich. de Cantia, elected in 1262 , so that, for the first thirty years, no prior is mentioned; yet there must have been one or more. We were in hopes that the register of Peter de Rupibus would have rectified this omission; but, when it was examined, no information of the sort was to be found. From the year 14ro the 
list is much corrected and improved, and the reader may depend on its being thenceforward very exact.

A list of the Priors of Selborne Priory, from Brown Willis's "Principals of Religious Houses," with additions within [ ] BY the AUthor.

[John . . . . was prior, sine dat.]*

Nich. de Cantia el. . . . . . . . I262

[Peter — was prior in . . . . . . I $27 \mathrm{I}]$

[Richard — was prior in . . . . . . . I280]

Will. Basing was prior in. . . . . . . 1299

Walter de Insula el. in . . . . . . . . . $\mathrm{r}^{224}$

[Some difficulties and a devolution; but the election confirmed by Bishop Stratford.]

John de Wintōn

Thomas Weston . . . . . . . . . . I377

John Winchester, [Wynchestre] . . . . . . I4IO

[Elected by Bishop Beaufort "per viam vel

formam simplicis compromissi."]

[John Stype, alias Stepe, in . . . . . . . . I4II]

Peter Bene [alias Berne or Bernes, appointed

keeper, and, by lapse to Bishop Waynflete,

prior] in . . . . . . . . . . . . . 1454

[He resigns in $\mathbf{1} 468$.

John Morton [Prior of Reygate] in . . . . 1468

[The canons by compromise transfer the power of election to the bishop.]

Will. Winsor [Wyndesor, prior for a few days] . . I47 I

[But removed on account of an irregular election.]

Thomas Farwill [Fairwise, vicar of Samborne]. . I $47 \mathrm{I}$

[By compromise again elected by the bishop.]

[Peter Berne, re-elected by scrutiny in . . . 1472]

[Resigns again in 1478 .]

* See, in Letter XI. of these Antiquities, the reason why Prior John . . . . who had transac.ions with the Knights Templars, is placed in the list before the year $\mathbf{1 2 6 2 .}$ 
John Sharper [Sharp], alias Glastonbury . . . . 1478

[Canon-reg. of Bruton, elected by the bishop

by compromise.]

[Thomas Ashford, canon of Selborne, last prior elected by the Bishop of Winchester, some time in the year . . . . . . . . . . . . . 1484 And deposed at the dissolution.]

\section{LETTER XXIV.}

Bishop Waynflete's efforts to continue the Priory still proved unsuccessful ; and the convent, without any canons, and for some time without a prior, was tending swiftly to its dissolution.

When Sharp's alias Glastonbury's priorship ended does not appear. The bishop says that he had been obliged to remove some priors for mal-administration; but it is not well explained how that could be the case with any unless with Sharp, because all the others chosen during his episcopate died in their office,viz., Morton and Fairwise ; Berne only excepted, who relinquished twice voluntarily, and was, moreover, approved of by Waynflete as a person of integrity. But the way to show what ineffectual pains the bishop took, and what difficulties he met with, will be to quote the words of the libel of his proctor, Rudolphus Langley, who appeared for the bishop in the process of the impropriation of the Priory of Selborne. The extract is taken from an attested copy.

"Item-that the said bishop, dicto prioratui et personis ejusdem pie compatiens, sollicitudines pastorales, labores, et diligentias gravissimas quam plurimas, tam per se quam per suos, pro reformatione premissorum impendebat; et aliquando illius loci prioribus, propter malam et inutilem administrationem, et dispensationem bonorum predicti prioratus, suis demeritis exigentibus, amotis; alios priores in quorum circumspectione et diligentia confidebat, prefecit; quos tamen male se habuisse ac inutiliter administrare, et administrasse, usque ad presentia tempora post 
debitam investigationem, \&c., invenit." So that he despaired with all his care: "statum ejusdem reparare vel restaurare:; et considerata temporis malicia, et preteritis timendo et conjecturando futura, de aliqua bona et sancta religione ejusdem ordinis, \&c., juxta piam intentionem primevi fundatoris ibidem habend. desperatur."

William Wainfleet, Bishop of Winchester, founded his college of Saint Mary Magdalene, in the University of Oxford, in or about the year 1459; but the revenues proving insufficient for so large and noble an establishment, the college supplicated the founder to augment its income by putting it in possession of the estates belonging to the Priory of Selborne, now become a deserted convent, without canons or prior. The president and fellows state the circumstances of their numerous institutions and scanty provision, and the ruinous and perverted condition of the Priory. The bishop appoints commissaries to inquire into the state of the said monastery ; and, if found expedient, to confirm the appropriation of it to the college, which soon after appoints attorneys to take possession, September 24 th, I 484 . But the way to give the reader a thorough insight respecting this transaction, will be to transcribe a farther proportion of the process of the impropriation, from the beginning, which will lay open the manner of proceeding, and show the consent of the parties.

\section{IMPROPRIATIO SELBORNE, 1485.}

"Universis sancte matris ecclesie filiis, \&c. Ricardus Dei gratia prior ecclesie conventualis de Novo Loco, \&c., ${ }^{*}$ ad universitatem vestre notitie deducimus, \&c., quod coram nobis commissario predicto in ecclesia parochiali $S^{\text {it }}$ Georgii de Esher

* Ecclesia Conventualis de Novo Loco was the monastery afterwards called the New Minster, or Abbey of Hyde, in the city of Winchester. Should any intelligent reader wonder to see that the prior of Hyde Abbey was commissary to the Bishop of Winton, and should conclude that there was a mistake in titles, and that the abbot must have been here meant; he will be pleased to recollect that this person was the second in rank ; for, " next under the abbot, in every abbey, was the prior."-Pref. to Notit. Monast., p. 29. Besides, abbots were great personages, and too high in station to submit to any office under the bishop. 
Dict. Winton. dioc. $3^{\circ}$. die Augusti, A.D. 1485: Indictione tertia pontificat. Innocenti 8 ann. $\mathrm{I}^{\mathrm{m} .}$. judicialiter comparuit venerabilis vir Jacobus Preston, S. T. P. infrascriptus, et exhibuit literas comissionis-quas quidem per magistrum Thomam Somercrotes notarium publicum, \&c., legi fecimus, tenorem sequentem in se continentes." The same as in No. 103, but dated-"In manerio nostro de Esher, Augusti I . A.D. I485, et nostre confec. anno. 39." [No $\mathrm{IO}_{3}$ is repeated in a book containing the like process in the preceding year by the same commissary, in the parish church of St. Andrew the Apostle, at Farnham, Sept. 6th, anno I 434.] "Post quarum literarum lecturam-dictus magister Jacobus Preston, quasdam procuratorias literas mag. Richardi Mayhewe presidentis, ut asseruit, collegii beate Marie Magdalene, \&c., sigillo rotundo communi, \&c., in cera rubea impresso sigillatas realiter exhibuit, \&c., et pro eisdem $\overline{\text { dnis suis }}$ \&c., fecit se partem, ac nobis supplicavit ut juxta formam in eisdem traditam procedere dignaremur," \&c. After these proclamations no contradictor or objector appearing- "ad instantem petitionem ipsius mag. Jac. Preston, procuratoris, \&c., procedendum fore decrevimus vocatis jure vocandis; nec non mag. Tho. Somercotes, \&c., in actorum nostrorum scribam nominavimus. Consequenter et ibidem tunc comparuit magister Michael Clyff, \&c., et exhibuit in ea parte procuratorium suum," for the prior and convent of the cathedral of Winton, "et fecit se partem pro eisdem. Deinde comperuit coram nobis, \&c., honestus vir Willmus Cowper," proctor for the bishop as patron of the Priory of Selborne, and exhibited his "procuratorium," \&c. After these were read in the presence of Clyff and Cowper, "Preston, viva voce," petitioned the commissary to annex and appropriate the Priory of Selborne to the college- "propter quod fructus, redditus, et proventus ejusdem coll. adeo tenues sunt, et exiles, quod ad sustentationem ejus, \&c., non sufficiunt." The commissary, "ad libellandum et articulandum in scriptis,"-adjourned the court to the $5^{\text {th }}$ August, then to be held again in the parish church of Esher.

W. Cowper being then absent, Radulphus Langley appeared for the bishop, and was admitted his proctor. Preston produced his libel or article in scriptis for the union, \&c. ; "et admitti petiit 
eundem cum effectu; cujus libelli tenor sequitur.-In Dei nomine, Amen. Coram nobis venerabili in Christo patre Richardo, priore, \&c., de Novo Loco, \&c., commissario, \&c." Part of the College of Magd. dicit. allegat, and in his "scriptis proponit," \&c.

"Imprimis - that said college consists of a president and eighty scholars, besides sixteen choristers, thirteen servientes inibi altissimo famulantibus, et in scientiis plerisque liberalibus, presertim in sacra theologia studentibus, nedum ad ipsorum presidentis et scholarium pro presenti et imposterum, annuente deo, incorporandorum in eodem relevamen; verum etiam ad omnium et singulorum tam scholarium quam religiosorum cujuscunque ordinis undequaque illuc confluere pro salubri doctrina volentium utilitatem multiplicem ad incrementa virtutis fideique catholice stabilimentum. Ita videlicet quod omnes et singuli absque personarum seu nationum delectu illuc accedere volentes, lecturas publicas et doctrinas tam in grammatica in loco ad collegiun contiguo, ac philosophiis morali, et naturali quam in sacra theologia in eodem collegio perpetuis temporibus continuandas libere atque gratis audire valeant et possint, ad laudem gloriam et honorem Dei, \&c., extitit fundatum et stabilitum."

For the first item in this process see the beginning of this letter. Then follows item the second- "that the revenues of the college non sufficiunt his diebus." "Item-that the premises are true, \&c., et super eisdem laborarunt, et laborante publica vox et fama. Unde facta fide petit pars eorundem that the priory be annexed to the college : ita quod dicto prioratu vacante liceat iis ex tunc to take possession, \&c." This libel, with the express consent of the other proctors, we, the commissary, admitted, and appointed the 6th August for proctor Preston to prove the premisses.

Preston produced witnesses, W. Gyfford, S.T.P., John Nele, A.M., John Chapman, chaplain, and Robert Baron, literatus, who were admitted and sworn, when the court was prorogued to the 6th August; and the witnesses, on the same 5th August, were examined by the commissary, "in capella infra manerium de Essher situata secrete et singillatim." Then follow the "literæ procuratoriæ:" first that of the college, appointing Preston and Langport their proctors, dated August 3 oth, I 484 ; then that of 
the prior and convent of the cathedral of Winton, appointing David Husband and Michael Cleve, dated September 4th, I 484 then that of the bishop, appointing W. Gyfford, Radulphus Langley and Will. Cowper, dated September 3rd, I484. Consec. $38^{\circ}$.- "Quo die adveniente in dicta ecclesia parochiali," appeared, "coram nobis," James Preston to prove the contents of his libel, and exhibited some letters testimonial with the seal of the bishop, and these were admitted; and consequenter Preston produced two witnesses, viz., Dominum Thomam Ashforde, nuper priorem dicti prioratus, et Willm. Rabbys, literatum, who were admitted and sworn, and examined as the others, by the commissary; "tunc \& ibidem assistente scriba secrete \& singillatim"; and their depositions were read and made public, as follows :-

Mr. W. Gyfford, S. T. P., aged 57, of the state of Magd. Coll. etc., etc., as before.

Mr. John Nele, aged 57 , proves the articles also.

Robert Baron, aged 56.

Johannes Chapman, aged 35, also affirmed all the five articles.

Dompnus Thomas Ashforde, aged 72 years-" dicit $2^{\text {dum }} \cdot 3^{\text {um }}$. $4^{\mathrm{u}^{\mathrm{m}}}$. articulos in eodem libello contentos, concernentes statum dicti prioratus de Selbourne, fuisse et esse veros."

W. Rabbys, ætat 40 ann., agrees with Gyfford, etc.

Then follows the letter from the bishop, "in subsidium probationis," above-mentioned-“W "Willmus, \&c., salutem, \&c., noverint universitas vestra, quod licet nos prioratui de Selbourne, \&c. pie compacientes sollicitudines pastorales, labores, diligentias quam plurimas per nos \& commissarios nostros pro reformatione status ejus impenderimus, justicia id poscente ; nihilominus tamen," etc., as in the article-to "desperatur," dated "in manerio nostro de Esher, Aug. 3d, 1485 , \& consec. 39." Then on the 6th August, Presto $\mathrm{n}$, in the presence of the other proctors, required that they should be compelled to answer; when they all allowed the articles, "fuisse \& esse vera ;" and the commissary, at the request of Preston, concluded the business, and appointed Monday, August 8th, for giving his decree in the same church of Esher, and it was that day read, and contains a recapitulation, with the sentence of union, etc., witnessed and attested. 
As soon as the president and fellows of Magdalen College had obtained the decision of the commissary in their favour, they proceeded to supplicate the Pope, and to entreat His Holiness that he would give his sanction to the sentence of union. Some difficulties were started at Rome; but they were surmounted by the college agent, as appears by his letters from that city. At length Pope Innocent VIII., by a bull* bearing date 8th June, in the year of our Lord 1486, and in the second year of his pontificate, confirmed what had been done, and suppressed the convent.

Thus fell the considerable and well-endowed priory of Selborne after it had subsisted about two hundred and fifty-four years; about seventy-four years after the suppression of priories alien by Henry V., and about fifty years before the general dissolution of monasteries by Henry VIII. The founder, it is probable, had fondly imagined that the sacredness of the institution, and the pious motives on which it was established, might have preserved it inviolate to the end of time-yet it fell-

"To teach us that God attributes to place

No sanctity, if none be thither brought

By men, who there frequent, or therein dwell."

Milton's Paradise Lost.

\section{LETTER XXV.}

WAINFLEET did not long enjoy the satisfaction arising from this new acquisition; but departed this life in a few months after he had effected the union of the priory with his late founded college; and was succeeded in the see of Winchester, by Peter Courtney, some time towards the end of the year $\mathbf{I} 486$.

* There is nothing remarkable in this bull of Pope Innocent, except the statement of the annual revenue of the Priory of Selhorne, which is therein estimated at 160 flor. auri ; whereas Bishop Godwin sets it at $£ 337$ 15s. $6 \frac{1}{4} d$. Now a floren, so named, says Camden, because made by Florentius, was a gold coin of King Edward III., in value $6 s$., whereof 160 is not one-seventh part of $£ 337$ 15s. 61: 
In the beginning of the following year, the new bishop released the president and fellows of Magdalen College from all actions respecting the priory of Selborne; and the priory and convent of Saint Swithun, as the chapter of Winchester cathedral, confirmed the release.*

N. 293. "Relaxatio Petri êpi Wintōn, Ricardo Mayew, Presidenti omnium actionum occasione indempnitatis sibi debite pro unione Prioratus de Selborne dicto collegio. Jan. 2. 1487 , et translat. anno $\mathrm{I}^{\circ} . "$

N. 374. "Relaxatio prioris et conventus Sti. Swithini Wintōn confirmans relaxationem Petri ep. Wintōn." I487., Jan. I3.

Ashforde, the deposed prior, who had appeared as an evidence for the impropriation of the priory at the age of seventy-two years, that he might not be destitute of a maintenance, was pensioned by the college to the day of his death; and was living on till 1490 , as appears by his acquittances.

\section{REG. A. ff. 46.}

"Omnibus Christi fidelibus ad quos presens scriptum pervenerit, Richardus Mayew, presidens, \&c. et scolares, salutem in Domino.

"Noveritis nos prefatos presidentem et scolares, dedisse, concessisse, et hoc presenti scripto confirmasse Thome Ashforde, capellano, quendam annualem redditum sex librarum tresdecim solidorum et quatuor denariorum bone et legalis monete Angliead terminum vite prefati Thome"- to be paid from the possessions of the college in Basingstoke.- "In cujus rei testimonium sigillum nostrum commune presentibus apponimus. Dat. Oxon. in coll. nostro supra dicto primo die mensis Junii anno regis Ricardi tertii secundo," viz. 1484. The college, in their grant to Ashforde, style him only capellanus; but the annuitant very naturally, and with a becoming dignity, asserts his late title in his acquittances, and identifies himself by the addition of the nuper priorem, or late prior.

As, according to the persuasion of the times, the depriving the founder and benefactors of the priory of their masses and services

* The Bishops of Winchester were patrons of the Priory. 
would have been deemed the most impious of frauds, Bishop Wainfleet, having by statute ordained four obits for himself to be celebrated in the chapel of Magdalen College, enjoined in one of them a special collect for the anniversary of Peter de Rupibus, with a particular prayer-" Deus Indulgentiarum."

The college also sent Nicholas Langrish, who had been a chantry priest at Selborne, to celebrate mass for the souls of all that had been benefactors to the said priory and college, and for all the faithful who had departed this life.

N. 356. Thomas Knowles, presidens, etc._" damus et concedimus Nicholao Langrish quandum capellaniam, vel salarium, sive alio quocunque nomine censeatur, in prioratu quondam de Selborne pro termino 40 annorum, si tam diu vixerit. Ubi dictus mag. Nicholaus celebrabit pro animabus omnium benefactorum dicti prioratus et coll. nostri, et omnium fidelium defunctorum. Insuper nos, \&c. concedimus eidem ibidem celebranti in sustentationem suam quandam annualem pensionem sive annuitatem octo librarum, \&c.-in dicta capella dicti prioratus-concedimus duas cameras contiguas ex parte boreali dicte capelle, cum una coquina, et cum uno stabulo conveniente pro tribus equis, cum pomerio eidem adjacente voc. le Orcheyard-Preterea 26s. 8d. per ann. ad inveniendum unum clericum ad serviendum sibi ad altare, et aliis negotiis necessariis ejus."-His wood to be granted him by the president on the progress.-He was not to absent himself beyond a certain time; and was to superintend the coppices, wood, and hedges.-Dat. $5^{\text {to }}$. die Julii. an ${ }^{\circ}$. Hen. VIII ${ }^{\text {vi. }}$ $36^{\circ}$." [viz. I 546.]

Here we see the priory in a new light, reduced, as it were, to the state of a chantry, without prior and without canons, and attended only by a priest, who was also a sort of bailiff or woodman, his assistant clerk, and his female cook. Owen Oglethorpe, president, and Magd. Coll. in the fourth year of Edward VI., viz. I $55 \mathrm{I}$, granted an annuity of ten pounds a year for life to Nich. Langrish, who, from the preamble, appears then to have been fellow of that society: but, being now superannuated for business, this pension is granted him for thirty years, if he should live so long. It is said of him-" cum jam sit provectioris etatis qua mut," etc. 
Laurence Stubb, president of Magd. Coll., leased out the priory lands to John Sharp, husbandman, for the term of twenty years, as early as the seventeenth year of Henry VIII., viz., 1526 : and it appears that Henry Newlyn had been in possession of the lease before, probably towards the end of the reign of Henry VII. Sharp's rent was $\mathrm{vi}^{\mathrm{il}}$. per ann.-Regist. B. p. 43.

By an abstract from a lease lying before me, it appears that Sharp found a house, two barns, a stable, and a duf-house [dove-house] built, and standing on the south side of the old priory, and late in the occupation of Newlyn. In this abstract also are to be seen the names of all the fields, many of which continue the same to this day.* Of some of them I shall take notice, where anything singular occurs.

And here first we meet with Paradyss [Paradise] mede. Every convent had its paradise; which probably was an enclosed orchard, pleasantly laid out, and planted with fruit-trees. Tylehouse grove, so distinguished from having a tiled house near it. $\dagger$ Butt-wood close ; here the servants of the priory and the villageswains exercised themselves with their long bows, and shot at a mark against a butt, or bank. -Cundyth [conduit] wood : the engrosser of the lease not understanding this name, has made a strange barbarous word of it. Conduit wood was and is a steep, rough cow-pasture, lying above the priory, at about a quarter of a mile to the south-west. In the side of this field there is a spring

* It may not be amiss to mention here that various names of tithings, farms, fields, woods, etc., which appear in the ancient deeds, and evidences of several centuries standing, are still preserved in common use with little or no variation:- -as Norton, Southington, Durton, Achangre, Blackmore, Bradshot, Rood, Plestor, etc., etc. At the same time it should be acknowledged that other places have entirely lost their original titles, as le Buri and Trucstede in this village; and la Liege, or la Lyge, which was the name of the original site of the Priory, etc.

$\dagger$ Men at first heaped sods, or fern, or heath, on their roofs to keep off the inclemencies of weather; and then by degrees laid straw or haum. The first refinements on roofing were shingles which are very ancient. Tiles are a late and imperfect covering, and were not much in use till the beginning of the sixteenth century. The first tiled house at Nottingham was in 1503.

$\ddagger$ There is also a Butt-close just at the back of the village. 
of water that never fails; at the head of which a cistern was built which communicated with leaden pipes that conveyed water to the monastery. When this reservoir was first constructed does not appear; we only know that it underwent a repair in the episcopate of Bishop Wainfleet, about the year r $462 .^{*}$ Whether these pipes only conveyed the water to the priory for common and culinary purposes, or contributed to any matters of ornament and elegance, we shall not pretend to say; nor when artists and mechanics first understood anything of hydraulics, and that water confined in tubes would rise to its original level. There is a person now living who had been employed formerly in digging for these pipes, and once discovered several yards, which they sold for old lead.

There was also a plot of ground called Tan-house garden : and "Tannaria sua," a tan-yard of their own, has been mentioned in Letter XVI. This circumstance I just take notice of, as an instance that monasteries had trades and occupations carried on within themselves. $\dagger$

Registr. B., p. Ir2. Here we find a lease of the parsonage of Selborne to Thomas Sylvester and Miles Arnold, husbandmenof the tythes of all manner of corne pertaining to the parsonagewith the offerings at the chapel of Whaddon belonging to the said parsonage. Dat. June r. $27^{\text {th }}$. Hen. $8^{\text {th }}$. [viz. 1536.$]$

As the chapel of Whaddon has never been mentioned till now, and as it is not noticed by Bishop Tanner in his "Notitia Monastica," some more particular account of it will be proper in this place. Whaddon was a chapel of ease to the mother church of Selborne, and was situated in the tithing of Oakhanger, at about two miles distance from the village. The farm and field whereon it stood are still called chapel farm and field : $\ddagger$ but there are no remains or traces of the building itself, the very

* N. 38r. "Clausure terre abbatie ecclesie parochiali de Seleburne, ixs. iiiid. Reparacionibus domorum predicti prioratus iiii. lib. xis. Aque conduct. ibidem. xxiiid."

$\dagger$ There is still a wood near the Priory, called Tanner's wood.

+ This is a manor-farm, at present the property of Lord Stawell; and belonged probably in ancient times to Jo. de Venur, or Venuz, one of the first benefactors to the Priory. 
foundations having been destroyed before the memory of man. In the farmyard at Oakhanger we remember a large hollow stone, of a close substance, which had been used as a hog-trough, but was then broken. This stone, tradition said, had been the baptismal font of Whaddon chapel. The chapel had been in a very ruinous state in old days; but was new-built at the instance of Bishop Wainfleet, about the year $\mathrm{I}_{4} 6_{3}$, during the first priorship of Berne, in consequence of a sequestration issued forth by that visitor against the priory on account of notorious and shameful dilapidations.*

The Selborne rivulet becomes of some breadth at Oakhanger, and, in very wet seasons, swells to a large flood. There is a bridge over the stream at this hamlet of considerable antiquity and peculiar shape, known by the name of Tunbridge : it consists of one single blunt Gothic arch, so high and sharp as to render the passage not very convenient or safe. Here was also, we find, a bridge in very early times; for Jacobus de Hochangre, the first benefactor to the priory of Selborne, held his estate at Hochangre by the service of providing the king one foot-soldier for forty days, and by building this bridge. "Jacobus de Hochangre tenet Hochangre in com. Southampton, per Serjantiam, $\uparrow$ inveniendi unum valectum in exercitu Domini regis [scil. Henrici III ${ }^{\text {tii }}$ ] per 40 dies; et ad faciendum pontem de Hochangre : et valet per ann. C. s."-“"Blount's Ancient Tenures," p. 84.

A dove-house was a constant appendant to a manerial divelling: of this convenience more will he said hereafter.

A corn-mill was also esteemed a necessary appendage of every manor; and therefore was to be expected of course at the priory of Selborne.

The prior had secta molendini, or ad molendinum; a power of

* See Letter XIX. of these Antiquities. - "Summa total. solut. de novis edificationibus, et raparacionibus per idem tempus, ut patet per comput."

"Videlicet de nova edificat. Capelle Marie de Wadden. xiiii. lib. vs. viii $d$. - Reparacionibus ecclesie Prioratus, cencellor. et capellar. ecclesiarum et capellarum de Selborne, et Estworhlam."-etc., etc.

† Sargentia, a sort of tenure of doing something for the king.

$\ddagger$ "Servitium, quo feudatorii grana sua ad Domini molendinum, ibi molenda perferre, ex consuetidine, astringuntur." 
compelling his vassals to bring their corn to be ground at his mill according to an old custom. He had also, according to Bishop Tanner, secta molendini de strete; but the purport of strete, we must confess, we do not understand. Strete, in old English, signifies a road or highway, as Watling Strete, etc., therefore the prior might have some mill on a high road. The priory had only one mill originally at Selborne; but, by grants of lands, it came possessed of one at Durton, and one at Oakhanger, and probably some on its other several manors.* The mill of the priory was in use within the memory of man, and the ruins of the mill-house were standing within these thirty years : the pond and dam, and miller's dwelling still remain. As the stream was apt to fail in very dry summers, the tenants found their situation very distressing, for want of water, and so were forced to abandon the spot. This inconvenience was probably never felt in old times, when the whole district was nothing but woodlands : and yet several centuries ago there seem to have been two or three mills between Well Head and the priory. For the reason of this assertion, see Letter XXIX. to Mr. Barrington.

Occasional mention has been made of the many privileges and immunities enjoyed by the convent and its priors; but a more particular state seems to be necessary. The author, therefore, thinks this the proper place, before he concludes these antiquities, to introduce all that has been collected by the judicious Bishop Tanner, respecting the priory and its advantages, in his "Notitia Monastica," a book now seldom seen, on account of the extravagance of its price, and being but in few hands cannot be easily consulted. $t \mathrm{He}$ also adds a few of its many privileges from other authorities:- the account is as follows. Tanner, page $\mathbf{1} 66$.

* Thomas Knowles, president, etc. ann. Hen. 8vi. xxiii ${ }^{\circ}$ [ [1532] demised to J. Whitelie their mills, etc., for twenty years. Rent xxiiis. iiiid.-Accepted Frewen, president, etc. ann. Caroli xv. [viz. 1640.] demised to Jo. Hook and Elizabeth his wife, the said mills. Rent as above.

† A few days after this was written a new edition of this valuable work was announced, in the month of April of the year 1787, as published by Mr. Nasmith. 


\section{SELBURNE.}

A priory of black canons, founded by the often-mentioned Peter de Rupibus, Bishop of Winchester, A. D. 1233, and dedicated to the blessed Virgin Mary; but was suppressed, and granted to William Wainfleet, Bishop of Winchester, who made it part of the endowment of St. Mary Magdalene College in Oxford. The Bishops of Winchester were patrons of it. [Pat. I 7, Edward II.] Vide. Mon. Ang. tom ii. p. 343. "Cartam fundationis ex ipso autographo in archivis Coll. Magd. Oxōn. ubi etiam conservata sunt registra, cartæ, rentali et alia munimenta ad hunc prioratum spectantia.

" Extracta qu ædam e registro MSS. in bibl. Bodl.-Dodworth vol. 89 , f. 140 .

"Cart. antiq. N. N. n. 33. P. P. n. 48. et. 7 r. Q. Q. n. 40. plac. coram justit. itin. [Southampton] 20. Hen. rot. 25. De eccl, de Basing \& Basingstoke. Plac. de juratis apud Winton. 40 Hen. III. rot.-Protecta molendini de Strete. Cart. 54. Hen. III. m. 3. [De mercatu, \& feria apud Seleborne, a mistake.] Pat. 9. Edw. I. m.-Pat. 3o. Edw. I. m.-Pat 33. Edw. I. p. i. m.-Pat. 35. Edw. I. m.-Pat. i. Edw. II. p. i. m. 9. Pat. 5. Edw. II. p.i. m. 21. De terris in Achanger. Pat. 6. Edw. II. p. i. m. 7 de. eisdem. Brev. in Scacc. 6. Edw. II. Pasch. rot. 8. Pat I 7. Edw. II. p. i. m.-Cart. Io. Edw. III. n. 24. Quod terræ suæ in Seleburn, Achangre, Norton, Basings, Basingstoke, an Nately, sint de afforestatæ, and pro aliis libertatibus. Pat. I2. Edw. III. p. 3. m. 3.-Pat. ro. Edw. III. p. i. m.-Cart. 18. Edw, III. n. 24."

"N. N. 33. Rex concessit quod prior, et canonici de Seleburn habeant per terras suas de Seleburne, Achangre, Norton, Brompden, Basinges, Basingstoke, \& Nately, diversas libertates.

"P. P. 48. Quod prior de Seleburne, habeat terras suas quietas de vasto, et regardo."-Extracts from Ayloffe's Calendars of Ancient Charters.

"Placita de juratis \& assis coram Salōm de Roff, \& sociis suis justic. itiner. apud Wynton in comitatu Sutht.-anno regni $R$. 
Edwardi filii reg. Henr. octavo.-Et Por de Seleborn ht in Selebr. fure, thurset. pillory, emendasse panis, \& suis." [cerevisæ.]Chapter House, Westminster.

"Placita Foreste apud Wyntōn in com. Sutham.-Anno reg. Edwardi octavo coram Rog. de Clifford, \&c. Justic. ad eadem placita audienda et tminand. assigtis.

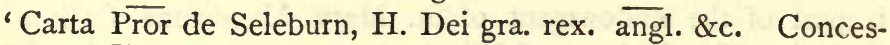

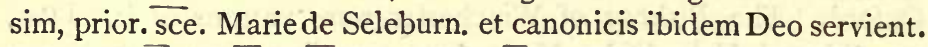

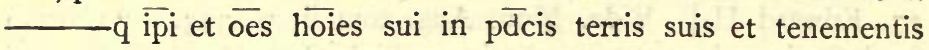
manentes sint in ppetum quieti de sectis Swanemotor. et omnium alior. placitor. for. et de espeltamentis canum. et de omnibus submonitoibz. placitis querelis et exaccuibus et occoibz. ad for. et for et viridar. et eor. ministros ptinentibz." - Chapter-house, Westminster.

"Plita Forestarum in com. Sutht. apud Suthamton-_anno regni regis Edwardi tcii post consequentum quarto coram $\overline{\mathrm{Joh} z}$ Mantvers. \&c., justic. itinand. \&c.,

"De hiis qui clamant libtates infra Forestas in com. Sutht.

"Prior de Selebourne clamat esse quietus erga dñm regem de omnibus finibus et amerciamentis $\mathrm{p}$ tnsgr. et omnibus, exaccoibe ad Dom. regem vel hered. suos ptinent. pret. plita corone reg.

"Item clamat $q^{d}$ si aliquis hominum suorum de terris et ten p. deliciato suo vitam aut membrum debeat amittere velfugiat, \& judico stare noluerit vel aliud delictum fecit pro quo debeat catella sua amittere, ubicuncq; justitia fieri debeat omnia catella illa sint $\overline{\mathrm{ptci}}$ Prioris et successor. suor. Et liceat eidem priori et ballis suis ponere se in seisinam in hujusmodi catall. in casibus pdcis sine disturbacone ballivor. dni. reg. quorumcunque.

"Item clam. quod licet aliqua Tibtatum $\mathrm{p} \overline{\mathrm{dnm}}$ regem concessar, pcessu temporis quocunq; casu contingente usi non fuerint, nlominus postea eadm libtate uti possit. Et pdcus prior quesitus p justic. quo waranto clamat omn. terr. et ten. sua in Seleburne, Norton, Basynges, Basyngestoke, \& Nattele. que prior domus $\overline{p d}$ te huit \& tenuit $\mathrm{X}^{\mathrm{mo}}$. die April anno regni dni Hen. reg. nue XVIII. imppm effe quieta de vasto et regardo, et visu forestarior. et viridarior. regardator. et omnium ministrorum foreste." etc., etc. Chapter House, Westminster. 


\section{LETTER XXVI.}

THough the evidences and documents of the Priory and parish of Selborne are now at an end, yet as the author has still several things to say respecting the present state of that convent and its Grange, and other matters, he does not see how he can acquit himself of the subject without trespassing again on the patience of the reader by adding one supplementary letter.

No sooner did the Priory (perhaps much out of repair at the time) become an appendage to the college, but it must at once have tended to swift decay. Magdalen College wanted now only two chambers for the chantry priest and his assistant ; and therefore had no occasion for the hall, dormitory, and other spacious apartments belonging to so large a foundation. The roofs neglected, would soon become the possession of daws and owls; and, being rotted and decayed by the weather, would fall in upon the floors, so that all parts must have hastened to speedy dilapidation and a scene of broken ruins. Three full centuries have now passed since the dissolution-a series of years that would craze the stoutest edifices. But, besides the slow hand of time, many circumstances have contributed to level this venerable structure with the ground, of which nothing now remains but one piece of wall about ten feet long, and as many feet high, which probably was a part of an outhouse. As early as the latter end of the reign of Henry VII., we find that a farmhouse and two barns were built to the south of the Priory, and undoubtedly out of its materials. . Avarice again has much contributed to the overthrow of this stately pile, as long as the tenants could make money of its stones or timbers. Wantonness, no doubt, has had a share in the demolition; for boys love to destroy what men venerate and admire. A remarkable instance of this propensity the writer can give from his own knowledge. When a school-boy, more than fifty years ago, he was eye-witness, perhaps a party concerned, in the undermining a portion of that fine old ruin at the north end of Basingstoke town, well known by the name of Holy Ghost Chapel. Very 
providentially the vast fragment, which these thoughtless little engineers endeavoured to sap, did not give way so soon as might have been expected; but it fell the night following, and with such violence that it shook the very ground, and, awakening the inhabitants of the neighbouring cottages, made them start up in their beds as if they had felt an earthquake. The motive for this dangerous attempt does not so readily appear; perhaps the more danger the more honour thought the boys, and the notion of doing some mischief gave a zest to the enterprise. As Dryden says upon another occasion-

"It look'd so like a sin it pleas'd the more."

Had the Priory been only levelled to the surface of the ground, the discerning eye of an antiquary might have ascertained its ichnography, and some judicious hand might have developed its dimensions. But besides other ravages, the very foundations have been torn up for the repair of the highways; so that the site of this convent is now become a rough, rugged pasture-field, full of hillocks and pits, choked with nettles and dwarf-elder, and trampled by the feet of the ox and the heifer.

As the tenant at the priory was lately digging among the foundations for materials to mend the highways, his labourers discovered two large stones, with which the farmer was so pleased that he ordered them to be taken out whole. One of these proved to be a large Doric capital, worked in good taste ; and the other a base of a pillar, both formed out of the soft freestone of this district. These ornaments, from their dimensions, seemed to have belonged to massive columns, and show that the church of this convent was a large and costly edifice. They were found in the space which has always been supposed to have contained the south transept of the priory church. Some fragments of large pilasters were also found at the same time. The diameter of the capital was two feet three inches and a half; and of the column, where it had stood on the base, eighteen inches and three-quarters.

Two years ago, some labourers, digging again among the ruins sounded a sort of rude thick vase or urn of soft stone, containing about two gallons in measure, on the verge of the brook, in the 
very spot which tradition has always pointed out as having been the site of the convent kitchen. This clumsy utensil,* whether intended for holy water, or whatever purpose, we were going to procure, but found that the labourers had just broken it in pieces, and carried it out on the highways.

The priory of Selborne had possessed in this village a grange, an usual appendage to manerial estates, where the fruits of their lands were stowed and laid up for use, at a time when men took the natural produce of their estates in kind. The mansion of this spot is still called the Grange, and is the manor-house of the convent possessions in this place. The author has conversed with very ancient people who remembered the old original Grange but it has long given place to a modern farm-house. Magdalen College holds a court-leet and court-baron $t$ in the great wheatbarn of the said Grange, annually, where the president usually superintends, attended by the bursar and steward of the college. $\neq$

The following uncommon presentment at the court is not unworthy of notice. There is on the south side of the king's field (a large common-field, so called) a considerable tumulus, or hillock, now covered with thorns and bushes, and known by the name of Kite's Hill, which is presented, year by year, in court as not ploughed. Why this injunction is still kept up respecting this spot, which is surrounded on all sides by arable land, may be a question not easily solved, since the usage has long survived the knowledge of the intention thereof. We can only suppose that as the prior, besides thurset and pillory, had also furcas, a power of life and death, he might have reserved this little eminence as the place of execution for delinquents. And there is the more

* A judicious antiquary who saw this vase, observed, that it possibly might have been a standard measure between the monastery and its tenants. The priory we have mentioned claimed the assize of bread and beer in Selborne manor ; and probably the adjustment of dry measures for grain, etc.

+ The time when this court is held is the mid-week between Easter and Whitsuntide.

$\ddagger$ Owen Oglethorpe, president, etc., an. Edw. Sexti, primo [viz. 1547.] demised to Robert Arden Selborne Grange for twenty years. Rent vili. Index of Leases. 
reason to suppose so, since a spot just by is called Gally (Gallows) Hill.

The lower part of the village, next the Grange, in which is a pond and a stream, is well known by the name of Gracious Street, an appellation not at all understood. There is a lake in Surrey, near Chobham, called also Gracious Pond; and another, if we mistake not, near Hedleigh, in the county of Hants. This strange denomination we do not at all comprehend, and conclude that it may be a corruption from some Saxon word, itself perhaps forgotten.

It has been observed already, that Bishop Tanner was mistaken when he refers to an evidence of Dodsworth, "De mercante feria de Seleburne." Selborne never had a chartered fair ; the present fair was set up since the year I68I, by a set of jovial fellows, who had found in an old almanack that there had been a fair here in former days on the Ist August; and were desirous to revive so joyous a festival. Against this innovation the vicar set his face, and persisted in crying it down, as the probable occasion of much intemperance. However, the fair prevailed, but was altered to the 29th May, because the former day often interfered with wheatharvest. On that day it still continues to be held, and is become an useful mart for cows and calves. Most of the lower housekeepers brew beer against this holiday, which is dutied by the exciseman, and their becoming victuallers for the day without a license is overlooked.

Monasteries enjoyed all sorts of conveniences within themselves. Thus, at the priory, a low and moist situation, there were ponds and stews for their fish; at the same place also, and at the Grange in Culver* Croft, there were dove-houses ; and on the hill opposite to the Grange the prior had a warren, as the names of The ConeyCrofts and Coney Croft Hanger plainly testify. $\dagger$

Nothing has been said, as yet, respecting the tenure or holding of the Selborne estates. Temple and Norton are manor farms, and freeholds; as is the manor of Chapel, near Oakhanger, and also the estate at Oakhanger House and Blackmoor. The priory

* Culver, as has been observed before, is Saxon for a pigeon.

+ A warren was an usual appendage to a manor. 
and grange are leasehold under Magdalen College, for twenty-one years, renewable every seven; all the smaller estates in and round the village are copyhold of inheritance under the college, except the little remains of the Gurdon Manor, which had been of old leased out upon lives, but have been freed of late by their present lord, as fast as those lives have dropped.

Selborne seems to have derived much of its prosperity from the near neighbourhood of the priory. For monasteries were of considerable advantage to places where they had their sites and estates, by causing great resort, by procuring markets and fairs, by freeing them from the cruel oppression of forest laws, and by letting their lands at easy rates. But, as soon as the convent was suppressed, the town which it had occasioned began to decline, and the market was less frequented; the rough and sequestered situation gave a check to resort, and the neglected roads rendered it less and less accessible.

'That it had been a considerable place for size, formerly, appears from the largeness of the church, which much exceeds those of the neighbouring villages; by the ancient extent of the buryingground, which, from human bones occasionally dug up, is found to have been much encroached upon; by giving a name to the hundred; by the old foundations and ornamented stones, and tracery of windows that have been discovered on the north-east side of the village; and by the many vestiges of disused fish-ponds still to be seen around it. For ponds and stews were multiplied in the times of popery, that the affluent might enjoy some variety at their tables on fast days; therefore, the more they abounded the better probably was the condition of the inhabitants.

More Particulars Respecting the old Family Tortoise, omitted in the Natural History.

BECAUSE we call this creature an abject reptile, we are too apt to undervalue his abilities, and depreciate his powers of instinct. Yet he is, as Mr. Pope says of his lord, 
and has so much discernment as not to fall down a haha, but to stop and withdraw from the brink with the readiest precaution.

Though he loves warm weather he avoids the hot sun; because his thick shell, when once heated, would, as the poet says of solid armour, "scald with safety." He therefore spends the more sultry hours under the umbrella of a large cabbage-leaf, or amidst the waving forests of an asparagus bed.

But, as he avoids heat in the summer, so, in the decline of the year, he improves the faint autumnal beams, by getting within the reflection of a fruit-wall; and, though he never has read that planes inclining to the horizon receive a greater share of warmth,* he inclines his shell, by tilting it against the wall, to collect and admit every feeble ray.

Pitiable seems the condition of this poor embarrassed reptile; to be cased in a suit of ponderous armour, which he cannot lay aside; to be imprisoned, as it were, within his own shell, must preclude, we should suppose, all activity and disposition for enterprise. Yet there is a season of the year (usually the beginning of June) when his exertions are remarkable. He then walks on tiptoe, and is stirring by five in the morning; and, traversing the garden, examines every wicket and interstice in the fences, through which he will escape if possible; and often has eluded the care of the gardener, and wandered to some distant field. The motives that impel him to undertake these rambles seem to be of the amorous kind; his fancy then becomes intent on sexual attachments, which transport him beyond his usual gravity, and induce him to forget for a time his ordinary solemn deportment.

* Several years ago a book was written entitled "Fruit Walls Improvèd by Inclining them to the Horizon:" in which the author has shown, by calculation, that a much greater number of the rays of the sun will fall on such walls than on those which are perpendicular. 


\section{OBSERVATIONS ON}

\section{VARIOUS PARTS OF NATURE.}

FROM MR. WHITE'S MSS.

WITH REMARKS BY MR. MARKWICK. 


\section{ADVERTISEMENT}

TO THE 8vo EDITION, PUBLISHED IN I802, EDITED BY JOHN WHITE, THE BROTHER OF THE AUTHOR.

"THE favourable reception with which the works on natural history of my late respected relation, the Rev. Gilbert White of Selborne, have been honoured by the persons best qualified to judge of their merit, has induced me to present them to the public in a collected and commodious form, free from the encumbrance of any extraneous matter. His largest work, entitled 'The Natural History of Selborne,' has probably been supposed by many to be formed upon a more local and confined plan than it really is. In fact, the greater part of the observations are applicable to al that portion of the island in which he resided, and were indeedl made in various places. Almost the only matter absolutely local is the account of the antiquities of the village of Selborne ; and this seemed to stand so much apart, that, however well calculated to gratify the lovers of topographical studies, it was thought that its entire omission would be considered no loss to the work, considered as a publication on natural history. Its place is occupied by the 'Naturalists' Calendar, and Miscellaneous Observations,' which appeared in a separate volume since the author's decease, extracted from his papers by Dr. Aitkin. That gentleman has also made some farther selections from the papers, which are now all in my possession; and has undertaken the revision and arrangement of the whole. A very valuable addition to the calendar and observations has been obtained from the kindness of William Markwick, Esq., F.L.S., well known as an accurate observer of nature, whose parallel calendar, kept in the county of Sussex, is given upon the opposite columns.

"The Editor flatters himself that the publication in its present form will prove an acceptable addition to the library of the naturalist; and will in particular, be useful in inspiring young persons, and those who pass their time in retirement, with a taste for the very pleasing branch of knowledge on which it treats.

"Fleet Street, i802." 


\section{OBSERVATIONS ON BIRDS.}

\section{BIRDS IN GENERAL.}

IN severe weather, fieldfares, redwings, sky-larks, and tit-larks, resort to watered meadows for food; the latter wades up to its belly in pursuit of the pupæ of insects, and runs along upon the floating grass and weeds. Many gnats are on the snow near the water, these support the birds in part.

Birds are much influenced in their choice of food by colour, for though white currants are a much sweeter fruit than red, yet they seldom touch the former till they have devoured every bunch of the latter.

Red-starts, fly-catchers, and black-caps, arrive early in April. If these little delicate beings are birds of passage (as we have reason to suppose they are, because they are never seen in winter), how could they, feeble as they seem, bear up against such storms of snow and rain, and make their way through such meteorous turbulences, as one should suppose would embarrass and retard the most hardy and resolute of the winged nation? Yet they keep their appointed times and seasons; and in spite of frosts and winds return to their stations periodically as if they had met with nothing to obstruct them. The withdrawing and appearance of the short-winged summer birds is a very puzzling circumstance in natural history.

When the boys bring me wasps' nests, my bantam fowls fare deliciously, and when the combs are pulled to pieces, devour the young wasps in their maggot state with the highest glee and 
delight. Any insect-eating bird would do the same ; and therefore I have often wondered that the accurate Mr. Ray should call one species of buzzard buteo apivorus sive vespivorus, or the honey buzzard, because some combs of wasps happened to be found in one of their nests. The combs were conveyed thither doubtless for the sake of the maggots or nymphs, and not for their honey, since none is to be found in the combs of wasps. Birds of prey occasionally feed on insects; thus have I seen a tame kite picking up the female ants full of eggs, with much satisfaction.WHITE.

That red-starts, fly-catchers, black-caps, and other slenderbilled insectivorous small birds, particularly the swallow tribe, make their first appearance very early in the spring, is a wellknown fact ; though the fly-catcher is the latest of them all in its visit (as this accurate naturalist observes in another place), for it is never seen before the month of May. If these delicate creatures come to us from a distant country, they will probably be exposed in their passage, as Mr. White justly remarks, to much greater difficulties from storms and tempests than their feeble powers appear to be able to surmount : on the other hand, if we suppose them to pass the winter in a dormant state in this country, concealed in caverns or other hiding-places sufficiently guarded from the extreme cold of our winter to preserve their life, and that at the approach of spring they revive from their torpid state and reassume their usual powers of action, it will entirely remove the first difficulty, arising from the storms and tempests they are liable to meet with in their passage; but how are we to get over the still greater difficulty of their revivification from their torpid state? What degree of warmth in the temperature of the air is necessary to produce that effect, and how it operates on the functions of animal life, are questions not easily answered.

How could Mr. White suppose that Ray named this species the honey buzzard, because it fed on honey, when he not only named it in Latin buteo apivorus et vespivorus, but expressly says that "it feeds on insects, and brings up its young with the maggots or nymphs of wasps"? 
That birds of prey, when in want of their proper food, flesh, sometimes feed on insects I have little doubt, and I think I have observed the common buzzard, falco buteo, to settle on the ground and pick up insects of some kind or other.-MARKwICK.

\section{ROOKS.}

Rooks are continually fighting, and pulling each other's nests to pieces : these proceedings are inconsistent with living in such close community. And yet if a pair offer to build on a single tree, the nest is plundered and demolished at once. Some rooks roost on their nest trees. The twigs which the rooks drop in building supply the poor with brushwood to light their fires. Some unhappy pairs are not permitted to finish any nest till the rest have completed their building. As soon as they get a few sticks together, a party comes and demolishes the whole. As soon as rooks have finished their nests, and before they lay, the cocks begin to feed the hens, who receive their bounty with a fondling tremulous voice and fluttering wings, and all the little blandishments that are expressed by the young, while in a helpless state. This gallant deportment of the males is continued through the whole season of incubation. These birds do not copulate on trees, nor in their nests, but on the ground in the open fields.-White.

After the first brood of rooks is sufficiently fledged, they all leave their nest trees in the day-time, and resort to some distant place in search of food, but return regularly every evening, in vast flights, to their nest trees, where, after flying round several times with much noise and clamour till they are all assembled together, they take up their abode for the night.-MARKwICY

\section{THRUSHES.}

Thrushes during long droughts are of great service in hunting out shell snails, which they pull to pieces for their young, and are thereby very serviceable in gardens. Missel thrushes do not 
destroy the fruit in gardens like the other species of turdi, but feed on the berries of misletoe, and in the spring on ivy berries, which then begin to ripen. In the summer, when their young become fledged, they leave neighbourhoods, and retire to sheepwalks and wild commons.

The magpies, when they have young, destroy the broods of missel thrushes, though the dams are fierce birds, and fight boldly in defence of their nests. It is probably to avoid such insults, that this species of thrush, though wild at other times, delights to build near houses, and in frequented walks and gardens.WHITE.

Of the truth of this I have been an eye-witness, having seen the common thrush feeding on the shell snail.

In the very early part of this spring (1797) a bird of this species used to sit every morning on the top of some high elms close by my windows, and delight me with its charming song, attracted thither, probably, by some ripe ivy berries that grew near the place.

I have remarked something like the latter fact, for I remember, many years ago, seeing a pair of these birds fly up repeatedly and attack some larger bird, which I suppose disturbed their nest in my orchard, uttering at the same time violent shrieks. Since writing the above, I have seen more than once a pair of these birds attack some magpies that had clisturbed their nest, with great violence and loud shrieks.-MARKWICK.

\section{POULTRY.}

Many creatures are endowed with a ready discernment to see what will turn to their own advantage and emolument : and often discover more sagacity than could be expected. Thus my neighbour's poultry watch for waggons loaded with wheat, and running after them, pick up a number of grains which are shaken from the sheaves by the agitation of the carriages. Thus, when my brother used to take down his gun to shoot sparrows, his cats would run out before him, to be ready to catch up the birds as they fell. 
'The earnest and early propensity of the gallinæ to roost on high is very observable; and discovers a strong dread impressed on their spirits respecting vermin that may annoy them on the ground during the hours of darkness. Hence poultry, if left to themselves and not housed, will perch the winter through on yew-trees and fir-trees; turkeys and guinea fowls, heavy as they are, get up into apple-trees ; pheasants also in woods sleep on trees to avoid foxes ; 1 while pea-fowls climb to the tops of the highest trees round their owner's house for security, let the weather be ever so cold or blowing. Partridges, it is true, roost on the ground, not having the faculty of perching; but then the same fear prevails in their minds; for through apprehension from pole-cats and stoats, they never trust themselves to coverts, but nestle together in the midst of large fields, far removed from hedges and coppices, which they love to haunt in the day, and where at that season they can skulk more secure from the ravages of rapacious birds.

As to ducks and geese, their awkward splay web-feet forbid them to settle on trees: they therefore, in the hours of darkness and danger, betake themselves to their own element the water, where amidst large lakes and pools, like ships riding at anchor, they float the whole night long in peace and security.-WHITE.

Guinea fowls not only roost on high, but in hard weather resort, even in the daytime, to the very tops of the highest trees. Last winter, when the ground was covered with snow, I discovered all my guinea fowls, in the middle of the day, sitting on the highest boughs of some very tall elms, chattering and making a great clamour : I ordered them to be driven down lest they should be frozen to death in so elevated a situation, but this was not effected without much difficulty; they being very unwilling to quit their lofty abode, notwithstanding one of them had its feet so much frozen that we were obliged to kill it. I know not how to account for this, unless it was occasioned by their aversion to the

1 The pheasants run into equal danger when' they roost in the trees; for, although they are secure from ground vermin, yet do they often fall victims to the poacher, who can see them plainly against the sky. 
snow on the ground, they being birds that come originally from a hot climate.

Notwithstanding the awkward splay web-feet (as Mr. White calls them) of the duck genus, some of the foreign species have the power of settling on the boughs of trees apparently with great ease; an instance of which I have seen in the Earl of Ashburnham's menagerie, where the summer duck, anas sponsa, flew up, and settled on the branch of an oak-tree in my presence: but whether any of them roost on trees in the night, we are not informed by any author that I am acquainted with. I suppose not, but that, like the rest of the genus, they sleep on the water, where the birds of this genus are not always perfectly secure, as will appear from the following circumstance which happened in this neighbourhood a few years since, as I was credibly informed. A female fox was found in the morning drowned in the same pond in which were several geese, and it was supposed that in the night the fox swam into the pond to devour the geese, but was attacked Dy the gander, which being most powerful in its own element, buffeted the fox with its wings about the head till it was drowned. - MarkWICK.

\section{HEN PARTRIDGE.}

A hen partridge came out of a ditch, and ran along shivering with her wings and crying out as if wounded and unable to get from us. While the dam acted this distress, the boy who attended me saw her brood, that was small and unable to fly, run for shelter into an old fox-earth under the bank. So wonderful a power is instinct.-W W WITE.

It is not uncommon to see an old partridge feign itself wounded and run along on the ground fluttering and crying before either dog or man, to. draw them away from its helpless unfledged young ones. I have seen it often, and once in particular I saw a remarkable instance of the old bird's solicitude to save its brood. As I was hunting a young pointer, the dog ran on a brood of very small partridges : the old bird cried, fluttered, and ran tumbling 
along just before the dog's nose till she had drawn him to a considerable distance, when she took wing, and flew still farther off, but not out of the field: on this the dog returned to me, near which place the young ones lay concealed in the grass, which the old bird no sooner perceived than she flew back again to us, settled just before the dog's nose again, and by rolling and tumbling about, drew off his attention from her young, and thus preserved her brood a second time. I have also seen, when a kite has been hovering over a covey of young partridges, the old birds fly up at the bird of prey, screaming and fighting with all their might to preserve their brood.-MARKwICK.

\section{A HYBRID PHEASANT.}

Lord Stawell sent me from the great lodge in the Holt a curious bird for my inspection. It was found by the spaniels of one of his keepers in a coppice, and shot on the wing. The shape, air, and habit of the bird, and the scarlet ring round the eyes, agreed well with the appearance of a cock pheasant; but then the head, and neck, and breast, and belly were of a glossy black : and though it weighed three pounds three ounces and a half,* the weight of a full-grown cock pheasant, yet there were no signs of any spurs on the legs, as is usual with all grown cock pheasants, who have long ones. The legs and feet were naked of feathers and therefore it could be nothing of the grouse kind. In the tail were no bending feathers such as cock pheasants usually have, and are characteristic of the sex. The tail was much shorter than the tail of a hen pheasant, and blunt and square at the end. The back, wing, feathers, and tail, were all of a pale russet curiously streaked somewhat like the upper parts of a hen partridge. I returned it with my verdict, that it was probably a spurious or hybrid hen bird, bred between a cock pheasant and some domestic fowl. When I came to talk with the keeper who brought it, he told me that some pea-hens had been known last summer to haunt the coppices and coverts where this mule was found.

*. Hen pheasants usually weigh only two pounds ten ounces 
Mr. Elmer, of Farnham, the famous game painter, was employed to take an exact copy of this curious bird.

$N . B$. - It ought to be mentioned, that some good judges have imagined this bird to have been a stray grouse or blackcock; it is however to be observed, that Mr. W. remarks, that its legs and feet were naked, whereas those of the grouse are feathered to the toes.-WHiTE.

Mr. Latham observes that "pea-hens, after they have done laying, sometimes assume the plumage of the male bird," and has given a figure of the male-feathered pea-hen now to be seen in the Leverian Museum; and M. Salerne remarks, that "the hen pheasant, when she has done laying and sitting, will get the plumage of the male." May not this hybrid pheasant (as Mr. White calls it) be a bird of this kind? that is, an old hen pheasant which had just begun to assume the plumage of the cock.MARKWICK.

\section{LAND-RAIL.}

A man brought me a land-rail or daker-hen, a bird so rare in this district, that we seldom see more than one or two in a season, and those only in autumn. ${ }^{2}$ This is deemed a bird of passage by all the writers; yet from its formation, seems to be poorly qualified for migration ; for its wings are short, and placed so forward, and out of the centre of gravity, that it flies in a very heavy and embarrassed manner, with its legs hanging down; and can hardly be sprung a second time, as it runs very fast, and seems to depend more on the swiftness of its feet than on its flying.

When we came to draw it, we found the entrails so soft and tender in appearance, they might have been dressed like the ropes of a wood-cock. The craw or crop was small and lank, containing a mucus; the gizzard thick and strong, and filled with small shell

2 The land-rail is common in Shropshire, and I have found three or four nests in a single hayfield. One of these birds was once brought in, in a load of hay, and when discovered feigned to be dead. It was laid aside, and recovered so quickly, that it made good its escape with remarkable speed 
snails, some whole, and many ground to pieces through the attrition which is occasioned by the muscular force and motion of that intestine. We saw no gravels among the food: perhaps the shell snails might perform the functions of gravels or pebbles, and might grind one another. Land-rails used to abound formerly, I remember, in the low wet bean-fields of Christian Malford in North Wilts, and in the meadows near Paradise Gardens at Oxford, where I have often heard them cry crex, crex. The bird men-

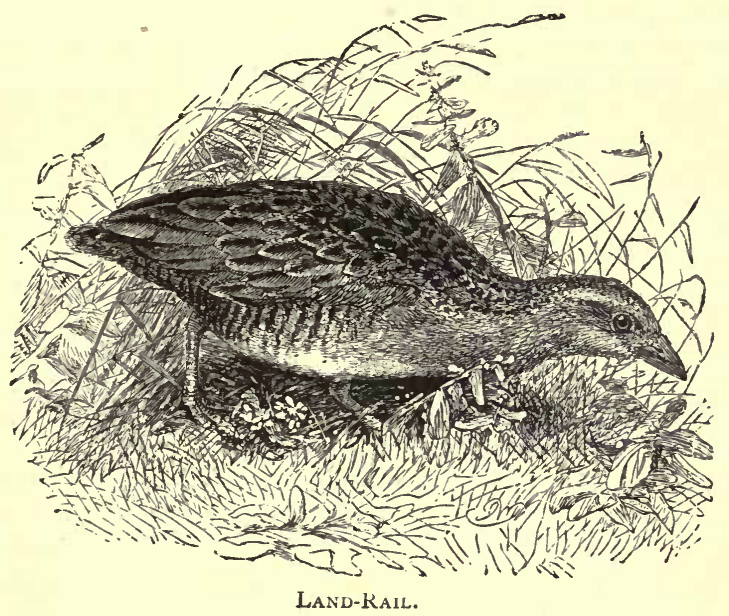

tioned above weighed seven and a half ounces, was fat and tender, and in flavour like the flesh of a woodcock. The liver was very large and delicate.-WHITE.

Land-rails are more plentiful with us than in the neighbourhood of Selborne. I have found four brace in an afternoon, and a friend of mine lately shot nine in two adjoining fields; but I never saw them in any other season than the autumn.

That it is a bird of passage there can be little doubt, though Mr. White thinks it poorly qualified for migration, on account of the wings being short, and not placed in the exact centre of gravity; how that may be I cannot say, but I know that its heavy sluggish 
flight is not owing to its inability of flying faster, for I have seen it fly very swiftly, although in general its actions are sluggish. Its unwillingness to rise proceeds, I imagine, from its sluggish disposition, and its great timidity, for it will sometimes squat so close to the ground as to suffer itself to be taken up by the hand, rather than rise; and yet it will at times run very fast.

What Mr. White remarks respecting the small shell snails found in its gizzard, confirms my opinion, that it frequents corn-fields, seed clover, and brakes or fern, more for the sake of snails, slugs, and other insects which abound in such places, than for the grain or seeds ; and that it is entirely an insectivorous bird.-MARKWICK.

\section{FOOD OF THE RING-DOVE.}

One of my neighbours shot a ring-dove on an evening as it was returning from feed, and going to roost. When his wife had picked and drawn it, she found its craw stuffed with the most nice and tender tops of turnips. These she washed and boiled, and so sat down to a choice and delicate plate of greens, culled and provided in this extraordinary manner.

Hence we may see that graminivorous birds, when grain fails, can subsist on the leaves of vegetables. There is reason to suppose that they would not long be healthy without; for turkeys, though corn fed, delight in a variety of plants, such as cabbage, lettuce, endive, etc., and poultry pick much grass; while geese live for months together on commons by grazing alone.

" Nought is useless made;

- On the barren heath

The shepherd tends his flock that daily crop

Their verdant dinner from the mossy turf

Sufficient : after them the cackling goose,

Close-grazer, finds wherewith to ease her want."

Philips's Cyder.

WHITE.

That many graminivorous birds feed also on the herbage or leaves of plants, there can be no doubt : partridges and larks frequently feed on the green leaves of turnips, which give a peculiar 
flavour to their flesh, that is, to me, very palatable : the flavour also of wild ducks and geese greatly depends on the nature of their food; and their flesh frequently contracts a rank unpleasant taste, from their having lately fed on strong marshy aquatic plants, as I suppose.

That the leaves of vegetables are wholesome and conducive to the health of birds, seems probable, for many people fat their ducks and turkeys with the leaves of lettuce chopped small.

MARKWICK.

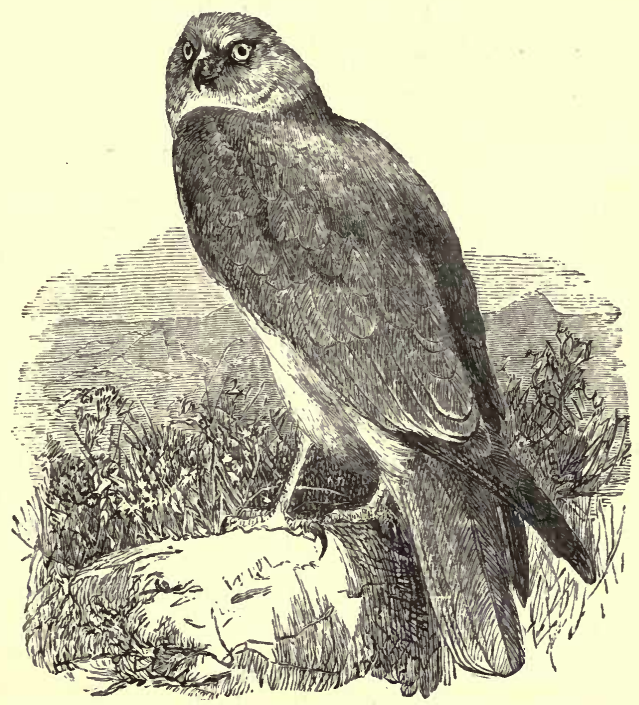

The Hen-Harrier (Circus cyaneus).

\section{HEN-HARRIER.}

A neighbouring gentleman sprung a pheasant in a wheat stubble, and shot at it ; when, notwithstanding the report of the gun, it was immediately pursued by the blue hawk, known by the name of the hen-harrier, but escaped into some covert. He then sprung a second, and a third, in the same field, that got away in the same manner; the hawk hovering round hin all the while that he was 
beating the field, conscious no doubt of the game that lurked in the stubble. Hence we may conclude that this bird of prey was rendered very daring and bold by hunger, and that hawks cannot always seize their game when they please. We may farther observe, that they cannot pounce their quarry on the ground where it might be able to make a stout resistance, since so large a fowl as a pheasant could not but be visible to the piercing eye of a hawk, when hovering over the field. Hence that propensity of cowering and squatting till they are almost trod on, which no doubt was intended as a mode of security; though long rendered destructive to the whole race of gallinæ by the invention of nets and guns.-White.

Of the great boldness and rapacity of birds of prey when urged on by hunger, I have seen several instances; particularly, when shooting in the winter in company with two friends, a woodcock flew across us, closely pursued by a small hawk : we all three fired at the woodcock instead of the hawk, which, notwithstanding the report of three guns close by it, continued its pursuit of the woodcock, struck it down, and carried it off, as we afterwards discovered.

At another time, when partridge-shooting with a friend, we saw a ring-tail hawk rise out of a pit with some large bird in its claws; though at a great distance; we both fired and obliged it to drop its prey, which proved to be one of the partridges which we were in pursuit of ; and lastly, in an evening, I shot at and plainly saw that I had wounded a partridge, but it being late, was obliged to go home without finding it again. The next morning I walked round my land without any gun, but a favourite old spaniel followed my heels. When I came near the field where I wounded the bird the evening before, I heard the partridges call, and seeming to be much disturbed. On my approaching the bar-way, they all rose, some on my right and some on my left hand; and just before and over my head, I perceived (though indistinctly from the extreme velocity of their motion) two birds fly directly against each other, when instantly, to my great astonishment, down dropped a partridge at my feet; the dog immediateily 
seized it, and on examination, I found the blood flow very fast from a flesh wound in the head, but there was some dry clotted blood on its wings and side; whence I concluded that a hawk had singled out my wounded bird as the object of his prey, and had struck it down the instant that my approach had obliged the birds to rise on the wing; but the space between the hedges was so small, and the motion of the birds so instantaneous and quick, that I could not distinctly observe the operation.-MARKwICK.

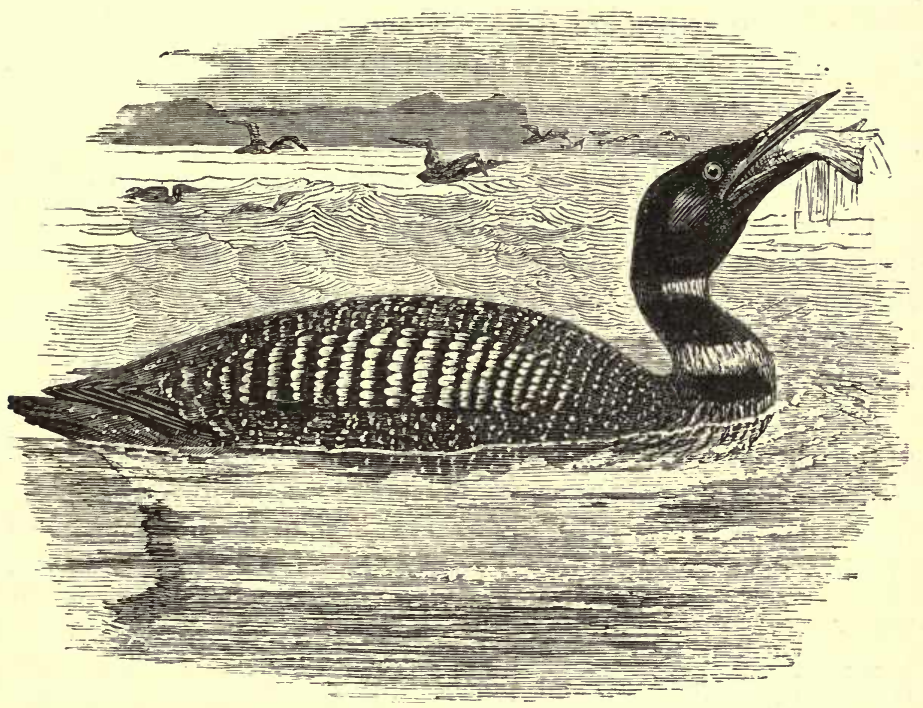

The Great Northern Diver (Colymbus glacialis)

\section{GREAT SPECKLED DIVER, OR LOON.}

As one of my neighbours was traversing Wolner Forest from bramshot across the moors, he found a large uncommon bird fluttering in the heath, but not wounded, which he brought home alive. On examination it proved to be colymbus glacialis, Linn., the great speckled diver or loon, which is most excellently described in Willughby's Ornithology. 
Every part and proportion of this bird is so incomparably adapted to its mode of life, that in no instance do we see the wisdom of God in the creation to more advantage. The head is sharp and smaller than the part of the neck adjoining, in order that it may pierce the water; the wings are placed forward, and out of the centre of gravity, for a purpose which shall be noticed hereafter; the thighs quite at the podex, in order to facilitate diving; and the legs are quite flat, and as sharp backwards almost as the edge of a knife, that in striking they may easily. cut the water; while the feet are palmated, and broad for swimming, yet so folded up when advanced forward to take a fresh stroke, as to be full as narrow as the shank. The two exterior toes of the feet are longest; the nails flat and broad, resembling the human, which give strength, and increase the power of swimming. The foot, when expanded, is not at right angles to the leg or body of the bird: but the exterior part inclining towards the head, forms an acute angle with the body; the intention being not to give motion in the line of the legs themselves, but by the combined impulse of both in an intermediate line, the line of the body.

Most people know, that have observed at all, that the swimming of birds is nothing more than a walking in the water, where one foot succeeds the other as on the land; yet no one, as far I am aware, has remarked that diving fowls, while under water, impel and row themselves forward by a motion of their wings, as well as by the impulse of their feet: but such is really the case, as any person may easily be convinced, who will observe ducks when hunted by dogs in a clear pond. Nor do I know that any one has given a reason why the wings of diving fowls are placed so forward : doubtless, not for the purpose of promoting their speed in flying, since that position certainly impedes it; but probably for the increase of their motion under water, by the use of four oars instead of two; yet were the wings and feet nearer together, as in land-birds, they would, when in action, rather hinder than assist one another.

This colymbus was of considerable bulk, weighing only three drachms short of three pounds avoirdupois. It measured in length from the bill to the tail (which was very short) two feet, 
and to the extremities of the toes four inches more; and the breadth of the wings expanded was forty-two inches. A person attempted to eat the body, but found it very strong and rancid, as is the flesh of all birds living on fish. Divers or loons, though bred in the most northerly parts of Europe, yet are seen with us in very severe winters; and on the Thames they are called sprat loons, because they prey much on that sort of fish.

The legs of the colymbi and mergi are placed so very backward, and so out of all centre of gravity, that these birds cannot walk at all. They are called by Linnæus compedes, because they move on the ground as if shackled or fettered.-WHITE.

These accurate and ingenious observations, tending to set forth in a proper light the wonderful works of God in the creation, and to point out His wisdom in adapting the singular form and position of the limbs of this bird to the particular mode in which it is destined to pass the greatest part of its life in an element much denser than the air, do Mr. White credit, not only as a naturalist, but as a man, and as a philosopher, in the truest sense of the word, in my opinion; for were we enabled to trace the works of nature minutely and accurately, we should find, not only that every bird, but every creature was equally well adapted to the purpose for which it was intended; though this fitness and propriety of form is more striking in such animals as are destined to any uncommon mode of life.

I have had in my possession two birds, which, though of a different genus, bear a great resemblance to Mr. White's Colymbus, in their manner of life, which is spent chiefly in the water, wher? they swim and dive with astonishing rapidity, for which purpose their fin-toed feet, placed far behind, and very short wings, are particularly well adapted, and show the wisdom of God in the creation as conspicuously as the bird before mentioned. Thesi birds were the greater and lesser crested grebe, podiceps cristatus et auritsu. What surprised me most was, that the first of these birds was found alive on dry ground, about seven miles from the sea, to which place there was no communication by water. How did it get so far from the sea? its wings and legs being so ill 
adapted either to flying or walking. The lesser crested grebe was also found in a fresh water pond which had no communication witn other water at some miles' distance from the sea.-MARKwICK.

\section{STONE-CURLEW.}

On the 27 th February, I 788 , stone-curlews were heard to pipe : and on March Ist, after it was dark, some were passing over the village, as might be perceived by their quick short note, which they use in their nocturnal excursions by way of watchword, that they may not stray and lose their companions.

Thus, we see, that retire whithersoever they may in the winter, they return again early in the spring, and are, as it now appears, the first summer birds that come back. Perhaps the mildness of the season may have quickened the emigration of the curlews this year.

They spend the day in high elevated fields and sheep-walks; but seem to descend in the night to streams and meadows, perhaps for water, which their upland haunts do not afford them.WHITE.

On the 3 Ist January, I 792, I received a bird of this species which had been recently killed by a neighbouring farmer, who said he had frequently seen it in his fields during the former part of the winter: this perhaps was an occasional straggler, which by some accident was prevented from accompanying its companions in their migration.-MARKWICK.

\section{THE SMALLEST UNCRESTED WILLOW WREN.}

The smallest uncrested willow wren, or chiff-chaff, is the next early summer bird which we have remarked; it utters two sharp piercing notes, so loud in hollow woods, as to occasion an echo, and is usually first heard about the 2oth March.-WHite.

This bird, which Mr. White calls the smallest willow-wren or chiff-chaff. makes its appearance very early in the spring, and is 
very common with us; but I cannot make out the three different species of willow-wrens which he assures us he has discovered. Ever since the publication of his History of Selborne I have used my utmost endeavours to discover his three birds, but hitherto without success. I have frequently shot the bird which "haunts only the tops of trees, and makes a sibilous noise," even in the very act of uttering that sibilous note, but it always proved to be the common willow wren or his chiff-chaft. In short, I never could discover more than one species, unless my greater pettychaps, sylvia hortensis of Latham, is his greatest willow wren.

MARKWICK.

\section{FERN-OWL, OR GOAT-SUCKER.}

The country people have a notion that the fern-owl, or churnowl, or eve-jarr, which they also call a puckeridge, is very injurio:ss to weanling calves, by inflicting as it strikes at them, the fatal distemper known to cow-leeches by the name of puckeridge. ${ }^{3}$ Thus does this harmless ill-fated bird fall under a double imputation which it by no means deserves-in Italy, of sucking the teats of goats, whence it is called caprimulgus; and with us, of communicating a deadly disorder to cattle. But the truth of the matter is, the malady above-mentioned is occasioned by the astrus bovis, a dipterous insect, which lays its eggs along the chines of kine, where the maggots, when hatched, eat their way through the hide of the beast into the flesh, and grow to a very large size. I have just talked with a man who says he has more than once stripped calves who have died of the puckeridge; that the ail or complaint lay along the chine, where the flesh was much swelled, and filled with purulent matter. Once I myself saw a large rough maggot of this sort squeezed out of the back of a cow.

These maggots in Essex are called wornils.

The least observation and attention would convince men, that these birds neither injure the goatherd nor the grazier, but are

${ }^{3}$ The goat-sucker, like other birds, finds insects in attendance on cattle; hence its apparent "striking at them." Magpies and starlings will coolly perch on the backs of animals and leisurely make their meal. 
perfectly harmless, and subsist alone, being night birds, on night insects, such as scarabai and phalance; and through the month of July mostly on the scaraboeus solstitialis, which in many districts abounds at that season. Those that we have opened, have always had their craws stuffed with large night moths and their eggs, and pieces of chaffers : nor does it anywise appear how they can, weak and unarmed as they seem, inflict any harm upon kine, unless they possess the powers of animal magnetism and can affect them by fluttering over them.

A fern-owl, this evening (August 27th) showed off in a very unusual and entertaining manner, by hawking round and round the circumference of my great spreading oak for twenty times following, keeping mostly close to the grass, but occasionally glancing up amidst the boughs of the tree. This amusing bird was then in pursuit of a brood of some particular phalæna belonging to the oak, of which there are several sorts; and exhibited on the occasion a command of wing superior, I think, to that of the swallow itself.

When a person approaches the haunt of fern-owls in an evening, they continue flying round the head of the obtruder; and by striking their wings together above their backs, in the manner that the pigeons called smiters are known to do, make a smart snap; perhaps at that time they are jealous for their young, and their noise and gesture are intended by way of menace.

Fern-owls have attachment to oaks, no doubt on account of food; for the next evening we saw one again several times among the boughs of the same tree; but it did not skim round its stem over the grass, as on the evening before. In May these birds find the Scarabaus melolontha on the oak, and the Scarabaus solstitialis at midsurnmer. These peculiar birds can only be watched and observed for two hours in the twenty-four; and then in dubious twilight an hour after sunset and an hour before sunrise.

On this day (July I $4^{\text {th }}$, I 789 ), a woman brought me two eggs of a fern-owl or evening jarr, which she found on the verge of the Hanger, to the left of the hermitage under a beechen shrub. This person, who lives just at the foot or the Hanger, seems well acquainted with these nocturnal swallows, and says she has often found their 
eggs near that place, and that they lay only two at a time on the bare ground. The eggs were oblong, dusky, and streaked somewhat in the manner of the plumage of the parent bird, and were equal in size at each end. The dam was sitting on the eggs when found, which contained the rudiments of young, and would have been hatched perhaps in a week. From hence we may see the time of their breeding, which corresponds pretty well with that of the swift, as does also the period of their arrival. Each species is usually seen about the beginning of May. Each breeds but once in a summer ; each lays only two eggs.

July 4th, I 790. The woman who brought me two fern-owl's eggs last year on July I $4^{\text {th, }}$ on this day produced me two more, one of which had been laid this morning, as appears plainly, because there was only one in the nest the evening before. They were found, as last July, on the verge of the down above the hermitage under a beechen shrub, on the naked ground. Last year those eggs were full of young, just ready to be hatched.

These circumstances point out the exact time when these curious nocturnal migratory birds lay their eggs and hatch their young. Fern-owls, like snipes, stone-curlews, and some other birds, make no nest. Birds that build on the ground do not make much of nes.s.-White.

No author that I am acquainted with has given so accurate and pleasing an account of the manners and habits of the goat-sucker as Mr. White, taken entirely from his own observations. Its being a nocturnal bird, has prevented my having many opportunities of observing it. I suspect that it passes the day in concealment amidst the dark and shady gloom of deep-wooded dells, or as they are called here gills; having more than once seen it roused from such solitary places by my dogs, when shooting in the daytime. I have also sometimes seen it in an evening, but not long enough to take notice of its habits and manners. I have never seen it but in the summer, between the months of May and Septe:nber.-MARKWICK. 


\section{S.AND-MARTINS.}

March 23rd, I788. A gentleman, who was this week on a visit at Waverley, took the opportunity of examining some of the holes in the sand-banks with which that district abounds. As these are undoubtedly bored by bank martins, and are the places where they avowedly breed, he was in hopes they might have slept there also, and that he might have surprised them just as they were awaking from their winter slumbers. When he had dug for some time, he found the holes were horizontal and serpentine, as I had observed before; and that the nests were deposited at the inner end, and had been occupied by broods in former summers, but no torpid birds were to be found. He opened and examined about a dozen holes. Another gentleman made the same search many years ago, with as little success.

These holes were in depth about two feet.

March 2rst, I790. A single bank or sand-martin was seen hovering and playing round the sand-pit at Short Heath, where in the summer they abound.

April 9th, I793. A sober hind assures us, that this day, on Wishhanger common between Hedleigh and Frinsham, he saw several bank martins playing in and out, and hanging before some nest-holes in a sand-hill, where these birds usually nestle.

The incident confirms my suspicions, that this species of hirundo is to be seen first of any ; and gives great reason to suppose that they do not leave their wild haunts at all, but are secreted amidst the clefts and caverns of those abrupt cliffs, where they usually spend their summers.

The late severe weather considered, it is not very probable that these birds should have migrated so early from a tropical region, through all these cutting winds and pinching frosts ; but it is easy to suppose that they may, like bats and flies, have been awakened by the influence of the sun, amidst their secret latebræ, where they have spent the uncomfortable foodless months in a torpid state, and the profoundest of slumbers.

There is a large pond at Wish-hanger, which induces these sand- 
martins to frequent that district. For I have ever remarked that they haunt near great waters, either rivers or lakes.-WHite.

Here, and in many other passages of his writings, this very ingenious naturalist savours the opinion that part, at least, of the swallow tribe pass their winter in a torpid state in the same manner as bats and flies, and revive again on the approach of spring.

I have frequently taken notice of all these circumstances, which induced Mr. White to suppose that some of these hirundines lie torpid during winter. I have seen so late as November, on a finer day than usual at that season of the year, two or three swallows flying backwards and forwards under a warm hedge, or on the sunny side of some old building; nay, I once saw on the 8th December two martins flying about very briskly, the weather being mild. I had not seen any considerable number either of swallows or martins for a considerable time before; from whence, then, could these few birds come, if not from some hole or cavern where they had laid themselves up for the winter? Surely it will not be asserted that these birds migrate back again from some distant tropical region, merely on the appearance of a fine day or two at this late season of the year. Again, very early in the spring, and sometimes immediately after very cold severe weather, on its growing a little warmer, a few of these birds suddenly make their appearance, long before the generality of them are seen. These appearances certainly favour the opinion of their passing the winter in a torpid state, but do not absolutely prove the fact; for who ever saw them reviving of their own accord from their torpid state, without being first brought to the fire, and as it were, forced into life again; soon after which revivification they constantly die.MARKWICK.

\section{SWALLOWS, CONGREGATING AND DISAPPEARANCE OF.}

During the severe winds that often prevail late in the spring, it is not easy to say how the hirundines subsist ; for they withdraw themselves, and are hardly ever seen, nor do any insects appear 
for their support. That they can retire to rest, and sleep away these uncomfortable periods, as bats do, is a matter rather to be suspected than proved; or do they not rather spend their time in deep and sheltered vales near waters, where insects are more likely to be found? Certain it is, that hardly any individuals of this genus have at such times been seen for several days together.

Sept. I $3^{\text {th }}$ I 79r. The congregating flocks of hirundines on the church and tower are very beautiful and amusing! When they fly off together from the roof, on any alarm, they quite swarm in the air. But they soon settle in heaps, and preening their feathers, and lifting up their wings to admit the sun, seem highly to enjoy the warm situation. Thus they spend the heat of the day, preparing for their emigration, and, as it were, consulting when and where they are to go. The flight about the churcn seems to consist chiefly of house-martins, about 400 in number ; but there are other places of rendezvous about the village frequented at the same time.

It is remarkable that though most of them sit on the battlements and roof, yet many hang or cling for some time by their claws against the surface of the walls, in a manner not practised by them at any other time of their remaining with us.

The swallows seem to delight more in holding their assemblies on trees.

November 3 rd, I789. Two swallows were seen this morning at Newton vicarage-house, hovering and settling on the roofs and outbuildings. None have been observed at Selborne since October I I th. It is very remarkable, that after the hirundines have disappeared for some weeks, a few are occasionally seen again; sometimes, in the first week in November, and that only for one day. Do they not withdraw and slumber in some hiding-place in the interval? For we cannot suppose they had emigrated to warmer climes and so returned again for one day. Is it not more probable that they are awakened from sleep, and like the bats, are come forth to collect a little food? Bats appear at all seasons through the autumn and spring months, when the thermometer is at $50^{\circ}$, because then phalænæ and moths are stirring.

These swallows looked like young ones.-White. 
Of their migration the proofs are such as will scarcely admit of a doubt. Sir Charles Wager and Captain Wright saw vast flocks of them at sea, when on their passage from one country to another Our author, Mr. White, saw what he deemed the actual migration of these birds, and which he has described at p. 184 of his "History of Selborne" ; and of their congregating together on the roofs of churches and other buildings, and on trees, previous to their departure, many instances occur; particularly I once observed a large stock of house-martins on the roof of the church here at Catsfield, which acted exactly in the manner here described by Mr. White, sometimes preening their feathers and spreading their wings to the sun, and then flying off all together, but soon returning to their former situation. The greatest part of these birds seemed to be young ones.-MARKWICK.

\section{WAGTAILS.}

While the cows are feeding in the moist low pastures, broods of wagtails, white and gray, run round them, close up to their noses, and under their very bellies, avaiiling themselves of the flies that settle on their legs, and probably finding worms and larva that are roused by the trampling of their feet. Nature is such an economist, that the most incongruous animals can avail themselves of each other!

Interest makes strange friendships.-W ḢiтE.

Birds continually avail themselves of particular and unusual circurnstances to procure their food; thus wagtails keep playing about the noses and legs of cattle as they feed, in quest of flies and other insects which abound near those animals; and great numbers of them will follow close to the plough to devour the worms, etc., that are turned up by that instrument. The redbreast attends the gardener when digging his borders; and will, with great familiarity and tameness, pick out the worms, almost close to his spade, as I have frequently seen. Starlings and magpies very often sit on the backs of sheep and deer to pick out their ticks.-MARKwICK. 


\section{WRYNECK.}

These birds appear on the grass plots and walks; they walk a little as well as hop, and thrust their bills into the turf, in quest, I conclude, of ants, which are their food. While they hold their

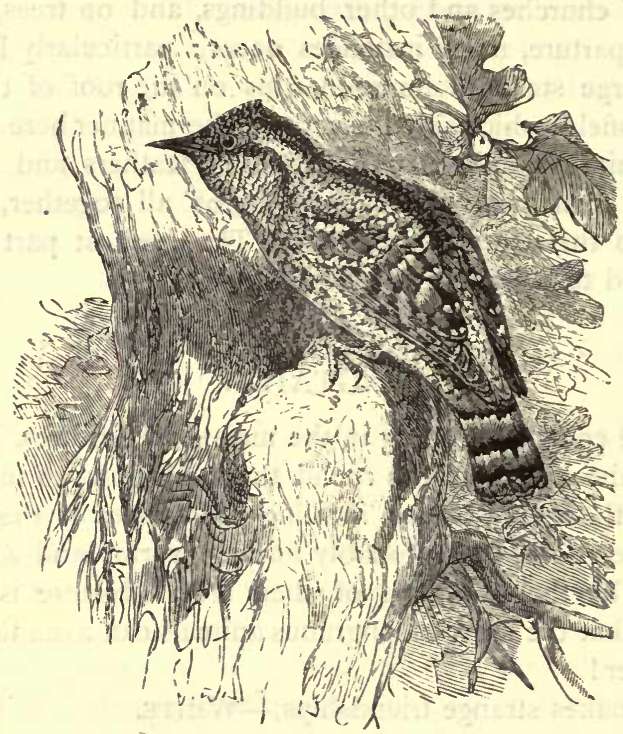

The Wryneck (Yunx torquilla).

bills in the grass, they draw out their prey with their tongues, which are so long as to be coiled round their heads. - WhITE.

\section{GROSBEAK.}

Mr. B. shot a cock grosbeak which he had observed to haunt his garden for more than a fortnight. I began to accuse this bird of making sad havoc among the buds of the cherries, gooseberries, and wall-fruit of all the neighbouring orchards. Upon opening its crop or craw, no buds were to be seen; but a mass of kernels of the stones of fruits. Mr. B. observed that this bird frequented 
the spot where plum-trees grow, and that he had seen it with somewhat hard in its mouth, which it broke with difficulty; these were the stones of damsons. The Latin ornithologists call this bird Coccothraustes, i.e., berry-breaker, because with its large horny beak it cracks and breaks the shells of stone-fruits for the sake of the seed or kernel. Birds of this sort are rarely seen in England, and only in winter.-WhiTe.

I have never seen this rare bird but during the severest cold of the hardest winters; at which season of the year I hare had in my possession two or three that were killed in this neighbourhood in different years.-MARKWICK.

\section{OBSERVATIONS ON QUADRUPEDS.}

\section{SHEEP.}

THE sheep on the downs this winter ( $\left.{ }^{769}\right)$ are very ragged, and their coats much torn; the shepherds say they tear their fleeces with their own mouths and horns, and they are always in that way in mild wet winters, being teased and tickled with a kind of lice.

After ewes and lambs are shorn, there is great confusion and bleating, neither the dams nor the young being able to distinguish one another as before. This embarrassment seems not so much to arise from the loss of the fleece, which may occasion an alteration in their appearance, as from the defect of that notus odor, discriminating each individual personally; which also is confounded by the strong scent of pitch and tar wherewith they are newly marked; for the brute creation recognise each other more from the smell than the sight; and in matters of identity and diversity, appeal much more to their noses than their eyes. After sheep have been washed there is the same confusion, from the reason given above.-WHite. 


\section{RABBITS.}

Rabbits make incomparably the finest turf, for they not only bite closer than larger quadrupeds, but they allow no bents to rise; hence warrens produce much the most delicate turf for gardens. Sheep never touch the stalks of grasses. - White.

\section{CAT AND SQUIRRELS.}

A boy has taken three young squirrels in their nest or drey as it is called in these parts. These small creatures he put under the care of a cat who had lately lost her kittens, and finds that she nurses and suckles them with the same assiduity and affection as if they were her own offspring. This circumstance corroborates my suspicion, that the mention of exposed and deserted children being nurtured by female beasts of prey who had lost their young, may not be so improbable an incident as many have supposed; and therefore may be a justification of those authors who have gravely mentioned, what some have deemed to be a wild and improbable story.

So many people went to see the little squirrels suckled by a cat, that the foster mother became jealous of her charge, and in pain for their safety; and therefore hid them over the ceiling, where one died. This circumstance shows her affection for these fondlings, and that she supposes the squirrels to be her own young. Thus hens, when they have hatched ducklings, are equally attached to them as if they were their own chickens.-WHITE.

\section{HORSE.}

An old hunting mare, which ran on the common, being taken very ill, ran down into the village, as it were, to implore the help of men, and died the night following in the street.-White.

\section{HOUNDS.}

The king's stag-hounds came down to Alton, attended by a huntsman and six yeomen prickers, with horns, to try for the stag 
that has hainted Hartley Wood for so long a time. Many hundreds of people, horse and foot, attended the dogs to see the deer unharboured; but though the huntsmen drew Hartley Wood, and Long Coppice, and Shrubwood, and Temple Hangers, and in their way back Hartley and Wardle-ham Hangers, yet no stag could be found.

The royal pack, accustomed to have the deer turned out before them, never drew the coverts with any address and spirit, as many people that were present observed; and this remark the event has proved to be a true one. For as a person was lately pursuing a pheasant that was wing-broken in Hartley Wood, he stumbled upon the stag by accident, and ran in upon him as he lay concealed amidst a thick brake of brambles and bushes.-Wнiтe.

\section{OBSERVATIONS ON INSECTS AND VERMES.}

\section{INSECTS IN GENERAL.}

THE day and night insects occupy the annuals alternately; the papilios, muscæ, and apes, are succeeded at the close of day by phalænæ, earwigs, woodlice, etc. In the dusk of the evening, when beetles begin to buz, partridges begin to call; these two circumstances are exactly coincident.

Ivy is the last flower that supports the hymenopterous and dipterous insects. On sunny days quite on to November they swarm on trees covered with this plant; and when they disappear, probably retire under the shelter of its leaves, concealing themselves between its fibres and the trees which it entwines. ${ }^{4}$ - White.

This I have often observed, having seen bees and other winged

4 The ivy is haunted at night by swarms of moths and other insects. I have seen an ivy bush, on a warm summer night, literally moving with the number of moths which were feeding on it. The eyes of the larger ones glowed like sparks of fire. 
insects swarming about the flowers of the ivy, very late in the autumn.-MARKWICK.

Spiders, woodlice, lepismæ in cupboards and among sugar, some empedes, gnats, flies of several species, some phalænæ in hedges, earth-worms, etc., are stirring at all times when winters are mild; and are of great service to those soft-billed birds that never leave us.

On every sunny day the winter through, clouds of insects usually called gnats (I suppose tipulæ and empedes) appear sporting and dancing over the tops of the evergreen trees in the shrubbery, and striking about as if the business of generation was still going on. Hence it appears that these diptera (which by their sizes appear to be of different species, are not subject to a torpid state in the winter, as most winged insects are. At night, and in frosty weather, and when it rains and blows, they seem to retire into those trees. They often are out in a fog.-WHiTE.

This I have also seen, and have frequently observed swarms of little winged insects playing up and down in the air in the middle of winter, even when the ground has been covered with snow.MARKWICK.

\section{HUMMING IN THE AIR.}

There is a natural occurrence to be met with upon the highest part of our down in hot summer days, which always amuses me much, without giving me any satisfaction with respect to the cause of it; and that is, a loud audible humming of bees in the air, though not one insect is to be seen. The sound is to be heard distinctly the whole common through, from the Money-dells to Mr. White's avenue gate. Any person would suppose that a large swarm of bees was in motion, and playing about over his head. This noise was heard last week, on June 28 th.

" Resounds the living surface of the ground, Nor undelightful is the ceaseless bum To him who muses at noon." 
" Thick in yon stream of light a thousand ways.

Upward and downward, thwarting and convolv'd,

The quivering nations sport."-THOMson's SEAsons.

WHITE.

\section{CHAFFERS.}

Cockchaffers seldom abound oftener than once in three or four years; when they swarm, they deface the trees and hedges. Whole woods of oaks are stripped bare by them.

Chaffers are eaten by the turkey, the rook, and the housesparrow.

The scarabceus solstitialis first appears about June 26th: they are very punctual in their coming out every year. They are a small species, about half the size of the May-chaffer, and are known in some parts by the name of the fern-chaffer.-WHITE.

A singular circumstance relative to the cockchaffer, or, as it is called here, the May-bug, scarabaus mclolontha, happened this year (1800). My gardener, in digging some ground, found, about six inches under the surface, two of these insects alive and perfectly formed, so early as the $24^{\text {th }}$ March. When he brought them to me, they appeared to be as perfect, and as much alive as in the midst of summer, crawling about as briskly as ever; yet I saw no more of this insect till the 22 nd May, when it began to make its appearance. How comes it, that though it was perfectly formed so early as the $24^{\text {th }}$ March, it did not show itself above ground till nearly two months afterwards?MARKWICK.

\section{PTINUS PECTINICORNIS.}

Those maggots that make worm-holes in tables, chairs, bedposts, etc., and destroy wooden furniture, especially where there is any sap, are the larvæ of the ptinus pectinicornis. This insect, it is probable, deposits its eggs on the surface, and the worms eat their way in. 
In their holes they turn into their pupæ state, and so come forth winged in July; eating their way through the valances or curtains of a bed, or any other furniture that happens to obstruct their passage.

They seem to be most inclined to breed in beech: hence beech will not make lasting utensils, or furniture. If their eggs are deposited on the surface, frequent rubbing will preserve wooden furniture.-WHITE.

\section{BLATTA ORIENTALIS.-COCKROACH.}

A neighbour complained that her house was overrun with a kind of black beetle, or, as she expressed herself, with a kind of black-bob, which swarmed in her kitchen when they got up in a morning before daybreak.

Soon after this account, I observed an unusual insect in one of my dark chimney closets, and find since, that in the night, they swarm also in my kitchen. On examination I soon ascertained the species to be the blatta orientalis of Linnæus, and the blatta molendinaria of Mouffet. The male is winged; the female is not, but shows somewhat like the rudiments of wings, as if in the pupa state.

These insects belonged originally to the warmer parts of America, and were conveyed from thence by shipping to the East Indies; and by means of commerce begin to prevail in the more northern parts of Europe, as Russia, Sweden, etc. How long they have abounded in England I cannot say; but have never observed them in my house till lately.

They love warmth, and haunt chimney closets and the backs of ovens. Poda says that these and house crickets will not associate together; but he is mistaken in that assertion, as Linnæus suspected he was. They are altogether night insects, lucifuge, never coming forth till the rooms are dark and still, and escaping away nimbly at the approach of a candle. Their antennæ are remarkably long, slender, and flexile.

October I 790. After the servants are gone to bed, the kitchen 
hearth swarms with young crickets, and young blattce molendinaria of all sizes, from the most minute growth to their full proportions. They seem to live in a friendly manner together, and not to prey the one on the other.

August 1792. After the destruction of many thousands of blattce molendinarice, we find that at intervals a fresh detachment of old ones arrives, and particularly during this hot season; for the windows being left open in the evenings, the males come flying in at the casements from the neighbouring houses, which swarm with them. How the females, that seem to have no perfect wings that they can use, can contrive to get from house to house, does not so readily appear. These, like many insects, when they find their present abodes overstocked, have powers of migrating to fresh quarters. Since the blatice have been so much kept under, the crickets have greatly increased in number. -White.

\section{GRYLLUS DOMESTICUS.-HOUSE CRICKET.}

November. After the servants are gone to bed, the kitchen hearth swarms with minute crickets not so large as fleas, which must have been lately hatched. So that these domestic insects, cherished by the influence of a constant large fire, regard not the season of the year, but produce their young at a time when their congeners are either dead, or laid up for the winter, to pass away the uncomfortable months in the profoundest slumbers, and a state of torpidity.

When house-crickets are out, and running about in a room in the night, if surprised by a candle, they give two or three shrill notes, as it were for a signal to their fellows, that they may escape to their crannies and lurking holes, to avoid danger. -WHITE.

\section{CIMEX LINEARIS.}

August $\mathrm{I} 2$ th, $\mathrm{I} 775$. Cimices lineares are now in high copulation on ponds and pools. The females, who vastly exceed the males 
in bulk, dart and shoot along on the surface of the water with the males on their backs. When a female chooses to be disengaged, she rears, and jumps, and plunges, like an unruly colt; the lover thus dismounted, soon finds a new mate. The females, as fast as their curiosities are satisfied, retire to another part of the lake, perhaps to deposit their fœetus in quiet; hence the sexes are found separate, except where generation is going on. From the multitude of minute young of all gradations of sizes, these insects seem without doubt to be viviparous.-WHITE.

\section{PHALÆNA QUERCUS.}

Most of our oaks are naked of leaves, and even the Holt in general, having been ravaged by the caterpillars of a small phalana which is of a pale yellow colour. These insects, though a feeble race, yet, from their infinite numbers, are of wonderful effect, being able to destroy the foliage of whole forests and districts. At this season they leave their aurelia, and issue torth in their fly-state, swarming and covering the trees and hedges.

In a field at Greatham, I saw a flight of swifts busied in catching their prey near the ground; and found they were hawking after these phalane. The aurelia of this moth is shining and as black as jet; and lies wrapped up in a leaf of the tree, which is rolled round it, and secured at the ends by a web, to prevent the maggot from falling out.-WHITE.

I suspect that the insect here meant is not the phalana quercus, but the phalcena viridata, concerning which, I find the following note in my "Naturalist's Calendar" for the year 1785 .

About this time, and for a few days last past, I observed the leaves of almost all the oak-trees in Denn copse to be eaten and destroyed, and, on examining more narrowly, saw an infinite number of small beautiful pale green moths flying about the trees; the leaves of which that were not quite destroyed were curled up, and withinside were the exuvia or remains of the chrysalis, from whence 
I suppose the moths had issued, and whose caterpillar had eaten the leaves.-MARKWICK.

\section{EPHEMERA CAUDA BISETA.-MAY-FLY.}

June roth, 177r. Myriads of May-flies appear for the first time on the Alresford stream. The air was crowded with them, and

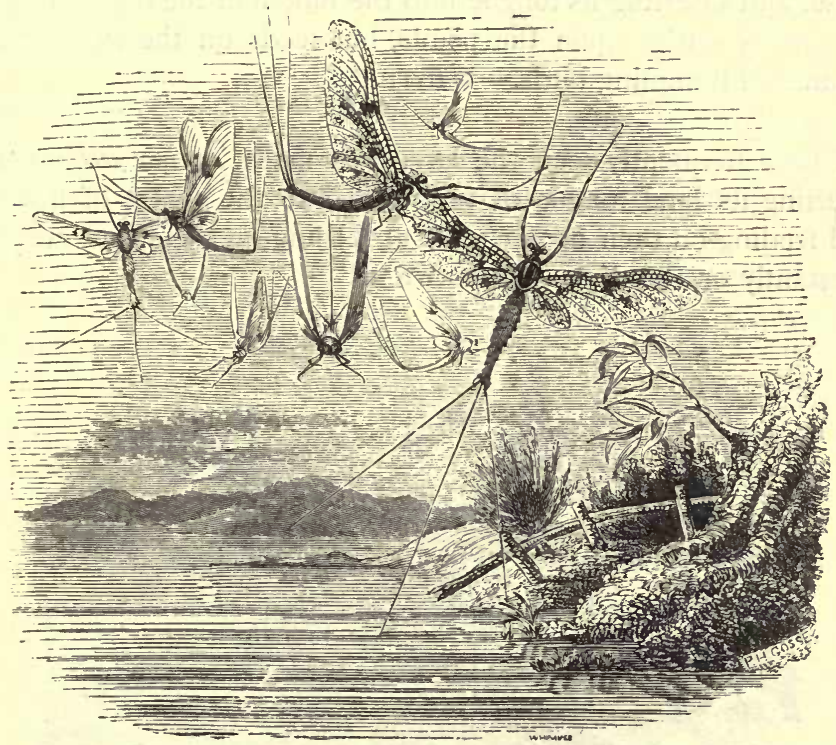

May-Flies in Sunset Dance.

the surface of the water covered. Large trouts sucked them in as they lay struggling on the surface of the stream, unable to rise till their wings were dried.

This appearance reconciled me in some measure to the wonderful account that Scopoli gives of the quantities emerging from the rivers of Carniola. Their motions are very peculiar, up and down for many yards almost in a perpendicular line.-WHITE. 


\section{IBSERVATIONS ON INSECTS AND VERMES.}

I cnce saw a swarm of these insects playing up and down ove: the surface of a pond in Denn Park, exactly in the manner described by this accurate naturalist. It was late in the evening of a warm summer's day when I observed them.-MaRKWICK.

\section{SPHYNX OCELLATA.}

A vast insect appears after it is dusk, flying with a humming noise, and inserting its tongue into the bloom of the honey-suckle; it scarcely settles upon the plants, but feeds on the wing in the manner of humming birds.-WHITE.

I have frequently seen the large bee moth, sphinx stellatarum, inserting its long tongue or proboscis into the centre of flowers, and feeding on their nectar, without settling on them, but keeping constantly on the wing.-MARKwick.

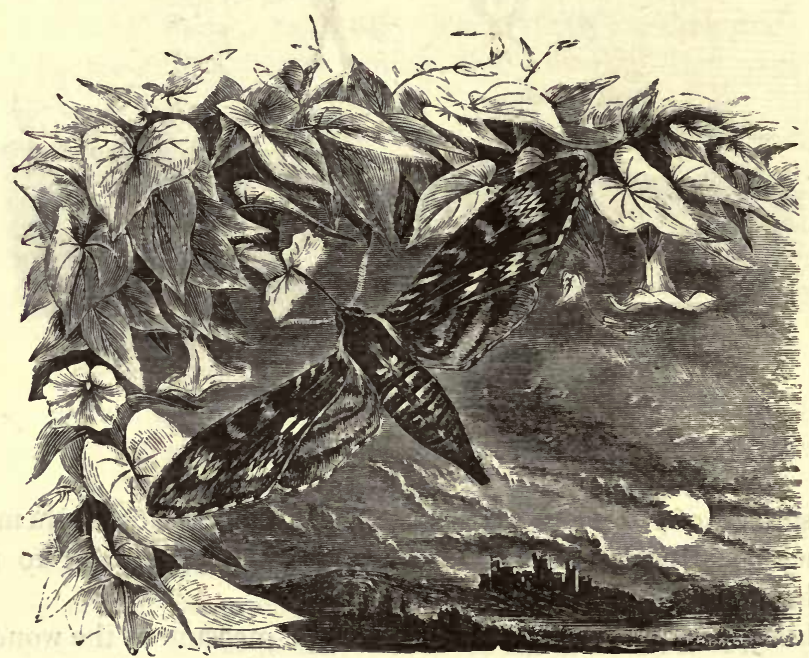

Convolvulus Hawk-Moth. 


\section{WILD BEE.}

There is a sort of wild bee frequenting the garden-campion for the sake of its tomentum, which probably it turns to some purpose in the business of nidification. It is very pleasant to see with what address it strips off the pubes, running from the top to the bottom of a branch, and shaving it bare with all the dexterity of a hoop-shaver. When it has got a vast bundle, almost as large as itself, it flies away, holding it secure between its chin and its fore legs.

There is a remarkable hill on the downs near Lewes in Sussex, known by the name of Mount Carburn, which overlooks that town, and affords a most engaging prospect of all the country round, besides several views of the sea. On the very summit of this exalted promontory, and amidst the trenches of its Danish camp, there haunts a species of wild bee, making its nest in the chalky soil. When people approach the place, these insects begin to be alarmed, and, with a sharp and hostile sound, dash and strike round the heads and faces of intruders. I have often been interrupted myself while contemplating the grandeur of the scenery around me, and have thought myself in danger of being stung.WHITE.

\section{WASPS.}

Wasps abound in woody wild districts far from neighbourhoods; they feed on flowers, and catch flies and caterpillars to carry to their young. Wasps make their nests with the raspings of sound timber ; hornets, with what they gnaw from decayed : these particles of wood are kneaded up with a mixture of saliva from their bodies and moulded into combs.

When there is no fruit in the gardens, wasps eat flies, and suck the honey from flowers, from ivy blossoms and umbellated plants; they carry off also flesh from butchers' shambles.-WHITE.

In the year 177.5 , wasps abounded so prodigiously in this neighbourhood, that, in the month of August, no less than seven or 
eight of their nests were ploughed up in one field : of which there were several instances, as I was informed.

In the spring, about the beginning of April, a single wasp is sometimes seen, which is of a larger size than usual; this I imagine is the queen or female wasp, the mother of the future swarm.-MARKWICK.

\section{OESTRUS CURVICAUDA.}

This insect lays its nits or eggs on horses' legs, flanks, etc., each on a single hair. The maggots, when hatched, do not enter the horses' skins, but fall to the ground. It seems to abound most in moist, moorish places, though sometimes seen in the uplands. -White.

\section{NOSE-FLY.}

About the beginning of July, a species of fly (musca) obtains, which proves very tormenting to horses, trying still to enter their nostrils and ears, and actually laying their eggs in the latter of those organs, or perhaps in both. When these abound, horses in woodland districts become very impatient at their work, continually tossing their heads, and rubbing their noses on each other, regardless of the driver, so that accidents often ensue. In the heat of the day, men are often obliged to desist from ploughing. Saddle-horses are also very troublesome at such seasons. Country people call this insect the nose-fly.-White.

Is not this insect the Oestrus nasalis of Linnæus, so well described by Mr. Clark in the third volume of the "Linnæan Transactions," under the name of Oestrus veterinus?-MARKwick.

\section{ICHNEUMON FLY.}

I saw lately a small ichneumon fly attack a spider much larger than itself on a grass -walk. When the spider made any resistance, the ichneumon applied her tail to him, and stung him with great vehemence, so that he soon became dead and motionless. The 
ichneumon then running backward drew her prey very nimbly over the walk into the standing grass. This spider would be deposited in some hole where the ichneumon would lay some eggs; and as soon as the eggs were hatched, the carcase would afford ready food for the maggots.

Perhaps some eggs might be injected into the body of the spider, in the act of stinging. Some ichneumons deposit their eggs in the aurelia of moths and butterflies. - WhiтE.

In my "Naturalist's Calendar" for I 795, July 2 Ist, I find the following note :

It is not uncommon for some of the species of ichneumon flies to deposit their eggs in the chrysalis of a butterfly; some time ago I put two of the chrysales of a butterfly into a box, and covered it with gauze, to discover what species of butterfly they would produce; but instead of a butterfly, one of them produced a number of small ichneumon flies.

There are many instances of the great service these little insects are to mankind in reducing the number of noxious insects, by depositing their eggs in the soft bodies of their larve; but none more remarkable than that of the ichneumon tipula, which pierces the tender bodies and deposits its eggs in the larva of the Tipula tritici, an insect which, when it abounds greatly, is very prejudicial to the grains of wheat. This operation I have frequently seen it perform with wonder and delight.-MARKwICK.

\section{BOMBYLIUS MEDIUS.}

The Bombylius medius is much about in March and the beginning of April, and soon seems to retire. It is a hairy insect, like a humble-bee, but with only two wings, and a long straight beak, with which it sucks the early flowers. The female seems to lay its eggs as it poises on its wings, by striking its tail on the ground, and against the grass that stands in its way, in a quick manner, for several times together.-White.

I have often seen this insect fly with great velocity; stop un 
a sudden, hang in the air in a stationary position for some time, and then fly off again; but do not recollect having ever seen it strike its tail against the ground, or any other substance..MARKWICK.

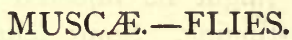

In the decline of the year, when the mornings and evenings become chilly, many species of flies (Musca) retire into houses, and swarm in the windows.

At first they are very brisk and alert; but as they grow more torpid, one cannot help observing that they move with difficulty, and are scarce able to lift their legs, which seem as if glued to the glass ; and by degrees many do actually stick on till they die in the place.

It has been observed that divers flies, besides their sharp hooked nails, have also skinny palms, or flaps to their feet, whereby they are enabled to stick on the glass and other smooth bodies, and to walk on ceilings with their backs downward, by means of the pressure of the atmosphere on those flaps; the weight of which they easily overcome in warm weather, when they are brisk and alert. But in the decline of the year, this resistance becomes too mighty for their diminished strength; and we see flies labcuring along, and lugging their feet in windows as if they stuck to the glass, and it is with the utmost difficulty they can draw one foot after another, and disengage their hollow caps from the slippery surface.

Upon the same principle that flies stick and support themselves, do boys, by way of play, carry heavy weights by only a piece of wet leather at the end of a string clapped close on the surface of a stone.-WHITE.

\section{TIPULÆ, OR EMPEDES.}

May.-Millions of empedes, or tipula, come forth at the close of dav, and swarm to such a degree as to fill the air. At this juncture thiey sport and copulate; as it grows more dark they 
retire. All day they hide in the hedges. As they rise in a cloud they appear like smoke.

I do not remember to have seen such swarms, except in the fens of the Isle of Ely. They appear most over grass grounds.WHITE.

\section{APHIDES.}

On the rst August, about half an hour after three in the afternoon, the people of Selborne were surprised by a shower of aphides which fell in these parts. They who were walking in the streets at that time found themselves covered with these insects,

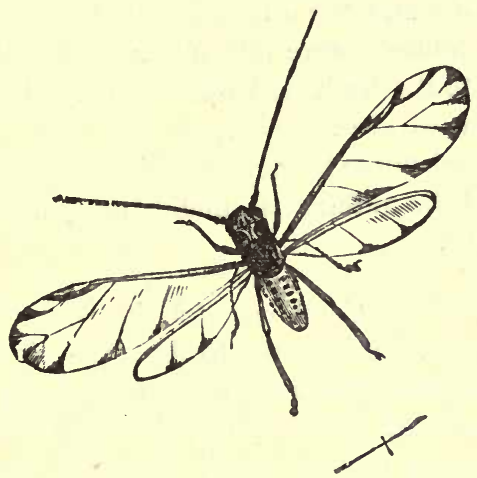

LIME-TREE APHIS.

(The lines under the figure show the actual size.)

which settled also on the trees and gardens, and blackened all the vegetables where they alighted. These armies, no doubt, were . then in a state of emigration, and shifting their quarters; and might perhaps come from the great hop-plantations of Kent or Sussex, the wind being that day at north. They were observed at the same time at Farnham, and all along the vale to Alton.WHITE.

\section{ANTS.}

August 23rd.-Every' ant-hill about this time is a strange hurry 
and confusion; and all the winged ants, agitated by some violent impulse, are leaving their homes, and, bent on emigration, swarm by myriads in the air, to the great emolument of the hirundines, which fare luxuriously. Those that escape the swallows return no more to their nests, but looking out for fresh settlements, lay a foundation for future colonies. All the females at this time are pregnant; the males that escape being eaten, wander away and die.

October 2nd.-Flying-ants, male and female, usually swarm and migrate on hot sunny days in August and September : but this day a vast emigration took place in my garden, and myriads came forth, in appearance from the drain which goes under the fruitwall, filling the air and the adjoining trees and shrubs with their numbers. The females were full of eggs. This late swarming is probably owing to the backward wet season. The day following, not one flying ant was to be seen.

Horse-ants travel home to their nests laden with flies which they have caught, and the aureliæ of smaller ants, which they seize by violence.-WhiтE.

In my "Naturalist's Calendar" for the year $\mathbf{1 7 7 7}$, on September 6th, I find the following note to the article Flying Ants.

I saw a prodigious swarm of these ants flying about the top of some tall elm-trees (close by my house); some were continually dropping to the ground, as if from the trees, and others rising up from the ground; many of them were joined together in copulation; and I imagine their life is but short, for as soon as produced from the egg by the heat of the sun, they propagate their species, and soon after perish. They were black, somewhat like the small black ant, and had four wings. I saw also, at another place, a large sort, which were yellowish. On the 8th September, I785, I again observed the same circumstance of a vast number of these insects flying near the tops of the elms and dropping to the ground.

On the 2 nd March, 1777 , I saw great numbers of ants come out of the ground. - MARKWICK. 


\section{GLOW-WORMS.}

By observing two glow-worms which were brought from the field to the bank in the garden, it appeared to us that these little creatures put out their lamps between eleven and twelve, and shine no more for the rest of the night.

Little glow-worms, attracted by the light of the candles, come into the parlour.-WHITE.

\section{EARTH-WORMS.}

Earth-worms make their casts most in mild weather, about March and April; they do not lie torpid in winter, but come forth when there is no frost; they travel about in rainy nights, as appears from their sinuous tracks on the soft muddy soil, perhaps in search of food.

When earth-worms lie out a-nights on the turf, though they extend their bodies a great way, they do not leave their holes, but keep the ends of their tails fixed therein, so that on the least alarm they can retire with precipitation under the earth. Whatever food falls within their reach when thus extended, they seem to be content with, such as blades of grass, straws, fallen leaves, the ends of which they often draw into their holes ; even in copulation their hinder parts never quit their holes; so that no two, except they lie within reach of each other's bodies, can have any commerce of that kind; but as every individual is an hermaphrodite, there is no difficulty in meeting with a mate, as would be the case were they of different sexes.-WHITE.

\section{SNAILS AND SLUGS.}

The shell-less snails called slugs are in motion all the winter in mild weather, and commit great depredations on garden plants, and much injure the green wheat, the loss of which is imputed to earth-worms ; while the shelled snail, the фєєєоккоs, does not come forth at all till about April roth, and not only lays itself up pretty early in autumn, in places secure from frost, but also throws out 
round the mouth of its shell a thick operculum formed from its own saliva; so that it is perfectly secured and corked up, as it were, from all inclemencies. The cause why the slugs are able to endure the cold so much better than shell-snails is, that their bodies are covered with slime, as whales are with blubber.

Snails copulate about Midsummer; and soon after deposit their eggs in the mould by running their heads and bodies under ground. Hence the way to be rid of them is to kill as many as possible before they begin to breed.

Large, grey, shell-less cellar-snails lay themselves up about the

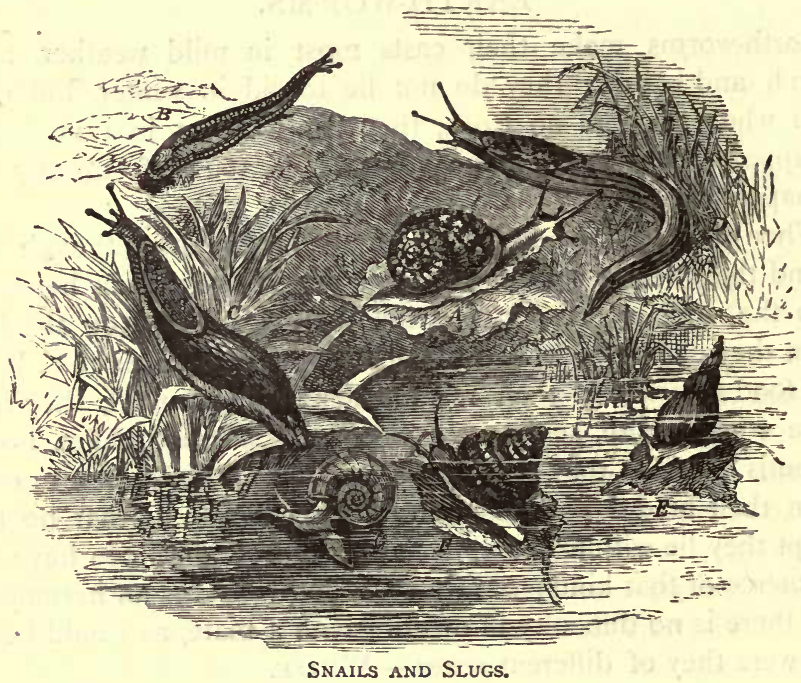

same time with those that live abroad; hence it is plain that a defect of warmth is not the only cause that influences their retreat. -WHITE.

\section{SNAKE'S SLOUGH.}

"—-There the snake throws her enamell'd skin."

SHAKespeare's Mids. Night's DREAM.

About the middle of this month (September) we found in a field near a hedge the slough of a large snake, which seemed to 
have been newly cast. From circumstances it appeared as if turned wrong side outward, and as drawn off backward, like a stocking or woman's glove. Not only the whole skin, but scales from the very eyes are peeled off, and appear in the head of the slough like a pair of spectacles. The reptile, at the time of changing his coat, had entangled himself intricately in the grass and weeds, so that the friction of the stalks and blades might promote this curious shifting of his exuviæ.

\section{Exuit in spinis vestem."-LUCRET.}

It would be a most entertaining sight could a person be an eyewitness to such a feat, and see the snake in the act of changing his garment. As the convexity of the scales of the eyes in the slough is now inward, that circumstance alone is a proof that the skin has been turned; not to mention that now the present inside is much darker than the outer. If you look through the scales of the snake's eyes from the concave side, viz., as the reptile used them, they lessen objects much. Thus it appears from what has been said, that snakes crawl out of the mouth of their own sloughs, and quit the tail part last, just as eels are skinned by a cook maid. While the scales of the eyes are growing loose, and a new skin is forming, the creature in appearance must be blind, and feel itself in an awkward uneasy situation.-WHITE.

I have seen many sloughs or skins of snakes entire, after they have cast them off; and once in particular I remember to have found one of these sloughs so intricately interwoven amongst some brakes that it was with difficulty removed without being broken; this undoubtedly was done by the creature to assist in getting rid of its encumbrance.

I have great reason to suppose that the eft or common lizard also casts its skin or slough, but not entire like the snake; for on the 3 oth March, I777, I saw one with something ragged hanging to it, which appeared to be part of its old skin.-MARKwick. 


\section{OBSERVATIONS ON VEGETABLES.}

\section{TREES, ORDER OF LOSING THEIR LEAVES.}

ONE of the first trees that becomes naked is the walnut; the mulberry, the ash, especially if it bears many keys, and the horsechestnut come next. All lopped trees, while their heads are young, carry their leaves a long while. Apple-trees and peaches remain green very late, often till the end of November: young beeches never cast their leaves till spring, till the new leaves sprout and push them off; in the autumn the beechen-leaves turn of a deep chestnut colour. Tall beeches cast their leaves about the end of October.-WHite.

\section{SIZE AND GROWTH.}

Mr. Marsham of Stratton, near Norwich, informs me by letter thus: "I became a planter early; so that an oak which I planted in $I 720$ is become now, at one foot from the earth, twelve feet six inches in circumference, and at fourteen feet (the half of the timber length) is eight feet two inches. So if the bark was to be measured as timber, the tree gives $116 \frac{1}{2}$ feet, buyer's measure. Perhaps you never heard of a larger oak while the planter was living. I flatter myself that I increased the growth by washing the stem, and digging a circle as far as I supposed the roots to extend, and by spreading sawdust, etc., as related in the Phil. Trans. i wish I had begun with beeches (my favourite trees as well as yours), I might then have seen very large trees of my own raising. But I did not begin with beech till I 74I, and then by seed; so inat .ny largest is now at five feet from the ground, six feet three inches in girth, and with its head spreads a circle of twenty yards diameter. This tree was also dug round, washed, etc."-Stratton, 24th July, I 790 . 
The circumference of trees planted by myself at one foot from the ground ( 1790$)$.

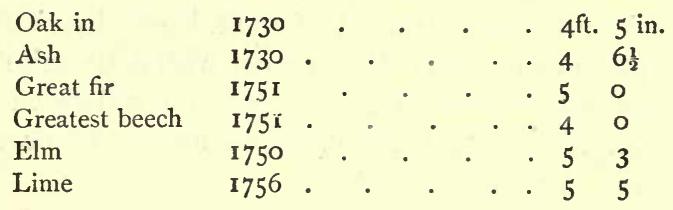

The great oak in the Holt, which is deemed by Mr. Marsham to be the biggest in this island, at seven feet from the ground, measures in circumference thirty-four feet. It has in old times lost several of its boughs, and is tending to decay. Mr. Marsham computes, that at fourteen feet length this oak contains 1000 feet of timber.

It has been the received opinion that trees grow in height only by their annual upper shoot. But my neighbour over the way, whose occupation confines him to one spot, assures me, that trees are expanded and raised in the lower parts also. The reason that he gives is this: the point of one of my firs began for the first time to peep over an opposite roof at the beginning of summer; but before the growing season was over, the whole shoot of the year, and three or four joints of the body beside, became visible to him as he sits on his form in his shop. According to this supposition, a tree may advance in height considerably, though the summer shoot should be destroyed every year.-WHite.

\section{FLOWING OF SAP.}

If the bough of a vine is cut late in the spring, just before the shoots push out, it will bleed considerably; but after the leaf is sut, any part may be taken off without the least inconvenience. So oaks may be barked while the leaf is budding; but as soon as they are expanded, the bark will no longer part from the wood, because the sap that lubricates the bark and makes it part, is evaporated off through the leaves. - WHITE. 


\section{RENOVATION OF LEAVES.}

When oaks are quite stripped of their leaves by chaffers, they are clothed again soon after Midsummer with a beautiful foliage : but beeches, horse-chestnuts and maples, once defaced by those insects, never recover their beauty again for the whole season.WHITE.

\section{ASH TREES.}

Many ash trees bear loads of keys every year, others never seem to bear any at all. The prolific ones are naked of leaves and unsightly; those that are sterile abound in foliage, and carry their verdure a long while, and are pleasing objects. - White.

\section{BEECH.}

Beeches love to grow in crowded situations, and will insinuate themselves through the thickest covert, so as to surmount it all: are therefore proper to mend thin places in tall hedges. - WhiTE.

\section{SYCAMORE.}

May I 2 th. - The sycamore or great maple is in bloom, and at this season makes a beautiful appearance, and affords much pabulum

- for bees, smelling strongly like honey. The foliage of this tree is very fine, and very ornamental to outlets. All the maples have saccharine juices.-White.

\section{GALLS OF LOMBARDY POPLAR.}

The stalks and ribs of the leaves of the Lombardy poplar are embossed with large tumours of an oblong shape, which by incurious observers have been taken for the fruit of the tree. These galls are full of small insects, some of which are winged, and some not. The parent insect is of the genus of cynips. Some poplars in the garden are quite loaded with these excrescences.-WHITE. 


\section{CHESTNUT TIMBER.}

John Carpenter brings home some old chestnut trees which are very long; in several places the wood-peckers had begun to bore them. The timber and bark of these trees are so very like oak, as might easily deceive an indifferent observer, but the wood is very shakey, and towards the heart cup-shakey (that is to say, apt to separate in round pieces like cups), so that the inward parts are of no use. They are bought for the purpose of cooperage, but must make but ordinary barrels, buckets, etc. Chestnut sells for half the price of oak; but has sometimes been sent into the king's docks, and passed off instead of oak.-WHrTE.

\section{LIME BLOSSOMS.}

Dr. Chandler tells that in the south of France, an infusion of the blossoms of the lime tree, Tilia, is in much esteem as a remedy for coughs, hoarsenesses, fevers, etc., and that at Nismes, he saw an avenue of limes that was quite ravaged and torn to pieces by people greedily gathering the bloom, which they dried and kept for these purposes.

Upon the strength of this information we made some tea of lime blossoms, and found it a very soft, well-flavoured, pleasant, saccharine julep, in taste much resembling the juice of liquorice.WHITE.

\section{BLACKTHORN.}

This tree usually blossoms while cold north-east winds blow; so that the harsh rugged weather obtaining at this season, is called by the country people, blackthorn winter.-WHITE.

\section{IVY BERRIES.}

Ivy berries form a noble and providential supply for birds in winter and spring; for the first severe frost freezes and spoils all the haws, sometimes by the middle of November; ivy berries do not seem to freeze.-White. 


\section{HOPS.}

The culture of Virgil's vines corresponds very exactly with the modern management of hops. I might instance in the perpetual diggings and hoeings, in the tying to the stakes and poles, in pruning the superfluous shoots, etc., but lately I have observed a new circumstance, which was a neighbouring farmer's harrowing between the rows of hops with a small triangular harrow, drawn by one horse, and guided by two handles. This occurrence brought to my mind the following passage :

\section{Flectere luctantes inter vineta juvencos."-GEORG.}

Hops are diœcious plants; hence perhaps it might be proper, though not practised, to leave purposely some male plants in every garden, that their farina might impregnate the blossoms. The female plants without their male attendants are not in their natural state: hence we may suppose the frequent failure of crop so incident to hop-grounds; no other growth, cultivated by man, has such frequent and general failures as hops.

Two hop gardens much injured by a hailstorm, June $5^{\text {th, show }}$ now (September 2 nd) a prodigious crop, and larger and fairer hops than any in the parish. The owners seem now to be convinced that the hail, by beating off the tops of the binds, has increased the side-shoots, and improved the crop. Query. Therefore should not the tops of hops be pinched off when the binds are very gross, and strong?-WHITE.

\section{SEED LYING DORMANT.}

The naked part of the Hanger is now covered with thistles of various kinds. The seeds of these thistles may have lain probably under the thick shade of the beeches for many years, but could not vegetate till the sun and air were admitted. When old beech trees are cleared away, the naked ground in a year or two becomes covered with strawberry plants, the seeds of which must have lain in the ground for an age at least. One of the slidders or trenches 
down the middle of the Hanger, close covered over with lofty beeches near a century old, is still called " strawberry slidder," though no strawberries have grown there in the memory of man. That sort of fruit did once, no doubt, abound there, and will again when the obstruction is removed.-WHITE.

\section{BEANS SOWN BY BIRDS.}

Many horse-beans sprang up in my field-walks in the autumn, and are now grown to a considerable height. As the Ewel was in beans last summer, it is most likely that these seeds came from thence; but then the distance is too considerable for them to have been conveyed by mice. It is most probable therefore that they were brought by birds, and in particular by jays and pies, who seem to have hid them among the grass and moss, and then to have forgotten where they had stowed them. Some pease are growing also in the same situation, and probably under the same circumstances.-WHITE.

\section{CUCUMBERS SET BY BEES.}

If bees, who are much the best setters of cucumbers, do not happen to take kindly to the frames, the best way is to tempt them by a little honey put on the male and female bloom. When they are once induced to haunt the frames, they set all the fruit, and will hover with impatience round the lights in a morning, till the glasses are opened. Probatum est.-White.

\section{WHEAT.}

A notion has always obtained that in England hot summers are productive of fine crops of wheat; yet in the years 1780 and $178 \mathrm{I}$, though the heat was intense, the wheat was much mildewed, and the crop light. Does not severe heat, while the straw is milky, occasion its juices to exude, which being extravasated, occasion spots, discolour the stems and blades, and injure the health of the plants?-WHITE. 


\section{TRUFFLES.}

August.-A truffle-hunter called on us, having in his pocket several large truffles found in this neighbourhood. He says these roots are not to be found in deep woods, but in narrow hedgerows and the skirts of coppices. Some truffles, he informed us, lie two feet within the earth, and some, quite on the surface; the latter, he added, have little or no smell, and are not so easily discovered by the dogs as those that lie deeper. Half-a-crown a pound was the price which he asked for this commodity. Truffles never abound in wet winters and springs. They are in season, in different situations, at least nine months in the year.-WHITE.

\section{TREMELLA NOSTOC.}

Though the weather may have been ever so dry and burning, yet after two or three wet days, this jelly-like substance abounds on the walks. -WHite.

\section{FAIRY RINGS.}

The cause, occasion, call it what you will, of fairy rings, subsists in the turf, and is conveyable with it: ${ }^{1}$ for the turf of my gardenwalks, brought from the down above, abounds with those appearances, which vary their shape, and shift situation continually, discovering themselves now in circles, now in segments, and sometimes in irregular patches and spots. Wherever they obtain, puffballs abound; the seeds of which were doubtless brought in the turf.-White.

1 Fairy rings are caused by certain fungi which throw their seeds outwarts, so that a gradually increasing circle is formed of greener and brighter vegetation. 


\section{METEOROLOGICAL OBSERVATIONS.}

\section{BAROMETER.}

November 22nd, 1768 . A remarkable fall of the barometer all over the kingdom. At Selborne we had no wind, and not much rain; only vast, swagging, rock-like clouds appeared at a distance.WHITE.

\section{PARTIAL FROST.}

The country people, who are abroad in winter mornings long before sunise, talk much of hard frosts in some spots, and none in others. The reason of these partial frosts is obvious, for there are at such times partial fogs about; where the fog obtains, little or no frost appears; but where the air is clear, there it freezes hard. So the frost takes place either on hill or in dale, wherever the air happens to be clearest and freest from vapour.-WHITE.

\section{THAW.}

Thaws are sometimes surprisingly quick, considering the small quantity of rain. Does not the warmth at such times come from below? The cold in still, severe seasons seems to come down from above; for the coming over of a cloud in severe nights raises the thermometer abroad at once full ten degrees. The first notices of thaws often seem to appear in vaults, cellars, etc.

If a frost happens, even when the ground is considerably dry, as soon as a thaw takes place, the paths and fields are all in a batter. Country people say that the frost draws moisture. But the true philosophy is, that the steam and vapours continually ascending from the earth, are bound in by the frost, and not suffered to escape till released by the thaw. No wonder then that the surface is all in a float ; since the quantity of moisture by evaporation that arises daily from every acre of ground is astonishing.-WHrte. 


\section{FROZEN SLEET.}

January 2oth.-Mr. H.'s man says that he caught this dry in a lane near Hackwood park, many rooks, whick, attempting to fly, fell from the trees with their wings frozen together by the sleet, that froze as it fell. There were, he affirms, many dozen so dis. abled.-White.

\section{MIST, CALLED LONDON SMOKE.}

This is a blue mist which has somewhat the smell of coal smoke, and as it always comes to us with a N.E. wind, is supposed to come from London. It has a strong smell, and is supposed to occasion blights. When such mists appear they are usually followed by dry weather.-WHitF.

\section{REFLECTION OF FOG.}

When people walk in a deep white fog by night with a lanthorn, if they will turn their backs to the light, they will see their shades impressed on the fog in rude gigantic proportions. This phenomenon seems not to have been attended to, but implies the great density of the meteor at that juncture.-WhitE.

\section{HONEY DEW.}

June 4 th, I 783 . - Fasthoney dews this week. The reason of these seem to be, that in hot days the effluvia of flowers are drawn up by a brisk evaporation, and then in the night fall down with the dews with which they are entangled.

This clammy substance is very grateful to bees, who gather it with great assiduity, but it is injurious to the trees on which it happens to fall, by stopping the pores of the leaves. The greatest quantity falls in still close weather; because winds disperse it, and copious dews dilute it, and prevent its ill effects. It falls mostly in hazy warm weather.-WHite. 


\section{MORNING CLOUDS.}

After a bright night and vast dew, the sky usually becomes cloudy by eleven or twelve o'slock in the forenoon, and clear again towards the decline of the day. The reason seems to be, that the dew, drawn up by evaporation, occasions the clouds; which, towards evening, being no longer rendered buoyant by the warmth of the sun, melt away, and fall down again in dews. If clouds are watched in a still warm evening, they will be seen to melt away and disappear. - W HITE.

\section{DRIPPING WEATHER AFTER DROUGHT.}

No one that has not attended to such matters, and taken down remarks, can be aware how much ten days' dripping weather will influence the growth of grass or corn after a severe dry season. This present summer, $\mathbf{1} 776$, yielded a remarkable instance : for till the 3 oth May the fields were burnt up and naked, and the barley not half out of the ground; but now, June 1 oth, there is an agreeable prospect of plenty. - WHITE.

\section{AURORA BOREALIS.}

November Ist, I 787. - The N. aurora made a particular appearance, forming itself into a broad, red, fiery belt, which extended from $\mathrm{E}$. to $\mathrm{W}$. across the welkin : but the moon rising at about ten o'clock, in unclouded majesty, in the E., put an end to this grand, but awful meteorous phenomenon.-WHitE.

\section{BLACK SPRING, I77I.}

Dr. Johnson says, that "in I77I the season was so severe in the island of Sky, that it is remembered by the name of the 'black spring.' The snow, which seldom lies at all, covered the ground for eight weeks, many cattle died, and those that survived were so emaciated that they did not require the male at the usual season." 
The case was just the same with us here in the south; never were so many barren cows known as in the spring following that dreadful period. Whole dairies missed being in calf together.

At the end of March the face of the earth was naked to a surprising degree. Wheat hardly to be seen, and no signs of any grass; turnips all gone, and sheep in a starving way. All provisions rising in price. Farmers cannot sow for want of rain. WHITE.

\section{ON THE DARK, STILI, DRY, WARM WEATHER,}

OCCASIONALLY HAPPENING IN THE WINTER MONTHS.

TH' imprison'd winds slumber within their caves Fast bound : the fickle vane, emblem of change, Wavers no more, long-settling to a point.

All nature nodding seems composed : thick steams

From land, from flood up-drawn, dimming the day,

“"Like a dark ceiling stand : " slow thro' the air

Gossamer floats, or stretch'd from blade to blade The wavy net-work whitens all the field.

Push'd by the weightier atmosphere, up springs

The ponderous Mercury, from scale to scale Mounting, amidst the Torricellian tube.*

While high in air, and pois'd upon his wings Unseen, the soft, enamour'd wood-lark runs Thro' all his maze of melody ; - the brake Loud with the black-bird's bolder note resounds.

Sooth'd by the genial warmth, the cawing rook Anticipates the spring, selects her mate, Haunts her tall nest-trees, and with sedulous care Repairs her wicker eyrie, tempest torn.

The ploughman inly smiles to see upturn His mellow glebe, best pledge of future cron: With glee the gardener eyes his smoking beas: E'en pining sickness feels a short relief.

* The Barometer. 
The happy schoolboy brings transported forth

His long-forgotten scourge, and giddy gig:

O'er the white paths he whirls the rolling hoop,

Or triumphs in the dusty fields of taw.

Not so the museful sage :- abroad he walks

Contemplative, if haply he may find

What cause controls the tempest's rage, or whence

Amidst the savage season winter smiles.

For days, for weeks, prevails the placid calm.

At length some drops prelude a change : the sun

With ray refracted bursts the parting gloom;

When all the chequer'd sky is one bright glare.

Mutters the wind at eve : th' horizon round

With angry aspect scowls : down rush the showers,

And float the delug'd paths, and miry fields.

\section{SUMMARY OF THE WEATHER.}

MEASURE OF RAIN IN INCHES AND HUNDREDS.

\begin{tabular}{|c|c|c|c|c|c|c|c|c|c|c|c|c|c|}
\hline Year. & Jan. & Feb. & Mar. & April. & May. & June. & July. & Aug. & Sept. & Oct. & Nov. & Dec. & Total. \\
\hline 1782. & $4^{\circ} 64$ & ז'98 & 6.54 & 457 & $6 \cdot 34$ & I*75 & $7^{\circ} \circ 9$ & 8.28 & $37^{2}$ & r'93 & $2{ }^{\circ} 1$ & OII & $5^{\circ} \cdot 26$ \\
\hline 1783. & 443 & 5.54 & $2 \cdot 16$ & 0.88 & $2 \cdot 84$ & 282 & $I 45$ & 2.21 & $55^{2}$ & 171 & $3^{\circ}$ or & r'ro & $33^{\circ} 71$ \\
\hline 1784. & 318 & 0.77 & $3 \cdot 82$ & $3^{\circ} 92$ & 1.52 & $3^{6} 65$ & 2.40 & 3.88 & $2 \cdot 51$ & 0.39 & $4^{\circ} 70$ & $3^{\circ} 06$ & $33^{8} 80$ \\
\hline 1785. & $2 \cdot 84$ & 180 & 0.30 & o'I 7 & 0.6 & $1 \cdot 39$ & $3 \cdot 80$ & $3^{*} 21$ & $5 \cdot 94$ & $5^{\circ} 21$ & $2 \div 27$ & $4^{\circ} 2$ & $3 \mathrm{I} \cdot 55$ \\
\hline 1786. & 6.91 & $I^{\circ} 42$ & 162 & $I .8 I$ & $2 \cdot 40$ & $I .20$ & $x .99$ & 4.34 & 479 & 5.4 & $4 \cdot 3^{8}$ & & \\
\hline 1787. & 0.88 & $3^{\circ} 67$ & $4^{\circ} 28$ & 0.74 & $2 \cdot 6$ & $I^{\circ} 50$ & 6.53 & 0.83 & $1 \cdot 56$ & $5^{\circ} 4$ & 49 & $5^{\cdot} 6$ & $36^{\circ} .24$ \\
\hline I 788. & $I^{6} 60$ & $3 \cdot 37$ & $I \cdot 3 r$ & 0.61 & 0.76 & $\therefore 27$ & 3.58 & 322 & $5^{\circ} 71$ & $0^{\circ} \circ$ & 0.86 & 0.23 & $22^{\circ} 5^{\circ}$ \\
\hline I789. & 4.48 & 4 II & $2 \cdot 47$ & $I .8 I$ & $4^{\circ} 5$ & 4.24 & 3.69 & 0.99 & 2.82 & $5^{\circ} 4$ & $3 \cdot 67$ & 4.62 & $42^{\circ}-$ \\
\hline I 790. & I.99 & 0.49 & 0.45 & $3^{\circ} 6_{4}$ & $4^{\circ} 3^{8}$ & 0.13 & 3.24 & $2 \cdot 30$ & 0.66 & 2 '10 & 6.95 & $5^{\circ} 94$ & $3^{2 * 27}$ \\
\hline I791. & $6 \cdot 73$ & 4.64 & 4.59 & 1.13 & I. 33 & $0.9 \mathrm{I}$ & $5^{\circ} 5^{6}$ & 173 & $I^{\circ} 73$ & $6: 49$ & $8 \cdot 16$ & 493 & $44^{\circ} 93$ \\
\hline 1792. & $6 \cdot 7$ & I.68 & 6.70 & $4^{\circ} 08$ & $3^{\circ} \circ 0$ & 278 & $5 \cdot 16$ & 4.25 & 5.53 & 5.55 & $x^{\circ} 65$ & $2 \cdot 11$ & $48 \cdot 56$ \\
\hline 1793. & $3^{\circ} 7^{1}$ & $2^{*} 32$ & $2 \cdot 33$ & $3^{\circ} 19$ & 1.21 & & & & & & & & \\
\hline
\end{tabular}

${ }_{1} 768$ begins with a fortnight's frost and snow; rainy during February. Cold and wet spring; wet season from the beginning of June to the end of harvest. Latter end of September foggy without rain. All October and the first part of November rainy, and thence to the end of the year alternate rains and frosts.

r769. January and February, frosty and rainy, with gleams of 
fine weather in the intervals. To the middle of March, wind and rain. To the end of March, dry and windy. To the middle of April, stormy, with rain. To the end of June, fine weather with rain. To the beginning of August, warm, dry weather. To the end of September, rainy with short intervals of fine weather. To the latter end of October, frosty mornings, with fine days. The next fortnight rainy; thence to the end of November dry and frosty. December, windy, with rain and intervals of frost, and the first fortnight very foggy.

I 770. Frost for the first fortnight: during the $14^{\text {th }}$ and $15^{\text {th }}$ all the snow melted. To the end of February, mild hazy weather. The whole of March, frosty, with bright weather. April, cloudy, with rain and snow. May began with summer showers, and ended with dark, cold rains. June, rainy, chequered with gleams of sunshine. The first fortnight in July, dark and sultry; the latter part of the month, heavy rain. August, September, and the first fortnight in October, in general fine weather, though with frequent interruptions of rain; from the middle of October to the end of the year almost incessant rains.

I 77 . Severe frosts till the last week in January. To the first week in February, rain and snow : to the end of February, spring weather. To the end of the third week in April, frosty weather. To the end of the first fortnight in May, spring weather, with copious showers. To the end of June, dry, warm weatl.er. The first fortnight in July, warm, rainy weather. To the end of September, warm weather, but in general cloudy, with showers. October rainy. November frost, with intervals of fog and rain. December, in general, bright, mild weather, with hoar frosts.

I 772. To the end of the first week in February, frost and snow. To the end of the first fortnight in March, frost, sleet, rain, and snow. To the middle of April, cold rains. To the middle of May, dry weather, with cold piercing winds. To the end of the first week in June, cool showers. To the middle of August, hot, dry, summer weather. To the end of September, rain with storms and thunder. To December 2 2nd, rain with mild weather. December $23 \mathrm{rd}$, the first ice. To the end of the month cold, foggy weather.

1773. The first week in January, frost; thence to the end of 
the month, dark rainy weather. The first fortnight in February, hard frost. To the end of the first week in March, misty, showery weather. Bright spring days to the close of the month. Frequent showers to the latter end of April. To the end of June, warm showers, with intervals of sunshine. To the end of August, dry weather with a few days of rain. To the end of the first fortnight in November, rainy. The next four weeks, frost : and thence to the end of the year, rainy.

1774. Frost and rain to the end of the first fortnight in March; thence to the end of the month, dry weather. To the 15 th April, showers; thence to the end of April, fine spring days. During May, showers and sunshine in about an equal proportion. Dark rainy weather to the end of the third week in July; thence to the 24th August, sultry, with thunder and occasional showers. To the end of the third week in November, rain, with frequent intervals of sunny weather. To the end of December, dark, dripping fogs.

1775. To the end of the first fortnight in March, rain almost every day. To the first week in April, cold winds, with showers of rain and snow. To the end of June, warm, bright weather, with frequent showers. The first fortnight in July, almost incessant rains. To the 26th August, sultry weather with frequent showers. To the end of the third week in September, rain with a few intervals of fine weather. To the end of the year, rain with intervals of hoar-frost and sunshine.

I 776. To January 24 th, dark frosty weather, with much snow. March 24 th, to the end of the month, foggy with hoar-frost. To the 3 oth May, dark, dry, harsh weather, with cold winds. To the end of the first fortnight in July, warm, with much rain. To the end of the first week in August, hot and dry, with intervals of thunder showers. To the end of October, in general, fine seasonable weather, with a considerable proportion of rain. To the end of the year, dry, frosty weather, with some days of hard rain.

I 777. To the roth January, hard frost. To the 20 th January, foggy, with frequent showers. To the i 8 th February, hard dry frost with snow. To the end of May, heavy slowers, with intervals of warm dry spring days. To the 8th July, dark, with 
heavy rain. To the $\mathrm{r}$ 8th July, dry, warm weather. To the end of July, very heavy rains. To the 12 th October, remarkably fine warm weather. To the end of the year, grey mild weather, with but little rain, and still less frost.

I778. To the I $3^{\text {th }}$ January, frost, with a little snow: to the 24th January, rain: to the 3 oth, hard frost. To the $23 \mathrm{rd}$ February, dark, harsh, foggy weather, with rain. To the end of the month, hard frost, with snow. To the end of the first fortnight in March, dark, harsh weather. From the first, to the end of the first fortnight in April, spring weather. To the end of the month snow and ice. To the IIth June, cool, with heavy showers. To the rgth July, hot, sultry, parching weather. To the end of the month, heavy showers. To the end of September, dry warm weather. To the end of the year wet, with considerable intervals of sunshine.

1779. Frost and showers to the end of January. To 2 ist April, warm dry weather. To 8th May, rainy. To the 7 th June, dry and warm. To the 6 th July, hot weather, with frequent rain. To the I8th July, dry hot weather. To August 8th, hot weather, with frequent rains. To the end of August, fine dry harvest weather. To the end of November, fine autumnal weather, with intervals of rain. To the end of the year, rain with frost and snow.

I 780. To the end of January, frost. To the end of February, dark, harsh weather, with frequent intervals of frost. To the end of March, warm showery spring weather. To the end of April, dark harsh weather, with rain and frost. To the end of the first fortnight in May, mild, with rain. To the end of August, rain and fair weather in pretty equal proportions. To the end of October, fine autumnal weather, with intervals of rain. To the 24th November, frost. To December r6th, mild dry foggy weather. To the end of the year frost and snow.

I78r. To January $25^{\text {th, }}$, frost and snow. To the end of February, harsh and windy, with rain and snow. To April 5th, cold, drying winds. To the end of May, mild spring weather, with a few light showers. June began with heavy rain, but thence to the end of October, dry weather, with a few flying showers. To the end of the year, open weather with frequent rains. 
1782. To February $4^{\text {th }}$, open mild weather. To February 22nd, hard frost. 'To the end of March, cold blowing weather, with frost and snow and rain. To May 7 th, cold dark rains. To the end of May, mild, with incessant rains. To the end of June, warm and dry. To the end of August warm, with almost perpetual rains. The first fortnight in September mild and dry: thence to the end of the month, rain. To the end of October, mild with frequent showers. November began with hard frost, and continued throughout with alternate frost and thaw. The first part of December frosty : the latter part mild.

1 783. To January 16 th, rainy with heavy winds. To the $24^{\text {th, }}$ hard frost. To the end of the first fortnight in February, blowing, with much rain. To the end of February, stormy dripping weather. 'To the 9 th May, cold harsh winds (thick ice on $5^{\text {th }}$ May). To the end of August, hot weather, with frequent showers. To the $23^{\text {rd }}$ September, mild, with heavy driving rains. To November I 2 th, dry mild weather. To the I 8 th December, grey soft weather, with a few showers. To the end of the year, hard frost.

1784. To February I 9 th, hard frost, with two thaws: one the I 4 th January, the other 5 th February. To February 28 th, mild wet fogs. To the 3 rd March, frost with ice. To March soth, sleet and snow. To April 2nd, snow and hard frost. To April 27 th, mild weather, with much rain. To May I 2 th, cold drying winds. To May 20 th, hot cloudless weather. To June 27 th, warm with frequent showers. To July 18 th, hot and dry. To the end of August, warm with heavy rains. To November 6th, clear mild autumnal weather, except a few days of rain at the latter end of September. To the end of the year, fog, rain, and hard frost (on December roth, the thermometer $\mathrm{I}^{\circ}$ below $\mathrm{o}$ ).

1785. A thaw began on the 2nd January, and rainy weather with wind continued to January 28 th. To i 5 th March, very hard frost. 'To 2 Ist March, mild, with sprinkling showers. To April 7 th, hard fiost. To May i 7 th, mild windy weather, without a drop of rain. To the end of May, cold, with a few showers. To June 9 th, mild weather, with frequent soft showers. To July $\mathrm{r} 3$ th, hot dry weather, with a few showery intervals. To July 22 nd, heavy rain. 
To the end of September, warm with frequent showers. To the end of October, frequent rain. To 18th November, dry, mils, weather. (Hay-making finished November 9th, and the wheat harvest November 14th.) To December 23 rd, rain. To the end of the year, hard frost.

I 786 . To the 7 th January, frost and snow. To January 13 th, mild with much rain. To 2 ist January, deep snow. To February I I th, mild with frequent rains. To 2 Ist February, dry, with high winds. To Ioth March, hard frost. To I 3 th April, wet, with intervals of frost. To the end of April, dry mild weather. On the Ist and and May, thick ice. To Ioth May, heavy rain. To

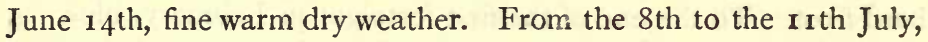
heavy showers. To October 13 th, varm, with frequent showers. To October $19^{\text {th }}$, ice. To October $24^{\text {th }}$, mild pleasant weather. 'To November 3 rd, frost. To December 16 th, rain, with a few detached days of frost. To the end of the year frost and snow.

1 787. To January 24 th, dark, moist, mild weather. To January 28 th, frost and szoow. To February Ióth, mild showery weather. To February z8th, dry, cool weather. To March Ioth, stormy with driving rain. To March 24 th, bright frosty weather. To the end of April mild, with frequent rain. To May $22 \mathrm{nd}$, fine bright weather. To the end of June, mostly warm, with frequent showers (on June 7 th, ice as thick as a crown piece). To the end of July, hot and sultry, with copious rain. To the end of September, hot dry weather, with occasional showers. To November 23 rd, mill, with light frosts and rain. To the end of November, hard frost. To December 2 Ist, still and mild, with rain. To the end of the year, frost.

I 788 . To January $\mathbf{I}^{\text {th }}$, mild and wet. To January $\mathrm{s} 8$ th, frost. To the end of the month, dry windy weather. To the end of February, frosty, with frequent showers. To March I4th, hard frost. To the end of March, dark, harsh weather, with frequent showers. To April 4th, windy, with showers. To the end of May, bright, dry, warm weather, with a few occasional showers. From June 28 th to July $\mathrm{I} 7$ th, heavy rains. To August $\mathrm{r} 2$ th, hot dry weather. To the end of September, alternate showers and 
sunshine. To November 2 and, dry, cool weather. To the end of the year, hard frost.

I 789 . To January $\mathbf{I}^{\text {th }}$, hard frost. To the end of the month, mild, with showers. To the end of February, frequent rain, with snow-showers and heavy gales of wind. To I $3^{\text {th }}$ March, hard frost, with snow. To April 18th, heavy rain, with frost and snow and s'eet. To the end of April, dark, cold weather, with trequent rains. To June 9 th, warm spring weather, with brisk winds and frequent showers. From June $4^{\text {th }}$ to the end of July, warm, with much rain. To August 2 th, hot, dry, sultry weather. To September I I th, mild, with frequent showers. To the end of September fine autumnal weather, with occasional showers. To November 17 th, heavy rain, with violent gales of wind. To December 18 th, mild dry weather, with a few showers. To the end of the year, rain and wind.

1790. To January 16 th, mild foggy weather, with occasional rains. To January $2 \mathrm{Ist}$, frost. To January 28 th, dark, with driving rains. To February 14 th, mild, dry weather. To February 2 2nd, hard frost. To April 5th, bright cold weather, with a few showers. To Aprii 15 th, dark and harsh, with a deep snow. To April 2 rst, cold cloudy weather, with ice. To June 6th, mild spring weather, with much rain. From July $3^{\text {rd, }}$ to July ${ }_{4}$ th, cool, with heavy rain. To the end of July, warm, dry wcather. To August 6th, cold, with wind and rain. To August 24 th, fine harvest weather. To September 5 th, strong gales, with driving showers. To November 26 th, mild autumnal weather, with frequent showers. To December rst, hard frost and snow. To the end of the year, rain and snow, and a few days of frost.

179r. To the end of January, mild, with heavy rains. To the end of February windy, with much rain and snow. From March to the end of June, mostly dry, especially June. March and April rather cold and frosty. May and June, hot. July, rainy. Fine harvest weather, and pretty dry, to the end of September. Wet October, and cold towards the end. Very wet and stormy in November. Much frost in December.

1792. Some hard frost in January, but mostly wet and mild. February, some hard frost and a little snow. March, wet and cold. 
April, great storms on the $\mathrm{I}_{3}$ th, then some very warm weather. May and June, cold and dry. July, wet and cool; indifferent harvest, rather late and wet. September, windy and wet. October, showery and mild. November, dry and fine. December, mild. 
A

COMPARATIVE VIEW

OF THE

\section{NATURALIST'S CALENDAR,}

AS KEPT AT

SELBORNE, IN HAMPSHIRE,

BY THE LATE

REV. GILBER'T WHITE, M.A.;

AND AT

CATSFIELD, NEAR BATTLE,

IN SUSSEX,

BY WILLIAM MARKWICK, EsQ., F.L.S.,

From the year ${ }_{17} 68$ to the year ${ }_{1793 .}$ 
II.B. The dates in the following Calendars, when more than one, express the earliest and latest times in which the circumstance noted was observed. 


\section{A COMPARATIVE VIEW}

OF

\section{WHITE'S AND MARKWICK'S CALENDARS.}

Of the abbreviations used, f. signifies flowering; 1 . leafing; and ap. the first appearance.

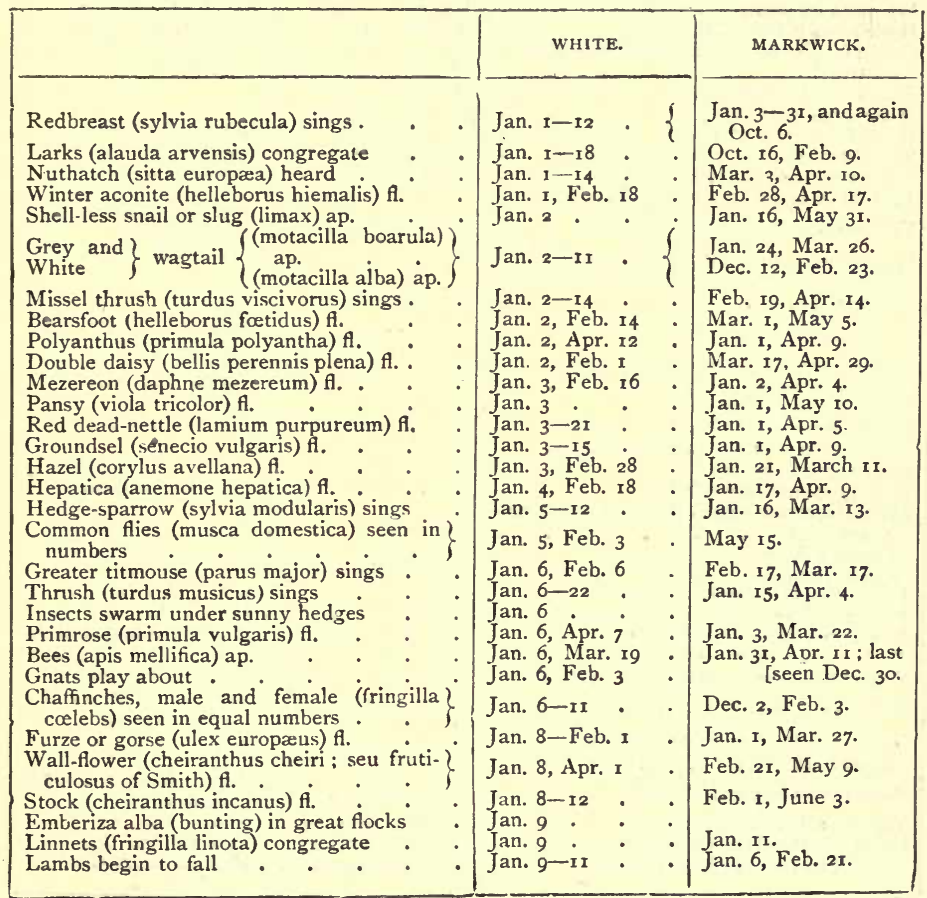




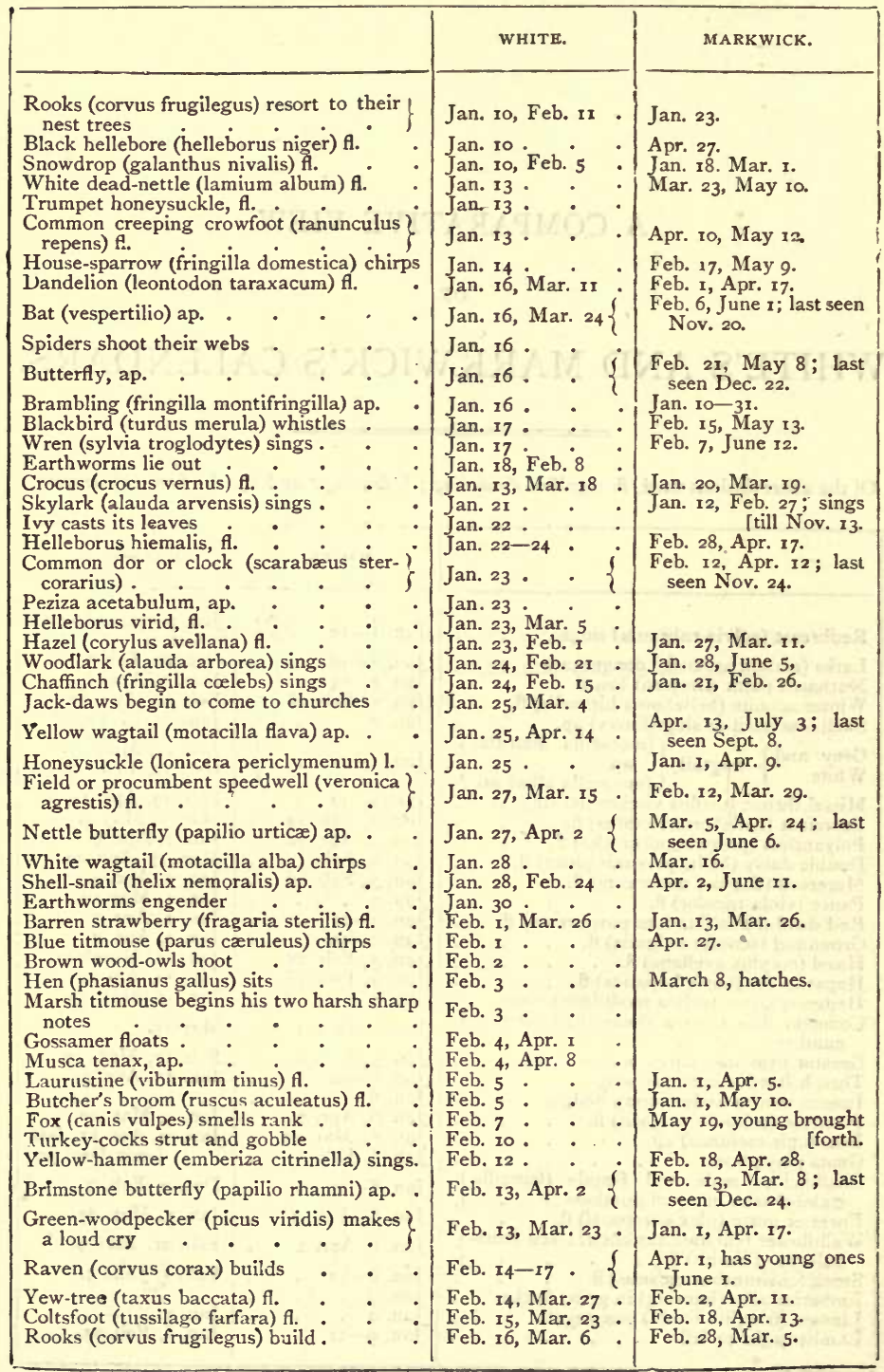




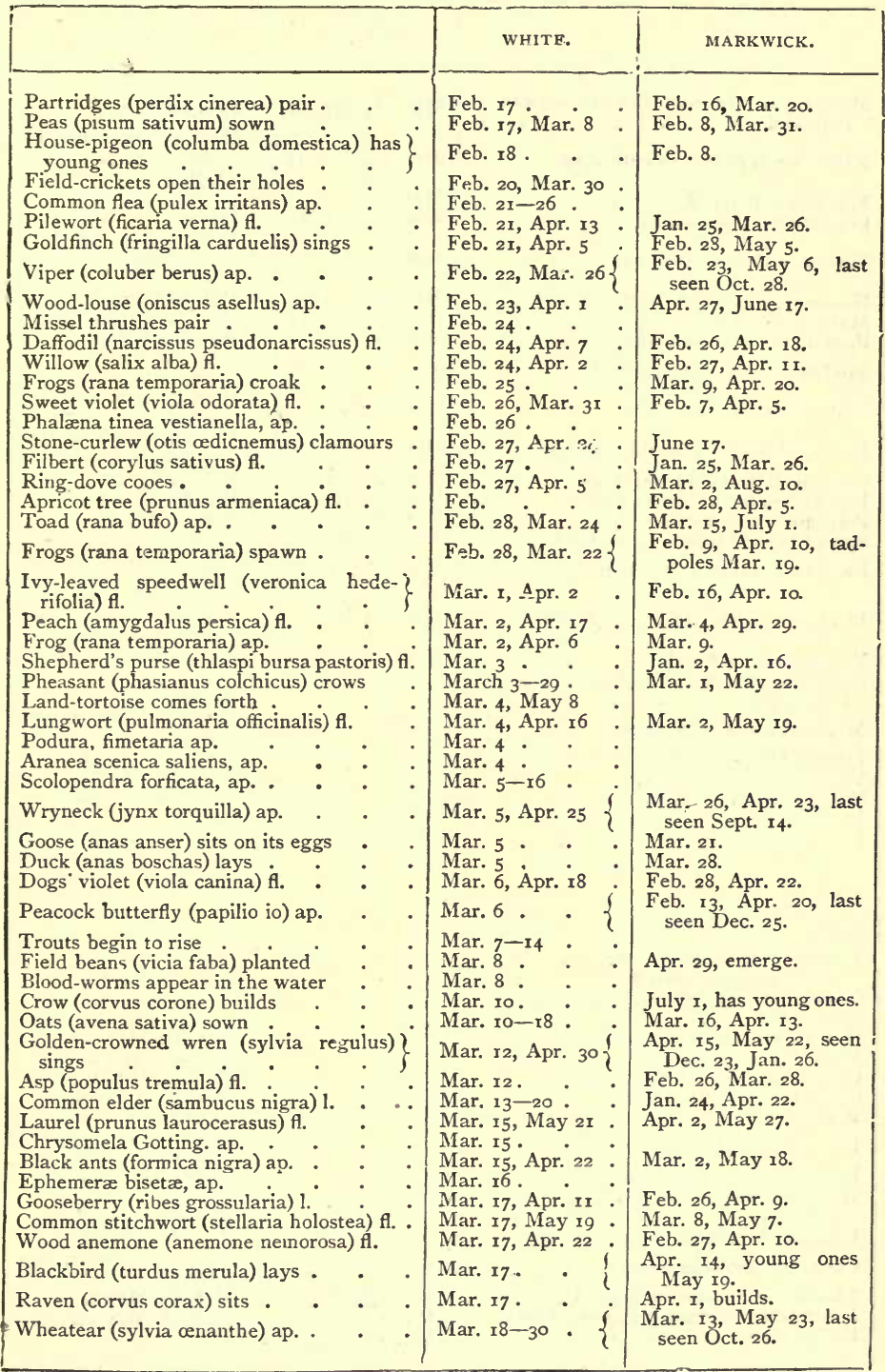




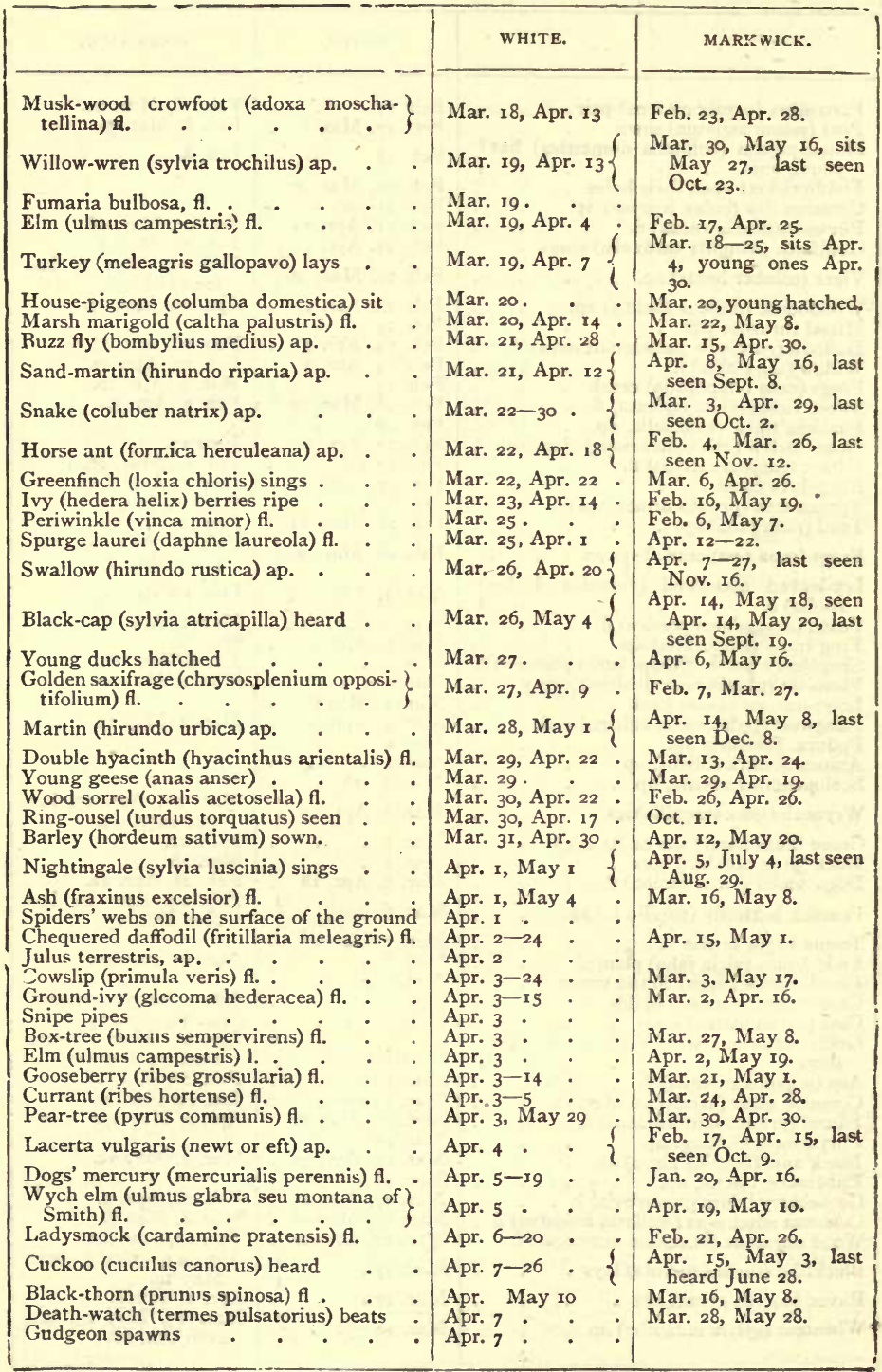


Red-start (sylvia phænicurus) ap. Crown imperial (fritillaria imperialis)'fl. Tit-lark (alauda pratensis) sings

Beech (fagus sylvatica) 1 .

Shell-snail (helix nemoralis comes out in troops

Middle yellow wren. ap.

Swift (hirundo apus) ap.

Stinging-fly (conops calcitrans) ap.

Whitlow-grass (draba verna) $\mathrm{fl}$. .

Larch-tree (pinus-larix rubra) 1.

Whitethroat (sylvia cinerea) ap.

Red ant (formica rubra) ap:

Mole cricket (gryllus gryllotalpa) churs

Second willow or laughing wren, ap.

Red rattle (pedicularis sylvatica) fl. .

Common flesh-fly (musca carnaria) ap.

Lady-cow (coccinella bipunctata) ap.

Grasshopper lark (alauda locustæ voce) \} ap.

Willow wren, its shivering note heard

Middle willow wren (regulus non cristatus medius) ap.

Wild cherry (prunus cerasus) fl.

Garden cherry (prunus cerasus) $\mathrm{fl}$.

Plum (prunus domestica) $\mathrm{f}$.

Harebell (hyacinthus non-scriptus seu scilla rutans of Smith) f.

Turtle (columba turtur) cooes : .

Hawthorn (cratægus seu mespilus oxy- ) cantha of Smith) fl.

Male fool's orchis (orchis mascula) $\mathrm{fl}$.

Blue-flesh fly (musca vomitoria) ap.

Black snail or slug (limax ater) abounds

Apple-tree (pyrus malus sativus) fl.

Large bat, ap.

Strawberry, wild wood (fragaria vesca) sylv.) $f$.

Sauce alone (erysimum alliaria) $\dot{f}$.

Wild or bird cherry (prunus avium) $\dot{f}$.

Apis hypnorum, ap.

Musca meridiana, ap.

Wolf-fly (asilus) ap.

Cabbage butterfly (papilio brassicæ) ap.

Dragon-fly (libellula) ap.

Sycamore (acer pseudoplatanus) fl.

Bombylius minor, ap. .

Glow-worm (lampyris noctiluca) shines

Fern-owl or goatsucker (caprimulgus europæus) ap. .

Common bugle (ajuga reptans) $\dot{f}$.

Field crickets (gryllus campestris) crink

Chaffer or May-bug (scarabæus melolontha) ap

Honeysuckle (lonicera periclymenum) fl. .

Toothwort (lathræa squamaria) $\mathrm{f}$.

Shell-snails copulate

Sedge warbler (sylvia salicaria) sings:
WHITE.

Apr. 8-28

Apr. 8-24

Apr. 9- I9

Apr. Io, May 8

Apr. II, May 9

Apr. II.

Apr. 13. May 7

Apr. I4, May I7.

Apr. 14

Apr. 14 .

Apr: I4, May 14

Apr. I4

Apr. 14.

Apr. I4-I9-23.

Apr. 15- I9 .

Apr. 15.

Apr. 16.

Apr. 16-30.

Apr. I7, May 7.

Apr. 17-27.

Apr. I8, May I2

Apr. I8, May II

Apr. I8, May 5

Apr. 19-25 .

Apr. 20-27 .

Apr. 20, June II .

Avr. 2 I.

Apr. 21, May 23

Apr. 22

Apr. 22, May 25

Apr. 22, June II

Apr. 23-29 .

Apr. 23 .

Apr. 24 .

Apr. 24.

Apr. 24, May 28

Apr. 25.

Apr. 28, May 20.

Apr. 30, May 21

April 30, June 6

May I june it

May I-26

May I.

May 2-24.

May 2-26

May $3-30$

May 4-12.

May 4 , June 17

May 4
MARKWICK.

Apr. 5, sings Apr. 25, last seen Sept. 30.

Apr. I, May r3.

Apr. 14-29, sits June I6-I7.

Apr. 24, May 25.

May I7, June I I ap.

Apr. 28, May I9.

Jan. I5, Mar 24.

Apr. I, May 9.

Apr. I4, May 5, sings

May 3-ro, last seen

Sept. 23.

Apr. 9, June 26.

Apr. 10, June 4.

Apr. 28, May 14.

Mar. 30, May 10.

Mar. 25, May 6 .

Mar. 24, May 6 .

Mar. 27, May 8.

May r4, Aug. ro, seen.

Apr. I9, May 26.

Mar. 29, May 13.

Feb. I, Oct. 24 ap.

Apr. Ir, May 26.

Apr. 8-9.

Mar. 3r, May 8.

Mar. 30, May Io.

Apr. 29, June ro.

Apr. I8, May I3, last seen Nov. Io.

Apr. 20, June 4.

June I9, Sept. 28.

May I6, Sept. 14.

Mar. 27, May ro.

May 2, July 7 .

Apr. 24, June 2 I.

June $2-30$. 


\begin{tabular}{|c|c|c|}
\hline & wHITE. & MARKWICK. \\
\hline 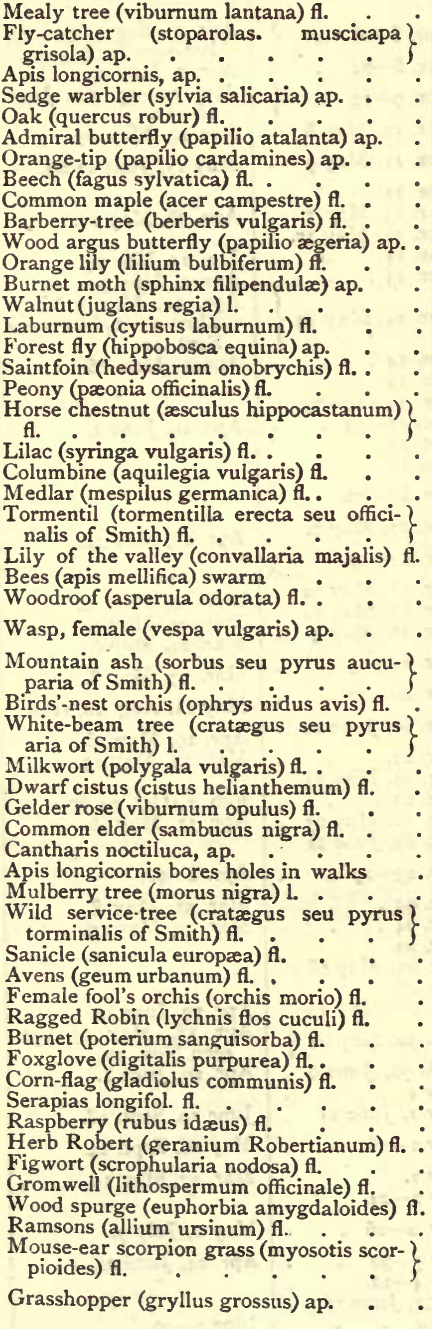 & 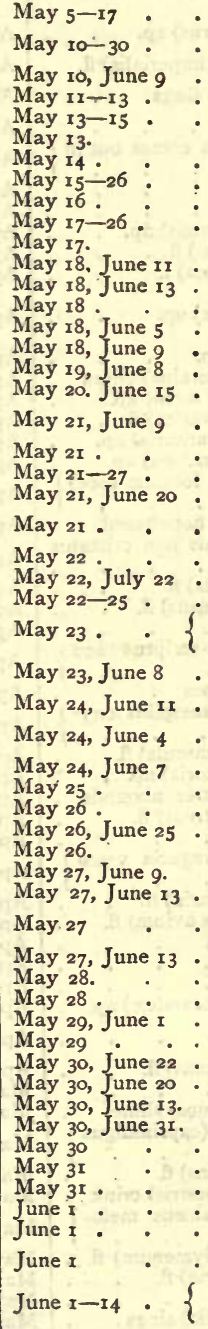 & 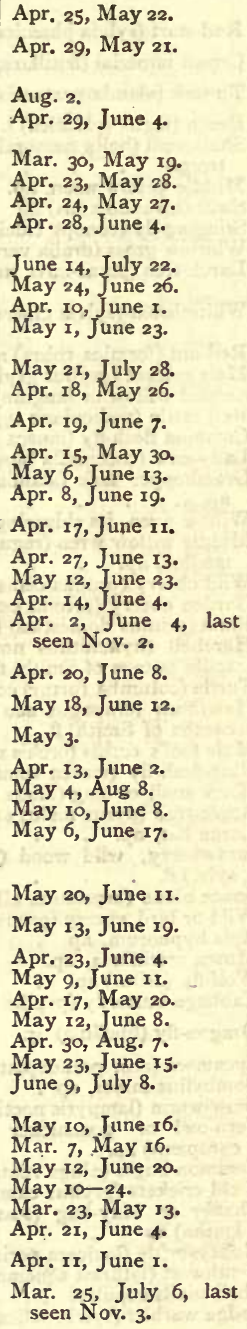 \\
\hline
\end{tabular}




\begin{tabular}{|c|c|c|}
\hline. & WHITE. & MARKWICK. \\
\hline 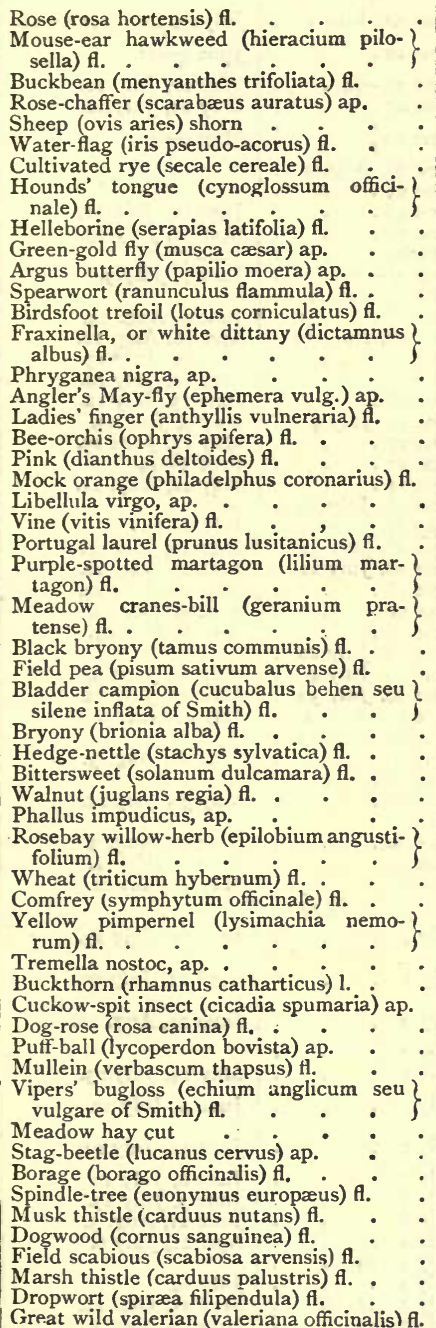 & 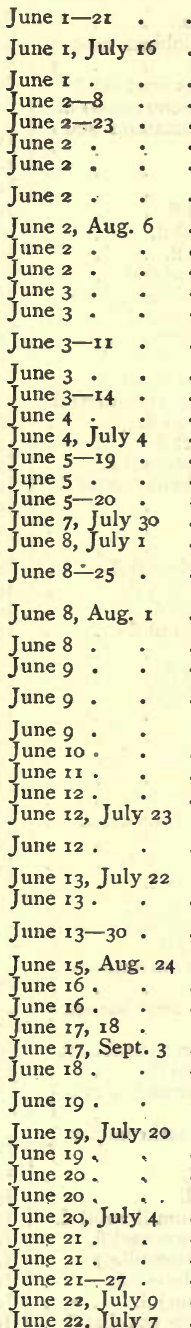 & $\begin{array}{l}\text { May 25. } \\
\text { June 2-2r. } \\
\text { May 24, June 21. } \\
\text { May 6, Aug. 19. } \\
\text { June 10, July } 22 . \\
\text { May 27, July 3. } \\
\text { June 13, July 7. } \\
\text { June 14-21. } \\
\text { Apr. 22, July } 26 . \\
\text { May 11, June 25. } \\
\text { June 4, July 25. } \\
\text { May 28, June 27. } \\
\text { June 16, Aug. 14. } \\
\text { May 15, June r9. } \\
\text { May 8, Sept. 3. } \\
\text { May 22, July 21. }\end{array}$ \\
\hline
\end{tabular}




\begin{tabular}{|c|c|c|}
\hline 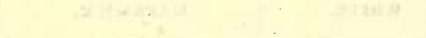 & WHITE. & MARKWICK. \\
\hline Quail (perdix coturnix) calls .. & June 22, July 4 & July 23 , seen Sept. $1-18$. \\
\hline $\begin{array}{l}\text { Mountain willow-herb (epilobium mon- } \\
\text { tanum) f. }\end{array}$ & June 22 . & June $5-21$. \\
\hline Thistle upon thistle (carduus crispus) ff. & June $23-29$. & May 22, July 22 \\
\hline $\begin{array}{l}\text { Cow-parsnip (heracle in sphonaylium) fl. } \\
\text { Earth-nut (bunium bulbocastanum seu }\end{array}$ & June $23 \ldots$ & May 27, July 12. \\
\hline $\begin{array}{l}\text { Earth-nut (bunium bulbocastanum seu } \\
\text { flexuosum of Smith) f. }\end{array}$ & June 23 . & May $4-31$ \\
\hline Young frogs migrate. $\quad \cdot \quad \cdot \quad:$. & June 23, Aug. 2 & \\
\hline $\begin{array}{l}\text { Estrus curvicauda, ap. } \\
\text { Vervain (verbena officinalis) } \mathrm{fl}:\end{array}$ & $\begin{array}{l}\text { June } 24: \text { : } \\
\text { June } 24 .\end{array}$ & June ro, July r7. \\
\hline Corn poppy (papaver rhoeas) fl. & June 24 . & Apr. 30, July r5. \\
\hline Self-heal (prunella vulgaris) fl. & June $24 \cdot$ & June $7-23$ \\
\hline $\begin{array}{l}\text { Agrimony (agrimonia eupatoria) fl. } \\
\text { Great horse-fly (tabanus bovinus) ap. }\end{array}$ & $\begin{array}{l}\text { June } 24-29 . \\
\text { June } 24, \text { Aug. } 2\end{array}$ & June 7 , July 9. \\
\hline $\begin{array}{l}\text { Greater knapweed (centaurea scabiosa) f. } \\
\text { Mushroom (agaricus campestris) ap. }\end{array}$ & June 25 . Aug. 30 & $\begin{array}{l}\text { June 7, Aug. } 14 \\
\text { Apr: } 16 \text {, Aug. } 16 .\end{array}$ \\
\hline Common mallow (malva sylvestris) f. & June 26 . & May 27 , July 13 \\
\hline $\begin{array}{l}\text { Dwarf mallow (malva rotundifolia) fl. } \\
\text { St. John's wort (hypericum perforatum) fi. }\end{array}$ & $\begin{array}{l}\text { June } 26 . \\
\text { June } 26 .\end{array}$ & $\begin{array}{l}\text { May 12, July } 20 . \\
\text { June } 15 \text {, July } 12 .\end{array}$ \\
\hline Broom-rape (orobanche major) fl. & June 27 , July 4 & May 9, July 25 . \\
\hline Henbane (hyoscyamus niger) fl. & June $27 . \quad \because$ & May is, June 19. \\
\hline $\begin{array}{l}\text { Goats-beard (tragopogon pratense) fl. } \\
\text { Deadly nightshade (atropa belladonna) fl. }\end{array}$ & $\begin{array}{l}\text { June } 27 \cdot: \\
\text { June } 27:\end{array}$ & $\begin{array}{l}\text { June 5-14. } \\
\text { May 22, Aug. } 14 .\end{array}$ \\
\hline Truffles begin to be found. & June 28, July:29 & \\
\hline Young partridges fly & June 28 , July $3 \mathbf{I}$ & July $8-28$. \\
\hline $\begin{array}{l}\text { Lime-tree (tilia europæa) fl. } \\
\text { Spearthistle (carduus lanceolatus) f. }\end{array}$ & June 28 , July $3 \mathrm{I}$ & June 12, July 30. \\
\hline Meadow-sweet (spiræa ulmaria) fl. . & June 28 . & June 16 , July 24 . \\
\hline Greenweed (genista tinctoria) fl. & June 28 . & June 4 , July 24 . \\
\hline $\begin{array}{l}\text { Wild thyme (thymus serpyllum) fl. } \\
\text { Stachys germanic. fl. }\end{array}$ & June 28 . July 20 & June 6, July rg. \\
\hline Day-lily (hemerocallis flava) ff. $\quad:$ & June 29 , July 4 & May 29, June 9. \\
\hline Jasmine (jasminum officinale) fl. & June 29, July 30 & June 27 , July 21 . \\
\hline $\begin{array}{l}\text { Holly-oak (alcea rosea) fl. } \cdot \quad \cdot \quad: \\
\text { Monotropa hypopithys, fl. }\end{array}$ & $\begin{array}{l}\text { June } 29, \text { Aug: } 4 \\
\text { June } 29, \text { July } 23\end{array}$ & July 4, Sept. 7 . \\
\hline Ladies' bedstraw (galium verum) f. & June $29:$ & June 22, Aug. 3. \\
\hline $\begin{array}{l}\text { Galium palustre, fl. } \\
\text { Nipplewort (lapsana communis) fl. }\end{array}$ & $\begin{array}{l}\text { June } 29 . \\
\text { June } 29 \text { : }\end{array}$ & May 30 , July 24 \\
\hline Welted thistle (carduus acanthoides) ff. & June 29 . & \\
\hline $\begin{array}{l}\text { Sneezewort (achillea ptarmica) fl. } \\
\text { Musk mallow (malva moschata) f. }\end{array}$ & $\begin{array}{l}\text { June } 30 . \\
\text { June } 30 .\end{array}$ & $\begin{array}{l}\text { June 22, Aug. 3. } \\
\text { June 9; July I4. }\end{array}$ \\
\hline $\begin{array}{l}\text { Pimpernel (anagallis arvensis) fl. } \\
\text { Hoary beetle (scarabrus solstit.) ap. }\end{array}$ & June 30 . July 17 & May 4, June 22. \\
\hline $\begin{array}{l}\text { Corn saw-wort (serratula arvensis seu } \\
\text { carduus arvensis of Smith) f. }\end{array}$ & July $\mathrm{x}$ & June 15 , July 15. \\
\hline $\begin{array}{l}\text { Pheasant's eye (adonis annua seu autumn- } \\
\text { alis of Smith) } \mathrm{fl} \text {. }\end{array}$ & July x . & April II, July I5. \\
\hline $\begin{array}{l}\text { Red eyebright (euphrasia seu bartsia } \\
\text { odontites of Smith) fl. }\end{array}$ & July 2 & June 20, Aug. ro. \\
\hline $\begin{array}{l}\text { Thorough wax (bupleurum rotundifol.) fl. } \\
\text { Cockle (agrostemma githago) fl. }\end{array}$ & July $2:$ : & May 14, July 25. \\
\hline $\begin{array}{l}\text { Ivy-leaved wild lettuce (prenanthes mu- } \\
\text { ralis) fl. }\end{array}$ & July 2 : & June 2 , July 25 . \\
\hline $\begin{array}{l}\text { Feverfew (matricaria seu pyrethrum par- } \\
\text { thenium of Smith) fl. }\end{array}$ & July 2 : & June $x$, July 24 . \\
\hline Wall pepper (sedum acre) fi. : . & July 3 • & June 8 , July 12. \\
\hline $\begin{array}{l}\text { Privet (ligustrum vulgare) fl. } \\
\text { Common toadflax (antirrhinum linaria) fl. }\end{array}$ & July 3 & June 3, July 13. \\
\hline $\begin{array}{l}\text { Common toadflax (antirrhinum linaria) fl. } \\
\text { Perennial wild flax (linum perenne) } \mathrm{f} \text {. }\end{array}$ & July $3:$ & $\begin{array}{l}\text { June } 21 \text {, Aug. } 3 . \\
\text { Apr. 21, July } 6 .\end{array}$ \\
\hline Whortleberries ripe (vaccinium ulig.) & July $4-24$ & \\
\hline Yellow base rocket (reseda lutea) fl. . & July 5 . & July rg. \\
\hline $\begin{array}{l}\text { Blue-bottle (centaurea cyanus) fl. } \\
\text { Dwarf carline thistle (carduus }\end{array}$ & July 5 : & $\begin{array}{l}\text { May i5, Oct. I4. } \\
\text { June } 30 \text {, Aug. } 4 \text {. }\end{array}$ \\
\hline & & \\
\hline
\end{tabular}




\begin{tabular}{|c|c|c|}
\hline & WHITE. & MARKWICK. \\
\hline 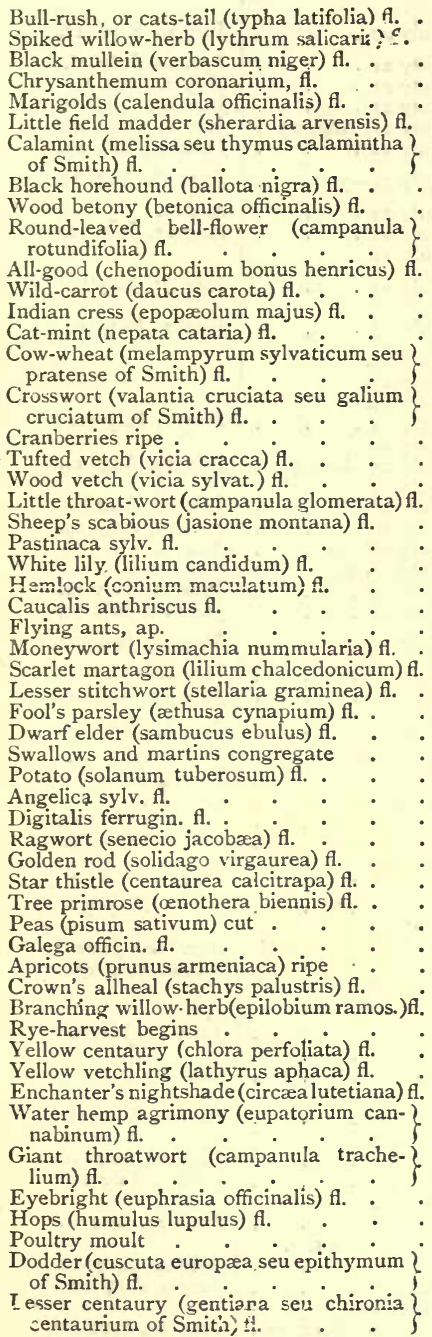 & 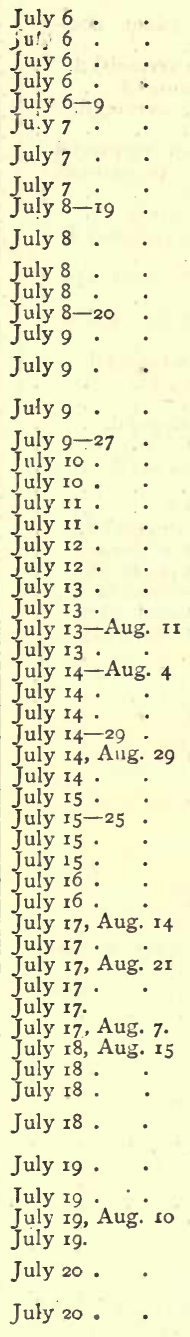 & $\begin{array}{l}\text { Aug. 29, Sept. 19. } \\
\text { June 14, Aug. 16. } \\
\text { June 21, Aug. } 6 . \\
\text { May 8, June 23. } \\
\text { June 9, Aug. } 9 . \\
\text { Aug. 12, Sept. } 8 . \\
\text { June 3, July 12. } \\
\text { June 22, July 13. } \\
\text { July 7, Aug. } 29 . \\
\text { July 16, Aug. 16. } \\
\text { June 12, July 18. } \\
\text { July 13, Aug. 15. } \\
\text { July 5, Aug. 16. } \\
\text { June 12, July 14 } \\
\text { June 15, Aug. 13. } \\
\text { June 20, July 27. } \\
\text { July 4, Aug. } 6 . \\
\text { July 13, Aug. } 14 . \\
\text { May 28, July 19. } \\
\text { July 20, Aug. 17. } \\
\text { July 9, Aug. 7. } \\
\text { June 3, July 19. }\end{array}$ \\
\hline
\end{tabular}




\begin{tabular}{|c|c|c|}
\hline & WHITE. & MARKWICK. \\
\hline 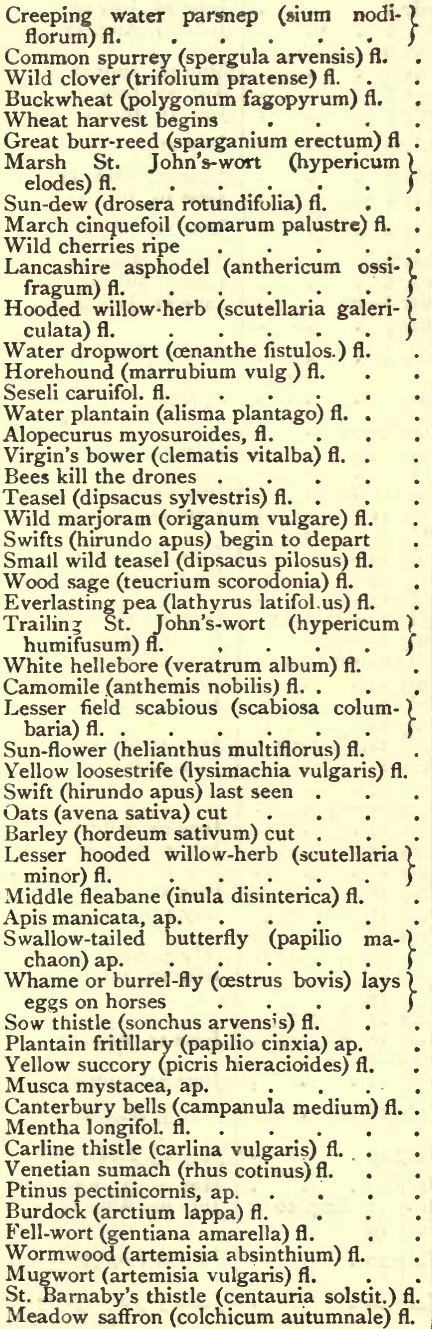 & 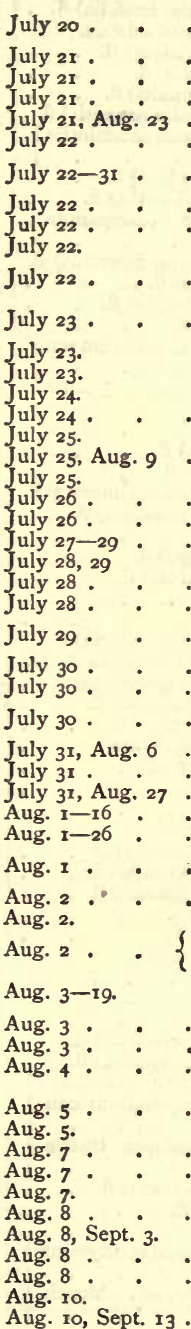 & 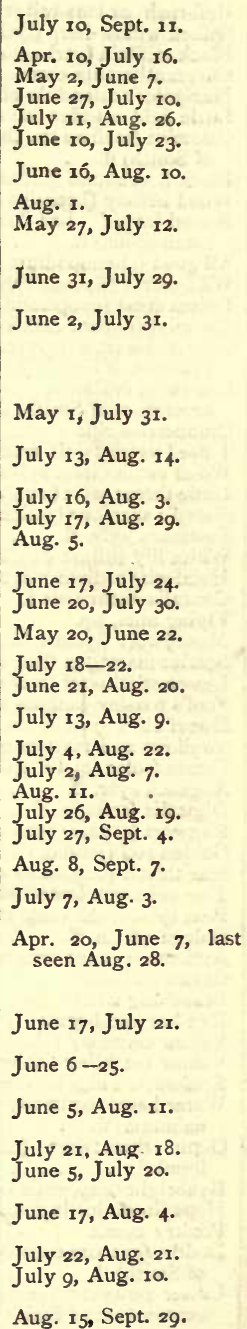 \\
\hline
\end{tabular}




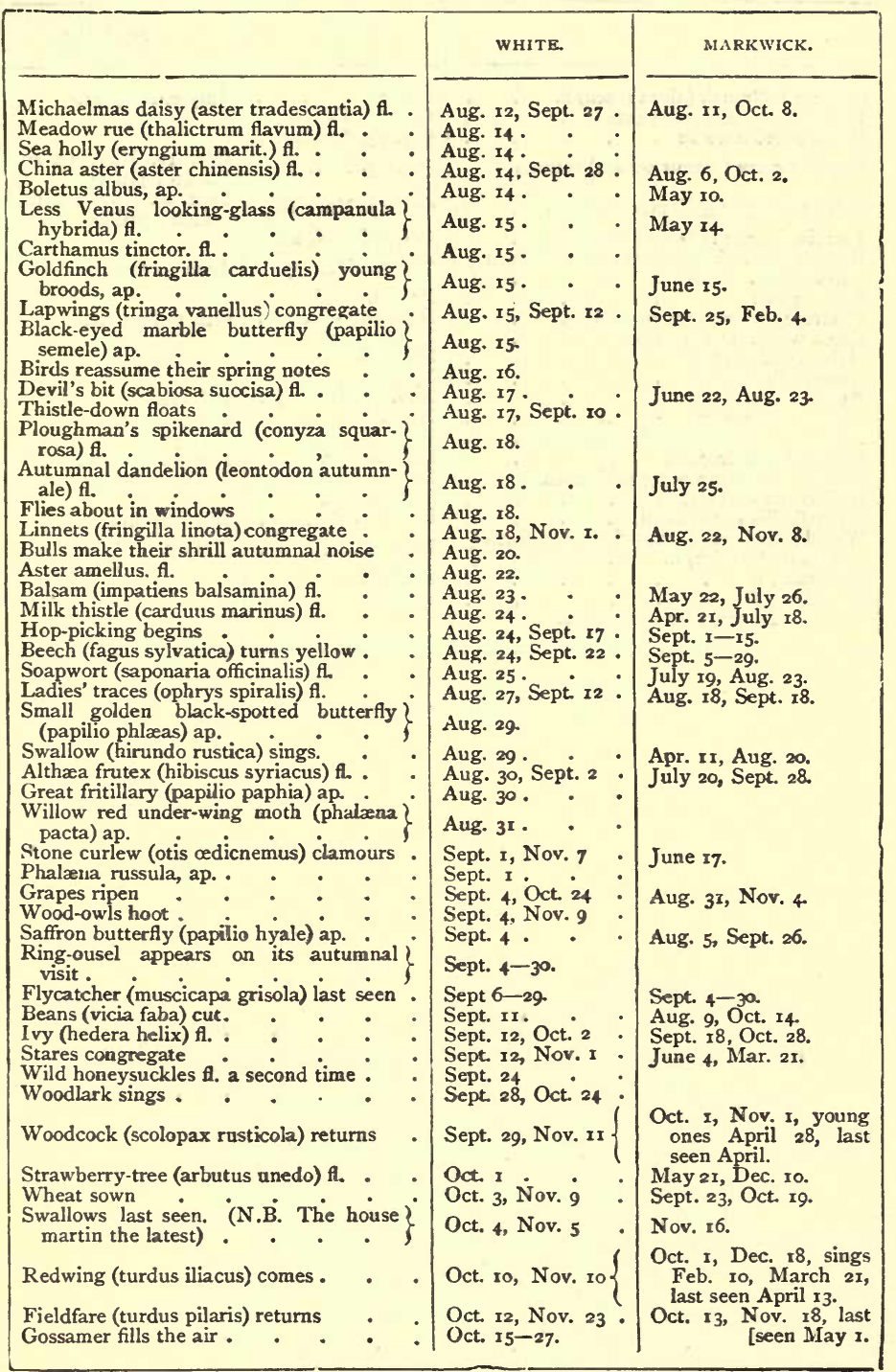




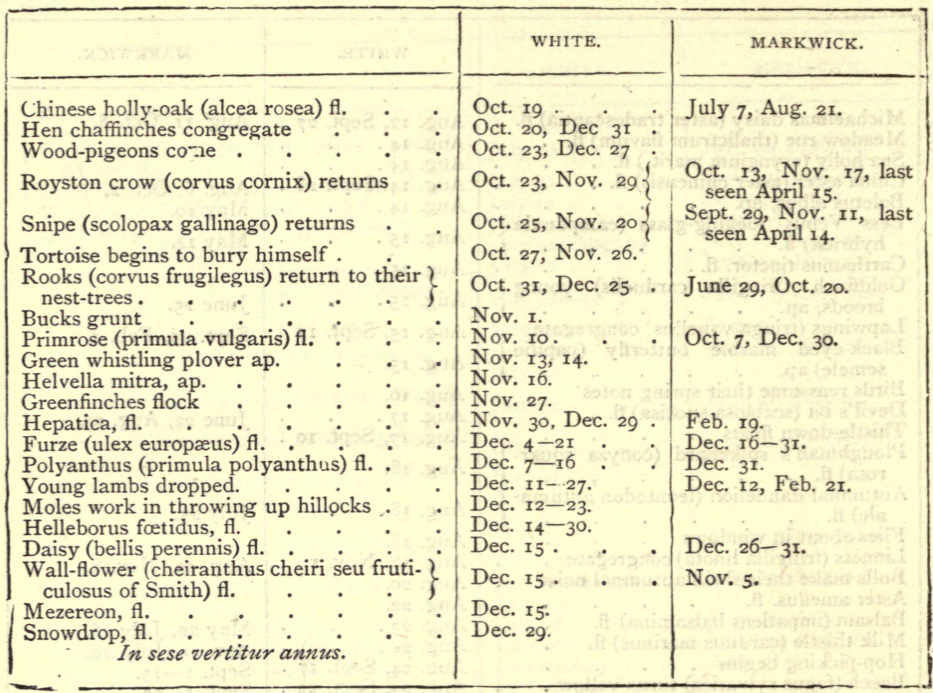


P O E M S

SELECTED FROM THE MSS. OF THE

REV. GILBERT WHITE. 



\section{P O E M S.}

\section{THE INVITATION TO SELBORNE.}

SEE Selborne spreads her boldest beauties round, The varied valley, and the mountain ground, Wildly majestic! what is all the pride Of flats, with loads of ornament supplied ? Unpleasing, tasteless, impotent expense, Compared with Nature's rude magnificence.

Arise, my stranger, to these wild scenes haste; The unfinish'd farm awaits your forming taste : Plan the pavilion, airy, light, and true; Through the high arch call in the length'ning view; Expand the forest sloping up the hill; Swell to a lake the scant, penurious rill; Extend the vista, raise the castle mound In antique taste with turrets ivy-crown'd; O'er the gay lawn the flowery shrub dispread, Or with the blending garden mix the mead; Bid China's pale, fantastic fence, delight ; Or with the mimic statue trap the sight.

Oft on some evening, sunny, soft, and still, The Muse shall lead thee to the beech-grown hill, To spend in tea the cool, refreshing hour, Where nods in air the pensile, nest-like bower; *

* A kind of an arbour on the side of a hill. 
Or where the Hermit hangs the straw-clad cell,* Emerging gently from the leafy dell;

By Fancy planned; as once the' inventive maid

Met the hodr sage amid the secret shade;

R.omantic spot! from whence in prospect lies

Whate'er of landscape charms our feasting eyes;

The pointed spire, the hall, the pasture-plain.

The russet fallow, or the golden grain,

The breezy lake that sheds a gleaming light,

Till all the fading picture fail the sight.

Each to his task; all different ways retire;

Cull the dry stick; call forth the seeds of fire;

Deep fix the kettle's props, a forky row,

Or give with fanning hat the breeze to blow.

Whence is this taste, the furnish'd hall forgot,

To feast in gardens, or the unhandy grot?

Or novelty with some new charms surprises,

Or from our very shifts some joy arises.

Hark, while below the village-bells ring round,

Echo, sweet nymph, returns the soften'd sound;

But if gusts rise, the rushing forests roar,

Like the tide tumbling on the pebbly shore.

Adown the vale, in lone, sequester'd nook,

Where skirting woods embrown the dimpling brook,

The ruin'd convent lies; here wont to dwell

The lazy canon midst his cloister'd ce!l ; $†$

While papal darkness brooded o'er the land,

Ere Reformation made her glorious stand :

Still oft at eve belated shepherd-swains

See the cowl'd spectre skim the folded plains.

To the high Templo would mi stranger go,

* A grotesque building, contrived by a young gentleman, who used on occasion to appear in the character of a hermit.

$\dagger$ The ruins of a priory, founded by Peter de Rupibus, Bishop of Winchester.

¥ The remains of a preceptory of the Knights Templars; at least it was a farm dependent upon some preceptory of that order. I find it was a preceptory called the Preceptory of Sudington; now called Southington. 
Thie mountain-brow commands the woods below :

In Jewry first this order found a name,

When madding Croisades set the world in flame;

When western climes, urged on by Pope and priest,

Pour'd forth their millions o'er the deluged East :

Luxurious knights, ill suited to defy

To mortal fight Turcéstan chivalry.

Nor be the Parsonage by the muse forgot;

The partial bard admires his native spot;

Smit with its beauties, loved, as yet a child,

(Unconscious why) its scapes grotesque, and wild.

High on a mound th' exalted gardens stand,

Beneath, deep valleys scoop'd by Nature's hand.

A Cobham here, exulting in his art,

Might blend the General's with the Gardener's part ;

Might fortify with all the martial trade

Of rampart, bastion, fosse, and palisade ;

Might plant the mortar with wide threatening bore,

Or bid the mimic cannon seem to roar.

Now climb the steep, drop now your eye below, Where round the blooming village orchards grow; There, like a picture, lies my lowly seat,

A rural, shelter'd, unobserved retreat.

Me far above the rest Selbornian scenes, The pendent forests, and the mountain greens Strike with delight; there spreads the distant view, That gradual fades till sunk in misty blue:

Here Nature hangs her slopy woods to sight, Rills purl between. and dart a quivering light. 


\section{SELBORNE HANGER.}

A WINTER PIECF.

\section{TO THE MISS BATTIES.}

THE Bard, who sang so late in blithest strain Selbornian prospects, and the rural reign, Now suits his plaintive pipe to sadden'd tone, While the blank swains the changeful year bemoan.

How fallen the glories of these fading scenes! The dusky beech resigns his vernal greens, The yellow maple mourns in sickly hue, And russet woodlands crowd the dark'ning view.

Dim, clustering fogs involve the country round, The valley and the blended mountain-ground Sink in confusion; but with tempest-wing Should Boreas from his northern barrier spring, The rushing woods with deafening clamour roar, Like the sea tumbling on the pebbly shore. When spouting rains descend in torrent tides, See the torn Zigzag weep its channel'd sides : Winter exerts its rage; neavy and slow, From the keen east rolls on the treasured snow; Sunk with its weight the bending boughs are seen, And one bright deluge whelms the works of men. Amidst this savage landscape, bleak and bare, Hangs the chill hermitage in middle air ; Its haunts forsaken, and its feasts forgot, A leaf-strown, lonely, desolated cot!

Is this the scene that late with rapture rang, Where Delphy danced, and gentle Anna sang: With fairy-step where Harriet tripped so late, And on her stump reclined the musing Kitty sate?

Return, dear Nymphs ; prevent the purple spring, Ere the soft nightingale essays to sing; 
Ere the first swallow sweeps the freshening plain, Ere love-sick turtles breathe their amorous pain. Let festive glee th' enliven'd village raise, Yan's blameless reign, and patriarchal days; With pastoral dance the smitten swain surprise, And bring all Arcady before our eyes. Return, blithe maidens ; with you bring along Free, native humour, all the charms of song, The feeling heart, and unaffected ease, Each nameless grace, and every power to please.

Nov. Ist, i763.

\section{ON THE RAINBOW.}

"Look upon the Rainbow, and praise him that made it ; very beautiful is the brightness thereof." - Ecciles. xliii. II.

ON morning or on evening cloud impress'd, Bent in vast curve, the watery meteor shines Delightfully, to the levell'd sun opposed ; Lovely refraction! while the vivid brede In listed colours glows, th' unconscious swain With vacant eyes gazes on the divine Phenomenon, gleaming o'er the illumined fields,

Or runs to catch the treasures which it sheds.

Not so the sage, inspired with pious awe; $\mathrm{He}$ hails the federal arch ; * and looking up, Adores that God, whose fingers form'd this bow Magnificent, compassing heaven about, With a resplendent verge, "Thou madest the cloud, Maker Omnipotent, and thou the bow ; And by that covenant graciously hast sworn Never to drown the world again $: \dagger$ henceforth,
* Gen. ix. I2-I7.
† Gen. viii. 22. 
Till time shall be no more, in ceaseless round,

Season shall follow season : day to night,

Summer to winter, harvest to seed time,

Heat shall to cold in regular array

Succeed."-Heaven-taught, so sang the Hebrew bard. *

\section{A HARVEST SCENE.}

WAKED by the gentle gleamings of the morn, Soon clad, the reaper, provident of want, Hies cheerful-hearted to the ripen'd field; Nor hastes alone; attendant by his side His faithful wife, sole partner of his cares, Bears on her breast the sleeping babe ; behind, With steps unequal, trips her infant train : Thrice happy pair, in love and labour join'd! All day they ply their task ; with mutual chat, Beguiling each the sultry, tedious hours. Around them falls in rows the sever'd corn, Or the shocks rise in regular array.

But when high noon invites to short repast, Beneath the shade of sheltering thorn they sit, Divide the simple meal, and drain the cask : The swinging cradle lulls the whimpering babe, Meantime; while growling round, if at the tread () hasty passenger alarm'd, as of their store Protective, stalks the cur with bristling back, To guard the scanty scrip and russet frock.

* Moses. 


\section{IN D E X.}

Advertisement to original edition, v. Affection of birds for young, 9, I6I, 227

Ammonites, Io

Anne, Queen, at Wolmer Forest, 19 Antiquities of Selborne, 29I-380

Ants, 42 I

Aphides, 259-42 I

Ash, 428

Ass, 193

Aurora Borealis, 435

Bacon-fly, Iọ

Barometer, 433

Bat, 39, 88, I03

Beans sown by birds, 43I

Bee-moth, 4I6

Bee, wild, 4I 7

Beech, 428

Birds, confidence of, in man, 106

,, washing of, I45

, dusting of, 145

,, flight of, 233

, mating of, 93

", of passage, 57,129

, sex of, 144

, singing of, I32, I37, 237

Black spring, 435

Blackthorn, 429

Blackcap, 3I, II 5

Black game, I9

Blind-worm, 62

Boar, wild, 28

Bogwood, I 7

Bombylius medius, 419

Botany of Selborne, 228, 230

Brambling, 85
Brutes, sociality of, 198

Bullfinch, 52

Bull-head, 37

Bunting, 47

Burning the gorse, 22

Bustard, I 35

Butcher-birds, 107. 68

Buzzard, honey, I22

Calculus from ox, 103

Candles, rush, 20I

Cane, 5I, II 3

Cannibalism, 228

Carp, I I4

Cat and leveret, 2 I4

Cat and squirrel, 408

Chafers, 4 I I

Chaffinch, 46

Chestnut, 429

Chiff-chaff, 56, 398

Chough, I08

Cliffs, fall of, 242

Cockroach, $4 \mathrm{I} 2$

Cricket, field, 245

", house, 248, 4I 3

, mole, 250

Crossbill, 37, I46

Crow, ro8

Cuckoo, $\mathrm{I}_{3} 8, \mathrm{I}_{42} 2, \mathbf{1 4} 6,210$

Cuckoo pints, 53

Cucumber set by bees, 43I

Curlew, stone, 54, 99, 270, 396

Deer killing dog, 22

,, stealing, 2I

", red, 19

2 spiracula of, 50 
Diver, Great Northern, 395

Dog, Chinese, 268

Echo, 223

Eel, 37

Empedes, 420

Earth-worms, 423

Fairy rings, 432

Falco peregrinus, 34, 36, 266

Fern-owl, 104, 399

Ferret, 5I

Fern-chafer, $1 \times 4$.

Fieldfare, 86, 90

Fish, gold, 259

Flies, 420

Fly-catcher, 3I, 57, II 6

Fossils, 9

Food of birds, I I 7, I 52

Freestone, II

Fog, 207

Frog, 59

Frozen sleet, 434

Frost, partial, 433

Game at Selborne, I3

Geology of Selborne, 6

Gibraltar, birds frum, 98

Gipsies, 199

Glow-worm, 423

Goatsucker, IO4, 399

Gold-crest, 58

Gossamer, I 95

Grasshopper warbler, 30, II 3

Grosbeak, 37

Hanger, 464

Hare, white, 87

Harvest-bug, I00

Harvest-mouse, 42, 49

Hawk, sparrow, I I 3,123

Heath fires, 22

Hedgehog, 88

Heliotrope, 24I

Hen harrier, I I 3, 393

Heronry, 74

Hog, 213

Hollow lanes, I3

Honey dew, 434

Hoopoe, 37

Hops, 430

Horse, 408

Hounds, 408
House-martins, 39, 105, 167, 255, 26I

Humming in the air, 410

Humming-bird moth, 416

Ichneumon fly, 418

Idiot boy and bees, 204

Insects, observations on, 409

Introduction, ix

Invitation to Selborne, 461

Instinct, 263

Ivy berries, 429

Jackdaw, 72

Kestrel, I 13

Lampern, 37

Landrail, 390

Landslip, 242

Leprosy, 219

Lime-tree, 429

Linnet, 47

Lizard, 70, 77

Loach, 65

Martin, house, 39, 105, 167, 249, 261

Mayfly, 4I5

Meteorological observations, 433

Migration, 15 I, 78

Miller's thumb, 37

Missel-thrush, 194

Mist, 434

Moose-deer, 9 I

Morning clouds, 435

Musical pitch of bird notes, 154

Naturalist's walk, 8r

Newt, 6o, 6I

Nightingale, II 3

Night-jar, 75, I04

Nuthatch, 57

Oak, 8

Estrus curvicauda, 418

Osprey, I07

Otter, 94

Ousel, water, 146

, ring, 68, 79, 105

Owl, brown, 38 , 166

," white, or barn, 163

Partridge, 18, 388

Peacock, 103 
Peregrine falcon, 34, 36, 266

Pheasant, hybrid, 389

Pigeon, wood, 108, 123

Plants, list of, 230

Plestor, 8

Poems, 46I

Polecat, $5 \mathrm{I}$

Ponds, 25, 209

Poultry, 386

Quail, 47

Queen's bank, 19

Quadrupeds, observations on, 407

Rabbit, 408

Rain, quantity of, 14

Rainbow, on the, 465

Rat, water, 32, 35

Raven, 9

Redbreast, I I 4

Red deer, 19

Redwing, I 55

Redstart, 1 I3, I I6

Reptiles, 59

Rooks, 175, 270, 385

,, white, 52

Rush candles, 201

Sandpiper, 69

Scallop, fossil, 9

Sedge warbler, 83

Seed lying dormant, 430

Selborne, 3

$$
\begin{array}{ll}
, & \text { botany of, } 228,230 \\
, \quad & \text { geology of, } 6 \\
\text { superstitions of, } 205
\end{array}
$$

Sheep, 1 73, 407

Shells, fossil, 9

Shrew ash, 206

Shrike, 68, I07

Silkworm moth, 76

Slug, 423

Snail, 423

Snakes, 63

Snipe, 31

slough of, 424

,, humming of, 35, I I I

Snow-flake, 86

Sparrow-hawk, II3, I 23

Spring, perennial, 5

Squirrel nourished by a cat, 408

Stickleback, 65

Stilt plover, 252
Stoat, 51

Stock-dove, I24

Sussex Downs, 172

Swallow, 30, 44, I I 2, I 58, I 75, I93:403

," hibernation of, 30, 34

Swan, II 3

Swift, 186, 227, 256

Sycamore, 428

Teal, 163

Thrush, 385

Thaw, 433

Titlark, I08

Titmouse, I 19

Toad, 59, 66

Tortoise, 147, I 59, I 75, 254

Trees, $426,427,428$

Trout. 37

Truffles, 432

Turnip-fly, Ior

Vegetables, observations on, $\mathbf{4 2 6}$

Vine, parasite of, 257

Viper, 62, 211

Wagtails, 47, 405

Waltham blacks, 2 I

Wasp, 4I 7

Water-rat, 32, 35

Water-ouzel, 146

Waxwing, Bohemian, 43

Weasel, 5 I, I I 3

Weather, summary of, 437

Well-head, 5

observations on, 273

Wheat, 43I

Wheat-ear, 48, 120, 174

Whinchat, 120

Whitethroat, I I 5

White and Markwick's calendars, 447

Wild fowl, 17, 25

Willow wrens, 55,67

Wolmer Forest, I5, 24, 26

Wood fossil, 270

Woodcock, 97, I49, I56

Worms, 216

Worms, blind, 62

,, glow, 423

Wryneck, 406

Wych-elm, 7 


\section{LIST OF ILIUSTRATIONS.}

Frontispiece (facing title)

Beech, 4

Elm, 7

Partridge, 18

Black grouse, 19

Red deer, 20

Wild duck, 26

Wild boar, 28

Swallow, 29

Spotted fly-catcher, 3I

Blackcap, 32

Water-rat, 30

Snipe, 33

Common rat, 34

Hoopoe, 36

Grosbeak, 37

Crossbill, 38

Miller's thumb, 38

House martin, 39

Pipistrelle bat, 40

Harvest-mouse and nest, 42

Waxwing, 43

Chaffinch, 46

Linnet, 47

Quail, 47

Wheatear, 48

Weasel, $5 \mathrm{I}$

Polecat, 52

Bullfinch, 53

Curlew, 55

Chiff-chaff, 56

Nuthatch, 58

Metamorphosis of Newt, 6r

Viper, 62

Ringed snake, 62

Blindworm, 63

Knot sandpiper, 69

Puffin, 7I

Heron, 74

Nightjar, 75

Silkworm-moth, 76

Fieldfare, 85

Brambling, 86

Hedgehog, 89
Otter, 94

Peacock, I02

Osprey, 107

Shrike, I08

Woodpigeon, I09

Whinchat, 109

Lapwing, I Io

Nightingale, II 2

Carp, II 5

Whitethroat, 116

Gold-crest, I 18

Longtailed tit and nest, IIy

Blue titmouse, I 20

Sparrow-hawk, 122

Stock-dove, I24

Great bustard, I36

Cuckoo, I39

Redwing, 14I

Woodcock, 149

Tortoise, 159

Barn-owl, I64

Brown-owl, 165

Sand-martin, 182

Swift, 187

Missel-thrush, 194

Gipsies, 200

Shrew, 206

Raven, 234

Magpie, 235

Jay, 235

Moor-hen, 236

Coot, 237

House-cricket, 248

Mole-cricket, 250

Squirrel, 264

Peregrine falcon, 267

Landrail, 39I

Hen harrier, 393

Great Northern Diver, 395

Wryneck, 406

May-flies, 4I 5

Convolvulus hawk-moth, 416

Lime-tree aphis, 42 I

Snails and slugs, 424 


A Complete Catalogue of all the Works published by Messrs. FREDERICK WARNE \& CO. can be had on application to any Bookseller, or direct from

Chandos House, Bedford Street, Strand, LONDON.

\section{SELECTION FROM the LIST of BOOKS}

\section{PUBLISHED BY \\ FREDERICK WARNE \& CO.}

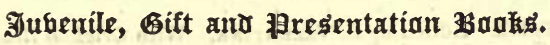

Adams (Rev. H.C.). The Woodleigh Stories. With Illustra. tions. Crown 8vo, gilt. 036

The Falcon Family. With Illustrations. Crown 8vo, gilt $0 \begin{array}{llll}0 & 3 & 6\end{array}$

Esop's Fables. Translated by SAmued Croxall, D.D. Edited by Rev. GEORGE FYLER TOWNSEND and L. VALENTINE, with Additions from Sir ROGER L'ESTRANGE. I Io Illustrations, square crown 8vo, gilt . . . . ?

Andersen's (Hans) Fairy Tales. By Mrs. Paulz. Fully Illustrated. Square crown 8vo, gilt . . . . Fairy Tales. With numerous Illustrations and 16 page Plates, printed in Colours from Original Designs. 512 pages, demy 8vo, handsome gilt binding, bevelled boards ? ? ? $^{0} 76$ Ditto ditto Gilt and gilt edges $\quad$ : 086

Fairy Tales. With numerous Illustrations. Crown 8 vo, gilt, bevelled boards ?. . . 036

Arabian Nights. Revised Edition. With I6 large page Plates by HoughtoN, Dalziel, \&c. Square crown 8vo, gilt .

Arabian Nights. A New Edition. With 16 finely-printed Coloured Plates and very numerous Illustrations in the Text, besides fullpage Pictures. In square crown $8 \mathrm{vo}$, bandsome binding, gilt, bevelled boards . . . . .

Arablan Nights. Edited by the Rev, G. F. Townsend. With Original Illustrations. Crown 8vo, gilt, bevelled boards .

Beach (C. A.). Waifs of the World. With Original Illustrations. Crown 8vo, gilt, bevelled boards .

Bell (M. M.). Seven to Seventeen. With Original Illustrations. Crown 8vo, gilt - • • • • • • •

Seventeen to Twenty one. With Original Illustrations.

Bowman (Anne). Among the Tartar Tents; or, The Lost Fathers. With Original Illustrations. Crown 8vo, gilt, bevelled boards .

Bramston (M.). The Carbridges. With Original Illustrations. Crown 8vo, gilt .

Burnett (Frances Hodgson). Little Lord Fauntleroy. With numerous Original Illustrations by REGINALD B. BIRCH. In medium 8vo, gilt, bevelled boards
Price

$£$ s. $d$. $\begin{array}{llll}0 & 5 & 0\end{array}$ $\begin{array}{llll}0 & 5 & 0\end{array}$ 


\section{Selections from Frederick Warne \& Co.'s Publications.}

\section{Jubentile, Bift and 羽esentation \$onak. Price}

Camcron (Commander V. Lovett, R.N.). Harry Raymond: His Adventures with Pirates, Slavers and Cannibals. With Original Illustrations by F. A. FRASER. In square crown 8 vo, gilt, bevelled boards . . . . . . .

Coleridge (Christobel). Lady Betty. With Original Illustrations. Crown 8vo, gilt . - • • • • •

Coolidge (Susan). What Katy did at Home and at School. With Original Illustrations. Crown 8vo, gilt What Katy did Next. With Original Illustrations.

Cummins (Miss). The Lamplighter. With Original Illustrations. Crown 8 vo, gilt, bevelled boards . . . .

Davy and the Goblin ; or, What followed Reading "Alice in Wonderland." By Charles E. CARRYL. Profusely and Artistically Illustrated. Demy 4 to, bevelled boards, gilt edges .

Dodge (Mary Mapes). Donald and Dorothy. Fully Illustrated.

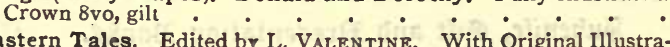
tions. Crown $8 v 0$, gilt, bevelled boards ?

Edgar (J. G.). Cavaliers and Roundheads. With Original Illustrations. Crown 8vo, gilt, bevelled boards . .

Edgeworth .(Maria). Early Lessons, Frank, Rosamond, \&c., and The Parent's Assistant. With Original Illustrations. Crown 8 vo, gilt, bevelled boards

Eiloart (Mrs.). Cris Fairlie's Boyhood. With Original Illustrations. Crown 8vo, gilt, bevelled boards. . . . . The Young. Squire. With Original Illustrations. Crown 8vo, gilt, bevelled boards . .. . . . .

Ethel Fortescue ; or, Left in Charge. By Mrs. C. SELBy Lowndes, Author of "Lena Graham," "New Honours," \&c. With Illustrations by Edith'ScanNell. Crown 8vo, gilt, bevelled boards.

Foote (M. H.). The Led Horse Claim. With Original Illustra. tions. Crown 8vo, gilt .

Godfrey Malden; or, The Squire's Grandsons. By Mrs. J. F. B. FirTH. With 35 Original Illustrations. Large crown 8vo, gilt .

Greene (Honourable Mrs. R J.). Gilbert's Shadows. With Original Illustrations. Crown 8vo, git, bevelled boards. The Star in the Dust Heap, With Original Illustrations. Crown 8vo, gilt, bevelled boards.. . . God's Silver; or, Youthful Days. With Original Illustrations. Crown 8vo, gilt, bevelled boards . . . .

Grimm's Fairy Tales and Stories. Translated by Mrs. PAULL. New Edition, New Type, \&c. With 16 finely-printed Coloured Plates, and very numerous Illustrations, including, full-page pictures. Square crown $8 \mathrm{vo}$, handsome binding, gilt, bevelled boards

- Fairy Tales and Stories. Translated by. Mrs. PAULL. With I6 Original Illustrations. Square crown 8vo, gilt .

- Fairy Tales and Stories. With numerous Illustrations. Crown 8vo, gilt, bevelled boards.

Hall (M.). A Perilous Venture. With Original Illustrations. Crown 8vo, gilt, bevelled boards . $8 \mathrm{vo}$, gilt, bevelled boards 


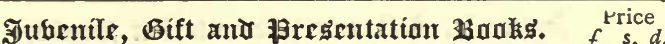
Hocking's (Silas K.) Works. With Original Illustrations. Small
crown 8vo, gilt edges.

CROOKLEIGH: A Village Story . . . . . . 026

REAL GRIT : $\quad \vdots \quad \vdots 026$

Cale b Carthew : A Life Story. With Steel Portrait of the Author 0

CRICKET: A Tale of. Humble Life, $\cdot 0^{0} \cdot 026$

Dick's FaIRY: A Tale of the Streets - . . . . . 026

SEA-WAIF: A Tale of the Sea $0.0 \quad 0026$

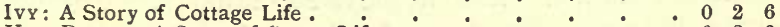

Her BENNY: A Story of Street Life $: \vdots \quad \vdots \quad \vdots 026$

His FATHER; or, A Mother's Legacy - . . . . . 026

Alec Green : $: 0026$

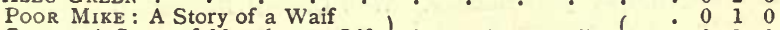

CHIPS: A Story of Manchester Life
OUR JOE

Howitt (Mary). Tales of English Life. With 12 Illustrations. Square crown 8vo, gilt . . . . . . .

Tales for all Seasons. With i2 Illustrations. Square

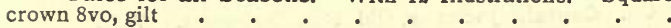

Ingraham (Revi J. H.). The Prince of the House of Vavid. With Original Illustrations. Crown 8 vo, gilt, bevelled boards, gilt edges

$\begin{array}{lll}0 & 5 & 0\end{array}$

$\begin{array}{llll}0 & 5 & 0\end{array}$

$\begin{array}{lll}0 & 3 & 6\end{array}$

$\begin{array}{lll}0 & 3 & 6\end{array}$ Crown 8 vo, gilt, bevelled boards, gilt edges

The Pillar of Fire. With Original Illustrations. Crown $8 \mathrm{vo}$, gilt, bevelled boards, gilt edges . . . . ". .

Irving (Washington). Christmas Stories from the Sketch Book.

groom.

Legend of Sleepy Hollow, and The Spectre Bride-

Rip Van Winkle.

English Sketches.

The Pride of the Village, \&c. \&c.

Choice Editions, with numerous Illustrations. Small 4to, bevelled boards, gilt edges .. . . each

Keary (Annie). Sidney Grey. With Original Illustrations. Crown 8 vo, gilt, bevelled boards . $\quad \cdot$. $0^{0} \quad 36$

Kennedy (Grace). Dunallan. With Original Illustrations. Crown 8 vo, gilt .

Keyworth (Thomas). Granny's Boy; or, Not Kin but Kind. With Original Illustrations. Crown 8vo, gilt and gilt edges, bevelled boards

A Long Delay. With Original Illustrations. Crown 8vo, gilt and gilt edges, bevelled boards . . . . . .

Kingston (W. H. G.). Adrift in a Boat and Washed Ashore. With 16 Illustrations. Crown 8vo, gilt, bevelled boards .

Knight (Arthur Lee). Ronald Hallifax; or, $\mathrm{He}$ would be a Sailor. With Original Illustrations by W.S. STACEX. In square crown 8 vo, gilt, bevelled boards .

Language and Sentiment of Flowers (The); or. Flora Symbolica. With Original Coloured Illustrations. Square crown $8 \mathrm{vo}$, gilt.

Ditto gilt edges

(Popular Edition). Small crown 8vo, gilt, and

Lewis (Angelo J.) (Professor Hoffmann). Conjuror Dick. With Original Illustrations. Crown $8 \mathrm{vo}$, gilt, bevelled boards . ${ }^{0} 36$ 
Selections from Frederick Warne \& Co.'s Publications.

\section{Jubenile, Gift and 㭁esentation 3adks.}

Marryat (Captain, R. N.). Masterman Ready; or, The Wreck of the "Pacific." Elegantly printed, and containing upwards of 75 New Illustrations. Square crown 8vo, gilt, bevelled boards - 050

The Settlers in Canada. With numerous New and Original Illustrations, finely printed. Square crown 8vo, gilt, bevelled boards ' With 4 illustrations after designs by SON Stanfield, R.A. Crown 8vo, gilt, bevelled boards Clark-

Marryat (Augusta). The Young Lamberts. With Original Illustrations. Crown 8vo, gilt, bevelled boards . $~ 0.036$

Marryat (Emilia). Jack Stanley. With Original Illustrations. Crown 8 vo, gilt, bevelled boards .

May and Her Friends. By E. M. B. With Original Illustrations. Crown 8vo, gilt

Mayne Reid (Captain). The Land of Fire. With numerous Original Illustrations. Square crown 8vo, gilt, bevelled boards. $0 \begin{array}{lll}0 & \mathbf{6}\end{array}$

McKnight (C.). Captain Jack ; or, Old Fort Duquesne. With Original Illustrations. Crown 8vo, gilt, bevelled boards . . 036

National Books. Coloured Plates. Imperial r6mo, gilt . . 010 Ditto ditto

Gilt edges. $\begin{array}{llll}0 & 1 & 6\end{array}$

I. Bunyan's Pilgrim's Progress.

2. FOXE'S BOOK OF MARTYRS.

3. Robinson Crusoe.

4. Buffon's Natural History.

5. BUNYAN'S HOLY WAR.

6. BASKET OF FLOWERS.

7. Swiss Family Robinson.

8. Military ENTERPRise.
9. Naval ENTERPRise.

10. UNCLE TOM'S CAB1N.

II. THE ROBIN REDBREASTS.

12. RICHMOND'S (LEGH) ANNALS OF THE POOR.

13. SANDFord AND MERTON. I4. Evenings at HOME.

Nursery Rhymes, Tales and Jingles of Great Britain. (Camden Edition.) With 400 Illustrations. Large crown 8vo, gilt .

Old Friends and New Friends. With numerous Illustrations. Crown 8vo, gilt . . . . . .

On the Edge of the Storm. By the Author of "Mdlle. Mori." With Original Illustrations. Crown 8vo, gilt. . . .

Peard (F. M.). One Year. With Original Illustrations, Crown 8vo, gilt

Pepper's Cyclopædic Science Simplified. By J. H. Pepper. A new Edition, with many Illustrations. Square crown 8vo, gilt

Pioneer Life and Frontier Adventures. By. Dewitx C. Peters. With many powerful and graphic Illustrations. Square crown $8 \mathrm{vo}$, gilt

Robinson Crusoe. Unabridged Edition. With Life, Notes and fully Illustrated with Woodcuts and large Plates by GRISET. Crown 8vo, gilt

Robinson Crusoe. Unabridged Edition. With Illustrations. Crown 8vo, gilt, bevelled boards . . . . .

Somerton (Alice). The Torn Bible. New Edition. With Original Illustrations. Crown 8vo, gilt and gilt edges . . . .

_ Layton Croft ; or, The Story of a Prodigal. With Original Illustrations. Crown 8vo, gilt and gilt edges .

Stowe (H. Beecher). Uncle Tom's Cabin. With Original Illustrations. Crown 8vo, gilt, bevelled boards . 


\section{Selections from Frederick Warne \& Co.'s Publications.}

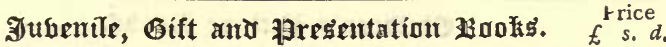

Swiss Family Robinson. Translated from the Uriginal German, by Mrs. PAULL. With numerous Choice Illustrations. 640 pages. In square crown $8 \mathrm{vo}$, gilt. .

Swiss Family Robinson. With numerous Illustrations. Crown 8 vo, gilt, bevelled boards

Sylvia's Daughters. By Florence Scannell. With Original Illustrations by EDITH ScaNNELL. Printed in Monochrome by EDMUND Evans. In small 4 to, picture boards, coloured edges . Ditto ditto. Gilt, gilt edges, and bevelled boards

Treasures of the Earth; or, Mines, Minerals and Metals. By WiLliam Jones. With Illustrations. Square crown $8 v 0$, gilt .

Trowbridge (J. T.). Who Won at Last? With Original Illustrations. Crown 8 vo, gilt, bevelled boards . . . .

Valentine (L.). The Queen: Her Early Life and Reign. With nearly 10o Illustrations. In crown 8vo, picture cover, boards .

Ditto (Presentation Edition), cloth gilt, bevelled boards .

We Three Boys; or, A Year of Adventure. Fully Illustrated. Large crown 8vo, gilt - Heroism and Adventure. With Illustrations. Crown

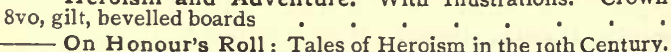
With Illustrations. Crown 8vo, gilt, bevelled boards. With Illustrations. Crown $8 \mathrm{vo}$, gilt, bevelled boards. and Hastings to Inkerman. With Original Illustrations. Crown $8 \mathrm{vo}$, gilt, bevelled boards . . . . . .

Valentine (Mrs.). Home Book for Young Ladies. Entirely re-edited. 250 Illustrations. Square crown 8vo, gilt . .

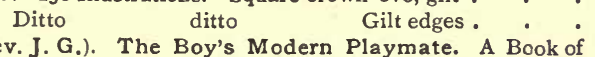

Wood (Rev. J. G.). The Boy's Modern Playmate. A Book of
Games, Sports and Diversions. With 600 Illustrations, engraved by DALZ1ELs, HoDGKIN, \&c. In square crown 8vo, gilt engraved Ditto ditto

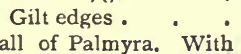

Ware (Rev. W.). Zenobia ; or, The Fall of Palmyra. With
Original Illusts. Crown 8vo, gilt, gilt edges, bevelled boards Original Illusts. Crown 8vo, gilt, gilt edges, bevelled boards
Aurelian ; or, Rome and Early.Christians. With Original Illustrations. Crown 8vo, gilt, gilt edges, bevelled boards .

Julian; or, Scenes in Judea. With Original Illustrations. Crown 8 vo, gilt, gilt edges, bevelled boards. . . .

Wetherell (E.). Say and Seal. With Original Illustrations. Crown 8 vo, gilt, bevelled boards . . . . . .

Wilfrid (Florence) Vivia. With Original Illustrations. Crown

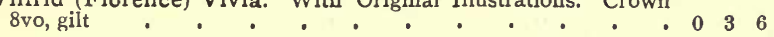

Golden Play Book (The). With 18 full-page Pictures printed in Gold and Colours with Descriptive Letterpress. Crown 4to, gilt, bevelled boards, gilt edges
Ditto

Holiday Playmate (The). With 12 most Attractive page Coloured Plates and roo Illustrations, 96 pages of large type Letterpress. Extra large 4to, gilt, bevelled boards . .

Little People's Favourite Album (The). With 12 most Attractive page Coloured Plates, 96 pages of Letterpress, and 100 Illustrations. In extra large 4 to, gilt, bevelled boards 


\section{Children's 䄧icture bionks.}

Afternoon Tea Painting Book. With roo Illustrations suitable for Colouring. Super-royal 8vo, picture cover . . . .

Army and Navy Drolleries. With 24 Original Designs by Lieut.Col. SECCOMBE, and Descriptive Alphabetical Letterpress. Demy 4 to, gilt edges

Seccombe (Lieut..Col.). Cinderella, Retold in Rhyme. With 70 Original Illustrations by the Author; the 12 page Plates elegantly printed in Colours. 72 pp., small 4 to, gilt edges . .

Shaksperian Tales in Verse. Illustrated with 24 page Plates in Colours and numerous Illustrations in Tints in the Itxt. Royal 4to, gilt .

Young England's Nursery Rhymes. With 96 pages of beautifully-printed Coloured Pictures from Designs by Miss HASLEWOOD. In small crown $8 v o$, picture boards

Ditto handsomely bound in cloth, gilt, bevelled boards Ditto ditto in full rcan, gilt edges.

Our Favourite Nursery Rhymes. With roo Original Illustrations. Imperial r6mo, re2 pp., picture wrapper
ditto

Our Favourite Nursery Songs. With Illustrations on every alternate page, picture wrapper. Imperial r6mo $\quad \cdot \quad ? \begin{array}{lll}0 & 1 & 0\end{array}$ Ditto ditto Gilt $\quad: \quad \begin{array}{lll}0 & 0\end{array}$

Our Favourite Nursery Tales. With Illustrations on every alternate page, picture wrapper. Imperial $16 \mathrm{mo}$. .

$\begin{array}{lll}\text { Ditto } & \text { ditto } & \text { Gilt } \\ \text { Pinafore's Picture Book. With numerous page Coloured }\end{array}$

Little Pinafore's Picture Book. With numerous page Coloured
Illustrations and Descriptive Letterpress. Small crown 8 vo, gilt

Tiny Tot's Picture Book. With numerous page Coloured Illus. trations and Descriptive Letterpress. Sm 11 l crown 8vo, gilt .

Our Dog Laddie. With 20 full-page Pictures printed in Colours, and numerous Illustrations in the Letterpress Square royal 8vo, picture boards, with cover printed in gold and colours .

Three Kittens (The). With 20 full-page Pictures printed in Colours, and numerous Illustrations in the Letterpress. Square royal $8 \mathrm{vo}$, picture boards, with cover printed in gold and colours

Birthday Present (The). With numerous page Coloured Illu:trations and Descriptive Letterpress. Demy 8vo, gilt, bevelled boards . . . . . . . . . . . .

Globe Picture Book (The). With numerous page Coloured Illustrations and Descriptive Letterpress. Demy 8vo, cloth gilt, bevelled boards . . . . . ? .

Little Folks' Gift Book (The). With numerous page Colo ured Illustrations. Small 4 to, gilt, bevelled boards .

Nursery Wonder Book (The). With 12 Coloured Plates, roo Flain Illustrations, and 96 pages of large ty pe Letterpress. Large crown 4to, gilt, bevelled boards - '

Our Little Ones' Own Picture Book. With 12 Coloured Plates, roo $\mathrm{Pl}$ ain Illustrations, and 96 pages of large type Letterpress. Large crown 4to, gilt, bevelled boards.

Robinson Crusoe. Nursery Edition. With 12 Attractive Coloured Plates and numerous Illustrations, large type Letterpress. In extra 4 to, Coloured picture cover, boards, cloth back .

Gulliver's Travels. By Dean Swift. Re-told by Mrs. Valentine for Young Children. With 12 attractive Coloured Pictures and nimerous Illustrations, large type Letterpress. In extra 4to, Coloured cover, boards, cloth back . . .

$\begin{array}{lll}0 & 1 & 0\end{array}$ $\begin{array}{lll}0 & 2 & 0\end{array}$

$\begin{array}{lll}0 & 1 & 0\end{array}$

$\begin{array}{lll}0 & 1 & 0\end{array}$

$\begin{array}{llll}0 & 1 & 0\end{array}$

$\begin{array}{lll}0 & 1 & 0\end{array}$

$\begin{array}{lll}0 & 2 & 0\end{array}$

$\begin{array}{lll}0 & 2 & 0\end{array}$

$\begin{array}{lll}0 & 2 & 6\end{array}$

$\begin{array}{lll}0 & 3 & 6\end{array}$

$\begin{array}{lll}0 & 3 & 6\end{array}$

$\begin{array}{lll}0 & 3 & 6\end{array}$ 

